\title{
Contested cultural property : the return of nazi spoliated art and human remains from public collections
}

Citation for published version (APA):

Lubina, K. (2009). Contested cultural property : the return of nazi spoliated art and human remains from public collections. [Doctoral Thesis, Maastricht University]. Datawyse / Universitaire Pers Maastricht. https://doi.org/10.26481/dis.20091125kl

Document status and date:

Published: 01/01/2009

DOI:

10.26481/dis.20091125kl

Document Version:

Publisher's PDF, also known as Version of record

\section{Please check the document version of this publication:}

- A submitted manuscript is the version of the article upon submission and before peer-review. There can be important differences between the submitted version and the official published version of record.

People interested in the research are advised to contact the author for the final version of the publication, or visit the DOI to the publisher's website.

- The final author version and the galley proof are versions of the publication after peer review.

- The final published version features the final layout of the paper including the volume, issue and page numbers.

Link to publication

\footnotetext{
General rights rights.

- You may freely distribute the URL identifying the publication in the public portal. please follow below link for the End User Agreement:

www.umlib.nl/taverne-license

Take down policy

If you believe that this document breaches copyright please contact us at:

repository@maastrichtuniversity.nl

providing details and we will investigate your claim.
}

Copyright and moral rights for the publications made accessible in the public portal are retained by the authors and/or other copyright owners and it is a condition of accessing publications that users recognise and abide by the legal requirements associated with these

- Users may download and print one copy of any publication from the public portal for the purpose of private study or research.

- You may not further distribute the material or use it for any profit-making activity or commercial gain

If the publication is distributed under the terms of Article 25fa of the Dutch Copyright Act, indicated by the "Taverne" license above, 


\section{Contested Cultural Property}

The Return of Nazi Spoliated Art and Human Remains

from Public Collections

Katja Lubina 
Photo front cover:

'Penitent Magdalene with a skull', paper laid down on panel, 63,5 x 48,5 cm, Anthony van Dyck. The image has been taken from the RKD Database:

http://www.rkd.nl/rkddb/dispatcher.aspx?action $=$ search\&database $=$ ChoiceImages\&search=priref $=48318$.

Photo back cover:

With the emergence of claims for the restitution of art works spoliated during WWII from the mid-1990s onwards, greater emphasis is put on the backs of art works. Stamps and stickers on the back of paintings often provide relevant information for the reconstruction of a painting's whereabouts during the years 19331945. The image here shows the back of a painting from the former Goudstikker Collection: 'Study of an apostle's head', paper on panel, 19 x 15,5 cm, Anthony van Dyck. The stickers reveal that the work was listed under inventory number 2550 in Goudstikker's inventory book ("the black book") and after the war became part of the Netherlands Art Property Collection (Nederlands Kunstbezit). The work has been loaned to and exhibited by the museum in Maastricht, now the Bonnefantenmuseum. Photo: Muller / Schretlen, 2002, p. 248.

Book design: Mixed Media (Josh Moll)

Published by Katja Lubina

Maastricht 2009 


\section{Contested Cultural Property}

The Return of Nazi Spoliated Art and Human Remains
from Public Collections

\section{PROEFSCHRIFT}

ter verkriiging van de graad van doctor aan de Universiteit Maastricht, op gezag van de Rector Magnificus, Prof. mr. G.P.M.F. Mols, volgens het besluit van het College van Decanen, in het openbaar te verdedigen op woensdag 25 november 2009 om 10:00 uur.

door

Katja Rita Maria Lubina 


\section{Promotores}

Prof. dr. Hildegard Schneider

Prof. dr. Gerard-René de Groot

\section{Beoordelingscommissie}

Prof. dr. Gerrit van Maanen (voorzitter)

Prof. dr. Bruno De Witte

Prof. dr. Menno Kamminga

Prof. dr. Kerstin Odendahl

Prof. dr. Inge van der Vlies 
To my Family

Ancestors, Contemporaries, Descendants

Yesterday, today, tomorrow

Verteilen sachlicher Güter

Ist aufteilen - dividieren

Verteilen geistiger Güter

Ist verbreiten - multiplizieren

Ergreifen erwirkt Besitz

Begreifen bewirkt Einsicht

Albers, J., 2006. 



\section{Outline}

$\begin{array}{ll}\text { OUTLINE } & 7\end{array}$

TABLE OF CONTENTS

$\begin{array}{ll}\text { LIST OF ILLUSTRATIONS } & 20\end{array}$

LIST OF FREQUENTLY USED ABBREVIATIONS AND TERMS 21

$\begin{array}{ll}\text { PREFACE } & 25\end{array}$

\begin{tabular}{ll} 
INTRODUCTION & 29 \\
\hline
\end{tabular}

\$1. The presence of the past in public collections and recent impulses challenging public collections 29

\$2. The research task emerging from recent developments 33

I. Methodology \& delimitation 34

II. Structure of the book $\quad 37$

III. Terminology 39

IV. Summary of the research aim and specific research questions $\quad 45$

V. Reading Instructions $\quad 46$

CHAPTER 1: ANALYSIS OF INTERNATIONAL LAW WITH REGARD TO THE RISE OF OBLIGATIONS TO RETURN CULTURAL OBJECTS 49

\$1. The protection of cultural objects in times of war 51

I. From Ancient Times until the end of the 19th Century 51

II. The 1899 and 1907 Hague Conventions 56

III. Peace Treaties concluding the First World War 61

$\begin{array}{ll}\text { IV. The Interbellum } & 68\end{array}$

V. $\quad$ Restoration of rights after World War II $\quad 68$

VI. The aftermath of World War II: 1954 Hague Convention and its protocols 82

VII. Intermediary conclusions on the restitution of cultural objects in the context of armed $\begin{array}{ll}\text { conflicts under treaty law } & 92\end{array}$

VIII. Customary law 94

\$2. Protection of cultural objects in times of peace 99

I. First attempts by the International Museums Office 101 
II. Treaty of Washington, 1935

III. 1970 UNESCO Convention 103

IV. 1995 UNIDROIT Convention 110

V. European Convention on Offences relating to Cultural Property (1985) 114

VI. EEC Regulation No 3911/92 and EC Directive 93/7/EEC 115

VII. Bilateral treaties 116

VIII. Intermediary conclusions with regard to the return of illicitly traded cultural objects under treaty law

IX. Customary law 118

\$3. Return of cultural objects to their country / territory of origin 123

I. The work of the United Nations and UNESCO 125

II. Rules on State succession: the creation of legally binding rights or obligations? 131

III. Reconceptualisation of circumstances of acquisition as international wrongful act? 135

IV. Intermediary conclusions on the legal bases to reclaim objects removed during $\begin{array}{ll}\text { colonisation } & 140\end{array}$

\4. Restitution of cultural objects to their original owners 141

I. Law No. 52 concerning the Blocking and Control of Property 144

II. Military Government Regulation No. 59 on the Restitution of Identifiable Property 145

III. The Treaty of Bonn: section III 146

IV. BRüG: the Federal Restitution Law 146

$\begin{array}{ll}\text { V. Intermediary conclusions } & 147\end{array}$

\$5. Restitution of cultural objects to a people 147

\$6. Conclusions for chapter $1 \quad 151$

I. Legal obligations to return cultural objects 151

II. Special status of public collections in international law? 153

CHAPTER 2: THE CASES OF THE RECENT DEBATES ON THE RETURN OF NAZI SPOLIATED ART AND HUMAN REMAINS: GENESIS, (LEGAL) CONTEXT AND THE ADOPTION OF VARIOUS INTERNATIONAL DECLARATIONS AND PRINCIPLES 159

\$1. The case of Nazi spoliated art 160

I. Nazi spoliated art: genesis of the debate on the return of Nazi spoliated art $\quad 160$

II. The case of Nazi spoliated art from the legal perspective 166

III. Recent developments: principles, resolutions and declarations adopted by the international community in reaction to the re-emergence of the debate on Nazi spoliated $\begin{array}{ll}\text { art } & 174\end{array}$

IV. Intermediary conclusions on the case of Nazi spoliated art 184

\2. The case of human remains $\quad 185$

I. The history of collecting human remains 186 
II. Human remains: genesis of the debate on the return of human remains

III. The case of human remains from the legal perspective

IV. Recent developments: principles, resolutions and declarations adopted by the international community in reaction to the re-emergence of the debate on human remains

V. Intermediary conclusions on the case of human remains

§3. Conclusions for chapter 2

I. The status and relevance of soft law

II. Solutions proposed by the instruments to facilitate the return of Nazi spoliated art and human remains

CHAPTER 3: COMPARATIVE OVERVIEW OF NATIONAL LEGAL FRAMEWORKS APPLICABLE TO CULTURAL OBJECTS IN PUBLIC COLLECTIONS IN VIEW OF THEIR DISPOSAL AND EXPORT

\$1. European Community law on the export of national treasures

I. Council Regulation No. 3911/92 on the Export of Cultural Goods

II. Relevance of the Regulation in light of requests for the return of cultural objects

\$2. National law

I. The Netherlands

II. United Kingdom

$\begin{array}{ll}\text { III. France } & 269\end{array}$

\3. Conclusions for chapter $3 \quad 287$

CHAPTER 4: SOLUTIONS ADOPTED FOR THE RETURN OF NAZI SPOLIATED ART AND HUMAN REMAINS AT THE NATIONAL LEVEL 293

\$1. Nazi spoliated art 294

I. The Netherlands: the introduction of a liberalised government policy and the work of the $\begin{array}{ll}\text { Restitutions Committee } & 294\end{array}$

II. United Kingdom $\quad 342$

$\begin{array}{ll}\text { III. France } & 370\end{array}$

\$2. Human remains 379

I. The Netherlands: various forms of self-governance at museum level 379

II. United Kingdom $\quad 412$

III. France 436

§3. Conclusions for chapter 4

I. Nature and content of the policies with regard to the return of Nazi spoliated art and human remains

II. Towards rules of customary law on the return of Nazi spoliated art works and human remains? 
\$1. Summary and main findings from the previous chapters

Chapter 1: from the ius praedae to the heritage of mankind: the increasing protection of cultural objects as cultural property, including restorative but no retroactive protection 463

Chapter 2: the genesis of current claims and their legal status

Chapter 3: the confines of the law

Chapter 4: national solutions pertaining to the return of Nazi spoliated art and human remains - different perceptions about the need to return

\$2. Recommendations

I. (Re-) Opening of the debate on just \& fair solutions with regard to Nazi spoliated art 470

II. Human remains: open dialogue and common sense

III. "Walk the talk": living up to raised expectations in enabling returns

IV. Take protection of objects in public collections seriously 476

§3. Relevance for the protection and return of cultural objects more in general 477

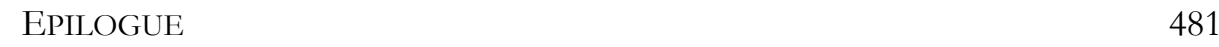

$\$ 1$ The Spoliation Advisory Panel's recommendation on the Glaser case 481

$\$ 2$ The Terezin Declaration on Holocaust era assets and related issues 484

$\$ 3$ Directions for the future $\quad 485$

$\begin{array}{ll}\text { BIBLIOGRAPHY } & 489\end{array}$

$\begin{array}{ll}\text { SAMENVATTING } & 533\end{array}$

$\begin{array}{ll}\text { ACKNOWLEDGMENTS } & 547\end{array}$

$\begin{array}{ll}\text { CURRICULUM VITAE } & 549\end{array}$ 


\section{Table of Contents}

$\begin{array}{ll}\text { OUTLINE } & 7\end{array}$

$\begin{array}{ll}\text { TABLE OF CONTENTS } & 11\end{array}$

$\begin{array}{ll}\text { LIST OF ILLUSTRATIONS } & 20\end{array}$

LIST OF FREQUENTLY USED ABBREVIATIONS AND TERMS 21

$\begin{array}{ll}\text { PREFACE } & 25\end{array}$

INTRODUCTION 29

\$1. The presence of the past in public collections and recent impulses challenging public $\begin{array}{ll}\text { collections } & 29\end{array}$

\$2. The research task emerging from recent developments 33

I. Methodology \& delimitation 34

II. Structure of the book $\quad 37$

III. Terminology 39

1. 'Museum \& Public Collection' 39

2. 'Cultural Property' 40

3. 'Nazi spoliated art' 41

4. 'Human remains' 42

5. 'Restitution', 'Restoration', 'Return', 'Recovery', 'Repatriation' 42

6. 'De-accessioning' 44

IV. Summary of the research aim and specific research questions 45

V. Reading Instructions $\quad 46$

CHAPTER 1: ANALYSIS OF INTERNATIONAL LAW WITH REGARD TO THE RISE OF OBLIGATIONS TO RETURN CULTURAL OBJECTS 49

\$1. The protection of cultural objects in times of war 51

I. From Ancient Times until the end of the 19th Century 51

II. The 1899 and 1907 Hague Conventions 56

III. Peace Treaties concluding the First World War $\quad 61$

$\begin{array}{ll}\text { IV. The Interbellum } & 68\end{array}$

V. $\quad$ Restoration of rights after World War II $\quad 68$

1. Restitution of Cultural Objects looted from the occupied Territories ("external

$\begin{array}{ll}\text { Restitution after the Bonn Treaty } & 77\end{array}$ 
2. External restitution from the Allies 79

3. Intermediary conclusions of the external restitutions after World War II 81

VI. The aftermath of World War II: 1954 Hague Convention and its protocols 82

1. The 1954 Hague Convention 82

2. The First Protocol of the 1954 Hague Convention 87

Intermediary conclusions and Application of the 1954 Hague Convention and its

Protocol 88

3. The Second Protocol of the 1954 Hague Convention 91

VII. Intermediary conclusions on the restitution of cultural objects in the context of armed $\begin{array}{ll}\text { conflicts under treaty law } & 92\end{array}$

$\begin{array}{ll}\text { VIII. Customary law } & 94\end{array}$

1. State practice 94

2. Opinio iuris 95

\$2. Protection of cultural objects in times of peace 99

I. First attempts by the International Museums Office 101

II. Treaty of Washington, 1935

III. 1970 UNESCO Convention 103

IV. 1995 UNIDROIT Convention 110

V. European Convention on Offences relating to Cultural Property (1985) 114

VI. EEC Regulation No 3911/92 and EC Directive 93/7/EEC 115

VII. Bilateral treaties 116

VIII. Intermediary conclusions with regard to the return of illicitly traded cultural objects under treaty law

$\begin{array}{ll}\text { IX. Customary law } & 118\end{array}$

1. State practice 119

2. Opinio iuris 120

\$3. Return of cultural objects to their country / territory of origin 123

I. The work of the United Nations and UNESCO 125

II. Rules on State succession: the creation of legally binding rights or obligations? 131

III. Reconceptualisation of circumstances of acquisition as international wrongful act? 135 Prior to / during the process of colonisation 136

Once colonial rule had been established 137

International wrongful act? Reconceptualisation of the process of colonisation as war 138

IV. Intermediary conclusions on the legal bases to reclaim objects removed during $\begin{array}{ll}\text { colonisation } & 140\end{array}$

§4. Restitution of cultural objects to their original owners 141

I. Law No. 52 concerning the Blocking and Control of Property 144

II. Military Government Regulation No. 59 on the Restitution of Identifiable Property 145 
III. The Treaty of Bonn: section III 146

IV. BRüG: the Federal Restitution Law 146

V. Intermediary conclusions $\quad 147$

\5. Restitution of cultural objects to a people $\quad 147$

\$6. Conclusions for chapter $1 \quad 151$

I. Legal obligations to return cultural objects 151

II. Special status of public collections in international law? 153

CHAPTER 2: THE CASES OF THE RECENT DEBATES ON THE RETURN OF NAZI SPOLIATED ART AND HUMAN REMAINS: GENESIS, (LEGAL) CONTEXT AND THE ADOPTION OF VARIOUS INTERNATIONAL DECLARATIONS AND PRINCIPLES 159

\1. The case of Nazi spoliated art 160

I. Nazi spoliated art: genesis of the debate on the return of Nazi spoliated art $\quad 160$

II. The case of Nazi spoliated art from the legal perspective 166

1. Public international law 166

2. A brief excursus on time limitations applicable to recovery in private law 169

$\begin{array}{ll}\text { a) Dutch Law } & 169\end{array}$

b) English / Common Law 171

$\begin{array}{ll}\text { c) French Law } & 173\end{array}$

d) Intermediary conclusions 173

III. Recent developments: principles, resolutions and declarations adopted by the international community in reaction to the re-emergence of the debate on Nazi spoliated $\begin{array}{ll}\text { art } & 174\end{array}$

1. The 1998 Washington Principles on Nazi-Confiscated Art 175

2. Council of Europe Resolution 1205 (1999) on Spoliated Jewish cultural property 177

3. The Vilnius International Forum on Holocaust-Era Spoliated Cultural Assets, 2000181

4. Resolutions adopted by the European Parliament 182

IV. Intermediary conclusions on the case of Nazi spoliated art 184

\$2. The case of human remains $\quad 185$

I. The history of collecting human remains 186

II. Human remains: genesis of the debate on the return of human remains 190

1. Intra-national claims regarding newly disinterred human remains 191

2. Intra-national claims concerning human remains in public collections in the former

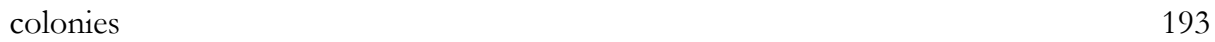

a) United States and its landmark legislation NAGPRA 194

$\begin{array}{ll}\text { Bonnichsen v. U.S } & 195\end{array}$

b) Australia $\quad 197$

Tasmanian Museums (Aboriginal Remains) Act $1984 \quad 198$

c) New Zealand 198

d) South Africa 199 
3. Spill over to the international realm 199

III. The case of human remains from the legal perspective 200

1. Public international law touching explicitly on human remains 200

2. Relevance of cultural property law for human remains: human remains $=$ cultural property?

IV. Recent developments: principles, resolutions and declarations adopted by the international community in reaction to the re-emergence of the debate on human remains

1. The Vermillion Accord on Human Remains 209

2. Mataatua Declaration 211

3. The ICOM Code 212

4. Convention for the Safeguarding of the Intangible Cultural Heritage 214

5. United Nations Declaration on the Rights of Indigenous Peoples 215

V. Intermediary conclusions on the case of human remains 217

\$3. Conclusions for chapter $2 \quad 218$

$\begin{array}{ll}\text { I. The status and relevance of soft law } & 218\end{array}$

II. Solutions proposed by the instruments to facilitate the return of Nazi spoliated art and human remains 221

1. Legal solutions 221

2. Alternative solutions 222

CHAPTER 3: COMPARATIVE OVERVIEW OF NATIONAL LEGAL FrAMEWORKS APPLICABLE TO CULTURAL OBJECTS IN PUBLIC COLLECTIONS IN VIEW OF \begin{tabular}{ll} 
THEIR DISPOSAL AND EXPORT & 225 \\
\hline
\end{tabular}

§1. European Community law on the export of national treasures 226

I. Council Regulation No. 3911/92 on the Export of Cultural Goods 230

II. Relevance of the Regulation in light of requests for the return of cultural objects 233

\$2. National law 233

I. The Netherlands 233

1. Cultural Heritage Preservation Act (Wet tot behoud van cultuurbezit) 235

a) Cultural Heritage Preservation Act and objects in public collections: applicable to objects in public collections? 236

b) The Mondriaan Case 238

c) The CHP Act and objects in public collections: extensive interpretation? 240

d) Analogous application of the criteria of the CHP Act 240

2. Restrictions from donations and testamentary dispositions 242

$\begin{array}{ll}\text { a) Donations } & 242\end{array}$

b) Testamentary dispositions 243

3. Competency to decide on disposal 247

4. Export restrictions 249 
II. United Kingdom

1. Trust and charity law 253

a) Attorney-General v. Trustees of the British Museum (the Feldmann case) 255

2. The English National Collections: statutory powers and restrictions on disposal 256

a) British Museum and Natural History Museum 257

b) Other National Museums 259

National museums with statutory restrictions on disposal similar to the British

Museum 259

National museums with more stringent statutory restrictions on disposal 260

c) Restrictions applicable to public collections in Scotland, Wales and Nothern$\begin{array}{ll}\text { Ireland } & 262\end{array}$

3. Restrictions on disposal from donations and testamentary dispositions 263

4. Export restrictions 264

$\begin{array}{ll}\text { III. France } & 269\end{array}$

1. Domaine public 270

2. The Cultural Heritage Code (CHC) 273

a) The structure and protection of the Cultural Heritage Code (CHC) 273

b) Book IV of the Cultural Heritage Code (CHC) on the Musées de France 275

c) The designation as "Musée de France" 275

d) Legal Consequences of the designation of a collection as "Musée de France" 277

e) De-classification via the National Scientific Commission of Museum Collections of France 279

f) Book VI of the Cultural Heritage Code (“Act on Historical Monuments") 281

Classification as historical monument 282

Registration of non-classified movable heritage in a special inventory 283

3. Export restrictions: Book I CHC 284

\$3. Conclusions for chapter $3 \quad 287$

Export restrictions $\quad 289$

CHAPTER 4: SOLUTIONS ADOPTED FOR THE RETURN OF NAZI SPOLIATED ART AND HUMAN REMAINS AT THE NATIONAL LEVEL 293

\$1. Nazi spoliated art 294

I. The Netherlands: the introduction of a liberalised government policy and the work of the Restitutions Committee 294

1. The results of the investigations of the post-war restitution regime with regard to art works recovered from Germany 295

2. The Development of a liberalised return policy in a dialogue between the Government and the Ekkart Committee 299

a) First series of recommendations of the Ekkart Committee, April $2001 \quad 301$

$\begin{array}{ll}\text { Settled cases and new facts (nova) } & 302\end{array}$

$\begin{array}{ll}\text { Forced sales } & 303\end{array}$

$\begin{array}{ll}\text { Evidence of ownership } & 303\end{array}$ 
Administration costs occurred by the Dutch Government 304

Repurchasing $\quad 304$

b) Reaction of the Dutch Government to the first series of recommendations of the Ekkart Committee $\quad 304$

c) The more detailed reaction followed by letter dated 16 November $2001 \quad 305$

d) Second series of recommendations of the Ekkart Committee, January 2003306

e) Reaction of the Dutch Government to the second series of recommendations of the Ekkart Committee 308

f) Final recommendations of the Ekkart Committee, September $2004 \quad 309$

g) Reaction of the Dutch Government to the final recommendations of the Ekkart Committee 310

h) Putting the Ekkart Recommendations and the Government Reactions together: the current policy of the Dutch Government regarding restitution of cultural property spoliated during the Second World War

3. The role and work of the 'Advisory Committee on the Assessment of Restitution Applications for Items of Cultural Value and the Second World War'

Cases

a) The Gutmann Case $\quad 315$

b) The Goudstikker Case 318

c) The Toorop Case: the estate of E. Flersheim against the Zeeuws Museum in Middelburg 330

Regulations of the Restitutions Committee in dealing with claims concerning objects not in possession of the Dutch State 330 The Facts: the Flersheim Collection, the loss of the painting during the war era and the acquisition by the Zeeuwse Museum Foundation The Recommendation by the Ethical Code Committee of the Dutch Museum Association in 2000

The binding advice by the Restitutions Committee from $2008 \quad 336$

4. Intermediary conclusions for the Netherlands

II. United Kingdom

1. The Spoliation Advisory Panel 344

a) The case of 'A View of Hampton Court Palace' by Jan Griffier the Elder' claimed from the Tate Gallery

b) The case of 'Still Life' formerly attributed to Jean-Baptist- Siméon Chardin claimed from the Glasgow City Council 349

c) The case of the 'Beneventan Missal' claimed from the British Library

d) Portrait of a Young Girl in a Bow window, attributed to von Landshut claimed from the Ashmolean Museum

e) Four drawings claimed from the British Museum $\quad 354$

f) Three drawings claimed from the Courtauld Institute of Art 355

g) Three Rubens paintings claimed from the Courtauld Institute of Art 356

h) Pieces of porcelain claimed from the British Museum and the Fitzwilliam Museum 
i) Analysis of the cases and recommendations

2. Changing the law to extend the possibility for museums to dispose of objects that have been lost during the Nazi era?

3. Intermediary conclusions for the United Kingdom 369

III. France 370

1. The Mattéoli Committee 371

2. The reports to the Prime Minister 373

3. Commission pour l'indemnisation des victimes de spoliations intervenues du fait des législations antisémites en vigueur pendant l'Occupation (CIVS) 375

4. Claims dealing with artworks: split responsibility by CIVS and the Archives Department of the Ministry of Foreign Affairs 376

5. Intermediary conclusions for France 379

§2. Human remains 379

I. The Netherlands: various forms of self-governance at museum level 379

1. The "West Frisian Eskimo" from the collection of the Westfries Museum in Hoorn 382
a) The Facts 382
b) The Recommendation by the NMV Ethical Code Committee 386
c) Developments after the recommendation 389
d) Extrapolation of principles 390

2. The case of the Toi Moko from the collection of the National Museum of Ethnology 392
a) The facts
392
b) The recommendation of the (preparatory) 'SVCN Ethnological Ethics Committee'
c) Recommendation on behalf of the state secretary 397
d) Stakeholder question 398
The return of the Toi Moko 400
Extrapolation of principles $\quad 400$
3. The pro-active approach of the KIT Tropenmuseum 402
a) The facts 402
Extrapolation of principles 406

4. Comparison of the principles extrapolated in view of identifying key elements for a Dutch policy on the repatriation of human remains $\quad 407$

5. Intermediary conclusions for the Netherlands 411

II. United Kingdom $\quad 412$

1. The Working Group on Human Remains in Museum Collections 413

a) The main conclusions of the WGHR 417

The main recommendations of the WGHR 419

b) Dissenting recommendations $\quad 421$

2. Human Tissue Act 2004 and the power to dispose of human remains 424

3. 'Guidance for the Care of Human Remains in Museums' 428

a) Part 1 of the Guidance: legal and ethical framework 429 
b) Part 2 of the Guidance: guiding principles $\quad 430$

c) Part 3 of the Guidance: framework for handling claims 431

4. Intermediary conclusions for the United Kingdom 436

III. France 436

1. 'Vénus Hottentote': the return of the remains of Sarah Baartman to South Africa 437

Sarah Baartman's life: $\quad 438$

The remains in the museum 439

Requesting party? $\quad 440$

The return to South Africa 445

Intermediary summary of the Sarah Baartman case 446

2. The Toi Moko from the Museum of Natural History in Rouen 447

3. Intermediary conclusions for France 449

\$3. Conclusions for chapter 4

I. Nature and content of the policies with regard to the return of Nazi spoliated art and human remains $\quad 453$

Nazi spoliated art $\quad 453$

Human remains 456

II. Towards rules of customary law on the return of Nazi spoliated art works and human remains? 459

CHAPTER 5: CONCLUSIONS 463

\$1. Summary and main findings from the previous chapters 463

Chapter 1: from the ius praedae to the heritage of mankind: the increasing protection of cultural objects as cultural property, including restorative but no retroactive protection 463

Chapter 2: the genesis of current claims and their legal status 466

Nazi spoliated art 466

Human remains $\quad 467$

Nazi spoliated art and human remains compared: similarities and differences 467

Chapter 3: the confines of the law 468

Chapter 4: national solutions pertaining to the return of Nazi spoliated art and human

remains - different perceptions about the need to return 469

\$2. Recommendations $\quad 470$

I. (Re-) Opening of the debate on just \& fair solutions with regard to Nazi spoliated art 470

1. Redrafting of the 1998 Washington Principles 473

II. Human remains: open dialogue and common sense 474

III. "Walk the talk": living up to raised expectations in enabling returns 474

IV. Take protection of objects in public collections seriously 476

§3. Relevance for the protection and return of cultural objects more in general $\quad 477$

\begin{tabular}{ll} 
EPILOGUE & 481 \\
\hline
\end{tabular} 
$\$ 1$ The Spoliation Advisory Panel's recommendation on the Glaser case 481

$\$ 2$ The Terezin Declaration on Holocaust era assets and related issues 484

$\$ 3$ Directions for the future

BIBLIOGRAPHY 


\section{List of illustrations}

no 1 Eric Heuvel, 'De schedel van sultan Mkwawa', 1990, published in Heemstede by Big Balloon. CRedhill V.O.F.

$\mathrm{n}^{\circ} 2$ Piet Mondriaan, 'Compositie met twee lijnen', 1931, oil on canvas, diagonal 112 X 112 $\mathrm{cm}$. Signature monogrammed and dated, lower left: P.M.'31. CMondrian/Hotzman Trust c/o HCR International.

$\mathrm{n}^{\circ} 3$ Inktstand with integrated clock from ca. 1750, bronze and porcelain, 28 x 26 x $21 \mathrm{~cm}$. Photo: Muller / Schretlen, 2002, p. 174.

$\mathrm{n}^{\circ} 4$ Salomon van Ruysdael, Ferry boat with cattle on the river Vecht near Nijenrode, Oil on panel, 58 x $84 \mathrm{~cm}$.CTim Koster/ICN.

no 5 Jan Toorop, 'A prayer before Supper', oil on canvas, 73,5 x $98 \mathrm{~cm}$, signed and dated lower right: J.Th. Toorop 1907 CRKD.

$\mathrm{n}^{\circ} 6$ Jan Griffier the Elder, View of Hampton Court Palace, oil on copper, 38 x $51 \mathrm{~cm}$. Photo: Tate Gallery, London/Art Resources NY.

$\mathrm{n}^{\circ} 7$ Joseph Vernet, Marine, clair de lune, oil on canvas, 115x $163 \mathrm{~cm}$. CRéunion des musées nationaux.

$\mathrm{n}^{\circ} 8$ Flyer from the exhibition at the Kunsthal Rotterdam titled "Bone by Bone - human remains in museums", 7 November 1998 - 10 January 1999.

$\mathrm{n}^{\circ} 9$ Photo of the remains and the kayak from G. Nooter's book on 'Old Kayaks in the Netherlands', 1971, p. 29.

no 10 Toi Moko. Photo: Timmer, P.M.Y. / Gubbels, G.J., Niets gaat verloren: twintig jaar selectie en afstoting uit Nederlandse museale collecties, (Amsterdam, Instituut Collectie Nederland, Boekmanstudies) (2007), p. 188.

$\mathrm{n}^{\circ} 11$ French cartoon 'Les curieux en extase ou les cordons de souliers', 1814, in which the French cartoonist pokes fun at the British fascination for the 'Venus hottentote'. (C) Bibliotheque Nationale, Paris. 


\section{List of frequently used abbreviations and terms}

Act on Historical Monuments

ATSIHPA

(First) Protocol

1970 UNESCO Convention

1995 UNIDROIT Convention

Art. /Artt.

BRüG

cf.

$\mathrm{CHC}$

CHP Act

chp.

CIVS

DCC

DCMS

DM

e.g.

EC

ECJ

ECR

EEC

ETS

EU

EWCA

$f$

f./ff.

fn

Foundation of Ethnological

Collections (SVCN)
Historical Monuments from 31 December 1913 (Loi du 31 décembre 1913 sur les monuments historiques) (F)

Aboriginal and Torres Strait Islander Heritage Protection Act (AU)

Protocol to the Hague Convention for the Protection of Cultural Property in the Event of Armed Conflict, signed at The Hague, 14 May 1954

UNESCO Convention on the Means of Prohibiting and Preventing the Illicit Import, Export and Transfer of Ownership of Cultural Property

UNIDROIT Convention on Stolen or Illegally Exported Cultural Objects

Article(s)

German Federal Restitution Law (Bundesrückerstattungsgesetz)

confer / compare

Cultural Heritage Code (Code du Patrimoine) (F)

Cultural Heritage Preservation Act (Wet tot behoud cultuurbezit) (NL)

chapter

Commission pour l'indemnisation des victimes de spoliations intervenues du fait des législations antisémites en vigueur pendant l'occupation (F)

Dutch Civil Code (Burgerlijk Wetboek)

Department for Culture Media and Sport (UK)

Deutschmarks

example given

European Community

European Court of Justice

European Court Reports

European Economic Community

European Treaty Series

European Union

England and Wales Court of Appeal (UK)

florin = Dutch Guilder

and the following (page(s), paragraph(s), etc.)

footnote

Foundation of Ethnological Collections in the Netherlands (Stichting Volkenkundige Collectie Nederland) 
GCPPP

High Court

HR

ibid.

ICJ

ICOM

ICOM Code

ILC

$\mathrm{IMO}$

Intergovernmental Committee

$\mathrm{JO}$

$\mathrm{KB}$

KIT

London Declaration

Mattéoli Committee

MNR-Collection

MvA

MvT

NAGPRA

NK-Collection

NMDC

NMV Ethical Code Committee

nr.

OGEL

OIELS

OJ

p./pp.

Panel

para.

PCIJ

Restitutions Committee

Second Protocol

SNK
Code général de la propriété des personnes publiques (General Code Regarding the Property of Public Entities) (F)

High Court of Justice (England and Wales)

Hoge Raad (Supreme Court) (NL)

ibidem

International Court of Justice

International Council of Museums

ICOM Code of Professional Ethics

International Law Commission

International Museums Office

Intergovernmental Committee for Promoting the Return of Cultural Property to its Countries of Origin or its Restitution in case of Illicit Appropriation

Journal Officiel de la République Française

Koninklijk Besluit (Royal Decree) (NL)

Royal Tropical Institute (Koninklijk Instituut voor de Tropen) (NL)

Inter-Allied Declaration against Acts of Dispossession committed in territories under Enemy Occupation or Control

Study Mission on the Spoliation of Jews in France (Commission pour l'indemnisation des victimes de spoliations intervenues du fait des législations antisémites en vigueur pendant l'Occupation) (F)

Collection of unrestituted works of art in France known as the Musées Nationaux Récupération

Memorie van Antwoord (memorandum of reply) (NL)

Memorie van Toelichting (explanatory memorandum) (NL)

Native American Graves Protection and Repatriation Act (US)

Netherlands Art Property Collection (Nederlands Kunstbezit)

National Museum Directors' Conference (UK)

Ethische Codecommissie voor Musea (NL)

number

Open General Export Licence (UK)

Open Individual Export Licences (UK)

Official Journal of the European Union

page/pages

Spoliation Advisory Panel (UK)

paragraph

Permanent Court of International Justice

Advisory Committee on the Assessment of Restitution Applications for Items of Cultural Value and the Second World War (NL)

Second Protocol to the Hague Convention of 1954 for the Protection of Cultural Property in the Event of Armed Conflict, signed at The Hague, 26 March 1999

Netherlands Art Property Foundation (Stichting Nederlandsch Kunstbezit) 
s./ss.

Stb.

Te Papa

the Directive

the National Scientific

Commission

the Regulation

UN

UNESCO

UNIDROIT

UNTS

WGHR section(s)

Staatsblad (Bulletin of Acts, Orders and Decrees) (NL)

Museum of New Zealand Te Papa Tongarewa

Council Directive 93/7/EEC of 15 March 1993 on the return of cultural objects unlawfully removed from the territory of a Member State

National Scientific Commission of Museum Collections of France

Council Regulation (EEC) No 3911/92 of 9 December 1992 on the export of cultural goods

United Nations

United Nations Educational, Scientific and Cultural Organization

International Institute for the Unification of Private Law

United Nations Treaty Series

Working Group on Human Remains in Museum Collections (UK) 



\section{Preface}

The image of the 'Penitent Magdalene' by Anthony van Dyck adorns the cover of this book. ${ }^{1}$ In this version, Mary Magdalene is depicted as a repentant sinner holding a skull in her hands. ${ }^{2}$ The skull as an attribute in the representation of saints was used as a "symbol of the transitory nature of life on earth" because it suggested "the useless vanity of earthly things". ${ }^{3}$ The image of the 'Penitent Magdalene' in contemplation over a skull in this very version by Anthony van Dyck is representative of this book's subject - the return of cultural objects - for three reasons:

In the first place, the skull held by Mary Magdalene is a reference to the case of human remains in public collections. Different from the skull held by the 'Penitent Magdalene', symbolizing transitoriness, human remains in public collections seem to

\footnotetext{
1 'Penitent Magdalene with a skull', paper laid down on panel, 63,5 x 48,5 cm, Anthony van Dyck. Provenance: Großherzogliches Museum Oldenburg; sale Frederik Muller, Amsterdam, 25 June 1924 (I22); J. Goudstikker, Amsterdam (inventory number from the 1940 Goudstikker inventory: 1355); A. Miedl; Frederick Mont, New York, 1979; Mr and Mrs Bernard Solomon, Beverly Hills; sale Sotheby's, New York,6 June 1985 (82); private collection Germany (Rheinland); sale, Van Ham, Cologne, 11-13 April 2002 (1124); restituted to the heirs of Goudstikker N.V. 2002; with Alex Wengraf, London. Exhibited: Sammlung Goudstikker, Rotterdam-Amsterdam 1928-1929, Nr. 18; The Art Museum, Princeton University, New Jersey: Van Dyck as Religious Artist, April-Mai 1979, Nr. 8 (Katalog J.R. Martin und G. Feigenbaum). Literature: Smith, J., Catalogue Raisonné, Bd III, 1831, p. 109, no. 388; Bode, W. von, Die Grossherzogliche Gemäldegalerie zu Oldenburg, 1888, p. 75; Schaeffer, E., Van Dyck, des Meisters Gemälde, 1909, p. 44; Rosenbaum, H., Der junge van Dyck, 1928, p. 62; Glück, G., Van Dyck, 1931, p. 10; Larsen, E., Freren 1988, Vol. II, p. 99, Cat.-No. 228. Korrespondenz: Frans Baudouin, Rubenianum Antwerpen, Dec. 2000; Julius Held, Old Bennington, Oct. 1991; Barnes, S.J., Van Dyck - A complete Catalogue of the Paintings, 2004, pp. 58-59, I.41. The image has been taken from the RKD Database:

http://www.rkd.nl/rkddb/dispatcher.aspx?action $=$ search\&database $=$ ChoiceImages\&search=priref $=48318$. 2 "Maria Magdalena poenitens", "Magna Peccatrix", "Die Büsserin, die büssende Magdalena, die reuige Sünderin". See further: Réau, L., 1958, pp. 846-859.

${ }^{3}$ Ferguson, G., 1954, p. 69.
} 
symbolize the opposite or at least defy the normal course of nature. The expression 'ashes to ashes'4 does not apply to curated human remains that have been collected for future exhibition and study. Secondly, on the grounds of the paintings provenance, the painting serves as a bridge to the case of Nazi looted art. As a painting that had belonged to the trading stock of the Dutch art gallery Goudstikker N.V. it fell in the hands of the German banker Alois Miedl and Reichsmarschall Hermann Göring. ${ }^{5}$ In 2002, when the painting was offered for sale at a German auction house, it was identified by the Art Loss Register and restituted to the heirs of the Goudstikker N.V. Finally, the pose of Mary Magdalene of contemplation and reflection is representative of the overall aim of this book, i.e. to reflect upon current developments with regard to claims challenging public collections and the return of cultural property.

My interest for the field of cultural property law was raised towards the end of my studies when I attended the course 'Law and Art: The Free Movement of Cultural Property' by Prof. Dr. Hildegard Schneider. The course was a perfect link between my two studies, the study of law and the study of cultural sciences with an emphasis on 'Arts and Heritage: Policy, Management and Education'. Inspired by the 'Law and Art' course, I chose to write my master thesis on the restitution of art works looted during the Second World War. ${ }^{6}$ Since then, my fascination for the subject has never left me. While it is difficult to put my interest into words I have come to find that the research into the looting of artworks during the era of WWII allows for unique insights in the history of World War II. According to critical theory, the Holocaust cannot be represented. ${ }^{7}$ The atrocities of the Holocaust, the mass-slaughter of the Jews are to some extent incomprehensible. While I do not wish to make a claim about whether the studying of the Nazi appropriation of cultural property may constitute a form of representing the Holocaust it certainly constitutes a "prism" that allows us to better grasp the horrors of the Nazi Regime. Studying the cultural policy and ideology of the Nazis, which included the looting of art works and cultural objects on a scale unmatched in history, allows for a more indirect approach of the Holocaust and thereby contributes to the level of understanding. It seems that the aesthetic value of art works looted by the Nazis provides us with a visible spectrum that allows us to absorb the horrors of the Holocaust.

My interest into the subject of human remains in public collections stems from my personal reaction when I first learnt about claims seeking the return of human remains in the beginning of the millennium. Mummies and other dead bodies in museums have always intrigued me, and I believe it is fair to state that this fascination is shared by

\footnotetext{
${ }^{4}$ The phrase is an adaption from Genesis 3:19.

${ }^{5}$ Cf.: Harclerode, P. / Brendan, P., 1999, pp. 149-153.

${ }^{6}$ Lubina, K.R.M., 2002. The thesis was awarded with the award for the best master thesis of the year (Scriptieprijs) 2002 of the Maastricht University.

${ }^{7}$ See, e.g.: Lyotard, J.-F., 1988; Levy, D., et al., 2005, p. 135. See further on the problem of representing the Holocaust, e.g.: Friedlander, S., 1992; LaCapra, D., 1994. See also the film: Lanzmann, C., 1985 as an example of a work discussing and reflecting the Holocaust without representing it.
} 
many, as may be deducted from the success of exhibitions like the travelling exhibition 'Mummy: the inside story", 'Botje bij Botje - Menselijke resten in Musea', or Gunther von Hagens' 'Body Worlds'. ${ }^{10}$ It was only when the presence of human remains was actively challenged by claims seeking their return that I became fully aware of the fact that they were the remains of once sentient human beings and that their presence in public collections should not be taken for granted. While it might appear a trivial moral question how to treat dead bodies, it is an illuminating reflection of our self-conception and self-understanding. ${ }^{11}$

Starting from these two fascinations, I decided to dedicate my $\mathrm{PhD}$ research to the description, analysis and evaluation of the developments I witnessed with regard to the challenging of Nazi looted art and human remains in public collections and to put them in the greater context of the return of cultural objects from public collections. The main research of this book was closed in June 2009. Sporadic adaptations have been made after that time.

\footnotetext{
${ }^{8}$ See, e.g: http://www.hmns.org/exhibits/special_exhibits/mummy_the_inside_story.asp? (last visited: 1 July 2009). See also: Ägyptische Mumien - Unsterblichkeit im Land der Pharaonen, October 2007 - 4 March 2008, Landesmuseum Württemberg, Stuttgart; Mumien - Traum vom ewigen Leben, October 2007 May 2008, Reiss-Engelhorn Museen, Mannheim.

9 Kunsthal Rotterdam, (translated: "Bone by Bone - human remains in museums"), November 1998 January 1999.

${ }^{10}$ http:/ /www.bodyworlds.com/en.html (last visited: 1 July 2009). Cf.: Lohman, J., 2006b, p. 22.

${ }^{11}$ Cf.: Kass, L.R., 1985, p. 24.
} 



\section{Introduction}

\section{\$1. THE PRESENCE OF THE PAST IN PUBLIC COLLECTIONS AND RECENT IMPULSES CHALLENGING PUBLIC COLLECTIONS}

At some point in time, probably about 35,000 years ago, human beings started to create pictures. ${ }^{12}$ Ever since, art works and cultural property more in general have fascinated humankind: the creative accomplishments of ancient cultures, such as the ancient Egyptians, Greek, and Maya continue to mesmerize present-day spectators and students; monarchs have used art works to confirm and strengthen their claim to power; and even the periods of iconoclasm did not impair the adoration and relevance of the visual arts in the long run. Hand in hand with this fascination for cultural objects goes an interest in their preservation.

An interesting period for the preservation of cultural objects are the 18th and 19th Century in Western Europe: on the one hand, the period is marked by the establishment of the first public museums (e.g. the British Museum in London was opened to the public in 1759; the Teylers Museum in Haarlem was the first Dutch museum to open in 1784, and the Musée Français, better known as the "Louvre" opened its doors in 1793). ${ }^{13}$ On the other hand, the period is marked by Napoleon's art looting campaigns (1792-1814), whose scale was unprecedented in history. Sadly, the art looting by Napoleon was dwarfed during the 20th century by Hitler's looting campaigns and his

\footnotetext{
${ }^{12}$ Some of the oldest traces of human creativity are the cave paintings dating back to prehistoric times. Among the earliest cave art are the paintings found at the "Apollo 11 caves" (http://www.metmuseum.org/toah/hd/apol/hd_apol.htm) in Namibia. The images are estimated to date from approximately $23,000-24,000$ B.C. See for an introduction to the relevance of cultural objects for humankind's understanding of the world and the far-reaching influence of art on society: British Broadcasting Corporation (BBC), 2006.

${ }^{13}$ See for other examples: Pomian, K., 1998, pp. 66-67.
} 
megalomaniac vision to establish a Führer-Museum in Linz as the world's grandest art gallery. The establishment of the Führer-Museum was of such priority that it determined the organisational structure of Hitler's executive forces. Estimates and figures of the looting may vary; they all confirm that the Nazi art deprivation by far exceeded the looting campaigns of Napoleon. An often quoted figure for the number of works of art spoliated from the occupied countries speaks of more than three million works of art, which corresponds to about "one-fifth of the world's entire art". ${ }^{14}$ Another aspect making the looting by the Nazis exceptional is the fact that the looting formed an explicit part of the policy of Hitler. ${ }^{15}$ Art was exploited to serve the bigger, political and ideological end of Hitler. ${ }^{16}$ Not only did the amassing of works of art seek to glorify the German people ${ }^{17}$, it was simultaneously used as an instrument to dehumanize nonAryan races, in particular the Jews. ${ }^{18}$

In both cases, the looting of art works by Hitler and earlier by Napoleon was followed by immediate efforts to restore the objects to their countries of origin and to return them to their former owners. After the end of WWII, the Allies went to great lengths to provide for the return and restitution of looted art works and cultural objects. By 1952, more than $90 \%$ of the cultural objects that had been removed from the occupied territories had been returned to the state of origin ${ }^{19}$ and by the 1960 s the subject of Nazi looted art and its restitution seemed completed. As for the returns of artworks after Napoleon's defeat, they may differ from the post WWII restitutions in that a proper legal ban on looting emerged only at the turn of the 19th to the 20th Century. However, the peace treaties concluded at the beginning of the 19th century and the negotiations by the Congress of Vienna (September 1814 - June 1815) provided

\footnotetext{
14 (Chesnoff, R.Z., 2000, p. 38). Another source states that the Nazi loot "totalled more than 21,000 items of art, paintings, furniture, textiles and similar valuable antiquities", suggesting a number less great (Marchisotto, 1974, p. 701). Another author speaks of an estimate of 220,000 stolen works of art from museums and private collections throughout Europe (Kempster, N., 1998). As for France, one source speaks of some 21,000 art objects that were gathered during the four years of the plundering under the Einsatzstab Reichsleiter Rosenberg (ERR) (Chamberlin, R., 1983, p. 161). Another source speaks about 100.000 works of art that have been clearly identified as being stolen during the years 1941-1944 (Mattéoli Report I, p. 80 cited by Anglade, L., 1999, p. 301). The value of the stolen works has been set at $\$ 2.5$ billion in 1945 which corresponds to $\$ 20.5$ billion in 2000 (M.B., November 71998 \& Bazyler, M., 2001, p. 161). The difference in estimates and figures can to some extent be explained both by different understandings of what constitutes a cultural object and whether a figure aims solely at straightforward thefts and confiscations or whether it covers also forced sales and other involuntary form of loss. See for further details and specification: Petropoulos, J., 2000, para. 369.

${ }^{15}$ Nicholas, L., H., 1997, p. 39.

${ }^{16}$ See in general: Petropoulos, J., 1996.

${ }^{17}$ Ibid., p. 308.

18 Petropoulos, J., 1997, p. 111. Cf.: Nicholas, L., H., 1997, pp. 40-41. See in this respect below chp. 1.§.4 where the misappropriation of cultural objects from German Jews is discussed.

${ }^{19}$ Cf.: Engstler, L., 1964, pp. 149-150; Hipp, A., 2000, p. 56, fn. 40.
} 
for the return of a great number of art works and give ample evidence of an emerging awareness of the need to protect cultural property against removal. ${ }^{20}$

The moment the ban on the looting of cultural property during armed conflict started to emerge coincides with the heyday of the colonial empires of Great Britain, France, the Netherlands and other European countries. While Western European countries started to subject the looting of art works amongst each other to legal rules, a similar tendency for cultural objects found in the colonised territories was absent. As a consequence, a great number of cultural objects were removed from the colonised territories and were brought to the territory of the colonising state where many of the objects are still held in public collections as of today. It was not until after WWII and the period of decolonisation that the return of cultural property removed during the era of colonialism was put on the political agenda. During the 1970s, representatives of former colonies began to demand the return of cultural objects from Western public collections that had been removed from their territories prior to their independence. ${ }^{21}$ While their efforts resulted in a number of UN resolutions appealing for the return of objects d'art, monuments, museum pieces, manuscripts and documents to their countries of origin, ${ }^{22}$ the case for the return of cultural objects removed during the colonial era soon lost momentum: resolutions became weaker and more indirect in their formulation of the claim for the restitution of cultural objects. ${ }^{23}$ But for a limited number of bilateral agreements on the return of objects from public collections to their territory of origin ${ }^{24}$, there are overall very few instances in which cultural objects taken during the colonial era have been returned to the now independent State of origin. ${ }^{25}$ In this respect it must not surprise that the most prominent case of cultural property removed from a country in a state of occupation, the case concerning the Elgin or Parthenon Marbles, has not yet been resolved. The marbles had been removed from the Parthenon in Athens by the Seventh Earl of Elgin in the beginning of the $19^{\text {th }}$ century and were brought to London. ${ }^{26}$ At that time, Greece was part of the Ottoman Empire

\footnotetext{
20 See further on the emergence of a legal ban on looting and the obligation to return looted cultural property in chp. 1.S.1.

${ }^{21}$ Cf.: Siehr, K., 1993. A related development, which started from the 1970s /1980s is the civil rights movements and the struggle of indigenous peoples for self-determination. See further on intra-national claims for the return of cultural objects below in chp. 2.\$2.II.

22 Restitution of Works of Art to Countries Victims of Expropriation, G.A. Res. 3187, U.N. GAOR, 28th Sess., U.N.Doc.A/Res/3187(XXVIII) (1973); Restitution of Works of Art to Countries Victims of Expropriation, G.A. Res. 3391, U.N. GAOR, 30th Sess., U.N.Doc.A/Res/3391(XXX) (1975). See further on Resolution 3187: Schulze, D., 1983, pp. 13-14. See further on Resolution 3391: Nafziger, J.A.R., 1983, p. 802.

${ }^{23}$ Cf.: Schulze, D., 1983, p. 14; Odendahl, K., 2005, p. 183.

${ }^{24}$ E.g. during the 1970s, negotiations between the Netherlands and Indonesia resulted in the transfer of historical and archaeological objects in accordance with a specific program. Cf.: Pott, P.H. / Sutaarga, M.A., 1979, p. 41. See for further examples and references below in chp. 1.\$3.

${ }^{25}$ Cf.: Siehr, K., 1993, p. 155, para. 196.

${ }^{26}$ Cf.: Reppas II, M.J., 1999, p. 915; Merryman, J.H., 2000b, p. 24 with further references.
} 
and Elgin was the British Ambassador. ${ }^{27}$ Elgin had received a formal written document that granted him permission to take away "any pieces of stone with inscriptions and figures from the temple building". ${ }^{28}$ As to whether this provision covers the amount of objects taken is disputed in the literature. ${ }^{29}$ The collection was then vested in the Trustees of the British Museum in perpetuity and are presently held under the terms of the British Museum Act (1963). The British title to the Elgin Marbles and the British position with regard to the marbles is decisively challenged by the Greek Government that seeks the return of the marble objects to Greece as Greek cultural heritage. For the Greek, the marbles represent their identity, their culture and democratic philosophy. ${ }^{30}$

During the last fifteen to twenty years, academics, curators, politicians, as well as the general public have noticed new impulses for the return of cultural objects. In particular two cases have led to a recalibration of the debate on how to deal with objects that have been acquired in the past: claims for the return of Nazi spoliated art and claims for the return of human remains. ${ }^{31}$ One of the first and without any doubt the most prominent case dealing with Nazi spoliated art within the Netherlands is the Goudstikker case, which dealt with some 200 paintings from the former trading stock of the art dealer Goudstikker. At the beginning of 1998 the heirs of Goudstikker requested the return of all objects that had been part of the trading stock of Goudstikker's art gallery and which had been integrated into the Netherlands Art Property Collection (Nederlands Kunstbezit) after the war. In 2006, the paintings were returned to the heirs. ${ }^{32}$ Claims for the return of human remains proliferated after the passing of the Native American Graves Protection and Repatriation Act ("NAGPRA") in the United States in 1990.33 While this federal act is limited in scope of application to the territory of the United States, the fact that the US Congress had adopted legislation providing for legally enforceable procedures to recover human remains and cultural objects from federally funded museums nevertheless sparked the debate on the return of human remains on a global scale and inspired claims such as the request received in 2002 by the National Museum of Ethnology (Rijksmuseum voor Volkenkunde) in Leiden to return all Māori and Moriori ${ }^{34}$ remains from its collection to New Zealand. ${ }^{35}$

\footnotetext{
${ }^{27}$ Cf.: Merryman, J.H., 2000b, p. 37.

28 Cf.: Ibid., p. 38 who provides for a translation of the only surviving copy of the document. See also for further references.

${ }^{29}$ See, e.g.: Cook, B., 1984, pp. 38-39; Reppas II, M.J., 1999, p. 921; Merryman, J.H., 2000b, p. 39; Thorn, B., 2005, p. 14; Greenfield, J., 2007, p. 81. In total, Elgin had acquired approximately $247 \mathrm{feet}(1 \mathrm{ft}=0,305$ $\mathrm{m}$ ) of the 524 feet long frieze, fifteen of the 92 metopes and seventeen pedimental figures. Merryman, J.H., 2000 b, p. 25.

${ }^{30}$ Speech by Melina Mercouri to the Oxford Union. Available online at:

http://www.uk.digiserve.com/mentor/marbles/ (last visited: 29.01.2009). The case is further introduced in chp. $1 § 3 . \mathrm{I}$

31 Cf.: with regard to Nazi looted art: Schönenberger, B., 2009, pp. 1, 5 \& 9.

32 See for a detailed chronology and analysis of the case below in chp. 4.\$1.I.3.b).

33 The Native American Graves Protection and Repatriation Act (NAGPRA) 25 U.S.C.3001 - 13 (1994).

34 Māori are the native Polynesian people of New Zealand. Moriori are the native inhabitants of the Chatham Islands of New Zealand. Cf.: Moriori (2009). In Encyclopædia Britannica. Retrieved April 17,
} 
The (re-) emergence of the debate on the return of Nazi spoliated art and human remains is particularly interesting in that the restitution after WWII seemed completed in the 1960s and was little discussed during the 1970s and 1980s. While the return of human remains as human remains has not yet been debated in the past, the present developments cannot be seen isolated from the more general issue of the return of cultural objects removed during the colonial era. After all, while human remains in public museum collections originate from all over the world, including domestic regions, the majority of claims focus on human remains that have been acquired in a colonial context. ${ }^{36}$

\section{§2. THE RESEARCH TASK EMERGING FROM RECENT DEVELOPMENTS}

In light of the developments sketched above, the overall aim of this study is three-fold: first, to take stock and analyse present law and practice with regard to the return of cultural objects from public collections through the lens of the cases of Nazi spoliated art and the holding of human remains. Secondly, to formulate recommendations for the future course of restitution in these two specific categories and for the protection and return of cultural property more in general. Finally, to reflect upon the relevance of the developments with regard to Nazi spoliated art and human remains for the protection and return of cultural property more in general.

In focusing on the cases of Nazi spoliated art works on the one hand and human remains on the other hand, it could be argued that the results of the research will be difficult to generalize to other objects. Palmer, who examined the fate which befell works of art taken during the period 1933-194537, and chaired the United Kingdom Working Group on Human Remains ${ }^{38}$ noted a parallel between requests for the return of spoliated objects and human remains in the ways in which the objects are nowadays returned (or retained) by holding institutions and the modern initiatives that have been taken to assist claimants. ${ }^{39}$ According to Palmer, this parallel consists in a "closer similarity, in terms of the need for sensitivity and recognition and respect between these two areas than between any two others". ${ }^{40}$ The finding that the cases of Nazi spoliated

\footnotetext{
2009 from Encyclopædia Britannica Online; Maori (2009), In Encyclopædia Britannica. Retrieved April 17, 2009, from Encyclopædia Britannica Online.

35 See for an analysis of the case below in chp. 4.\$2.I.2.

${ }^{36}$ Weeks, J. / Bott, V., 2003, pp. 28-30.

${ }^{37}$ Palmer, N., 2000a, p. 109.

${ }^{38}$ As the chairman of the United Kingdom Working Group on Human Remains and member of the United Kingdom Spoliation Advisory Pane, Professor Palmer's working experience, as well as academic interest, spans both categories. See: Ibid., p. 169; Vrdoljak, A.P., 2006, p. 148.

${ }^{39}$ Lijkresten gevonden in depot Tropenmuseum, 2007. The human remains legislation that Palmer refers to is a clause in the Tasmanian Museums (Aboriginal Remains) Act 1984 that grants protection to museum professionals who deal with or transact in objects that are in the possession of the museum. He further points out that "at least two common law countries have legislated for relinquishment by museums".

${ }^{40}$ Palmer, N., 2000a, p. 169; Woodhead, C., C., 2002, pp. 324 \& 346.
} 
art and human remains are particularly sensitive does not mean, however, that the results will be irrelevant to other objects in public collections: as collection items, Nazi spoliated art and human remains, or rather claimants challenging their inclusion in the collections face the same obstacles that apply to other objects. Secondly, they raise critical questions as to how to deal with claims concerning objects acquired in the past in a manner that was not unlawful then but that would be unacceptable, if not unlawful, today. Consequently, taken together as a diptych, the analysis of the cases of Nazi spoliated art and human remains should generate valuable insights for the more general debate on the return of objects from public collections.

\section{METHODOLOGY \& DELIMITATION}

Unlike most other social sciences, law is still in the process of reflecting on and developing methodologies for legal research. Consequently, in elaborating on the methodology applied in the present study, it is not possible to start from a set of predefined methodologies but is necessary to depart from the concept of method as such. A method is in the first place nothing more or less than answering a question by means of obtaining data - information classified into usable conceptual units - and a means of ordering and measuring data. ${ }^{41}$

Starting from the overall aim of this study, to take stock of and analyse recent developments with regard to the return of cultural objects from public collections, the present study will rely upon the followings methods / methodologies: first, following a rule-based approach, it will analyse the law de lege lata with regard to the protection and return of cultural objects. Beginning with the realm of international (public) law and European law, it will subsequently address a number of national jurisdictions. In analysing the law, it will focus on the rules that are specific to cultural objects rather than including law applicable to any chattel. This approach is sometimes referred to as the "cultural property or cultural heritage approach". ${ }^{42}$ While property law and the law of torts are also relevant to cultural property in that cultural property is treated no differently than the often quoted example of a bicycle, ${ }^{43}$ they generally do not offer a legal ground for the return of (cultural) property several decades after the original owner has lost possession of the object concerned. In fact, the legal principles of good faith acquisition, extinctive and acquisitive prescription, limitation periods and laches often prevent the restitution of cultural objects. ${ }^{44}$ Another reason to exclude property law and tort law from the present analysis is that there already exists a significant body of literature on this aspect. ${ }^{45}$ For the same reason, the analysis also excludes the human

\footnotetext{
${ }^{41}$ Roberts, G.K., 1972, p. 51; Örücü, A.E., 2006, p. 446.

42 Cf.: Frigo, M., 2008, p. 438.

43 Siehr, K., 1999, p. 3.

44 See on the obstacles of recovery in private law below in chp. 2.\$1.II.2.

45 See, e.g.: Siehr, K., 1993; Bibas, S., 1996; Kaye, L., M., 1996a; Lerner, R., E., 1998; Palmer, N., 1998b; Redmond-Cooper, R., 1998; Blom, J., 2000; Müller-Katzenburg, A., 2000; Miller, D.L.C.M., David W.
} 
rights approach, according to which the return of cultural objects would be addressed through the lens of human rights and in particular the rights of indigenous peoples. ${ }^{46}$

In wishing to take stock of the evolution with regard to the return of cultural objects more in general, this analysis cannot be limited to the law de lege lata. In order to allow for a more substantial assessment, it is also necessary to take note of the initiatives and practices that have been introduced in the last two decades in addition to the traditional legal rules. Not only may some of the recently introduced instruments and practices acquire the status of legal rules over time or may in fact have already done so, the initiatives and practices introduced at the international and national level already influence and change the current climate and dynamics with regard to the return of cultural objects. This study will identify, describe and analyse the instruments introduced at the international level, ranging from principles and declarations to resolutions. In scrutinising these instruments, particular attention will be paid to the solutions proposed for current claims and how these instruments may be qualified from a legal perspective.

This study will also describe and analyse laws and policies at the national level, in particular those adopted in the Netherlands, France and the United Kingdom. While a broader country coverage would have been profitable in light of further generalisations, it would have been at the expense of preciseness and accurateness as demanded by the research subject. The choice of jurisdictions is the result of a number of factors: first, all three countries are so-called art market nations. Art market nations are characterized by a greater demand than supply in art and cultural objects. ${ }^{47} \mathrm{Next}$ to their vivid art markets, the countries also share in the history of the museum as a uniquely Western institution. ${ }^{48}$ Secondly, all three countries have successfully established overseas empires during the 17 th century outside Europe. This finding is relevant in that the majority of claims seeking for the return of human remains concern remains that have been acquired in a colonial context. ${ }^{49}$ Another historical binding factor between the countries is the Second World War in that all three countries officially opposed the Axis powers..$^{50}$

\&Cowe, Anne L., 2001; Plehwe, T.v., 2001; Hartung, H., 2005, Chps. 5 \& 6; Schönenberger, B., 2009, pp. 111-157.

46 See e.g.: Donders, Y.M., 2002; Vrdoljak, A.P., 2006; Francioni, F., 2008; Francioni, F. / Scheinin, M., 2008; Vrdoljak, A.P., 2008.

47 See, e.g.: Merryman, J.H., 1986, p. 832; Mark, L.F., 1990; Mackenzie, S., 2005, p. 8. Other typical examples of art market countries are Switzerland and the United States. The complement to art market nation are source nations (or art-rich nations). Source nations are countries in which the supply of cultural objects exceeds the internal demand. There exists a general north-south divide between art market and source nations and the latter are often unable to protect their cultural objects against illegal exports to market nations. Cf.: Merryman, J.H., 1986, p. 832

48 Cf.: Carrier, D., 2006, p. 10. See further below on the emergence of public museums in chp. 1S1.I.

${ }^{49}$ Weeks, J. / Bott, V., 2003, pp. 28-30.

50 While Germany would have been an interesting jurisdiction to be included in the analysis several reasons argued against doing so and for leaving Germany as a follow up project. First, the exact same reason that makes Germany an interesting jurisdiction to analyse, i.e. its legal succession to the Third Reich and the internal dimension of the restoration of rights after WWII, makes the study of Germany significantly more complex than that of other countries. See, e.g.: Barron, S., 1991; Rudolph, S., 2007. In addition, when 
However, different from its continental Allies, the Netherlands and France, neighbouring Germany, the UK has not been occupied during World War II. Consequently, there have not been any losses of works of art by UK citizens comparable to those by French or Dutch citizens, first and foremost Jews. However, due to the strength of its art market, the UK attracted a significant number of spoliated art works. Either forced sales were directly realised in the UK or spoliated art works entered the UK art market at some stage after the forced sale or spoliation. ${ }^{51}$ Next to these characteristics that allow for a certain level of comparability, the jurisdictions have also been chosen for their different approaches in protecting their national heritage. The Netherlands has adopted a very liberal approach towards the protection of cultural property in the sense of restrictions on the disposal and export of objects from public collections. The United Kingdom and France, on the other hand, adopted more farreaching approach in protecting objects in public collections.

The analysis of the national jurisdictions is two-fold: on the one hand, the national regulation of (objects in) public collections will be scrutinised to identify potential obstacles to the return of cultural objects. Obstacles can exist in the form of rules limiting the de-accessioning of objects from the collections or in export regulations. On the other hand, and more importantly for the present study, the national solutions dealing with Nazi spoliated art and human remains will be scrutinised. Where no legislation or official policies have been adopted, the study will rely on case studies. Case studies are frequently relied upon in the museum sector and in the field of cultural property law. ${ }^{52}$ It is important to note that case studies are first and foremost studies of a singular case only: a "[c]ase study is the study of the particularity and complexity of a single case, coming to understand its activity within important circumstances". 53 In

analysing recent developments and practices within Germany with regard to return of cultural property one must take into account the debate on the so-called trophy art. 'Trophy art' refers to those cultural objects that were removed from Germany at the end of WWII by Soviet "trophy brigades" as war reparations. In total, the trophy brigades removed an estimated 2.6 million art objects and archaeological material (Mastroberardino, M.M., 1997, p. 322). While a number of objects have been returned by the Russian Federation, the majority of objects remain within the territory of the Russian Federation and have been legally declared Russian property. The trophy-art debate raises important questions about the legality of taking cultural property as restitution in kind but exceeds the scope of the present thesis. The exclusion of the subject of Trophy art does not mean that the present thesis does not touch upon it or is irrelevant to the debate. In particular chp. 1, mapping the evolution of public international law with regard to the protection and return of cultural objects, touches at certain points upon the subject of Trophy art. See further on the Russian Trophy art, e.g.: Fiedler, W., 1995; Depta, S., L., 1996; Burchardi, K., 2000; Elmer, T., G., 2000. Finally, the complexity of German jurisdiction is compounded by the fact that Germany is a federal state with the protection of cultural property falling under the competency of the Länder. The German Basic Law does not grant legislative competency to the Government of the German Federal Republic in such matters. In accordance with Art. 70 of the German Basic Law competency rests therefore with the sixteen states (Länder).

51 See further below in chp. 4.\$1.II.

52 See, e.g.: Seligman, T.K., 1999; Timmer, P.M.Y. / Gubbels, G.J., 2007;

http://www.culturalpropertyadvice.gov.uk/public_collections/case_studies (last visited 8 June 2009).

53 Stake, R.E., 1995, p. xi. 
addition to their importance in their own right, case studies may also contribute to the formulation of models of good practice by raising general problems and helping to extrapolate common patterns and principles with regard to the actors involved, the interests at stake, and the solutions found.

\section{STRUCTURE OF THE BOOK}

Chapter 1 provides a legal and historical background to the current debate on the return of cultural objects from public collections by mapping the emergence of relevant rules of public international law. The aim of the chapter is to clarify (the emergence of) obligations to return cultural objects and to identify the status of objects in public collections in public international law. Five different constellations must be distinguished under public international law that may give rise to restitution obligations: the restitution of cultural objects removed in times of war, the restitution of illegally exported cultural objects, the restitution of cultural objects to their country / territory of origin, the restitution of cultural objects to their original owners and finally, the restitution of cultural objects to a people. The analysis will at the same time provide an introduction to the historical and political background of the colonial era, during which many human remains were collected, and the period of Nazi rule. ${ }^{54}$

Chapter 2 deals with the origins of recent claims for the return of Nazi spoliated art works and human remains. The chapter begins with a description of the background and context in which the two cases have emerged during the last decades. In doing so, it seeks to explain why these discussions emerged only in the 1990s - some fifty years after the end of World War II and thirty years after post-war restitution efforts had come to an end and where an even greater time span with regard to active collection of human remains for public collections has passed. With regard to human remains, the chapter will also reflect upon the past and present reasons for and the contexts of the collection of human remains. After sketching the emergence of the debates, Chapter 2 will situate the two cases in the greater legal- and para-legal framework affecting public collections: first, the relationship between the recent "waves of restitution claims" concerning Nazi spoliated art and human remains with the existing framework on restitution of cultural property under public international law as outlined in Chapter 1. Subsequently, the chapter continues by introducing and analyzing various declarations, principles and resolutions that have been adopted at the international level since the 1990s with regard to Nazi looted art and human remains.

Having explored the international legal and para-legal framework, the subsequent two chapters will zoom in on the national dimensions. Chapter 3 analyses Dutch, UK and French national laws that govern the position of cultural property in public collections. In the context of the present study, the main aspect to be addressed is the question whether legal obstacles preventing the return an object from a public collection

\footnotetext{
${ }^{54}$ See with regard to the reactionary nature of rules of international law: Keane, D., 2004, p. 1.
} 
exist. Such obstacles could lay in rules with regard to the de-accessioning of objects but also in the export regulation. Given the fact that all three jurisdictions addressed are Member States of the European Community, the analysis of the export regulation must also take into account European law. The analysis of the national laws governing public collections will also contribute for a better understanding and assessment of national reactions to claims for the return of Nazi spoliated art and human remains that will be analysed in Chapter 4.

Chapter 4 makes the transition from the analysis of the general legal regulation of public collections to the national reactions to claims for the return of Nazi spoliated art and human remains. In analysing countries' reactions to the increase in claims for the return of Nazi looted art and human remains, this chapter seeks to provide insights about the following aspects: first, what are the policies implemented in these different countries? This is an important question as there is often confusion about the nature of the policy and its contents. ${ }^{55}$ The analysis will be fuelled by insights emerging from Chapters $1 \& 2$. Secondly, the analysis of national reactions to claims for the return of Nazi looted art and human remains in public collections will allow an assessment of whether one can speak of a (n emerging) state practice as an indication of (emerging) rules of customary law on the return of cultural property. While customary law with its two cumulative elements of opinio iuris and state practice is introduced in Chapter 1 as one of the sources of international legal rules, an analysis of the possible existence of a rule of customary international law by means of an inductive process starting from the current practice at the national level in returning Nazi spoliated art and human remains takes place in Chapter 4. The analysis of this chapter might, furthermore, be of assistance as a reference guide to the decision-making process in future claims and for policy makers and institutions affected by claims for the return of Nazi spoliated art and human remains.

The final Chapter 5 first summarises the main findings before presenting recommendations that follow from the present research. The chapter will round off by discussing the relevance of the developments in the cases of Nazi spoliated art and human remains for the protection and return of cultural objects from museums in general: what can be learnt from the solutions developed in the context of the cases of Nazi spoliated art and human remains for the protection of cultural property more in general and for other disputes concerning cultural property? Have the cases of Nazi spoliated art and human remains opened the so-called "floodgates" feared by museum directors? 56 According to the "flood-gate", "slippery slope" or "domino" argument, the

\footnotetext{
55 See, e.g.: Kuitenbrouwer, F., 18 April 2002; Rijghard, R., 7 February 2006.

56 In 2002, as a strategy of defence against repatriation claims, more than thirty of the world's most renowned museums signed a declaration stressing their status as "universal" museums. The declaration is available online at:

http://www.clemusart.com/ASSETS/37CD35CFA0F6454EAFE2C5EAA2714919/UniversalMuseums.pd $\mathrm{f}$ (last visited 17.06.2009). See further on the declaration, e.g.: O'Neill, M., 2004.
} 
return of an object from a collection will set an irreversible precedent "forcing museums all over the world to return their holdings". 57

\section{TERMINOLOGY}

In the previous section a number of terms crucial for this study have been used as if they have an accepted meaning. In the following, we will elaborate on these terms and their use in the context of the present study.

\section{1. 'Museum \& Public Collection'}

In the course of this study the terms 'museum' and 'public collections' will be used as synonyms. The term museum is not legally protected. ${ }^{58}$ Where we speak of museums or public collections we understand, in line with the definition of public collections provided by Council Directive 93/7/EEC, that:

"the property of a State, local or regional authority or an institution situated in the territory of a state and defined as public in accordance with the legislation of that state, such institution being the property of, or significantly financed by, that state or a local or regional authority". ${ }^{59}$

The definition clarifies that public collections are not limited to state museums but includes foundations, trusts, or companies that are indirectly controlled by the state and are subsidized by public money. ${ }^{60}$ The reason for focusing on public rather than private collections lies in the role of public collections to assemble, conserve and preserve the national cultural heritage for the benefit of the public. ${ }^{61}$ Objects in public collections may be owned by the State or lower public authority but in a larger sense the object

57 Joyce, R., http://www.uk.digiserve.com/mentor/marbles/ethics.htm; Shek, T., 2000, p. 280. Cf.: Simpson, M., 1997, p. 80; Specht, J., 2008, p. 449. The floodgate argument is borrowed from American courts that use the "opening of the floodgates of litigation" as reason not to allow a certain case to proceed for fear that it would trigger a new class of lawsuits and therewith overburden the courts. Cf.: Bazyler, M., 2001 , p. 5.

58 Waidacher, F., 2000, p. 1.

59 The definition is derived from Art. 1(1) of the Council Directive 93/7/EEC of 15 March 1993 on the return of cultural objects unlawfully removed from the territory of a Member State, OJ L 74/74 of 27.3.93 Cf.: Art 3(7) of the 1995 UNIDROIT Convention on Stolen or Illegally Exported Cultural Objects, which defines a public collection as consisting of a group of inventoried or otherwise identified cultural objects owned by: (a) a Contracting State; (b) a regional or local authority of a Contracting State; (c) a religious institution in a Contracting State; or (d) an institution that is established for an essentially cultural, educational or scientific purpose in a Contracting State and is recognised in that State as serving the public interest. The definitions of Council Directive 93/7/EEC and the UNIDROIT Convention both start from a Western European understanding, according to which museums are or were, for the most part, state institutions. However, by including foundations, trusts, or other institutions that are to some extent financed by public money, the definition is much broader than the mere inclusion of state museums. See further on the Directive and on the UNIDROIT Convention below in chp. 1.\$2.III / VI.

${ }^{60}$ Siehr, K.G., 2005, p. 1086. See, e.g. below the Toorop Case in chp. 4.S1.I.3.c).

${ }^{61}$ Cf.: Wood, J.N., 2003, p. 106; Weiss, L.J., 2007, p. 837. 
belongs to the general public. ${ }^{62}$ For public museum collections, claims challenging the presence of an object in their collection imply a process inimical to the entire purpose of museums. ${ }^{63}$ Furthermore, there exists a practical reason for focusing on public collections: due to their accessibility, which is a consequence of their public role, public collections are particularly prone to claims for the return of objects from their collection. ${ }^{64}$ For these reasons, this research brackets objects held in public collections on loan from private collectors.

\section{2. 'Cultural Property'}

There exists consensus in the literature that no universally valid definition of cultural property can be given. ${ }^{65}$ It is, however, possible to extract common elements from the use of the term "cultural property" in national, European and international norms as has been undertaken by Odendahl in her study on the multi-level system of the protection of cultural property. ${ }^{66}$ Based on the common elements extrapolated from international, European and national law she derived the following characterisation of cultural property:

"[o]bjects qualifying as cultural property are corporeal objects, movable or immovable, either unique or consisting of collections / ensembles, which have been either created, changed or formed by buman effort or which represent human cultural development, and which are accorded historical, artistic, scientific, arcbitectural, archaeological or any other cultural value of different dimensions" (emphasis added). ${ }^{67}$

The characterisation "created, changed or coined by human effort or which represent human cultural development" indicates that cultural property cannot exist without an anthropocentric element. In other words, the object must have a link with human kind. Furthermore, an object must also be "accorded historical, artistic, scientific, architectural, archaeological or any other cultural value of different dimensions". 68 According to Odendahl, the accordance of value to an object by a

62 Cf.: Meyer, K.E., 1977, p. 13.

63 Cf.: Wilson, D.M., 1989, p. 23; Becker, A., 1994, p. 16; Seventh Report of the House of Commons Select Committee on Culture Media and Sport, Cultural Property: Return and Illicit Trade, 2000, para. 239; Woodhead, C., C., 2002, p. 326; Effert, R.A.H.D., 2003, pp. 1 \& 8; Delingpole, J., March 17 2006; Vrdoljak, A.P., 2006, p. 277.

${ }^{64}$ See for further differences between public museum collections and private collections: Pomian, K., 1998, pp. 67-68.

65 Cf.: Schorlemer, S.v., 1992, p. 82; Weidner, A., 2001, p. 6 with further references; Jenschke, C., 2005 , p. 30; Schönenberger, B., 2009, p. 44.

${ }^{66}$ Odendahl, K., 2005, p. 386.

${ }^{67}$ Ibid., p. 387.

68 The same approach has been adopted by UNESCO in its Recommendation for the Protection of Movable Cultural Property as adopted by the UNESCO's General Conference on 28 November 1978. According to its first paragraph, ''movable cultural property' shall be taken to mean all movable objects which are the expression and testimony of human creation or of the evolution of nature and which are of archaeological, historical, artistic, scientific or technical value and interest (...)". 
society (rather than a single human being) constitutes the most important element in the definition of cultural property. ${ }^{69}$ Consequently, the crucial criterion as to whether or not an object qualifies as cultural property is not an inherent characteristic of the object as such but is externally imposed. ${ }^{70}$

As an external subjective process, the accordance of cultural value to an object may be subject to change: an object can at one point in time be a simple tool and at a later stage qualify as cultural property of eminent value. ${ }^{71}$ Likewise, the cultural value accorded to an object can diminish over time. By referring to "culture value of different dimensions", Odendahl clarifies that it is irrelevant for the qualification as cultural property whether an object is of value (only) for a certain group of the population, a people, a continent or humanity as a whole. Neither is it crucial for the qualification of an object as cultural property that it is of outstanding cultural relevance: cultural property may be of outstanding, special, extraordinary or any other cultural value. ${ }^{72}$ Consequently, territorial and qualitative dimensions are irrelevant to the qualification of an object as cultural property. They become relevant when it comes to the question of whether an object falls under the scope of application of a specific legal norm. ${ }^{73}$

The reflection on the constitutive elements of cultural property, as provided by Odendahl, helps to grasp the characteristics of cultural property but cannot (and does not attempt to) take away a certain degree of subjectivity and legal uncertainty. ${ }^{74}$ However, in most cases the question of whether or not an object qualifies as cultural property does not constitute a problem. ${ }^{75}$ Whether this is also the case for human remains in public collections, as the remains of once sentient beings, requires some further reflection. For this reason, we will postpone this question until a later stage of the analysis (Chapter 2.\$2.III.2).

\section{3. 'NAZI SPOLIATED ART'}

Nazi spoliated art refers to cultural objects, especially works of art, which were stolen, or which were otherwise taken from their owners, during the period of the Nazi

\footnotetext{
${ }^{69}$ Odendahl, K., 2005, p. 388.

${ }^{70}$ Cf.: Schönenberger, B., 2009, pp. 48-51. Schönenberger discusses a number of elements, such as age, origin, uniqueness, authenticity, aesthetic or financial value and comes to the conclusion that none of these elements can serve as defining element singling out cultural property from other goods.

${ }^{71}$ Cf.: Jenschke, C., 2005, p. 31 gives the example of an antique goblet.

${ }^{72}$ Cf.: Müller-Katzenburg, A., 1996, p. 140 This interpretation is also supported by the analysis of O'Keefe on the definition of cultural property under the 1954 Hague Convention for the Protection of Cultural Property in the Event of Armed Conflict. While its first Article seems to introduce a rather high standard by requiring an object to be of "great importance to the cultural heritage of every people"72, O'Keefe came to the conclusion "that the Convention applies to all movable (...) property considered by each respective state to form part of its national cultural heritage". O'Keefe, P., 1999b, p. 36.

73 Odendahl, K., 2005, p. 388.

${ }^{74}$ Cf.: Schönenberger, B., 2009, p. 51.

${ }^{75}$ Cf.: Ibid., p. 47.
} 
reign (1933-1945). ${ }^{76}$ In the present debate, the understanding of that which constitutes "spoliated" art is not limited to confiscations and plunder but includes also involuntary losses that are considered as being precipitated by the Nazi Regime. An example of a loss precipitated by the Nazi Regime is the sale of a work in exchange of an exit visa. At the end of World War II, a substantial number of these spoliated cultural objects were not reunited with their former owners or their heirs, some of which became part of public collections.

\section{4. 'HUMAN REMAINS'}

As for the understanding of 'human remains', we rely on the definition as provided for by the United Kingdom Working Group on Human Remains. The Working Group was established in 2003 and thoroughly examined the legal status of human remains within the collections of publicly funded museums and galleries in the United Kingdom. ${ }^{77}$ Based on its research, the Working Group decided that human remains' should be understood as including all forms of human material in public collections and should be specifically taken as including:

"all forms of human material, in particular osteological material (skeletons, but also individual bones and even fragments of bones and teeth); soft tissue such as organs, skin, hair, nails both preserved in spirit or wax and dried/ mummified); slide preparations of human tissue; as well as artefacts made wholly or largely from any of the above". ${ }^{78}$

\section{5. 'Restitution', 'Restoration', 'Return', 'Recovery', 'RePatriation'}

Legal instruments and academic writings discussing the return of cultural property show little coherence in the usage and application of terms such as "restitution", "repatriation", "restoration", "recovery", and "return".79 Only restitution is a "term of art, either in international law or in national law" 80 . In public international law, restitution seeks to remedy the consequences of an internationally wrongful act. The commitment of an internationally wrongful act by one subject of international law against another brings about liability for reparations. ${ }^{81}$ The duty to provide reparation is a new and separate obligation arising from the breach of international law. ${ }^{82}$ Reparations are guided by the Latin maxim restitutio in integrum: the state "must, as far as possible,

\footnotetext{
${ }^{76}$ Cf:: The Oxford English Dictionary. 2nd ed. 1989. OED Online. Oxford University Press: "spoliate, v." .

77 The Working Group on Human Remains was established in the United Kingdom in May 2001. See: Working Group on Human Remains, 2003, p. 1, para. 1 for the exact terms of reference. The Working Group and its findings are further discussed below in chp. 4.\$2.II.1.

${ }^{78}$ Ibid., pp. 7-8, para. 19.

${ }^{79}$ Cf.: Prott, L.V. / O'Keefe, P.J., 1989, p. 802; Turner, S., 2002, p. 1, fn.1.

80 Prott, L.V. / O'Keefe, P.J., 1989, p. 835.

${ }^{81}$ Wolfrum, R., 1987, p. 352.

82 Ibid.
} 
wipe out all the consequences of the illegal act and re-establish the situation which would, in all probability, have existed if that act had not been committed". ${ }^{83}$ According to Art. 34 of the ILC Articles ${ }^{84}$, reparations can take the form of "restitution, compensation and satisfaction ${ }^{85}$, either singly or in combination (...)".86 While restitution is only one form that reparations for the injury caused by an internationally wrongful act can take, it is the most adequate form of reparations where it concerns cultural property, which is characterised by its unique character. ${ }^{87}$

With regard to municipal law, restitution is "the return or restoration of some specific thing to its rightful owner or status". .8 Consequently, under municipal law restitution seeks to protect property rights. Depending on whether a case is of intrastate relevance only or touches upon more than one jurisdiction it will be solved according to the respective national private law or will rely upon the rules of private international law ("conflict of laws") to determine the national legal order to determine questions concerning ownership. As a general rule, public international does not interfere with property rights as an internal affair of sovereign states. The protection of property in form of restitution is not a task of public international law. The latter's role in protecting property has traditionally been limited to the protection of property in armed conflicts in the sense of protecting property against destruction, damage and removal (preventive protection). ${ }^{89}$ However, the separation between national law and public international law with regard to ownership structures is not waterproof. In reaction to the atrocities of the Nazis committed both in the occupied countries and within German territory the Allied Forces decided to disregard the distinction between external and internal restitution and to adopt measures under public international law also with regard to internal restitution. ${ }^{90}$ Consequently, the notion of restitution under public international law has come to include also to a limited extent the protection of property rights.

Different from restitution the terms "repatriation", "restoration", "recovery", and "return" do not have a technical legal meaning. The Oxford English Dictionary defines repatriation as "return or restoration to one's own country". ${ }^{91}$ Consequently, while the terms are to some extent synonyms, repatriation emphasises the link with a country -

${ }^{83}$ Crawford, J., 2002, pp. 47-48. Cf.: Wolfrum, R., 1987, p. 352.

${ }^{84}$ International Law Commission, 2001, p. 28.

${ }^{85}$ See further on satisfaction as a means of reparation: Shaw, M., N., 2003, p. 719-720, See: Brownlie, I., 1983, pp. 441 \& 443-444.

${ }^{86}$ Brownlie, I., 2003, p. 442 furthermore lists: "apology, the punishment of the individuals responsible, the prevention of a reoccurrence of the breach in the future, as well as any other form of satisfaction".

87 Jenschke, C., 2005, p. 211.

${ }^{88}$ Garner, B., A., 1999, "restitution", sub. 3.

${ }^{89}$ Cf.: Odendahl, K., 2005.

${ }^{90}$ Schwarz, W., 1974, p. 26.

91 The Oxford English Dictionary defines repatriation as "return or restoration to one's own country". "Repatriation" The Oxford English Dictionary. 2nd ed. 1989. OED Online. Oxford University Press. 17 May 2007, http://dictionary.oed.com. Available online at: http://dictionary.oed.com, last visited on 17 May 2007. 
patria. Compared with "restitution", the terms "return", "restoration" as well as "recovery" are more neutral: while they do convey a certain geographical and restorative direction, they do not imply any legal obligations. Of these three neutral terms, the term "return" is used most frequently. It has become a catch-all concept for those cases in which the displacement of a cultural property does not constitute a clear violation of a legal obligation. ${ }^{92}$ In the following chapters we will use the terms 'return' and 'restitutions' interchangeably. ${ }^{93}$ Where a return / restitution is based on a legal claims right it shall be indicated.

In anticipation of sketching the genesis of claims in Chapter 2 and the case studies in Chapter 4 we would like to state a few words on the terminology used in relation to human remains. Claimants seeking the return of human remains often claim for the "reburial" of the remains. In the dictionary term reburial is defined as "a second interment (of a corpse)". ${ }^{4}$ This understanding is too narrow in this context, as not all human remains in public collections have had a first burial. ${ }^{95}$ The Latin prefix re- must not only be understand as meaning 'again', or 'anew', but also in its original sense of 'back' or 'backwards', that is back to the original place. Reburial must also be understood to include any cultural practices related to the deposing of the human body after death, such as burial, interment, cremation, and sky-burial. In this thesis, the terms 'repatriation', and 'return' shall be used as synonyms. 'Reburial' shall be reserved for claims explicitly motivated by the wish to (re-)bury the remains. With regard to claims not stressing this aspect we will use the term return or one of its synonyms such as repatriation.

\section{6. 'DE-ACCESSIONING'}

De-accession refers to the procedure to remove an object from a public collection. The expression is mainly used in the United States ${ }^{96}$ but has been adopted by

\footnotetext{
92 Kowalski, W.W., 2004, p. 49. See for an analysis of the gradual restriction of the term "restitution": Prott, L.V. / O'Keefe, P.J., 1989, pp. 834-835.

93 Other authors opted for the term 'restitution' as general term comprising different claim categories. See, e.g.: Schönenberger, B., 2009, p. 43; Odendahl, K., 2005, p. 182.

${ }^{94}$ Gerstenblith, P., 2001. See for a discussion of the term 'repatriation': Kowalski, W.W., 2001. Kowalski understands 'repatriation' as "a return to patria, which means fatherland understood as a State", p. 163.

${ }^{95}$ Cf.: below the case study on the return of Saartjie Baartmans, better known as the 'Vénus hottentote' from the French National Museum of Natural History. Immediately after her death in 1815, Baartman's corpse was taken to the laboratory of anatomy in the Museum National d'Histoire Naturelle. A plaster cast of her body was made, and after dissection of the body several organs and body parts were conserved in glass jars with alcohol. Baartman's remains were kept in the museum collection until 2002. Hence her remains were never buried strictly speaking when her "re-burial" was discussed in the French Senate.

96 The expression is mainly used in the United State as referring to the "removal of an entry from the accessions register of a museum, library, etc., usually in order to sell the item concerned". "de-accession, v." The Oxford English Dictionary, 2nd ed. 1989, OED Online, Oxford University Press, 29 June 2009, . See, e.g: Calhoun, A., 1985; Park, G.S., 1985; Weil, S., 2000.
} 
the museum sector outside of the US. ${ }^{97}$ For this reason, we will use the term as synonym for the disposal of objects from public collections, regardless of the actual reason for the removal (e.g. transfer, sale, intentional destruction).

\section{SUMmary OF THE RESEARCH AIM AND SPECIFIC RESEARCH QUESTIONS}

The overall aim of this book is three-fold: first, to take stock of and to analyse the present law and practice with regard to the return of cultural property from public (museum) collections through the lens of the cases of Nazi spoliated art and human remains. Secondly, to reflect upon the relevance of the developments with regard to Nazi spoliated art and human remains for the protection and return of cultural property more in general. The final aim of this study is to make recommendations for the specific cases of Nazi spoliated art and human remains, as well as the return of cultural objects more in general. In order to be able to give a substantiated view on this matter the following more specific research questions will be addressed in the course of this research:

Chapter 1:

What rights and obligations for the return of cultural property are recognized in public international law?

What were the guiding principles in restituting cultural property after WWII?

What is the status of (public) museum collections in public international law?

Chapter 2:

What are the developments underlying the recent emergence of the debates on the return of Nazi spoliated art and human remains?

To what extent is public international law relevant for current claims seeking the return of Nazi spoliated art and human remains?

Which instruments have been introduced in reaction to the rise in claims and what is their legal status and relevance?

To what extent do the solutions proposed at the international level with regard to Nazi spoliated art take account of the restoration of rights as affected during the post-WWII period?

Chapter 3:

What are the applicable national regimes with regard to cultural property in public museum collections?

What obstacles to or prohibitions on returns can be identified?

\footnotetext{
${ }^{97}$ See, e.g.: Seventh Report of the House of Commons Select Committee on Culture Media and Sport, Cultural Property: Return and Illicit Trade, 2000, para. 166; Palmer, N., 2001; Instituut Collectie Nederland, 2006
} 
Chapter 4:

What laws and policies were introduced at the national level in reaction to claims seeking the return of Nazi spoliated art and human remains? How do they relate to the solutions proposed at the international level?

Specifically for Nazi spoliated art, what is the relevance accorded in present solutions to compensation payments possibly received in the past?

Specifically for human remains, what is the relevance accorded to the fact that they are the remains of once sentient human beings? Put differently, can one denote a greater urgency to return human remains compared to other cultural objects?

Do national practices allow for the suggestion of (an emerging) rule of customary international law in constituting settled state practice?

\section{Chapter 5:}

What are the main findings with regard to the cases of Nazi spoliated art and human remains?

Which recommendations can be made?

For the specific cases of Nazi spoliated art and human remains?

For the development of the law more in general?

What is the relevance of the developments with regard to Nazi looted art and human remains to other claims seeking the return of cultural objects?

\section{READING INSTRUCTIONS}

This $\mathrm{PhD}$ thesis follows the bad habit of doctoral dissertations of exceeding the number of recommended pages. ${ }^{98}$ As pointed out by van der Veen, and earlier by Michiels, ${ }^{99}$ this is not a catastrophe but the author "will have to accept the economic usage of the book" in the sense that not all readers will read the book integrally but will pick those aspects that they find most interesting. According to the above cited authors, such economic use of the thesis can be facilitated by the provision of reading instructions as well as an index.

In line with this advice, the following reading instructions may be suggested: law students and others interested in the historical evolution of cultural property law and the existing legal framework as offering enforceable rights may be particularly interested in Chapter 1. Furthermore, the extended bibliography may refer them to other interesting publications in the field of cultural property law. Academics, lawyers, claimants, or museum workers who are interested in the particular case of Nazi spoliated art are advised to focus on $\int 1$ in Chapters 2 and 4. Those interested in the case of human remains are advised to focus on $\ 2$ of those chapters. Curators and others interested in

98 Cf.: Polak, J.M., 1992, p. 1176; Kortmann, C.A.J.M., 1996, p. 345. “Angst voor een "dun” proefschrift” as referred to by Nieskens-Isphording, 1996, p. 150 did not play a role.

${ }^{99}$ Michiels, F.C.M.A., 1994, p. 227; Veen, G.A.v.d., 1997, p. 14. 
de-accessioning of cultural property from public collections more in general may find Chapter 3 most interesting. The final Chapter 5 will be relevant to all readers in that it summarizes the main findings of the research, presents recommendations, as well as beginning ideas for future research steps. As a final "reading instruction" we use 'he' to include 'she' whenever gender is unknown or irrelevant. 



\section{CHAPTER 1}

\section{Analysis of International Law with regard to the Rise of Obligations to Return Cultural Objects}

In this chapter we will analyse public international law in view of the emergence of rules on the protection of cultural property. International rules on the protection of cultural property can be roughly divided into two categories: rules dealing with the preventive protection of cultural property on the one hand and norms providing for the restitution (or return) on the other hand. The preventive protection of cultural property against damage or destruction (preservation) is considered as the primary aim of cultural property law. 100 It corresponds to the uniqueness and irreplaceability of cultural property. ${ }^{101}$ The protection of an object of cultural relevance against removal, such as looting in times of war as well as theft and (illegal) exports in times of peace, can be seen as subsidiary means to support the objects' preservation. This view also exists for the return of cultural property that has been removed despite any preventive measure of protection. While the return of a cultural object does not necessarily contribute to its preservation, it is more and more recognised as another facet of the protection of cultural property and is sometimes referred to as restorative (protection). ${ }^{102}$

It is the category dealing with the return of cultural objects that lies at the heart of the present analysis. The focus on the return of cultural objects to a certain state, people or private individual does not mean that rules on the preventive protection of cultural property will be excluded. In fact, given the interdependence of the two sets of categories, an analysis of the applicable rules with regard to the return of cultural objects presupposes the analysis of rules of preventive protective character. ${ }^{103}$ Furthermore, the analysis of rules dealing with the preventive protection of cultural property will also

\footnotetext{
100 Fechner, F.G., 1998, p. 382.

101 Ibid.

102 Cf.: Odendahl, K., 2005, p. 162.

103 Cf.: Ibid.
} 
allow us to identify specific protection granted under public international law to public collections as institutions in the service of society, established for and dedicated to the conservation and exhibition of (cultural) objects. ${ }^{104}$

In short, the aim of this chapter is to situate public collections in the context of public international law with special attention paid to potential obligations arising from public international law return cultural objects while also taking into account the specific status granted to public collections originating from the same source.

The two main sources of public international law are treaty law and customary law. ${ }^{105}$ In the last three decades treaty law has replaced customary law as primary source of international law. ${ }^{106}$ For this reason, as well as the relevance of treaty law in establishing the existence of an opinio iuris, we will first concentrate on obligations created in treaty law before addressing the existence of obligations of customary law. ${ }^{107}$

The structure of this chapter follows the chronology of the development of rules on the protection of cultural property in international law. Starting with the protection of cultural property in times of war $(\mathbb{S} 1)$, the analysis will then turn to the protection of cultural property in time of peace. The latter consists of rules for the protection of cultural property against illicit trafficking, especially illegal exports ( $(2)$. Furthermore, the question of the legal status of (cultural) objects removed during the colonial era also belongs to this category $(\mathbb{S} 3)$. Although it seems odd from the present perspective to discuss the removal of (cultural) objects during the colonial era in the context of peacetime, the colonial activities do not fall under armed conflict in the legal sense. ${ }^{108}$ After having discussed the more classical fields of cultural property protection in public international law as constellations between states, the analysis will discuss the relevance of public international law with regard to the restitution of cultural objects to private individuals $(\$ 4)$ or a people $(\Omega 5)$. Historically, only states qualified as subjects of international law as is captured in the German designation of public international law as "Völkerrecht" - the law applicable between states. ${ }^{109}$ It was only during the 20th century that a growing body of international law was devoted to defining the rights and responsibilities of individuals. The broadening of the scope of public international law from its focus on states to including individuals has been characterised as the most

\footnotetext{
104 Cf.: http://portal.unesco.org/culture/en/ev.php-

URL_ID=35032\&URL_DO=DO_TOPIC\&URL_SECTION=201.html (last visited 26 January 2009).

Cf.: Seventh Report of the House of Commons Select Committee on Culture Media and Sport, Cultural Property: Return and Illicit Trade, 2000, para. 239 where it is suggested that the return of cultural property is "inherently undesirable" because it implies a process inimical to the entire purpose of museums. Cf.: Becker, A., 1994, p. 16.

105 Cf.: Art. 38 of the Statute of the International Court of Justice.

106 Dixon, M., 2007, p. 30.

107 See further below chp. 1\1.VIII where we discuss the existence of customary law with regard to the restitution of cultural objects for an introduction to the two elements a rule must fulfill in order to qualify as customary law - opinio iuris and state practice.

108 Cf.: Odendahl, K., 2005, p. 181.

109 This is equally true for the Scandinavian and Slavonic language area.
} 
important change in public international law over the past century. ${ }^{110}$ This shift in the focus of public international law occurred inter alia in response to the Holocaust. ${ }^{111}$ Since the first "codification" of this development in the form of the 1948 Universal Declaration of Human Rights, the rights of individuals under international law have been the subject of various human rights instruments and agreements considerations.

After an intermediary conclusion of the analysis of the existing legal framework under public international law with regard to the protection of cultural objects, especially with regard to the obligation to return them $(\mathbb{S} 6)$, the chapter will round off with a reflection on the special status granted to public collections.

\section{$\$ 1$ THE PROTECTION OF CULTURAL OBJECTS IN TIMES OF WAR ${ }^{112}$}

\section{From Ancient Times until the end of the 19Th Century}

Accounts of looting of objects of cultural relevance date back to Ancient Times. Amongst the Ancient Greeks and Romans, looting was not considered illegal. ${ }^{113}$ On the contrary, the ius praedae, the right of the victorious party to loot, was often the reason to wage war in the first place. ${ }^{114}$ Consequently, the looting of cultural objects was a wellestablished practice ${ }^{115}$ and early accounts on the return of looted objects are sporadic. ${ }^{116}$ Where an object was returned at all, it was only in exchange for another object. ${ }^{117}$

In fact, it is not until the adoption of the Treaty of Westphalia in 1648 that the literature notes the first signs of an emerging ban on the looting of cultural property. However, to interpret this early-modern peace treaty as providing for the restitution of cultural property disregards political reality. ${ }^{118}$ While it is true that the Treaty of

\footnotetext{
${ }^{110}$ Less, S., 2008.

${ }^{111}$ See for a concise summary of other relevant influences and schools of thoughts: Partsch, K.J., 1987.

112 The analysis is structured according to chronology, thereby integrating multilateral treaties and peace treaties rather than discussing them separately from one another. This approach allows for the best overview of the historical development of the ban on looting and the obligation to restitute cultural property, while highlighting the reactionary nature of the international rules. Cf.: Keane, D., 2004, p. 1.

113 See, e.g.: Xenophon, Cyropaedia (VII, 5, 73): UNESCO,

http://unesdoc.unesco.org/images/0013/001394/139407eb.pdf; Hedrick, L., 2006.

It was only with regard to sacred objects that some authors, such as the historian Polybius in $146 \mathrm{BC}$, pleaded for restrictions of the right to pillage. See, e.g.: Nahlik, S.E., 1976, p. 1069; Krause, K.-J., 1986; Hammer, F., 1995, p. 9; Toman, J., 1996, p. 4; Merryman, J.H., 2005, p. 13 with further references to antique scholars.

${ }^{114}$ Kowalski, W.W., 1996a, p. 1.

115 Ibid., pp. 1-2; Toman, J., 1996, pp. 3-4. See for examples of looting and looted objects e.g.: Engstler, L., 1964, pp. 80-83; Fuhrmann, M., 1995, IV, 58, 94, 98, 33, 39.

116 Engstler, L., 1964, pp. 80-83. Engstler discusses a number of returns of cultural objects but stresses that the return of cultural objects was the exception rather than the rule in antique times.

117 Rudolf, W., 1989, p. 856; Jote, K., 1994, pp. 263-264; Jenschke, C., 2005, p. 114; Odendahl, K., 2005, p. 14.

118 The Treaty of Westphalia actually consists of two treaties, the Instrumentum Pacis Osnabrugensis (Treaty of Osnabrück) and the Instrumentum Pacis Monasteriensis (Treaty of Münster). The Treaties ended the series of wars fought by various nations during the first half of the $17^{\text {th }}$ century that went down in history as
} 
Westphalia provides for the "restoration of records, writings, documents, and other movables" that have been removed from places such as towns and castles ${ }^{119}$ it is anachronistic to understand the Treaty of Westphalia as providing for the restitution of cultural property as such: while several international conventions yet to be adopted throughout the $20^{\text {th }}$ century explicitly refer in their definition of cultural property to "manuscripts, incunabula, books, documents, publications and archives"120, this does not make the Treaty of Westphalia the first instrument of international law to provide for the restitution of cultural property as such as it is often stated. ${ }^{121}$ In particular such an interpretation disregards the fact that "records, writings, documents" are of direct relevance for a state's administration, which is the reason for these type of documents to be included in the Treaty of Westphalia. ${ }^{122}$

In the developments towards the emergence of a ban on the destruction and looting of cultural objects and obligations to restitute objects removed in spite of such a ban the $18^{\text {th }}$ century played an important role. During the $18^{\text {th }}$ century new notions about the role of states and the ius in bello emerged. Different from the practice during the $17^{\text {th }}$

the Thirty Years' War (1618- 1648) and the Eighty Years' War (1568-1648). The Treaty of Osnabrück regulates the matters of dispute between the Holy Roman Emperor Ferdinand II and Sweden; the Treaty of Münster regulates the relationship between the Holy Emperor and France. See further on the qualification of the Treaty of Westphalia as early-modern peace treaty: Lesaffer, R.C. / Broers, E.-J., 2007, p. 2, http://ssrn.com/paper=1002389.

119 \ 108 of the Treaty of Münster reads in an anonymous English translation: "That the Records, Writings and Documents, and other Movables, be also restor'd; as likewise the Cannon found at the taking of the Places, and which are still in being. But they shall be allow'd to carry off with them, and cause to be carry'd off, such as have been brought thither from other parts after the taking of the Places, or have been taken in Battles, with all the Carriages of War, an what belongs thereunto (...)". Die Westfälischen Friedensverträge vom 24. Oktober 1648. Texte und Übersetzungen. Anonymous English Translation from 1710 (available online at: http://www.pax-westphalica.de/ipmipo/pdf/m_1710en-treatys.pdf Last visited 14 May 2008), 2004. Art. XVI, 15 of the Treaty of Osnabrück is identical in wording. The finding that the provisions of the treaty did not provide for the return of cultural property as such is also true for the Treaty of Olivia (1666), the Treaty of Nijmegen (1678-79), and the Treaty of Rijswijk (1697). However, similar to the Treaty of Westphalia, they provide for the return of archives, libraries and other documents of importance. See further on the treaties and their provisions to return archival material and books: Engstler, L., 1964, pp. 8889; Kowalski, W.W., 1996b. See more in general: Meyer-Landrut, J., 1953.

${ }^{120}$ Cf.: the definitions of cultural property as provided for by the 1954 Convention for the Protection of Cultural Property in the Event of Armed Conflict; the Convention on the Means of Prohibiting and Preventing the Illicit Import, Export and Transfer of Ownership of Cultural Property and the UNIDROIT Convention on Stolen or Illegally Exported Cultural Objects. The 1954 Hague Convention is discussed in chp. 1.\$1.VI.1. The 1970 UNESCO Convention and the 1995 UNIDROIT Convention are discussed in chp. 1.\$2.III /IV.

121 See, e.g.: Schulze, D., 1983, p. 31; Jote, K., 1994, p. 264; Maurer, C.H.M., 1997, p. 9; Odendahl, K., 2005, p. 14.

122 Cf.: Walter, B., 1988, p. 121; Schorlemer, S.v., 1992; Schorlemer, S.v., 1996; Schorlemer, S.v., 1998 , p. 318; Odendahl, K., 2005, pp. 153-154 \& 185. See for a clear separation between the restitution of archival material and the emergence of a principle providing for the restitution of cultural property: Jenschke, C., 2005, p. 117 ; Nahlik, S.E., 1958, p. 133 (quoted by Kowalski, W.W., 1998, p. 8). Cf.: Engstler, L., 1964, p. 93 where he discusses the requests of pope Pius VII in 1814 for the restoration of historical archives rather than the restitution of looted art works. 
century, there exists little evidence of looting during the $18^{\text {th }}$ century. ${ }^{123}$ Rather, a general shift in the perception concerning the ius in bello and the ius ad bellum can be noted. In particular the works by Jean Jacques Rousseau and Emer de Vattel reveal a revised notion of war: as a result of changing perceptions of the "State" and greater attention for human rights, war came to be regarded as a relationship between states only. ${ }^{124}$ Consequently, warfare started to distinguish between the civilian population and the army. ${ }^{125}$ As a result of the greater respect for the lives of the civil population, there was also an increase in the protection of private property. Whereas the legality to loot stateowned property, in particular material of military relevance, was confirmed ${ }^{126}$, the looting of private property and property of non-military relevance, such as cultural property, became subject to growing criticism. However, before these developments would result in a proper legal ban on the looting of cultural property they were challenged by Napoleon's massive looting campaigns in the period 1792-1815.

Roughly at the same time, towards the end of the age of Enlightenment the first public collections were established. After princes and noblemen had started collecting rare and exotic objects for their cabinets of curiosities during the Renaissance $\left(14^{\text {th }}-16^{\text {th }}\right.$ centuries) it was during the Enlightenment that the collections were made available to the public. ${ }^{127}$ The first public museum to be opened to the public in 1759 was the British Museum in London. ${ }^{128}$ The first museum to open in the Netherlands was the Teylers Museum in Haarlem in 1784, when the private collection of Pieter Teyler van der Hulst was made accessible to the public. ${ }^{129}$ The Musée Français, better known under its current designation the "Louvre" opened its ports to the public in 1793; only one year after the start of Napoleon's looting campaigns. ${ }^{130}$

The practice of art looting under Napoleon was unmatched in history. ${ }^{131}$ The French troops were accompanied by art historians that picked the most valuable cultural objects to be transferred to the Louvre. ${ }^{132}$ Despite the extent of Napoleon's looting the

123 Engstler, L., 1964, p. 91. Engstler reports that during the Seven Years' War the belligerent parties refrained from taking any paintings from the picture galleries in Berlin and Dresden despite various chances of doing so. See also: McGuire, T., 1990, p. 35.

${ }^{124}$ Rousseau, J.-J., 1762, Book 1, chp. IV ("La guerre n'est donc une relation d'homme à homme, mais une relation d'État à Etat") ; Vattel, 1758, Book 3, chp. 9, para. 168. Cf.: e.g.: Kowalski, W.W., 1998, pp. 21-22.

${ }^{125}$ Engstler, L., 1964, p. 89.

126 Vattel, 1758, Book 3, chp. 8, para. 138.

127 Cf.: Effert, R.A.H.D., 2003, p. 19.

128 The nucleus of its collection was the formerly private collection of Sir Hans Sloane. After Sloane's death his trustees sold his collection to the Crown. Pancaldi, G., 2003, p. 550.

${ }^{129}$ Effert, R.A.H.D., 2003.

${ }^{130}$ See further: McClellan, A., 1994.

131 Odendahl, K., 2005, p. 19. See for historical accounts on the looting: Vogt, H., 1956; Engstler, L., 1964, pp. 91-92; Wescher, P., 1976; Chamberlin, R., 1983; Toman, J., 1996, p. 6; Gould, C., 2007; Quynn, D.M., 2007.

132 Odendahl, K., 2005, p. 19; Gould, C., 2007, p. 4-6. One example that must be mentioned here is the mosasaurus that had been discovered in 1770 in Maastricht and that had been taken by Napoleon's troops to Paris in 1794 where it since belongs as national treasure to the collection of the Museum of Natural History. From 8 March - 212009 June the mosasaurus could be admired in the exhibition 'Darwin, Cuvier 
literature also denotes signs of an emerging awareness on the illegality of the removal of cultural objects. In a number of peace treaties the transfer of cultural objects has been explicitly addressed. ${ }^{133}$ This practice, which was unprecedented in history, is interpreted in the literature as indirect recognition of a(n emerging) ban on the looting of cultural objects. ${ }^{134}$

Equally important with regard to the emergence of a ban on looting and the obligation to restitute looted objects is the change in attitude of the Allies after they had defeated the French troops in the Battle of Paris. During the first round of negotiations at the Congress of Vienna (September 1814 - June 1815) the return of cultural objects was not an interest shared by the Allies. ${ }^{135}$ The primary aim of all Allies was the stable reorganisation of the distorted map of Europe and the prevention of future wars. ${ }^{136}$ In fact, the British firmly rejected the recovery of cultural objects in order not to risk the restoration of peace in Europe. ${ }^{137}$ Prussia, however, attached great value to the "restitution of the nations' looted art treasures to the nations". Its negotiations with France resulted in the return of one third of the cultural objects looted from Prussia. ${ }^{138}$ The return was based upon a French proposal according to which only those cultural objects were to be returned that had not been placed in a museum by the time the Peace Treaty of Paris was concluded on 30 May 1814.139

It was only after the return of Napoleon from Elba and the Battle of Waterloo of 18 June 1815 that the attitude of the Allies, in particular of the British, changed towards

et le Grand Animal de Maestricht' on the basis of a loan to the Natural History Museum Maastricht. See further: http://www.nhmmaastricht.nl/nederlands/exposities/darwin/index.html (last visited: 21 March 2009). See for information on further ethnographic objects that had been taken by Napoleon's army: Campen, J.v., 2000, pp. 282-286.

133 See e.g.: Peace Treaty of Tolentino between the Holy See and the French Republic, Tolentino, 18th February, 1797, Art. 8. See further: Vogt, H., 1956, p. 141; Engstler, L., 1964, pp. 109-110; Kowalski, W.W., 1996b; Poulos, A., Helleni, 2000, p. 12.

${ }^{134}$ Cf.: Odendahl, K., 2005, p. 19.

135 See for an historical account on the negotiations at the Congress of Vienna: Zamoyski, A., 2007.

136 Engstler, L., 1964, pp. 95 \& 97. This does not mean that no agreement was reached during the first round of negotiations. According to a report dating from March 1815, one third of the cultural objects looted from Prussia had been returned in response to the agreement that came to be known as (part of the) "Vienna Acte Final of 9 June 1815" (Acte du Congrès à Vienne du 9 juin 1815, in: Israel, F.L., et al., 1967, p. 519). However, most of the returns were based upon a French proposal according to which only those cultural objects were to be returned that had not been placed in a museum by the time the Peace Treaty of Paris was concluded on 30 May 1814 (Engstler, L., 1964, p. 96). Further negotiations resulted in the restitution of a number of specifically designated objects (e.g. three works by Voltaire with handwritten comments of the author himself, which had been taken from Berlin and other "works of art". See further: Engstler, L., 1964, p. 97 and Müntz, 1895, p. 707 \& 714. Also, the German Princes negotiated for the return of some cultural objects).

${ }^{137}$ Engstler, L., 1964, p. 95 and according to the latter: Webster, C., 1947-1950, p. 189.

138 See: Acte du Congrès à Vienne du 9 juin 1815, in: Engstler, L., 1964, p. 100; Israel, F.L., et al., 1967, p. 519.

139 Engstler, L., 1964, p. 96. Further negotiations resulted in the restitution of a number of specifically designated objects (E.g. three works by Voltaire with handwritten comments of the author himself, which had been taken from Berlin and other "works of art". See further: Engstler, L., 1964, p. 97 and Müntz, 1895, p. $707 \& 714$. Also, the German Princes negotiated for the return of some cultural objects). 
attaching significance to the return of cultural objects and that there was greater emphasis put on the (territorial) link between a cultural object and its country of origin. Subsequent to the Allied victory of the Battle of Waterloo, the question of how to proceed with cultural objects looted by France was discussed by the Allies during their Ministerial Conference which took place in Paris between 12 July 1815 and 21 September 1815. ${ }^{140}$ At first, there was great variance in the attitude of the Allies: whereas Prussia confirmed its interest to have all objects restituted ${ }^{141}$, Russia opposed the idea of restitution and stressed the overriding interest in restoring peace within Europe. ${ }^{142}$ In the end, the attitude of the British proved decisive.

Despite the rejection of the recovery of cultural objects only a couple of months earlier, the British representatives Castlereagh and Hamilton had in the meantime adopted the view that the looted cultural objects should not be left in France. A letter of Prime Minister Liverpool to Castlereagh clearly expressed the need to remove the looted cultural objects from France. ${ }^{143}$ At this point, however, removal from France did not necessarily mean that the objects were to be returned to the countries from where they had been looted (status quo ante). Rather, the letter clearly mentions the redistribution of looted works amongst the Allies (including Britain) as an option. ${ }^{144}$ The final British position according to which cultural objects were to be restituted to the country from where they had been looted was formulated by Castlereagh in his response to Prime Minister Liverpool's letter. Castlereagh wrote that "only the principle of restitution could reconcile politics with justice". ${ }^{145}$ On 11 September 1815, the British delegation communicated its revised point of view to the Allied parties. The note, which has been qualified as a key element in the negotiations, constitutes the first explicit recognition of the existence of link between cultural objects and the country where they have been removed from:

\footnotetext{
140 The delegations of England (Wellington and Castlereagh), Austria (Metternich and v. Schwarzenberg, later on Wesenberg), Prussia (von Hardenberg and Wilhelm von Humboldt), Russia (Count Rasumoffski and Count Nesselrode) met in 53 sessions. Smaller nations, e.g. The Netherlands, were represented by one of these delegations. Engstler, L., 1964, p. 105.

141 Ibid., p. 100.

142 Ibid., p. 105; Sandholtz, W., 2008, p. 113.

${ }^{143}$ Letter of Prime Minister Liverpool to Castlereagh: "The reasonable part of the world are for general restoration to the original possessors, but they say with truth that we have a better title to such objects; and they blame the policy of leaving the trophies of the French victories in Paris (...). It is most desirable, in point of policy, to remove them if possible from France, as whilst in that country they must necessarily have the effect of keeping up the remembrance of their former conquests and of cherishing the military spirit and vanity of the nation". Vane, C., 1852, p. 435 quoted by: Engstler, L., 1964, pp. 105-106. See also: Harold Nicholson, 1946, p. 99 quoted by Hollander, B., 1959, p. 24.

144 The distribution of cultural objects amongst the Allies rather than restitution to the countries of origin was also discussed by the representative of the Pope, Canova and the British representatives Wellington and Hamilton in September 1815. See further: Vogt, H., 1956, p. 132; Engstler, L., 1964, p. 107.

145 Vogt, H., 1956, p. 132.
} 
“(...) upon what principle deprive France of her late territorial acquisitions, and preserve to her the spoliations appertaining to those territories, which all modern conquerors have invariably respected, as inseparable from the country to which they belonged?"'146

Consequently, the Allies no longer accepted the French argument of the integrity of French Public institution, museums and libraries ${ }^{147}$ but instead engaged in the recovery of cultural objects. By the end of 1815, an essential part of the cultural objects removed during the Napoleonic Raids had been returned to their countries of origin. This was even true for cultural objects whose removal had been sanctioned by documenting and legalising their transfer in (peace) treaties. The return of cultural objects was, however, not complete: excluded were cultural objects held in public collections other than the Louvre. ${ }^{148}$ Therefore, the French emphasis of the integrity of its public collections was to some extent recognised, despite their recent establishment only and the foreign origin of part of the objects. Also excluded were objects held in public collections which, after the rearrangement of the map of Europe, no longer fell on French territory. ${ }^{149}$ Consequently, whereas the beginning of the 19th century saw the rise of the notion of a territorial link between cultural objects and their countries of origin, the notion did not yet translate into a full principle. For the confirmation of such a principle we need to jump to the beginning of the 20th century when the ius in bello became the subject of multilateral negotiations unrelated to any specific armed conflict.

\section{The 1899 and 1907 Hague Conventions}

In 1899, following the initiative of Nicholas II, Tsar of Russia, the First Hague Peace Conference was convened with the object of seeking the most effective means of ensuring to all peoples the benefits of a real and lasting peace, and, above all, of limiting the progressive development of existing armaments. ${ }^{150}$ The initiative of the Tsar was inspired by the US American Lieber Code of 1863 and the Brussels Declaration of 1874. ${ }^{151}$ The non-binding Brussels Declaration was the result of the initiative of Tzar

\footnotetext{
146 Note to the Allied Ministers and placed upon their Protocol, Paris, 11 September, 1815. Reproduced in: Martens, Nouveau Recueil de Traités, II (1814-1815), Goettingen 1887, pp. 632-642. See therein also the note by Wellington to Castlereagh, Paris 23 September 1815, p. 642. The extract of the note quoted above is quoted by: Engstler, L., 1964, p. 108.

147 Quynn, D.M., 2007, p. 7.

148 Odendahl, K., 2005, p. 20.

149 Ibid. Odendahl gives Mainz as an example, in particular its Landesmuseum. Mainz had been occupied in 1797 when the Napoleon's army occupied the German territory to the west of the Rhine River. With the Treaty of Campo Formio (17 October 1797) France was awarded this entire area. In 1803 Mainz was awarded a collection of art works by the French government which built the fundament of its current museum Landesmuseum. See further on the museum and the collection: Paas, S. / Mertens, S., 2003.

150 Russian note of 30 December 1898/11 January 1899; referenced by Schindler, D. / Toman, J., 2004 , p. 41.

151 The Lieber Code of 1863, in full: Instructions for the Government of Armies of the United States in the Field by order of the Secretary of War, 24.4.1863, contained instructions for the government of armies of the United States of America. The Code played a significant role in the development of the modern
} 
Alexander II of Russia to arrive at an 'International Declaration concerning the Laws and Customs of War'. ${ }^{152}$ While the Hague Conference, with twenty-six governments present, failed to reach agreement on the Conference's primary object - the reduction of armaments, it did result in the adoption of number of conventions dealing with the regulation of armed conflict. One of these conventions, the 1899 Hague Convention on the Laws and Customs of War on Land ${ }^{153}$ (hereinafter: "the 1899 Hague Convention") is relevant also for the protection of cultural property. Furthermore, provision was made during the conference for the convening of a second conference, which took place in 1907. One of the results of this Second Hague Conference was the adoption of the 1907 Hague Convention on the Laws and Customs of War on Land154 (hereinafter: "the 1907 Hague Convention"), which, like its 1899 predecessor, contains provisions relevant for the protection of cultural property. The adoption and entry into force of the 1907 Hague Convention would not annul the 1899 Hague Convention. While it supersedes its predecessor in situations where all belligerents have become a State Party, the 1899 Hague Convention remains in force between those State Parties that did not become a State Party to the 1907 Convention. ${ }^{155}$

The 1899 and 1907 Hague Convention show great similarity in structure and content: both consist of a general part and an annex that contains the actual rules on warfare. Two sections of these annexed 'Regulations respecting the laws and customs of

international laws of war, as it was the first attempt of codification. While its Art. 31 recognises the appropriation of public property, Art. 34 excludes the following objects from public property as defined in Art. 31: the property belonging to churches, to hospitals or other establishments of an exclusively charitable nature, to establishments of education, or foundations for the promotion of knowledge, whether public schools, universities, academies of learning or observatories, museums of the fine arts, or of a scientific character. Moreover, Art. 35 determines that "classical works of art, libraries, scientific collections or precious instruments (...) must be secured against all avoidable injury, even when they are contained in fortified places whilst besieged or bombarded". A next step heightening the awareness for the protection of cultural property, was the Brussels Conference held in 1874. Initiated by Henry Dunant and supported by the Russian Emperor, the aim of the conference was the adoption of an international declaration on the laws and customs of war. Art. 8 of the draft-declaration stipulated that "the property of municipalities, that of institutions dedicated to religion, charity and education, the arts and sciences, even when State property, shall be treated as private property. All seizure or destruction of, or wilful damage to, institutions of this character, historic monuments, works of art and sciences, should be made the subject of legal proceedings by the competent authorities". Furthermore the draft declaration introduced a marking-system, that is the marking of buildings dedicated to art, science or charitable purposes by distinctive and visible signs. While the besieged had the duty to mark the buildings and to inform the enemy about the signs, the attacking force on the other hand had the corresponding plight to spare these buildings. Although the declaration has never been ratified, as the first international attempt to provide for the protection of cultural property, it did have influence on the development of the codification of laws (Toman, J., 1996, p. 9).

152 Projet d'une déclaration internationale concernant les lois et coutumnes de la guerre (Brussels Declaration) from 27 August 1874. See further on the Brussels Declaration: Ibid; Kaye, L., M., 1997, pp. 101-102; Odendahl, K., 2005, p. 28 with further references to English and German literature.

153 Convention (II) with Respect to the Laws and Customs of War on Land and its annex: Regulations concerning the Laws and Customs of War on Land. The Hague, 29 July $1899 .$.

154 Convention (IV) respecting the Laws and Customs of War on Land and its annex: Regulations concerning the Laws and Customs of War on Land. The Hague, 18 October 1907.

155 Ibid., Art. 4. 
war on land' hold provisions relevant for the protection of cultural property both against destruction and removal. In the following, the relevant articles from Section II on hostilities and Section III on military authority over hostile territory will be discussed. Given the close similarity between the 1899 and 1907 Hague Convention they can be discussed simultaneously. ${ }^{156}$ In the few instances that the protection granted by the 1907 Hague Convention surpasses the level of protection of the 1899 Hague Convention it will be indicated and discussed.

In analysing the 1899 and 1907 Hague Conventions as to the protection granted to cultural property during hostilities one must distinguish between articles of general application that apply to any objects, including cultural objects and articles dealing specifically with cultural property. Art. 23 is an article that belongs to the first category. It prohibits the destruction and seizure of the enemy's property unless it is imperatively demanded by the necessities of war. Hence, Art. 23 indirectly protects cultural objects against destruction and seizure. The protection is, however, limited by the exception of military necessity. According to the legal concept of military necessity the rules of the ius in bello may be overridden where imperatively demanded by the necessities of war.

Art. 27 deals specifically with the protection of different objects of cultural relevance against destruction during attack. ${ }^{157}$ It requests that "all necessary steps should be taken to spare as far as possible edifices devoted to religion, art, science, and charity (...), provided they are not used at the same time for military purposes (...)". Under Art. 27 in the version of the 1907 Hague Convention, the protection is extended to historic monuments. ${ }^{158}$ While Art. 27 aims at the protection of specific categories of immovable property, including buildings housing public collections, against damage and destruction, it indirectly contributes to the protection of movable cultural heritage included in these buildings. One last article that must be mentioned as being relevant for the protection of cultural property during hostilities is Art. 28 of the 1899 and 1907 Hague Conventions, which prohibits the pillage of a town or place, even when taken by assault. As an Article of general application, Art. 28 also prohibits the pillage of cultural property held within these towns or places.

\footnotetext{
156 Cf.: Odendahl, K., 2005, pp. 110-111. See also: Schindler, D. / Toman, J., 2004, pp. 55-87 where the provisions of the 1899 and the 1907 conventions are printed next to each other, allowing for more convenient comparison.

157 Art. 27 must be read in conjunction with Art. 25. While Art. 25 prohibits the attack of undefended towns or villages, Art. 27 seeks to limit the destructive impact of such attacks where they are not prohibited. Art. 27 is hence relevant for the protection of property of cultural relevance against damage or destruction when defended towns or villages are attacked.

158 Art. 27(1) of the regulation annexed to the 1907 Hague Convention reads: "In sieges and bombardments all necessary steps must be taken to spare, as far as possible, buildings dedicated to religion, art, science, or charitable purposes, historic monuments (Emphasis added) (...) provided they are not being used at the time for military purposes. It is the duty of the besieged to indicate the presence of such buildings or places by distinctive and visible signs, which shall be notified to the enemy beforehand". See further on the preventive protection against removal, destruction and damage of cultural property under the 1907 Hague Conventions, e.g.: Schorlemer, S.v., 1992, pp. 263-265; Kowalski, W.W., 1998, pp. 8-9.
} 
Section III of the Conventions deals with the rights and duties of the occupying authorities. Art. 46 clearly prohibits the confiscation of private property. Art. 47 prohibits any form of pillage more in general. The prohibition of Art. 47 is, however, compromised by Art. 53 that enumerates a number of categories of public property that may be requisitioned by the occupying army. Cultural property is not amongst the property listed. On the contrary, Art. 56(1) extends the protection granted to private property to public property that is of religious, charitable and educational character or that is dedicated to the arts and sciences. Furthermore, Art. 56(2) specifically bans any seizure of, or wilful destruction or damage to religious, charitable, and educational institutions, as well as to historical monuments, works of art or science, and makes them subject of legal proceedings. ${ }^{159}$

Whereas the previous sections discussed a number of rights and duties of belligerent parties and occupying authorities, they did not discuss the question of restitution. It is with regard to state liability that the wording of the 1899 and the 1907 Hague Conventions differ. While the 1899 Hague Convention does not elaborate upon the consequences in case its provisions have been breached ${ }^{160}$, the 1907 Hague Convention includes a provision on state liability. According to its Art. 3 "[a] belligerent party which violates the provisions of the said Regulations shall, if the case demands, be liable to pay compensation (...)". While Art. 3 must not be underestimated for the development of international law ${ }^{161}$, its relevance lies essentially in its signalling function rather than in introducing a different regime compared to its 1899 predecessor. This point can be illustrated with reference to the Chorzów Factory Case, which was ruled shortly after the Hague Conventions have been adopted. ${ }^{162}$

In the Chorzów Factory Case, the Permanent Court of International Justice (PCIJ) confirmed the principle that for the obligation to make reparations it is sufficient that a breach of a treaty-provision has occurred. There is no need for the treaty to state that the failure to apply the convention results in an obligation to make reparations:

"[i]t is a principle of international law, and even a general conception of the law, that any breach of an engagement involves an obligation to make reparation (...). Reparation is the indispensable complement of a failure to apply a convention, and there is no necessity for this to be stated in the convention itself'. 163

\footnotetext{
159 See further on the preventive protection against removal, destruction and damage of cultural property under the 1899 Hague Convention in particular Toman, J., 1996, pp. 10-13; Kaye, L., M., 1997, p. 102; Jenschke, C., 2005, pp. 38-47.

${ }^{160}$ See, e.g.: Körbs, H., 1996, p. 146; Jenschke, C., 2005, p. 47; Odendahl, K., 2005, p. 163.

161 Cf.: Kowalski, W.W., 1998, p. 9 with quotations from and references to Garner, J., 1920, p. 469; Freeman, A.V., 1955, p. 324.

162 Chorzów Factory Case (Germany v. Poland) PCIJ, Series A, No. 17, 1928, p. 29. The fact that the ruling postdates the adoption of the Hague Conventions does not take away that the principle that lies at the heart of the case was valid already prior to the Hague Conventions' adoption.

163 Ibid., S 103. Cf.: Henckaerts, J.-M. / Comité international de la Croix-Rouge, 2005, p. 537.
} 
Put differently, for an obligation to make reparations to exist, there is no need for what Jenschke calls a "primary restitution right". A primary right is a right explicitly provided for in treaty. Instead, the mere breach of a treaty provision suffices for the emergence of a right to reparations as "secondary right". ${ }^{64}$ If one applies this finding to the present analysis of the 1899 and 1907 Hague Convention, it appears that the inclusion of Art. 3 in the 1907 Hague Convention is not a necessary precondition for the obligation to make reparations. Instead, behaviour in breach of a treaty provision suffices as trigger for the obligation to make reparations. Consequently, such an obligation was implied in the provisions of the 1899 Hague Convention as secondary right.

Further to clarifying the relationship between breaching treaty provisions and the obligation to make reparations, the PCIJ in the Chorzów Factory Case also confirmed the primacy of restitution over other forms of reparations. The PCIJ held that the mere fact that a treaty obligation has been breached requires the state responsible to "wipe out, as far as possible, all the consequences of the illegal act and re-establish the situation which would, in all probability, have existed if that act had not been committed".165 The responsible State was under "the obligation to restore the undertaking and, if this be not possible, to pay its value at the time of the indemnification, which value is designed to take the place of restitution which has become impossible". ${ }^{166}$

With regard to the 1899 and 1907 Hague Conventions this primacy of restitution as established by the PCIJ means that despite Art. 3 not being tailored to cultural objects but constituting an abstract liability for violating one of the annexed provisions ${ }^{167}$ it provides for the physical restitution of cultural property. Only where restitution is impossible, can the responsible State take to other forms of reparations. ${ }^{168}$ Putting this finding together with the first finding of the Chorzów Factory Case, according to which the obligation to make reparations does not depend on being spelled out in a treaty provision, the supremacy of restitution applies also to the 1899 Hague Convention. Consequently, the obligation to restitute looted cultural property existed already under the 1899 Hague Convention despite the absence of an explicit provision in this respect.

The above analysis revealed that no material difference exists between the 1899 and the 1907 Hague Convention. ${ }^{169}$ While it is true that the 1899 Hague Convention misses

\footnotetext{
164 Jenschke, C., 2005, pp. 32-33.

${ }^{165}$ Crawford, J., 2002, pp. 47-48.

166 Factory at Chorzów, PCIJ Series A, No. 17 (1928), pp. 47-48. Cf.: International Law Commission, 2001, pp. 96-97.

${ }_{167}^{16}$ Jenschke, C., 2005, p. 364.

168 Cf.: Walter, B., 1988, p. 77; Freytag, C., 1996, p. 180; Jenschke, C., 2005, p. 48; Berezowski, C., 1948, p. 132(quoted by Kowalski, W.W., 1998, p. 9); Körbs, H., 1996, p. 146; Schorlemer, S.v., 1998, pp. 327 \& 330; See for a different opinion, according to which the provision cannot be interpreted as providing for the legal obligation to physically restitute cultural property: Kaye, L., M., 1997, p. 102; Kowalski, W.W., 1998, p. 10.

${ }^{169}$ An exception is the inclusion of historical monuments in Art. 27 of the 1907 Hague Convention.
} 
an explicit provision comparable to Art. 3 of the 1907 Hague Convention, this does not mean that the obligation to make reparations, i.e. to restitute cultural property removed in breach with the convention, was inexistent already under the 1899 Hague Convention. It is hence the 1899 Hague Convention that constitutes a watershed for the protection of cultural property in times of war as the first international legally binding instrument holding provisions relevant for the protection of cultural objects. ${ }^{170}$ Consequently, as per 4 September 1900, the date when the 1899 Hague Convention entered into force, a ban existed on looting of cultural property in armed conflicts and an obligation to restitute objects taken in breach of the 1899 Hague Convention.

The ban on looting and the obligation to restitute looted objects applied, however, only to State Parties of the Conventions. The Conventions' scope of application is furthermore limited by the so-called "general participation clause", according to which the rules of the Conventions apply only in the situation that all belligerents are state party. ${ }^{171}$ The influence of the Hague Conventions was put to a test only shortly after their entry into force with the outbreak of the First World War. ${ }^{172}$

\section{Peace Treaties CONCluding the First World War}

Accounts of the First World War (1914-1918) generally stress the destructive impact of the war as the first major conflict fought in the technological age. The rapid development of technology also resulted in massive destructions of cultural property. ${ }^{173}$ One prominent example is the destruction of the University Library of Louvain. ${ }^{174}$ While the First World War had devastating effects on the physical integrity of cultural property; it is generally portrayed as a war without remarkable looting of cultural

170 Schulze, D., 1983, p. 33; Kaye, L., M., 1997, p. 100; Jenschke, C., 2005, p. 47; Odendahl, K., 2005, p. 109. The relevance of the 1907 Hague Convention, which entered into force on 26 January 1910, lies essentially in extending the preventive protection regime to historical monuments (Art. 27 of the annexed Regulations) and in reminding the state parties in its Art. 3 of the consequences when failing to comply with the provisions. Its application is subject to the same limitations, in particular the "general participation clause" as its predecessor.

171 Art. 2 of the 1899 Convention reads: "The provisions contained in the Regulations mentioned in Art. 1 are only binding on the Contracting Powers, in case of war between two or more of them. These provisions shall cease to be binding from the time when, in a war between Contracting Powers, a non-Contracting Power joins one of the belligerents". Art. 2 of the 1907 Hague Convention reads:" The provisions contained in the Regulations referred to in Art. 1, as well as in the present Convention, do not apply except between Contracting powers, and then only if all the belligerents are parties to the Convention". Cf.: the 1954 Convention for the Protection of Cultural Property in the Event of Armed Conflict discussed below in chp. 1.\$1.VI.1 that does not contain such a general participation clause.

172 All powers of the Allied Entente were State Parties to both the 1899 and 1907 Hague Conventions. From the Central Powers, Germany and Austria-Hungary were also State Parties to both Conventions. Italy, that later joined the Allies, as well as the Ottoman Empire and Bulgaria that both joined the Central Powers were only State Parties to the 1899 Hague Convention. Source: http://www.icrc.org/ihl.nsf/WebSign?ReadForm\&id=195\&ps=P and http://www.icrc.org/ihl.nsf/WebSign?ReadForm\&id=150\&ps=P (last visited 4 August 2008). 173 See, e.g.: Siehr, K., 1993, p. 112; Poulos, A., Helleni, 2000, p. 19.. Cf.: Odendahl, K., 2005, p. 163.

174 See further on the destruction of the library, e.g.: Schivelbusch, W., 1988. 
property. ${ }^{175}$ Regardless of the fact that looting of cultural property did not reach the intensity known from the Napoleonic raids, the restoration of culturally relevant objects was addressed in the peace treaties. All of the peace treaties concluded (Versailles ${ }^{176}$, St. Germain $^{177}$, Trianon ${ }^{178}$, Neuilly ${ }^{179}$, Sèvres/Lausanne ${ }^{180}$ and Riga ${ }^{181}$ ) include provisions on the restitution of cultural objects, as well as reparations concerning cultural objects. ${ }^{182}$

In the following paragraphs, the relevant provisions of the Treaty of Versailles signed between the Principal Allies, the associated powers and Germany shall be discussed. ${ }^{183}$ We will discuss specific obligations for Germany as provided for in the Artt. 245-247 and show that the articles encompass a variety in obligations. Before turning to these articles, which explicitly deal with specific objects of cultural relevance, reference should be made to Art. 238 of the Treaty holding a general provision on restitution. ${ }^{184}$ Providing for the restitution of "objects of every nature", the Article is also relevant for cultural objects provided they could be identified in German territory or that of the German Allies. ${ }^{185}$

175 Engstler, L., 1964, p. 122; Jenschke, C., 2005, p. 139.

176 Treaty of Peace between the Allied and Associated Powers and Germany signed at Versailles, June 28th, 1919.

177 Treaty of Peace between the Allied and Associated Powers and Austria; Protocol, Declaration and Special Declaration signed at St. Germain-en-Laye, 10 September 1919.

178 Treaty of Peace Between The Allied and Associated Powers and Hungary; Protocol and Declaration signed at Trianon, 4 June 1920.

179 Treaty of Peace between Poland, Russia, and Ukraine signed at Riga, 18 March 1921.

${ }^{180}$ See on the failure and content of the Treaty of Sèvres and the subsequent Treaty of Lausanne: Jenschke, C., 2005, pp. 144-145.

${ }^{181}$ Treaty of Peace between Poland, Russia, and Ukraine signed at Riga, 18 March 1921.

182 E.g. the Treaties of Saint Germain and Trianon included provisions under which Austria and Hungary had to: "to surrender to each of the Allied and Associated Powers respectively all records, documents, objects of antiquity and of art, and all scientific and bibliographical material taken away from the invaded territories, whether they belong to the State or to provincial, communal, charitable or ecclesiastical administrations or other public or private institutions" (Art. 175 of the Treaty of Saint German. Art. 177 of the Treaty of Trianon provides that "[w]ith regard to all objects or documents of an artistic, archaeological, scientific or historic character forming part of collections which formerly belonged ot the Government or the Crown of the Austro-Hungarian Monarchy and are not otherwise provided for by the present Treaty, Hungary undertakes to negotiate, when requuired, with the States concerned for an amicable arrangement whereby any portion thereof or any objects or documents belonging thereto which ought to form part of the intellectual patrimony of the said States may be returned to their country of origin on terms of reciprocity”. Cf.: Jote, K., 1994, p. 265; Odendahl, K., 2005, p. 163; Prott, L.V., 2008, p. 176

${ }^{183}$ For elaborations on the other peace treaties see: Engstler, L., 1964, pp. 129-131; Jote, K., 1994, pp. 265269; Jenschke, C., 2005, pp. 142-149; Vrdoljak, A.P., 2006, pp. 80-86.

184 Art. 238 reads: "In addition to the payments mentioned above Germany shall effect, in accordance with the procedure laid down by the Reparation Commission, restitution in cash of cash taken away, seized or sequestrated, and also restitution of animals, objects of every nature and securities taken away, seized or sequestrated, in the cases in which it proves possible to identify them in territory belonging to Germany or her allies (...)”. See also: Engstler, L., 1964, p. 124.

${ }^{185} \mathrm{Ibid}$; Jenschke, C., 2005, p. 140. 
Art. 245 stipulates that Germany should restore to France "the trophies, archives, historical souvenirs or works of art" that had been removed during the war years 19141918, as well as cultural objects that had been removed previously during the FrancoPrussian War of 1870-1871. The exact scope of the objects to be returned was yet to be communicated by the French Authorities to the German Government. ${ }^{186}$ Noteworthy about this Article is that it orders not only the restitution of cultural objects that have been looted by the Germans during the First World War. Instead, the Article also provides for the return of "the trophies, archives, historical souvenirs or works of art" that had been removed during the Franco-Prussian War of 1870-1871.187 While the looting of "trophies, archives, historical souvenirs or works of art" during the First World War breaches Art. 23 of the 1899 and 1907 Hague Conventions ${ }^{188}$, the removal during the Franco-Prussian War in the years 1870-1871 preceded the adoption of the Hague Conventions. However, regardless of the fact that the removal did not constitute a breach of an international treaty ${ }^{189}$, the Parties to the Versailles Treaty could of course include a retroactive provision due to their contractual freedom. Rather than restitution the return of the objects removed during the Franco-Prussian War must be considered as a form of reparations for the losses suffered by France. After all, from a strict legal point of view the taking of the objects the Franco-Prussian War occurred before the formulation of the ban on looting. ${ }^{190}$

Art. 246 consists of two obligations, each providing for the return of one specifically denoted object. ${ }^{191}$ According to the first obligation, Germany has to return a rare and ancient Quran to the King of the Hedjaz. The Quran originally belonged to the Caliph

\footnotetext{
186 Art. 245 reads: "Within six months after the coming into force of the present Treaty the German Government must restore to the French Government the trophies, archives, historical souvenirs or works of art carried away from France by the German authorities in the course of the war of 1870-1871 and during this last war, in accordance with a list which will be communicated to it by the French Government; particularly the French flags taken in the course of the war of 1870-1871 and all the political papers taken by the German authorities on October 10,1870, at the chateau of Cercal, near Brunoy (Seine-et-Oise) belonging at the time to Mr. Rouher, formerly Minister of State".

187 Jenschke reports that Germany first protested against the restitution of objects that had been it its possession for some fifty years but finally gave in. Jenschke, C., 2005, p. 140.

188 Both Germany and France were state parties to the 1899 and 1907 Hague Conventions. Germany had ratified the 1899 Convention on 04.09 .1900 and the 1907 on 27.11.1909. France had ratified the 1899 Convention on 04.09.1900 and the 1907 Convention on 07.10.1910.

189 In the section discussing the emergence of customary law further below (chp. 1.\$1.VIII) it will be shown that the Franco-Prussian War also preceded the existence of a ban on looting of customary international law.

190 See below on the Development of Customary Law.

191 Art. 246 reads: "Within six months from the coming into force of the present Treaty, Germany will restore to His Majesty the King of the Hedjaz the original Koran of the Caliph Othman, which was removed from Medina by the Turkish authorities and is stated to have been presented to the ex-Emperor William II. Within the same period Germany will hand over to His Britannic Majesty's Government the skull of the Sultan Mkwawa which was removed from the Protectorate of German East Africa and taken to Germany. The delivery of the articles above referred to will be effected in such place and in such conditions as may be laid down by the Governments to which they are to be restored".
} 
Osman and had been removed from Medina by the Turkish authorities. ${ }^{192}$ Whether the Quran was ever presented to the Emperor William II, as is presumed in the Article, is not established. ${ }^{193}$ The German State held that the Quran had never been given to the Emperor, nor had it been taken to Germany. ${ }^{194}$ In any event, the Quran was never returned by Germany. ${ }^{195}$ What is noteworthy about this obligation is the fact that the party to receive the Quran was not amongst the parties negotiating the Versailles Treaty. Instead, the Quran was to be returned to the king of Hedjaz, Sharif Husayn ibn 'Ali. The inclusion of this provision as lobbied for by the British must be understood as being in the general interest of the British in supporting the Hedjaz revolt against the Turkish rule. ${ }^{196}$ In how far such a provision must be considered as a form of reparation will be discussed further below, together with the question in how far the second obligation qualifies as a form of reparation.

The second obligation of Art. 246 was also lobbied for by the British. According to the second part of Art. 246, Germany had to return the skull of Sultan Mkwawa to his Britannic Majesty's Government in Tanganyika. ${ }^{197}$ When the Versailles Treaty was

192 The literature does not specify the period in time.

193 Engstler, L., 1964, p. 127.

194 Letter by the German Delegation dated 21 January 1921 to the President of the Peace Conference (Department of State Publication 2724, Conference Series 92, The Treaty of Versailles and After, Annotations of the text of the Treaty, Washington 1947, p. 523) quoted by: Ibid.

195 Ibid. The current whereabouts of this Quran are unknown. An inquiry with the Research Center for Islamic History, Art and Culture (IRCICA) in Istanbul did not confirm that the rare and ancient copy of the Quran, attributed to Caliph Osman that is presently held at Topkap1 Palace in Istanbul is the same Quran as referred to in Art. 246 of the Versailles Treaty. According to the information received from IRCICA, the Quran held at Topkapi Palace "has been safeguarded in Istanbul for more than one century prior to the First World War. For this reason there is no chance that the Topkap1 Mushaf is the same one that is referred to in the Treaty of Versailles". Information received by email dated 28 May 2008, on file with the author.

${ }^{196}$ The Hedjaz region in western Saudi Arabia (now included in the Kingdom of Saudi Arabia) was occupied in 1517 by the Turks. Nominal rule remained in the hands of the sharifs ("nobles") of Mecca until the religious upheavals at the beginning of the 19th century. The Ottomans directly controlled the Hedjaz after 1845. In 1916, during World War I, Sharif Husayn ibn 'Alī, who claimed lineal descent from the Prophet Muhammad, revolted against Turkish rule. Hedjaz. (2008). In Encyclopædia Britannica. Retrieved June 12, 2008, from Encyclopædia Britannica Online,

http://www.britannica.com/EBchecked/topic/259797/Hejaz. In 1916, an agreement was concluded between the Hedjaz and the British. The agreement concerned alleged assurances made by the British to support the founding of an independent Arab kingdom stretching from Damascus to Palestine. In particular, Britain had expressed its preparedness to recognize the independence of the Arabs across the Middle East. Ratliff, W., 1996, p. 185.

197 Under British Administration, former German East Africa was renamed as Tanganyika Territory. Tanganyika became independent on December 9, 1961 and in 1964 the United Republic of Tanzania was founded by the presidents of Tanganyika and Zanzibar. Tanzania (2008). In Encyclopædia Britannica. Retrieved May 16, 2008, from Encyclopædia Britannica Online, http://www.search.eb.com/eb/article37594. 
negotiated, Great Britain had just taken over the rule over Tanganyika, the former German East Africa from the Germans. ${ }^{198}$

In the literature, Art. 246 and the obligation to return Mkwawa's skull receive little attention. While Art. 246 has raised academic legal interest for its specificity ${ }^{199}$, the subject matter and the motivation of the British for including such a provision has received little interest. ${ }^{200}$ Where Art. 246 is mentioned in the literature, it is in the context of Art. 245 and Art. 247, as articles "providing for the restitution of works of art" 201 or cultural property 202 respectively as articles holding "specific obligation for Germany concerning cultural property". ${ }^{203}$ However, none of the obligations constitute a form of restitution or reparation: none of the obligations contained in Art. 246 contributes to "wiping out all the consequences of the illegal act and re-establish the situation which would, in all probability, have existed if that act had not been committed". ${ }^{204}$ For this reason, neither the provision on the return of the Quaran nor the provision on the sultan's skull constitutes a form of reparation. ${ }^{205}$ Instead, both provisions are essentially unrelated with the subject-matter of the peace treaty but were included in the treaty due to the British negotiating power. ${ }^{206}$

Art. 247 holds obligations for Germany with regard to the destruction of the Library of Louvain and specific artworks. ${ }^{207}$ In the first place, Germany had to provide the University of Louvain with "manuscripts, incunabula, printed books, maps and objects of collection corresponding in number and value to those destroyed in the burning of

198 See Art. 119 of the Versailles Treaty and Art. 22(5) of the Convenant of the League of Nations. On May 7, 1919, the Supreme War Council of the Allied Powers decided on the allocation ofthe Geman colonies to the various mandatories.

${ }^{199}$ See, e.g.: Wilson, G.G., 1939, p. 337 who uses the example of the skull to underline his main thesis that during the twentieth century there has been a change in international agreements from general topics and provisions to specific ones. See also: Bottom, W.P., pp. 16-17.

200 Winans, E.V., 1994, p. 234. See for a more elaborate discussion of the provision and the motivation of the British below in chp. 2.\$2.III.1.

201 See, e.g.: Hollander, B., 1959, p. 32.

202 See, e.g.: Gattini, A., 1996, p. 5; Birov, V.A., 1998, p. 209; Keane, D., 2004, pp. 7-8.

203 Engstler, L., 1964, p. 126; Jenschke, C., 2005, p. 139; Odendahl, K., 2005, p. 164. An exception is Siehr who discusses only Artt. 245 and 247 but does not mention Art. 246: Siehr, K., 1993, pp. 116-117.

${ }^{204}$ Crawford, J., 2002, pp. 47-48. Cf.: Wolfrum, R., 1987, p. 352.

205 Cf.: Gattini, A., 1996 , p. 5.

${ }^{206}$ Cf.: Bottom, W.P., p. 16 who comments upon the Article as "being of secondary importance, to say the least".

207 Art. 247 reads: "Germany undertakes to furnish to the University of Louvain, within three months after a request made by it and transmitted through the intervention of the Reparation Commission, manuscripts, incunabula, printed books, maps and objects of collection corresponding in number and value to those destroyed in the burning by Germany of the Library of Louvain. All details regarding such replacement will be determined by the Reparation Commission. Germany undertakes to deliver to Belgium, through the Reparation Commission, within six months of the coming into force of the present Treaty, in order to enable Belgium to reconstitute two great artistic works:

(1) The leaves of the triptych of the Mystic Lamb painted by the Van Eyck brothers, formerly in the Church of St. Bavo at Ghent, now in the Berlin Museum;

(2) The leaves of the triptych of the Last Supper, painted by Dierick Bouts, formerly in the Church of St. Peter at Louvain, two of which are now in the Berlin Museum and two in the Old Pinakothek at Munich". 
the Library of Louvain" (first paragraph). The library had been burned at the end of August 1914 by German Soldiers. 208 As an "edifice devoted to science" the library of Louvain was granted protection under the 1899 and 1907 Hague Conventions (Art. 27). ${ }^{209}$ For this reason, the destruction of the library qualifies as violation of the Hague Conventions. ${ }^{210}$

Given the impossibility for Germany to physically restitute the burned collection, Belgium could only seek reparations. Rather than seeking financial compensation, Art. 247 obliges Germany to replace the lost collection. This measure clearly qualifies as a measure of reparations as it seeks to re-establish (in as far as it is possible) the situation which would have prevailed if no breach of an international obligation had occurred.211 Siehr fittingly qualifies the reparation as "compensation in specie"212; Gattini speaks of "replacement in kind". 213

According to the second obligation of Art. 247, Germany had to hand over panels from polyptychs by Van Eyck, respectively by Dierick Bouts. The panels had originally been placed in the church of St. Bavo in Ghent, respectively the church of St. Peter in Louvain. ${ }^{214}$ At the time when the Versailles Treaty was drafted, the panels had been held in the Bode Museum in Berlin (The panels of the Mystic Lamb by Van Eyck plus two panels from the polyptych of Bouts), respectively the Old Pinakothek at Munich (the other two panels from the polyptych The Last Supper by Dierick Bouts). ${ }^{215}$ The panels had not been looted during the First World War but instead had been legally transferred to Germany prior to the war. ${ }^{216}$ For this reason, the return of the panels to Belgium does not qualify as restitution but as reparation for the serious losses suffered by Belgium during the war. ${ }^{217}$

The legal analysis of Artt. 245-247 reveals a more nuanced picture with regard to their substance than it is generally sketched in literature according to which provisions

\footnotetext{
208 The library and some 300.000 books and 500 manuscripts were destroyed. See further: Garner, J., 1920, p. 438; Schivelbusch, W., 1988.

209 Both Germany and Belgium had ratified the 1899 and the 1907 Hague Convention.

210 The Germans sought to justify the act by claiming that Belgian civilians were using the building to shoot at German troops. In other words, the Germans sought to invoke the exception of Art. 29 in case buildings were used for military purposes. Eirinberg, K.W., 1994, p. 27.

211 Wolfrum, R., 1987, p. 352. Graham, G.M., 1987, p. 760; Jenschke, C., 2005, p. 141, fn. 549.

212 Siehr, K., 1993, p. 116. For the reasons set out above the term is more appropriate than "restitution in kind" as proposed by Kowalski, W.W., 1998, p. 35.

213 Gattini, A., 1996, p. 5.

214 As for the panels of the Mystic Lamb it is known that they had been acquired by King Fredrick William III in 1821 from an English collector. Ibid. See further: Visscher, C.d., 1935.

215 Art. 247 sub 1 and 2 Versailles Treaty.

216 Siehr, K., 1993, p. 152; Siehr, K.G., 2006, p. 128. See further on the sale of the panels: Thalheimer, S., 1967, pp. 119-121. The return of the panels by Germany to Belgium would not be the first time that the panels were returned: in 1794, the panels had been looted by the French Revolutionary Troops from the St. Bavo Cathedral in Ghent (then still falling under the Republic of the Seven United Netherlands) and were taken to Paris. Engstler, L., 1964, p. 108. See further: Gheyn, C.v.d., 1945.

217 Gattini, A., 1996, p. 5; Kowalski, W.W., 1998, p. 36; Jenschke, C., 2005, p. 141.
} 
provide for the "restitution" of "works of art" or "cultural property". 218 According to our analysis, only Art. 245, which provides for the restoration of cultural objects to France, provides for the restitution in the strict legal sense. This statement must be further narrowed down to the objects that were removed during the war years 19141918. Art. 246 and Art. 247 do not provide for restitution in the strict legal sense. Art. 247 does, however, constitute a form of reparation. For this reason, we will first turn to Art. 247 before making some concluding remarks on Art. 246, which neither provides for restitution nor another form of reparation. ${ }^{219}$ Art. 247, concerning the burned collection of the library of Louvain and the polyptychs by Van Eyck and Bouts, provides for two different forms of reparations: first, the obligation to provide the University of Louvain with "manuscripts, incunabula, printed books etc." qualifies as a reparation measure for replacement/ compensation in kind. It does not provide for restitution in kind. The second obligation provided for by Art. 247, to return valuable polyptychs by Van Eyck and Bouts to Belgium constitutes a specific obligation of reparation. ${ }^{220}$ As the works had been legally acquired already prior to the war, their return does not qualify as restitution. As a form of reparation it falls in the same category as the obligation of Art. 245 providing for the return of the cultural objects removed during the Franco-Prussian War in 1870-1871.

Art. 246, finally, concerning an ancient Quran and the skull of Mkwawa, cannot be understood as a form or reparation. Reparations seek to "wipe out all the consequences of the illegal act and re-establish the situation which would, in all probability, have existed if that act had not been committed". ${ }^{221}$ The obligations to return the Quran to the King of Hedjaz and to transfer the skull of Mkwawa to the British do not seek to reestablish the situation as it existed prior to the war. Instead, the obligations imposed on Germany seek to improve British political ties with the Hedjaz and the Uhewe in Tanganyika. Consequently, the Article has to be understood as the result of British negotiating power in the context of the peace treaty negotiations.

In conclusion, Artt. $245-247$ of the Treaty of Versailles have in common that they provide for transfers of culturally relevant objects. However, not all deal with the restitution of cultural property. This is only the case for that part of Art. 245 that deals with the restitution of cultural property removed during the war years 1914-1918. The provision with regard to objects removed prior to the emergence of the ban on looting

\footnotetext{
${ }^{218}$ Merryman, J.H., 2007, pp. 57-58.

${ }^{219}$ Cf.: Gattini, A., 1996, p. 5 where he states that "of the three relevant Artt. (Artt. 245-247 K.L.) only one seems to be connected with the issue of reparations".

${ }^{220}$ The polyptychs have been returned to the churches where they had originally been held. The polyptych by Van Eyck is in the St. Bavo Cathedral in Ghent whereas the polyptych by Bouts is in the Church of St. Peter at Louvain. Both works are protected by the Belgian Monument Decree of 3 March 1976 as later amended (Decreet tot bescherming van monumenten en stads- en dorspgezichten"). The Belgian act for the protection of immovable cultural property includes movable works that form an integral part of an immovable structure in its scope of protection. See further on the Belgian Monuments act: Draye, A.M., 2007, pp. 62-68.

${ }^{221}$ Crawford, J., 2002, pp. 47-48. Cf.: Wolfrum, R., 1987, p. 352.
} 
in the 1899 and 1907 Hague Conventions qualifies as a form of reparation, as it is also the case with for Art. 247.

\section{THE INTERBELLUM}

Artt. 245-247 of the Versailles Treaty have been characterised as having created "a positive precedent for the restitution of cultural property following conflict". ${ }^{222}$ In first instance, however, the developments following the Treaty of Versailles did not change the protection available. Attempts taken during the Interbellum to improve the protection of cultural property by legal means failed.223 The only treaty of relevance for the protection of cultural property in times of war concluded in this period is the Roerich Pact on the Protection of Artistic and Scientific Institutions and Historic Monuments. ${ }^{224}$ It constitutes the first treaty ever adopted that was dedicated to the protection of cultural objects. ${ }^{225}$ The Roerich Pact, which covers both situations of war and peace, seeks to protect historic monuments, museums, scientific, artistic, educational and cultural institutions (Art. 1). Its relevance and significance is, however, limited due to its geographical application: as a multilateral treaty concluded between the United States of America and the other American Republics it applies only to the protection of cultural property on the American continent. Furthermore, it is very general in approach and does not provide for the restitution of cultural property. ${ }^{226}$

Consequently, in respect of treaty law, the legal situation at the outbreak of the Second World War was unchanged from the time of the First World War. The relevant treaties in force were the 1899 and 1907 Hague Convention on the Laws and Customs of War on Land. 227

\section{RESTORATION OF RIGHTS AFTER WORLD WAR II}

The destruction and displacement of cultural property during the Second World War (1939-1945) dwarfed any previous looting or destruction of cultural property.228

\footnotetext{
222 Birov, V.A., 1998, p. 209.

${ }^{223}$ See further on the draft convention considered by the League of Nations 'for the Protection of Historic Buildings and Works of Art in Time of War': Strebel, H., 1955/56, p. 41-44; Kaye, L., M., 1997, p. 103; Odendahl, K., 2005, pp. 112-115. This convention must not be confused with three other draft conventions discussed by the League of Nations during the period 1933-1939 which concerned the return of cultural objects removed against national export rules in times of peace, which are discussed in chp. 1.S2.I. dealing with the protection of cultural objects in times of peace.

224 Roerich Pact: Protection of Artistic and Scientific Institutions and Historic Monuments, Montevideo, April, 15, 1935, 49 Stat. 3267, TS No. 899, 167 LNTS 279.

${ }^{225}$ Cf.: Odendahl, K., 2005, p. 131.

${ }^{226}$ See further: Merryman, J.H., 1986, p. 835; Odendahl, K., 2005, pp. 115-116.

${ }^{227}$ See further below in chp. 1. \$1.VIII on the question in how far the legal situation had changed due to the developments of rules of customary law.

228 See, e.g.: Nicholas, L., H., 1997, p. 39; Schmidt, W., 1997, p. 95.
} 
World War II is especially associated with the looting of cultural property, which is a result of the looting's extent, its organisation, as well as the underlying intent. ${ }^{229}$

Estimates and figures of the looting may vary, however, they all confirm that the Nazi art deprivation by far exceeded earlier lootings, including the campaigns of Napoleon outlined above. ${ }^{230}$ In the following, background information to the looting of the Nazis in the occupied territories will be given before turning to the question of restitution. The question of the "internal Nazi art looting", i.e. the confiscation of Jewish property within German state borders from 1933 onwards and the internal restitution will be discussed separately below. ${ }^{231}$

The art looting by the Nazis was outstanding both for the amount of looted cultural objects and for the professional and bureaucratic organization of the raids. Never before had the "looters" been that well trained in the fields of the fine arts. ${ }^{232}$ The Nazi art looting constitutes "the most coherent attempt by one group of people to loot material on a systematic basis and on a breathtaking (...) scale". ${ }^{233}$ Out of Hitler's obsession for art, the megalomaniac illusion to establish a Führer-Museum in Linz as the world's richest gallery had been born. The museum's collection was to include only the finest art of Europe. The exhibits were to be compiled by either purchase, barter or simple theft. ${ }^{234}$ The establishment of the Führer-Museum was of such priority that it influenced the organisational structure of Hitler's executive forces: within the National Socialist German Workers' Party (NSDAP), there was a genuine looting bureaucracy: well organized, powerful, and answering only to the top leaders of the party. ${ }^{235}$ In January

${ }^{229}$ Cf.: Clay, L.D., 1950, p. 341; Odendahl, K., 2005, p. 117.

230 An often quoted figure for the number of works of art spoliated from the occupied countries speaks of more than three million works of art, which corresponds to about "one-fifth of the world's entire art" (Chesnoff, R.Z., 2000, p. 38). Another source states that the Nazi loot "totalled more than 21,000 item of art, paintings, furniture, textiles and similar valuable antiquities", suggesting a number less great (Marchisotto, 1974, p. 701). Another author speaks of an estimated of 220,000 stolen works or art from museums and private collections throughout Europe (Kempster, N., 1998). As for France, one source speaks of some 21,000 art objects that were gathered during the four years of the plundering under the Einsatzstab Reichsleiter Rosenberg (ERR) (Chamberlin, R., 1983, p. 161). Another source speaks about 100.000 works of art that have been clearly identified as being stolen during the years 1941-1944 (Mattéoli Report I, p. 80 cited by Anglade, L., 1999, p. 301). The value or the stolen works has been set at $\$ 2.5$ billion in 1945 which corresponds to $\$ 20.5$ billion in 2000 (M.B., November 71998 \& Bazyler, M., 2001, p. 161). The difference in estimates and figures can to some extent be explained both by different understandings of what constitutes a cultural object and whether a figure aims solely at straightforward thefts and confiscations or whether it covers also forced sales and other involuntary form of loss. See for further details and specification: Petropoulos, J., 2000, para. 369.

${ }^{231}$ Whereas it might surprise the reader at first sight that questions of internal looting and restitution are discussed in a chapter dealing with the emergence of rights and obligations with regard to the protection of cultural objects under public law there are several reasons to include these subjects. At this point, we limit ourselves to referring to the fact that the internal restitution was to a great extent brought about by public international law.

232 Nicholas, L., H., 1997, p. 39.

${ }^{233}$ Kowalski, W.W., 1998, p.ix.

234 Weil, S., 1999, p. 287.

235 Turner, M.I., 1999, p. 1512. 
1934, Alfred Rosenberg received orders by Hitler to command the 'Dienststelle des Beauftragten des Führers für die Überwachung der gesamten geistigen und weltanschaulichen Schulung und Erziehung der NSDAP' (DBFU). ${ }^{236}$ To carry out this mission, Rosenberg turned the DBFU into an extremely well- organized apparatus by introducing several (sub-) offices. In July 1940, the notorious Einsatzstab Reichsleiter Rosenberg (ERR) was established. As the largest and most powerful of all organizational units dealing with arts it became the Reich's art plunder instrument in the occupied territories. ${ }^{237}$ Its official mission was the tracking and seizure of works of art and the transfer of these objects to Germany. ${ }^{238}$ At first, the mission of the ERR focussed on "ownerless" Jewish propery. 239 However, within two months, the mission was extended to cover any "Ownerless" cultural property. ${ }^{240}$ The ERR consisted of several 'Sonderstäbe' (individual command forces) each responsible for a specific field of expertise. As to the relation between the ERR and the DBFU, each office of the DBFU was supported by one corresponding Sonderstab, which moved parallel to the German occupation forces. The occupied territories became scene of the greatest systematic theft of cultural property ever to occur in history.

Another aspect making the looting by the Nazis exceptional is the fact that the looting formed an explicit part of the policy of Hitler. ${ }^{241}$ Art was instrumentalised to serve the bigger, political and ideological end of Hitler. ${ }^{242}$ Not only did the amassing of works of art seek to glorify the German people ${ }^{243}$, it was simultaneously used as an instrument to dehumanize non-Aryan races, in particular the Jews. ${ }^{244}$

In the Eastern European countries, especially the Soviet Union, the Nazi looting revealed its most destructive character. ${ }^{245}$ The occupation of the U.S.S.R, seen as inferior culture, was marked by wilful and systematic looting. Everything of the Eastern cultures was to be destroyed and the only objects to be spared were those of 'Germanic origin'. The invasion of Russia started in 1941 and in the following three years, the Nazis destroyed more than 1200 churches, 500 synagogues, and 500 museums. ${ }^{246}$ The ERR confiscated objects without caring at all about any justification. A special commission established after the war to investigate the looting in the Soviet Union came

\footnotetext{
${ }^{236}$ In English: "Plenipotentiary of the Führer for the Supervision of the Entire Intellectual and Ideological Enlightenment of the Nazi Party".

237 Poulos, A., Helleni, 2000, p. 34.

238 Palmer, N., 2000a, p. 7.

${ }^{239}$ Führerbefehl of 5 July 1940. Cf.: Petropoulos, J., 1996, p. 128.

240 Order of Field Marshal Keitel, High Command of the Armed Forces, dated 17 September 1940. Cf.: Petropoulos, J., 1996, p. 130.

241 Nicholas, L., H., 1997, p. 39.

${ }^{242}$ See in general: Petropoulos, J., 1996.

243 Ibid., p. 308.

244 Petropoulos, J., 1997, p. 111. Cf.: Nicholas, L., H., 1997, pp. 40-41. See in this respect below chp. 1. $\$ .4$ where the misappropriation of cultural objects from German Jews is discussed.

${ }^{245}$ Kowalski, W.W., 2000, p. 218.

246 Elmer, T., G., 2000, p. 119.
} 
to the conclusion that about 546,723 museum objects worth $\$ 1.25$ billion had been removed, destroyed, or damaged. ${ }^{247}$

In contrast to the operations in the Eastern occupied territories, the looting of artworks by the ERR in the Western occupied territories was less overtly in the sense that transactions were often disguised as sales transactions and focused more on private collections. Needless to say, the price often corresponded only to a fraction of the real market value. Palmer refers to these purchases as "pseudo-consensual transactions". 248 Public collections were hardly affected, as the museums and public collection were expected to become part of the Reich anyway. ${ }^{249}$

Due to the increasing of Allied bombings in 1943 and the advance of the Allies from summer 1944 onwards, the situations of the Nazis turned from aggressor into defender. Art treasures be it looted, purchased or originally in the possession of German museums had to be evacuated. Vast quantities of cultural objects, amongst it looted art, were transferred from Berlin to other parts of the Reich, especially to Upper Silesia, where the objects were hidden in churches, castles, depots, etc. ${ }^{250}$ The salt mine at Alt Aussee was only one of the more than thousand safeguarding places.

\section{Restitution of Cultural Objects loOted FROM the OCCUPied TERRITORIES ("EXTERNAL RESTITUTION")}

Given the complexities and the extent of the looting in the occupied territories the restitution of looted art works constituted a complex and difficult sub-task of the greater reparations to be paid by Germany. ${ }^{251}$ The (external) restitution regime splits in two phases. The first phase lasted until the early 1950s and consisted of the shaping and execution of the restitution under the auspice of the Allied countries occupying Germany. The second phase commenced in 1955 after Germany had regained its status as sovereign state with full responsibility for outstanding external restitutions.

The first phase breaks down into two sub-phases. At first, the Allied Forces closely cooperated during the preparatory process of agreeing on how restitution should be organised. During the second sub-phase, when the agreed principles had to be translated into legally binding instruments the Allies no longer acted in unison. In light of the rising tensions of the Cold War, the Allies introduced different laws in their respective Occupational Zone.

The Allied deliberations on how to shape restitution started already prior to the end of the war. On 5 January 1943, the Allies signed the 'Inter-Allied Declaration against

\footnotetext{
${ }^{247}$ Fiedler, W., 1997, p. 153; Wilske, S., 1998, p. 229.

248 Palmer, N., 2000a, p. 59.

249 Wilske, S., 1998, p. 227.

250 Vries, W.d., 1995, pp. 4-8.

251 Cf.: Kowalski, W.W., 1998, p. 37.
} 
Acts of Dispossession committed in territories under Enemy Occupation or Control'.252 The declaration, generally known as the 'London Declaration', warned the Axis powers and neutral countries that the signatory countries had the right to declare invalid any transaction within an occupied territory, regardless of the circumstances of the transaction. ${ }^{253}$ The London Declaration as such did not declare any transactions as invalid. With regard to the transactions possibly affected, the London Declaration covered outright confiscations, forced sales, forced donations and abandonments..$^{254}$ The Explanatory Note to the London Declaration confirms that the Declaration covers "all forms of looting to which the enemy has resorted. It applies, e.g., to the stealing or forced purchase of works of art just as much as to the theft or forced transfer of bearer bonds". ${ }^{255}$ The denunciation of forced sales and other forms of misappropriation other than confiscations is particularly important as these transactions are not covered by the ban on confiscation and pillage from the 1899 and 1907 Hague Conventions.

The warning that acquisitions might be declared invalid, also in neutral countries, was especially important in respect of bona fide third parties who might have acquired looted cultural objects in the meantime. While a great number of cultural objects had been gathered by the Germans in caves and other protected sites to hide and shelter the objects from the Allies other cultural objects had spread over collections in Germany, Europe or worldwide. ${ }^{256}$ This is especially the case for cultural objects that had been lost not as result of direct Nazi intervention but whose loss was nevertheless precipitated by the political, social and economical exclusions of the persecuted groups, in particular the Jews (e.g. forced sales).

As a declaration the London Declaration is not legally binding. This does not mean, however, that its provisions did not affect the course of restitution. On the contrary, the London Declaration significantly influenced the restitution regime and its provisions were referred to in numerous instruments and agreements dealing with the restitution of (cultural) property such as the Final Act of the Bretton Woods Conference, the Paris Conference on Reparations that are elaborated in the following. ${ }^{257}$ It is for this reason that the London Declaration has been coined the "nucleus of the restitution laws".258

\footnotetext{
252 Inter-Allied Declaration Against Acts of Dispossession Committed in Territories Under Enemy Occupation or Control, 8 Dep't St. Bull. 21 (1943).

253 The full text of the London Declaration is available online at:

http://www.lootedartcommission.com/inter-allied-declaration (last visited: 6 July 2008). The London Declaration is not numbered; hence no specific reference to the quoted passage can be given.

${ }^{254}$ Cf.: Schwarz, W., 1974, p. 15.

255 Para. 4 of the Explanatory Memorandum (Emphasis added). Online available at:

http://www.lootedartcommission.com/inter-allied-declaration (last visited: 6 July 2008). See further: Palmer, N., 2000a; Department for Culture Media and Sport, 2006a, p. 23, p. 61.

256 In 1943, with the increase of the Allied bombings of Germany the Nazis started to move and evacuate cultural objects, be it looted, purchased or from German collections, to hiding places in churches, castles and depots. Vries, W.d., 1995, pp. 4-8. One of the most prominent hiding places was the salt mine at Alt Aussee. It was, however, only one of some 1800 caches. Wilske, S., 1998, p. 228.

${ }^{257}$ Not further discussed here are the national laws adopted by countries not belonging to the main four Allies. It should, however, be pointed out that Sweden, Portugal and The Netherlands adopted national laws
} 
In July 1944, the Final Act of the Bretton Woods Conference was adopted during the United Nations Monetary and Financial Conference. ${ }^{259}$ While the Act as such does not include an explicit reference to the London Declaration, the latter was referred to by the participants of the conference. ${ }^{260}$ Also, Section VI of the Final Act on 'Enemy Assets and Looted Property' alludes to the London Declaration in emphasising that further to "open looting and plunder", property had been taken by "transfers under duress, as well as by subtle and complex devices (...) to give the cloak of legality to their robbery". Based on this awareness and in anticipation of the pending defeat of Nazi Germany and its Allies, the forty-four participants of the conference agreed to

"take immediate measures to prevent any disposition or transfer within territories subject to their jurisdiction of any (...) looted gold, currency, art objects, securities, other evidences of ownership in financial or business enterprises, and of other assets looted by the enemy". ${ }^{261}$

One of the measures to preserve and protect property, including cultural property, until concrete regulations on restitution had been adopted was Law No. 52 concerning the blocking and control of property. ${ }^{262}$ Law No. 52 was adopted by the Allied Governments in 1944. Due to its early adoption, Law No. 52 entered into force the moment the Allies started the military occupation of Germany. ${ }^{263}$ The aim of Law No. 52 was to safeguard external restitution by bringing all property under the control of the Military Government. 264 In accordance with the one but last sentence of the 1943 London Declaration ${ }^{265}$, Law No. 52 was directed not only at property that had been

implementing the London Declaration. None of these were, however, as extensive in scope as the London Declaration. See further: Prott, L.V. / O'Keefe, P.J., 1989, p. 810, Veraart, W., 2005, p. 59. The influence of the London Declaration furthermore extended to the protection of cultural property in times of peace. See futher below on the UNESCO Resolution 3.428 that explicitly refers to the London Declaration. Cf.: Prott, L.V. / O'Keefe, P.J., 1989, p. 816.

${ }^{258}$ Schmoller, G.v., et al., 1957, \53, p. 56.

259 United Nations Monetary and Financial Conference, Bretton Woods, New Hampshire, 1 July to 22 July 1944. 'Final Act and related documents. VI: Enemy assets and looted property'1946, p. 4.

${ }^{260}$ Kowalski, W.W., 1998, p. 42.

${ }^{261}$ Section VI, sub 2 of the Final Act of the Bretton Woods Conference

262 Military Government for Germany. U.S. Zone. Law No. 52: 'Blocking and control of property', Military Government Gazette (Germany, U.S. Zone, issue A). See for the full text of the Law No. 52: Kowalski, W.W., 1998, pp. 108-109, Annex 107. See further: Engstler, L., 1964, p. 140; Schwarz, W., 1974, pp. 25-28.

263 Law No. 52 as amended 3 April 1945. See for full text of the Law: Kowalski, W.W., 1998, pp. 108-109, Annex 107. See further: Dölle, H. / Zweigert, K., 1947; Schwarz, W., 1974, p. 25.

264 Art. 1(2) of Law No. 52 reads as follows: "Property which has been the subject of duress, wrongful acts of confiscation, dispossession or spoliation from territories outside Germany, whether pursuant to legislation or by procedures purporting to follow forms of law or otherwise, is hereby declared to be equally subject to seizure of possession or title, direction, management, supervision or otherwise being taken into control by Military Government". Schwarz, W., 1974, p. 25.

265 The relevant sentence of the 1943 London Declaration reads: This warning applies whether such transfers or dealings have taken the form of open looting or plunder or of transactions apparently legal in form, even when they purport to be voluntarily effected. The Declaration has been discussed in detail above. 
taken from territories outside Germany under a form of open looting but applied equally to objects that had been taken pursuant to legislation.

Half a year after the German capitulation in May 1945, the question of German war reparations was addressed by eighteen Allied countries that had convened for this purpose in Paris. ${ }^{266}$ In particular, the Paris Conference focussed on the policies and procedures to be established for the division of German assets among the eighteen governments. The conference resulted in the passing of a Final Act with an annexed 'Resolution on the Subject of Restitution'. ${ }^{267}$ The principles contained in this Resolution would serve as the basis for the later acts adopted by the Allied Control Council for Germany. ${ }^{268}$

According to the Resolution all cases of property loss precipitated by the Germans had to be examined in light of the 1943 London Declaration. Any identifiable object that had been removed from an occupied territory with or without payment was to be restituted. Where objects (not qualifying as cultural property) had been removed by the enemy but could not be located, the claims were to be taken into account under the general reparation claim. Claims concerning cultural property were explicitly exempted from the previous rule. Instead, the Resolution suggested compensation in specie / restitution in kind as appropriate remedy. 269

The restitution policies were further shaped in meetings of the Co-ordination Committee of the Allied Control Council. ${ }^{270}$ The Allied Control Council had been established by the Governments of the United States of America, the Soviet Union, the United Kingdom and the French Republic in August 1945. ${ }^{271}$ The Council's task was the central administration of Germany following the latter's unconditional surrender and the formal abolition of any German governance over the nation. In view of restitution, agreement had to be reached upon the definition of the term 'restitution'. In January 1946, the Allied Control Council issued a 'Declaration on the Definition of the Term

\footnotetext{
266 Paris Conference on Reparation (9th November, 1945, to 21st December, 1945).

${ }^{267}$ Final Act and Annex of the Paris Conference on Reparations, 14 January 1946, Annex: Resolution on the Subject of Restitution, p. 131, sub a)-d).

268 Kowalski, W.W., 1998, p. 42. See further below on the Allied Control Council's Handout on the Definition of the Term "Restitution".

269 The relevant provision reads: "As an exception to the above principle, objects (including books, manuscripts and documents) of an artistic, historical, scientific (excluding equipment of an industrial character), educational or religious character which have been looted by the enemy occupying Power shall, so far as possible, be replaced by equivalent objects if they are not restored".

270 See further: Kowalski, W.W., 1998, pp. 45-46.

271 Control Council Proclamation No. 1 from 30 August 1945. Available online at:

http://www.loc.gov/rr/frd/Military_Law/Enactments/01INT02.pdf (Last visited: 20 June 2008). The American, British, and French zones together made up the western two-thirds of Germany, while the Soviet zone comprised the eastern third. Berlin, the former capital, which was surrounded by the Soviet zone, was placed under joint four-power authority but was partitioned into four sectors for administrative purposes. Germany. (2008). In Encyclopædia Britannica. Retrieved June 24, 2008, from Encyclopædia Britannica Online, http://www.britannica.com/eb/article-58214.
} 
"Restitution".. 272 The Declaration essentially follows the 'Resolution on the Subject of Restitution' as annexed to the Final Act of the Paris Conference on Reparations. 273 Both, the Declaration and the Resolution, confirm the principles of the 1943 London Declaration in limiting restitution to identifiable objects. The general rule for objects whose loss was documented but that could not be identified was compensation in the form of reparation payments. Unique objects, however, were exempted from this rule. Rather than adding their value to reparation payments, these missing objects were to be replaced by equivalent objects. ${ }^{274}$

The preparatory instruments discussed above not only demonstrate awareness of the extent and form of the looting, they also reveal general agreement about the shaping of the external restitution. Furthermore, the preparatory instruments suggested that cultural objects that could not be restituted should be replaced by an equivalent object rather than addressing the claim by compensation. This preparatory stage constituted, however, only the first step towards the shaping of the restitution framework. In order to take effect, the principles agreed needed to be implemented in restitution laws.

While the Allied Forces initially intended to introduce one regime applicable to the entire territory of occupied Germany, the common approach did not outlast the preparatory stage. During the last phase of consolidating the agreed principles into binding laws, the Allied Forces no longer acted in concert. Consequently, the four military governments each introduced their own laws applicable in their respective Occupational Zone. ${ }^{275}$ The Soviet regime completely differed from the regimes adopted in the American, British and French Zones, which largely coincided. ${ }^{276}$

The subsequent analysis focuses on the U.S. implementation of restitution for the following reasons: not only did the regimes adopted in the Western Allied Zones largely coincide, the majority of looted cultural property was found in the U.S. Occupation Zone. ${ }^{277}$ Furthermore, the U.S. Government proved to be the most active proponent of

${ }^{272}$ Kowalski, W.W., 1998, p. 45. For the full text of the document titled 'Definition of the Term "Restitution"', Press Handout No. 151 see Annex 5 of Kowalski's book (p. 106).

273 Final Act and Annex of the Paris Conference on Reparations, 14 January 1946, Annex: Resolution on the Subject of Restitution, p. 131. See further above at fn. 267.

${ }^{274}$ While the agreement did not further define unique objects it called for a special instruction to do so. The instruction fixing the categories of unique goods subject to replacement was issued in April 1947 by the Allied Control Authority and listed the following categories as qualifying for objects of a unique character: a) works of art of the masters of painting, engraving and sculpture; b) the most important works of distinguished masters of applied art and outstanding anonymous examples of national art; c) historical relics of any kind; d) manuscripts, books (such as rare incunabula), books having an intrinsic value or historical character, or constituting rare examples even of modern times; e) objects of importance to the history of science. For the full text of the document titled 'Restitution: Objects of a Unique Character' from April 1947 see: Annex 6 in Kowalski, W.W., 1998, p. 107.

275 Kurtz, M., J., 1997, p. 113. An exception was the area of Great Berlin that was governed by a joined law of all Western Allies: Anordnung BKO (4) 180 of 26.7.1949. See further on the regime in the British Zone: Bentwich, N., 1955-56. See further on the failure of drafting laws applicable in all zones and the subsequent developments per zone: Schwarz, W., 1974, pp. 23-59.

${ }^{276}$ Cf.: Heuer, C.-H., 1999, p. 2562; Schönenberger, B., 2009, p. 243.

${ }^{277}$ See, e.g.: Hall, A.R., 1951, p. 337, Kurtz, M.J., 1998, p. 632; Harclerode, P. / Brendan, P., 1999, p. 164. 
an effective restitution regime and significantly influenced the other Western restoration regimes. ${ }^{278}$ The attitude by the United States can be explained by the fact that different from France and the United Kingdom it had not suffered destructions on its territory and therefore could act independently of any interest in reparation payments. ${ }^{279}$ On 12 February 1947, 'Military Government Regulations: Title 18: Monuments, Fine Arts and Archives' (hereinafter: "MGR Title 18”) was adopted for the U.S. Military Zone. 280 Further to implementing the provisions of Law No. 52 281 , MGR Title 18 also contained provisions on the preservation and administration, as well as on the exchange and replacements of cultural material. ${ }^{282}$ Part 1 of the title on "Policy and Organization" contains the provisions that are relevant for the restitution of cultural objects. According to Art. 18-106 "[i]dentifiable looted works of art and cultural materials will be restituted to the governments of the countries from which they were taken". With regard to the understanding of what constitutes 'looting', MGR Title 18 adopts a broad vision. The Art. 18-104 not only refers to acquisitions "directly by duress (...) or confiscation, dispossession or spoliation" but also refers to any "purchase or transaction regardless of whatever consideration may have been employed". Consequently, any transfer of an object qualifying as cultural material during the Nazi reign was considered as a form of looting and qualified for restitution to the governments of the countries from which they were taken.

The term 'cultural material' is defined in Art. 18-101 as including “all movable goods of importance or value either religious, artistic, documentary, scholarly or historic, the disappearance of which constitutes a loss to the cultural heritage of the country concerned (...)". ${ }^{283}$ The restitution practice of the Military Government, however, went further than only restituting objects of national relevance:284 until 1951 more than one million cultural objects had been identified and restituted on the basis of MGR Title $18 .^{285}$

\footnotetext{
${ }^{278}$ Schwarz, W., 1974, p. 24.

${ }^{279}$ Cf.: Lillteicher, J., 2003, p. 95

280 Office of Military Government for Germany, U.S. Military Government Regulations, Title 18: 'Monuments, fine arts and archives', February 12, 1947. For the full text see: Annex 10 in Kowalski, W.W., 1998, pp. 153-160.

${ }^{281}$ See above for short description of Law No. 52: 'Blocking and control of property', Military Government Gazette (Germany, U.S. Zone, issue A).

282 The provisions of MGR Title 18 dealing with aspects of protection of cultural property different from the question of restitution will not be further discussed here.

283 The Article lists the following examples: "recognised works of art, as well as such objects as rare musical instruments, books and manuscripts, scientific documents of a historic or cultural nature, and all objects usually found in museums, collections, libraries and historic archives".

${ }^{284}$ Engstler, L., 1964, p. 143. The Military Governor for the U.S. Zone in Germany, General Clay stated that "restitution of all cultural objects was self-evident". Clay, L.D., 1950, p. 342.

285 Engstler, L., 1964, p. 149; Final Report - Monuments, Fine Arts and Archives Section, 30 December 1948, File "Final Reports - Reparations and Restitution", Record Group 260, Records of Property Division, Records of the Reparations and Restitution Branch, Reports and Related Records Re: Restitution, 19451950, cited in Kurtz, M., J., 1997, p. 116. See also:
} 


\section{Restitution after the Bonn Treaty}

So far, the principles of the Allies with regard to the restitution of cultural objects looted by the Nazis from their occupied territories, as well as the U.S. implementation in the form of MGR Title 18 have been outlined. The fact that each Occupation Zone introduced its own implementation regime did not mean a definitive end to common action in respect of the restitution of cultural property, at least not for the three Western Allies. With regard to the Soviet Union, however, the different perception of how to reconstruct the post-war world, including the restitution of cultural property, became ever more apparent. The cooperation between the Western Allies and the Soviet Union ended in March 1948, when the Soviet representative left the Allied Control Council, which resulted in an intensification of the Cold War. Consequently, the following elaborations apply only to the Federal Republic of Germany that was established by the three Western Allies on 23 May 1949 and not to the German Democratic Republic, which was established by the Soviet Union on 7 October 1949.

With the establishment of the Federal Republic of Germany, the Western Allied Forces had laid the foundations for re-integrating their individual restitution regimes on the basis of an international treaty. In 1952, the Western Allies took the initiative for such a treaty that would serve as explicit legal basis for further external restitutions from Germany. ${ }^{286}$ The 'Convention on the Settlement of Matters Arising out of the War and the Occupation' (hereinafter: "the Bonn Treaty") was signed on 26 May 1952.287 The Bonn Treaty did not stand by itself but was one of the "satellite conventions" to the 'Germany Treaty' that ended Germany's status as an occupied territory and reestablished it with the rights of a sovereign state. 288 The Bonn Treaty entered into force only after the adoption of a Protocol signed on 23 October 1954 in Paris. ${ }^{289}$ In the following, the Bonn Treaty as amended by this 1954 Protocol will be discussed in as far as it is relevant for the restitution of cultural objects. ${ }^{290}$

The Bonn Treaty deals with a range of subjects both future-oriented and directed at the "liquidation of the past". ${ }^{291}$ Section V of the Bonn Treaty determines how Germany had to carry out the external restitutions of cultural objects that had been taken from the

\footnotetext{
http://149.217.72.46/ww/en/pub/research/details/publications/institute/prax/pr98.cfm?fuseaction_prax $=$ act\&act $=$ pr98_53 (Last visited: 30 June 2008).

286 Odendahl, K., 2005, p. 165.

${ }^{287}$ Convention on relations between the Three Powers and the Federal Republic of Germany (Vertrag über die Beziehungen zwischen der Bundesrepublik Deutschland und den Drei Mächten), signed at Bonn, 26 May 1952 (Bundesgesetzblatt 1955 II. 29.03.1954, No 3).

288 Vertrag über die Beziehungen zwischen der Bundesrepublik Deutschland und den Drei Mächten ("Deutschlandvertrag") vom 26. Mai 1952 in der Fassung vom 23. Oktober 1954, 332 U.N.T.S. 219. Cf.: Engstler, L., 1964, p. 144.

289 Protocol on the Termination of the Occupation Regime in the Federal Republic of Germany, 23 Oct. 1954, 331 U.N.T.S. 327.

290 The 1952 Convention never entered into force in the original version. Hollander, B., 1959, p. 42.

${ }^{291}$ Engstler, L., 1964, p. 144.
} 
occupied territories. ${ }^{292}$ The implementation and execution of these provisions became the responsibility of the Federal Office External Regulations, the establishment of which had been required by Art. 1(1) of Section V.293

The Bonn Treaty distinguishes between two categories of cultural objects: "jewellery, silverware and antique furniture" 294 on the one hand and "cultural property" on the other. Cultural property is defined in Art. 1(4) as comprising: "movable goods of religious, artistic, documentary, scholarly or historic value, or of equivalent importance, including objects customarily found in museums, public or private collections, libraries or historic archives". Both categories could be reclaimed by the government from whose territory the cultural object in question had been removed during the occupation by the German or Allied Forces or their individual members. ${ }^{295}$ Restitution was ordered for acquisition by duress (with or without violence), by theft, requisition or other forms of dispossession by force. ${ }^{296}$

With regard to "cultural property", Art. 1(2) extended the restitution regime to apply also to cultural property that was acquired by way of gift made under direct or indirect pressure or in consideration of the official position of the recipient. Furthermore, cultural property that had been acquired by way of purchase was to be restituted unless it had been brought into the country concerned for the purpose of sale. A precondition for the extended restitution regime to apply to cultural property was its presence in the respective territory at the start of the occupation. ${ }^{297}$

Different from "cultural property", restitution of jewellery, silverware or antique furniture could be denied if it was established that the object concerned was removed after acquisition from the original owner for value by way of a regular commercial transaction, even if payment was made in occupation currency. ${ }^{298}$ The burden of proof, however, rested upon Germany, as a result of which there was a great likelihood that the objects would be restituted. ${ }^{299}$ The possibility for governments to assert claims was

\footnotetext{
292 All references to specific articles must be understood as referring to articles from Section V. (Each Section in the Bonn Treaty restarts the numbering of the articles with the consequence that each of the twelve sections has an Art. 1). See further below in chp.1.\$4.III on Section III of the Bonn Treaty dealing with questions of internal restitution.

293 Art. 1(1) requires the Federal Republic to establish an administrative agency to search for, recover, and restitute cultural objects as provided for in Section V of the Bonn Treaty. The Federal Office External Restitutions (Bundesamt für äussere Restitutionen was founded by Law dating from 8 June 1955 (BGBl. II, p. 700). Cf.: Engstler, L., 1964, p. 146.

294 Art. 1(4) specifies the term "antique" as "property which upon the entry into force of the present Convention is one hundred or more years old. The term "substantial value" shall mean a value of not less than 200,000 French francs at the 1 January 1951 purchasing power".

295 Art. 1(1) and Art. 3 (1) of Section V of the Treaty of Bonn.

296 Art. 1(1) and Art. 3 (1) of Section V of the Treaty of Bonn.

297 See for the relevant dates for the different territories: Art. 5(1).

298 Art. 1(3) of Section V of the Treaty of Bonn.

299 Engstler, L., 1964, p. 146.
} 
subject to time limitations. The deadline to filing a claim lapsed on 8 May 1965 (Art. 2(1)). 300

Art. 4(1) of Section V of the Bonn Treaty deals with the situation that cultural property, which had been identified in Germany as qualifying for restitution ${ }^{301}$ was destroyed, stolen, lost or otherwise disposed before it could have been restituted. In those cases, the person who was entitled to restitution will be granted financial compensation. ${ }^{302}$ According to Art. 4(5), the amount of the compensation was to be set at the replacement value of the object at the time of the decision granting compensation. ${ }^{303}$

With the adoption of the Bonn Treaty, responsibility for the external restitution of cultural property was handed over to Germany. ${ }^{304}$

\section{EXTERNAL RESTITUTION FROM THE ALLIES}

In the following, the restitution of cultural objects by the United States on behalf of Germany will be addressed. 305 Cultural property was not only looted by the Nazis, it was also taken by (members of) the Allied Forces from German territory during the

\footnotetext{
${ }^{300}$ Next to governments, the Bonn Treaty also granted certain restitution rights to private individuals who had lost their possession during the occupation due to theft or duress to German or Allied Forces or individual members (Art. 3). However, different from claims asserted by the governments, the right to claim does not exist where the present possessor had possessed the object in good faith for at least ten years or until 8 May 1956. This limitation was an important aspect for claimants to take into account, the more as Art. 2(4) of the Bonn Treaty ruled out a double claim from a dispossessed individual and a Government (Art. 2(4) reads: "Submission of a claim for restitution pursuant to Art. 1 of this chapter on behalf of any person or entity shall preclude such submission pursuant to Art. 3; likewise, action for restitution pursuant to Art. 3 shall preclude submission of a claim for restitution pursuant to Art. 1"). In those cases where restitution was not prevented by the protection of a subsequent good faith possessor, it was nevertheless subject to the requirement that the holder is reimbursed for expenditures. Furthermore, if the claimant had previously received any financial consideration for the loss, the amount had to be repaid to the German authorities. While the rights that the Bonn treaty accords to private individuals is secondary in standing compared with the rights of governments, the fact that it does accord rights to private parties is remarkable in that it deviates from general restitution practise that is limited to the relationship between governments. 301 See for an elaboration on the meaning of "identifiable": Engstler, L., 1964, pp. 147-149. Engstler elaborates upon the difference between the identification of an object and the mere theoretical possibility to identify an object. In order to qualify for restitution only de facto identification is relevant.

302 Art. 4(1) reads in German: "Ist eine zu restituierende Sache nach ihrer Identifizierung in Deutschland, aber vor Rückgabe an den Restitutionsberechtigten entweder in Deutschland verwendet oder verbraucht worden, oder vor ihrem Eingang bei der den Anspruch erhebenden Regierung oder bei einer zuständigen Dienststelle einer der Drei Mächte zwecks Ablieferung an den Restitutionsberechtigten zerstört oder gestohlen worden oder abhanden gekommen, so wird die Bundesrepublik die Personen entschädigen, die sonst gemäß Artikel 1 und 3 dieses Teils restitutionsberechtigt wären oder deren Restitutionsansprüche bei Inkrafttreten dieses Vertrags durch eine der Drei Mächte bereits gebilligt waren".

303 Art. 4(5) reads in German: "Die in diesem Artikel vorgesehene Entschädigung ist in der Höhe des Wiederbeschaffungswertes der Sachen zur Zeit der Entscheidung darüber zu leisten".

${ }^{304}$ See further below in chp. 1. \$4.III on the relevance of the Bonn Treaty for internal restitutions.

305 See further on restitutions from the Soviet Union, Poland and Czechoslovakia: Engstler, L., 1964, pp. 170-174.
} 
liberation and after the end of the war. In respect of the Western Allies, the looting of cultural property was officially banned and remained limited to actions by individual soldiers. 306 In respect of the Soviet Union, official "trophy brigades" had been established to seize works of art from Germany as war reparations. ${ }^{307}$ While the taking of cultural objects by (members of) the Allied Forces differed from the seeking of reparations by the Soviet Union to personal enrichment of individual soldiers from all Allied Armies, it did not have the ideological baggage of the looting under the Nazi Regime. The absence of such ideological baggage does not mean that the taking did not breach the 1899 and 1907 Hague Conventions. The restitution by the US Allies constitutes the first time that cultural objects were restituted to a former aggressor state. ${ }^{308}$ The only incident in which cultural objects had been returned to a former aggressor state in the past was in the context of restitutions after Napoleon's campaigns: in 1816, the Allied Powers returned a number of art works to France. However, the return is different from the restitution by the US Allies in that the objects returned to France were objects that had mistakenly been restituted from France to the Allied Powers rather than objects that had been looted by the Allied Powers from France. ${ }^{309}$.

The first official document touching upon U.S. restitutions of cultural objects removed from Germany dates from 1945. It concerns a circular issued by the American Commission for the Protection and Salvage of Artistic and Historic Monuments in War Areas that appealed to everybody to return cultural objects removed from Germany to its rightful owner. ${ }^{310}$ On 28 January 1947, the War-Navy-Coordinating-Committee issued guidelines for the return of "Looted Objects of Art to Countries of Origin". 311 The guidelines declared it the responsibility of the United States Government "to return to their countries of origin those cultural objects which have been wrongfully taken and brought to the United States during and after the War". 312 The guidelines were followed up with a circular from the State Department that was sent to all universities, museums,

\footnotetext{
306 See for an example of private looting the case of the Quedlinburg Treasure (Siehr, K., 1992a; Kogelfranz, S. / Korte, W., A., 1996; Kline, T., R., 1997; Weil, S., 1999).

307 In total, the trophy brigades removed an estimated 2.6 million art objects and archaeological material (Mastroberardino, M.M., 1997, p. 228).

308 The Treaty of Versailles concluding the First World War only dealt with the restitution of cultural property from Germany. The analysis of restitutions preceding the Treaty of Versailles, starting with the Treaty of Westphalia also did not reveal any restitutions on behalf of an aggressor state. Odendahl, K., 2005 , p. 170. See further for a few more examples of restitutions to a defeated party: Walter, B., 1988, p. 80. ${ }^{309}$ Kowalski, W.W., 1998, p. 28.

310 Hall, A.R., 1951, p. 340. See also: Engstler, L., 1964, p. 168. Another document that should be mentioned here is the so-called Wiesbaden Manifest that was published by officers of the Monuments Fine Arts and Archives section working in the Wiesbaden Central Collecting Point on 7 November 1945 as protest to the order to ship a selection of German "works of art of greatest importance" to the United States. See further: Siehr, K., 1998, pp. 275-276.

311 Engstler, L., 1964, p. 168.

312 Department of State Bulletin, February 23, 1947, pp. 358-360.
} 
libraries and art dealers in the United States with the request to contribute to the restitution of the dispersed cultural objects. ${ }^{313}$ The circular stated that

"it is the responsibility and desire of the Government of the United States to recover and return to owner nations those cultural objects, including works of art, archival material and books, looted, stolen or improperly dispersed from public and private collections in war areas and brought to the United States during and following World War II".314

The assessment of the actual cases and subsequent restitutions followed the regime as provided for under the 'Military Government Regulations: Title 18: Monuments, Fine Arts and Archives', which has been outlined above. ${ }^{315}$

By providing for the restitution of cultural property looted from public and private German collections, the United States lived up to its obligations under the 1907 Hague Convention and confirmed the principle that all cultural property looted during hostilities or under occupation must be restituted, also to a former aggressor state.

\section{INTERMEDIARY CONCLUSIONS OF THE EXTERNAL RESTITUTIONS AFTER WORLD WAR II}

When World War II broke out in 1939, the only relevant treaties in force were the 1899 /1907 Hague Convention on the Laws and Customs of War on Land. The failure of the two Hague Conventions in protecting cultural objects both against destruction and removal was evident long before the German surrender in May 1945. Against this background it must not surprise that the Allied Forces started with preparing the post-war restitutions already prior to the end of the war. There was no debate whether cultural objects should be restituted. Instead, the discussions focussed on the form that restitution should take. 316

The final restitution regime as introduced by the Allied Forces accords great relevance to the restitution of cultural objects. By stressing the need to restitute cultural objects rather than subsuming the loss under the sum of reparations to be paid, the restitution measures recognised the uniqueness of cultural objects. The understanding and respect of the uniqueness of cultural objects was consequentially followed, also with regard to those cultural objects that could not be physically restituted. While the instruments from the preparatory phase ${ }^{317}$ suggested meeting the inability to restitute cultural objects that had been destroyed or were in any event not traceable by

\footnotetext{
313 Engstler, L., 1964, p. 168.

314 See for full text of the document: Hall, A.R., 1951, p. 344.

315 Ibid., p. 340. See for examples of affected restitutions of cultural objects that originated first and foremost from public German Collections: Engstler, L., 1964, pp. 169-170.

316 Cf.: Sandholtz, W., 2008, p. 121.

317 See 'Resolution on the Subject of Restitution' annexed to the Final Act of the Paris Conference on Reparations and the 1946 Allied Control Council's 'Declaration on the Definition of the Term "Restitution" further discussed above.
} 
compensation in specie / restitution in kind ${ }^{318}$ this idea was not realised in the restitution regime as finally introduced by the Western Allies. ${ }^{319}$ While the renunciation of compensation in specie / restitution in kind at first sight seems to dismiss the perception of the uniqueness of cultural objects, it is the only logically sound consequence in that it recognises the uniqueness of cultural objects that would have served as replacements.

The restitution regime furthermore stands out for corresponding with the reality of Nazi art looting and for its efficiency: until 1952 more than $90 \%$ of the cultural objects that had been removed from the occupied territories had been returned to the state of origin. ${ }^{320}$ To conclude this section discussing the external restitutions of cultural objects to the countries from where they had been taken during World War II it must be emphasised that the restitution under public international law is completed the moment that the object concerned was handed over to the claiming state. ${ }^{321}$

\section{THE AFTERMATH OF WORLD WAR II: 1954 Hague CONVENTION AND ITS PROTOCOLS}

\section{THE 1954 Hague CONVENTION}

The massive looting of cultural property during World War II had painfully highlightened the need to improve the legal protection of cultural property. ${ }^{322}$ It must therefore not surprise that the United Nations Educational, Scientific and Cultural Organization ("UNESCO”) looked into improving the protection of 'objects of cultural value'. ${ }^{323}$ In 1954 UNESCO accepted an offer from the Dutch government to hoist an intergovernmental conference on this matter. ${ }^{324}$ The conference was held in April - May 1954 in The Hague and resulted in the adoption of the Hague Convention of May 1954 for the Protection of Cultural Property in the Event of Armed Conflict (hereinafter: "the 1954 Hague Convention") and the (First) Protocol for the Protection of Cultural

\footnotetext{
318 For those cases in which the original object has been destroyed the expression "compensation in specie" as suggested by Siehr (Siehr, K., 1993, p. 116) or "replacement in kind" as suggested by Gattini (Gattini, A., 1996, p. 5) is more appropriate than "restitution in kind". See further on the choice of terminology in chp.1.\$1.III discussing Art. 247 of the Versailles Treaty.

319 See Military Government Regulations: Title 18: Monuments, Fine Arts and Archives and the Bonn Treaty, in particular its Art. 4 further discussed above. Cf.: Schnabel, G. / Tatzkow, M., 2007, p. 140.

${ }^{320}$ Cf.: Engstler, L., 1964, pp. 149-150; Hipp, A., 2000, p. 56, fn. 40.

321 Readers interested in the implementation of the Allied restitution regime may be referred to e.g.: Smyth, C., Hugh, 1988; Farmer, W.I., 2000.

322 Toman, J., 1996, p. 21.

323 UNESCO was founded in November 1945 as result of a conference held by United Nations on the establishment of an educational and cultural organization. One of the purposes of UNESCO is to "assure the conservation and protection of the world's inheritance of books, works of art and monuments of history and science, and recommending to the nations concerned the necessary international conventions" (Art. I.2 (c) of the UNESCO Constitution). See for early initiatives of UNESCO on the protection of cultural objects e.g. resolution 6.42 adopted by UNESCO at its fourth session in Paris 1949. See further on the resolution and subsequent preparatory works: ibid., p. 22.

${ }^{324}$ Ibid., p. 23.
} 
Property in the Event of Armed Conflict. ${ }^{325}$ The 1954 Hague Convention was the first truly international treaty dedicated to the protection of cultural property. 326

The adoption of the 1954 Hague Convention did not abolish the 1899 and 1907 Hague Conventions, nor did it make them redundant. While the 1954 Hague Convention introduced novel concepts and concrete measures for the protection of cultural property, it is supplementary to the 1899 and 1907 Hague Conventions. ${ }^{327}$ In the following, the improvements that were introduced by the 1954 Hague Conventions for the protection of cultural property will be outlined.

The most innovative aspect of the 1954 Hague Convention was the introduction of the concept of "common property". 328 The protection of cultural property law under public international law was no longer based upon the notion that cultural property was first and foremost the property of a single state, but instead assumes that cultural property is the property of all mankind. ${ }^{329}$ Merryman has coined this perception of cultural property as "cultural internationalism".330

The understanding of an object as cultural property or cultural heritage of mankind implies two sets of obligations. First, it puts greater responsibility on a belligerent or occupying force for the protection of cultural property located in the battlefields, respectively in the occupied territories of another State Party. Secondly, the qualification of cultural property as the heritage of mankind also increases the responsibility of the holding state. With cultural property situated in its own territory being understood as the property of all mankind the holding state is required to take protective measures for the safeguarding of cultural property.

\footnotetext{
325 Convention for the Protection of Cultural Property in the Event of Armed Conflict, signed at The Hague, 14 May 1954 (249 UNTS 215); Protocol to the Hague Convention for the Protection of Cultural Property in the Event of Armed Conflict, signed at The Hague, 14 May 1954 (249 UNTS 358); Schindler, D. / Toman, J., 2004, pp. 999-1025.

326 Odendahl, K., 2005, p. 119. While the Roerich Pact on the Protection of Artistic and Scientific Institutions and Historic Monuments preceded the 1954 Hague Convention it applied only between the United States of America and the other American Republics.

327 See Art. 36 of the 1954 Hague Convention on the Convention's relation to previous conventions.

328 Vernon, C., 1994, p. 457; Kastenberg, J., E., 1997, p. 277. Cf.: Odendahl, K., 2005, p. 118.

329 See, in particular the preamble of the 1954 Hague Convention that reads: "[b]eing convinced that damage to cultural property belonging to any people whatsoever means damage to the cultural heritage of all mankind, since each people makes its contribution to the culture of the world". To be precise, the notion of cultural property being the heritage of mankind had been introduced already at the end of the 19th century in the correspondence between Quatremère de Quincy and General Miranda and had been included in a number of declarations and international treaty drafts. The 1954 Hague Convention was, however, the first adopted and legally binding instrument that was based upon the notion that cultural property belonged to all mankind. See further: Quatremère de Quincy, 1796, Lettres à Mirande sur le déplacement des d'Art de l'Italie. See further on the draft conventions that were not adopted: Strebel, H., 1955/56, p. 41-44; Kaye, L., M., 1997, p. 103; Odendahl, K., 2005, pp. 112-115 on the draft by the League of Nations 'for the Protection of Historic Buildings and Works of Art in Time of War'). See further on the 1939 (draft) 'International Convention for the Protection of National Collections of Art and History: Engstler, L., 1964, pp. 49-52.

330 Merryman, J.H., 1986, p. 836. The other "way of thinking about cultural property" according to Merryman is "cultural nationalism" according which conceives cultural property as part of a national cultural heritage (p. 832).
} 
Further to introducing the notion of cultural heritage of mankind, the 1954 Hague Convention constitutes the first international treaty to provide for a definition of "cultural property". 331 The definition of "cultural property" in Art. 1 comprises three categories of cultural objects:"332 first movable or immovable property of great importance to the cultural heritage of every people, secondly buildings whose main and effective purpose is to preserve or exhibit movable cultural property (that is of great importance to the cultural heritage of every people) and finally centres containing a large amount of cultural property from the previous two categories.

The requirement of Art. 1 that a cultural object must be of "great importance to the cultural heritage of every people" 333 in order to qualify as cultural property in the sense of the Convention suggests a rather high threshold. However, the analysis of the evidence available "points overwhelmingly to the conclusion that the Convention applies to all movable (...) property considered by each respective state to form part of its national cultural heritage". 334 Put differently, the reference to "every people" must be understood as referring to "each respective people". 335 Consequently, states enjoy a great margin of appreciation in determining which cultural objects qualify as cultural property in the sense of the Convention. ${ }^{336}$ In conclusion, the definition of cultural property of the 1954 Hague Convention allows for a broad, almost unlimited interpretation of the objects that can qualify as cultural property. ${ }^{337}$

\footnotetext{
331 Boguslavsky, M., M, 1994, p. 5; O'Keefe, P., 1999 b.

332 Art. 1 reads: "For the purposes of the present Convention, the term 'cultural property' shall cover, irrespective of origin or ownership:

(a) movable or immovable property of great importance to the cultural heritage of every people, such as monuments of architecture, art or history, whether religious or secular; archaeological sites; groups of buildings which, as a whole, are of historical or artistic interest; works of art; manuscripts, books and other objects of artistic, historical or archaeological interest; as well as scientific collections and important collections of books or archives or of reproductions of the property defined above;

(b) buildings whose main and effective purpose is to preserve or exhibit the movable cultural property defined in sub-paragraph (a) such as museums, large libraries and depositories of archives, and refuges intended to shelter, in the event of armed conflict, the movable cultural property defined in sub-paragraph (a);

(c) centers containing a large amount of cultural property as defined in sub-paragraphs (a) and (b), to be known as 'centers containing monuments"'.

333 (Emphasis added).

334 O'Keefe, P., 1999b, p. 36. The broad interpretation is furthermore supported by the listing of examples of (movable) cultural property in Art. 1 a) of the Convention such as: "works of art; manuscripts, books and other objects of artistic, historical or archaeological interest; as well as scientific collections and important collections of books or archives or reproductions (...) of cultural property".

$335 \mathrm{Ibid}$. O'Keefe points for further support of the finding of his analysis to the Preamble of the 1954 Hague Convention, para. 2: "Being convinced that damage to cultural property belonging to any people whatsoever means damage to the cultural heritage of all mankind, since each people makes its contribution to the culture of the world".

$336 \mathrm{Ibid}$. In the literature, the broad understanding of the definition is generally confirmed: see, e.g.: Toman, J., 1996, p. 54; Jenschke, C., 2005, p. 59; Draye, A.M., 2007, p. 29; Memorie van Toelichting, 30 165, no. 3, p. 5.

${ }^{337}$ Cf.: Jenschke, C., 2005, p. 59.
} 
The Convention's scope of protection applies both to situations of international and non-international character. ${ }^{338}$ Situations of international character are not limited to armed conflicts but include situations of occupation even when met by no armed resistance. Different from the 1899 and 1907 Hague Conventions, the application of the 1954 Hague Convention is not limited by a "general participation requirement". Instead, in situations where not all parties to a conflict are State Parties, the Convention applies in the mutual relation between State Parties. ${ }^{339}$

The scope of protection granted by the 1954 Hague Convention is outlined in its Artt. 2-7. In order to ensure for an efficient protection, and in light of the notion of common heritage, the obligations of State Parties commence already prior to the outbreak of a conflict. State Parties are required to take (preparatory) measures in peacetimes to allow for the most effective protection during armed conflicts and occupations. ${ }^{340}$ Once an international or internal conflict has erupted and endangers cultural property, the Convention seeks to protect the objects against destruction, as well as against looting. While the emphasis of the Convention is on the physical protection of cultural property against damage or destruction ${ }^{341}$, the Convention also provides for a ban on the looting of cultural property. With regard to the looting of cultural property in the event of armed conflict ${ }^{342}$, Art. 4(3) of the 1954 Hague Convention provides that:

"[t]he High Contracting Parties further undertake to prohibit, prevent and, if necessary, put a stop to any form of theft, pillage or misappropriation of, and any acts of vandalism directed against, cultural property. They shall refrain from requisitioning movable cultural property situated in the territory of another High Contracting Party".

If one squares this provision with the protective regime introduced by the 1899 and 1907 Hague Conventions, it becomes evident that Art. 4(3) of the 1954 Hague Convention constitutes on the hand a positive re-formulation of Artt. 23 and Art. 28 of the Hague Conventions. On the other hand, it exceeds the protection granted by the 1899 and 1907 Hague Conventions: first, the 1954 Hague Convention does not allow

\footnotetext{
338 Art. 19(1) declares the provisions of the Convention to apply to conflicts not of an international character. This provision was crucial with regard to the destructions in former Yugoslavia. See further: Prosecutor v. Tadic, Case No. IT-94-1-AR72, Decision on Defence Motion for Interlocutory Appeal on Jurisdiction, para. 98 (Oct. 2, 1995). See further: Abtahi, H., 2001.

339 Art. 18(3) of the 1954 Hague Convention.

340 See Artt. 3, 6, 7 of the 1954 Hague Convention.

341 With regard to protection of cultural property during armed conflict / occupation Art. 4(1) provides: "The High Contracting Parties undertake to respect cultural property situated within their own territory as well as within the territory of other High Contracting Parties by refraining from any use of the property and its immediate surroundings or of the appliances in use for its protection for purposes which are likely to expose it to destruction or damage in the event of armed conflict; and by refraining from any act of hostility, directed against such property".

${ }^{342}$ Cf.: Art. 4(1) that speaks only of the situation of armed conflict and not about occupation. Art. 5, on the other hand, focuses on the protection of cultural property under occupation.
} 
for military necessities to constitute a waiver of the safeguarding of cultural property: the ban on looting as formulated by Art. 4(3) is absolute. ${ }^{343}$ Secondly, Art. 4(3) introduces new obligations: further to prohibiting State Parties from requisitioning movable cultural property situated in the territory of another High Contracting Party, it also introduces a duty of care for State Parties in that they must "undertake to prohibit, prevent and, if necessary, put a stop to any form of theft, pillage or misappropriation of (...) cultural property". Put differently, Art. 4(3) not only regulates the active behaviour of State Parties and takes away the military necessity waver clause with regard to looting of cultural property during armed conflict; it also requires State Parties to monitor and regulate the behaviour of third parties. The latter is again an expression of the understanding of cultural property as the heritage of mankind.

Art. 5 complements this regime with rules applicable during periods of occupation. The article requires the State Parties to support the national authorities in the protection of their cultural heritage:

"[a]ny High Contracting Party in occupation of the whole or part of the territory of another High Contracting Party shall as far as possible support the competent national authorities of the occupied country in safeguarding and preserving its cultural property". ${ }^{344}$

It should be pointed out that while Art. 5 does not explicitly provide for a ban on looting, the ban on looting as introduced in Art. 4(3) applies also to situations of occupation. Art. 5 functions in addition to Art. 4 rather than as lex specialis. ${ }^{345}$ What is missing in the 1954 Hague Convention with regard to objects removed during armed conflict and occupation is a provision providing explicitly for the restitution of removed cultural objects. ${ }^{346}$ The reason that the 1954 Hague Convention does not include such a provision stems from the objections voiced by a number of states against such provision especially with regard to the return of cultural property removed from occupied territories. ${ }^{347}$

The absence of such a primary right for restitution does not mean that cultural property requisitioned in breach of Art. 4(3) must not be restituted. As outlined above with reference to the Chorzów Factory Case 1928 the breach of a treaty-provision is

\footnotetext{
${ }^{343}$ Cf.: Jenschke, C., 2005, pp. 60-61. It should be noted here that the military necessities clause is not fully abolished under the 1954 Hague Convention. It may still be evoked in cases where military necessity imperatively requires the damaging or destructing cultural property.

344 The other provisions of Art. 5 read: (2). Should it prove necessary to take measures to preserve cultural property situated in occupied territory and damaged by military operations, and should the competent national authorities be unable to take such measures, the Occupying Power shall, as far as possible, and in close co-operation with such authorities, take the most necessary measures of preservation.

(3). Any High Contracting Party whose government is considered their legitimate government by members of a resistance movement, shall, if possible, draw their attention to the obligation to comply with those provisions of the Convention dealing with respect for cultural property.

345 Cf.: Jenschke, C., 2005, p. 61.

346 Cf.: Kennon, H., 1996, pp. 385-386; Jenschke, C., 2005, p. 62.

347 Nahlik, S.E., 1976, p. 1083; Boylan, P.J., 1993, p. 99, para. 10.93.
} 
sufficient for an obligation to make reparations to arise. ${ }^{348}$ Consequently, cultural property requisitioned in breach of Art. 4(3) of the 1954 Hague Convention must be restituted. ${ }^{349}$ This is, however, not the case for cultural objects removed during a period of occupation. The more indirect application of Art. 4(3) to situations of occupation and the fact that the loss of cultural objects during occupation is often caused also by civilians stand in the way of such an effect. The obligation to restitute cultural objects that have removed from an occupied territory has, however, been included in a protocol that was adopted simultaneously with the 1954 Hague Convention.

\section{The First Protocol of the 1954 Hague Convention}

The (First) Protocol for the Protection of Cultural Property in the Event of Armed Conflict (hereinafter: "the (First) Protocol") 350 was adopted together with the 1954 Hague Convention. It entered into force on 7 August 1956.351

The (First) Protocol relies upon the definition of cultural property as provided for in Art. 1 of 1954 Hague Convention. It deals with the obligations of State Parties with regard to the protection of cultural property in an occupied territory and provides for the return of cultural property that has been removed nevertheless.

The key provisions of the (First) Protocol are contained in its Art. I. ${ }^{352}$ According to Art. I 1, which is directed at a State Party occupying another country during an armed conflict, any exportation of cultural property from the occupied territories must be prevented. For the (First) Protocol to apply it is irrelevant whether the occupied country is a State Party; it is sufficient that the occupying country is a State Party. The obligation for the occupying State Party to prevent the exportation of cultural property is

\footnotetext{
348 Factory at Chorzów, PCIJ Series A, No. 17 (1928). See further above in chp. 1. \$1.II discussing state liability under the 1899 Hague Convention.

${ }^{349}$ See also the Chorzów Factory Case discussed above in chp. 1.\$1.II on the primacy of restitution over other forms of reparations.

350 Protocol to the Hague Convention for the Protection of Cultural Property in the Event of Armed Conflict, signed at The Hague, 14 May 1954 (249 UNTS 358). When speaking of "Protocol" reference is always to the First Protocol.

351 As of the end of June 2009, 100 countries had become a State Party. See for the actual list: http://www.icrc.org/ihl.nsf/WebSign?ReadForm\&id=410\&ps=P.

352 1. Each High Contracting Party undertakes to prevent the exportation, from a territory occupied by it during an armed conflict, of cultural property as defined in Art. 1 of the Convention for the Protection of Cultural Property in the Event of Armed Conflict, signed at The Hague on 14 May, 1954. 2. Each High Contracting Party undertakes to take into its custody cultural property imported into its territory either directly or indirectly from any occupied territory. This shall either be effected automatically upon the importation of the property or, failing this, at the request of the authorities of that territory. 3. Each High Contracting Party undertakes to return, at the close of hostilities, to the competent authorities of the territory previously occupied, cultural property which is in its territory, if such property has been exported in contravention of the principle laid down in the first paragraph. Such property shall never be retained as war reparations.

4. The High Contracting Party whose obligation it was to prevent the exportation of cultural property from the territory occupied by it shall pay an indemnity to the holders in good faith of any cultural property which has to be returned in accordance with the preceding paragraph.
} 
complemented with obligations concerning cultural property that was nevertheless exported from the occupied territories. These obligations, which consist of taking the objects into custody (Art. I 2) and of returning them at the close of hostilities (Art. I 3) apply to all State Parties, rather than only the occupying one. ${ }^{353}$

According to Art. I 3, the obligation to return cultural property at the close of hostilities to the competent authorities of the formerly occupied territory is absolute: it is neither subject to any prescription, nor does it recede from any rights that might have been acquired after the export by a bona fide purchaser. ${ }^{354}$ The obligation of a State Party to return an object even in the case that one of its own citizens has in the meantime acquired the object in good faith or even acquired full legal title is complemented by the obligation for the (formerly) occupying State Party to pay compensation to the potential good faith purchaser. ${ }^{355}$ The amount and modalities of the compensation depend on the respective national laws. ${ }^{356}$

\section{Intermediary conclusions and Application of the 1954 Hague Convention and its Protocol}

The 1954 Hague Convention was the first truly international treaty dedicated to the protection of cultural property. ${ }^{357}$ It is hailed as a mile stone for the protection of cultural property. 358 This qualification is based both on abstract and concrete changes brought about by the convention for the protection of cultural property: on a more abstract level, the 1954 Hague Convention is relevant from a conceptual point of view in stressing the notion that cultural property is not only the property of one nation but instead is the property or heritage of humankind. Further to introducing the notion of "cultural internationalism"359 the 1954 Hague Convention was also the first truly international binding instrument to provide for a definition of the term "cultural property". The definition as provided for in Art. 1 is particularly relevant for explicitly mentioning movable cultural objects and for its broad understanding of cultural property: prior to the 1954 Hague Convention movable objects of cultural relevance were protected only indirectly via the protection of the immovable structures in which they were housed. The broadness of the definition of cultural property as provided for

\footnotetext{
353 Further to the obligations provided for under Art. I 2 and Art. I 3, the (First) Protocol holds another obligation in Art. II 5 that did not exist under the 1954 Hague Convention. According to Art. II 5, cultural property that had been deposited with a State Party for reasons of safeguarding must be returned at the end of the hostilities. This obligation is, however, less significant than Art. I 3 that seeks to address situations of long-lasting occupations as it had been the case during World War II. During the occupation of e.g. The Netherlands and France numerous works of art were acquired by the Nazi leaders, as well as by German museums and private collectors. Engstler, L., 1964, p. 151.

354 Jenschke, C., 2005, p. 66.

355 Toman, J., 1996, p. 346; Jenschke, C., 2005, p. 69.

${ }^{356}$ Jenschke, C., 2005, p. 69.

357 Odendahl, K., 2005, p. 119. While the Roerich Pact on the Protection of Artistic and Scientific Institutions and Historic Monuments preceded the 1954 Hague Convention it applied only between the United States of America and the other American Republics.

${ }^{358}$ Toman, J., 1996, p. 24; Odendahl, K., 2005, p. 118.

359 Merryman, J.H., 1986, p. 836.
} 
by the 1954 Hague Convention is not only the result of comprising both movable and immovable property. Instead, it also the result of the significant margin of appreciation granted to State Parties for determining which objects are of great importance to "its people". By combining universal protection with decentralised decision-making of what constitutes cultural property the definition fits the notion of cultural internationalism: not only are all State Parties obliged to protect the cultural heritage of humankind, they also have to respect different views on what constitutes cultural heritage.

Concrete improvements of the protection of cultural property lie in the following characteristics of the conventions: first, the absence of a "general participation requirement". ${ }^{360}$ Secondly, Art. 4(3) formulates an explicit ban on the looting of cultural property. While looting was already banned under the 1899 and 1907 Hague Conventions, the ban was not explicitly expressed with regard to cultural objects but was contained in more general bans on looting (Art. 23 and Art. 28 of 1899 and 1907 Hague Convention). Thirdly, the 1954 Hague Convention offers greater protection than the 1899 and 1907 Hague Convention in that it does not allow for the protection against looting to be waived in case of military necessity. Finally, Art. 4(3) of the Hague Convention extends the obligation of State Parties of refraining from requisitioning movable cultural property to monitoring and regulating the behaviour of third parties.

The previous passage reflected upon the most significant improvements brought about by the 1954 Hague Convention for the protection of cultural property against looting. ${ }^{361}$ Despite generally supporting the praise for the 1954 Hague Convention, the analysis also showed that the Convention does not explicitly provide for the restitution of cultural property looted during armed conflicts or removed from a territory under occupation. Such a provision has, however, been included in the (First) Protocol to the Hague Convention, which has been adopted to absorb the gaps of the 1954 Hague Convention.

The (First) Protocol significantly extends the protection of cultural property situated in occupied territories. Not only does it explicitly ban any removal of cultural property from an occupied territory and obliges State Parties to actively prevent such removal, it also provides for the restitution of cultural property whose removal from a territory under occupation during an armed conflict could not be prevented. The obligation to restitute cultural property as provided for in Art. I 3 is far-reaching: it applies also to a State Party that is not involved in the occupation; it is not subject to prescription, and works also against a bona fide purchaser. The (First) Protocol hence significantly improved the protection of cultural property against removal during occupations and the chances for the restitution of the removed objects.

360 Cf:: Art. 2 of the Regulations annexed to the 1899 and 1907 Hague Conventions discussed above. 361 The relevance of the 1954 Hague Convention was emphasised with the inclusion of Art. 53 in the first and Art. 16 in the Second Protocol Additional to the Geneva Conventions of 12 August 1949, and relating to the Protection of Victims of International Armed Conflicts. Cf.: Wyss, M.P., 1994, p. 92. 
The rules as provided for in the 1954 Hague Convention and the (First) Protocol have been confirmed in reaction to the conflicts in the Middle East, in particular the (First) Gulf War (1990-91).362 The United Nations Security Council Resolution from March $1991^{363}$ determined that Iraq, which had ratified the 1954 Hague Convention and its (First) Protocol in 1967, had to return to Kuwait, which had accessed to the 1954 Hague Convention in 1969 and to the (First) Protocol in 1970, all looted (cultural) property. ${ }^{364}$

In response to the 2003 invasion of Iraq by the United States and United Kingdom (also referred to as Second Gulf War) UN Security Council Resolution 1483 was adopted. ${ }^{365}$ This resolution, which resolved a number of ambiguities that resulted from the 2003 invasion of Iraq by the United States and United Kingdom, requires Member States:

"to take appropriate steps to facilitate the safe return to Iraqi institutions of Iraqi cultural property and other items of archaeological, historical, cultural, rare scientific, and religious importance illegally removed from the Iraq National Museum, the National Library, and other locations in Iraq by establishing Iraq since the adoption of resolution 661 (1990) of 6 August 1990, including a prohibition on trade in or transfer of such items and items with respect to which reasonable suspicion exists that they have been illegally removed (...)".366

What is interesting about the provision is that it applies not only to objects that were illegally removed from 2003 onwards but instead applies to all objects illegally removed since 6 August 1990. This retroactivity is strictly limited to the legal situation addressed by Resolution 1483. While the Resolution, being adopted under chapter VII of the United Nations Charter, is binding on all Member States of the United Nations ${ }^{367}$ its legal force is limited to the specific legal situation it addresses, i.e. cultural property

\footnotetext{
362 During the Iran - Iraq War of 1980 belligerents in general lived up to the obligations of the 1954 Hague Convention. No looting of cultural objects worth mentioning occurred (Jenschke, C., 2005, p. 174). With regard to the 2003 invasion of Iraq (or Second Gulf War) it has been stated that the main looting occurred by the civil population of Iraq (Jenschke, C., 2005, p. 176; Zelig, J.M., 2005, p. 289 ). With the United States not being a State Party to the 1954 Hague Convention, which imposes on State Parties a specific obligation not only to refrain from looting but also to "prohibit, prevent and, if necessary, put a stop to any form of theft, pillage or misappropriation of (...) cultural property", the question whether the provisions of the 1954 Hague Convention have become binding of customary law becomes relevant not only from a theoretical point of view. See further below in chp. 1. SVIII.

363 Resolution S/RES/686-1991, para. 2 (d) reads: “(...) that Iraq immediately begin[s] to return all Kuwaiti property seized by Iraq, to be completed in the shortest possible period".

${ }^{364}$ See further on the relevance of the 1954 Hague Convention to the 1990-1991 (First) Gulf War: Oyer III, H.E., 1999.

365 Security Council Resolution 1483, P 7, U.N. Doc. S/RES/1483 (May 22, 2003).

366 Ibid., para. 7. For Member States of the European Community Resolution 1483 was implemented by Council Regulation (EC) No 1210/2003 of 7 July 2003.

367 This is particularly relevant for those countries that are not a State Party to the 1954 Hague Convention and particular its (First) Protocol, such as the United States and the United Kingdom. The United States adopted the 'Iraq Cultural Heritage Protection Act' to implement the Resolution whereas the UK adopted the 'Iraq Order 2003'.
} 
illegally removed, or suspicioned to be illegally removed from Iraq since the adoption of resolution 661 (1990) of 6 August 1990. As a resolution of the United Nations Security Council, it does not have the same legal relevance as an international treaty that seeks to provide a more general and future oriented solution.

The fact that the 1954 Hague Convention and its (First) Protocol have been confirmed by these resolutions of the Security Council must not hide the fact that especially the (First) Protocol's practical relevance has been very limited. In his 1993 Report on behalf of UNESCO Boylan concludes that

“(...) I have not seen or received evidence of a single example of State Parties to the Protocol taking action of any kind in order to bring its provisions into practical effect in order to 'freeze' trade in, or other transfers or movements of, cultural property from areas affected by either international or internal armed conflicts. (...) The almost universal ignoring by actual or potential 'importing' countries of the principles of the 1954 Hague Protocol is one of the most serious breaches of the fundamental principles and objectives of the 1954 Convention, and all High Contracting Parties should be asked to review their policy and practice in this respect." 368

In reaction to Boylan's finding and the armed conflict in former Yugoslavia that arose in 1991, and which involved deliberate destructions of cultural property, triggered the initiative for a Second Protocol to the Hague Convention. 369

\section{The Second Protocol of the 1954 Hague Convention}

The Second Protocol, which was adopted on 26 March 1999 and entered into force in 2004,370 enhances the protection of cultural property against damage and destruction. In particular, the Second Protocol provides for a clearer definition of military necessity, an improved system of enhanced protection, the extension of the application to non-international armed conflicts, and the reinforcement of individual criminal responsibility. ${ }^{371}$

\footnotetext{
368 Boylan, P.J., 1993, p. 101, para. 110.109. See also: Jenschke, C., 2005, p. 168.

${ }^{369}$ Keane, D., 2004, p. 36. See further on the destructions of cultural property during the war in the former Yugoslavia, e.g.: Detling, K.J., 1993, pp. 65-72; Destruction of cultural property report (Annex XI) to the Final report of the United Nations Commission of Experts established pursuant to Security Council Resolution 780 (1992) S/1994/674/Add.2 (Vol. V), 1994; Abtahi, H., 2001.

370 Second Protocol to the Hague Convention of 1954 for the Protection of Cultural Property in the Event of Armed Conflict, signed at The Hague, 26 March 1999. The exact date of entry into force was 9 March 2004. See Art. 43 according to which the Second Protocol shall enter into force three months after twenty instruments of ratification, acceptance, approval or accession have been deposited. As of June 2009, 53 countries had become a State Party. See for the actual list: http://www.icrc.org/ihl.nsf/WebSign?ReadForm\&id=590\&ps=P.

371 Cf.: Schindler, D. / Toman, J., 2004, pp. 1037 \& 1038-1052 for the text of the Second Protocol. These points correspond to the key areas that had been identified by a meeting of twenty government experts in 1997. According to the experts the Second Protocol needed to address: institutional aspects, precautionary measures to be taken in peacetime, the "military necessity" exception, the system of special protection and individual criminal responsibility. Cf.: Keane, D., 2004, pp. 27-28.
} 
The relevance of the Second Protocol with regard to the protection of cultural property against removal lies in the introduction of criminal responsibility for "theft, pillage or misappropriation of (...) cultural property protected under the Convention" (Art. 15 (1) sub e). The Second Protocol thereby complements the 1954 Hague Convention, which requires its State Parties to introduce criminal reasonability but does so without explicit reference to the removal of cultural property. ${ }^{372}$ Furthermore, with regard to the protection of cultural property in occupied territories, Art. 9 of the Second Protocol extends the protection granted to archaeological excavations. ${ }^{373}$ Hence, while the Second Protocol touches upon the question of looting of cultural property by reinforcing criminal responsibility and by extending the protection granted to cultural property during occupations to archaeological excavations, its main contribution lies in the realm of protecting (the substance of) cultural property against damage and destruction. 374

\section{INTERMEDIARY CONCLUSIONS ON THE RESTITUTION OF CULTURAL OBJECTS IN THE CONTEXT OF ARMED CONFLICTS UNDER TREATY LAW}

The analysis of the protection of cultural property started with the ius praedae, the right of the victorious party to loot as the prevailing attitude during Ancient Times and traced the evaluation of treaty law from the 1648 Treaty of Westphalia onwards. Scrutinizing both peace treaties and multilateral treaties, it became evident that it was only at the turn of the $19^{\text {th }}$ to the $20^{\text {th }}$ century that public international law provided for a ban on the looting of cultural objects and the obligation to restitute looted cultural objects.

The relevant legal instruments were the 1899 and 1907 Hague Conventions on the Laws and Customs of War on Land. While the literature so far pushed the 1907 Hague Convention as watershed in establishing a ban on the removal of cultural property and the obligation to restitute cultural property that had been removed in spite of such a $\operatorname{ban}^{375}$, the results of the present analysis point to the 1899 Hague Convention as being the crucial legal instrument. Not only was the 1899 Hague Convention the first treaty to introduce a ban on the removal of property of cultural relevance in times of war ${ }^{376}$, it also provides for the restitution of cultural objects. Hence, as of 4 September 1900, the date when the 1899 Hague Convention entered into force, Member States to the Hague Convention had to refrain from destroying and removing cultural property, and had to

\footnotetext{
372 Art. 28 of the 1954 Hague Convention.

373 Art. 9 reads: 1. Without prejudice to the provisions of Artt. 4 and 5 of the Convention, a Party in occupation of the whole or part of the territory of another Party shall prohibit and prevent in relation to the occupied territory: a. any illicit export, other removal or transfer of ownership of cultural property; b. any archaeological excavation, save where this is strictly required to safeguard, record or preserve cultural property. (...).

374 See further on the Second Protocol: Desch, T., 1999; Hladík, J., 1999; Gioia, A., 2003; Hladík, J., 2004.

375 Cf.: Select Committee on Culture Media and Sport, 2000, para. 371.

376 Schulze, D., 1983, p. 33; Kaye, L., M., 1997, p. 100; Jenschke, C., 2005, p. 47; Odendahl, K., 2005, p. 109.
} 
restitute cultural objects they had removed nevertheless. The relevance of this finding is not so much the fact that the ban on the removal of cultural property and the obligation to return removed objects emerged ten years earlier than assumed. ${ }^{377}$ Rather, the relevance lies in the principle of international law according to which the obligation to restitute cultural property is implied in treaty provisions banning the removal of cultural property.

For failure of the attempts to improve the protection of cultural property during the Interbellum, the rules of the 1899 and 1907 Hague Convention governed not only the legal situation of the First World War but also that of the Second World War. While the First World War had no significant effect on the future course of restitutions, the Second World War did. This must not surprise given the extensive art looting by the Nazis and the great effort undertaken by the Allied Forces to arrive at restitution. The restitution measures not only comprised objects that have been looted in the narrow sense of the term but also comprised objects that had been subject to forced sales and other forms of transactions unless their voluntary character could be confirmed. Interesting, also with regard to the Soviet Trophy Art debate is the finding that the Allied Forces had favoured for a short time during the preparatory process the idea of restitution in kind in situations where cultural objects could not be physically restituted. ${ }^{378}$ However, in the restitution regime as finally realised by the Western Allies, the idea of restitution in kind was renounced therewith thinking the notion of the uniqueness of cultural objects to its logical conclusion. Finally, the restitutions as affected after the Second World War also constitute the first that cultural objects were restituted to a former aggressor state.

An important development in the post-war era was the adoption of the 1954 Hague Convention and its protocols. While the main focus of the 1954 Hague Convention lies on explicating and re-enforcing the protection against destruction and damaging of cultural objects, it also prohibits the confiscation of cultural property during armed conflict and occupation and seeks to prohibit removal by third parties. More important with regard to the restitution of objects that have been looted in spite of the ban on removal is the (First) Protocol. In fact, the (First) Protocol not only requires the restitution of looted cultural objects but requires also the return of cultural objects that have been removed from a territory under occupation. According to Art. I 3, the obligation to return cultural property at the close of hostilities is absolute: it is neither

\footnotetext{
377 The 1899 Hague Convention entered into force in 1900 whereas the 1907 Hague Convention entered into force in 1910 .

378 While the analysis does not further discuss the Russian trophy art debate the research suggests that Russia has objected consistently to the idea that restitution in kind is illegal thus possibly being able to rely upon the concept of "persistent objector". Where a state behaves as persistent objector, i.e. showing initial and sustained objection to a rule, it will not be bound by a rule of customary law. Cf.: Dixon, M., 2007, pp. $32-33$.
} 
subject to any prescription, nor does it recede from any rights that might have been acquired after the export by a bona fide purchaser. ${ }^{379}$

\section{CUSTOMARY LAW}

Next to treaty law, customary law is one of the sources of international law recognised in Art. 38 of the Statute of the International Court of Justice. While treaty law has replaced customary law over the last three decades as primary source of international law, customary law is nevertheless still important for the development of general principles and to fill in voids left by treaty law. ${ }^{380}$ It has the advantage of applying to all States regardless of their adherence to relevant treaty-law.

Customary law consists of two cumulative elements: an objective element in the form of the actual behaviour of states and a subjective element or belief that this behavious is 'law'. ${ }^{381}$ The second element, the opinio iuris is more difficult to establish than state practice in that it is a subjective element and to some extent paradoxical in stating that something must be considered as law in order to become law. ${ }^{382}$

Taking account of the greater difficulty to assess the existence of an opinio iuris the International Court of Justice (ICJ) has suggested that "a set of customary rules whose presence in the opinio iuris of States can be tested by induction based on the analysis of a sufficiently extensive and convincing practice, and not by deduction from preconceived ideas". ${ }^{383}$ Consequently, the analysis of the existence of a rule of customary law is an inductive process based on the analysis of a sufficiently extensive and convincing state practice. $^{384}$

\section{STATE PRACTICE}

In order to qualifiy as state practice as required for the creation of a rule of customary law the state practice concerned must be constant and uniform. ${ }^{385}$ This does not mean that the state practice needs to be "perfect": instances of inconsistent state conduct do not necessarily undermine the validity of a given rule. ${ }^{386}$ With regard to the time period that must have passed in order to speak of a settled state practice, it is is not

\footnotetext{
379 Jenschke, C., 2005, p. 66.

380 Dixon, M., 2007, p. 30. Cf.: Shaw, M., N., 2008, pp. 73-74.

381 Shaw, M., N., 2008, p. 74.

382 Cf.: Dixon, M., 2007, p. 35.

383 Case Concerning Delimitation of the Maritime Boundary in the Gulf of Maine Area (Canada/United States of America), ICJ Reports, 1984, p. 246, para. 111.

384 Cf.: Bossuyt, M.J.M. / Wouters, J., 2005, p. 107; Shaw, M., N., 2008, p. 73.

385 Asylum Case (Colombia v. Peru), ICJ Reports, 1950, p. 266, p. 277.

386 Case Concerning Military and Paramilitary Activities in and against Nicaragua (Nicaragua v. United States of America), ICJ Reports, 1986, p. 14, para. 186.
} 
required that the practice must go back to "times immemorial". 387 The ICJ held in the North Sea Continental Shelf Cases:

"[a]lthough the passage of only a short period of tim is not necessarily, or of itself, a bar to the formation of a new rule of customary international law (...), an indispensable requirement would be that within the period in question, short though it might be, State practice, including that of States whose interest are specially affected, should have been both extensive and virtually uniform (...): - and should moreover have occurred in such a way as to show a general recognition that a rule of law or legal obligation is involved". 388

Examples of rules of customary rule that have been established within a short period of time are the right of a coastal state to explore and exploit the resources of its continental shelf and the freedom to explore outer space. ${ }^{389}$

As for the question which kind of behaviour qualifies as 'state practice' evidence can be derived from the following sources: administrative acts, legislation, decisions of courts and activities on the international stage, such as treaty-making. ${ }^{390}$ Obviously, a state is not a living entity but is a complex composition of governmental departments, legislative institutions, courts, diplomatic agents, political leaders and thousands of officials. ${ }^{391}$ Furthermore, state practice can be obtained from resolutions in the United Nations General Assembly, comments made by governments on drafts produced by the International Law Commission, decisions of the international judicial institutions, decisions of national courts, treaties, and the general practice of international organisations. ${ }^{392}$ Put differently, state practice covers any act or statements by an organ or actor that is qualified to represent the state from which views about customary law may be inferred. ${ }^{393}$

\section{OPINIO IURIS}

The element of opinio iuris has been explicated by the ICJ. ${ }^{394}$ According to the ICJ in the North Sea Continental Shelf Cases, for a rule of customary law to exist

\footnotetext{
387 Jurisdiction of the European Commission of the Danube between Galatz and Braila, Advisory Opinion, PCIJ, Series B, No. 14 (1927), p. 105, p. 105.

388 North Sea Continental Shelf cases, ICJ Reports, 1969, p. 3, para. 74.

${ }^{389}$ Cf.: Bossuyt, M.J.M. / Wouters, J., 2005, p. 106.

390 Shaw, M., N., 2008, p. 82.

391 Ibid.

392 Ibid. Cf.: Bossuyt, M.J.M. / Wouters, J., 2005, p. 108; Dixon, M., 2007, p. 31. Bossuyt remarks that it is not entirely clear whether, in the eyes of the ICJ, the resolutions in the United Nations General Assembly provide evidence of state practice or of an opinio iuris (or both).

${ }^{393}$ Shaw, M., N., 2008 , p. 84.

394 North Sea Continental Shelf cases, ICJ Reports, 1969, p. 3; Case Concerning Military and Paramilitary Activities in and against Nicaragua (Nicaragua v. United States of America), ICJ Reports, 1986, p. 14; Lotus Case PCIJ, Series A, No. 10, 1827, p. 18; Anglo-Norwegian Fisheries Case ICJ Reports, 1951, p. 116. Cf.: Dixon, M., 2007, p. 31. See further on the North Sea Continental Shelf Cases and the "mysterious process" by which rules of customary law evolve: Nelson, L.D.M., 1972; Brownlie, I., 2003, pp. 6-12.
} 


\begin{abstract}
"the acts concerned must not only amount to a settled practice, but they must also be such, or be carried out in such a way, as to be evidence of a belief that this practice is rendered obligatory by the existence of a rule of law requiring it. The need for such a belief, i.e., the existence of a subjective element, is implicit in the very notion of the opinio juris sive necessitaties. The States concerned must therefore feel that they are conforming to what amounts to a legal obligation. The frequency, or even habitual character of the acts is not in itself enough". 395
\end{abstract}

According to the ICJ in the Nicaragua Case, opinio iuris could be found, among other things in General Assembly resolutions, statements made by state representatives and the existence of treaties covering similar grounds. ${ }^{396}$ When analysing treaties, different weight must be accorded to peace treaties and multilateral treaties: peace treaties are directed at a specific armed conflict and cannot be generalised. Multilateral treaties, on the other hand, are not limited to one specific occasion but instead seek to provide a more general and future oriented solution. ${ }^{397}$ Consequently, multilateral treaties play a more important role in providing evidence of an opinio iuris than peace-treaties. No clearcut answer can be given to the question in how far the existence of an opinio iuris must be proven once evidence of a state practice has already been provided. On this point, a majority within the ICJ held in the North Sea Continental Shelf Cases that the frequency or even habitual character of a practice is not enough to establishish opinio juris. The majority did not reflect as to how the existence of opinio iuris can otherwise be established. A minority of the Court found that opinio iuris could be presumed from consistent practice, unless a contrary intentention was apparent. ${ }^{398}$ In light of these two approaches to the relevance of establishing opinio iuris independantly of the element of state practice the following view has become accepted as compromise: the degree of proof required for opinio iuris will vary according to the subject matter of the disputed customary rule. 399

Having elaborated on customary law and its two constitutive elements we can now apply the findings to the international instruments and the restitution of cultural objects in the aftermath of the different conflicts outlined above. Most evidence points to the 1899 and 1907 Hague Conventions as manifestations of a rule of customary international law providing for a ban on removal and the restitution of removed cultural objects. The view of a number of scholars that such a rule emerged as early as during the Vienna Congress in the beginning of the $19^{\text {th }}$ century 400 must be refuted. While it is true that by the end of 1815 an essential part of the cultural objects removed during the Napoleonic Raids had been restituted, this does not suffice for a rule of customary law to emerge instantaneously. As the analysis of the negotiations above showed, neither a

\footnotetext{
395 North Sea Continental Shelf cases, ICJ Reports, 1969, p. 3, p. 44, para. 77.

396 Case Concerning Military and Paramilitary Activities in and against Nicaragua (Nicaragua v. United States of America), ICJ Reports, 1986, p. 14. Cf.: Dixon, M., 2007, p. 36.

${ }^{397}$ Bossuyt, M.J.M. / Wouters, J., 2005, p. 109.

398 North Sea Continental Shelf cases, ICJ Reports, 1969, p. 3, dissenting opinion of judge Lachs.

399 Dixon, M., 2007, p. 35.

400 See, e.g.: Fiedler, W., 1989, p. 217; Jenschke, C., 2005, p. 113 \& 129.
} 
settled state practice, nor an opinio iuris in this respect existed. In as far as the element of settled state practice is concerned the analysis of the acts of the Government representatives did not reveal a commonly shared support in favour of restitution. 401 Furthermore, it was not until the last round of negotiations that there was a certain consensus favouring restitution. This finding must, however, be evaluated against the background that the negotiations took place in the context of peace treaty negotiations, which means that they were significantly influenced by the self-interest of the Allies. In any event, the acts leading to restitution as affected subsequent to the Napoleonic wars cannot meet the requirement of a certain duration, uniformity and spreading of state practice.

With settled state practice as one of the two cumulative elements necessary for the emergence of a rule of customary law being absent ${ }^{402}$, it has already been established that such a rule could not have emerged during the Vienna Congress. Consequently, instead of characterising the Vienna Congress as constitutive moment for the formulation of a rule of customary law providing for the restitution of cultural property in times of war it is more correct to characterise the Vienna Congress as a first stage in the emergence of such a rule. ${ }^{403}$

For better situating the emergence of rules of customary law on the protection of cultural property against looting and on restitution, we can take to the findings of the International Military Tribunal at Nuremberg. The International Military Tribunal was established in agreement with the London Agreement of 8 August, 1945 to bring the major war criminals of the European axis to justice. ${ }^{404}$ When dealing with war crimes

401 Cf.: Engstler, L., 1964, p. 105; Sandholtz, W., 2008, p. 112-114. According to Sandholtz, Tsar Alexander argued in 1814 that the Allies could have relied upon their right of conquest to reclaim the works of art seized by France during the wars. Sandholtz refers to: Russian Memoir from 1815, .

402 With regard to the existence respectively absence of an opinio iuris we limit ourselves to pointing to the Prussian "Allgemeines Landrecht für die Preussischen Staaten" (ALR) as an example of national legislation that contradicts the existence of an opinio iuris. The ALR dating from 1794 explicitly mentions looting that is permitted by the State or commander-in-chief as mode of legal acquisition of ownership. Hattenhauer, H. / Bernert, G., 1970, Part I, title 9, JS 193-219. See further on the role of the Allgemeines Landrecht e.g.: Lokin, J.H.A. / Zwalve, W.J., 1992, pp. 198-207. While the relevance of the ALR must not be overestimated, it indicates that the right of pillage had not vanished at the turn of the 18th to the 19th century. Cf.: Siehr, K., 1993, p. 111.

403 Cf.: the witness statements of Professor Petropoulos in the context of the evidence gathering for Seventh Report of the House of Commons Select Committee on Culture Media and Sport, Cultural Property: Return and Illicit Trade, 2000 where Petropoulos refers to the 1907 Hague Convention on the Laws and Customs of War on Land as watershed between the era in which there exists no obligation to restitute cultural property (e.g. the Elgin Marbles) and the era in which such obligations come into existence: Select Committee on Culture Media and Sport, 2000, para. 371. See further on the variety of modes and stages of formation of customary international law: Verdross, 1969; Villiger, M.E., 1985, pp. 29-30.

404 Ibid, preambula. See for the Charter of the International Military Tribunal:

http://www.yale.edu/lawweb/avalon/imt/proc/imtconst.htm (last visited: 14 August 2008). At this point we would like to make a short comment on the question whether the looting of art works qualifies as crime against humanity as is sometimes argued (see, e.g. Lecture by Dr. A. Goepfert on "Art trade in works removed in times of wars; art trade in nationalized and expropriated works of art" held in Maastricht on 5 March 2008). The argument is interesting in that it is generally acknowledged that no limitation period exists 
covered by Artt. 46, 50, 52, and 56 of the Hague Convention of 1907, the International Military Tribunal had to take to customary law as a number of belligerents were not a State Party to the Convention. ${ }^{405}$ The International Military Tribunal held with regard to the 1907 Hague Convention that

"[t]he rules of land warfare expressed in the Convention undoubtedly represented an advance over existing international law at the time of their adoption. (...) but by 1939 these rules laid down in the Convention were recognized by all civilized nations, and were regarded as being declaratory of the laws and customs of $\operatorname{war}(\ldots) " .406$

The International Military Tribunal hence recognised that by 1939, at the outbreak of World War II, all rules of the Hague Conventions also constituted rules of customary law. The finding that the rules of the 1899 and 1907 Hague Convention are binding of customary law is generally accepted in the literature.407 There exists, however, disagreement as to when exactly the rules became legally binding as rules of customary law. ${ }^{408}$ If one approaches the emergence of rules of customary law as a process ${ }^{409}$, the results of our analysis allow us to date the emergence of such rules between the restitutions subsequent to the 1899/1907 Hague Conventions and the outbreak of World War II.

As to the content of the rules of customary law with regard to protection granted against the removal of cultural objects during international armed conflicts and occupation and with regard to restitution, these can be summarised as follows: 410 enemy property, including cultural objects, may not be seized or pillaged during armed

for crimes against humanity (see, e.g.: Bazyler, M., 1999, p. 154). The term crimes against humanity was defined by the Principles of International Law Recognized in the Charter of the Nuremberg Tribunal and in the Judgment of the Tribunal, 1950. The Principles were adopted by the International Law Commission, acting under instructions from the United Nations General Assembly and set down the laws and procedures by which the Nuremberg trials were to be conducted. According to Prinicle VI (c) crimes against humanity are: "murder, extermination, enslavement, deportation and other inhuman acts done against any civilian population, or persecutions on political, racial or religious grounds, when such acts are done or such persecutions are carried on in execution of or in connexion with any crime against peace or any war crime". The looting of art works consequently does not qualify as crime against humanity. It does, however, qualify as war crime.

405 The application of the 1907 Hague Convention was doubtful given the "general participation clause" in Art. 2 according to which the Convention only applies when all belligerents to a conflict are State Parties. See further on the "general participation clause" above in the paragraph discussing the 1899 and 1907 Hague Convention.

406 International Military Tribunal (Nuremberg), Judgment and Sentences, 1st October 1946, 1947, pp. 248 249. Cf.: Giovannini, T., 2002, p. 264.

407 See, e.g.: Fiedler, W., 1989, p. 199; Schorlemer, S.v., 1992, p. 298; Phuong, C., 2004, p. 986; Odendahl, K., 2005, p. 125.

408 Some authors argue that the rules of the 1899/1907 Hague Conventions were declaratory of customary law when they were adopted. See, e.g.: Engstler, L., 1964, p. 223; Fiedler, W., 1989, p. 217. Others point to the turn of the 19th to the 20th century as the moment in time when the rules manifested themselves of customary law. See, e.g.: Doehring, K., 1987, p. 139; Schorlemer, S.v., 1992, p. 298.

409 See, e.g.: Odendahl, K., 2005, p. 125.

${ }^{410}$ See for a summary including also the (preventive) protection against destruction: Ibid., p. 126. 
conflicts. ${ }^{411}$ While a waiver exists in case of military necessity, it is difficult to think of a situation where seizure of cultural objects is imperatively demanded by the necessities of war. ${ }^{412}$ Furthermore, during occupation following the hostilities, neither private property nor public property of cultural relevance may be confiscated, requisitioned or seized. ${ }^{413}$

The rules of customary law on the protection of cultural objects against removal during armed conflict and occupation are complemented by the obligation to restitute objects removed in breach of these rules. ${ }^{414}$ With regard to the obligation of customary law to restitute looted objects, a distinction must be drawn between the defeated and the victorious powers: until World War II the obligation to restitute looted cultural objects concerned only the defeated parties. It was only in reaction to the developments towards the end and after World War II that the obligation to restitute looted objects of customary law became fully applicable to the victorious powers also. ${ }^{415}$

The literature is divided as to whether the provisions of the 1954 Hague Convention constitute customary law. ${ }^{416}$ Boylan in his study for UNESCO came to the conclusion that the 1954 Hague convention is so well established that it must be regarded as an integral part of customary law. 417 Given the convention's focus on the protection of cultural property against damage and destruction the status of its provisions of customary law is, however, less relevant for the present study. Of greater relevance is the (First) Protocol whose provisions extend the restitution regime in particular with regard to objects removed from occupied territories. Given the "almost universal ignoring" of its principles ${ }^{418}$, however, the provisions of the (First) Protocol do not (yet) constitute rules of customary law.

\section{$\S 2$. Protection of Cultural objects in times of peace}

Cultural property is not only endangered in times of war. Destruction, damaging and removal of cultural objects are also problems in times of peace. Given the subject of the present thesis we will not further address the protection of cultural objects against destruction or damage but will focus on the relevance of public international law in fighting the illicit art trade. ${ }^{419}$ The need to take redress to public international law to

\footnotetext{
411 Cf.: Art. 23 and Art. 28 of the 1899 and 1907 Hague Convention.

412 Cf.: the 1954 Hague Convention where the exception of military necessity applies only to cases of damage or destruction and is no longer mentioned with regard to removal.

${ }^{413}$ Cf.: Art. 46 juncto Art. 56 of the 1899 and 1907 Hague Convention.

414 Cf.: Walter, B., 1988, p. 78 \& 80; Rudolf, W., 1989, p. 860; Odendahl, K., 2005, p. 170 with further references.

415 Odendahl, K., 2005, p. 170. Odendahl refers to the 1943 London Declaration as evidence of an opinio iuris.

${ }^{416}$ Cf.: Ibid., p. 126 with further references.

417 Boylan, P.J., 1993 , p. 7.

418 Ibid., p. 101, para. 110.109. See also: Jenschke, C., 2005, p. 168.

419 See on protection against damage or destruction e.g.: Schorlemer, S.v., 1996.
} 
fight the illegal art trade became apparent especially with the intensification of globalisation. ${ }^{420}$

The category of illicit trade comprises various categories. An object being illicitly trafficked is one in respect of which some offence has been committed: such an offence is defined by the laws of the country of origin and may include clandestine excavation, theft, breach of inalienability or rights of pre-emption, failure to comply with trading regulations or violation of export control. ${ }^{421}$ The category of illicit trade thus combines offenses of public laws (e.g. illegal export) with offences of laws vesting ownership (theft). From an international legal perspective this difference is crucial: whereas courts of all countries are in theory open to actions for the recovery of stolen property, not only to domestic but also to foreign owners, they will not enforce another state's penal or public laws. As a result of the latter an object may well be legally owned or traded in one country even though it has at some stage been the object of a violation of criminal or administrative provision in another country. ${ }^{422}$ Consequently, there is a greater need for measures under public international law with regard to the return of cultural objects removed from one country in breach of a public law than is the case with regard to the restitution of stolen objects. Where a case of a stolen cultural object involves a foreign law element and where a difference in result will occur depending on which law will be applied private international law or the law of conflicts will be adhered todecide the case. In the context of this chapter we will not further discuss the restitution of stolen cultural property unless where public international law provides for specific, more favorable rules for restitution. The main focus of this chapter is on the existence or emergence of rules of public international law for the return of cultural objects that have been illegally exported.

Given the international dimension of the illicit art trade driven by the demand from the art market nations ${ }^{423}$ and reinforced by the North-South divide ${ }^{424}$ the problem of the illicit trade can only be addressed at the international level. In the following, we will scrutinise public international law (treaty law and customary law) as to the (coming into) existence of binding rules on the return of illicitly removed cultural objects. The analysis is structured according to chronology, unless where coherence is better served by discussing international treaties separate from regional ones.

\footnotetext{
${ }^{420}$ Cf.: Odendahl, K., 2005, pp. 171-172. While it is impossible to estimate the size of the illicit trade an estimate given in the 1999 United Nations Global Report on Crime and Justice nevertheless gives an idea of the extent: according to the report the current annual trade in illicit antiquities is estimated at around $\$ 7.8$ billion, ranking behind drugs ( $\$ 160$ billion) and arms ( $\$ 100$ billion) as the most profitable black market.

${ }^{421}$ Cf.: Prott, L.V., 1989, p. 561; Mackenzie, S., 2005, p. 3.

422 Mackenzie, S., 2005, p. 3.

423 See above in the introduction \$2.I for an explanation on the difference between art market and source nations.

${ }^{424}$ The North-South Divide is the socio-economic and political division that exists between the wealthy developed countries, known collectively as "the North", and the poorer developing countries (least developed countries), or "the South".
} 


\section{First attempts by the International Museums OfFice}

The first attempts to adopt an international treaty on the protection of cultural objects in times of peace date from the $1930 \mathrm{~s} .{ }^{425}$ On the recommendation of the League of Nations, the International Museums Office (IMO) ${ }^{426}$ presented three draft conventions: ${ }^{427}$ the 1933 (draft) 'Convention on the Repatriation of Objects of Artistic, Historical or Scientific Interest, which have been lost, stolen, or unlawfully alienated or exported'428, the 1936 (draft) 'International Convention for the Protection of National Artistic and Historical Treasures'429, and finally, the 1939 (draft) 'International Convention for the Protection of National Collections of Art and History'. ${ }^{430}$

The circle of cultural objects that fell under the draft conventions' scope of application was narrowed with each revised draft. While the first draft applies to objects of "artistic, historical or scientific interest" which are not further qualified, the second draft applied to "objects of particular palaeontologic, archaeological, historical or artistic interest". 431 The $1939 \mathrm{draft}$ applied to "objects of particular palaeontologic, archaeological, historical or artistic interest" but limited the scope of application by requesting the objects to be the property of a state or a public institution, to be held in public collections and to be mentioned in the collections' inventory. ${ }^{432}$

Further to the circle of objects concerned, the three draft conventions differed in the extent to what cultural objects had to be returned. According to the first draft State Parties would be required to consider transfers of cultural objects undertaken in breach

\footnotetext{
${ }^{425}$ Odendahl, K., 2005, p. 173

426 The International Museums Office (IMO) had been established in 1926 by the Sub-Commission on Arts and Letters of the International Commission for Intellectual Cooperation, which existed since 1921 under the umbrella of the League of Nations as a predecessor of the later United Nations Educational, Scientific and Cultural Organization ("UNESCO"). The task of the IMO was to enhance the cooperation between museums internationally, to support international agreements and international exhibitions. Engstler, L., 1964, p. 49. There exists no link between IMO and the later established ICOM (International Council of Museums), which will be introduced in chp. 2.\$2.IV.3. IMO went out of existence in 1946. ICOM was established the same year as a non-governmental organisation.

${ }^{427}$ These draft conventions must not be confused with the draft convention prepared simultaneously for the League of Nations 'for the Protection of Historic Buildings and Works of Art in Time of War', which has been introduced above in 3.1.I.

${ }^{428}$ Mouseion, Vol. 23-24, Nos III-IC, 1933, pp. 243-244.

${ }^{429}$ United States Department of State, Documents and State Papers, Vol. I, No 15, June 1949, p. 866 ff.; Mouseion, Vol. 33-34, Nos I-II, 1936, p. 283-289.

430 United States Department of State, Documents and State Papers, Vol. I, No 15, June 1949, p. 869 ff. Cf.: Engstler, L., 1964, pp. 49-52.

431 Cf.: Odendahl, K., 2005, pp. 130-131.

432 Cf.: Ibid., p. 131. See for a detailed discussion of the drafts: Engstler, L., 1964, pp. 49-53; Schorlemer, S.v., 1992, p. 420-423. A similar approach has been chosen in the EC Council Directive 93/7/EEC of 15 March 1993. A cultural object in the sense of the Directive is either classified by a Member State as 'national treasures possessing artistic, historic or archaeological value' within the meaning of Art. 30 of the EC Treaty, provided it also belongs to one of the categories listed in the Annex or forms an integral part of a public collection and is listed in the institution's inventory (Art. 1). See further below in chp. 1.\$2.VI for an analysis of the Directive.
} 
of national export rules as void and to cooperate in the return of the object. A potential good faith purchaser was to be granted compensation from the returning state. The second draft version did not contain the obligation to consider transfers undertaken in breach of national export rules as void. Nevertheless, the right of State Parties to claim cultural property that had been lost, stolen or illegally transferred or exported from its territory was confirmed. The third draft version further limited the envisaged recovery regime. The state of origin could only reclaim property that had been removed in breach of national rules of penal character. This very limited recovery regime was, however, complemented by the possibility to reclaim cultural objects that had been lost on foreign territory e.g. in the context of exhibition. The returning state was granted the possibility to make the return subject to compensation payments from the requesting state to a bona fide possessor. ${ }^{433}$

While none of the drafts was ever adopted due to outbreak of the Second World War ${ }^{434}$ and the dissolving of the League of Nations in 1946, they mark the beginning of the regulation of the restitution of cultural objects in times of peace under public international law. Also, the efforts undertaken for the draft conventions were not completely futile as they contributed to the preparatory works for the adoption of an international convention at a later stage. Before turning to this convention, the 1970 UNESCO Convention ${ }^{435}$, the first legally binding instrument on the protection of cultural property in peacetime of regional relevance will be discussed.

\section{TREATY OF WASHINGTON, 1935}

The first treaty that outgrew the stage of preparations and good intentions was the 'Treaty on the Protection of Movable Property of Historic Value'.436 The treaty, which is generally known as "Treaty of Washington" entered into force on 1 May 1936.437 It regulates the export and import of a set of narrowly defined cultural objects between North America and countries in Middle and South America. ${ }^{438}$

The Treaty of Washington grants protection by making the import of specific groups of cultural objects dating from the pre-Columbian, Colonial or the "period of emancipation and the republic" (Art. 1) dependent on the presentation of valid export license from the country of origin (Artt. 2 and 3). In case an attempt to import an object

\footnotetext{
433 Odendahl, K., 2005, p. 174.

434 Cf.: Schorlemer, S.v., 1992, p. 422; Odendahl, K., 2005, p. 131.

435 In full: 1970 UNESCO Convention on the Means of Prohibiting and Preventing the Illicit Import, Export and Transfer of Ownership of Cultural Property.

${ }^{436}$ Treaty on the Protection of Movable Property of Historic Value, April 15, 1935, OASTS 28. Cf.: Walter, B., 1988, p. 46. The full text of the treaty is reprinted in: Hudson, M.O., 1972, pp. $59 \mathrm{ff}$.

437 It was signed by the member states of the Pan-American Union, the precursor of the Organization of American States (OAS) on 15 April 1935. It was ratified by Chile (1936), El Salvador (1936), Guatemala (1936), Mexico (1939), and Nicaragua (1935) and went into force on 1 May 1936.

438 See for the different categories of "movable monuments": Art. 1 of the Treaty of Washington. The categories are further elaborated upon in: Walter, B., 1988, p. 47.
} 
without a valid export license was thwarted, the object will be confiscated and returned to the public authorities of the country of origin (Art. 5). For those cases in which the illegal import could not be prevented, Art. 6 of the Treaty of Washington provides the countries of origin with the right to turn to the state into whose territory the objects has been illegally imported to seek its return (Art. 6). The holding state has to undertake the necessary steps to return the object to the applicant (Art. 7). ${ }^{439}$ The applicant state's right to restitution is supported by the possibility to start a procedure in the civil courts of the holding state for the restitution of illegally exported and imported "movable monuments". 440

The Treaty of Washington is the first multilateral treaty solely dedicated to the protection of cultural property in times of peace. ${ }^{441}$ It stands out for introducing a workable enforcement mechanism that complements the obligations to return cultural property. In particular, granting State Parties the possibility to start a procedure in the civil courts constituted an innovative and effective mechanism. While this mechanism would eventually also be employed in an international convention ${ }^{442}$, the Treaty of Washington is as of today unmatched in making the legality of an import of a cultural object dependant on the existence of a valid export license. ${ }^{443}$ The relevance of the Treaty of Washington is, however, limited by its application to specifically designated cultural objects, as well by its regional rather than international character. ${ }^{444}$

\section{1970 UNESCO CONVENTION}

After the attempts to adopt an international convention under the umbrella of the League of Nations had failed and the organisation itself was dissolved, the movement towards greater protection of cultural objects at the international level was given new impetus during the $11^{\text {th }}$ session of UNESCO's General Assembly in 1960 in the form of two resolutions made by Mexico and Congo. ${ }^{445}$ In 1962, the impetus was reconfirmed

\footnotetext{
439 Cf.: Engstler, L., 1964, pp. 53-54; Walter, B., 1988, pp. 46-48; Schorlemer, S.v., 1992, pp. 423-234.

${ }_{440}$ According to Art. 4 of the Treaty of Washington "the signatory countries understand that those who have objects declared to be movable monuments, can only enjoy the usufruct, which is transferable only within the same country and the undertake to legislate to that effect". What Art. 4 effectively does is to qualify the objects as defined under Art. 1 as rei extra commercium. Private property is not possible as a consequence of which the state of origin can pursue its claim to the object in the national courts. Cf.: Walter, B., 1988, pp. 46-47.

${ }^{441}$ Cf.: the elaborations in chp. 1. IIV on the Roerich Pact, which was the first multilateral treaty ever dedicated to cultural property. Its focus lies on the protection of cultural property in armed conflicts but does not provide for the restitution or return of removed cultural property.

${ }^{442}$ See further below in chp. 1.\$2.IV for the analysis of the 1995 UNIDROIT Convention.

443 See further below in chp. 1. \$2.III discussing the February 1970 Draft UNESCO Convention for the failure to introduce this mechanism at the international level.

${ }^{444}$ The Treaty of Washington has been ratified by Chile, El Salvador, Guatemala, Mexico and Nicaragua. Cf.: http://www.oas.org/juridico/english/sigs/c-4.html (last visited: 23 June 2009. The information has been confirmed by the OAS Department of International Law.

${ }^{445}$ Engstler, L., 1964, p. 56.
} 
by UNESCO Resolution 4.413.446 During the $13^{\text {th }}$ General Assembly of UNESCO in 1964 the 'Recommendation on the means of prohibiting and preventing the illicit export, import and transfer of ownership of cultural property' was adopted.447 The Recommendation appealed to State Parties to agree upon measures to allow for the return of illegally exported cultural objects. ${ }^{448}$ However, the Recommendation was limited in seeking for close collaboration between the State Parties in accordance with the respective national laws rather than pleading for the adoption of rules under public international law.

Not being satisfied with the limitation of the protection of cultural objects to the collaboration on the basis of national laws the UNESCO Secretariat developed a proposal for a convention which was presented in February 1970.449 The proposal was based on the preparatory work undertaken in the 1930s by the predecessor of UNESCO under the League of Nations. 450 This proposal, which Bator referred to as "a document designed for a Heavenly City in which everything is utterly orderly, tidy, and subject to perfect and all-encompassing controls" 451 proved to be too ambitious for a number of State Parties, above all the United States. ${ }^{452}$ In particular Art. 7 of the proposal according to which Member States were obliged to amend their national laws to render any export of cultural property subject to an export license, was rejected. ${ }^{453}$

In reaction to the concerns about Art. 7, the requirement of rendering all exports subject to an export license was dropped in the 'Revised Draft Convention concerning the Means of Prohibiting and Preventing the Illicit Import, Export and Transfer of Ownership of Cultural Property'. ${ }^{454}$ Instead, the convention as adopted in November 1970 (hereinafter: 1970 UNESCO Convention) ${ }^{455}$ required Member States to undertake certain measures with regard to illegally exported and stolen cultural property as will be outlined below. The 1970 UNESCO Convention is not self-executing but requires the State Members to change their domestic laws in accordance with its provisions (Art. 3).

\footnotetext{
${ }_{446}$ Resolution 4. 413, adopted by the General Conference of UNESCO at its twelfth session, p. $51 \mathrm{f}$. Cf.: Walter, B., 1988, p. 49.

447 Recommandation concernant les mesures à prendre pour interdire et empêcher l'exportation, l'importation et le transfert de propriété illicites des biens culturels, adoptée par la Conférence Générale de l'UNESCO à sa 13e session, Paris, 19 Novembre 1964. UNESCO, Records of the General conference, 13th session, 1964, Resoutiens, p. 1481 and Conventions and Recommendations p. 137ff. Cf.: Walter, B., 1988, p. 49.

448 UNESCO Convention on the Means of Prohibiting and Preventing the Illicit Import, Export and Transfer of Ownership of Cultural Property, Nov. 14, 1970 (823 U.N.T.S. 231). Cf.: Schorlemer, S.v., 1992, p. 425.

${ }_{449}$ UNESCO Doc. SHC/MD/5 (1970). Walter, B., 1988, p. 49; Odendahl, K., 2005, p. 134.

450 Walter, B., 1988, p. 49; Odendahl, K., 2005, p. 134.

${ }^{451}$ Bator, P.M., 1993, p. 95.

452 Walter, B., 1988, p. 50; Schorlemer, S.v., 1992, p. 428.

${ }^{453}$ Cf.: Abramson, R. / Huttler, S., 1973, p. 956-957; Edelson, S., 1984, pp. 1038 ff..

${ }^{454}$ Cf.: Schorlemer, S.v., 1992, p. 431.

455 Cf.: Ibid., p. 425.
} 
Before further addressing the measures introduced by the 1970 UNESCO Convention with regard to stolen cultural property (transfer of ownership) and illegal exports and, if applicable illegal imports, the definition of cultural property as provided for in Art. 1 shall be addressed. ${ }^{456}$ According to this Article cultural property is:

"property which, on religious or secular grounds, is specifically designated by each State as being of importance for archaeology, prehistory, history, literature, art or science".

The six disciplines (archaeology, prehistory, history, literature, art or science) are further explicated in a list of eleven categories. ${ }^{457}$ Given the broad range of categories, the requirement that an object must belong to one of these categories is not restrictive. In fact, the quality of the list of categories is more illustrative than defining. ${ }^{458}$

One aspect that deserves further consideration is the question whether the definition of cultural property requires any special relation between the object and the State where the object is held. ${ }^{459}$ Of the categories listed in Art. 1 only sub b), property relating to the history of a country, makes special reference to a national link between the object

456 The 1970 UNESCO Convention also works with the term "cultural heritage", which is defined in Art. 4. Given the definition is relevant only for the domestic activities aimed at the protecting of cultural heritage (see Arts. 5 and 14), it will not be further discussed here. See instead: Siehr, K., 1993, p. 206.

457 (a) Rare collections and specimens of fauna, flora, minerals and anatomy, and objects of palaeontological interest;

(b) property relating to history, including the history of science and technology and military and social history, to the life of national leaders, thinkers, scientists and artist and to events of national importance;

(c) products of archaeological excavations (including regular and clandestine) or of archaeological discoveries;

(d) elements of artistic or historical monuments or archaeological sites which have been dismembered;

(e) antiquities more than one hundred years old, such as inscriptions, coins and engraved seals;

(f) objects of ethnological interest;

(g) property of artistic interest, such as:

(i) pictures, paintings and drawings produced entirely by hand on any support and in any material (excluding industrial designs and manufactured articles decorated by hand);

(ii) original works of statuary art and sculpture in any material;

(iii) original engravings, prints and lithographs ;

(iv) original artistic assemblages and montages in any material;

(h) rare manuscripts and incunabula, old books, documents and publications of special interest (historical, artistic, scientific, literary, etc.) singly or in collections;

(i) postage, revenue and similar stamps, singly or in collections;

(j) archives, including sound, photographic and cinematographic archives;

(k) articles of furniture more than one hundred years old and old musical instruments.

${ }^{458}$ Cf.: the comment of the Select Committee on Culture Media and Sport of the House of Commons on the concept of cultural property of the 1970 UNESCO Convention as being "extremely broad and subjective, in that it is assumed that importance is to be defined by a State. Objects that can be subject to trading restrictions or prohibitions range from human remains to postage stamps". Seventh Report of the House of Commons Select Committee on Culture Media and Sport, Cultural Property: Return and Illicit Trade, 2000, para. 124.

${ }^{459}$ Cf.: Siehr, K., 1993, p. 204. 
and the state 460 All other categories do not require a special link between the object and the state. Consequently, cultural objects do not have to originate from the territory of a state to qualify them as its cultural property. There is no legal or moral test that challenges the link between an object and a state. ${ }^{461}$

With the definition of cultural property being clarified, we can now look at the protective regime brought about by the Convention. The most relevant provisions are Artt. 3, 6 and 7. According to these provisions an illegal export from one country constitutes an illegal import in other Member States. The latter have to accept the national export limitations of other Member States regardless of whether their own export control supports such regime. The provisions thus break with the general principle of public international law that denies the extraterritorial application of national law. ${ }^{462}$ This finding does not, however, answer the question what happens where cultural property has nevertheless been imported into a Member State in breach of another Member State's national law. For this aspect we need to turn to Art. 7, which deals both with illegally exported cultural property (sub a) and cultural property stolen from further defined institutions (sub b(i)):

"The States Parties to this Convention undertake:

(a)

To take the necessary measures, consistent with national legislation, to prevent museums and similar institutions within their territories from acquiring cultural property originating in another State Party which has been illegally exported after entry into force of this Convention, in the States concerned. Whenever possible, to inform a State of origin Party to this Convention of an offer of such cultural property illegally removed from that State after the entry into force of this Convention in both States;

(b)

(i) to prohibit the import of cultural property stolen from a museum or a religious or secular public monument or similar institution in another State Party to this Convention after the entry into force of this Convention for the States concerned, provided that such property is documented as appertaining to the inventory of that institution;

460 Art. 1 (b) refers to "property relating to history, including the history of science and technology and military and social history, to the life of national leaders, thinkers, scientists and artist and to events of national importance.

461 This point can be illustrated with the example of the Rosetta Stone from the collection of the British Museum. The Rosetta Stone, which became famous for allowing the deciphering of the hieroglyphs, originates from Egypt from where it had been removed under the British occupation during the 19th century to England. Despite originating from Egypt and its eminent relevance for the latter's cultural and history, the Rosetta Stone qualifies as cultural property of the United Kingdom under Art. 1 of the UNESCO Convention. See further on the Rosetta Stone: Giblin, J.C., 1992; http://www.geocities.com/TimesSquare/Alley/4482/Rosetta.html (Last visited: 30 June 2008). Whether the Rosetta Stone would qualify as "cultural heritage"in the sense of Art. 4 of the 1970 UNESCO Convention is a different question but as Art. 4 is irrelevant for protection against exports and questions of restitution the question will not be further addressed here.

462 Odendahl, K., 2005, p. 134. 
(ii) at the request of the State Party of origin, to take appropriate steps to recover and return any such cultural property imported after the entry into force of this Convention in both States concerned, provided, however, that the requesting State shall pay just compensation to an innocent purchaser or to a person who has valid title to that property. Requests for recovery and return shall be made through diplomatic offices. $(\ldots) \cdot{ }^{463}$

The Article, which deals both with illegally exported and stolen cultural property, does not stand out for its clarity. ${ }^{464}$ In particular, the relationship between Art. 7 sub (a) dealing will illegally exported cultural property and Art. 7 sub (b)(ii) introducing the regime for the recovery and return of "any such cultural property" is unclear: does the obligation to recover and return (Art. 7 (b)(ii)) apply only to cultural property stolen from a museum or a religious or secular public monument or similar institution (Art. 7 (b)(i)) or does it extend also to cultural property that has been illegally exported from another State Party (Art. 7 (a))? The literature disagrees as to whether the obligation of Art. 7 (b)(ii) to recover and return cultural property applies both to illegally exported and stolen cultural property or only to the latter. While some authors argue for a more extensive interpretation of Art. 7(b)(ii) applying also to illegally exported cultural property ${ }^{465}$, others hold the obligation only applicable to the objects stolen under the circumstances outlined in Art. 7 (b)(i). ${ }^{466}$

Different available methods of interpretation support the more limited understanding of Art. 7(b)(ii) according to which it applies only to a narrowly defined group of stolen objects - i.e. cultural objects stolen from a museum or a religious or secular public monument or similar institution. It does not include unlawfully excavated cultural objects nor does it include illegally exported cultural objects. ${ }^{467}$ Where stolen

463 (Emphasis added).

464 See in particular for a critical discussion: Siehr, K., 1993, p. 203 and p. 211 who states that the Convention is not a perfect specimen of an international convention: "too many cooks spoiled the broth and too many different meals were prepared at the same time".

465 See, e.g.: Ibid., pp. 207-208.

466 Walter, B., 1988, p. 51, Freytag, C., 1996, p. 181; Merryman, J.H., 2007, p. 187; Mackenzie, S., 2005 , p. 90.

467 The general rule of treaty interpretation, as codified in the Vienna Convention on the Law of Treaties 1969 , states that treaty provisions are to be interpreted "in accordance with the ordinary meaning to be given to the terms of the treaty in their context and in light of its object and purpose" (Art. 31(1) of Vienna Convention on the Law of Treaties 1969). As restated by the International Court of Justice "interpretation must be based above all upon the text of the treaty. As supplementary measure recourse may be had to means of interpretation such as the preparatory work of the treaty and the circumstances of its conclusion" (Territorial Dispute (Libyan Arab Jamahiriya/Chad), Judgment, I.C.J. Reports 1994, p. 21, para. 41). A literal interpretation is not conclusive but there are nevertheless some aspects that speak against the subsection's application to illegally exported cultural property. While the English version leaves some doubts as to whether "any such cultural property imported after the entry into force of this Convention" refers only "cultural property stolen form a museum or a religious or secular public monument (...)" (Art. 7(b)(i)) or applies also to "cultural property originating in another State Party which has been illegally exported (...)" (Art. 7(a)), the French and Spanish versions, which are authoritative texts next to the English and Russian versions, are less ambiguous. Art. 7(b)(ii) in the French and Spanish version refers to "tout bien culturel ainsi volé et importé après l'entrée en vigueur de la présente Convention" respectively "todo bien cultural robado e importado despues de la entrada en vigor de la Convencion". Both the French and the Spanish text 
objects have in the meantime been acquired by good faith purchaser or valid title has been vested, the requesting state has to pay just compensation. 468 As none of the other Articles of the Convention introduce a basis for a claim the Convention's relevance for the return of illegally exported cultural objects lies essentially in awareness raising. ${ }^{469}$

As far as the Convention's application in time is concerned, Art. 7 leaves no doubt that the 1970 Convention does not apply retroactively. During the drafting process China had proposed the inclusion of an article providing for retroactive effect:

“(...) any State party which, when the Convention comes into force, is in possession of important cultural property, illicitly acquired, inalienable to, and inseparable from, the history and civilization of another State, shall, in the interest of international goodwill, endeavour to restore such property to that State". 470

The article was not incorporated in the final text; it was not even included in the 1969 draft version. On the contrary, the preliminary draft did include a provision according to which State Parties were required to recognize the ownership vested in each State or its nationals acquired before the Convention entered into force for the state concerned. ${ }^{471}$ After significant debate on the recognition of the status quo

speak exclusively of stolen cultural property that has been imported after the Convention's entry into force. The finding of the literal analysis that subsection (b)(ii) of Art. 7 does not provide for the return of illegally exported cultural property is supported by a contextual / systematic analysis: Art. 7 consists of two sections that are marked by the use of the letters a) and b). Subsection a) obliges State Parties to take legal measures to prevent a limited circle of potential buyers from acquiring illegally exported cultural property. Subsection b)(i) obliges State Parties to prohibit the import of stolen cultural property originating from specifically designated collections. With the obligation to return "any such property" being situated in subsection b), the system of the Article suggests that the provision on the recovery and return applies solely to stolen cultural property (See further for a critical discussion of the requirements stolen cultural property has to fulfill in order to be eligible for return: Mackenzie, S., 2005, p. 94). A look at the preparatory instruments of the Convention also speaks in favour of the more limited interpretation. As seen above, the original draft for the 1970 UNESCO Convention was considered too all-encompassing for a number of State Parties, above all the United States. The delegation of the latter had complemented its criticism with detailed suggestions to amend the proposal. In particular, the circle of cultural objects affected by the convention should be limited by introducing a clause according to which the convention should "prohibit the importation into one country of cultural property stolen from a museum or a similar institution in another country, and providing for the recovery and return of such property" (Cf.: Walter, B., 1988, pp. 50-51; Schorlemer, S.v., 1992, p. 428; Bator, P.M., 1993, p. 97). It was this proposal that is reflected in the current form of Art. 7. In conclusion, the interpretation of Art. 7 in accordance with the rules on interpretation as contained 31(1) of the Vienna Convention on the Law of Treaties 1969 suggests that the obligation to return cultural property as provided for by Art. 7(b)(ii) is limited to a narrowly defined group of stolen objects - i.e. cultural objects stolen from a museum or a religious or secular public monument or similar institution. It does not include unlawfully excavated cultural objects nor does it include illegally exported cultural objects.

468 See Art. 7(b)(ii). Cf.: Odendahl, K., 2005, p. 175.

${ }^{469}$ Cf.: Mackenzie, S., 2005, p. 94 who remarks that "the protection afforded by the Convention to source States is so narrow that it seems the US courts and the UK legislature have moved beyond it of their own accord".

470 UNESCO Doc. SHC/MD/5 Annex II, 10. Cf.: Prott, L.V. / O'Keefe, P.J., 1989, p. 813.

471 Art. 4(f). UNESCO Doc. SHC/MD/5 Annex II, 10. 
ownership of cultural ownerships (draft) Art. 4(f) was deleted by the Special Committee of Governmental Experts in 1970.472

In the final and adopted version of the 1970 UNESCO Convention Art. 15 is the only reminder of this discussion on the application of the convention for cultural objects removed prior to its entry into force. Art. 15 emphasizes the general principle that

"nothing (...) shall prevent States Parties (...) from concluding special agreements among themselves or from continuing to implement agreements already concluded regarding the restitution of cultural property removed, whatever the reason, from its territory of origin, before the entry into force of this Convention for the States concerned".

The 1970 UNESCO Convention entered into force on 24 April 1972. This date is crucial only for those states that had deposited their instruments of ratification, acceptance or accession by that date. ${ }^{473}$ For all other states, the Convention enters into force three months after their respective instruments have been deposited. ${ }^{474}$ Until recently, countries, in particular art market nations were reluctant to ratify the 1970 UNESCO Convention. ${ }^{45}$ Art market nations, in contrast to source nations, are characterized by a greater demand than supply in art and cultural objects. Typical examples are the United Kingdom, Switzerland and the United States. Until the early 1980s not one art market nation had become a State Party to the Convention. In 1983, the United States of America was the first art market country to become State Party. 476 Over the last decade there was a significant increase in ratifications, including art market countries. In 1997, France ratified the Convention and more art market countries, including the United Kingdom, Switzerland, Japan, Germany followed. ${ }^{477}$ By the end of 2008, more than 100 countries had become a State Party, including the most prominent art market countries. The Netherlands finally ratified the 1970 UNESCO Convention on 9 June 2009.

\footnotetext{
472 See: Prott, L.V. / O'Keefe, P.J., 1989, para. 1416. Unesco Doc. 16 C/17 Annex II, 4.

473 The States that had deposited their instruments of acceptance respectively ratification were: Ecuador, Bulgaria, Nigeria and the Central African Republic. See for a chronological overview of State Parties to the Convention: http://portal.unesco.org/la/convention.asp?KO=13039\&language $=\mathrm{E}$ (last visited: 21 July 2008).

${ }^{474}$ See Art. 21 which sets the date of the Convention's entry into force at three months after the date of the deposit of the third instrument of ratification, acceptance or accession.

${ }^{475}$ Cf.: Odendahl, K., 2005, p. 179. See above in the introduction (\$2.I) for an explanation on the difference between art market and source nations.

476 The U.S. Instrument of Acceptance was deposited on 2.09.1983. The 1970 UNESCO Convention hence entered into force for the U.S. on 2.12.1983. It should be mentioned that the increase in art market countries becoming State Parties to the 1970 UNESCO Convention started the year after the 1995 UNIDROIT Convention, discussed in the next section, was adopted. Whether there exists any correlation or whether this is simply coincidence cannot be discussed here and requires are more sociological research approach.

${ }^{477}$ See for a chronological overview of State Parties to the Convention:

http://portal.unesco.org/la/convention.asp? $\mathrm{KO}=13039$ \&language $=\mathrm{E}$ (last visited: 21 July 2008).
} 
One of the main reasons for countries not to become a State Party to the 1970 UNESCO Convention was the fact that the Convention interferes with the private laws of State Parties, especially the rules on good faith purchase. ${ }^{478}$ For this reason, UNESCO decided to call in the help of UNIDROIT, the International Institute for the Unification of Private Law for the creation of an additional harmonized system of private law. ${ }^{479}$

\section{1995 UNIDROIT CONVENTION}

In 1984, the International Institute for the Unification of Private Law (hereinafter: UNIDROIT) ${ }^{480}$ was approached by UNESCO with the request to complement the rules of public international law of the 1970 UNESCO Convention with harmonized rules of private law, in particular in respect of bona fide purchase. Preliminary research led to the conclusion that rather than amending the 1970 UNESCO Convention or adding a protocol harmonising rules of private law a separate convention should be introduced. ${ }^{481}$ After the first draft was presented in $1990^{482}$ the final version of the 'UNIDROIT Convention on Stolen or Illegally Exported Cultural Objects' (hereinafter: 1995 UNIDROIT Convention) was adopted in 1995.483

As the title of the 1995 UNIDROIT Convention indicates, it speaks of "cultural objects" rather than following the terminology of the 1970 UNESCO Convention that speaks of "cultural property". There exists, however, no conceptual difference between "cultural objects" as defined by the 1995 UNIDROIT Convention and "cultural property" as defined by the 1970 UNESCO Convention. ${ }^{484}$

According to Art. 1, the 1995 UNIDROIT Convention applies to "claims of an international character for (a) the restitution of stolen cultural objects" and "(b) the return of cultural objects removed from the territory of a Contracting State contrary to its law regulating the export of cultural objects for the purpose of protecting its cultural heritage". In line with the 1970 UNESCO Convention, the 1995 UNIDROIT Convention deals both with stolen and illegally exported cultural objects. As will be shown below, the protection afforded by the 1995 UNIDROIT Convention goes further than the protection afforded by the 1970 UNESCO Convention. Moreover, the

\footnotetext{
${ }^{478}$ Reichelt, G., 1994, p. 68.

479 Odendahl, K., 2005, p. 176.

480 UNIDROIT was founded in 1926 with the aim to draft uniform private law legislation. Siehr, K., 1993, p. 95. See further on the history and aim of UNIDROIT: David, R., 1971.

481 Odendahl, K., 2005, p. 177.

482 Preliminary Draft Unidroit Convention on Stolen or Illegally Exported Cultural Objects (approved by the UNIDROIT Study Group on the International Protection of Cultural Property at its Third Session on 26 January 1990). See for the full text: Siehr, K., 1992b. See for comments on the draft: Siehr, K., 1992c; Reichelt, G., 1994.

${ }^{483}$ UNIDROIT Convention on Stolen or Illegally Exported Cultural Objects signed at Rome, 24 June 1995. ${ }^{484}$ See Art. 2 of the 1995 UNIDROIT Convention and the list of categories of cultural objects included in the Convention's annex.
} 
protection afforded is available even when State Parties fail to implement the 1995 UNIDROIT Convention (correctly) as its provisions are self-executive.

The applicable regimes for stolen and illegally exported cultural objects are outlined in two separate chapters of the Convention. The rules concerning the restitution of stolen cultural objects are contained in Chapter II. The possessor of a stolen cultural object has to return it but is granted a fair and reasonable compensation if he had acted in good faith (Art. 3(1) and Art. 4(1)). 485 Different from the 1970 UNESCO Convention, the 1995 UNIDROIT Convention grants State Parties access to the national courts, rather than limiting the possibility of recovery through diplomatic channels. ${ }^{486}$ Furthermore, it extends this right to seek restitution to private parties (Art. 3) rather than reserving it to contracting states.

The possibility to recover a cultural object is, however, not unlimited in time. The claiming party has to bring its claim within a period of three years from the moment the location of the cultural object and the identity of its possessor are known (Art. 3(3)). This relative limitation period of 3 years is complemented by an absolute limitation period of fifty years from the time of the theft after which no claim can be brought (Art. 3(3)). Cultural objects stolen from a public collection are exempted from the absolute limitation period (Art. 3(4)): a claim for restitution of a cultural object belonging to a public collection, an identified monument or archaeological site is not subject to any time limitation other than a period of three years from the time when the claimant knew the location of the cultural object and the identity of its possessor. The same applies for claims for restitution of a sacred or communally important cultural object belonging to and used by a tribal or indigenous community in a Contracting State provided that it has been stolen (Art. 3(8)). Member States are granted discretion to subject claims for the restitution of a cultural object from a public collection to an absolute limitation period. The period may not undercut a period of seventy-five years (Art. 3(5)). Where a Member State chooses to subject claims from another Member States for the restitution of a cultural object from a public collection to a time limitation the same period is held applicable where the former claims objects from public collections abroad. ${ }^{487}$

The regime applicable to the return of illegally exported cultural objects is provided for in Chapter III of the Convention. The key provision is Art. 5, which requires State Parties to act differently from the general rule according to which no state is required to enforce another state's export controls. ${ }^{488}$ According to this Article a State Party may request the courts in another State Party to order the return of cultural objects that have

\footnotetext{
485 The compensation is to be paid by the person who transferred the cultural objective to the possessor if permitted by the law of the State in which the claim is brought (Art. 4(2)).

486 See Art. 7(b)(ii) of the 1970 UNESCO Convention.

487 See further for an analysis of the relevance of the 1995 UNIDROIT Convention further to existing rights in law: Mackenzie, S., 2005, p. 95.

${ }^{488}$ Merryman, J.H., 2007, p. 215.
} 
been illegally exported from its territory (Art. 5(1)). ${ }^{489}$ Different from the case of stolen cultural property, the return of illegally exported cultural objects is not automatic but requires active intervention between State parties. Furthermore, and different from the regime governing stolen cultural objects outlined in Chapter II, the right to seek return of illegally exported cultural objects is limited to State Parties. As such a claim is brought on the ground of breach of public laws; the drafters of the 1995 UNIDROIT Convention explicitly ruled out that private owners may bring a claim. ${ }^{490}$ Furthermore, the State Parties' right to claim for the return is limited: the court has to order the return of the requested object only if the requesting state establishes that the object is of "significant cultural importance" or if the removal of the object impairs one of the interests listed in Art. 5(3):
a. the physical preservation of the object or of its context;
b. the integrity of a complex object;
c. the preservation of information of, for example, a scientific or historical character;
d. the traditional or ritual use of the object by a tribal or indigenous community.

The interests listed sub (a), (b) and (c) correspond with the main general aims of the protection of cultural property - the physical preservation of original objects and the preservation in the original context. ${ }^{491}$ What is interesting about the interest listed sub (d) - the traditional or ritual use of the object by a tribal or indigenous community - is that it seeks to protect an interest of a different order. Rather than seeking to protect the object as such it seeks to protect its traditional or ritual use. In this respect the 1995 UNIDROIT Convention anticipates the UNESCO Convention for the Safeguarding of the Intangible Cultural Heritage that was adopted in October 2003. For those cultural objects that do not fit into any of these four categories, the general interest of "significant cultural importance" has been introduced. 492

In case the court orders the return of an illegally exported cultural object, the current possessor, provided he acted in good faith, is granted fair and reasonable compensation to be paid by the requesting state (Art. 6(1)).493 A state's ability to seek the return of an illegally exported cultural object is subject to the same limitation periods that apply to stolen cultural objects (Art. 5(5)). Different from the case of stolen cultural objects,

\footnotetext{
489 The same applies to cultural objects whose export might have been lawful but which are not returned in accordance with the export permit (Art. 5(2)).

490 UNIDROIT Convention on Stolen or Illegally Exported Cultural Objects: Explanatory Report prepared by the UNIDROIT Secretariat, 2001, p. 526.

491 See further on the main aims of cultural property law: Fechner, F.G., 1998, pp. 382-383.

492 Cf.: UNIDROIT Convention on Stolen or Illegally Exported Cultural Objects: Explanatory Report prepared by the UNIDROIT Secretariat, 2001, p. 530. The explanatory report refers to the Taranaki sculptures in the case of Attorney General of New Zealand v. Ortiz [1984] 1 A.C 1, 35 (H.L.) as an example of objects that would be caught be the general category.

493 Art. 6(3) mentions a number of alternatives to the payment of compensation to meet the interest of the bona fide possessor provided the latter agrees.
} 
objects from public collections are not exempted from the absolute limitation period after which no claim can be brought.

The provisions in Chapter II on stolen cultural objects and Chapter III on illegally exported cultural objects are complemented with articles further regulating the implementation of the Convention. Art. 10 of Chapter IV on General Provisions stresses that the 1995 UNIDROIT Convention does not apply retroactively. Its provisions apply only to cultural objects that have been stolen or illegally exported after the entry into force of the Convention for the requesting State Party and the holding State. The entry into force of the 1995 UNIDROIT Convention on 1 st July 1998 is hence only relevant for the first five countries that ratified the Convention. ${ }^{494}$ In case of illegal export both States must have ratified the Convention prior to the illegal export. In case of theft, it suffices if the holding State Party ratified the Convention before the stolen object was brought into its territory. ${ }^{495}$ Art. 10(3) emphasizes that while the Convention cannot be used to remedy illegal transfers that occurred prior to the entry into force of the Convention (for the respective State Party), it does not legitimize these transfers nor does it prevent any remedies available outside of its own regime. ${ }^{496}$

The 1995 UNIDROIT Convention is the first international convention to introduce a legal right to seek the return of illegally exported cultural objects. While legally enforceable, this right is rather limited both in scope and practical relevance. As outlined above, Art. 5(3) makes the return dependant on the relevance of a cultural object. As for the practical relevance, this may change over time as has been experienced with the 1970 UNESCO Convention. Currently, the 1995 UNIDROIT Convention counts only 29 State Parties. ${ }^{497}$ All of the State Parties are source nations or at least not typical art market nations. The latter have so far refused to become State Parties for reasons that the 1995 UNIDROIT Convention would mean a disproportionate interference in legal trade. 498

\footnotetext{
${ }^{494}$ The 1995 UNIDROIT Convention entered into force on that date for the following countries: Cyprus, Hungary, Lithuania, Pakistan, Paraguay and Romania. Art. 12 states that the Convention enters into force on the first day of the sixth month following the date of deposit of the fifth instrument of ratification, acceptance, approval or accession.

495 Art. 10 (1) and (2).

${ }^{496}$ This convention does not in any way legitimise any illegal transaction of whatever nature which has taken place before the entry into force of this Convention or which is excluded under paragraphs (1) and (2) of this article, nor limit any right of a State or other person to make a claim under remedies available outside the framework of this convention for the restitution or return of a cultural object stolen or illegally exported before the entry into force of this Convention.

${ }^{497}$ See for an alphabetical overview of State Parties to the Convention:

http://www.unidroit.org/english/implement/i-95.pdf (last visited: 23 July 2008). In an email received from the UNIDROIT Secretariat dated 23 July 08 the list was confirmed as being up-to-date.

498 See, e.g.: Lalive, P., 1999; Kuitenbrouwer, F., 16 May 2003.
} 


\section{European Convention On OFFences relating to Cultural Property (1985)}

The European Convention on Offences relating to Cultural Property (hereinafter: "the 1985 European Convention") was drawn up by the Council of Europe in 1985.499 While the 1985 European Convention was adopted in the period between the 1970 UNESCO Convention and the 1985 UNIDROIT Convention, we have chosen to wait with its analysis until after the evaluation of the 1995 UNIDROIT Convention. Not only does the latter complement the 1970 UNESCO Convention, which asks for joint evaluation; the 1985 Convention is also different in that it is an instrument of regional relevance only. ${ }^{500}$ Furthermore, the 1985 European Convention has not yet entered into force despite its adoption more than twenty years ago. 501

The 1985 European Convention provides for a basis to claim for the return of cultural property where the objects concerned fall under the definition of cultural property as provided for in Annex II to the Convention and that have been brought into a State Party's territory in breach of one of the offences listed in Annex III to the Convention (Art. 8(2) $)^{502}$. The exportation of cultural property in breach of national laws is listed as one of the relevant offences in Art. 2(h) of Annex III. ${ }^{503}$ Different from the international treaties discussed above the 1985 European Convention does not rely on a breach of a national export law. Instead, it relies upon the committing of an offence as defined in its catalogue of offences (Annex II). ${ }^{504}$ While this approach circumvents the problems generally encountered in the realm of illegal exports, i.e. the unwillingness of countries to enforce other national public laws, the agreement on a common catalogue of offences is complicated to an extend that experts fear that the

499 European Convention on Offences relating to Cultural Property, signed at Delphi, 23 June 1985 (ETS No. 119). Available online at: http://conventions.coe.int/Treaty/EN/Treaties/Html/119.htm (last visited: 6 July 2009).

500 See for a list of the current Member States of the Council of Europe:

http://www.coe.int/T/E/Com/About_Coe/Member_states/ (last visited: 23 July 2008).

501 At the end of June 2009, not a single state had ratified the Convention. See for an update: http://conventions.coe.int/treaty/Commun/ChercheSig.asp?NT=119\&CM=8\&DF=6/17/2009\&CL=EN $\mathrm{G}$. The convention requires 3 ratifications to enter into force.

502 Art. 8(2) reads: "Each Party shall execute in the manner provided for by its law any letters rogatory relating to proceedings addressed to it by the competent authorities of a Party that is competent in accordance with Art. 13 for the purpose of seizure and restitution of cultural property which has been removed to the territory of the requested Party subsequent to an offence relating to cultural property. Restitution of the property in question is however subject to the conditions laid down in the law of the requested Party".

503 List of legal provisions that provide for offences other than offences dealt with under criminal law: actual or attempted exportation of cultural property the exportation of which is prohibited by the law of a Party (2(h)(i)); exportation or attempted exportation, without authorisation of the competent authorities, of cultural property the exportation of which is made conditional on such an authorisation by the law of a Party (2(h)(ii)).

${ }^{504}$ Cf.: Odendahl, K., 2005, p. 176. 
1985 European Convention will never enter into force. ${ }^{505}$ As to the question to what extent the 1985 European Convention would alter the protection available to illegally exported cultural objects should it eventually enter into force the prognosis is limited: as an instrument of penal character it can only be applied against the person who committed an offence listed in the annex. Consequently, only cultural property still possessed by the offender could be seized and returned. ${ }^{506}$

\section{EEC Regulation No 3911/92 And EC Directive 93/7/EEC}

In 1992 and 1993, the European Community adopted two measures to reconcile the fundamental principle of European Community Law of the free movement of goods with the protection of objects classified as "national treasures possessing artistic, historic or archaeological value" in the sense of Art. 30 EC Treaty $^{507}$ : Council Regulation (EEC) No 3911/92 of 9 December 1992 on the export of cultural goods (hereinafter: "the Regulation") and Council Directive 93/7/EEC of 15 March 1993 on the return of cultural objects unlawfully removed from the territory of a Member State (hereinafter: "the Directive"). 508

The adoption of these two related measures occurred against the background of the completion of the internal market in December 1992.509 With the opening of the internal borders within the European Community the national export regulations as a policy measure to protect the national heritage lost some of the effectiveness given the possibility of a "cultural drain" 510 to third countries via the borders of Member States with less stringent export restrictions. ${ }^{511}$ The Regulation, which came into force on 30 March 1993, seeks to counteract such "cultural drainage" by introducing EU wide uniform export controls at the external borders. ${ }^{512}$

\footnotetext{
505 Ibid., p. $176 \& 275$.

506 Freytag, C., 1996, p. 182.

507 Art. 30 EC Treaty grants an exception to the provisions of Artt. 28 and 29, in prohibitions or restrictions on imports, exports or goods in transit justified on grounds of $(\ldots)$ the protection of national treasures possessing artistic, historic or archaeological value (...) that shall not precluded (...).

508 Council Regulation (EEC) No 3911/92 of 9 December 1992 on the export of cultural goods, OJ No L 395, 31.12.1992, p. 1, as amended by information of 27 March 1993, OJ No L 74, 27.3.1993, p. 80; Council Directive 93/7/EEC of 15 March 1993 on the return of cultural objects unlawfully removed from the territory of a Member State, OJ No L 74, 27.3.1993, p. 74.

509 The completion of the internal market as "an area without internal frontiers in which the free movement of goods, persons, services and capital" was provided for under the Single European Act, which had been signed in 1986. See Art. 8a of the Rome Treaty as inserted by the Single European Act and Artt. 3(1)c) and 14 of the EC Treaty.

510 Siehr, K., 1993, p. 226.

511 Cf.: Odendahl, K., 2005, p. 212.

512 In order to facilitate uniform controls, the Regulation introduces an EU wide system of export licenses for the export of cultural goods outside the customs territory of the Community. The system of export licenses is further outlined in Commission Regulation (EEC) No 752/93 of 30 March 1993. See further on the Regulation below in chp. $1 ฐ 2 . V I \&$ 3. $\$ 1 . I$.
} 
More important in the context of the present chapter is the Directive, which introduces domestic obligations in all Member States to return cultural objects unlawfully removed from another Member State. ${ }^{513}$ According to Art. 1(2) of the Directive unlawful removal means removal in breach of EEC Regulation No 3911/92, in breach of national laws or that an object is not returned after temporary lawful removal. The protection under the Directive is only available for cultural objects in the sense of the Directive, which have been removed after 1 January 1993 (Art. 13). A cultural object in the sense of the Directive is an object that is classified by a Member State as 'national treasures possessing artistic, historic or archaeological value' within the meaning of Art. 30 of the EC Treaty, provided it either belongs to one of the categories listed in the Annex or forms an integral part of a public collection and is listed in the institution's inventory (Art. 1).

The general obligation of the Directive to return unlawfully removed cultural objects to their Member State of origin is put into more concrete terms in Art. 7: in particular, it clarifies that the obligation to return unlawfully removed cultural objects is not absolute but is subject to two different kinds of time limits. In the first place, a Member State looses its right to seek return of a cultural object if it does not start return proceeding within one year after becoming aware of the whereabouts of the object and the identity of the possessor / holder. In the second place, Art. 7 introduces an absolute time limit irrespective of the knowledge of the Member State seeking a return: after the lapse of thirty years for objects from private collections and after the lapse of 75 years for public collections a Member State can no longer seek the return of an object, unless the legislation of the Member State in which the object is residing does not know time limits for such proceedings or in case of bilateral agreements stating otherwise. Art. 8 of the Directive clarifies that there can be no bona fide acquisition of a cultural object in the sense of the Directive. However, Art. 9(1) of the Directive takes the interest of a bona fide possessor into account in determining that he or she must be awarded a fair indemnity. ${ }^{514}$

\section{BILATERAL TREATIES}

Further to the international and regional instruments discussed above, there exist a number of bilateral treaties that provide for the return of cultural property. ${ }^{515}$ Most of

\footnotetext{
513 Siehr, K., 1993, p. 232.

514 The European Commission is currently working on a (re-) codification of Council Directive 93/7/EEC of 15 March 1993. The new Directive will supersede the various acts incorporated in the Directive in order to make it clearer and more accessible. The Proposal for a Directive of the European Parliament and of the Council on the return of cultural objects unlawfully removed from the territory of a Member State (COM/2007/0873 final - COD 2007/0299) fully preserves the content of the acts.

515 E.g.: Treaty of Cooperation between the United States of America and the United Mexican States Providing for the Recovery and Return of Stolen Archaeological, Historical and Cultural Properties; Agreement on Cultural Cooperation between the Government of Spain and the Government of the
} 
these treaties are concerned with cultural property originating from the American continent ${ }^{516}$ and oblige the State Party into whose territory stolen or illegally exported cultural property has been brought to return the object in accordance with its national laws. ${ }^{517}$ Similar to the multilateral treaties discussed above, the bilateral treaties do not apply retroactively. By relying on the protection afforded under national laws and different from the multilateral treaties, the bilateral treaties do not afford protection in case of a bona fide purchase or in case of prescription. ${ }^{518}$

\section{INTERMEDIARY CONCLUSIONS WITH REGARD TO THE RETURN OF ILLICITLY TRADED CULTURAL OBJECTS UNDER TREATY LAW}

The analysis of the available protection of cultural property in times of peace revealed that public international law is less developed when it comes to the restitution or return of cultural objects removed outside the context of armed conflicts. This does not mean that public international law is irrelevant for the restitution or return of cultural objects removed during peacetimes or put less euphemistically as a result of the illicit trade. While the restitution of stolen cultural objects is first and foremost an activity that falls under private (international) law, the analysis revealed a number of contributions of instruments of public international law to the restitution of cultural objects.

With regard to stolen cultural objects, the legal instruments analysed do extend the protection offered under private (international) law. However, one must distinguish between different categories of stolen objects: the greatest protection is granted to cultural objects stolen from institutions recognised as housing such objects. Art. 7(b) of the 1970 UNESCO Convention provides for the return of cultural property stolen from a museum or a religious or secular public monument or similar institution in another State Party after the convention's entry into force. While the return is to be achieved by diplomatic channels, the 1995 UNIDROIT Convention grants State Parties access to the national courts. Under the 1995 UNIDROIT Convention stolen cultural property has to be returned, even when acquired in good faith. The possibility to recover a cultural object is, however, limited in time. The claiming party has to bring its claim within a period of three years from the moment the location of the cultural object and the identity of its possessor are known (Art. 3(3)). This relative limitation period of 3 years is complemented by an absolute limitation period of fifty years from the time of the theft after which no claim can be brought (Art. 3(3)). Cultural objects stolen from a public collection or certain objects of important cultural relevance for a tribal or indigenous community are exempted from the absolute limitation period (Art. 3(4));

Republic of Venezuela. No. 14947, signed at Madrid on 28 June 1973. See for more examples of bilateral treaties: Walter, B., 1988, pp. 62-70.

516 Odendahl, K., 2005, p. 178.

517 Freytag, C., 1996, p. 182.

518 Ibid. 
they are subject only to the subjective period of three years from the time when the claimant knew the location of the cultural object and the identity of its possessor. Member States are, however, granted discretion in introducing an absolute limitation period for the recovery of objects from public collections, albeit no shorter than 75 years.

With regard to the return of illegally exported cultural objects or other illicitly traded object other than being stolen the international instruments are more reserved in granting protection: only the 1935 Washington Treaty, the 1995 UNIDROIT Convention and the EC Directive 93/7/EEC provide for obligations to return illegally exported cultural objects. According to the 1935 Washington Treaty, which is limited in geographical application certain categories of objects that have been illegally exported (and hence illegally imported) must be returned to the country of origin. The first international rather than only multilateral treaty that provides for the return of illegally exported cultural objects is the 1995 UNIDROIT Convention. While its definition of cultural objects is broader than the range covered by the 1935 Washington Treaty the obligation to return illegally exported cultural objects is available only to a small portion of cultural objects: only where objects are of significant cultural importance or whre their removal impairs one the four listed interests in Art. 5(3) (physical preservation, integrity, preservation of information, traditional use by indigenous community) will the court in the holding state order for their return.

Amongst EU Member States EC Directive 93/7 covers a broader range of objects and situations in which objects must be returned to the Member State of origin: the obligation to return cultural objects extends to all objects that have been classified in national law as 'national treasures possessing artistic, historic or archaeological value'. The obligation to return cultural objects exists not only where objects have been illegally exported under national law but also where the removal breached Regulation 3911/92 or where an object was not returned after a temporary lawful removal. However, while Directive $93 / 7$ goes further in scope of application than the other two instruments, it must be stressed that it applies only amongst EC Member States and is thus regionally limited. Consequently, international law, at least as far as treaty law is concerned, is very reserved in providing for the return of illegally exported cultural objects.

\section{Customary LaW}

In light of the very reserved obligations under treaty law with regard to the return of illegally exported cultural objects a number of authors have tried to identify such an obligation of customary international law. ${ }^{519}$ The majority of scholars, however, deny the existence of such an obligation of customary law. ${ }^{520}$ The results of our analysis of the

\footnotetext{
519 Seferiades, S., 1932, p. 69; Becher, K., 1974; Zschiedrich, K. / Hoffmann, E., 1984, p. 87.

520 Engstler, L., 1964; Goy, R., 1979, p. 966; Walter, B., 1988, p. 71; Schorlemer, S.v., 1992, p. 419; Odendahl, K., 2005, p. 179.
} 
existence of a uniform state practice of certain duration and spreading and an opinio iuris with regard to the return of illegally exported cultural objects will be summarised in the following. ${ }^{521}$

\section{STATE PRACTICE}

Scrutinising the activities that amount to the element of state practice, i.e. actual activity (acts and omissions), statements made in respect of concrete situations or disputes, statements of legal principle made in the abstract, national legislation and the practice of international organisations does not allow but the conclusion that at present one cannot speak of state practice of a certain duration, uniformity and spreading with regard to the return of illegally exported cultural objects. So far, only a limited number of returns of illegally exported cultural objects have been effected. ${ }^{522}$ The analysis of national legislation providing for the return of illegally exported cultural objects revealed only a limited number of jurisdictions that have introduced such legislation. Examples of such national laws are the Canadian Cultural Property Export and Import Act ${ }^{523}$, and the US Statute on the importation of pre-Columbian monumental or architectural sculpture or murals. ${ }^{524}$ The limited number of jurisdictions with little geographical spreading is not sufficient to speak of state practice. Furthermore, the legal provisions are often limited to specifically designated cultural objects, such as pre-Columbian artefacts or objects originating from certain jurisdictions only. Consequently, with none of the activities discussed in this section amounting to state practice (actual acts in the sense of returns, national legislation and the practice of international organisations) the existence of state practice concerning the return of illegally exported cultural objects must be clearly rejected. ${ }^{525}$

\footnotetext{
${ }^{521}$ See above in chp. $1 \$ 1$.VIII discussing the restitution of cultural property removed during armed conflict for an analysis of opinio iuris and state practice as the two constitutive elements of customary law. 522 Greenfield, J., 1989, pp. 5 \& 260-261 \& 264-266; Freytag, C., 1996, p. 183.

523 Cultural Property Export and Import Act ( R.S., 1985, c. C-51 ), Section "Foreign Cultural Property", which prohibits the import of cultural property that has been illegally exported from a country with which Canada has a cultural property agreement on illicit traffic, including the 1970 UNESCO Convention.

524 Act on the Regulation of Importation of Pre-Columbian Monumental or Architectural Sculpture or Murals, 19 USCA \2091-2095 (1976). See further: Nafziger, J.A.R., 1982, p. 191; Siehr, K., 1993, pp. 172176.

525 This conclusion is also supported by the analysis included in the next section (chp. 1.\$3) where we discuss the relevance resolutions and developments within the framework of UNESCO for the return of cultural objects that have been removed during the colonial era. While some the resolutions and the 'Intergovernmental Committee for Promoting the Return of Cultural Property to its Countries of Origin or its Restitution in case of Illicit Appropriation' are also relevant for the return of illegally exported cultural objects they do not provide for legally binding obligations nor do they give sufficient evidence of constant and uniform state practice.
} 


\section{OPINIO IURIS}

Given the cumulative relationship between state practice and opinio iuris no rule of customary can have evolved in the absence of the former. While we will not further elaborate upon the element of opinio iuris in the absence of a settled state practice, we would like to recall the results of our analysis of treaty law above. Treaty law is one form that can give rise to opinio iuris where it covers similar grounds as the potential rule of customary law. ${ }^{526}$

With regard to the relevance of the 1970 UNESCO Convention we must first recall the results of the analysis of its scope of application undertaken above. By various means of interpretation it was established that the 1970 UNESCO Convention does not oblige State Parties to return illegally exported cultural property. The obligation to return cultural property as provided for by Art. 7(b)(ii) does not include unlawfully excavated cultural objects nor does it include illegally exported cultural objects.527 Against this background the 1970 UNESCO Convention cannot serve as proof of State Parties' convictions with regard to the restitution of illegally exported cultural object, despite the significant increase in ratifications.

Different from the 1970 UNESCO Convention, the 1995 UNIDROIT Convention does provide for an obligation to return illegally exported cultural objects in its Art. 5. In evaluating the relevance of this provision as proof of an (emerging) opinio iuris to return illegally exported cultural objects, attention must be paid to the fact that by the end of 2008 only 29 State Parties had ratified the 1995 UNIDROIT Convention, all of which are source nations. The obligation to return illegally exported cultural objects in accordance with Art. 5 of the Convention has not been put forward as an obstacle. Consequently, while the behaviour of the art market nations does not give evidence of the (emergence) of an opinio iuris, it does not contradict it. However, given the limited number of State Parties to the Convention, it is premature to speak of more than an emerging opinio iuris on the return of illegally exported cultural objects.

This finding that the 1970 UNESCO Convention and the 1995 UNIDROIT Convention do not give evidence of an existing opinio iuris to return illegally exported cultural objects, but at the utmost allow to conclude for an emerging opinio iuris is supported by the analysis of supranational, multilateral, as well as bilateral instruments. At the supranational level we have discussed Council Directive 93/7/EEC of 15 March 1993 (hereafter: the Directive). The Directive introduces domestic obligations in all Member States to return cultural objects illegally removed from another Member State. ${ }^{528}$ However, as the Directive must be understood as a reaction to the European

\footnotetext{
${ }^{526}$ Freytag, C., 1996, p. 188; Dixon, M., 2007, p. 36.

527 Cf.: Mackenzie, S., 2005, p. 90.

528 Siehr, K., 1993, p. 232. The obligation equally applies to cultural property removed from or a contracting party to the European Economic Area Agreement. The Agreement on the European Economic Area entered into force in 1994. Its current relevance for the protection of cultural objects is that Norway, Iceland and Liechtenstein are able to participate in the Internal Market, while not assuming the full
} 
Single Market, which was realised by 1 January $1993^{529}$, the provisions of the Directive seek first and foremost to prevent the drainage of the Member States' national cultural heritage due to the abolition of customs inspection. ${ }^{530}$

As for multilateral instruments, the 1935 Treaty of Washington and the 1985 European Convention on Offences relating to Cultural Property were discussed. Both are regional treaties that are limited in geographical application to the Americas, respectively to the Europe of the Council of Europe. Of all instruments discussed here, the Treaty of Washington provides for the most elaborate system to grant the return of illegally exported cultural objects. Not only does it allow applicant states access to civil courts, it also makes the legality of an import dependant on the legality of the export. The Treaty of Washington, hence, can be understood as being supportive of an (emerging) opinio iuris. The 1985 European Convention, on the other hand, does not support the evidence to an opinio iuris. In the first place, the Convention has not entered into force despite having been adopted more than twenty years ago. Furthermore, experts are pessimistic that the Convention will never enter into force. Even then, the convention would provide only for a very limited regime under which cultural property has to be returned.

The analysis of international treaties as to the question whether and in how far they give evidence of an opinio iuris on the return of illegally exported cultural objects revealed that while there is not sufficient evidence to speak of an opinio iuris, there might be evidence of an emerging opinio iuris. The finding is supported by the tendency in national case law to provide for a remedy in cases where cultural objects have been removed from a country of origin after having been illicitly excavated. ${ }^{531}$ Traditionally, and in line with the principles of state sovereignty national courts refused to order the return of the

responsibilities of EU membership. Hence, the protection available to cultural objects originating from EU Member States as discussed in this section, is also available to objects originating in these three countries.

529 See Art. 8a of the Single European Act (SEA).

530 Freytag, C., 1996, p. 189.

531 A few comments must be made at this point on the role and relevance of national case law in the creation of customary law. In the past national case law was considered to constitute only evidence of custom but could not constitute a force of creating custom (Nollkaemper, A., 2003, p. 282, fn. 217). This view closely followed the role accorded to judicial decisions in Art. 38 of the Statute of the International Court according to which judicial decisions may be used (only) as a "subsidiary means for the determination of rules of law". At present, international law scholarship accepts the idea that national case law can be an element in the formation of customary law (Jennings, R.Y., 1996, p. 41; International Law Association (ILA), 2000, principle 9. Cf.: Nollkaemper, A., 2003). National case law can qualify as both state practice or opinio iuris (Nollkaemper, A., 2003. The idea that State practice can consist only of the practice of organs that normally enter into binding relations with other states is no longer generally supported. See with regard to the element of opinio iuris: Freytag, C., 1996, p. 184). In the present analysis, however, national case law falls short of both elements. As for state practice the cases reported in the literature (Greenfield, J., 1989, pp. 328-329; Freytag, C., 1996, pp. 184-185; Siehr, K.G., 2006, p. 121; Merryman, J.H., 2007, pp. 247-280) cannot constitute state practice for lack of a certain duration, uniformity and spreading. As for the element of opinio iuris none of the cases allowed for the return of illegally exported cultural objects as such. It is only where the foreign national law allows for reconceptualising the removal as theft, i.e. removal in breach of laws vesting ownership in a state that national courts have been willing to offer a remedy. 
objects in cases dealing with illegally exported cultural objects as this would constitute the enforcement of a foreign public law. ${ }^{532}$ Starting with the case United States v. McClain and leading to the recent case of Iran v Barakat Gallery courts in the United States and the United Kingdom have adopted a more nuanced position towards the return of cultural objects that have been removed from their country of origin after having been illegally excavated. ${ }^{533}$ The cases United States v. McClain, Peru v. Johnson, United States v. Schultz, and Iran v The Barakat Gallery all allowed for the return of cultural objects that had been removed from a foreign country of origin after having been clandestinely excavated. It is important to note that the courts did not provide for the return of illegally exported cultural objects as such, but provided for the return on the basis of laws vesting ownership of the objects with the states. By relying on foreign laws vesting ownership in cultural objects the courts were able to construe the cases as dealing with stolen cultural objects rather than objects that had been illegally exported. Further to extensively interpreting "stolen" cultural objects, the case law also indicates

532 See for a typical case in this respect the Ortiz Case: Attorney General of New Zealand v. Ortiz [1984] 1 A.C 1, 35 (H.L.). In this case, which was tried in the early 1980s in the United Kingdom, New Zealand sought the return of Maori panels that had been illegally exported under its cultural property export law in the early 1970s. Aware of the reluctance of courts to enforce public (export) laws, the Attorney General of New Zealand presented the case as a private law suit for recovery of State property (See presentation of the facts by Lord Denning: [1948] 1 AC at pp. 13 et seq. (CA). Also reproduced in: Siehr, K., 1993, pp. 184186). The reason that this strategy failed was that New Zealand law (See the New Zealand Historic Articles Act 1962, Section 5 and Section 12(2) and the New Zealand Customs Act 1939, Section 274) died not provide for automatic forfeiture. Consequently, the title to the panels had not been vested in the government of New Zealand. With the panels' exit of New Zealand territory, the authorities of New Zealand authority to seize the panels ceded. Under public international law, seizure is limited to the territory of the sovereign state. With the option of solving the case via the New Zealand Historic Articles Act and the New Zealand Customs Act, the court had to address the question as to the enforcement of New Zealand's export prohibitions. While the judge in first instance, Judge Slaughton held that "comity requires that we should respect the natural heritage of other countries by according both recognition and enforcement to their laws" (ILR 78, 591, 607. See further: Shyllon, F., 1998, pp. 114-115), the House of Lords declined to order the return of the panels due to the classification of the export rules under international law as being de 'jure imperii'. Acts that are done by a sovereign 'jure imperii' are those acts done by virtue of this sovereign authoritiy. The others are acts which are done 'jure gestionis'. With regard to the Maori penals Lord Denning reached the conclusion that legislation forbidding export of works of art and providing for automatic forfeiture to the state when exported fell into the category of "other public laws" (next to penal and revenue laws) and therefore would not be enforced by foreign courts. Cf.: Barker, I., 2006, p. 146. See for another case in which the Kingdom of Spain anticipated that the English courts would not order the return of an illegally exported painting: Kingdom of Spain v. Christie, Manson \& Woods Ldt. [1986] 1 W.L.R. 1120 (Ch.D). Instead the Kingdom of Spain asked for a declaratory judgment that the painting, which had been consigned with Christie's, had been illegally exported therewith tainting the painting's provenance. Cf.: Siehr, K.G., 2006, p. 121.

533 See cases United States v. McClain 545 F.2d 988 (5th Cir. 1977) and 593 F.2d 658 (5th Cir. 1979) (decided in two stages).; Government of Peru v Benjamin Johnson 720 F. Supp. 810 (C.D. Cal. 1989); US v. Schultz 178 F. Supp. 2d 445 (S.D.N.Y. 2002); 333 F.2d 393 (2nd Cir. 2003). 147 L.Ed 2d 891 (2004); Government of Islamic Repub. of Iran v. The Barakat Galleries Ltd., [2007] EWHC 705 (Q.B.D. 2007), March 29; Islamic Republic of Iran v. The Barakat Galleries Ltd [2007] EWCA Civ 1374, 21 December, [2008] 1 All E. R. 1177. See further on the cases, e.g.: Mastalir, R.W., 1993, p. 1052; Merryman, J.H., 2000a; Gerstenblith, P., 2002; Gerstenblith, P., 2003; Lufkin, M., 2003. 
significant good will of the courts in addressing the question whether the national laws vesting ownership were sufficiently clear in vesting title with the State. ${ }^{534}$ While this tendency to return cultural objects that have been illegally excavated and subsequently removed from their country of origin where the respective national law vests ownership in the state constitutes a step towards greater respect for the national cultural heritage and should be taken into account also by national legislators, especially of source countries, this tendency does not alter the general finding that international customary law does not presently provide for a rule providing for the return of illegally exported cultural objects.

\section{§3. RETURN OF CULTURAL OBJECTS TO THEIR COUNTRY / TERRITORY OF ORIGIN}

In the previous section we have discussed public international law - both treaty law and customary law as to the existence of rules providing for the return of illegally exported cultural objects. The question to be addressed in this section is whether international law provides for an obligation to return (cultural) objects that have been removed from their country of origin during the colonial era. At first, this question might seem counter-intuitive: did not the analysis of the previous section indicate that there exist only limited obligations to return cultural objects that have been illegally exported? Why then discuss the question whether obligations exist for the return of cultural objects that had been removed long before any of the international instruments were adopted? The reason for doing so is twofold: first, while the international instruments adopted since the 1970s did not apply retroactively they also did not rule out the return of cultural objects removed prior to their entry into force. Secondly, a number of authors explicitly pleaded for the possibility that a specific rule dealing with the return of cultural objects removed from formerly colonised countries could have come into existence or was emerging. Both aspects shall be further introduced before turning to the actual analysis of the question whether international law provides for an obligation to return (cultural) objects that have been removed from their country of origin during the colonial era.

Commenting upon the discussions with regard to the question of retroactivity during the drafting process of the 1970 UNESCO Convention it was noted that the

"debate (...) made it clear that, by 1970 , title to cultural property taken from colonies and recognized to that date by the domestic law of the holding States, and by that version of international law which they had insisted upon in the preceding centuries, was subject to substantial opposition and that nothing in the 1970 Convention settled the question". ${ }^{535}$

534 Government of Islamic Repub. of Iran v. The Barakat Galleries Ltd., [2007] EWHC 705 (Q.B.D. 2007), March 29; Islamic Republic of Iran v. The Barakat Galleries Ltd [2007] EWCA Civ 1374, 21 December, [2008] 1 All E. R. 1177, para. 96.

535 Prott, L.V. / O'Keefe, P.J., 1989, p. 813. 
During the drafting process of the 1970 UNESCO Convention China had proposed the inclusion of an article providing for retroactive effect: “(...) any State party which, when the Convention comes into force, is in possession of important cultural property, illicitly acquired, inalienable to, and inseparable from, the history and civilization of another State, shall, in the interest of international goodwill, endeavour to restore such property to that State". ${ }^{536}$ The article was not incorporated in the final text; it was not even been included in the $1969 \mathrm{draft}$ version. On the contrary, the preliminary draft did include a provision according to which State Parties were required to recognize the ownership vested in each State or its nationals acquired before the Convention entered into force for the state concerned. ${ }^{537}$ After a significant debate on the recognition of the status quo ownership of cultural ownerships (draft) Art. 4(f), which would have put an end to the claiming of cultural objects removed during the colonial era, was deleted by the Special Committee of Governmental Experts in 1970.538

In the final and adopted version of the 1970 UNESCO Convention Art. 15 is the only reminder of this discussion on the application of the convention for cultural objects removed prior to its entry into force. The Article emphasizes the general principle that

“nothing (...) shall prevent States Parties (...) from concluding special agreements among themselves or from continuing to implement agreements already concluded regarding the restitution of cultural property removed, whatever the reason, from its territory of origin, before the entry into force of this Convention for the States concerned".

The Article does not change the status quo - of course State Parties are free to enter into agreements outside of the scope of a convention.

With regard to the 1995 UNIDROIT Convention attention must be drawn to Art. 10(3). The article emphasizes that while the Convention cannot be used to remedy illegal transfers that occurred prior to the entry into force of the Convention (for the respective State Party), it does not legitimize these transfers nor does it prevent any remedies available outside of its own regime. ${ }^{539}$ Consequently, both the 1970 UNESCO and the 1995 UNIDROIT Convention take a neutral position with regard to the return of cultural objects removed prior to their entry into force: they neither constitute an $a$ posteriori legitimation of the removals nor do they introduce obligations to return the removed objects.

\footnotetext{
536 UNESCO Doc. SHC/MD/5 Annex II, 10. Cf.: Ibid. 537 Art. 4(f). UNESCO Doc. SHC/MD/5 Annex II, 10. 538 See Prott, L.V. / O'Keefe, P.J., 1989, para. 1416. Unesco Doc. 16 C/17 Annex II, 4.

539 This convention does not in any way legitimise any illegal transaction of whatever nature which has taken place before the entry into force of this Convention or which is excluded under paragraphs (1) and (2) of this article, nor limit any right of a State or other person to make a claim under remedies available outside the framework of this convention for the restitution or return of a cultural object stolen or illegally exported before the entry into force of this Convention.
} 
The second reason for investigating the question as to the existence or emergence of a rule of international law providing for the return of cultural objects removed from formerly colonised countries lies in the perception of a number of eminent legal scholars. Bernhard Walter, e.g., who refutes the existence of a rule of customary law providing for the return of illegally exported cultural objects, states that “(...) such a rule of customary law on the return of cultural objects could, however, have come into existence with respect to formerly colonised countries". ${ }^{540}$ Kurt Siehr, another eminent German scholar finds that there is an "(...) emerging rule of international law that cultural treasures lost in times of occupation or dependence have to be returned to the countries of origin". 541

In the following we will scrutinise whether any of the following doctrines can provide a basis for claims for the restitution of cultural objects removed during the colonial era. First, we will scrutinize the resolutions adopted within the frameworks of the United Nations and UNESCO and other developments within UNESCO. Secondly, we will focus on the rules of state succession. Finally, we will discuss whether a reassessment of the circumstances of acquisition of the (cultural) objects during the colonial era, both prior and past the establishment of colonial rule may give rise to an obligation for the return of objects removed during the colonial era.

\section{THE WORK OF THE UNITED NATIONS AND UNESCO}

Following the decolonisation in the 1960s-70s, many former colonies began to demand the restitution of cultural objects that had been misappropriated by the colonial powers or their subjects. The discussion was triggered in September 1973 by the request made by the then president of then Zaire (now Congo) Mobute Sese Seko during the $3^{\text {rd }}$ Conference of the International Association of Arts Critics for the restitution of all cultural objects that had been removed under Belgian Colonialism. ${ }^{542}$ Zaire subsequently repeated the request during the $28^{\text {th }}$ General Assembly of the United Nations on 4 October 1973.543 As a result, on 18 December 1973, the United Nations General Assembly adopted Resolution 3187 on the "Restitution of Works of Art to Countries Victims of Expropriation" 544 . Resolution 3187 was "crude and unconditional" in its wording. ${ }^{545}$ It regrets "the wholesale removal, virtually without payment, of "objects d'art" from one country to another, frequently as a result of colonial or foreign occupation" and "recognizes the special obligations in this connection of those countries which had access to such valuable objects only as a result of colonial or

\footnotetext{
540 Walter, B., 1988, p. 71.

${ }^{541}$ Siehr, K.G., 2006, pp. 133-134.

542 Cf.: Ganslmayr, H., 1980, p. 88.

543 Walter, B., 1988, p. 93.

${ }^{544}$ Restitution of Works of Art to Countries Victims of Expropriation, G.A. Res. 3187, U.N. GAOR, 28th Sess., U.N. Doc.A/Res/3187(XXVIII) (1973).

${ }^{545}$ Cf.: Nafziger, J.A.R., 1983, p. 802.
} 
foreign occupation". ${ }^{546}$ The resolution was adopted by 113 votes in favour to none opposing it with 17 abstentions. Most of the abstainers were the countries referred to by the Resolution as having special obligations. ${ }^{547}$

While UN Resolution 3391 dating from 1975 slightly sharpened the appeal to States to return objects d'art, monuments, museum pieces, manuscripts and documents to their countries of origin, ${ }^{548}$ subsequent resolutions became weaker and more indirect in their formulation of the claim for the restitution of cultural objects. ${ }^{549}$ At first, the argumentation of returns as reparations for damage done was changed due to the improvement of international relations between developing countries and developed countries. ${ }^{550}$ Subsequently, the explicit appeal to return cultural objects that had been obtained as result of colonial or foreign occupation was dropped completely. Instead, the emphasis of the resolutions shifted to curbing the ongoing illegal trafficking of cultural objects in general. ${ }^{551}$ One commentator stated that the resolutions "very simply, (...) have become less strident and more accommodating of the interests of the target states". 552 Only one provision can be identified in the resolutions adopted since the 1980s that resisted the trend of moderation: ${ }^{53}$ Paragraph 7 of the 1985 UN Resolution

"[a]ppeals to museums and public and private collectors to return totally or partially, or make available to the countries of origin, particularly the items kept in the store-houses of such museums and help the countries of origin, with the co-operation of the United Nations Educational, Scientific and Cultural Organization, in their endeavours to formulate an inventory of these collections". 554

A separate vote was undertaken on this provision, which received fewer votes in favour than the other provisions and also a vote against. ${ }^{555}$

Within UNESCO, the adoption of the 1973 UN Resolution 3187 first resulted in the passing of Resolution 3.428 in 1974 by the $18^{\text {th }}$ General Assembly. ${ }^{556}$ The Resolution invited the Director-General to take up and contribute to the aims set out in the 1973

\footnotetext{
546 See further on Resolution 3187: Schulze, D., 1983, pp. 13-14.

547 The abstainers were Austria, Belgium, Canada, Denmark, France, the Federal Republic of Germany, Ireland, Italy, Japan, Luxembourg, The Netherlands, Norway, Portugal, South Africa, Sweden, the United Kingdom and the United States.

548 Resolution 3391 stresses the "need for prompt restitution of cultural property, without charge, as just reparation for damage". Restitution of Works of Art to Countries Victims of Expropriation, G.A. Res. 3391, U.N. GAOR, 30th Sess., U.N.Doc.A/Res/3391(XXX) (1975). Cf.: Nafziger, J.A.R., 1983, p. 802.

${ }^{549}$ Cf.: Schulze, D., 1983, p. 14; Odendahl, K., 2005, p. 183.

${ }^{550}$ Cf.: Odendahl, K., 2005, p. 183.

551 Cf.: Thomason, D., 1990, pp. 55-60; Vrdoljak, A.P., 2006, p. 213.

552 Cf.: Nafziger, J.A.R., 1983, p. 803.

553 Cf.: Ibid.

554 UN Resolution 40/19 from 21.11.1985.

555 The United States voted against. 19 U.N. Monthly Chronicles, February 1982, at 49. See further: Nafziger, J.A.R., 1983, p. 803.

556 Resolution 3.428 adopted by the General Conference of UNESCO at its eighteenth session in UNESCO.
} 
UN Resolution 3187.557 While Resolution 3.428 referred to the London Declaration signed by the Allies in 1943 as to the right to declare certain transactions null and void 558 its concrete demands were more conservative: Resolution 3.428 asked for a definition in general terms of the most suitable methods for the "return" of cultural objects and suggested the convening of an expert group for this purpose. ${ }^{559}$

In 1976, the expert group which became known as the 'Venice Committee of Experts' was set up. Its mandate was to investigate the restitution or return of cultural property lost either due to foreign or colonial occupation, or following illicit traffic before the entry into force of relevant international treaties and to identify legal and practical problems.560 One result of the Experts Committee's report was the "codification" of the linguistic turn from "restitution" as previously employed by the United Nations to a dual system employing both "restitution" and "return" depending on the alleged illegality of the original taking under international law. "Restitution of cultural objects" was to be reserved to those cases in which the original taking of the objects was illegal under international law. In respect of cultural objects that had been lost during the colonial era, or due to illegal export outside of the international treaties' scope of application the term "return" was to be employed to signify the absence of any illegal behaviour. ${ }^{561}$ The suggested dichotomy between restitution and return was employed in all subsequent UNESCO resolutions. ${ }^{562}$ By employing the proposed dichotomy between restitution and return in Resolution 3.428 and all subsequent UNESCO resolutions UNESCO implicitly stated that the removal of cultural objects during the colonial era had not been illegal.

${ }^{557}$ Cf.: Prott, L.V. / O'Keefe, P.J., 1989, p. 815.

558 Inter-Allied Declaration Against Acts of Dispossession Committed in Territories Under Enemy Occupation or Control, 8 Dep't St. Bull. 21 (1943). Cf.: Prott, L.V. / O'Keefe, P.J., 1989, p. 816. See for an analysis of the London Declaration above in chp. 1.\$1.V.

559 UNESCO, Section 'Second Legal Development: The institutional response of the International Community within UNESCO, http://unesdoc.unesco.org/images/0013/001394/139407eb.pdf.

${ }^{560}$ Unesco Doc.SHC-76/CONF.615/3. Cf.:

http://portal.unesco.org/culture/en/ev.php-

URL_ID=36194\&URL_DO=DO_PRINTPAGE\&URL_SECTION=201.html (last visited: 28 July 2008).

561 Prott, L.V. / O'Keefe, P.J., 1989, p. 817; Kowalski, W.W., 2004, p. 49. See further on the development of the terminology: A Brief History of the Creation by UNESCO of an Intergovernmental Committee for Promoting the Return of Cultural Property to its Countries of Origin or its Restitution in Case of Illicit Appropriation, 1979; Ganslmayr, H., 1980, p. 88; Thomason, D., 1990.

562 Resolution 4128, UNESCO, 19th Session, Nairobi 1976, p. 48; Resolution 4/7.6/5 adopted at the 20th session of the General Conference (October - November 1978) Records of the General Conference, Resolutions, p. 92; Resolution 4/09, UNESCO, 21 Session, Belgrad 1980, p. 62; Resolution 2/11, UNESCO, 4th extraordinary Session, Paris 1982, p. 39 ff.; Resolution 11/9, UNESCO, 22nd Session, Paris 1983, p. 59 ff. From 1979 onwards, the use in terminology was also adopted by the United Nations. Cf.: Walter, B., 1988, p. 94. Most prominently, however, the terminology is reflected in the 1995 UNIDROIT Convention on Stolen or Illegally Exported Cultural Objects. The Convention provides for the restitution of stolen objects (Art. 3) but for the return of illegally exported cultural objects (Art. 5). See for an analysis of the different regimes introduced by the Convention above in chp. 1.\$2.IV. 
The linguistic dichotomy is also reflected in the name of the 'Intergovernmental Committee for Promoting the Return of Cultural Property to its Countries of Origin or its Restitution in case of Illicit Appropriation (hereinafter: "the Intergovernmental Committee")' that was set up in reaction to the Venice Experts Committee's recommendation to establish a permanent international body to further research the ways and means of facilitating bilateral negotiations for the restitution or return of cultural property and to encourage the countries concerned to reach agreements. The Intergovernmental Committee was established in $1978 .{ }^{563}$ It consists of elected members from the UNESCO Member States (Art. 2 Statutes). According to Art. 1 of its Statutes, the Intergovernmental Committee has solely an advisory role. It cannot impose a resolution on the parties. ${ }^{564}$ Instead, Art. 4 of its Statues lists a number of tasks that might contribute to finding agreement on returns and restitutions whether it concerns individual cases or the cause more in general. ${ }^{565}$ In line with its two guiding principles the coherence of reconstituted heritage and the primacy of cultural objects ${ }^{566}$ - the Intergovernmental Committee only deals with disputes concerning still-existing objects. It does not consider claims for restitution in kind or compensation. ${ }^{567}$

The services of the Intergovernmental Committee are limited to States that are Member States or Associate Members of UNESCO. ${ }^{568}$ As indicated by its name, the Intergovernmental Committee cannot be called upon by non - State groups. ${ }^{569}$ Art. 3 of the Statutes furthermore restricts the services of the Intergovernmental Committee to "any

${ }^{563}$ Resolution 4/7.6/5 adopted at the 20th session of the General Conference (October - November 1978) Records of the General Conference, Resolutions, p. 92; See further: A Brief History of the Creation by UNESCO of an Intergovernmental Committee for Promoting the Return of Cultural Property to its Countries of Origin or its Restitution in Case of Illicit Appropriation, 1979.

564 See further: UNESCO Doc. CLT 83/ Conf. 216/ 8 p. 4-6 where the use of the term arbitration was explicitly refused as the Intergovernmental Committee was not supposed to function as an arbitrating body. Instead "its path is that of mediation and moral pressure". Cf.: Walter, B., 1988, p. 98.

565 The Committee shall be responsible for: 1 . seeking ways and means of facilitating bilateral negotiations for the restitution or return of cultural property to its countries of origin when they are undertaken according to the conditions defined in Art. 9; 2. promoting multilateral and bilateral co-operation with a view to the restitution and return of cultural property to its countries of origin; 3 . encouraging the necessary research and studies for the establishment of coherent programmes for the constitution of representative collections in countries whose cultural heritage has been dispersed; 4. fostering a public information campaign on the real nature, scale and scope of the problem of the restitution or return of cultural property to its countries of origin; guiding the planning and implementation of UNESCO's programme of activities with regard to the restitution or return of cultural property to its countries of origin; encouraging the establishment or reinforcement of museums or other institutions for the conservation of cultural property and the training of the necessary scientific and technical personnel; 7. promoting exchanges of cultural property in accordance with the Recommendation on the International Exchange of Cultural Property; 8 reporting on its activities to the General Conference of UNESCO at each of its ordinary sessions.

566 See ICOM Study, Annex 1, paras. 9-20. Cf.: Vrdoljak, A.P., 2006, p. 217.

567 UNESCO Doc. 21C/83, para. 29 \& 31. Vrdoljak reports of a Peruvian draft resolution covering compensation (UNESCO Doc. DR. 346) that was unsuccessful: UNESCO Doc. CC-81/CONF. 203/4, Annex 1, 2, para. 257. Cf.: Ibid., p. 216.

568 Art. 3(2), Committee Statute, UNESCO Doc. CC-79/CONF.206/4, Annex, para. 343. Cf.: Ibid., p. 214. 569 Ibid., p. 215. 
cultural property which has a fundamental significance from the point of view of the spiritual values and cultural heritage of the people". ${ }^{570}$ However, this limitation is less relevant than it appears at first sight as it is the claiming state that determines the significance of an object. ${ }^{571}$ In its recommendations the Intergovernmental Committee is not limited to legal standards but may apply moral and ethical standards. ${ }^{572}$

UNESCO Documentation ${ }^{573}$ and the literature generally focus on two cases when discussing the work of the Intergovernmental Committee: the case of the Elgin Marbles and the case of the Boğazköy Sphinx. The Elgin or Parthenon Marbles lie at the centre of a dispute between Greece and the United Kingdom, which has become "a metaphor for repatriation and relocation claims at large".574 The dispute concerns parts of the frieze, metopes and pediments of the Parthenon in Athens. ${ }^{575}$ After individual claims for the return of the objects date back to the first half of the $19^{\text {th }}$ century the Greek Government first sought the return in 1965. After the fall of the military dictatorship in Greece in 1974, the Parthenon sculptures began to take on a new role as a symbol of the revived democracy and from 1982 were championed by the Greek Government. Since then, the claim has been a feature of Greek Government policy, national and international. In 1984, the request for the return of the Parthenon Marbles has been filed with the Intergovernmental Committee by Greece and is still pending. ${ }^{576}$

The case of the Boğazköy Sphinx concerns a dispute between Turkey and Germany. Back in 1986, Turkey field a request with the Intergovernmental Committee for the return of the Sphinx then kept in the collection of the Staatliches Museum Vorderasiatische Abteilung, Berlin in the former German Democratic Republic. Whereas Germany has since been unified, the dispute is unresolved as of today.

\footnotetext{
570 Art. 3 of the Statue reads: 1. For the purposes of these statutes, "cultural property" shall be taken to denote historical and ethnographic objects and documents including manuscripts, works of the plastic and decorative arts, palaeontological and archaeological objects and zoological, botanical and mineralogical specimens.

2. A request for the restitution or return by a Member State or Associate Member of UNESCO may be made concerning any cultural property which has a fundamental significance from the point of view of the spiritual values and cultural heritage of the people of a Member State or Associate Member of UNESCO and which has been lost as a result of colonial or foreign occupation or as a result of illicit appropriation.

3. Cultural property restituted or returned shall be accompanied by the relevant scientific documentation.

571 Goy, R., 1979, p. 969; Schulze, D., 1983, p. 26; Walter, B., 1988, p. 15 \& 96.

572 UNESCO Doc. CC-79/CONF. 206/4, Annex, para. 348.

573 UNESCO, http://unesdoc.unesco.org/images/0013/001394/139407eb.pdf in the section titled "Examples of cases pending before the Committee".

574 Palmer, N., 2000b, p. 343.

575 The frieze originally extended 524 feet $(\mathrm{ca} .160 \mathrm{~m})$ around the Parthenon's main inner chamber and depicted the Panathenaic Procession. It is three-foot-high and carved in low relief. The metopes, a series of ninety-two four-foot square panels surrounded the top of the Parthenon' outer colonnade and depicted historical and mythical battles. The pediments, the low triangles at the ends of the building formed by the pitch of the roof, were filled with sculptures. Cf.: Merryman, J.H., 2000b, p. 25.

576 See further on the dispute concerning the Elgin or Parthenon Marbles, e.g.: Reppas II, M.J., 1999; Merryman, J.H., 2000b.
} 
What the literature does not mention, at least not explicitly, is the fact that the cases of the Elgin Marbles and the Boğazköy Sphinx were, until recently, the only cases heard by the Intergovernmental Committee. In 2006 the United Republic of Tanzania filed a request concerning a Makonde Mask located in Switzerland. While the mask is privately owned the Swiss State nevertheless expressed its willingness to facilitate negotiations with a view to restitution. ${ }^{577}$ Until present, the cases brought to the attention of the Intergovernmental Committee did not concern illegally exported cultural objects but mainly deal with objects removed in the past.

Other cases that have been brought to the Intergovernmental Committee's attention were never officially filed with the Committee. Some cases failed as the current location of the object sought after is unknown. ${ }^{578}$ Other cases were referred back for bilateral negotiations. ${ }^{579}$ With an output of three unresolved cases over the thirty years of its existence the output of the Intergovernmental Committee, at least with regard to individual cases, is disappointing. While its existence and work on general issues on the subject of return and restitution contributed to engross the debate and bilateral negotiations, there is clearly need to strengthen the mandate and raison d'être of the Intergovernmental Committee.

It is in this light that one must see the adoption of $33 \mathrm{C} /$ Resolution 44 during the $33^{\text {rd }}$ session of UNESCO's General Conference: the resolution adds mediation and conciliation to the mandate of the Committee. ${ }^{580}$ At present, the (draft) rules of procedure are being examined. ${ }^{581}$ Whether UNESCO's Member States or Associate Members will make use of the possibility of mediation and conciliation remains to be seen in the future. As of today, the resolutions and developments within the framework

\footnotetext{
577 Cf.: Report on the 2006/2007 Activities of the Intergovernmental Committee for promoting the return of Cultural Property to its Countries of Origin or its restitution in case of illicit appropriation, 34 C/REP/14, paras 10-11. See further on the case: Shyllon, F., 2006, p. 140.

578 See, e.g.: Report by the Intergovernmental Committee for promoting the return of Cultural Property to its Countries of Origin or its restitution in case of illicit appropriation on its Activities (1990-1991), 26 C/92, para. 9 where the request for help by Egypt for the recovery of three stolen documents could only be met by circulating information on the stolen objects.

579 See Report by the Intergovernmental Committee for promoting the return of Cultural Property to its Countries of Origin or its restitution in case of illicit appropriation on its Activities (1991-1993), 27 C/102, para. 4 on a request by the Union of Myanmar in April 1991 seeking help in retrieving eleven golden royal statues said to be held in the United Kingdom. UNESCO asked Myanmar to first initiate bilateral negotiations. According to para. 5 Zambia requested help with the return of the 'Broken Hill' skull from the United Kingdom in 1991. Zambia was informed to first enter into bilateral negotiations. See further on the 'Broken Hill' skull: Greenfield, J., 1989, p. 159. See further on the Broken Hill Skull below in chp.2.\$2.III.1. See also: Walter, B., 1988, pp. 98 -99 who reports of a request by Sri Lanka and of a request by Jordan on the return of the "sandstone panel of Tyche with the Zodiac" from the United States that were referred back for bilateral negotiations. Cf.: UNESCO Doc. CLT 85/ Conf. 202 / 7 Annex 1. The latter case was resolved between the parties with the United States providing Jordan with plaster copies of the original. Cf.: UNESCO Doc. 24 C/94 p. 2; UNESCO Doc. CC 87/ Conf. 207/3, pp. 1-2.

580 Cf.: Report on the 2006/2007 Activities of the Intergovernmental Committee for promoting the return of Cultural Property to its Countries of Origin or its restitution in case of illicit appropriation, 34 C/REP/14, para. 12.

${ }^{581} \mathrm{Ibid}$. The reference to the draft rules of procedure is CLT-2007/CONF.211-COM.14/3.
} 
of the United Nations and UNESCO, including the work of the Intergovernmental Committee do not provide for legal obligations with regard to the return of cultural objects removed during the colonial era.

\section{Rules on STATE SUCCESSiOn: THE CREATION OF LEgALLY BINDING RightS OR OBLIGATIONS?}

The process of decolonisation, which was based upon the principle of selfdetermination laid down in the UN Charter and in Art. 1 of the 1966 International Human Rights Convenants ${ }^{582}$, was one of the most important structural transitions of the international legal system subsequent to the end of World War II. ${ }^{583}$ The colonial empires of Britain, France, the Netherlands and other European countries eroded with the political independence of their former colonies. ${ }^{584}$ By the 1960s, the decolonisation process had reached its climax and resulted in an increase of the total number of states by almost one hundred. ${ }^{585}$

The process of decolonisation falls under the greater notion of state succession. State succession has been defined as "the replacement of one state by another in the responsibility for the international relations of territory". 586 Decolonisation as a process in which only a part of a State's territory (i.e. the territory of the colonising state) is detached and makes up a new international subject (the newly independent state) qualifies as a form of partial succession. ${ }^{587}$

The law of state succession deals with the legal problems arising from the transfer of territory between two subjects of international law. ${ }^{588}$ Where territory is transferred from the predecessor State (here: the colonising country) to a successor state (here: the formerly colonised country) the question arises how to treat bilateral and multilateral treaties concluded by the former state, as well as public and private property (which includes cultural objects), national archives, and the national debt. ${ }^{589}$ In most cases of state succession these questions are regulated in bilateral agreements. ${ }^{590}$

\footnotetext{
582 International Convenant on Civil and Political Rights 1966 and the International Convenant on Economic, Social and Cultural Rights 1966.

${ }^{583}$ Cf.: Malanczuk, P. / Akehurst, M.B., 1997, p. 28.

584 Cf.: Ibid.

${ }^{585}$ Cf.: Bleckmann, A., 1987, p. 76.

586 Art. 2(1)a) of the Vienna Convention on Succession of States in respect of State Property, Archives and Debts. Done at Vienna on 8 April 1983. Cf.: Ipsen, K., 2004, p. 307.

${ }^{587}$ Cf.: Fiedler, W., 1987, p. 447.

588 Cf.: Ibid., p. 446.

589 See for further questions concerning the succession of rights and obligations: Malanczuk, P. / Akehurst, M.B., 1997, p. 161.

590 See for examples of these agreements: Documentation concernant la succession d'états, Serie législative des Nations Unies, 1967 and Documentation concernant la succession d'états dans les materières autres que les traités, Serie législative des Nations Unies, 1978; Engstler, L., 1964, p. 229 ff.
} 
In the 1970s, in reaction to the process of decolonisation, and in order to bring some structure in the "chaotic" law on state succession"591, the International Law Commission (ILC) was asked by the United Nations to work on a codification of the law on state succession. The ILC was asked to pay appropriate attention to the attitude of those (successor) states that had reached independence only after WWII.592 As result and based upon the draft text presented by the ILC's work ${ }^{593}$, the Vienna Convention on State Succession in Respect of Treaties was adopted in 1978. A second convention followed in 1983: the Vienna Convention on State Succession in Respect of State Property, Archives and Debts (hereinafter: the 1983 Vienna Convention on State Succession).

With regard to the present study only the 1983 Vienna Convention on State Succession is relevant, albeit only indirectly. Each part of the Convention deals with a specific matter of state succession (Part II: State Property; Part III: Archives; Part IV State Debts). The 1983 Vienna Convention on State Succession introduces general rules on allocation, as well as more preferential rules for "newly independent states".594 According to Art. 2(1) (e) a "newly independent state", is a "successor State the territory of which, immediately before the date of the succession of States, was a dependent territory for the international relations of which the predecessor State was responsible". The introduction of specific rules with regard to newly independent States was the ILC's implementation of the United Nations request to pay specific attention to the attitude of the newly independent States. In the following section we will shortly discuss the general and preferential rule on the passing of movable State Property, which is the relevant category with regard to cultural objects in the absence of specific provisions comparable to that of archives. 595

As general rule, states are free to arrange for the passing of State property by mutual agreement (Art. 14(1)). For those cases where such an agreement is absent the article determines that "movable State property of the predecessor State connected with the activity of the predecessor State in respect of the territory to which the succession of States relates shall pass to the successor State" (Art. 14(2) (b)). This rule, which deviates from former state practise according to which only state property situated in the territory concerned ${ }^{596}$ passed from the predecessor to the successor State was declared mandatory for successions involving newly independent States (Art. 15 (d)). Thus with regard to newly independent states movable property is to be passed independent of the

\footnotetext{
591 Malanczuk, P. / Akehurst, M.B., 1997, p. 161.

592 A /Res/1686 (XVI); A/Res/1765 (SVII); 1902 (XVIII); 2272 (XXII); 2926 (XXVII) Cf.: Schulze, D., 1983, pp. 118-119.

593 Cf.: YBILC 1967 II/2, 368.

594 See Artt. 15; 28; 38 of the Convention.

595 Different from cultural objects the 1983 Vienna Convention on State Succession does contain specific rules on the passing of State Archives. See Artt. 19-31 of the Convention. In the following we will only discuss State property as the relevant category comprising cultural property.

${ }^{596}$ Cf.: Schulze, D., 1983, pp. 115-116; Walter, B., 1988, p. 130.
} 
question whether it is situated in the territory of the successor State or of the predeccessor State. ${ }^{597}$ The preferential position granted to newly independent states furthermore consists in the provision according to which "movable State property, having belonged to the territory to which the succession of States relates and having became State property of the predecessor State during the period of dependence, shall pass to the successor State" (Art. 15(1) (e)).

The preferential treatment of newly independent states, as well as the general rule on the allocation of movable State property reaching out to property located in the territory of the predecessor State (Art. 14(2) (b) \& Art. 15 (d)) were the main reason for most Western States to vote against the adoption of the treaty in 1983.598 While the 1983 Vienna Convention on State Succession was nevertheless adopted, it has not entered into force as of today. ${ }^{599}$ However, even if the Convention had entered into force at the earliest date conceivable it would not have applied to the majority of state successions that took place during the process of decolonisation, which had attained its climax by 1960. ${ }^{600}$ While an initial draft of the ILC did include a provision according to which the scope of application of the convention was not limited to future cases of state succession but did include "newly independent states" of recent origin the provision it was not included in the final draft. ${ }^{601}$ Instead, Art. 4(1) of the 1983 Vienna Convention on State Succession as finally adopted clearly rules out any retroactive application of the Convention's provision. Hence, the 1983 Vienna Convention on State Succession as such does not introduce legally binding rules on the return of cultural objects removed during the colonial era.

In the absence of any other multilateral treaty on state succession that are relevant for the return of (cultural) property, a general obligation to return cultural objects could only be based on customary law. The relevance of customary law as source of international law and its cumulative elements of settled state practise and opinio iuris have already been introduced above. ${ }^{602}$ In order to speak of a settled state practice, relevant acts of the state executives and other state organs representing stately interests in international relations must show a certain duration, uniformity and spreading. ${ }^{603}$ The

\footnotetext{
597 Walter, B., 1988, p. 130; Vrdoljak, A.P., 2006, p. 202.

598 The Convention was adopted with 54 votes in favour against 11 votes and with 11 abstentions. The following countries voted against adoption: Belgium, Germany, France, Israel, Italy, Canada, Luxemburg, the Netherlands, Switzerland, the United Kingdom, the United States. Cf.: Ipsen, K., 2004, p. 311.

599 The 1978 the Vienna Convention on State Succession in Respect of Treaties entered into force on 6 November 1996. With regard to the entry into force of the 1983 Vienna Convention on State Succession its Art. 50 requires the deposit of fifteen instruments of ratification or accession. By the end of June 2009, seven countries (Croatia, Estonia, Georgia, Liberia, Slovenia, The former Yugoslav Republic of Macedonia, Ukraine) had ratified / accessioned the convention. See for an update:

http://treaties.un.org/Pages/ViewDetails.aspx?src=IND\&mtdsg_no=III-12\&chp.=3\&lang=en.

${ }^{600}$ Cf.: Bleckmann, A., 1987, p. 76.

${ }^{601}$ Cf.: Report of the International Law Commission on works of its 28th session in: Yearbook of the ILC 1976, Vol. II, p. 141. See also Yearbook of the ILC 1981, Vol. II, p. 8 ff.

${ }^{602}$ See above chp. $1 . \$ 1$ on the Restitution of Cultural Objects removed in Times of War.

${ }^{603}$ Cf.: Freytag, C., 1996, p. 183.
} 
literature reports of a number of instances in which cultural objects have been returned to newly independent states in reaction to or shortly after their independence. In 1950 France and Laos concluded a bilateral agreement on the return of works of art to Laos. ${ }^{604}$ In 1954, Great Britain returned to Burma jewellery known as the crown jewels. ${ }^{605}$ In 1968, France and Algiers concluded an agreement on the return of cultural objects that had previously belonged to the collection of Algerian museums. ${ }^{606}$ In 1970, the governments of Belgium and the Republic of Zaire (formerly the Belgian colony Congo) concluded a bilateral agreement providing for the transfer of cultural objects from Belgium to Zaire. ${ }^{607}$ By the end of 1979 some 1000 cultural objects, including works of art had been returned to Zaire.608 Also during the 1970s, negotiations commenced between the Netherlands and Indonesia and resulted in the transfer of historical and archaeological objects in accordance with a specific programme. ${ }^{609}$

The mere existence of cases in which cultural objects have been returned does not mean that one can speak of state practise as is required for the existence of customary rules. The returns do not fulfil the requirements of a certain duration, uniformity and spreading to qualify as settled state practise. ${ }^{610}$ Not only is the greater share of cultural objects that have been removed during the colonial era still in Western museum collections; returns - when effected - are often the result of cooperation between museums rather than being concluded on a state basis. Actions of museums do not necessarily reflect the views held by the national government. ${ }^{611}$ This is especially the case where the museums are not restricted by national rules on inalienability. ${ }^{612}$

In the absence of settled state practise no customary law could have developed. For this reason, we will not further address the question of an opinio iuris in this respect but will confine ourselves to referring to the significant resistance of Western States against the adoption of the 1983 Vienna Convention on State Convention and the fact that it has still not entered into force. In conclusion, the analysis of the process of decolonisation and rules on state succession did not reveal a legal obligation to return cultural objects removed during the colonial era: no such basis for a claim could be

\footnotetext{
${ }^{604}$ Ganslmayr, H., 1980, p. 91.

605 Cf.: Walter, B., 1988, p. 124.

${ }^{606}$ Ganslmayr, H., 1980, p. 91.

${ }^{607}$ Cf.: Geluwe, H.v., 1979, p. 35.

608 Cf.: Ibid., p. 37. See for a critical discussion of the agreement between Zaire and Belgium: McGuire, T., 1990, pp. 63-64.

${ }^{609}$ Cf.: Pott, P.H. / Sutaarga, M.A., 1979, p. 41. Further to this list of bilateral arrangements one can add more examples of returns or transfers of cultural objects to formerly colonised territories: in 1977, the Australian Museum Trust returned to the national Museum and Art Gallery of Papua New Guinea a number of ethnographic objects. In 1979 the Trust presented a number of cultural objects to the Solomon Islands Museum. Specht, J., 1979, p. 28.

${ }^{610}$ Cf.: Walter, B., 1988, p. 124.

611 Cf.: Specht, J., 1979, p. 28.

612 See further on municipal rules governing public collections in the Netherlands, France and the United Kingdom and the question in how far disposal is prohibited in chp. 3.
} 
identified in treaty or customary law against a predecessor state, let alone against a third country. 613

\section{RECONCEPTUALISATION OF CIRCUMSTANCES OF ACQUISITION AS INTERNATIONAL WRONGFUL ACT?}

In this section we will discuss whether the removal could be qualified as an international wrongful act. Every internationally wrongful act of state entails its international responsibility and requires the responsible state to make reparations. ${ }^{614}$ The state responsible has to "wipe out, as far as possible, all the consequences of the illegal act and re-establish the situation which would, in all probability, have existed if that act had not been committed". ${ }^{615}$ Put differently, the responsible State has the obligation to physically restituted removed objects. Only where physical restitution has become impossible the state is required to compensate for the loss in an alternative way. ${ }^{616}$

In order to qualify certain behaviour as an international wrongful act the following elements must be present: the act in question must constitute a breach of an international obligation by a state and it must be attributable to the state. ${ }^{617}$ Furthermore, the act must be committed against another subject of international law. 618 Conseqeuntly, we first need to establish whether the colonised countries qualified as subject of international law before it makes sense to address the question whether the removal of (cultural) objects during the colonial era qualified as an attributable wrongful act. In addressing this question one must distinguish between the situation prior to the European "civilised" powers' establishment of colonial rule, and the situation once colonial rule had been established until the colonies' independence.

In analysing the status of formerly colonised countries both prior and post the establishment of colonial rule one must observe the principle of inter-temporal law according to which "(...) a juridical fact must be appreciated in light of the law contemporary with it, and not of the law in force at the time when a dispute in regard to it arises or falls to be settled."619 Put differently, the situation in question has to be examined according to the conditions and rules in existence at the time it was made or

\footnotetext{
613 Cf.: Vrdoljak, A.P., 2006, p. 205.

614 PCIJ, Chorzów Factory case (Merits) (ibid. \ 103). Cf.: Henckaerts, J.-M. / Comité international de la Croix-Rouge, 2005, P. 537. See also International Law Commission, 2001, Art. 1.

615 Crawford, J., 2002, pp. 47-48.

616 Chorzów Factory Case (Germany v. Poland) PCIJ, Series A, No. 17, 1928, p. 29, pp. 47-48. Cf.: International Law Commission, 2001, pp. 96-97.

${ }^{617}$ Cf.: International Law Commission, 2001.

618 German scholars speak of "passive Deliktsfähigkeit“، Cf.: Walter, B., 1988, pp. 105 \& 108.

${ }^{619}$ Island of Palmas case (The Netherlands v. USA, 1928), 2 RIAA, p. 829. See further on inter-temporal law: Shaw, M., N., 2003, pp. 429-430; Brownlie, I., 2008, pp. 124-125 both with further references.
} 
occurred and not at a later date. ${ }^{620}$ Similar cases may have different legal consequences depending on the time period. The law changes. ${ }^{621}$

\section{Prior to / during the process of colonisation}

The principle of inter-temporal law leads us to examine the state of public international law at the time of colonisation, in order to verify whether the countries in the process of being colonised by the European powers qualified as subjects of international law.

For a political entity to qualify as a state and therewith as an international legal person it had to fulfil the criteria of a permanent population, a defined territory and a government. ${ }^{622}$ Where a political entity met these criteria it also had to take the hurdle of recognition. Recognition refers to the willingness of the international community to accept a certain entity that fulfils the criteria of statehood as a member of the international community.

There exist two competing theories on recognition: the declaratory theory and the constitutive theory. The names of the theories refer to the legal effect that is accorded to the recognition of a state: according to the declaratory theory recognition of a state is no more than a formal acceptance of already existing facts. Its origin lies in the naturalist school of law. The constitutive theory, on the other hand, is based on the positivist school and considers the act of recognition as necessary in creating the new state as an international legal person. ${ }^{623}$

Whereas the declaratory theory has become the dominant rule as of today ${ }^{624}$ it is the constitutive theory that was predominant during the era of colonisation. ${ }^{625}$ Consequently, and in line with the doctrine of inter-temporal law one would expect the constitutive theory to govern the decision whether the formerly colonised countries qualified as subjects of international law prior and during the process of colonisation, i.e. whether the requirement of recognition had been met. According to the constitutive theory the status of subject of international law would be denied. However, one must take into account that the currently prevailing doctrine of recognition, the declaratory

\footnotetext{
${ }^{620}$ Cf.: Shaw, M., N., 2003, p. 429.

${ }^{621}$ Walter, B., 1988, p. 109.

${ }^{622}$ Cf.: Jellinek, G., 1914, pp. 396-398; Berber, F., 1975, pp. 115-117; Rotter, M., 1982; Walter, B., 1988, p. 105. See also: Stengel Freiherr von, K., 1901, p. 8. Present legal doctrine also mentions the capacity to enter into relations with other States as an additional cumulative criterion for statehood. This element as laid down in Art. 1 of the 1933 Montevideo Convention on Rights and Duties of States in particular in reaction to South American legal doctrine does not yet reflect general state practice. Cf.: Ipsen, K., 2004, p. 55.

${ }^{623}$ Cf.: Malanczuk, P. / Akehurst, M.B., 1997, p. 83; Shaw, M., N., 2003, pp. 368-369; Brownlie, I., 2008, pp. 86-87.

${ }^{624}$ Cf.: Brownlie, I., 2008, pp. 88-89 with further references to modern adherents in fn. 7; Walter, B., 1988, p. 108; Shaw, M., N., 2003, p. 370; Ipsen, K., 2004, p. 234. See also: 1933 Montevideo Convention on Rights and Duties of States, Artt. 3 \& 6.

625 Walter, B., 1988, p. 108; Malanczuk, P. / Akehurst, M.B., 1997, p. 83. Well-known adherents of the constitutive doctrine include: Bluntschli, J., 1878, p. 72; Stengel Freiherr von, K., 1901, p. 8; Anzilotti, D., 1929, p. 160; Lauterpacht, 1939-1940; Kelsen, 1967, pp. 387-416.
} 
theory, is based on a naturalist perception of the law. One of the characteristics of natural law is that is static. While the eternal applicability of the natural law originated in the idea that it formed part of the law of God, Grotius, the father of international law stated that "natural law is to such a degree unchangeable that not even God can change it". ${ }^{626}$

If one accepts that under the present rule, the declaratory theory, a state becomes a subject of international law on the ground of natural law and that natural law is not subject to changes or fluctuations one has to accept that the political entities at the dawn of the colonial era also qualified as states possessing international legal personality. ${ }^{627}$ Consequently, rather than evaluating the status of the formerly colonised countries prior and during the process of colonisation by the constitutive theory, the current endorsement of the declaratory theory also changes the evaluation of past situations. While this indirect effect of the declaratory theory may at first sight seem to conflict with the doctrine of inter-temporal rule this is not the case: rather than directly applying the declaratory theory to the past situation in question the current endorsement of the declaratory theory results in the withdrawal of the issue of recognition from a positivist approach to the law and subsumes it under natural law. ${ }^{628}$ The doctrine of intertemporal rule deals with the collision of different legal rules in time; it does not prevent the subsumption of a subject matter under natural law that was previously dealt with under the positivist approach.

In conclusion, due to the indirect effect of the present declaratory doctrine on the recognition of states, the formerly colonised countries did qualify as subjects of international law (provided they fulfilled the three criteria on statehood). Therewith, at least with regard to the situation prior to the ultimate establishment of the colonial rule, the preliminary requirement for the removal of (cultural) objects to constitute an international wrongful act has been fulfilled. Whether the removal did constitute an international wrongful act must yet be addressed. Before, however, we will discuss whether and in what respect the ultimate establishment of the colonial rule did affect the status of the colonised under public international law. This question is important in that the repression might have effects on the international legal personality of the colonised countries and therewith for the question of whether the removal of (cultural) objects during the period of colonial rule qualifies as wrongful act and thus can give rise to restitution.

\section{Once colonial rule had been established}

In this section the status of a colony subsequent to the establishment of the colonial rule by the colonising state will be discussed. The term "colony" in a broad sense

\footnotetext{
${ }^{626}$ Grotius, H., 1625, p. 51. Cf.: Walter, B., 1988, p. 109.

${ }^{627}$ Cf.: Walter, B., 1988, p. 110.

${ }^{628}$ Cf.: Ibid.
} 
comprises different types of dependant territories: ${ }^{629}$ colonies in the narrow sense, protectorates, mandated territories and trust territories. A colony in the narrow sense is an entity which is subject to the territorial sovereignty of the colonising State and which is a part of that State. ${ }^{630}$ As a consequence, colonies do not qualify as separate international legal personalities different from the colonising state. 631 They are not subjects of international law and thus cannot suffer from an internationally wrongful act. The legal relationship between the colony and the colonising state is governed by the municipal law of the latter. ${ }^{632}$ Consequently, the removal of (cultural) objects after the colonial rule has been established cannot give rise to restitute as the removal could not constitute an internationally wrongful act. ${ }^{633}$ Whether the removal during the period prior to the establishment of colonial rule qualifies as breaching international law will be discussed in the following.

\section{International wrongful act? Reconceptualisation of the process of colonisation as war}

If one accepts the international legal personality of the political entities prior to the establishment of the colonial rule one must qualify the violent contentions with the European powers during the process of colonisation as armed conflict. ${ }^{634}$ Consequently, the removal of (cultural) objects during the process of colonisation may constitute a breach of the ius ad bellum or the ius in bello and thus an internationally wrongful act.

The ius ad bellum, or rather the limitation of the right to resort to war developed only after the First World War. The Convenant of the League of Nations was the first multilateral treaty to limit the right to resort to war. ${ }^{635}$ The impetus led to the banning of war in the Kellog-Briand Pact of 1928 and culminated in Art. 2(4) of the United Nations Charter according to which every threat or use of force is prohibited. ${ }^{636}$ Given the fact that the ius ad bellum started to develop only during the beginning of the $20^{\text {th }}$ century the waging of war upon the formerly colonised countries, which occurred prior to the emergence of limitations on the rule of force, does not constitute a breach of international law. According to the law in force during the process of colonisation

\footnotetext{
${ }^{629}$ Cf.: Ibid., p. 113.

${ }^{630}$ Cf.: Bleckmann, A., 1987, p. 75.

631 Cf.: Walter, B., 1988, p. 113.

632 Cf.: Ermacora, F., 1987, p. 41. Different from colonies in the narrow sense, protectorates, mandated territories and trust territories do possess international legal personality. A protectorate is the legal relationship between a "protector" State and a "protected" State or group of States. A protectorate is established by a treaty concluded between the protector and the "protected" State (also called the protectorate). Before and after the establishment of a complete protectorate the protected State is a subject of international law. During the protectorate for which it transferred to the protector the competence to act on its behalf in foreign relations, its sovereignty is restricted but the State nevertheless remains a subject of international law. Cf.: Hoffmann, G., 1987; Walter, B., 1988, p. 114.

${ }^{633}$ Cf.: Walter, B., 1988, p. 111.

${ }^{634}$ Cf.: Ibid.

${ }^{635}$ Cf.: Meng, W., 1982, p. 283.

${ }^{636}$ Cf.: Ibid.
} 
European powers were allowed to wage war upon non-European countries just like they were not limited in waging war upon each other. ${ }^{637}$

The ius in bello, the rules governing the actual conduct of armed conflict developed some hundred years earlier than the ius ad bellum. The first international treaties regulating the behaviour of state during an armed conflict were the 1899 and 1907 Hague Conventions on the Laws and Customs of War on Land (hereinafter: the Hague Conventions). ${ }^{638}$ Since the Hague Conventions' entry into force in September 1900 respectively January 1910 there existed a ban on looting of cultural property in armed conflicts and an obligation to restitute objects taken in breach of the Conventions' provision. The ban on looting and the obligation to restitute looted objects applied, however, only to State Parties of the Conventions. The Conventions' scope of application is furthermore limited by the so-called "general participation clause" according to which the rules of the Conventions apply only in the situation that all belligerents are state party. ${ }^{639}$ Consequently, with the formerly colonised countries not being state parties to the Hague Conventions they could not rely on their protection even were the colonising state was a State Party. The only remaining option for formerly colonised countries to establish that the removal of cultural objects constituted a breach of international law and thus gives rise to restitution lies in the existence of binding rules of customary law.

There exists agreement in legal doctrine that the rules of the 1899 and 1907 Hague Convention are binding of customary law. ${ }^{640}$ There exists, however, disagreement as to when exactly the rules became legally binding. ${ }^{641}$ If one approaches the emergence of rules of customary law as a process ${ }^{642}$, the results of our analysis above allows us to date the emergence of such rules between the restitutions subsequent to the Hague Conventions and the outbreak of World War II. The International Military Tribunal at

\footnotetext{
${ }^{637}$ Cf.: Walter, B., 1988, p. 112.

${ }^{638}$ Convention (II) with Respect to the Laws and Customs of War on Land, signed at The Hague, 29 July 1899 and Convention (IV) respecting the Laws and Customs of War on Land. See for a more extensive analysis of the Hague Conventions above in chp. 1.\$1.II on the restitution of cultural objects removed in times of war.

639 Art. 2 of the 1899 Convention reads: "The provisions contained in the Regulations mentioned in Art. I are only binding on the Contracting Powers, in case of war between two or more of them. These provisions shall cease to be binding from the time when, in a war between Contracting Powers, a non-Contracting Power joins one of the belligerents". Art. 2 of the 1907 Hague Convention reads: "The provisions contained in the Regulations referred to in Art. 1, as well as in the present Convention, do not apply except between Contracting powers, and then only if all the belligerents are parties to the Convention". Cf.: the 1954 Convention for the Protection of Cultural Property in the Event of Armed Conflict discussed in chp. 1.\$1.VI.1 that does not contain such a general participation clause.

${ }^{640}$ See, e.g.: Fiedler, W., 1989, p. 199; Schorlemer, S.v., 1992, p. 298; Phuong, C., 2004, p. 986; Odendahl, K., 2005, p. 125.

${ }^{641}$ Some authors argue that the rules of the 1899/1907 Hague Conventions were declaratory of customary law when they were adopted. See, e.g.: Engstler, L., 1964, p. 223; Fiedler, W., 1989, p. 217. Others point to the turn of the 19th to the 20th century as the moment in time when the rules manifested themselves of customary law. See, e.g.: Doehring, K., 1987, p. 139, Schorlemer, S.v., 1992, p. 298.

${ }^{642}$ See, e.g.: Odendahl, K., 2005, p. 125.
} 
Nuremberg held that by 1939 all rules of the Hague Conventions constituted rules of customary law. ${ }^{643}$

At that point, however, the process of colonisation, i.e. the period of establishing colonial rule, had long ended. An exeption is the relationship between Ethiopia and Italy. ${ }^{644}$ Around the end of the $19^{\text {th }}$ century many territories in Africa and Asia had been divided among the European States. ${ }^{645}$ The fact that the colonial rule might have continued once the obligation to restitute cultural objects had manifested itself for the victorious party is irrelevant with regard to restitution as the absence of international legal personality of the colony stands in the way of qualifying an act no matter how wrong as an illegally wrongful act. In conclusion, the question as to the existence of restitution rights with regard to objects removed from former colonies both during the process of colonisation and the period of established colonial rule on the grounds of an international wrongful act must be answered in the negative.

\section{INTERMEDIARY CONCLUSIONS ON THE LEGAL BASES TO RECLAIM OBJECTS REMOVED DURING COLONISATION}

None of the doctrines addressed - the resolutions adopted within the frameworks of UNESCO, the rules on state succession, and the analysis of the circumstances of acquisition as potentially constituting an international illegal act - provide a basis for claims for the restitution of cultural objects removed during the colonial era.

The resolutions and developments within the framework of the United Nations and UNESCO, including the work of the Intergovernmental Committee do not provide for a legal obligation. While the resolutions and the existence of the Intergovernmental Committee are important for keeping the problem of removed cultural objects on the political agenda outside of bilateral disputes, their relevance lies essentially with the fighting of ongoing illicit transfers rather than in addressing removals that occurred prior to the entry into force of any legal instruments banning the removal of cultural objects.

In the specific context of decolonisation, we analysed rules on state succession as to whether they provide for a claim for restitution. The analysis revealed that while the letter of the provisions of the 1983 Vienna Convention on State Succession does provide for the transfer of movable property, which includes cultural property, even when it is located in the territory of the predecessor State, the 1983 Vienna Convention is irrelevant for the present debate for various reasons: not only has it not entered into force, it also does not apply retrospectively nor did it contribute to the emergence of a similar rule of customary law. Consequently, the legal regime of decolonisation does not

\footnotetext{
${ }^{643}$ International Military Tribunal (Nuremberg), Judgment and Sentences, 1 st October 1946, 1947, pp. 248-

249. Cf.: Giovannini, T., 2002, p. 264.

${ }^{644}$ Cf.: Walter, B., 1988, p. 112.

${ }^{645}$ Cf.: Bleckmann, A., 1987, p. 76.
} 
provide for a basis for an obligation to return cultural objects removed from the colonised territory by the former colonial ruler, let alone by a third country.

With regard to the circumstances of acquisition, the analysis revealed that the removal does not constitute an internationally wrongful act. Even where one accepts, realying on natural law, that the formerly colonised countries did possess international legal personality prior to the establishment of colonial rule, the qualification of the removal does not constitute an internationally wrongful act as no limitations of the ius ad bellum existed at that point in time. While the ius in bello did provide for rules limiting the removal of cultural property and providing for its return as of the beginning of the $20^{\text {th }}$ century for State Parties to the 1899 and 1907 Hague Conventions and for the state community as rule of customary law as of the $21^{\text {st }}$ century, this finding is not relevant with regard to the removal of cultural objects during the colonial era as once colonial rule was fully established, the territory concerned becomes part of the state territory of the colonial power, therewith standing in the way of applying rules on the ius in bello.

\section{$\S 4$. Restitution OF CULTURAL OBJECTS TO THEIR ORIGINAL OWNERS}

As a matter of principle, ownership structures are governed by national law: ${ }^{646}$ intranational situations are governed by the private law applicable, whereas situations involving a "foreign" law element are solved by taking to private international law (or Conflict of laws). ${ }^{647}$ As a consequence, the restitution of objects that have been misappropriated or lost is governed by national rules. The principle of the separation between national law and public international law with regard to ownership structures has, however, been deviated from in reaction to the atrocities of the Nazis committed also within German territory. Different from earlier international conflicts set out above, the Nazi looting of cultural property was not confined to the territories it occupied from 1939 onwards but in fact started with the misappropriation of Jewish (cultural) property within the German territory after Hitler's rise to power.

Several phases and categories of Nazi art deprivation can be distinguished: ${ }^{648}$ the first phase consisted of the destruction and liquidisation of the so-called "degenerate art" from public collections in Germany 1936/1937. The term "degenerate art" refers to works of art that depicted Jewish subjects, works of art that were critical of Germany or

\footnotetext{
${ }^{646}$ Odendahl, K., 2005, p. 187. The separation between national law and public international law does of course not prevent the adoption of treaties whose provisions oblige state parties to harmonise their private laws. In chp. 1.\$1.IV discussing the restitution of illegally exported cultural objects the 1995 UNIDROIT Convention was discussed. The UNIDROIT Convention requires state parties to mutually amend the national rules concerning the acquisition of and the transfer of property rights. It does not provide for a superimposed regulation of ownership structures under public international law or an obligation to return certain objects to private individuals.

${ }^{647}$ Depending on the legal theory adhered to private international law is either considered as part of international law ("universalism") or as part of national law with each state creating its own unique norms of Conflict of Laws pursuing its own policy ("particularism").

${ }^{648}$ Cf.: Petropoulos, J., 1999, pp. 444-446.
} 
that contradicted the Nazi ideology. ${ }^{649}$ Subsequently, Jewish people and their (cultural) property were targeted. At first, directly after the annexation of Austria into the German Reich (the "Anschluss") in March 1938 artworks from private Jewish collections in Austria were misappropriated. ${ }^{650}$ Within the borders of the German 'Altreich', the expropriation of Jewish property started in the wake of the November 1938 Kristallnacht pogrom. ${ }^{651}$ Legal measures were adopted that targeted the Jewish population. Two instruments in particularly enabled the "aryanisation" of Jewish businesses (including art galleries) and the seizure of Jewish property, including works of art and other culturally valuable objects: the Law for the Attachment of the Property of the People's and State's Enemies ${ }^{652}$ and the Ordinance for the Employment of Jewish Property. ${ }^{653}$

The Nazi art deprivation within the German borders did not stay limited to outright confiscations and expropriations by the Nazi Party. A great number of losses occurred not as the result of direct Nazi intervention but were nevertheless precipitated by the political, social and economical exclusions of the persecuted groups, in particular the Jews. The passing of laws such as the Law for the Reestablishment of the Professional Civil Service ${ }^{64}$ had drastic impacts on the economical situation of the Jews. Excluded from the possibility of earning their living Jewish people were forced to sell their property in order to buy food or to finance their emigration or flights. ${ }^{655}$

\footnotetext{
${ }^{649}$ In the decree issued by Goebbels on June 30, 1937 "degenerate" art was defined as art that either "insulting German feeling, or to destroy or confuse natural form, or simply reveal an absence of adequate manual and artistic skill". See: Barron, S., 1991, p. 19. See for a broader definition of degenerate art including any art work in Jewish private collections: Merryman, J.H., 2007, p. 16. The purging of "degenerate art" from German state museums and galleries culminated in the 1937 Degenerate Art Exhibition. See further on the subject of degenerate art: Barron, S., 1991; Petropoulos, J., 1996, pp. 51-74; Petropoulos, J., 1997, pp. 106-107; Kunze, H.H., 2000. The sale of the confiscated "degenerate" artworks was based on a law passed by the Nazis on May 31st 1938. The law, which legalized the sale, was confirmed in the post-war era and no claims seeking restitution have been filed. Petropoulos, J., 1999, p. 444. For this reason, the subject of "degenerate art" will not be addressed in the present study.

${ }^{650}$ See further on particular collections: Lillie, S., 2003. See on a case involving art works removed from a Viennese Jewish Collector after the Anschluss: Spoliation Advisory Panel, 2008. A summary of this case dealing with porcelain spoliated from the Rothberger collection is included in chp. 4.\$1.II.1.h) where we discuss the work of the Spoliation Advisory Panel.

${ }^{651}$ Petropoulos, J., 1997, p. 107.

${ }^{652}$ Gesetz über die Einziehung volks- und staatsfeindlichen Vermögens vom 14. Juli 1933 (RGBl. I. S. 479). See further: Hirsch, M. / Majer, D., 1997, pp. 133-134.

${ }^{653}$ Verordnung über den Einsatz des jüdischen Vermögens (RGBl. 1938 I. S. 1709) vom 3. Dezember 1938. Petropoulos, J., 1997, p. 107. See further on the German misappropriation of Jewish property, e.g.: (in general): Schleunes, K.A., 1970; Hirsch, M. / Majer, D., 1997; Goschler, C., et al., 2003 and more specifically concerning cultural property: Petropoulos, J., 1996.

${ }^{654}$ Gesetz zur Wiederherstellung des Berufsbeamtentums vom 7 April 1933. See further on laws providing for the removal of Jews from other profession, e.g.: Edelheit, A.J. / Edelheit, H., 1994.

655 The proceeds for sales of artworks were generally far below the market value regardless of whether it concerned a private sale or sale in auction given the great offer of artworks on the market. See for an analysis of the development of sales prices for works of art and antiquities sold in auction: Rapport omtrent prijzenverloop kunstwerken op kunstveilingen etc. opgesteld door drie deskundigen voor de Raad voor het
} 
Technically speaking the looting of Jewish property within the German Territory was an internal affair of the German State. ${ }^{656}$ Different from the confiscation of private (cultural) property in the occupied territories the looting of Jewish property within Germany was not prohibited by the 1899 and 1907 Hague Conventions. ${ }^{657}$ While the Allied Forces observed this principle of State sovereignty in the beginning ${ }^{658}$ they soon extended the restitution measures to the restitution of internal misappropriations. ${ }^{659}$ The reason for doing so lay in the fact that the instrumentalisation of cultural deprivation of the Jewish people for the bigger political and ideological end of Hitler applied indiscriminately of state borders. The looting was employed to enhance the Aryan race and to weaken the non-aryan ones both within Germany and the occupied countries. ${ }^{660}$ It was the expression of a "superior claim of the Herrenvolk and the German State to property held by what was conceived as inferior types of people". ${ }^{661}$ Against this background, any distinction between external and internal restitution was perceived as artificial. Consequently, the Allied Forces disregarded this general principle of public international law and initiated internal restitutions parallel to the external ones. ${ }^{662}$

In the following, the influence of public international law on the internal restitution regime will be outlined. The relevant legal instruments of the occupying forces that will be further explored are Law No. 52 concerning the Blocking and Control of Property ${ }^{663}$, which has already been introduced in the context of external restitutions ${ }^{664}$, U.S. Military

Rechtsherstel, Afdeling Rechtspraak Amsterdam, 29 October 1947. It must be noted that the analysis is limited to the period 1940 - 1945.

656 Cf.: Walter, B., 1988, p. 105.

657 See for the provision banning confiscations of private property in an occupied territory Art. 46 of the 1899 and 1907 Hague Convention. See above in chp.1.\$1.II for an analysis of the Hague Conventions.

658 See e.g. above on the London Declaration whose scope of application does not extend to transfers of property within the German territory.

659 It should be mentioned here that the category of degenerate art was generally not affected by this extension in restitution measures. Cf.: Schönenberger, B., 2009, p. 225.

${ }^{660}$ Nicholas, L., H., 1997, p. 39; Kowalski, W.W., 1998, p. IX; Petropoulos, J., 1999, p. 443. See further:

Petropoulos, J., 1996.

661 Karasik, M., 1951, p. 448.

662 Cf.: Schwarz, W., 1974, p. 26.

663 Military Government for Germany. U.S. Zone. Law No. 52: 'Blocking and control of property', Military Government Gazette (Germany, U.S. Zone, issue A). 1 June 1946, p. 24. See for the full text of the Law No. 52: Kowalski, W.W., 1998, pp. 108-109, Annex 107. See further: Engstler, L., 1964, p. 140; Schwarz, W., 1974, pp. 25-28.

664 See above in chp. 1.\$1.V. 
Government Regulation No. 59 on the Restitution of Identifiable Property ${ }^{665}$, as well as Section III of the Treaty of Bonn. 666

\section{LAW NO. 52 CONCERNING THE BLOCKING AND CONTROL OF PROPERTY}

When Law No. 52 concerning the Blocking and Control of Property ${ }^{667}$ originally entered into force with the military occupation of Germany ${ }^{668}$ it focused solely on safeguarding external restitution by bringing all property under the control of the military government. ${ }^{669}$ Two months after the German surrender, the Allied Forces decided to extend the scope of Law No. 52 to apply also to transfers of property within Germany. ${ }^{670}$ Consequently, while Law No. 52 did not provide for the active restitution of cultural objects looted within German state borders, it constituted the first step in subsuming matters of internal restitution under the policy of the Allied Forces, and hence under the field of public international law. ${ }^{671}$

665 Military Government for Germany, U.S. Are of Control, Law No. 59: 'Restitution of Identifiable Property', Military Government Gazette (Germany. U.S. Zone. Issue G) No. 10, November 1947. What is held here for the U.S. Military Government Law is also true for the British Military Government Law No. 59 on the "Restitution of Identifiable Property to Victims of Nazi Oppression', Control Commission for Germany. B.E. Law No. 59: "Restitution of Identifiable Property to Victims of Nazi Oppression', Military Government Gazette (British Zone of Control), No. 28.

${ }^{666}$ Convention on relations between the Three Powers and the Federal Republic of Germany (Vertrag über die Beziehungen zwischen der Bundesrepublik Deutschland und den Drei Mächten), signed at Bonn, 26 May 1952 (Bundesgesetzblatt 1955 II. 29.03.1954, No 3).

${ }^{667}$ Military Government for Germany. U.S. Zone. Law No. 52: 'Blocking and control of property', Military Government Gazette (Germany, U.S. Zone, issue A). 1 June 1946, p. 24.

${ }^{668}$ Law No. 52 as amended 3 April 1945. See for full text of the Law: Kowalski, W.W., 1998, pp. 108-109, Annex 107. See further: Dölle, H. / Zweigert, K., 1947; Schwarz, W., 1974, p. 25.

669 Schwarz, W., 1974, p. 25. Art. 1(2) of the law reads: Property which has been the subject of duress, wrongful acts of confiscation, dispossession or spoliation from territories outside Germany, whether pursuant to legislation or by procedures purporting to follow forms of law or otherwise, is hereby declared to be equally subject to seizure of possession or title, direction, management, supervision or otherwise being taken into control by Military Government (Emphasis added). See further on Law No. 52 and its relevance for external restitutions above in chp. 1.\$1.V.1 where the Common Allied Restitution Regime is discussed.

${ }^{670}$ Military Government for Germany. U.S. Zone. Law No. 52: 'Blocking and control of property', Military Government Gazette (Germany, U.S. Zone, issue A). 1 June 1946, p. 24. In the U.S. Occupational Zone the U.S. version of the Law implemented the revision by deleting the words "from territories outside Germany" whereas the British edition explicitly included reference to property that has been affected within German territory. See further: Engstler, L., 1964, p. 140; Schwarz, W., 1974, pp. 25-28.

${ }^{671}$ Schwarz, W., 1974, p. 26. 


\section{Military Government Regulation No. 59 on the Restitution of IDENTIFIABLE PROPERTY}

The most relevant act regulating (internal) restitution of cultural objects in the U.S. occupied zone was Law No. 59 on the 'Restitution of Identifiable Property'. ${ }^{672}$ The main purpose of the law, which was enacted on 10 November 1947, was to effect:

"to the largest extent possible the speedy restitution of identifiable property (tangible and intangible property and aggregates of tangible and intangible property) to persons who were wrongfully deprived of such property within the period from 30 January 1933 to 8 May 1945 for reasons of race, religion, nationality, ideology or political opposition to National Socialism" (Article 1(1)).

By addressing the deprivation of property within the period 1933-1945 Law No. 59 explicitly extended the scope of restitutions to comprise also deprivations that occurred within German State territory since the Nazi's rise to power. The restitution regime as introduced by Law No. 59 is characterised by the following aspects: first, its understanding of what constitutes wrongful deprivation is very broad (Art. 2). Furthermore, Art. 3 of the Law provides for the presumption that all transactions made in the period 1933-1945 by a person belonging to a persecuted group qualify as an act of confiscation. Only if positive evidence was provided according to which the transfer would also have taken place in the absence of National Socialism or resulted in the successful protection of a property interest of the original owner could the presumption be refuted (Art. 4). Moreover, the restitution right existed irrespective of the interest of a potential good faith purchaser (Art. (2)). ${ }^{673}$ The initial deadline to file a claim with the Central Filing Agency until 14 May 1948 was extended until 14 August of the same year. ${ }^{674}$ By November 1948, more than 11,000 claims had been filed. ${ }^{675}$ Their settlement, however, would take many more years during which Germany regained its sovereignty as state. By complementing external restitution to foreign governments with provisions on the internal restitution, Law No. 59 was crucial in allowing for the termination of military government responsibility for property control and thus for ending the occupational status of Germany in the medium-term. ${ }^{676}$

\footnotetext{
672 Military Government for Germany, U.S. Are of Control, Law No. 59: 'Restitution of Identifiable Property', Military Government Gazette (Germany. U.S. Zone. Issue G) No. 10, November 1947.

${ }^{673}$ See for the discussion of Art. 10 of Law No. 59 below in chp. 1. \$5. Given the scope of Art. 10, which deals with unclaimed objects and their restitution to a Jewish successor organisation, the provision must be discussed in the context of restitutions to a people rather than to a state or individuals.

${ }^{674}$ Kurtz, M.J., 2006, pp. 149-150.

675 Ibid., p. 150.

${ }^{676}$ Cf.: Ibid.
} 


\section{ThE TREATY OF BONN: SECTION III}

The adoption of the 'Convention on the Settlement of Matters Arising out of the War and the Occupation' (hereinafter: "the Bonn Treaty") on 26 May 1952 was the decisive step to conferring on Germany the responsibility for both external and internal restitution. Further to the Bonn Treaty's section $\mathrm{V}$ on external restitutions, which has been discussed above ${ }^{677}$, section III of the Bonn Treaty obliges Germany to arrange for internal restitution in full agreement with the regulations as issued by the Allied Forces (Art. 2 of section III). ${ }^{678}$ Put differently, the Bonn Treaty superimposed rules of public international law character on the internal restitution within Germany.

\section{BRüG: THE FEDERAL Restitution LAW}

An important instrument to enforce the regulations concerning internal restitution as issued by the Allied Forces was the Federal Restitution Law (BRüG), which was adopted in $1957 .{ }^{679}$ At that point, the return of still-existing property had to a great extent been realised by the Allied restitution statutes. Consequently, the BRüG was in particular relevant for those claims dealing with property that no longer existed or which had disappeared. Compensation for lost property was calculated according to the estimated replacement value as of April 1, 1956.

The BRüG legislation represented the official recognition by the Federal Republic of Germany as successor state to the "Dritte Reich" of its obligation to pay compensation for lost or destroyed (cultural) objects. Initially, the BRüG legislation dealt only with the restitution of property that had been lost within the German territory. Its scope of application was, however, extended in four supplementary laws to comprise also losses of (cultural) property that had occurred outside of the German territory. In theory, any person who had suffered a loss of property for racial, ideological or religious reasons under the German occupation could profit under the BRüG legislation. In practise, the application of the BRüG legislation was more limited: first, claims had to be filed within the period of a year until 1 April $1958 .{ }^{680}$ Secondly, a claimant had to prove that there was a great likelihood that the object concerned had been brought into (West) German territory or Berlin. Furthermore, the question whether claimants could benefit from the BRüG legislation depended on their whereabouts at the time of making the claim. Claimants who lived in countries with whom Germany did not have diplomatic ties could not receive financial compensation for their losses. ${ }^{681}$ Thus, the restitution under

\footnotetext{
${ }^{677}$ See above in chp. 1. $\int 1 . \mathrm{V}$.

${ }^{678}$ Odendahl, K., 2005, p. 188.

${ }^{679}$ Bundesrückerstattungsgesetz (BRüG) 19 July 1957, BGBl. I-734.

680 \& 27 (2) BrüG. Cf.: Heuer, C.-H., 1999, p. 2562; Blume Huttenlauch, A., 2006, p. 822.

$681 \int 34$ BRüG. The countries affected were: Cambodia, North-Korea, Laos, Nepal, Taiwan, the countries of the Eastern Block with the exception of the Soviet Union. Cf.: Lillteicher, J., 2003, pp. 99-100.
} 
the BRüG legislation was significantly influenced by the intensification of the Cold War and remained limited to the formerly occupied territories in Western Europe.

\section{INTERMEDIARY CONCLUSIONS}

The initiatives after WWII providing for the restitution of (cultural) property to dispossessed private owners, both within Germany and in the occupied territories constituted novel developments of public international law. At first, the restitution to private individuals started in the context of the internal restitution of cultural objects looted within German state borders. Given the atrocities by the Nazis and their racial, ideological and religious motivation the Allies decided to complement external restitutions with internal ones. In the organisation of the internal restitution program the Allies closely followed the principles adhered to with regard to external restitutions. The second novel development followed in the late 1950s after Germany had been conferred responsibility for restitution. With the extension of the BRüG legislation restitution claims could also be filed by private persons for losses that had occurred outside of the German territory. The decision to extent the scope of application of the BRüG legislation had not been requested by the Allies but was an independent decision by Germany which must be understood in the context of an increasing awareness and historical insights of the atrocities of the Second World War. Another factor that might have contributed to Germany's decision to extent the restitution regime were the negotiations with the Conference on Jewish Material Claims against Germany. ${ }^{682}$ The Conference on Jewish Material Claims against Germany, also known as "the Claims Conference" was founded in 1951 as a body to engage the German government in negotiations for material compensation for Jewish victims of Nazi persecution. The Claims Conference had been formed by numerous Jewish organisations of different political and ideological orientations in order to establish a more powerful negotiating position. 683

While the restitution to private persons in the formerly occupied territories remained subject to significant limitations, especially in Eastern Europe, it nevertheless confirmed the development of restitutions of cultural objects moving beyond state actors to include individuals. ${ }^{684}$

\section{$\S 5$. RESTITUTION OF CULTURAL OBJECTS TO A PEOPLE}

Further to innovations with regard to the restitution of cultural objects to private individuals, the restoriation of rights in post WWII also introduced a novelty with regard to ownerless cultural property. According to the classical rules, Germany was obliged to

\footnotetext{
682 Cf.: Ibid., p. 101.

683 Barkan, E., 2000.

${ }^{684} \mathrm{Vrdoljak}$ A.P., 2006 , p. 146.
} 
return objects looted outside of its territory to the respective country of origin. Ownerless cultural objects from German Jews, however, would have fallen to the German State. ${ }^{685}$

As result of the genocide and the expulsion of Jews from Germany and the occupied territories the number of Jews had been drastically reduced in these countries. Consequently, Jewish successor organisations, especially those based in the United States sought to be transferred responsibility for ownerless cultural objects in order to distribute them amongst the Jews in their new places of residence. While this idea was initially rejected by Germany and Eastern European Countries, it was finally accepted. ${ }^{686}$

The plan of the successor organisations materialised in the form of Art. 10 of Law No. 59 on the 'Restitution of Identifiable Property'. ${ }^{687}$ According to this provision, the entire unclaimed estate of persecuted persons should be granted to a successor organisation to be appointed by the Military Government. ${ }^{688}$ By appointing a successor organisation rather than letting the unclaimed objects fall to the German State, Art. 10 represents a departure from how the disposition of unclaimed property has been treated in the past.

The return of cultural objects to the Jewish people is also dealt with in the Luxembourg Agreement. The Luxembourg Agreement was concluded between the State of Israel and the Federal Republic of Germany on 10 September 1952.. ${ }^{69}$ Under the terms of the Luxembourg Agreement, Germany bound itself to improving the existing legislation on restitutions and to pay close to 3.5 billion Deutschmarks (DM) ${ }^{690}$ to the State of Israel as reimbursement for the costs of accommodating Jewish emigrants from Germany and the occupied territories. ${ }^{61}$ Furthermore, in a Protocol to the Agreement, Germany agreed to pay 450 million DM to the Conference on Jewish Material Claims against Germany for the support of resettling Jewish emigrants worldwide. ${ }^{692}$

It is the monetary payment to Israel and the Claims Conference, rather than the promise to improve existing restitution legislation that makes the Luxembourg Agreement relevant with regard to return of cultural objects. While it did not create

\footnotetext{
685 Cf.: Hilberg, R., 1985, p. 1160.

${ }^{686}$ Cf.: Kurtz, M.J., 1985, p. 211, p. 217, p. 220; Odendahl, K., 2005, p. 192.

687 Military Government for Germany, U.S. Are of Control, Law No. 59: 'Restitution of Identifiable Property', Military Government Gazette (Germany. U.S. Zone. Issue G) No. 10, November 1947.

${ }^{688}$ For the U.S. American Zone this was the Jewish Restitution Successor Organization (JRSO). Schmoller, G.v., et al., 1957, \53, p. 15.

689 Agreement between Israel and the Federal Republic of Germany, No. 4961, signed at Luxembourg, on 10 September 1952.The full text of the agreement is available online at:

http://untreaty.un.org/unts/1_60000/10/12/00018584.pdf (last visited: 08 August 2008).

${ }^{690}$ In 1952, the exchange rate dollar - deutschmark (dm) was $1 \$=4,2 \mathrm{dm}$. See further: R.L. Bidwell, 1970 , pp. 22-24.

691 Müller-Marsall, M. / Coenen, M., 2000, p. 803.

${ }^{692}$ German restitution for National Socialist crimes, 1998, p. 287; Müller-Marsall, M. / Coenen, M., 2000 , p. 804.
} 
obligations under public international law to restitute cultural objects, the Luxembourg Agreement is relevant at a more abstract level. The monetary payments to Israel and the Claims Conference constituted a "radical innovation" 693 , a "res nova in international law" ${ }^{694}$. It was the first time that a state not only paid reparations to the "victors" of the war but also to its victims. ${ }^{695}$ According to Peresztegi, it opened a new chapter in the history of reparation and established a moral rule of reparation. ${ }^{696}$ Barkan describes the conclusion of the agreement between Germany and Israel as "the moment at which the modern notion of restitution for historical injustices was born". ${ }^{697}$ Thonke characterises it as a "change in paradigm". ${ }^{698}$ According to him, the "genesis of a second wave of restitutions" 699 as they emerged with regard to Holocaust Era assets since the mid-1990s and as outlined below ${ }^{700}$ - cannot be explained without reference to the Luxembourg Agreement. ${ }^{701}$

Further to public international law dealing directly with the restitution of cultural property or more in general with the protection of cultural property there are other fields of public international law that can have an indirect effect on the protection and return of cultural property. These are especially the doctrine of the right to selfdetermination, human rights, and the protection of minorities. ${ }^{702}$ Of these three fields of public international law it is the right to self-determination that is of most relevance for the indirect protection of cultural property. ${ }^{703}$ In the following, we will shortly reflect on ithe relevance of these three fields with regard to the protection of cultural property. It is for two reasons that we limit ourselves to a short outline: ${ }^{704}$ first, while the literature generally accepts the right to self-determination, human rights and the right to a cultural identity as granting certain rights for participating in a certain cultural life, for accession to and preservation of cultural property, it has not yet been established in how far these rights could also provide for the restitution of cultural objects. ${ }^{705}$ Secondly, it is not feasible to outline the content of these rights in abstracto.

\footnotetext{
693 Thonke, C., 2004, p. 14.

${ }^{694}$ Joffe, J., 1977, p. 1274.

695 Thonke, C., 2004, p. 14.

696 Peresztegi, Á. 2005, pp. 136 \& 146.

697 Barkan, E., 2000, p. XXIV.

${ }^{698}$ Thonke, C., 2004, p. 14.

${ }^{699}$ Ibid., p. 8.

700 See below in chp. 2. S1.I for the outline of the (re-) emergence of restitution claims for Nazi looted art.

701 Thonke, C., 2004, p. 14. See also: Barkan, E., 2000, pp. XXIII-XXIV \& 159; Levy, D. / Sznaider, N., 2001 , p. 237.

702 Odendahl, K., 2005, p. 204.

703 Schorlemer, S.v., 1992, pp. 42-46; Odendahl, K., 2005, p. 208 \& 209.

704 Cf.: the section on methodology above in the introduction ( $\$ 2 . I)$.

705 Cf.: Odendahl, K., 2005 who explicitly discusses restitution rights with regard to cultural property but does not refer to the right to self-determination, human rights and the right to a cultural identity in this section. Instead, she discusses these rights in a different section dedicated to international law indirectly supporting the protection of cultural property (pp. 204-209) where she stresses the protection of the status $q u o$ and future cultural expressions rather than a right to cultural property lost in the past. See also above on
} 
The right to self-determination was recognised with the adoption of the UN Charter in 1945.706 The right to self-determination was incorporated despite significant resistance. ${ }^{707}$ Art. 1(2) and Art. 55 refer to the right to self-determination as an aim respectively purpose of the United Nations and its Member States. The right to selfdetermination has also been codified in Art. 1 of the International Convenant of Civil and political Rights (ICCPR) and Art. 1 of the International Convenant of Economic, Social and Cultural Rights (ICSCR). Further to these codifications the right to selfdetermination is referred to in numerous non-binding instruments. ${ }^{708}$ More importantly, the right to self-determination has been recognised as a rule of customary law.709 Different from the classical rights in international law the right to self-determination constitutes a collective right rather than an individual one. Part and parcel of a group's right to self-determination is its right to design its cultural development. Consequently, the right to self-determination protects a group's rights to create their own cultural objects, to preserve them and to keep them within their own territory. ${ }^{710}$

Several human rights are relevant with regard to the protection of cultural property and the enjoyment and expression of culture more in general. First of all and most directly related is the right to freely to participate in the cultural life of the community. It has been codified in Art. 27(1) of the Universal Declaration on Human Rights, as well as in Art. 15(1a) of the International Convenant of Economic, Social and Cultural Rights (ICSCR). ${ }^{711}$ The right to freely participate in the cultural life comprises the right to have access to cultural property. Access to cultural property again implies the preservation and protection of the cultural property concerned. ${ }^{712}$ While the right to freely participate in the cultural life is the most evident right with regard to the protection of cultural property, human dignity, the right to freedom of thought, conscience and religion, freedom of expression and the right to education may also be relevant. ${ }^{713}$

Finally, minorities' rights are relevant, albeit indirectly, with regard to the protection of cultural property. ${ }^{714}$ One of the key elements of minority rights is the right to enjoy ones own culture. ${ }^{715}$ The enjoyment of ones own culture implies inter alia the

the scope of application of the UNESCO Intergovernmental Committee whose service is not available to non-state actors.

706 Vrdoljak, A.P., 2008, p. 51.

${ }^{707}$ Fitzmaurice, G., 1973, p. 233; Vrdoljak, A.P., 2008, p. 51.

708 See, e.g. the Final Act, 1975 of the Helsinki Conference on Security and Co-operation in Europe. Cf.: Odendahl, K., 2005, p. 208.

${ }^{709}$ Ibid. See further: Thürer, 2000, pp. 366-367.

710 Odendahl, K., 2005, p. 208. See also Schorlemer, S.v., 1992, p. 44; Sjouke, P.S., 1999.

711 Odendahl, K., 2005, p. 205.

712 Ibid.

713 See Artt. 1, 18, 19, 26 of the Universal Declaration of Human Rights; Artt. 9, 10 of the European Convention on Human Rights. Cf.: Ibid. See further: Wyss, M.P., 1992, p. 192; Chamberlain, K., 2003.

714 Odendahl, K., 2005, p. 206.

715 See Art. 27 International Convenant on Civil and Political Rights; Art. 5(1) of the Framework Convention for the Protection of National Minorities of the Council of Europe. Cf.: Ibid. 
safeguarding of the future existence of cultural objects. ${ }^{716}$ In how far minorities' rights, human rights and right to self-determination contribute or even provide for an obligation to return cultural objects that have been removed in the past, is yet to be established.

\section{$\S 6$. CONCLUSIONS FOR CHAPTER 1}

\section{LEGAL OBLIGATIONS TO RETURN CULTURAL OBJECTS}

In this chapter we have sketched and analysed the emergence of the existing legal framework under public international law with regard to the protection of cultural property, with an emphasis on the restorative protection in the form of returns and restitutions. The analysis comprised the development of rules on the protection of cultural property in times of war (2.1), as well as in times of peace. The analysis of rules for the protection of cultural property in times of peace not only dealt with the applicable legal regime in international law for the protection of cultural property against the illicit trade, especially the return and restitution of cultural property that has been illicitly removed from the territory of origin (2.2), but also addressed the question whether international law provides for an obligation to return cultural property that has been removed from a territory during the colonial era (2.3).

The analysis of these three classical categories in the sense of dealing with the relationship between state actors revealed that the most extensive rules on the return and restitution of cultural property emerged in the context of armed conflicts. By the turn of the $19^{\text {th }}$ to the $20^{\text {th }}$ century a ban on the looting of cultural property had come into existence in the form of 1899 and 1907 Hague Conventions. This ban was mirrored by the obligation to restitute any cultural object that had been removed in spite of the ban. After the adoption of the 1899 and 1907 Hague Conventions, the protection of cultural property in times of war has been extended in further international instruments, in particular the 1954 Hague Convention and its protocols and has been confirmed of customary law.

The fact that the protection of cultural property in times of war exceeds the protection available in times of peace must not surprise given the origins of international law as the law governing the relations of nation states, which were too often dominated by armed conflicts. Having said that the protection of cultural property in times of peace is nonetheless disappointing. While the relevant international treaties do extend the protection offered to stolen cultural property under private (international) law, the restorative protection they grant to illegally exported cultural property is rather limited. The only truly international legal instrument that provides for obligations to return illegally exported cultural property is the 1995 UNIDROIT Convention. This finding is the more critical if one takes into account the hesitation of countries, especially of art

${ }^{716}$ Ibid. See further: Pritchard, S., 2001. 
market countries, to ratify this instrument. Furthermore, the analysis revealed that this void left by treaty law is not filled by a rule of customary law.

The third constellation scrutinised in this section dealt with cases of cultural property that had been removed from their countries of origin prior to the existence of any international conventions fighting the illicit trafficking of cultural property. Departing from three starting points, first activities within the United Nations and UNESCO, secondly the process of decolonialisation and finally the circumstances of acquisition of cultural property, we tried to identify a basis for a claim for the restitution of cultural property removed during the colonial era. The results of our analysis, however, do not support the (coming into) existence of a rule of international law (treaty law or customary law) on the restitution of cultural property removed under colonialism. While it is theoretically possible to adopt an international binding legal instrument providing for the return of cultural property removed during the colonial era ${ }^{717}$, the likelihood of such a step of the state community is nihil as the deliberations during the adoption of the 1970 UNESCO and 1995 UNIDROIT Convention indicated. ${ }^{718}$

After we discussed these three constellations dealing with cultural property removed during armed conflicts, in peaceful times and during the colonial era (or in any event prior to the introduction of international instruments dealing with the protection of cultural property outside of armed conflicts) the analysis turned to the restitution of cultural property to private individuals (2.4) and a people (2.5). The broadening of the scope of public international law from its exclusive focus on states to including individuals has been characterised as the most important change in public international law over the past century. ${ }^{719}$ This shift in the focus of public international law occurred inter alia in response to the Holocaust. In a sense, one could state that the internal restitution of cultural property to Jews that had been dispossessed within the German borders was the result of a spill-over from external restitutions while subsequently making a back swing to introduce also restitutions to private individuals in external constellations. At a more abstract level the restitutions to private individuals both within and outside German borders indicate that public international law is less rigid and positive than often held. With regard to the restitutions to private individuals public international law (was) bent to cover situations that originally did not fall under its scope of application. The analysis furthermore revealed that where physical restitution was not an available option for the cultural object either being destroyed or lost, great emphasis was put on financial compensation. Where compensation was granted, it was calculated according to the estimated replacement value at the time of the compensation. ${ }^{720}$

\footnotetext{
717 See, e.g.: Vienna Convention on Succession of States in respect of State Property, Archives and Debts. Done at Vienna on 8 April 1983 with regard to the return of State Archives to newly independent states (Art. 28).

718 See above in the introductory remarks to chp. 1.§3.

719 Less, S., 2008.

${ }^{720}$ According to the BRüG, which was in particular relevant for those claims dealing with property that no longer existed or which had disappeared from either within or outside the German territory compensation
} 
However, there are also cases in which the object was neither restituted, nor was financial compensation received.

With regard to the restitution of cultural property to a people, the analysis stressed the relevance of the Luxembourg Agreement that was concluded between the State of Israel and the Federal Republic of Germany on 10 September 1952. While the Luxembourg Agreement could not create a general obligation in public international law to restitute cultural property to a people, it is nevertheless considered as an important development with regard to the greater question of restitution and reparation. According to Peresztegi, the Luxembourg Agreement opened a new chapter in the history of reparation and established a moral rule of reparation. ${ }^{721}$ Barkan describes the conclusion of the agreement between Germany and Israel as "the moment at which the modern notion of restitution for historical injustices was born". ${ }^{722}$ Thonke characterises it as a "change in paradigm". ${ }^{723}$ According to him, the "genesis of a second wave of restitutions" 724 as they emerged with regard to Holocaust Era assets since the mid-1990s and as outlined below ${ }^{725}$ - cannot be explained without reference to the Luxembourg Agreement. ${ }^{726}$ Before we will start with the analysis of this new chapter in the history of reparation with regard to Nazi looted art and human remains in the following chapters we need to round off this chapter by reflecting on the status of public collections in international law.

\section{SPECIAL STATUS OF PUBLIC COLlECTIONS IN INTERNATIONAL LAW?}

Further to the extrapolation of rules of public international law on the protection of cultural property in particular in view of obligations to restitute or return them, the analysis also allows us to reflect on the specific treatment granted to public collections.

The first time that public collections were granted specific treatment dates back to the Congress of Vienna addressing among other things Napoleon's art looting campaigns. Despite public collections being a fairly new development at the turn of the $20^{\text {th }}$ century, they were granted special treatment acknowledging their special character. Interestingly, the public collections benefiting from the special treatment were the French collections: at first, when France restored cultural property to Prussia, it was agreed that only those objects were to be returned that had not been placed in a museum by the time of the conclusion of the Peace Treaty of Paris. After the Battle of Waterloo, the French argument of the integrity of its public institutions, museums and

for lost property was calculated according to the estimated replacement value as of April 1, 1956. See further on the BRüG above in chp. 1. $44 . I V$.

721 Peresztegi, Á. 2005, pp. 136 \& 146.

722 Barkan, E., 2000, p. XXIV.

723 Thonke, C., 2004, p. 14.

724 Ibid., p. 8.

${ }^{725}$ See below in chp. 2. S1.I for the outline of the (re-) emergence of restitution claims for Nazi looted art.

726 Thonke, C., 2004, p. 14. See also: Barkan, E., 2000, pp. XXIII-XXIV \& 159; Levy, D. / Sznaider, N., 2001, p. 237. 
libraries was again accepted in that cultural property held in public collections did not have to be returned. The only objects that did have to be returned were the objects then held in the Louvre. Further to marking the starting point of an development of a rule banning looting and providing for restitution of customary law, the return of cultural property that had been amassed in Germany, the Netherlands, Italy, Austria and Spain also constituted an extra stimulus for further (re-) institution of public museums in those countries. ${ }^{727}$ With regard to the legal developments scrutinised in this chapter this rising awareness and appreciation of public museum collections soon manifested itself in legal obligations to protect these collections against damage and removal.

The first multilateral treaty to introduce specific protection to public collections was the 1899 Hague Convention. ${ }^{728}$ The protection granted to public collections comprises protection against damage and destruction as well as against removal: Art. 27 requests that "all necessary steps should be taken to spare as far as possible edifices devoted to religion, art, science, and charity (...)". While Art. 27 aims at the protection of specific categories of immovable property, including buildings housing public collections, against damage and destruction, it indirectly contributes to the protection of movable cultural heritage included in these buildings. Art. 56 extends protection by prohibiting any seizure of, destruction, or intentional damage done to charitable and educational institutions, to historical monuments, works of art or science. ${ }^{729}$ Consequently, while the emphasis of the 1899 and 1907 Hague Conventions lies on the protection of edifices devoted to the arts and sciences as immovable structures against destruction and damage, it is also relevant for the protection of individual collection items against seizure.

Between the adoption of the 1899 and 1907 Hague Conventions and the 1954 Hague Convention as the next truly international instrument providing for the protection of cultural property during armed conflicts, the Roerich Pact was adopted. The Roerich Pact is a regional multilateral treaty applying only to the Americas and seeks to protect museums and scientific, artistic, educational and cultural institutions, next to historic monuments. ${ }^{730}$ The Pact, which was initiated by the Roerich museum, seeks to protect these institutions at the institutional level rather than the individual objects both in times

\footnotetext{
${ }^{727}$ In 2008, the Huizinga Research Institute of Cultural History, Amsterdam and the Institute for Museum Research, Berlin organised a joint conference on the shift in European museums in reaction to Napoleon's looting campaigns: 'Napoleon's Legacy - The Development of National Museums in Europe 1794-1830', 31.1. - 2.02.2008, Amsterdam.

${ }^{728}$ Convention (II) with Respect to the Laws and Customs of War on Land and its annex: Regulations concerning the Laws and Customs of War on Land. The Hague, 29 July 1899.

729 Art. 56 reads in full: "The property of the communes, that of religious, charitable, and educational institutions, and those of arts and science, even when State property, shall be treated as private property. All seizure of, and destruction, or intentional damage done to such institutions, to historical monuments, works of art or science, is prohibited, and should be made the subject of proceedings".

${ }^{730}$ Roerich Pact: Protection of Artistic and Scientific Institutions and Historic Monuments, Montevideo, April, 15, 1935, 49 Stat. 3267, TS No. 899, 167 LNTS 279.
} 
of armed conflicts and in time of peace by requiring their respectful treatment as neutral institutions.

The protection granted to public museums was extended by the 1954 Hague Convention. ${ }^{731}$ The need for greater protection had become painfully evident during WWII. The Nazis looted and destroyed cultural property at unknown level. Ironically, the looting was in part motivated by Hitler's megalomaniac plans to establish a Führer Museum in Linz. The looting did not spare public collections, especially in the Eastern Occupied Territories. The integrity of public collections was only observed in the Western Occupied Territories for they were expected to become part of the German Reich.

Adopted within a decade from the end of WWII the 1954 Hague Convention was the first international treaty dedicated to the protection of cultural property and the first legal instrument to provide for a definition of cultural property: according to its Art. 1 the term "cultural property" not only covers "movable (...) property of great importance to the cultural heritage of every people, such as (...) works of art; manuscripts, books and other objects of artistic, historical or archaeological interest; as well as scientific collections (...)" but also extends to "buildings whose main and effective purpose is to preserve or exhibit the movable cultural property such as museums, large libraries and depositories of archives (...)". Consequently, the protective regime introduced by the 1954 Hague Convention and its protocols embraces both movable cultural property and immovables housing cultural property. While public museum collections are granted specific protection in times of armed conflict, objects from the collection do not enjoy additional protection with regard to their restitution. When it comes to the protection against removal and the obligation to restitute looted cultural property, objects in public museum collections are treated on equal footing with other cultural property and enjoy special protection only when they qualify as "movable property of great importance (...)".

Another international instrument that is not limited to cultural property from public museum collections is UN Security Council Resolution 1483 that was adopted in reaction to the 2003 invasion of Iraq. While it explicitly mentions cultural property removed from the Iraq National Museum, all cultural property that has been removed from Iraq since 1990 must be returned. In practise, objects from the Iraq National Museum will profit from the fact that they have been (at least to a certain extend) catalogued. Consequently, it will be easier to proof that these objects have been illegally removed from Iraq compared to objects that have not been listed in an inventory. Most problematic is the situation for illegally excavated objects that have been removed before anyone could take note of their existence.

Next to protection in times of armed conflicts, public museum collections have also been granted specific protection in times of peace. In fact, when the International

731 Convention for the Protection of Cultural Property in the Event of Armed Conflict, signed at The Hague, 14 May 1954 (249 UNTS 215). 
Museums Office (IMO) made the first attempt to adopt an international treaty on the protection of cultural property in the 1930s its final draft was limited in scope of application to objects that were the property of a state or a public institution, that were held in public collections and were mentioned in the collections' inventory. ${ }^{732}$ This draft treaty was however never adopted and it took four decades until the first international treaty on the protection of cultural property in times of peace was adopted.

The 1970 UNESCO Convention grants specific protection to cultural property stolen from a museum, a religious or secular monument or similar institution (Art. 7(b)). Next to granting specific protection to public museum collections with regard to the recovery of the cultural property concerned, the 1970 UNESCO Convention also requires its Member States to ensure that museums and similar institutions do not acquire cultural property that has been illegally exported from the territory of another State Party. Consequently, the 1970 UNESCO Convention stresses the specific role of public museum collections not only in confirming the status quo of the collection but also in respect of future acquisition policies.

The 1995 UNIDROIT Convention also grants specific protection to cultural objects stolen from public collections. While the recovery of stolen cultural objects is not limited to cultural objects stolen from public collections but is available to any object that qualifies as cultural object in the sense of the convention, objects from public collections are granted a preferential treatment with regard to the application of limiation periods. As a general rule, the recovery of objects that have been stolen from public collections is only subject to the relative period of three years after the location of the object and the identity of the current possessor have been known. The recovery is not subjected to the effects of an absolute limiation period, thus not limiting the recovery right in time unless where the claimant knew the identity of the possessor. States are, however, granted the possibility to introduce an absolute limitation period of 75 years. However, compared to the general limiation period of 50 years that is applicable to objects not originating from public collections, this is still a preferential treatment for objects from public collections.

The EC Directive also provides specific protection to cultural objects from the EC Members' public collections. However, theobligations for Member States for return cultural objects under the directive does not apply to all objects in public collections but applies only to those that have been designated as national treasures in the sense of Art. 30 of the EC Treaty.

In conclusion, public collections respectively objects that belong to public collections enjoy specific protection in international law, both in times of war and in times of peace. The content of the protection corresponds to the main threats of the situation concerned. During armed conflict it is in particular the immovable structures that house the collections that are granted protection against destruction and damage. However, the

${ }^{732}$ Cf.: Odendahl, K., 2005, p. 131. See for a detailed discussion of the drafts: Engstler, L., 1964, pp. 49-53; Schorlemer, S.v., 1992, p. 420-423. 
reason for protecting the immovable structures lies in the protection of the movable objects they house. Museums as such do not qualify as 'cultural property'. Put differently, while the concept of public museums certainly belongs to European cultural heritage, public museums as such do not qualify as cultural property, nor are their collections immune to obligations to restitutions. Where objects from public museum collections have been looted they must be restituted.

In times of peace, when the threats of physical damages to cultural property are better regulated at the national level international law is first and foremost relevant with regard to the return of cultural property that has been illicitly trafficked. While international law contains little rules with regard to the return of illegally exported cultural property it does extent the restitution regime for stolen cultural property. This is especially true for objects that have been stolen from public collections. The analysis furthermore revealed that international law, as it presently stands, does not impose any conditions with regard to an object's quality or provenance but accepts the inclusion of an object in a public collection (provided it is listed in the institution's inventory) as sufficient proof that it is worthy of protection. 



\section{CHAPTER 2}

\section{The Cases of the Recent Debates on the Return of Nazi Spoliated Art and Human Remains: Genesis, (legal) Context and the Adoption of various international Declarations and Principles}

This chapter focuses on the most prominent developments with regard to claims affecting public (museum) collections in the last fifteen to twenty years: ${ }^{733}$ requests for the return of Nazi spoliated art and human remains. It will sketch the rise of these claims, will situate the claims against the background of public international law and will discuss the principles adopted at the international level. The subsequent chapters then will deal with the national dimensions.

The present analysis splits in two parts: $\int 1$ of the chapter is dedicated to the case of Nazi spoliated art, whereas $\int 2$ deals with the case of human remains. Both parts follow a parallel structure in that they first address the developments that led to the recent rise in claims. With regard to Nazi spoliated art authors go as far as to speak of a "renaissance of restoration of rights" 734 or a "genesis of a second wave of restitution" 735 . What is particularly in this respect is the question why the claims and the debate emerged only in the 1990s - some fifty years after the end of World War II and thirty years after post-war restitution efforts had come to an end. While the events that led to the re-emergence of the debate on Nazi spoliated art are rather well-defined and occurred in quick succession of one another this is not the case with regard to human remains. The developments that led to the emergence of international claims for the

\footnotetext{
733 See, e.g.: ICOM Code of Ethics for Museums (as approved by the 21st General Assembly of ICOM in Seoul, Republic of Korea, 8 October 2004); Merryman, J.H., 2002.

734 Aalders, G., 2001, p. 344.

735 Thonke, C., 2004, p. 8. Another scholar described the developments as a "reawakening to the ongoing dispossession and loss suffered by Holocaust survivors and their heirs. Vrdoljak, A.P., 2006, p. 3.
} 
return of human remains from Western public collections are more diffuse in time and location. Consequently, the outlining of the developments is more extended and simplified at the same time. Before looking at the developments as they started in the United States and other formerly colonised countries from the 1960s onwards we will reflect upon the various circumstances of how human remains have become collection items in the first place. Such a background on the history of collecting of human remains is necessary to understand the complexities underlying claims for the return or repatriation of human remains.

After the genesis of the current debate is discussed in $\int 1$ and $\int 2$, we will address the relationship between the recent "wave of restitution claims" concerning Nazi spoliated art and human remains with the existing legal framework on the restitution of cultural objects under public international law as outlined in Chapter 1. Such demarcation contributes to a better understanding of the present claims and the reactions and initiatives by the international community in the form of principles, resolutions and declarations that will be addressed subsequently. In scrutinising the principles, resolutions and declarations adopted by the international community particular attention will be paid to the question whether these instruments introduce new legal rights and obligations to claim / restitute cultural objects and which solution they propose for current claims (\3).

\section{$\S 1$.THE CASE OF NAZI SPOLIATED ART}

\section{NAZI SPOLIATED ART: GENESIS OF THE DEBATE ON THE RETURN OF NAZI SPOLIATED ART}

An important development for the re-emergence of the debate on spoliated cultural objects was the end of the Cold War in 1989. The collapse of communism in Eastern Europe and the implosion of the Soviet Empire allowed for a greater exchange of information between East and West. Of particular relevance was the opening up of archives in the East. One of the crucial findings in these archives concerned the socalled Trophy Art. ${ }^{736}$ The term "Trophy Art" refers to those cultural objects that have been removed by Soviet "trophy brigades" at the end of and after the Second World War from the Soviet-occupied zone of Germany. While the subject of Trophy Art is a matter on its own and therefore bracketed from the present analysis ${ }^{737}$, the discoveries

\footnotetext{
736 The first publications on "Trophy Art" after the fall of the Iron Curtain were: Akinsha, K. / Grigorii, K., 1991a; Akinsha, K. / Grigorii, K., 1991b.

737 The Soviet "Trophy Art" debate focuses on the legality of restitution in kind. While the present study does not address the (il-)legality of restitution in kind, the analysis as presented in chp. 1. $\$ 1 . \mathrm{V}$ on the return and restitution of cultural objects removed during armed conflicts suggests that the Soviet Union / Russia has consistently objected to the idea that restitution in kind is illegal, thus possibly being able to rely upon the concept of "persistent objector".
} 
in the Eastern archives on the fate and whereabouts of the Trophy Art in Russian Collections also triggered a more general interest in the fate of cultural objects spoliated during World War II.

The opening of the archives resulted in a plethora of publications on the looting of cultural objects during WWII. Two books deserve explicit mentioning here for creating public awareness about the nature and quantity of the lootings by the Nazi's: Lynn Nicholas' 'The Rape of Europa'738 and Hector Feliciano's 'The Lost Museum: the Nazi

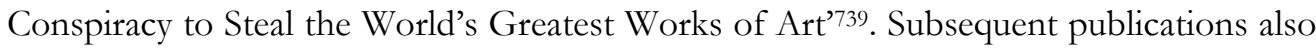
addressed the question of what had happened to cultural objects after the end of the war. Both the restitution from Germany to the formerly occupied territories, including France and the Netherlands, as well as the internal restitution regimes were analysed and criticised for incompleteness and irregularities. ${ }^{740}$

While the research of the looting during World War II profited from the opening of the Eastern archives, another consequence of the end of the Cold War might have been of even greater relevance. It was only after the threat of war between NATO and the Warsaw Pact countries had diminished that there was political willingness for introspection into the past. ${ }^{741}$ Until the fall of the Iron Curtain, the Soviet threat had united Western Europe and the US, making investigations into assets spoliated during World War II a sensitive issue or least one that was accorded little relevance. ${ }^{742}$ The question of spoliated cultural objects profited to a great extent from developments with regard to other spoliated assets, in particular the so-called 'dormant Swiss Bank accounts'. ${ }^{743}$ In 1996, the World Jewish Congress, with the support by the Clinton administration, had drawn public attention to the issue of the dormant and unclaimed Jewish bank accounts. ${ }^{744}$ Swiss banks were accused, inter alia, of wrongfully withholding

\footnotetext{
738 Nicholas, L., H., 1995.

${ }^{739}$ Feliciano, H., 1997.

${ }^{740}$ For publications dealing with national approaches to restitution see, e.g.: Simpson, E., 1997. For the Netherlands and France the post-war restitution efforts will be summarised below in the respective country section of chp. 4.\$1.I / III.

741 The change in the international geopolitical order also contributed to the developments that have been coined by proponents and critics as the "Americanization of the Holocaust". The term has been coined by the founders of the U.S. Holocaust Memorial Museum and was understood both as mandate and mission. See further: Thonke, C., 2004, p. 84; Berenbaum, M. / Kramer, A., 2006. While the Americanization of the Holocaust is also considered as an important (pre-) condition of the re-emergence of the discussion on World War II Spoils, it will be not further elaborated here. Instead, the reader may be referred to: Novick, P., 1999; Eizenstat, S.E., 2003, Piper, E. / Swamy, U., 2001.

${ }^{742}$ Novick, P., 1999, p. 86; Turner, M.I., 1999, p. 1520. The Cold War had also led to the decrease of international pressure on Germany to compensate victims of the Nazi-regime. The process of the "denazification" of the German society was no longer a priority of the Allies. The integration of the Federal Republic of Germany into the transatlantic cooperation of defence and its integration into the Western economic and cultural sphere became was pursued equally by the Federal Republic of Germany and the three Western Allies. Thonke, C., 2004, p. 44.

743 Cf., e.g.: Muller, E. / Schretlen, H., 2002, p. 19.

744 Braillard, P., 2000, p. 33. Amongst other initiatives, Under-Secretary of State Stuart Eizenstat was asked to engage the US Government in a renewed effort to assist Holocaust victims and to seek redress for Nazi
} 
monies that had been deposited by persecuted persons, primarily Jews, for safekeeping. ${ }^{745}$ Holocaust survivors and their heirs filed a federal class action suit in New York against Swiss governmental and private entities, in particular Swiss banks. ${ }^{746}$ The case 'In re Holocaust Victims' Assets Litigation'747, which received extensive media coverage, became a milestone for the subsequent development of claims involving wrongs committed during the Second World War. Not only was it the first successful class action suit in the context of World War $\mathrm{II}^{748}$; its settlement was the largest ever achieved in a human rights case in the history of American litigation. ${ }^{749}$

Further to the Swiss bank litigation, the developments with regard to the 1953 London Debt Agreement were relevant with regard to the increase in claims and the intensification of the restitution debate, in particular with regard to forced and slave labour practices. ${ }^{750}$ The 1953 London Debt Agreement ${ }^{751}$ settled Germany's war debts in order to allow the country to re-establish its role in international capital markets. The Agreement not only wrote-down the overall debt by about $50 \%$ but allowed the debtors to postpone some payments until such time as re-unification. ${ }^{752}$ As a result, early compensation claims had been thwarted by German courts since the 1950s for being

injustices. He co-organized the Washington Conference on Holocaust-era Assets, which is discussed below. A Special Envoy for Holocaust Issues was appointed under the chairmanship of Ambassador J.D. Bindenagel. Furthermore, research programmes in the National Archives were initiated.

745 Bazyler, M., 2001, pp. 33-36.

746 See: Complaint, Weisshaus v. Union Bank of Switzerland, No. CV-96-4849 (E.D.N.Y. filed October 3, 1996), which was amended on July 30, 1997. The action was consolidated in April 1997 with two actions that were filed against the same defendants later in 1996 and in early 1997 under the title: "In re Holocaust Victim Assets Litigation". Bazyler, M., 2001, p. 6; Eizenstat, S.E., 2003, p. 76. See further on the "phenomenon of class action suits" (Bazyler, p. 6.). See more in general: Mulheron, R., 2004.

747 In re Holocaust Victim Assets Litig., 1998 U.S. Dist. LEXIS 18014 (E.D.N.Y. Oct.7, 1998) (Joint Stipulation describing settlement in principle); In re Holocaust Victim Assets Litig., 105 F. Supp.2d 139 (E.D.N.Y. 2000) (upholding fairness of settlement under Rule 23(e)); In re Holocaust Victim Assets Litig., 225 F.3d 191 (2d Cir. 2000) (upholding definition of plaintiff class); In re Holocaust Victim Assets Litig., 2000 U.S. App. LEXIS 29529 (2d Cir. Nov. 20, 2000) (dismissing appeal for failure to comply with calendar); In re Holocaust Victim Assets Litig., 2000 U.S. Dist. LEXIS 20817 (E.D.N.Y. Nov. 22, 2000) (accepting Special Master's allocation plan); In re Holocaust Victim Assets Litig., 2001 WL 419967 (E.D.N.Y. Apr. 4, 2001) (defining membership in Slave Labor II class); In re Holocaust Victim Assets Litig., 14 Fed. Appx. 132 (2d Cir. 2001) (upholding plan of allocation); In re Holocaust Victim Assets Litig., 282 F.3d 103 (2d Cir. 2002) (vacating definition of Slave Labor II class; remand for determination of parties' intentions); In re Holocaust Victim Assets Litig., 2002 U.S. Dist. LEXIS 20195 (E.D.N.Y. Oct. 23, 2002) (denying risk multiplier).

748 Bazyler, M., 2001, p. 32.

749 Ibid.

750 Cf.: O’Donoghue, G., 2006, p. 1127.

751 See: Agreement on German External Debts, February 27, 1953, 4 U.S.T. 445, 449.

The London Debt Agreement was signed on February 27, 1953 by the Federal Republic of Germany on the one hand and, on the other hand, many of the victorious Allies. The main purpose of the Treaty was to enable the FRG to establish normal economic relations with other nations and to settle its external debt. Iwanowa, 67 F. Supp. 2d. at 452-53.

752 Guinnane, T.W., 2004, p. 1. 
non-justiciable pursuant to the 1953 London Debt Agreement. ${ }^{753}$ The adoption of the 1990 German Unification Treaty put an end to the prescribing of a moratorium on victims' claims against either Germany or its industrial entities. ${ }^{754}$

The process of coming to terms with the past did not stay limited to Germany and Switzerland. Soon after the German moratorium on victims' claims under the 1953 London Debt Agreement had been lifted and Switzerland had been hurtled "into the eye of the storm raging over the re-examination of the most wrenching years of the century and the Holocaust" 755 , other countries were questioned over their commercial ties with Nazi Germany and their negligence in restoring the rights of Jews. ${ }^{756}$ Countries, including France, and the Netherlands started investigations into the activities of (central) banks regarding Jewish financial assets during WWII, and the spoliation of Jewish assets more in general. ${ }^{757}$

In 1997, the British Government convened a conference in London dealing with the so-called "Nazi Gold" (hereafter: "the London Conference") ${ }^{758}$. The term refers to the gold transferred from the German central bank to Switzerland by the authorities of the Third Reich. Among the gold transferred into Switzerland from the German Reichsbank were gold reserves seized from the central banks of occupied countries. The transferred gold also included gold stolen from individual victims of Nazi persecution. ${ }^{759}$ The gold was either converted by Swiss banks, especially the Swiss National Bank ${ }^{760}$ into hard currency that was used to finance the German war expenditure, or was in transit in Switzerland. The Swiss bank affair and the London Conference galvanized attention on unresolved aspects of restitution after the Second World War. While the London Conference had focused on the looting, movement and disposition of "Nazi gold", the conference proceedings also referred to other assets, such as real property, securities, bonds, insurances and works of art (emphasis added).

While works of art were only one category of assets mentioned in the proceedings of the 1997 London Conference they became the centre of attention in the following year. The year of 1998 is marked by the first prominent cases dealing with Nazi spoliated art, which received great media attention. In reaction to these cases and the great media attention they generated a conference was held in late 1998 in Washington D.C.

\footnotetext{
${ }^{753}$ For an account of the early cases see: Ferencz, B.B., 2002.

754 This has been confirmed in German case law. See for a landmark case: Krakauer v. Federal Republic of Germany, LG (District Court) Bonn, 10 134/92.

755 Braillard, P., 2000, p. 33.

${ }^{756}$ Kemenade, J.A.v., 1999a. ${ }^{757}$ Foreign \& Commonwealth Office, 1998; Kemenade, J.A.v., 1999b; Study Mission on the Spoliation of Jews in France: Mattéoli Commission Final Report (Mission d'étude sur la spoliation des Juifs de France. Rapport Général), 2000.

${ }^{757}$ Foreign \& Commonwealth Office, 1998; Kemenade, J.A.v., 1999b; Study Mission on the Spoliation of Jews in France: Mattéoli Commission Final Report (Mission d'étude sur la spoliation des Juifs de France. Rapport Général), 2000.

${ }^{758}$ Nazi Gold - The London Conference, 2-4 December 1997. See for the conference proceedings: Foreign \& Commonwealth Office, 1998; Braillard, P., 2000, pp. 143-144.

${ }^{759}$ Rings, W., 1985.

${ }^{760}$ Until October 1941 the gold was also bought by some Swiss commercial banks.
} 
dedicated solely to spoliated art works. Before elaborating upon the 1998 Washington Conference, we will mention three cases we believe were crucial for the later developments: the disputes concerning Degas' "Landscape with Smokestacks"; the case of Schiele's "Portrait of Wally" and the Goudstikker case. The first two are considered in the literature as the first "Nazi-spoliated-art lawsuits". In August 1998, the dispute between the heirs of Fritz and Louise Gutmann and the collector Daniel C. Searle concerning the ownership of the painting "Landscape with Smokestacks" by Degas was settled on the eve of trial. ${ }^{761}$ The case is often cited in the literature as prime example of a "just and fair" solution: 762 the case was settled by a two-step agreement according to which ownership of the painting (then worth $\$ 1,2$ million) was equally divided between Searle and the Gutmann heirs. ${ }^{763}$ Searle subsequently donated his share to the Art Institute of Chicago, which bought the interest from the Gutmann heirs. The reason for lauding the settlement is the fact that the painting did not disappear into a private collection but was kept for the general public. ${ }^{764}$ It is exhibited alongside a label commemorating the provenance of the painting. ${ }^{765}$

The case dealing with Schiele's "Portrait of Wally" commenced when the heirs of Lea Bondi discovered the portrait when it was exhibited in 1997 in the context of a Schiele retrospective at the Museum of Modern Art in New York. Lea Bondi, a Jewish art dealer was forced to sell her art at greatly undervalued prices and to flee Vienna in 1938. After the war, the portrait was acquired by Viennese eye doctor Rudolf Leopold who sold his art collection in 1994 to the Austrian Government. Since then the portrait has been part of the collection of the Leopold Museum in Vienna. As of today, more than ten years later the case is still unsolved. ${ }^{766}$

Claims seeking the return of spoliated art works were not limited to the United States. Also in Europe claimants were stepping forward. One of the first and without any doubt the most prominent case within the Netherlands is the Goudstikker case, which dealt with some 200 paintings from the former trading stock of the art dealer Goudstikker. At the beginning of 1998 the heirs of Goudstikker requested the return of

\footnotetext{
${ }^{761}$ See further on this case, e.g.: Weil, S., 1999; Trienens, H.J., 2000. During his presentation on 19 October 2006 at the Conference on 'Dispute Resolution Methods for Holocaust Spoliated Art Claims' organised by the Institute of Art and Law (IAL), London Winston Chesterfield analysed the negotiating powers of the parties involved and came to the interesting conclusion that had the case been resolved in court it would have been likely that Mr Searle's title had been confirmed.

762 See, e.g.: Elmer, T., G., 2000, pp. 132-133. Cf.: Hartung, H., 2005, p. 96.

763 Buomberger, T., 1998, p. 24.

${ }^{764}$ Cf.: Kirby, C.L., 2000.

765 The label reads: "Purchase from the collection of Fritz and Louise Gutmann and a gift of Daniel C. Searle". Email dated 27 August 2002 from Eileen Harakal, Executive Director of Public Affairs, The Art Institute of Chicago.

766 United States v. Portrait of Wally, a Painting by Egon Schiele, No. 99 Civ. 9940--MBM, 2002 WL 553532 (S.D.N.Y. Apr. 12, 2002). In re Application to Quash Grand Jury Subpoena Duces Tecum Served on Museum of Modern Art, 677N.Y.S.2d 872 (N.Y. 1998), rev'd, 719 N.E.2d 897 (N.Y. 1999). See for an analysis of the case: Lufkin, M., 1999; Palmer, N., 2001, p. 482; Schnabel, G. / Tatzkow, M., 2007, pp. 392395.
} 
all objects that had been part of the trading stock of Goudstikker's art gallery and which had been integrated into the Netherlands Art Property Collection (Nederlands Kunstbezit (hereafter: NK-Collection)) after the war. It was not until 2006 that the paintings were finally returned to the heirs. ${ }^{767}$ In the meantime, the Dutch Government had adopted a liberalised return policy with regard to spoliated art works.

An important element that influenced the perception of national Governments and the general public was the Washington Conference on Holocaust-Era Assets (hereafter: "the 1998 Washington Conference"), which was organised in December 1998, one year after the London Conference on Nazi Gold, by the U.S. Holocaust Museum. ${ }^{768}$ The aim of the four-day conference was to "dismantle most if not all of the outstanding obstacles to a full-scale return of stolen art". ${ }^{769}$ The 1998 Washington Conference was attended by representatives of forty-four countries and more than a dozen interest groups and resulted in the adoption of a number of principles on the identification of art works that had been confiscated by the Nazis. The identification of art works as demanded by the Washington Principles would not have been feasible without certain technological prerequisites: computerised databases, as well as the Internet have made it easier if not possible in the first place to conduct research on the provenance of art works. ${ }^{770}$

While a number of representatives had understood the 1998 Washington Principles as final act of the renewed interest for Nazi spoliated art, they were only the first in a series of principles, resolutions and declarations to be adopted at the end of the 1990s and during the first decade of the new millennium. ${ }^{771}$ The fate of art spoliated during World War II raised and still raises great popular interest, not the least due to the flourishing of the art market until fall 2008 and the demand of the market for high quality art. ${ }^{772}$ Against this background the adoption of the 1998 Washington Principles marked the transition from the period in which awareness had been raised and

\footnotetext{
${ }^{767}$ See for a detailed chronology and analysis of the case below in chp. 4.\$1.I.3.b).

768 The four-day conference took place from November 30th- December 3rd 1998 and was co-hosted by the United States Department of State and the United States Holocaust Memorial Museum. The proceedings of the Washington Conference on Holocaust-Era Assets are available online at:

http://www.state.gov/www/regions/eur/wash_conf_material.html (last visited: 19 August 2008). See for a conference report: Rascher, A.F.G., 1999.

${ }^{769}$ Harclerode, P. / Brendan, P., 1999, p. 342.

770 Bailey, M., 2005, p. 56. A milestone in the development of current day databases was the 'relational database' as invented and described by Edgar Codd (Codd, E.F., 1970). The use of databases increased drastically during the 1990s, parallel with the computer and internet hype. E.g. the database of the Art Loss Register, the content of which was originally based on the art theft archive maintained by the International Foundation for Art Research (IFAR) since 1976, dates from 1991. Cf.:

http://www.artloss.com/content/history-and-business (last visited: 1.4.2009). In 1998 the Art Loss Register expanded the register with claims relating to the spoliation of art objects, and particularly those stolen from Nazi victims.

${ }^{771}$ Cf.: Schnabel, G. / Tatzkow, M., 2007, p. 139.

772 Weiss, L.J., 2007, p. 868. While the art market seemed less affected by the global financial crisis when it emerged in September 2008 auctions and fairs at the end of the year and beginning of 2009 indicated that the art market bubble has finally burst after having flourished for years.
} 
information on the looting and the international and national restitution regimes had been gathered to a period in which the composition of public collections were actively challenged. ${ }^{773}$

Before discussing the Washington Principles and other principles, resolutions and declarations more in detail in Chapter 2.\$1.III, we will shortly reflect upon the development against the background of public international law, more in specific the rights and obligations for restitution and return as extrapolated in Chapter 1.

\section{THE CASE OF NAZI SPOLIATED ART FROM THE LEGAL PERSPECTIVE}

\section{Public InTERnational LAW}

In Chapter 1 we have analysed in how far public international law is relevant for the return of cultural objects. The analysis distinguished between the following categories: the protection of cultural objects in times of war (2.1), the protection of cultural objects in time of peace $(2.2 \& 2.3)$; the return of cultural objects to private individuals (2.4), as well as to a people (2.5). Three of these five categories are relevant with regard to Nazi art looting: the restitution of cultural objects removed in times of war, the return of cultural objects to their original owners and finally, the return of cultural objects to a people.

The analysis revealed that by the outbreak of World War II in 1939 there existed a ban on the looting of cultural objects and an obligation to restitute spoliated cultural objects under treaty law as well as customary law. Furthermore, the analysis showed that the Western Allies undertook great efforts in restituting cultural objects: first, restitution sought to correspond to the reality of looting rather than limiting itself to the letter of the law. Restitution was not only effected for confiscated or stolen cultural objects but applied also to cultural objects that had been subject to other forms of removal, including e.g. forced sales. Also, restitution did not stay within the classical boundaries of restitution under public international as a matter in between states only but stretched the rules towards the introduction of rules dealing with restitution to private individuals as well as the Jewish people as a people.

In the second place, great relevance was accorded to physical restitution. When possible, cultural objects had to be restituted rather than the loss being financially compensated. The uniqueness of cultural objects was not only stressed by the emphasis put on its restitution but also by the renunciation of compensation in specie or restitution in kind. While this may seem paradoxical at first sight, the rejection of compensation in

\footnotetext{
773 Of course, not only public collections were affected but also private collections. See, e.g. the case in which the heirs of Margarete Mauthner sought the return of a painting by Van Gogh from the collection of Elizabeth Taylor; the case Gerda Dorothea de Weerth vs Edith Marks Baldinger or the case of the heirs of Carlotta Landsberg vs Marilynn Alsdorf. See for a short summary of the cases and a list of further cases: Schnabel, G. / Tatzkow, M., 2007.
} 
specie or restitution in kind is the only logical conclusion following from the uniqueness of cultural property. The Western Allies respected this uniqueness by choosing for compensation payments in those cases where cultural objects could not be physically returned for having being destroyed or lost.

Thirdly, the Western Allies not only arranged for the restitution of the cultural objects that had been misappropriated by the Nazis; they were also commited to restituting cultural objects that had been spoliated by their armed forces from German territory. In conclusion, the measures taken in the post-war era at the international level to arrive at restitution were remarkable and reveal great determination to reverse, in as far as possible, the Nazi art looting. In this respect the restitution measures positively mirror the abyss that was opened by the Nazi art looting and sent out positive signals for subsequent developments with regard to restitutions of cultural objects. In the light of the foregoing conclusion two questions arise: first, why are we presently witnessing so many claims?774 And secondly, in how far can claimants still rely on the regime as applicable more than half a century ago?

The first question is an apt illustration of the fact that the law as such is unable to lead to appropriate solutions: the mere fact of the existence of restitution rights did not result in the re-unification of a spoliated work of art with its former owner or his or her heirs: first, those who lost their lives during the Nazi regime could not seek restoration of their rights and potential successors in title were not always aware of the lost possessions. Secondly, where former owners or their heirs were able to seek restoration, physical restitution was often impossible for lack of knowledge of the whereabouts of an object. Where the whereabouts of an object were unknown or it was mistakenly believed to have been destroyed no physical restitution could have been affected. It is, however, possible that the former owner or heir received financial compensation. In other cases, restitutions could have been debarred by rules protecting good faith acquisitions. Another important factor preventing full restitution was the lapse of the terms of application for the filing of restitution claims. Furthermore, one must not forget that public international law first and foremost aims at the restitution of spoliated cultural objects to the state from whose territory the object had been removed. As a result, many cases of cultural objects spoliated in the occupied territories resulted in the objects' restitution, i.e. to the state of origin but did not result in the re-unification of the object with its former owner or his or her heirs. The latter aspect is a matter of national law. Where objects that have been restituted in the sense of restitution to their country of origin but were not returned by the national Governments to their former owners there is a significant chance that these objects have been introduced into the public

\footnotetext{
774 According to some figures more than $90 \%$ of the cultural objects that had been removed from the occupied territories had been returned to the state of origin by 1952. Cf.: Engstler, L., 1964, pp. 149-150; Hipp, A., 2000, p. 56, fn. 40.
} 
collections. ${ }^{775}$ However, objects that had been misappropriated under the Nazi regime also entered into public collections as acquisitions during or after the war, as well as donations.

With regard to the second question, as to whether the framework as developed and introduced under public international law still offers claimants a basis to make a claim the answer depends on the quality of the claimant: above, it has been stressed that the introduction of rights for private individuals under public international law for the restitution of (cultural) property removed under the Nazi regime qualifies as one of the most important changes in public international law over the past century. ${ }^{776}$ The restitution regime as introduced by the Western Allies in Law No. 59 on the 'Restitution of Identifiable Property 777 and as subsequently laid down in the Federal Restitution Law $(\mathrm{BRüG})^{778}$ was, however, limited in time. ${ }^{779}$ In fact, the period during which claimants had to file a claim was short: the deadline to file a claim with the Central Filing Agency under Law No. 59 was 14 August $1948 .{ }^{780}$ Under the BRüG legislation, which had entered into force in 1957, claims had to be filed within the period of a year until 1 April 1958. ${ }^{781}$ After that date private individuals were barred from seeking the restitution of their property.

Different from private individuals, states are not debarred by expired filing periods from seeking the restitution of cultural property. While the subject of prescription in international law is controversial ${ }^{782}$, the specialist literature tends to consider prescription with regard to the subject of restitution of cultural property inapplicable in the relations between States. ${ }^{783}$ Consequently, for those cases where the claimant is a state and the objects removed are still in the territory of the state that removed the objects in breach of international law it would still be possible, at least theoretically, for the state to seek restitution on the basis of public international treaty law and customary law. ${ }^{784}$

775 Cf.: Turner, M.I., 1999, p. 1522. See further on the Dutch and French national regimes with regard to the restitution of cultural objects below in chp. 4. \$1.I / III. See further on the restoration of rights in these two countries more in general: Veraart, W., 2005.

${ }^{776}$ Less, S., 2008.

777 British Military Government Law No. 59 on the "Restitution of Identifiable Property to Victims of Nazi Oppression', Control Commission for Germany. B.E. Law No. 59: "Restitution of Identifiable Property to Victims of Nazi Oppression', Military Government Gazette (British Zone of Control), No. 28.

778 Bundesrückerstattungsgesetz (BRüG) 19 July 1957, BGBl. I-734.

${ }^{779}$ Cf.: Blume Huttenlauch, A., 2006, p. 822.

${ }^{780}$ Kurtz, M.J., 2006, pp. 149-150.

${ }^{781}$ Cf.: Heuer, C.-H., 1999, p. 2562.

782 Gattini, A., 1996, p. 14.

783 Ibid; Schorlemer, S.v., 1998, p. 333. Cf.: Nahlik, S.E., 1967, p. 100.

784 See e.g. the restitution of some 140 drawings from the Koenigs collection by the Government of Ukraine in 2004 to the Netherlands. Fawkes, H., 20 April 2004. See on the German-Russian trophy art debate e.g.: Gattini, A., 1996. The principle that claims between states are not subject to prescription has been extended in the first protocol of the 1954 Hague Convention to apply to any object removed during armed conflict or occupation also where the object is subsequently located in a third country not having been a party to the conflict. 
However, due to the great efforts put into (external) restitutions by the Western Allies the majority of claims between states have been solved; the most prominent exception being the ongoing dispute between Germany and Russia on the so-called Trophy-Art. Consequently, most of today's claimants seeking the restitution of cultural objects lost during the Nazi regime are private individuals. With the time periods of the post-war restitution laws long having lapsed, the claimants can no longer rely on the special rules introduced under public international law but instead have to phrase their claim within the rules of private law. As the disputes concerning Degas' "Landscape with Smokestacks" and the Goudstikker collection, which have been shortly introduced above, indicate, the recovery under private law is significantly hampered by the significant period of time that has lapsed since the misappropriation or acquisition of the objects concerned. ${ }^{785}$ Time periods are relevant in view of good faith acquisition, prescriptive acquisition and extinctive prescription. In the following we will shortly summarise the applicable rules of Dutch, English and French law. The reason to reflect upon the national regimes at this point, rather than in one of the next two chapters dealing explicitly with the national dimensions, is that the principles to be discussed in Chapter 2.\$1.III take account of the difficulties if not impossibility for claimants to rely upon private national rules.

\section{A BRIEF EXCURSUS ON TIME LIMITATIONS APPLICABLE TO RECOVERY IN PRIVATE LAW}

\section{a) Dutch Law}

In Dutch private law the most important action for the recovery of a movable object is the action of revindication as laid down in Art. 5:2 Dutch Civil Code (hereinafter: DCC): "The owner of a thing is entitled to revindicate (recover) it from any person who holds it without right". The action of revindication is, however, subject to an extinctive prescription according to which the action is no longer available after a lapse of twenty years from the day that a different person from the right holder has taken possession of the property (Art. 3:306 DCC juncto Art. 3:314(2) DCC). The moment the original

\footnotetext{
785 See, e.g.: Kaye, L., M., 1997, p. 104; Palmer, N., 2000a, p. 74. It is sometimes argued that the looting of art works qualifies as crime against humanity (see, e.g. Lecture by Dr. A. Goepfert on "Art trade in works removed in times of wars; art trade in nationalized and expropriated works of art" held in Maastricht on 5 March 2008). The argument is interesting in that it is generally acknowledged that no limitation period exists for crimes against humanity (see, e.g.: Bazyler, M., 1999, p. 154). The term crimes against humanity was defined by the Principles of International Law Recognized in the Charter of the Nuremberg Tribunal and in the Judgment of the Tribunal, 1950. The Principles were adopted by the International Law Commission, acting under instructions from the United Nations General Assembly and set down the laws and procedures by which the Nuremberg trials were to be conducted. According to Prinicle VI (c) crimes against humanity are: "murder, extermination, enslavement, deportation and other inhuman acts done against any civilian population, or persecutions on political, racial or religious grounds, when such acts are done or such persecutions are carried on in execution of or in connexion with any crime against peace or any war crime". The looting of art works consequently does not qualify as crime against humanity.
} 
owner looses his right to recover his property the person in possession of the good will become the owner on the grounds of extinctive prescription of the revindication. Acquistion occurs "regardless of whether his possession was in good or bad faith" (Art. 3:105 DCC). ${ }^{786}$ Put differently, in the Netherlands even a person not acting in good faith can eventually the owner of a stolen object. Whether a thief himself can get full legal title as it is often claimed ${ }^{787}$ shall not be further addressed here as it is not relevant in the present context. ${ }^{788}$

Next to extinctive prescription, the owner may loose his title at an earlier point in time due to acquisitive prescription, as will be set out in the following:

The rules on transferring property are laid down in Book 3 of the Dutch Civil Code. The general rule on the transfer of property is provided by Art. 3:84 DCC and requires a "delivery pursuant to a valid title by the person who has the right to dispose of the property". There are hence three requirements that must be met for a valid transfer of property: delivery, valid title and the right to dispose of the object concerned. ${ }^{789}$ In case of stolen objects, and in accordance with the nemo dat rule, the third requirement, i.e. the right to dispose of an object, is not met. Consequently, according to the general rule, the property cannot be transferred.

The general rule on the transfer of property is, however, compromised by Art. 3:86 DCC, which holds a cure to the absence of the right to dispose of a property. According to this article, "a transfer (...) of a movable object (...) despite the alienator's lack of the right to dispose of the property is valid, provided that the transfer ${ }^{790}$ is not by gratuitous title and the acquirer acts in good faith". The requirement that the transfer must not be by gratuitous title does not mean that the acquirer has to pay full market value of the object to be transferred. As far as the requirement of good faith on behalf of the acquirer is concerned, the following aspects should be mentioned: the relevant moment that the acquirer must act in good faith is the moment he or she obtains possession of the object in question. While the Dutch Civil Code does not spell out what constitutes good faith, Art. 3:11 DCC sets out when an acquirer is considered not to act in good faith: "Where the good faith of a person is required to give legal effect to something,

\footnotetext{
786 Under the old Dutch Civil Code, extinctive prescription, i.e. the barring of the original owner's legal action for recovery was not linked with a provision granting the property to the person possessing it the moment the limitation period had lapsed. The consequence of a legal vacuum in which no one could subsequently acquire full legal title of the object was considered undesirable and hence changed with the introduction of the new Dutch Civil Code. Cf.: Klomp, R.J.Q., 2000, p. 61. Yet another interesting change concerned the length of the extinctive prescription period. Under the old Dutch Civil Code (Art. 2004) the legal action to recovery was barred after the lapse of thirty years from the moment of involuntary loss of the possession.

787 See, e.g.: Brunner, C.J.H., 1992, p. 53.

788 See further on the discussion: Jansen, J.E., 2005; Salomons, A.F., 2005; Schaik, A.C.v., 2005; Schaik, A.C.v., 2005.

${ }^{789}$ In case of movable property, delivery is generally achieved by giving the acquirer physical possession of the object. A title must be understood as the legal relationship between the alienator and acquirer that justifies a transfer. The most common title being sale.

790 The transfer must be in accordance with Artt. 3:90, 3:91 or 3:93 DCC.
} 
such person does not act in good faith if he or she knew, or ought to have known given circumstances, of the facts or the law to which is good faith must relate (...)".791 According to Art. 3:11 DCC an acquirer is presumed to have acted in good faith. The burden of proof to show that someone did not act in good faith rests upon the party seeking revindication (Art. 150 of the Civil Procedure Code). ${ }^{792}$ In case the acquirer did act in good faith and gave some form of remuneration, he or she acquires property despite the alienator's missing right to dispose of it. Consequently, the original owner can no longer recover the property. ${ }^{793}$

The cure offered by Art. 3:86 DCC against the absence of the right to dispose of a property, does not as such apply to cases where the original owner lost his possession of the object involuntarily, e.g. due to theft. In case of stolen objects, the original owner is granted a period of three years to recover his object as held by Art. 3:86(3) DCC: “(...) the owner of a moveable object, who has lost his possession though theft, may revindicate it as his property during a period of three years from the day of the theft". However, this exception to the exception knows yet another exception that allows immediate transfer of property even of stolen objects. The following requirements, as outlined in Art. 3:86(3)(a), must be met for a third purchaser to acquire property of a stolen object: the acquirer must be a natural person not acting in the exercise of a profession or business. The alienator, on the other hand, must be acting in the normal course of his business and must do so in his business premises. If these requirements, further to the requirements of non-gratuitous title and good faith on behalf of the acquirer are fulfilled, property, even of stolen objects, is directly transferred. In such instance, the original owner cannot recover the property.

As a consequence of the provisions on extinctive and acquisitive protection under the Dutch Civil Code claimants seeking the recovery of cultural objects spoliated under the Nazi regime will not have a leg to stand on in most cases to which Dutch law is applicable. ${ }^{794}$

\footnotetext{
791 Art. 3:11 DCC.

${ }^{792}$ In Dutch: Wetboek Burgerlijke rechtsvordering (Rv).

793 The possibility that the original owner might address the alienator for indemnity should be mentioned here but will not be further elaborated upon given the report's preoccupation with the protection of the cultural object itself rather than indemnity.

${ }^{794}$ HR 8 May 1998, 1st Chamber, Nos. 16.546, C97/025; NJ 1999, No.44, annotated by Th. M. de Boer. In a case before the Dutch Supreme Court (Hoge Raad) between the German Land Saxony, as the successor in rights of the former owner and a private individual who had acquired a painting in 1990 in Amsterdam, the Court stressed the relevance of extinctive limitation periods in the light of legal certainty. The Court stated that the fact that the original owner lost his action to recover his painting before he or she was even able to make use of the action (i.e. before he or she learnt about the painting's location) could not outweigh the need for legal certainty in judicial matters. See further for an analysis and discussion of the case: Blom, J., 2000 .
} 
b) English / Common Law

Different from the French and Dutch jurisdictions characterised by the civil law understanding of the recovery of tangible movable property as rei vindicatio, the English legal system, as a system characterised by common law, provides for a claim in tort. ${ }^{795}$ Under common law, the normal cause of action available for claimants seeking the return of an object is a claim for the tort of conversion. Conversion was defined by Atkin J. in the case Lancashire and Yorkshire Railway Company v MacNicoll as:

“(...) dealing with goods in a manner inconsistent with the rights of the true owner (...) provided (...) there is an intention on the part of the defendant in so doing to deny the owner's right or to assert a right which is inconsistent with the owner's right". ${ }^{796}$

A claim for the tort of conversion can be grounded on possession at the time of the wrongful act or the immediate right to possession at that time. In order to prove his or her immediate right to possession a claimant has to prove original title to the object concerned. Given the long lapse of time and the circumstances of loss many claimants are not able to produce the required documentation in the form of e.g. receipt of purchase or insurance records. Where claimants succeed in proving original title and there exists no doubts as to the identity of the object, the original title to the Paining is unimpeachable.

Conversion is a strict liability tort. Hence, a current possessor, whether a private person or a public institution, cannot argue that he/she or it acted in good faith when accepting the object. There exist, however, two defences a present holder can raise to resist a claim: the present holder either has to prove that the claimant has lost good title in the mean time, and with it the right to immediate possession, or that the limitation period to sue for conversion has lapsed.

The question whether the claimant lost good title, or whether anybody acquired better title depends on the circumstances of each individual case. Where an object has been the subject of a chain of transactions prior to the acquisition by the present holder, especially where such transactions are governed by a civil law country, the original legal title may have been invalidated. Depending on the jurisdiction where a transition took place the bona fide purchaser acquires ownership immediately ${ }^{797}$ or after the lapse of a certain amount of years. ${ }^{798}$ In those cases where the original title is not invalided, claimants may nevertheless have lost their right to immediate possession, depending on the question whether the limitation period to sue for conversion has lapsed.

Under the Limitation Act 1939, which is the relevant act for cases dealing with works of art spoliated during WWII, an owner's right to sue and his title extinguishes six years

\footnotetext{
795 Cf.: Siehr, K., 2001, p. 53.

796 Lancashire and Yorkshire Ry v MacNicholl, (1919) 88 L.J.K.B. 601, para. 605.

797 See, e.g. Artt. 1153 f. of the Italian Codice Civile. The consequence of this extremely liberal attitude are well-illustrated in the infamous case Winkworth v. Christie, Manson \& Woods Ltd., [1980] 1 All ER 1121.

798 Cf.: the Dutch and French system.
} 
after the misappropriation. Different from the Limitation Act 1980, this is also the case against a thief. Consequently, all original titles with regard to Nazi spoliated art have long lapsed. This does not mean that current possessors required good legal title: under the Limitation Act 1939 the lapse of the limitation period merely extinguishes the original title without giving new title. However, this leaves unchanged the fact that claimants no longer have a valid legal claim to spoliated artworks as any claim is statutebarred under the applicable English law.

\section{c) French Law}

The general starting point for the assessment of the possibility to recover (cultural) property under French law is Art. 2279 of the French Civil Code. ${ }^{799}$ According to the article the owner of a lost or stolen good is granted a period of three-years within which he has to reclaim the good: "Celui qui a perdu ou auquel il a été volé une chose peut la revendiquer pendant trois ans, a compter du jour de la perte ou du vol, contre celui dans les mains duquel il la trouve". 800 Where the current possessor is considered to be in good faith, the owner seeking recovery has to refund the former the purchase price..$^{801}$ The current possessor is profiting from the presumption of good faith as provided for in Art. 2279: "En fait de meubles, la possession vaut titre".

The lapse of the limitation period, which starts to run at the moment of loss, is fatal against a good faith possessor. Against a possessor not being considered of having acquired the object in good faith, revindication is possible until thirty years after the date of loss or theft. Art. 2262 Code Civile bars all claims after the lapse of thirty years: "Toutes les actions, tant réelles que personnelles, sont prescrites par trente ans, sans que celui qui allègue cette prescription soit obligé d'en rapporter un titre ou qu'on puisse lui opposer l'exception déduite de la mauvaise foi". Consequently, similar to the Dutch situation, claimants seeking the recovery of cultural objects spoliated under the Nazi regime can no longer enforce their claim in a case where French law is the applicable law.

\section{d) Intermediary conclusions}

In conclusion, not only can private parties seeking recovery of cultural objects misappropriated under Nazi reign no longer rely upon rules under public international law, they will also be debarred from recovery under national law. This is true not only for civil law countries, which accord great relevance to the protection of good faith purchases, but also for English law as a common law jurisdiction. The analysis of English law and the Limitation Act 1939 showed that the principle of nemo dat is less absolute than often argued.

\footnotetext{
${ }^{799}$ Cf.: Cornu, M., 2008.

800 Redmond-Cooper, R., 1996, pp. 11-12.

801 Art. 2280 French Civil Code.
} 
While the coincidence of different legal systems sometimes allows for a successful claim in court ${ }^{802}$ and there exist jurisdictions outside of the scope of the present study where a claim for the return of spoliated art works may still be successful ${ }^{803}$, litigation is generally considered as flawed medium for resolving claims concerning spoliated works of art. ${ }^{804}$ Given the complexity of the cases, due to the variety of jurisdictions often involved and the passage of time ${ }^{805}$, litigation is a time-intensive and costly solution. ${ }^{806}$ In the following, we will adress the solutions proposed by the principles, resolutions and declarations adopted since the end of the 1990s.

\section{RECENT DEVELOPMENTS: PRINCIPLES, RESOLUTIONS AND DECLARATIONS ADOPTED BY THE INTERNATIONAL COMMUNITY IN REACTION TO THE RE- EMERGENCE OF THE DEBATE ON NAZI SPOLIATED ART}

In this section, the principles, declarations and resolution that have been adopted by different international fora and organisations with regard to the restitution of spoliated cultural objects some fifty years after the end of World War II will be discussed. When the debate on Nazi spoliated art re-emerged in the 1990s the post-war restitution laws as outlined in Chapter 1. $\$ 1 . \mathrm{V} / \$ 4$ had long expired. Consequently, the international community adopted a number of new instruments that will be analysed in the following. Particular attention will be paid to the question whether the instruments introduce new legally enforceable rights and duties with regard to the return of Nazi spoliated art. The creation of new rights in the form of treaties or customary rules is still reserved to states, regardless of the fact that individuals and other none-state actors have gained a certain level of international legal personality since World War II. ${ }^{807}$

A second point of attention is the relevance the various instruments accord to financial compensation that might have been received by the original owners or their heirs in the immediate post-war era. This aspect is interesting given the findings of the analysis of the post war restitution regime in Chapter Chapter 1. $\$ 1 . \mathrm{V} / \$ 4$ with regard to the principles that guided the Allied and German external and internal restitution regime during the post-war years. The analysis revealed that where physical restitution was not

\footnotetext{
802 See, e.g. the case of City of Gotha and Federal Republic of Germany v. Sotheby's and Cobert Finance S.A..

803 See, e.g.: Solomon R. Guggenheim Found. v. Lubell, 569 N.E.2d 42, 431 (N.Y.1991) where the New York Court of Appeals held that the statute of limitations begins to run when the plaintiff demands the return of her artwork, regardless of how many years have passed or whether the plaintiff has been diligent in seeking her property. While the case was not about Nazi spoliated art but about normal theft the findings are nevertheless relevant for Nazi spoliated art cases. Cf.: Kaye, L., M., 1996b, p. 35; Kennon, H., 1996, p. 374; Lowenthal, C., 1996, p. 10.

${ }^{804}$ Cf.: Palmer, N., 2000a, p. 49.

805 Weil, S., 1999 , p. 290.

806 Cf.: Lerner, R., E., 1998, p. 36. E.g. in an American case it took the court eight years to clarify the issues dealing with the statue of limitation (Kunstsammlungen zu Weimar v. Elicofon, 536F.Supp.829 (E.D.N.Y. 1981), aff d, 678 F2d 1150 (2d Cir. 1982)). Cf.: Kaye, L., M., 1997, p. 104.

807 Cf.: Malanczuk, P. / Akehurst, M.B., 1997, pp. 103-104; Dixon, M., 2007, pp. 3 \& 20.
} 
an available option for the cultural object either being destroyed or lost, financial compensation was paid. Compensation for lost property was calculated according to the estimated replacement value at the time the compensation was granted. ${ }^{808}$ While it would be naïve to assume that compensation has been paid in each case where physical restitution was unavailable, the findings of Chapter $1 . \$ 1 . \mathrm{V} / \$ 4$ nevertheless suggest the aspect of financial compensations already received will be a factor in current dicucssions of what constitutes just and fair solutions. The analysis of the instruments will be structured according to chronological order. 809

\section{The 1998 Washington Principles on NaZi-Confiscated ART}

As stipulated already above the "Washington Conference Principles on NaziConfiscated Art" (hereinafter: the 1998 Washington Principles) were adopted by the delegates to the 1998 Washington Conference on Holocaust-Era Assets (hereafter: "the 1998 Washington Conference"). ${ }^{810}$ The eleven-point statement was based on draft principles that had been prepared by the American delegation, which on their part were based on a report and guidelines on the spoliation of art during the Nazi / World War II Era (1933-45) of a task force of the American Association of Art Museum Directors (AAMD). ${ }^{811}$ The principal aim of the 1998 Washington Conference for the American Delegation was to internationalize these principles. ${ }^{812}$

A reading of the principles shows, that the 1998 Washington Principles quintessentially boil down to two principles: works of art that had been confiscated by the Nazis and have not yet been restituted should be identified (Principle I) and secondly, claims should be solved in a "just and fair" manner (Principles VIII and IX). While the call for the "identification of works of art that had been confiscated by the Nazis and that have not yet been restituted" might seem clear at first sight, it contains a number of ambiguities. As far as the designation "works of art" is concerned, the 1998 Washington Principles do not define the term, nor did the drafters choose to describe what qualifies as works of art by adding an enumeration of examples. ${ }^{813}$ This omission

\footnotetext{
808 According to the BRüG, which was in particular relevant for those claims dealing with property that no longer existed or which had disappeared from either within or outside the German territory compensation for lost property was calculated according to the estimated replacement value as of April 1, 1956. See further on the BRüG above in chp. 1§4.IV.

809 Any attempt to bring developments within various fora in a chronological order is to some extend forced. Instruments have been ordered according to their date of adoption.

810 Washington Conference on Holocaust-Era Assets, 1998.

811 The task force had been convened in response to the seizure of the Schiele paintings from the Moma exhibition in 1998. See: Eizenstat, S.E., 2003, p. 193. See further: Rascher, A.F.G., 1999, p. 338. See also: Garner, B., A., 2004, p. 319.

812 Eizenstat, S.E., 2003, p. 193.

813 Legislators have found different ways to deal with the challenge of defining a "work of art". There is general agreement that "art" cannot be defined. A technique frequently employed is to combine a general but not conclusive definition with an enumeration of works that fall under that definition. This double approach, with both parts qualifying one another foresees both in the philosophical impossibility to define
} 
is, however, of little relevance as there are hardly any cases in which the question as to whether or not an object qualifies as a work of art proved problematic. ${ }^{814}$ With regard to the explicit reference to "Nazi-confiscated art", rather than "spoliated art" it might be interesting to learn that it was an accommodation to the Russian Federal Republic in the light of the discussions on the "Soviet Trophy Art". While a number of countries favoured a broader application of the principles to all spoliated artworks, their application was limited to "Nazi-confiscated art" to allow for the unanimous adoption of the principles. ${ }^{815}$

The principle of identification is elaborated by practical guidelines in Principles II IV: principle II stresses the necessity to make the relevant records and archives accessible to the public, while principle III acknowledges that the identification of Naziconfiscated works of art on the envisaged scale can only be achieved through the assignment of man-power and resources to this work. Principle IV takes account of the unavoidable gaps or ambiguities in the provenance of an object in light of the lapse of time and the circumstances of the 1933-1945 period. It stipulates that in case of doubt one should give credit to the original owner. Once a work of art has been identified as having been confiscated by the Nazis, Principles V and VI become relevant: principle V states that the original owners or their heirs should be identified. This task would profit from the introduction of central registry of the works having been identified as Naziconfiscated, as stipulated by Principle VI.

Principles VII-IX deal with claims that will result from the localisation of the original owners. While the 1998 Washington Principles aim primarily at the identification of the works that have not been restituted, they imply, prepare, and facilitate the subsequent stage of restitution, as the identification of works of art with a problematic provenance necessarily leads to the question of what to do with them. ${ }^{816}$ Principle VII encourages claims by former owners.

Principles VIII and IX stipulate that claims should be solved in a "just and fair" manner. The principles do not, however, further reflect on what just and fair solutions mean but the drafting history suggests that just and fair solutions were understood as a

art, and the practical necessity to differ between those goods that qualify as art and those that do not, i.e. which goods will generate a royalty levy, e.g. droit de suite, which object will grant the owner a tax reduction or which objects should not be exported. The fact that no definition is included in the 1998 Washington Principles is but another indicator for the fact that it is not a binding instrument.

814 Where there exists legal disputes as to the artistic character of a work these generally concern contemporary art works (See e.g. case Brancusi v. United States, 54 Treas. Dec. 428 (Cust. Ct. 1928). Given the lapse of half a decade since World War II this problem does no longer apply to Nazi spoliated art.

815 Countries such as Germany, the Netherlands and France with an interest of recovering cultural objects from the territory of the Russian Federation had favoured a broad application of the 1998 Washington Principles to all spoliated objects.

816 Rascher, A.F.G., 1999, p. 339. 
broad, multi-faceted category, with physical restitution being only one option amongst several others. ${ }^{817}$

Principles X and XI make suggestions as to how "just and fair" solutions can be achieved: through the establishment of commissions or other bodies with a balanced membership that will help in the identification of the confiscated works of art, and, more important here, resolve the dispute on ownership (Principle X). As far as this last aspect is concerned, i.e. the resolving of ownership issues, Principle XI puts specific emphasis on the introduction of alternative dispute resolution mechanisms. It also appeals to the countries that attended the conference to take the necessary measures to implement the set of principles on the national scale. The Washington Principles do not address the possibility (and the relevance of) financial compensation payments that might have been received for a work of art. Given its aim to find "just and fair" solutions which were understood as a broad, multi-faceted category, with physical restitution being only one option amongst several others ${ }^{818}$ it can be assumed that the question of any compensation payments received would be addressed in the determination of the "just and fair" solution in a specific case.

The circle of addressees profiting respectively having to take action is not further defined by the 1998 Washington Principles. With regard to the former owners of art works, the wording of the 1998 Washington Principles clarifies that it applies to any Nazi confiscated works of art. Consequently, any former owner (or heir) regardless of his or her racial background profits from the Washington Principles. With regard to the party that is demanded to act, these are first and foremost the countries that supported the 1998 Washington Principles. The participating countries were wary to create any binding obligations. The plan of the American Delegation to "draft binding obligations under international law" was abandoned at an early stage of the preparatory phase" 819 and consensus was reached only after including an explicit statement in the preamble reiterating the principles' non-bindingness and recognizing the differences in legal systems and that the individual states can only act within the context of its own laws. ${ }^{820}$

\section{Council of Europe Resolution 1205 (1999) on Spoliated Jewish CULTURAL PROPERTY}

After the 1998 Washington Principles had been adopted by an ad-hoc group of attendees to the 1998 Washington Conference, including national representatives and

\footnotetext{
817 As will be shown below in chp. 4.\$1, "just and fair" solutions would be interpreted more and more in the sense of physical restitution at the conferences and symposia following the 1998 Washington Conference. 818 As will be shown below, "just and fair" solutions would be interpreted more and more in the sense of physical restitution at the conferences and symposia following the 1998 Washington Conference.

${ }^{819}$ Rascher, A.F.G., 1999, p. 341.

820 The compromise was suggested by the Swiss delegation. See: Zingeris, E.R., 1999. The preamble reads as follows: "In developing a consensus on non-binding principles to assist resolving issues relating to Naziconfiscated art, the Conference recognizes that among participating nations there are differing legal systems and that countries act within the context of their own laws".
} 
interest groups, the momentum reached institutionalised fora dealing more in general with culture and the protection of cultural objects. One of these fora is the Council of Europe. ${ }^{821}$

On $5^{\text {th }}$ November 1999, the Parliamentary Assembly of the Council of Europe unanimously adopted Resolution 1205 on Spoliated Jewish Cultural Property (hereinafter: "Resolution 1205").822 As far as the general aim of Resolution 1205 is concerned, it aims at changing the national legal frameworks applicable to the identification and restitution of cultural property. According to Resolution 1205, provisions that are obstructing and / or preventing the identification and restitution must be abolished or amended.

With regards to the claimant group, Resolution 1205 explicitly limits itself to "Jewish property", in the sense of cultural objects that have been spoliated from Jews or Jewish organisations. ${ }^{823}$ While the Committee on Culture and Education of the Parliamentary Assembly acknowledged that there is "reason to attempt to locate and return all cultural property seized by the Nazis" and that "[i]f the Jews were deliberately targeted so too were the Gypsies-Roma and homosexuals" 824 it nevertheless chose to limit the scope of application to Jewish cultural property for two reasons: first, the limitation to Jewish cultural property would allow for a clearer focus". ${ }^{825}$ Secondly, the restitution of Jewish cultural heritage would contribute to the restoration of Jewish culture in Europe ${ }^{826}$, which is an aim that was pursued by the Council of Europe already prior to the (re-) emergence of the restitution debate. ${ }^{827}$

While Resolution 1205 is more limited in application than the 1998 Washington Principles by dealing only with cultural property formerly in Jewish possession, it is broader with regard to the circumstances of loss. Rather than being limited to Naziconfiscated objects, Resolution 1205 applies to all "spoliated" cultural objects, including forced sales. ${ }^{828}$ Different from the 1998 Washington Principles that called for the

821 The Council had been called upon by the attendees of a the international symposium on "Legal Aspects of Restitution of Cultural Values: Theory and Practice" organised by the National Commission of the Restitution of Cultural Treasures to Ukraine organized in Kiev in December 1996 to keep on taking efforts for further updating international legal norms in the sphere of protection, repatriation, restitution of cultural treasures. Cf.: Lust, J., 1996.

822 Resolution 1205 had been prepared by the Committee on Culture, Science and Education of the Parliamentary Assembly. On 19 April 1999, hearings were held in Paris. On 24 September 1999, the Committee adopted a draft version, which was sent to the full Assembly. See further on the process of adoption: O'Keefe, P., 1999a.

${ }^{823}$ Zingeris, E.R., 1999 , p. 10 at para. 47.

824 Ibid., p. 10 at para. 48.

825 See: Ibid., p. 10 at para. 49.

${ }^{826}$ See: O'Keefe, P., 1999 a, p. 314.

827 See for earlier instruments adopted by the Council of Europe: Resolution 885 (1987) and Recommendation 1291 (1996).

828 See: O'Keefe, P., 1999a, p. 314. One noteworthy aspect about Resolution 1205 is the fact that it declares the expropriation and nationalisation of cultural property by communist regimes and in countries occupied by the Soviet Union illegal ( $(3)$. Squared with the effort of the Russian delegates to the Washington Conference to get rid of the reference to "spoliated" works of art, which was feared to invoke the illegality 
identification of confiscated artworks and for just and fair solutions, Resolution 1205 explicitly calls for physical restitution of spoliated cultural property ( $\left.\int 8\right) .829$ If restitution to the (heirs of) former owners is not possible for reason of death, restitution is to be made towards the country where the item was located before the war. Paragraph 8 proved to be controversial as some Jewish organisations would have preferred the objects to be given to Israel rather than being returned to the countries of origin. ${ }^{830}$ The emphasis on restitution stricto sensu must be understood in the light of the resolution's general aim to enable "the reconstitution of the place of Jewish culture in Europe itself". This is a motive both wider and narrower at the same time than to "right the wrongs which were done many years ago". 831 What paragraph 8 does not take into consideration is the fact that restitution to original owners or their heirs would not necessarily lead to the reconstitution of Jewish culture in Europe. After all, many Jewish families have emigrated to the United States or Israel. ${ }^{832}$

Where physical restitution is not possible - in the case that a work has been destroyed, damaged or is untraceable, Resolution 1205 calls for financial compensation at full market value $(\$ 12)$. While Resolution 1205 itself takes to financial compensations and recognises the restitution efforts during the post war era $(\$ 4)$ it does not explicate whether it applies also to cultural property whose original owners or their heirs did receive (full) financial compensation during the post-war years. ${ }^{833}$

The emphasis on physical restitution as introduced in paragraph 8 is further elaborated upon by paragraphs 10,13 and 15. Together, these paragraphs form the core of Resolution 1205. They seek for legislative changes within the Member States to facilitate the return of Nazi spoliated art. Paragraph 10 appeals to the national

of the Soviet Trophy Art, this aspect deserves to be mentioned here, regardless of the fact that the Soviet Trophy Art discussion is not further dealt with. The inclusion of such a reference is astounding given that Russia had become a Member of the Council of Europe in 1996. The report prepared by the Committee on Culture and Education in the process of the adoption of Resolution 1205 states: "An enormous amount has been written on the Holocaust and on the looting of Jewish cultural property by the Nazis. Less has been written on the confiscation of Jewish cultural property by the communists". Zingeris, E.R., 1999, p. 5 at para. 11. Also, it is stated: "A special chapter is needed to shed light on the looting and expropriation of Jewish cultural heritage by communist regimes and in particular in the Baltic countries under Soviet occupation". O'Keefe, P., 1999 a, p. 314.

${ }^{829}$ Para 8 of Resolution 1205 reads: "The Assembly believes that restitution to original owners or their heirs (individuals, institutions or communities) or countries is a significant way of enabling the reconstitution of the place of Jewish culture in Europe".

830 Zingeris, E.R., 1999, para. 38. See for the ensuing discussion of whether Jewish religious object should be returned to Europe: Lipman, R., 2006. See in this respect Art. 10 of Military Government Regulation No. 59 on the Restitution of Identifiable Property discussed in chp. 1\$5. According to the provision unclaimed estate of persecuted persons were to be granted to Jewish successor organisations rather than falling to the German State.

831 O'Keefe, P., 2001, p. 128.

832 This has been acknowledged in the report prepared Reporter Zingeris. See: Zingeris, E.R., 1999, p. 9 at para. 43.

833 Para. 4 of Resolution 1205 reads: "Though early moves were made following the end of the second world war to find and return this spoliated property, a very considerable amount has not been recovered and has remained in private and public hands". 
parliaments to "give immediate consideration to ways in which they may be able to facilitate the return of spoliated Jewish cultural property". Given the fact that the Parliamentary Assembly of the Council of Europe cannot adopt any legally binding instruments, the legal impetus of its recommendations and resolutions depend on further action taken by either the Committee of Ministers or the Member States themselves. ${ }^{834}$ Given the fact that the Committee of Ministers did not act upon the views of the Parliamentary Assembly as laid down in the nineteen paragraphs of Resolution 1205 the national reactions that will be addressed in Chapter 4 ( $(\mathbb{1})$ are even more important.

The legislative changes to be considered by the national parliaments are listed in paragraph 13: the extension or removal of statutory limitation periods, the removal of restrictions on alienability, the provision of immunity from action for breach of duty on the part of those responsible for collections, the waiving of export controls. By suggesting legislative changes of statutory limitation periods, paragraph 13 touches upon one of the main problems encountered by (heirs of) former owner claiming their cultural objects. Sixty years after the end of the Second World War any post-war national legislation has long-since lapsed. ${ }^{835}$ Often, objects have passed through a number of hands, and in many cases these transactions involved different legal systems. ${ }^{836}$ A related problem experienced by (the heirs of) former owners are bona fide acquisitions. Resolution 1205 not only seeks for the extension or removal of limitation periods, it also indirectly recommends the cancellation of a good faith owner's title: Paragraph 15 (sub c) stipulates that consideration should be given to "annulling later acquired titles, that is, subsequent to the divestment". 837 While the Resolution 1205 puts strong emphasis on the suggested changes in national law, it also follows the Washington Principles in recommending the "exploration and evolution of out of court forms of dispute resolution such as mediation and expert determination" ( $(16)$. The call for further research was completed by a plea "for the organisation of a European conference, further to that held in Washington on the Holocaust-era assets, with special referents to the return of cultural property and the relevant legislative reform" ( $(19)$.

\footnotetext{
${ }^{834}$ See further on the role of the Parliamentary Assembly and the Committee of Ministers: Robertson, A.H., 1961, Benoit-Rohmer, F. / Klebes, H., 2005, p. 48. See on the influence of the Parliamentary Assembly on the adoption of treaties: König, H., 2006, p. 378.

835 An exception under certain conditions is the French decree of 21st April 1945. See: Redmond-Cooper, R., 1999.

836 See for general overview on time limits in art and antiquity claims under English law: Redmond-Cooper, R., 2000, and Giovannini, T., 2002, p. 271.

837 See: Choi, S., 2005, fn 221, O'Keefe, P., 2002, p. 264. See for an international treaty that does introduce an absolute obligation to return cultural property that is neither subject to any prescription, nor recedes from any rights that might have been acquired by a bona fide purchaser: (First) Protocol for the Protection of Cultural Property in the Event of Armed Conflict 1954. The relevant provision is Art. I 3. The protocol is discussed in chp. 1.\$1.VI.2.
} 


\section{The Vilnius international Forum on Holocaust-ERa SPOLIated Cultural Assets, 2000}

The International Forum on Holocaust Era Spoliated Cultural Assets, held in Vilnius in 2000, took place under the auspices of the Council of Europe as a follow-up to the 1998 Washington Conference, and in response to Resolution 1205 of the Council of Europe.

Paragraph 19 of Resolution 1205 called for the "organisation of a European conference, further to that held in Washington on the Holocaust-era assets, with special reference to the return of cultural property and the relevant legislative reform". While the proposed legislative reform loomed large in the draft declaration that formed the basis for discussion ${ }^{838}$ the explicit call for legal changes had been dropped in the final Vilnius Forum Declaration (hereinafter: “the Vilnius Declaration”).

Paragraph 1 of the Vilnius Declaration asks Governments to "undertake every reasonable effort to achieve the restitution of cultural assets spoliated during the Holocaust era to the original owners or their heirs (...) and encourages all participating states to take all reasonable measures to implement the Washington Principles (...) as well as Resolution 1205 (...)". The scope ratione materiae of the Vilnius Declaration is broad by applying to all "spoliated cultural assets". ${ }^{839}$ With regard to the application ratione temporis, the Vilnius Declaration remains vague by referring to the "Holocaust era". In particular, the reference does not clearly state whether it also applies to Jewish property taken prior to 1939, i.e. from Jewish citizens within the borders of Germany. 840 While the Vilnius Declaration clearly emphasizes Jewish losses, its preamble suggests that it also applies to "art and objects owned by others", where the reference to "others" only makes sense when read as referring to non-Jewish owners.

If one compares the mandate of the Vilnius Conference - the seeking of legal reforms - with the declaration as finally adopted, the conference must be considered a failure $^{841}$ : the final declaration does not appeal to countries to change their national legal systems but instead "welcomes the process being made by countries to take the

\footnotetext{
838 The draft resolution appealed to countries to "move towards changes in their legal systems that may be necessary to assist in the commitment to restitution and to work towards the creation of a future Convention”. See further: O'Keefe, P., 2002, p. 265.

${ }^{839}$ It is, however, unclear why preference has been given to the term "cultural assets" - which has been criticised as "ill-named" O'Keefe, P., 2001, p. 128. A reason could be the original name of the 1998 Washington Conference on Holocaust Era Assets and the Principles of Nazi-Confiscated Art.

840 Since the 1950s, when speaking of "the Holocaust", historians generally refer to the mass murder of the Jews by the Nazis during the war-years 1939-1945. Simpson, J.A. / Weiner, E.S.C., 1989, p. 315. Without the determiner "the", the term "Holocaust" denotes the destruction or slaughter on a mass scale. See: The Concise Oxford English Dictionary, 2004. See further on the history of the word 'holocaust' and the phrase 'the Holocaust': Herman, D., 2008. As to whether "the Holocaust" refers to Jewish victims only, or to all groups targeted by the Nazis, or to some subset of those groups is debated. While there exists general agreement that other groups, such as homosexuals or Gypsies were targeted by the National Socialist Party not all scholars consider them as victims of the Holocaust. Niewyk, D.L., 2000, p. 45.

${ }^{841}$ See, e.g.: O'Keefe, P., 2001, p. 129.
} 
measures necessary, within the context of their own laws, to assist in the identification and restitution" ( $(\mathbb{S} 6) .842$ The appeal to make legal changes was abandoned during the negotiations as countries attending the forum were not prepared to make any commitments to change their national legal systems, nor were they prepared to discuss suggestions on legal amendments. ${ }^{843}$ Furthermore, the final Vilnius Declaration had dropped the proposal to prepare an international convention on the legal aspects of the return. ${ }^{844}$ Neither did the delegates want to agree on the foundation of the proposed "institutionalised watchdog" that would monitor the implementation of the 1998 Washington Principles, Resolution 1205, and the Vilnius Declaration throughout Europe. 845 Instead of the introduction of such a 'Task Force on Holocaust Era Spoliated Assets' paragraph 5 of the final Vilnius Declaration suggests the organisation of periodical international expert meetings to "exchange views and experiences on the implementation (...) and to serve to address outstanding issues and problems". ${ }^{846}$ The last sentence of paragraph 5 , which stresses that solutions should be found within the existing legal systems rather than changing them is yet another indication of the unwillingness to make legal changes within national systems. ${ }^{847}$

In sum, the Vilnius Declaration did not introduce new principles to the restitution debate nor did it advance the legal reform introduced by Resolution 1205. Rather, as expressed by its first paragraph, the relevance of the Vilnius Declaration comes down to an encouragement of national Governments to "take all reasonable measures to implement the Washington Principles (...) as well as Resolution 1205 (...)" without even ironing out any ambiguities of the two earlier instruments. Like the Washington Principles and Resolution 1205 the Vilnius Declaration does not explicate whether it applies to all objects that had been spoliated or whether it excludes those objects whose loss was financially compensated during the post war era.

\section{RESOLUTIONS ADOPTED BY THE EUROPEAN PARLIAMENT}

At European Community level, a total of three resolutions have been adopted by the European Parliament that are relevant for the issue of Nazi spoliated cultural goods. ${ }^{848}$

\footnotetext{
842 O'Keefe, P., 2002, p. 265.

843 O'Keefe, P., 2001, p. 131.

${ }^{844}$ Ibid., p. 130.

845 Ibid.

846 See: Ibid.

847 The last sentence of para. 5 reads: "[t]hese [periodical international expert, K.L.] meetings should also serve to address outstanding issues and problems and develop, for governments to consider, possible remedies within the framework of existing national and international structures and instruments" (Emphasis added).

848 Council Directive 93/7/EEC of 15 March 1993 on the return of cultural objects unlawfully removed from the territory of a Member State does not apply with regard to Nazi spoliated art but for very exceptional cases where a cultural object in the sense of the Directive that has been unlawfully removed after 1 January 1993 happens to be Nazi spoliated art. See further on the Directive in chp. 1.\$2.VI.
} 
The first resolution was adopted in 1995 and dealt with the return of plundered property to Jewish communities. ${ }^{849}$ The resolution did not deal with spoliated cultural objects but with property in general and must be placed in the context of the transition of former communist states after the fall of the Iron Curtain. By its self-initiated resolution the European Parliament lauded the willingness of a number of Central and Eastern European states - which at that point in time had not yet become Member States - to return property of Jewish Communities. ${ }^{850}$ The Parliament furthermore called upon Central and Eastern European Countries to adopt appropriate legislation regarding the return of plundered property from Jewish communities, as well as for the return of other property plundered by the Communists or the Nazis. ${ }^{851}$

The second resolution was adopted in 1998 and dealt with the restitution of property belonging to Holocaust victims. ${ }^{852}$ It calls on the Council and Commission

"out of respect for the memory of millions of victims and the most elementary human rights, to bring every pressure to bear on the Governments concerned to ensure that these assets are disclosed and returned to their original owners or those now entitled to them".

While the first two resolutions were essentially steps to recognise the historical fact of art-looting the third resolution was more future-oriented in suggesting certain action to be taken.

The third resolution was adopted in 2003 endorsing a report drawn up by a Member of Parliament and published by the Committee on Legal Affairs and the Internal Market of the European Parliament. ${ }^{853}$ It calls upon the European Commission to undertake an extensive study by the end of 2004 on matters such as the establishing of a common cataloguing system, the developing of common principles regarding access to public or private archives, and the identification of common principles on how ownership or title is established (para. 4). ${ }^{854}$ Furthermore, it called for assigning the matter to a working

\footnotetext{
849 OJ C17, 22.01.1996. Committee on Legal Affairs and the Internal Market, 2003.

850 Paras. 1 and 2 of the Resolution.

851 Paras. 3 and 4 of the Resolution.

852 OJ C292, 21.09.1998.

853 European Parliament Resolution on a legal framework for free movement within the internal market of goods whose ownership is likely to be contested (2002.2114(INI)), Official Journal of the European Union C 91 E/500, 15/4/2004. Report on a Legal Framework for Free Movement Within the Internal Market of Goods Whose Ownership is Likely to be Contested, Commission on Legal Affairs and the Internal Market (Rapporteur Willy C.E.H. De Clercq), A5-A408/2003 (Nov. 26, 2003).

854 Para. 4 reads in full: "The European Parliament calls on the European Commission, with due regard for Art. 295 of the EC Treaty, to undertake a study by the end of 2004 on: establishing a common cataloguing system, to be used by both public entities and private collections of art to gather together data on the situation of spoliated cultural goods and the exact status of existing claims; developing common principles regarding access to public or private archives containing information on property identification and location and tying together existing databases of information about title to disputed properties; identifying common principles on how ownership or title is established, prescription, standards of proof, rights to export or import property which has been recovered; exploring possible dispute resolution mechanisms that avoid lengthy and uncertain judicial procedures and take into account principles of fairness and equity; the value
} 
group of the Council. Member States and applicant States are asked to make all necessary efforts to adopt measures to ensure the creation of mechanisms which favour the return of the property referred to in this resolution and to be mindful that the return of art objects spoliated as part of crime against humanity ${ }^{855}$ to rightful claimants is a matter of general interest for the purposes of Art. 1 of Protocol 1 to the European Convention of Human Rights (para. 5).

Further to these resolutions, no action was taken within the forum of the European Community. 856 The European Commission did not comply with the request of the Parliament to undertake an extensive study by the end of 2004, nor was a working group of the Council assigned to deal with the matter.

\section{INTERMEDIARY CONCLUSIONS ON THE CASE OF NAZI SPOLIATED ART}

In the previous section an array of declarations, principles and resolutions have been discussed that have been adopted by various fora in reaction to the re-emergence of the debate on Nazi-spoliated art. While a number of representatives had understood the 1998 Washington Principles as final act of the renewed interest for Nazi spoliated art, they proved to be only the first in a series of instruments adopted at the end of the 1990 s and during the first decade of the new millennium. ${ }^{857}$

The chronological analysis of the various instruments revealed that none of the instruments introduces new legal rights for the original owners or their heirs for thereturn of works of art that have been spoliated by the Nazis. The principles, resolutions and declarations discussed above do not qualify as international treaties. ${ }^{858}$ While both treaties and the instruments at hand are codified in writing and came into existence due to the corresponding wills of the parties involved, it is the intention of the authors of the specific document that determines whether or not a document constitutes binding law. ${ }^{859}$ The crucial difference lies in the will to be bound by the agreement (pacta sunt servanda) that is absent with regard to the instruments at hand. 860

of creating a cross-border coordination administrative authority to deal with disputes on title of cultural goods".

855 Cf.: fn. 404 for a comment on the question whether the looting of art works qualifies as crime against humanity.

856 Cf.: O'Keefe, P., 2002, p. 265.

857 Cf.: Schnabel, G. / Tatzkow, M., 2007, p. 139. In fact, the process has not yet been concluded. Within UNESCO, an initiative was taken in 1996 to adopt a 'Declaration of Principles relating to Cultural Objects displaced in connection with the Second World War'. When this study was concluded in summer 2009 the draft principles had not yet been adopted. See further on the praparatory steps and instruments: http://portal.unesco.org/en/ev.php-

URL_ID=32665\&URL_DO=DO_TOPIC\&URL_SECTION=201.html (last visited 24 June 2009). At the earliest, the declaration may be adopted by General Conference at its $35^{\text {th }}$ session, which is scheduled for Tuesday 6 to Friday 23 October 2009.

858 Selle, C.v. / Szchunke, U., 2006. See Art. 2 of the Vienna Convention for a definition of treaty.

859 See: Ibid., p. 386.

860 Aust, A., 2005, p. 12. 
The will to be bound is absent with regard to the instruments discussed above. Consequently, none of the instruments create rights that exist directly under international law, nor do they oblige states to grant municipal rights. This does not mean, however, that the instruments discussed constitute merely "legal surrealism". 861 At the end of this chapter, after having addressed the case of human remains, we will reflect upon the relevance of these instruments as soft law (2.§3.I). Furthermore, we will discuss the solutions to be implemented at the national level as proposed by the instruments (2.\$3.II).

Before turning to the case of human remains we need to summarise our findings with regard to the second focus of the present analysis, i.e. the question of how the instruments dealt with possible financial compensation payments received by the original owners or their heirs during the direct post-war era. According to our analysis the instruments put great emphasis on physical restitution. While physical restitution was considered as one alternative next to other "just and fair" solutions by the drafters of the Washington Principles subsequent instruments explicitly request physical restitution. None of the instruments address or explicitly factor in the possibility that the claimants of a specific work might have received financial compensation during the post war years. In fact, only Resolution 1205 makes explicit mentioning of financial compensations $(\mathbb{S} 12)$ as an alternative where the return of an object is impossible. It does not, however, explicate whether it applies also to cultural property whose original owners or their heirs did receive (full) financial compensation during the post-war years. ${ }^{862}$ Whether this absence in reflection upon the relevance of past financial compensation payments must be accorded to unawareness of the post-war restitution regime or whether it must be interpreted as signifying the absolute irrelevance of financial compensation received in the past cannot be established. However, the absence of any discussion on this point must be noted as lamentable and not contributing to the transparency of the debate. While the outcome of such discussion might still be that physical restitution is the only just and fair solution given the atrocities of the Nazi-era, in spite of any financial compensations received, the discussion is nevertheless worth having. It will be interesting to see how this is dealt with at the national level as will be scrutinised in Chapter 4. $\$ 1$.

\section{$\S 2$. THE CASE OF HUMAN REMAINS}

Compared with the case of Nazi spoliated art the developments that led to the emergence of international claims for the return of human remains from Western public collections are more diffuse in time and location. As a consequence, the outlining of the

861 Frigo, M., 2004, p. 70; Alda, K., 2006; Selle, C.v. / Szchunke, U., 2006, p. 383.

862 Para 4. of Resolution 1205 reads: "Though early moves were made following the end of the second world war to find and return this spoliated property, a very considerable amount has not been recovered and has remained in private and public hands". 
developments is more extended and simplified at the same time. Before looking at the developments as they started at intra-national level in the United States and other formerly colonised countries from the 1960s onward and their spill-over to Western Collections in the 1990s we will reflect upon how human remains have become collection items in the first place. Such a background on the history of collecting of human remains is necessary to understand the complexities underlying claims for the return or repatriation of human remains.

\section{THE HISTORY OF COLLECTING HUMAN REMAINS}

The earliest context in which human remains have been collected in Western countries was a religious one and dates back to the $4^{\text {th }}$ century AD. 863 Within the Roman Catholic Church, (parts) of a saint's body or other personal objects of someone of religious significance were preserved and collected. The devotion of these relics was based on the belief that the holy person is present in the relics, as is "God's grace and heavenly virtue". ${ }^{864}$ From the early Medieval Ages onwards bishops and rulers dedicated themselves to the collection of relics. ${ }^{865}$ The veneration of relics flourished until the end of the Middle Ages despite criticism by Thomas Aquinas (1225-1274)866.867

During the Renaissance $\left(14^{\text {th }}-16^{\text {th }}\right.$ centuries), a secular practice of collecting human remains emerged. ${ }^{868}$ Princes and noblemen started to collect rare and exotic objects both of natural origin (naturalia) and products that were the result of human labour (artificialia). ${ }^{869}$ The collected objects were kept in so called cabinets of curiosities (or "Wunderkammern" or "Kunstkammern"). ${ }^{870}$ With the discovery of the "New World" and the opening up of contacts with Africa, South-East Asia and the Far East at the end of the $15^{\text {th }}$ century, the geographical diversity of the collections significantly increased as the objects were often collected during exploring expeditions and trading voyages. ${ }^{871}$

\footnotetext{
863 Walker, P.L., 2000, p. 9.The earliest sources cited to support the efficacy of relics date back to the second century. See e.g.: the Book of the two Kings 13:20-21, and the records on the veneration of Polycarp's relics in the Martyrdom of Polycarp that was written 150-160 AD.

${ }^{864}$ Angenendt, A., 1994, pp. 155-156.

865 Ibid., p. 159.

866 See: Thomas Aquinas, Summa theologica III Suppl., qu.78,3, p. 268-272. Aquinas denied any kind of force (aliqua vis) to remain in the elements that remain of the dead body.

867 Angenendt, A., 1994, p. 158. Whether the religious display of bodies as relics might help to explain Western practise of displaying human remains cannot be verified. Cf.: Bennett, B., 2002, p. 11.

868 Pearce, S.M., 1995, p. 109; Lustig, A.J., 2003, p. 117.

${ }^{869}$ See: Boström, H.-O., 2001, pp. 125-128; Olmi, G., 2001, pp. 14-15; Raby, J., 2001, p. 347; Scheicher, E., 2001, pp. 41-43.

870 Pomian, K., 1990, p. 48; Pearce, S.M., 1995, p. 109; Impey, O. / MacGregor, A., 2001, p. XVI \& XIX; Mauriès, P., 2002, p. 23.

${ }^{871}$ Effert, R.A.H.D., 2003, p. 2.
} 
Amongst these objects were human remains, such as Toi Moko's (tattooed and preserved heads of Māori or Moriori origin). ${ }^{872}$

In the beginning, no clear differentiation between the objects exhibited was made. Rather, the arrangement reflected personal preferences of the collector. The administration of the collections became more and more standardized since the early $18^{\text {th }}$ century. ${ }^{873}$ From the second half of the eighteenth century onwards, achievements of the Scientific Revolution were reflected in new methodologies of collecting: collections were ordered along scientific lines and the labelling was according to the newly emerging scientific disciplines. ${ }^{874}$

From the dawn of the field of anthropology in the mid-19th century human remains have been the subject of anthropological studies and it was commonplace for bones and skeletons of indigenous people to be collected for scientific purposes. ${ }^{875}$ One of scientific disciplines that significantly contributed to the creation of (museum) collections of human remains was physical anthropology. ${ }^{876}$ Physical anthropology, which was based on the assumption that race was a major determinant of human behaviour, flourished in the climate of colonial interaction despite having its roots in the anatomical dissecting rooms rather than in the encounter with foreign peoples. ${ }^{877}$ While physical anthropologists worked mainly in situ during expeditions, the link of cultural anthropology with evolutionist anthropology resulted in the creation of (museum) collections. ${ }^{878}$ Consequently, there exists a coincidence between the zenith of European dominion over the rest of the world and the era in which the fundaments of current public collections have been laid. ${ }^{879}$ Museum collections of artefacts and human remains are, at least to some extent, enmeshed in the history of imperialism. ${ }^{880}$

After World War II, physical anthropology was no longer practised as a scientific discipline in its own right. To the contrary, it came to be regarded as bogus science for

\footnotetext{
${ }^{872}$ Cf.: Qureshi, S., 2004, p. 234. The volume of this "vivid trade in dead body parts" is reflected by the fact that the trade in preserved heads was banned in 1831 by the Governor of New South Wales. Cf.: Awekotuku, N.T., 2004, p. 84. See further below the case studies on a Toi Moko in the collection of the Rijksmuseum voor Volkenkunde in Leiden (chp. 4.\$2.I.2), respectively in the collection of the municipal museum in Rouen (chp. 4.\$2.III.2).

${ }^{873}$ Lustig, A.J., 2003, p. 117.

874 Ibid., p. 118.

875 Davies, P., 2004, p. 82. Davies reports the existence of official instructions on the best way to get skeletons, e.g. by the Australian Museum. Cf.: Turnbull, P., 1991. Similar instructions had been issued to the U.S. Army by a Surgeon-General in 1862 to acquire Native remains for study by collecting bones and crania form graves and following military suppression. Cf.: Zimmerman, L., 1997, p. 94; Simpson, M.G., 2001, p. 175; Thornton, R., 2002, pp. 17-18. See in particular on the situation in South Africa: Legassick, M. / Rassool, C., 2000.

876 Duuren, D.v., et al., 2007, pp. 15-16.

877 Ibid., pp. 13 \& 15-16.

878 See on the discussion whether anthropologists implicitly advanced the interests of colonial production and hegemony: Burton, J.W., 1992.

879 Peers, L. / Brown, A.K., 2003, p. 1.

${ }^{880}$ See for a lucid reflection upon the differences between "colonialism" and "imperialism": Kohn, M., 2006, http://plato.stanford.edu/archives/sum2006/entries/colonialism/, last visited 25 November 2007.
} 
its core concept of race had been discredited. ${ }^{881}$ Furthermore, scientists were no longer interested in physical characteristics in search of the key to understanding the origin of mankind but took to molecular biology. ${ }^{882}$ As a result, the original motivation for the inclusion of a great number of human remains in public collection was lost. The remains did not, however, loose their relevance for science. With the emergence of anthropobiology, which is concerned with human evolution, variation and growth, the earlier orientation of physical anthropology was redirected at "a complex of disciplines dealing with the origins of man and his physical and biosocial evolution; in other words, a synthetic approach to the study of man as a zoological species". 883 Genetics (DNA), biochemistry, ecology and ethnology moved into the centre of attention and changed the research on and therewith the purpose of human remains in public collections.

Other scientific disciplines that resulted in the collecting of human remains were and still are archaeology and medicine. Archaeologists study the material remains of past human life and activities, which consists both of everything made by human beings as well as the human remains themselves. ${ }^{884}$ Skeletal remains offer insight into human morphological variation in time and between groups. ${ }^{885}$ The data generated from the studying of human remains can provide information over population movement, migration, as well as specific genetic compositions of individual populations. ${ }^{886}$ Research of dentition and skeletal remains have contributed to the identification of prehistoric diets and health patterns. ${ }^{887}$

With regard to medical science, the examination of skeletons can provide insight into pathological conditions therewith contributing to the interpretation of human responses to various diseases. 888 The research findings are not limited to insights into the health and conduct of life of ancient peoples but also provide knowledge on trends affecting modern cultures. ${ }^{889}$ The identification of medical cures for diseases profits from the growing possibilities of DNA analyses of human remains. ${ }^{890}$ With regard to research and the relevance and (im-) possibilities of DNA analysis carried out on human remains biomedics stress the progress that was made in the last twenty years in the feasibility and use of DNA research and their hopes in future developments of the techniques and its

\footnotetext{
881 Duuren, D.v., et al., 2007, p. 16. See for a discussion whether anthropologists implicitly advanced the interests of colonial production and hegemony: Burton, J.W., 1992.

882 Lubina, K.R.M., 2007, p. 84.

883 Roede, M.J., 2002, p. 1037; Duuren, D.v., et al., 2007, p. 17.

884 Seidemann, R.M., 2004, p. 550.

885 Afrasiabi, P.R., 1997, p. 808; Seidemann, R.M., 2004, p. 550; Turner, C.G.I., 1986.

886 Seidemann, R.M., 2004, p. 551 with further references in fn. 26; Steckel, R., et al., 2006.

887 Seidemann, R.M., 2004, p. 551 with further references in fn. 28.

888 Ibid.

889 Afrasiabi, P.R., 1997, p. 808; Simpson, M.G., 2001, pp. 178-179; Bekvalac, J., et al., 2006.

${ }^{890}$ Cf.: Seidemann, R.M., 2004, p. 552. See for the concrete application with regard to like, e.g. thalassemia: Afrasiabi, P.R., 1997, p. 821. Thalassemia is described as a "group of anemias caused by a variety of genetic mutations at different sites of the gene coding for the structure of the globulin chains of hemoglobin". See further: Aufderheide, A.C. / Rodriguez-Martin, C., 1998, p. 347.
} 
application. ${ }^{891}$ Currently, the problem of the contamination of body samples of any age still significantly limits scientific research. Further to (bio-) medical application human remains find forensic application in contributing to the developments of techniques used or the identification of war dead, victims of mass disasters and of crimes. ${ }^{892}$

Nowadays, the conservation of human organs and other tissues for medical purposes is subject to the principle of informed consent. ${ }^{893}$ Informed consent refers to legal rules that amongst others promote patients rights of self-determination regarding their treatment. ${ }^{894}$ In former days, however, human organs and tissue were taken without such informed consent. This was not only the case in the obtaining of human material but is true for most cases in which human remains have been acquired in the past. While cultural objects more in general were obtained by a wide range of methods of acquisition such as gift, genuine trade, deception, conquest, confiscations ${ }^{895}$ it can be assumed that human remains except for some worked remains (e.g. a flute made of a human femur) were not freely given away. In particular with regard to the remains collected during the era of the European dominion over the rest of the world it can be concluded that not only was consent to collect human remains absent - but was the collecting in clear contravention of local laws, customs and belief systems. ${ }^{896} \mathrm{~A}$ case that illustrates this point is the case of "El Negro". ${ }^{897}$

${ }^{891}$ Lubina, K.R.M., 2007, pp. 87-88. Discussion recorded under MZ000027.WAV.

892 Seidemann, R.M., 2004, p. 552 with further references in fn. 32-39.

${ }^{893}$ Cf.: Gevers, J.K.M., 1990, p. 14; Bostyn, S., J.R., 1998, p. 291; Price, D., 2005. See for Dutch legislation: Wet op de orgaandonatie (Organ Donation Act, 24/05/1996, Stb. 370) but see e.g. Art. 7:467 Dutch Civil Code (BW) on the Dutch Medical Treatment Contract that allows for anonymous bodily material separated from the human body to be used for medical statistical or other medical research provided the patient did not expressly withhold his/her consent for such use. See for UK legislation: The Human Tissue Act 2004. See further on the Act in chp. 4.S2.II.2. The principle of informed consent also applies to Gunther van Hagens travelling exhibition 'Body Worlds', which has been a topic of heated discussion for years (Hagens, G.v., 1999a, pp. 74-75). See further for the views of supportive and dissenting lawyers, theologians, philosophers, medics e.g.: Hagens, G.v., 1999b; Wetz, F.J. / Tag, B., 2001.

${ }^{894}$ See further on informed consent, e.g.: Berg, J.W., et al., 2001.

${ }^{895}$ Davies, P., 2004, p. 81.

896 While there exists great diversity amongst societies with regard to moral ideas such as whose duty it is to support children, the aged, or the poor, the forms of sexual relationship permitted, the status of women, the right to property and what constitutes theft, the respect for the dead is shared to a great extend. See, e.g.: Westermarck, E., 1926, pp. 513-552. See also the work of Sir James G. Frazer who, after a lifetime of investigation of the origin of religious structure concluded that awe toward the dead was probably the most powerful force in forming primitive systems for grappling with the supernatural: Frazer, J.G., 1890. Cf.: Trope, J., F. / Echo-Hawk, W., R., 2000, pp. 124-125.

897 The case of "El Negro" concerned the remains of a Bechuana person that had been on display in the Natural History Museum of Banyoles in Catalonia, Spain since 1916. The initiative to take the remains that were displayed under the cognomen of "El Negro" off display and to return them to their home land started in 1991 by a Spanish citizen of Haitian origin who pressed the case in the months preceding the Spanish hosting of the Olympic Games. The controversy about El Negro lasted for almost ten years and in fact did not end with the return of the remains in October 2000 to the Republic of Botswana, which had been requested by the Organisation of African Unity to receive and lay to rest the body of El Negro. According to the literature, the final chapter of the repatriation of El Negro was disturbed by discussions on the true home grounds of the remains (at last moment it appeared that not nowadays Botwsana but South 
The remains which became known in the 1990s as "El Negro" had been removed from their grave near the Vaal River in what is now South Africa between 1829 and 1831 within days from their burial by the French brothers Verreaux. The brothers subsequently performed taxidermic work on the body, exhibited and sold it. 898 Other evidence of the acquisition of material that was unethical not only by current standards is available from the records of those who removed the remains in the first place. E.g. the notes of Ales Hrdlicka (1869-1943), a physical anthropologist whose research focused on reconstructing the origins and population histories of Native American populations make mention of a conflict he had with a woman whose husband's bones had had just removed from his grave and of the collecting of bones from sites he had to leave by a difficult route "to avoid notice". 899

The practice of removing indigenous remains from their graves was not confined to the colonial era but continued until recently. One commentator remarked in 1990 that "[d]esecrate a white grave and you get jail. Desecrate an Indian grave and you get a PhD". 900

\section{HUMAN REMAINS: GENESIS OF THE DEBATE ON THE RETURN OF HUMAN REMAINS}

Against the circumstances of acquisition outlined above it might not surprise that the debate on the repatriation of human remains emerged in the greater context of the struggle for indigenous rights in the post-colonial era following World War II. In the following we will outline the unfolding of the debate, which started with intra-national claims concerning newly disinterred human remains, shifted to intra-national claims human remains from public collections in former colonies before becoming truly international in character in the sense of affecting human remains in public collections worldwide, especially in Western public collections

\footnotetext{
Africa comprised El Negro's geographical roots) and the manner in which the remains had been returned by Spain, which was felt to be appropriate for a museum asset being donated to Botswana but not for the remains of a human being. Finally, there was discussion on the location of the grave in a public park rather than in proper burial grounds. See on the details of the case: Parsons, N., 2000; Bennett, B., 2002, p. 9; Parsons, N. / Sebobye, A., Kelo, 2002; Segobye, A., 2002, p. 14.

${ }^{898}$ Bennett, B., 2002, p. 9; Parsons, N. / Sebobye, A., Kelo, 2002, p. 245; Segobye, A., 2002, p. 14.

899 Cf.: Pullar, G.L., 1994, pp. 22-23; Working Group on Human Remains, 2003, para. 66. See for bibliographical information:

http://www.mnsu.edu/emuseum/information/biography/fghij/hrdlicka_ales.html (Last visited 4.11.2008). See also: Paczensky, G.v. / Ganslmayr, H., 1984, chp. 8 'Leichen fürs Museum’.

900 Remark by Echo-Hawk, Senior Staff Attorney for the Native American Rights Fund cited in: Arnold, D., 2 April 1990, p. 28.
} 


\section{INTRA-NATIONAL CLAIMS REGARDING NEWLY DISINTERRED HUMAN REMAINS}

The challenging of the treatment of indigenous human remains started in former (settler) colonies ${ }^{901}$ from the 1970s /1980s onwards in the context of civil rights movements and the struggle of indigenous peoples for self-determination. ${ }^{902}$ In the beginning, the focus lay on the treatment of recently disinterred remains, which received little respect and were treated different from non-indigenous remains. ${ }^{903}$ Given the relevance of the principle of sovereignty in international law, which is understood as the complete and undisturbed dominion over a territorial space ${ }^{904}$, it must not surprise that the disinterment of human remains came to play a significant role in the quest of indigenous peoples for self-determination.

In response to the campaigns of indigenous peoples various jurisdictions, especially in the United States, adopted legislation dealing with (the reburial of) recently excavated indigenous human remains.905 A number of laws may be mentioned here as representative examples: In 1980 the U.S. State Maine introduced laws that required all Indian skeletons disinterred after 1973 to be returned to the appropriate Indian tribes for reburial. ${ }^{906}$ In the Canadian province Saskatchewan the Heritage Property Act requires he return of Amerindian skeletal material, excavated or naturally exposed, to the Indian Band Council. ${ }^{907}$ In Australia, the Aboriginal and Torres Strait Islander Heritage Protection Act (hereinafter: ATSIHPA) was adopted in 1984 and provide for the protection from injury or desecration of areas and objects, including human remains in accordance with Aboriginal tradition. ${ }^{908}$ In South Africa, the only legislation dealing directly with human remains until 1999 was the 1969 National Monuments Act

\footnotetext{
${ }^{901}$ Different types of colonies can be distinguished, reflecting different colonial policies. Settler colonies arose from the emigration of peoples from a metropolis, or mother country, and involved displacement of the indigenous peoples to their permanent detriment. Examples of settler states that are relevant in the context of this study are the United States of America and New Zealand. Settler colonies may be contrasted with dependencies, where the colonizers did not arrive as part of a mass emigration, but rather as administrators over existing sizeable native populations, exercising control by use or threat of force. Examples in this category are the Dutch East Indies. Cf.: Ashcroft, B., et al., 2003.

902 Cf.: Brown, M.F., 2003, p. IX; Seidemann, R.M., 2003, p. 151; Seidemann, R.M., 2004, p. 547; Bristow, M., 2008, p. 211.

903 The following situations can be mentioned as examples of contexts in which human remains may be disinterred: the building of roads, bridges, railways, housing and commercial complexes, in the development of oil or mineral mining or in archaeological excavations. Cf.: Hubert, J., 1992, p. 106. See further below with regard to archaeological excavations the Vermillion Accord in chp.2.S2.IV.1

904 Cf.: Francioni, F., 2004, p. 1220.

905 Cf.: Prott, L.V. / O'Keefe, P.J., 1989, para. 389.

906 Indians and Tribes, Me. Rev. Stat. Ann.tit.22 s.4720 (1980). Cf.: Ibid. See further on state legislation passed in the United States on the protection for unmarked graves and statutes foreseeing in the reburial of disinterred human remains: Price III, H.M., 1988; Price III, H.M., 1991; Trope, J., F. / Echo-Hawk, W., R., 2000, pp. 134-136.

${ }^{907}$ Heritage Property Act Ch. H.-2.2 (1984). Cf.: Prott, L.V. / O'Keefe, P.J., 1989, para. 389.

908 Aboriginal and Torres Strait Islander Heritage Protection Act (ATSIHPA), No. 79, 1984, s 4. See further on ATSIHPA: Seidemann, R.M., 2004, pp. 570-573.
} 
(NMA). ${ }^{909}$ The protection provided for in the NMA applied to graves of individuals of lived before 1652; the date at which European settlers arrived. On top of that, protection was granted to graves of people who died in wars until 1914, and to gravestones older than fifty years. ${ }^{910}$ In 1999, the National Heritage Resources Act (NHRA) was passed. ${ }^{911}$ Under NHRA, all graves that are older than 60 years and are not in a formal cemetery (such as ancestral graves in rural areas) will be protected. Any action disturbing the graves requires a permit which is depending on consultation and agreement with communities with a vested interest in the graves. ${ }^{912}$ For New Zealand, the relevant law protecting human remains of Māori affiliation is the 1993 Historic Places Act. ${ }^{913}$ The main aim of the act is to 'promote the identification, protection, preservation, and conservation of the historical and cultural heritage of New Zealand'. ${ }^{114}$ In addition to archaeological sites, historic places and historic areas the 1993 Historic Places Act protects wāhi tapu ('sites sacred to Māori') and wāhi tapu areas, which include burial places. 915

Further to activities by state and federal legislators, the indigenous movement also resulted in the adoption of ethical standards by professional bodies. With archaeology being one of the main disciplines actively seeking the disinterment of human remains the World Archaeological Congress felt the need to take a stand about archaeological ethics and the treatment of the dead. ${ }^{916}$ In 1989, the World Archaeological Congress adopted the 'Vermillion Accord on Human Remains'917 as the first international expression of ethical standards with regard to the excavation of human remains. ${ }^{918}$ The Vermillion Accord emphasizes the need to respect mortal remains and the wishes of the local communities during and after archaeological excavations (paras. 1-3 and 5). At the same time, the Vermillion Accord recognises the need for mutual respect and cooperation between indigenous peoples and archaeologists and stresses the need to respect scientific research (para. 4). ${ }^{919}$

\footnotetext{
${ }^{909}$ Act 28 of 1969. Cf.: Seidemann, R.M., 2004, pp. 562-562.

910 These provisions lead to the bizarre situation that post-1952 graves of persons that had not died in wars, were left without any protection but for the gravestone (once older than fifty years).

911 Act 25 of 1999, available at http://www.sahra.org.za.-intor.htm.

912 The National Monuments Council, . See further: Seidemann, R.M., 2004, pp. 562-567.

913 Historic Places Act 1993 No 38.

914 See the Preamble (a) of the act.

915 Cf.: Tupara, N., 2000.

916 Cf.: Doumas, C., 1990.

917 The Vermillion Accord on Human Remains, adopted by the South Dakota WAC Inter-Congress in 1989

918 Cf.: Working Group on Human Remains, 2003, p. 176.

${ }^{919}$ See further on the Vermillion Accord: Hubert, J., 1992, pp. 110-113 and below in chp. 2.\&2.IV.1.
} 


\section{INTRA-NATIONAL CLAIMS CONCERNING HUMAN REMAINS IN PUBLIC COLLECTIONS IN THE FORMER COLONIES}

In the wake of campaigns focusing on recently disinterred remains and the introduction of burial protection laws, awareness shifted to the existence and exhibition of human remains such as skulls, mummified bodies and skeletons in public (museum) collections. At first, the campaigns sought to make an end to the displaying of human remains. ${ }^{920}$ After a "growing trend to remove human remains form museum displays" attention shifted to the reburial of the remains and therewith to the disposal of human remains from public collections. ${ }^{922}$ This question was by far more crucial for institutions and researchers than the removal of the remains from display. ${ }^{923}$

The responses by different Governments to the campaigns of local indigenous peoples varied from the adoption of laws compelling return to official policies suggesting the return of human remains to the granting of mandates to specific institutions pursuing repatriation. In the following we will shortly review the laws and policies introduced in the United States, South Africa, New Zealand and Australia.924 Whereas the legislation adopted in the United States will be discussed for constituting the most concise and clearest stand with regard to the treatment of curated human remains ${ }^{925}$ and was important in stimulating the debate well beyond the US borders; the analysis of the latter three jurisdictions is interesting in that most of the international requests dealt with in next Chapter $4(\$ 2)$ seek the return of human remains to Australia, South Africa and New Zealand. ${ }^{926}$

${ }^{920}$ Cf.: Prott, L.V. / O'Keefe, P.J., 1989, p. 224, para. 388.

${ }^{921}$ Prott, L.V. / O'Keefe, P., 1984, p. 141, para. 454; Prott, L.V. / O'Keefe, P.J., 1989, p. 224, para. 388. Prott and O'Keefe, e.g. report of a law adopted in the U.S. State Oregon according to which it was an offence to "[p]ublicly display or exhibit any native Indian human remains" (Protection of Indian Graves, Or. Rev. Stat. s.97.745(2)(b)(1981)).

922 Prott, L.V. / O'Keefe, P., 1984, paras. 448-545. See for an account of the situation in New Zealand: Watt, R., J., 1989; Watt, R., J., 1995. The emphasis of the claims is also mirrored by the evolution of the Code of Ethics for Museums developed by the International Council of Museums (ICOM). In its original version as adopted in 1986, the ICOM Code did not touch upon the return of human remains. It did however provide some guidance on the acquisition, researching and display of human remains. In the amended 2001 version of the Code greater emphasis is put on the interests and beliefs of source communities with regard to the treatment of human remains. The 2004 version introduced a paragraph dealing explicitly with request for removal of human remains from public display, respectively their return. See further on the ICOM Code below in chp. 2.\$2.IV.3.

${ }_{923}$ Cf.: Prott, L.V. / O'Keefe, P.J., 1989, p. 224, para. 388.

${ }^{924}$ While the laws or policies dealing with the return of human remains are more broad than focusing solely on this aspect we will only discuss the relevant portions of the instruments.

925 Cf.: Seidemann, R.M., 2004, p. 562.

926 Another country that witnessed intra-national claims for the return of human remains is Canada. We will not further discuss Canada as there is no national law governing human remains in Canada. Cf.: McAleese, K., 1998, p. 46. It would exceed the scope of this chapter to undertake a province-by-province analysis of the legislation in place. See further on the return of human remains within Canada: Bell, C., 1992/1993; Baikie, G., 1993; Ferris, N. / Leclair, L., 1998. 
a) United States and its landmark legislation $N A G P R A$

The Native American Graves Protection and Repatriation Act (hereinafter: "NAGPRA") ${ }^{927}$ was passed by the United States Congress in 1990.928 The federal act, which has repeatedly been characterised as "landmark legislation" 229 serves three purposes. First, it introduces legally enforceable procedures that allow Indian tribes to recover human remains and funerary objects from federally funded museums. ${ }^{930}$ Secondly, NAGPRA criminalises the trafficking of Indian human remains and cultural items. ${ }^{931}$ Thirdly, it provides for notification and consultation procedures for excavation of Native American human remains and cultural objects on federal and tribal lands. ${ }^{932} \mathrm{It}$ is the first portion of the Act on the repatriation of human remains from federal agencies and museums that is relevant in the present context. ${ }^{933}$

In order to facilitate the emergence of claims NAGPRA requires federal agencies ${ }^{934}$ and museums ${ }^{935}$ to adopt a proactive attitude towards repatriation. Not only does it require federal agencies and museums to compile and publish inventories of their collections; they also have to provide information to potential claimants who might be interested in making a claim. .336

For the situation that a claim is made for the return of human remains, as well as funerary objects, sacred objects and objects of relevance to the cultural patrimony,

927 The Native American Graves Protection and Repatriation Act (NAGPRA) 25 U.S.C.3001 - 13 (1994).

928 See for an engaging overview of the history that made NAGPRA necessary: Thomas, D.H., 2000. NAGRPA was, however, not the first legislative statement in the US on the return of human remains from museum collections. Prior to the enactment of NAGPRA the National Museum of the American Indian Act (NMAIA), 20 U.S.C. 80(q) provided for the repatriation of the Smithsonian Institution's collection. Cf.: Seidemann, R.M., 2004, p. 546, fn. 542. See further on NMAIA: Trope, J., F. / Echo-Hawk, W., R., 2000, pp. 137-138.

${ }_{929}$ E.g. Trope, J., F. / Echo-Hawk, W., R., 2000, p. 123; Brown, M.F. / Bruchac, M.M., 2006, p. 194.

93025 U.S.C. 3005 (2004).

93125 U.S.C. 1170 (2004).

93225 U.S.C. 3002(d) 2004.

933 See further on the third portion, the notification and consultation procedures for intentional and inadvertent excavations, e.g.: Lannan, R., W., 1998, pp. 397-400; Riley, A.R., 2002, part III.

934 See 25 U.S.C. 3001(4) for the definition of federal agency as "any department, agency, or instrumentality of the United States. Such term does not include the Smithsonian Institute".

935 See 25 U.S.C. 3001(8) for the definition of museum as "any institution or State or local government agency (including any institution of higher learning) that receives Federal funds and has possession of, or control over, Native American cultural items. Such term does not include the Smithsonian Institution or any other Federal agency".

936 See 25 U.S.C. 3003 on the compilation of inventories for human remains and associated funerary objects. To the extent possible, the inventory must include information of the geographical and cultural affiliation. Section 5 , which is dedicated to the compilation of inventories of human remains and associated funerary objects, is far more stringent in its requirements than section 6 which provides for written summaries of unassociated funerary objects, sacred objects, and cultural patrimony. The main difference is the quality of information demanded (itemized inventory vs summary of the scope of the collections). The difference is mirrored in the time-period available to fulfill the tasks; five years for the inventories concerning human remains an associated funerary objects, whereas the unassociated and sacred objects and the cultural patrimony as part of a museum or Federal agency collection must be summarized within only three years. 
NAGPRA prescribes the process for the assessment of the claim. ${ }^{937}$ Where human remains or associated objects are requested by a lineal descendant, the federal agencies and museum are legally required to repatriate the requested object. Where the claimant is not a lineal descendant, the Native American group must be able to show a cultural affiliation with the human remains claimed. Cultural affiliation is defined in section 2(1) as "a relationship of shared group identity which can be reasonable traced historically or prehistorically between a present day Indian tribe or Native Hawaiian organization and an identifiable earlier group". ${ }^{938}$ The existence of a cultural affiliation can either be asserted on the grounds of the inventories of the collections or where the inventories do not allow for such proof "by a preponderance of the evidence based on geographical, kinship, biological, archaeological, anthropological, linguistic, folkloric, oral tradition, historical, or other relevant information or expert opinion". ${ }^{939}$ Where cultural affiliation with human remains has been established the remains must be repatriated expeditiously.

That the concept of cultural affiliation can give rise to significant discussion is wellillustrated by the case Bonnichsen v. U.S. ${ }^{940}$, better known as the "Kennewick Man" case. While the case is strictly speaking not a case about the return of human remains from a public collection as it concerned newly discovered remains and therewith was judged against the provisions of NAGPRA dealing with notification and consultation procedures for excavation of Native American human remains and cultural objects on federal and tribal lands, the case is nevertheless relevant in the present context for highlighting the difficulties and stakes involved in repatriation cases of human remains: first, it pinpoints the difficulties in establishing the degree of relationship required between human remains and a claiming party. Secondly, the case illustrates that scientific research is not a universally shared value and can clash with beliefs and knowledge systems.

\section{Bonnichsen v. U.S}

In 1996 a human skull and scattered bones were discovered near Kennewick in the U.S. State Washington. The area where the remains were found was Federal lands. While initial research by local anthropologists concluded that the remains were of an early European settler or trapper further examination of the remains revealed characteristics inconsistent with those of a European settler, yet also inconsistent with any Native American Indian remains previously documented in the region. Subsequent radiocarbon analysis indicated that the remains were between 8340 and 9200 years old making them "one of the most complete early Holocene human skeletons ever

\footnotetext{
937 See 25 U.S.C. 3001(3) which subsumes all terms (human remains, funerary objects, sacred objects and objects of relevance to the cultural patrimony) under the definition of "cultural item". Note that NAGPRA does not provide for a separate definition of human remains.

93825 U.S.C.3001 (2) (2004).

93925 U.S.C.3005 (a)(4) (2004).

940 Bonnichsen v. United States, 969 F. Supp. 614 (D. Or. 1997).
} 
recovered in the Western Hemisphere". ${ }^{941}$ Due to the age and feature of the remains many scientists believed that the remains could shed considerable light on questions such as the origins of humanity in the Americas. ${ }^{942}$

In the course of arrangements made to transport the remains to the Smithsonian Institute for scientific research local Indian tribes came forward and objected to the removal and scientific study on religious grounds. According to the Indian tribes, the spirits of the remains remain at unrest until returned to the ground. The argument of the scientists pointing to relevance of the remains for the early history of the people in the Americas was rejected with reference to the oral histories of the tribes according to which their ancestors have populated the American continent since the beginning of time. Five Indian groups joined forces and claimed on the basis of NAGPRA for the immediate burial of the remains without further testing at a secret location. ${ }^{943}$

In response to the Indian groups' claim, the United States Army Corps of Engineers (the Corps), which is responsible for the management of the land, prevented the transport of the remains to the Smithsonian, ordered the halt to DNA testing and published a "Notice of Intent to Repatriate Human Remains" in the local newspaper. A number of scientists objected to the Corps' decision to return the remains. ${ }^{944}$ When the Corps did not respond to the objections and requests to allow for scientific study of the remains, and evidenced its intent to repatriate the remains, the group of scientists commenced litigation in the District Court of Oregon. Plaintiffs sought to prevent the transfer of the remains to the Indian Tribes for burial and to secure permission to study the remains. ${ }^{945}$

In court the case centred on the question of the cultural affiliation between the remains and the Indian tribes. The Oregon District Court held that the age and lack of information as to the era from which the remains originated made it impossible to say whether the remains were related to any identifiable indigenous group or culture in the United States or whether there was a shared group identity between his group and the living indigenous peoples on the basis of oral histories passed down through generations. Consequently, the Oregon District Court barred the transfer of the skeleton

\footnotetext{
941 Taylor, R.E., 2001.

942 The summary of the facts is based on: Jelderks, J., 2002, I. Background, A Pre-Litigation Events. See further on the theories that exist on the origins of people in North America: Lannan, R., W., 1998, pp. 383388. For an overview of the issues surrounding the fate of Kennewick Man, see Kelly, M., 1999; Tsosie, R., 1999.

943 See, e.g.: Fisher, D., 2000.

944 Plaintiff scientists included Robson Bonnichsen (Texas A\&M), C. Loring Brace (University of Michigan), George W. Gill (University of Wyoming), C. Vance Haynes, Jr. (University of Arizona), Richard L. Jantz (University of Tennessee), Douglas Owlsley and Dennis J. Stanford (Smithsonian Institution), and D. Gentry Steele (Texas A\&M).

945 The summary of the facts is based on: Jelderks, J., 2002, I. Background, A Pre-Litigation Events. See further for descriptions of the facts of the case e.g.: Flood, M., A., 2002, pp. 39-53; Lannan, R., W., 1998, pp. 371-386. For a description from an archaeological point of view see e.g.: Johansen, B.E., 2004; Stapp, D.C. / Longenecker, J.G., 2005.
} 
for immediate burial and permitted its scientific study instead. ${ }^{946}$ This decision was confirmed by the United States Court of Appeal for the Ninth Circuit, which stressed that the statute required some relationship between the remains and a presently existing tribe or culture to be considered Native American which was lacking in the present case. ${ }^{947}$

\section{b) Australia}

Different from the US American situation, no federal legislation exists in Australia that deals with the return of human remains from curated museums, let alone prescribes it. Except for Tasmanian state legislation, there exists no legislative regulation for public collections. ${ }^{948}$ In 1993, in the absence of federal legislation the Council of Australian Museum Associations, the precursor body to Museums Australia, introduced a policy document titled 'Previous Possessions, New Obligations: policies for museums in Australian and Aboriginal and Torres Strait Islander people'. ${ }^{949}$ In 2000, it was decided to undertake a formal review of the policies. ${ }^{950}$ In 2005, the revised guidelines were approved by the National Council of Museums Australia and published as 'Continuous Cultures, Ongoing Responsibilities - Principles and guidelines for Australian museums working with Aboriginal and Torres Strait Islander cultural heritage'. ${ }^{951}$ These nonbinding guidelines emphasise the need for Australian museums to enter into "meaningful consultations" with Aboriginal and Torres Strait Islander communities in relation to existing collections of their ancestral remains. ${ }^{952}$ According to the guidelines museums should adopt a pro-active attitude with regard to repatriation. Rather than waiting for a claim to be made, museums should actively identify claimants and approach them with the question whether they want to have human remains from the museum's collection to be repatriated (para. 1.4.4). While the guidelines recommend museums to return ancestral remains where a rightful custodian asks them to do so, they

\footnotetext{
946 Bonnichsen v. United States, 969 F. Supp. 628 (1997); Bonnichsen v. United States, 217 F. Supp. 2d 1116 (2002).

947 Bonnichsen v. United States, 367 F. $3 d 864$ (2004). See for a dissenting opinion according to which the remains are Native American within the meaning of NAGPRA and that the claimant tribes have established a "cultural affiliation": Flood, M., A., 2002. In reaction to the Kennewick Case a number of proposals were issued to amend NAGPRA to clarify the meaning of cultural affiliation. As of today, there have been no amendments to NAGPRA in this respect.

${ }^{948}$ ATSIHPA, the Australian Aboriginal and Torres Strait Islander Heritage Protection Act 1984 does not compel the return of human remains from museums or other institutions. Its main aim is to grant protection to objects of particular significance to Aborigines, according to Aboriginal tradition, from any threat of injury or destruction. Cf.: Working Group on Human Remains, 2003, p. 78, para. 231; Seidemann, R.M., 2004, pp. 570-573.

949 See for a description of the guidelines, e.g.: Watson, N., 2003; Working Group on Human Remains, 2003, pp. 80-81, paras. 239-241. See on the return of Australian public collections prior to the publication of the guidelines e.g.: Mulvaney, D.J., 1990 with regard to the Museum of Victoria; Mulvaney, D.J., 1989 with regard to the Murray Black collection.

${ }_{950}$ Museums Australia Inc, 2005, p. 3.

951 Ibid.

952 Ibid., p. 18, para. 11.14.
} 
do not explicitly demand it (para. 1.4.5). Instead, the guidelines stress the need to act with sensitivity and recommend the decision-making process to be a joint undertaking between the museum and the indigenous community rather than a unilateral activity by the former. Consequently, where museums want to repatriate human remains, they should do so in consultation with the community of origin (1.4.3). The joint decisionmaking process also implies that museums do not make the repatriations subject to conditions (1.4.6). ${ }^{953}$

\section{Tasmanian Museums (Aboriginal Remains) Act 1984}

Different from the general situation in Australia, the state of Tasmania introduced legislation explicitly dealing with the return of indigenous human remains in 1984.954 According to the Museums (Aboriginal Remains) Act 1984, all Tasmanian Aboriginal remains held in the Tasmanian Museum and Art Gallery and in the Queen Victoria Museum and Art Gallery became the property of the Crown with the entry into force of the act. ${ }^{955}$ The minister in charge has the task to provide for the delivery of the remains to the Tasmanian Aboriginal community. By 1986, most Aboriginal skeletal remains from the collections of the two museums had been handed over to the Tasmanian Aboriginal Centre Inc. ("TAC") on the Aboriginal's community's behalf. 956

\section{c) New Zealand}

New Zealand did not adopt national legislation on the treatment of curated human remains. Instead, the New Zealand Government mandated the Museum of New Zealand Te Papa Tongarewa (Te Papa) to undertake a repatriation programme for Māori and Moriori ancestral remains. The programme, titled 'Karanga Aotearoa Repatriation Programme', was formally adopted in July 2003.957 The policy pursued by Te Papa in repatriating Māori and Moriori ancestral remains, especially Toi Moko (preserved tattooed human heads), is set out in a briefing note that was especially drafted for overseas institutions on the role and status of the Te Papa in the repatriation of kōiwi tāngata. ${ }^{958}$ The repatriation policy is guided by six principles:

The government role is mainly one of facilitation - it does not claim ownership of kōiwi;

Repatriation from overseas institutions and individuals is by mutual agreement only;

The repatriation policy does not cover Māori remains in war graves maintained by the

Commonwealth War Graves Commission, or other similar institution;

No payment for kōiwi will be made to overseas institutions;

\footnotetext{
953 See further on the situation of human remains in Australian Museum Collections: Pickering, M., 2006.

954 Museums (Aboriginal Remains) Act 1984 (Tas.) (No. 75 of 1984).

955 Ibid., ss. 4(1) \& 6(1).

956 Cf.: Working Group on Human Remains, 2003, pp. 79-80, paras. 235-237.

957 Matthews, M., 2004; Te Herekiekie, H., 2008, p. 405.

958 The Museum of New Zealand Te Papa Tongarewa.
} 
Kōiwi must be identified as originating from New Zealand;

Māori are to be involved in the repatriation of köiwi, and to determine the final resting place, where possible. ${ }^{959}$

d) South Africa

The South African National Heritage Resources Act (NHRA) was passed in 1999.960 While NHRA explicitly provides for protection of in situ remains it is less clear with regard to human remains curated in public collections. However, by subsuming human remains under the meaning of "other objects referred to in section 3" it does require institutions holding public collections to "enter into a process of negotiation with the claimants regarding the future of the resource" where a bona fide claim for repatriation has been made. ${ }^{961}$

\section{SPILL OVER TO THE INTERNATIONAL REALM}

After a number of formerly colonised countries had adopted legislation ${ }^{962}$ dictating the return of human remains respectively general policies stressing meaningful relationships and consultation between indigenous communities and institutions housing public collections the debate on the repatriation spilled-over from the local to the international, cross-border stage. ${ }^{963}$

In particular, the role of NAGPRA as a rights-based approached must not underestimated in making the debate truly international. It seems that NAGPRA added authority to the developments of claiming the repatriation of human remains. On top of that, cases like the case of the "Kennewick Man" contributed to raising international awareness of the question of human remains in public collections. The Kennewick Case was extensively discussed by scientists, academics and the general public both within the United States and abroad and therewith contributed to raising the question of human remains at the international level. ${ }^{964}$ The spill-over from the intra-national level within former colonies to challenging public collections abroad, in particular in Western Europe furthermore profited from the fact that we live in a global village ${ }^{965}$ : news about the return of human remains from one country to another is no longer refined to these countries but travels and challenges long held beliefs about the composition of

959 Cf.: Matthews, M., 2004; Te Herekiekie, H., 2008.

960 Act 25 of 1999, available at http://www.sahra.org.za.-intor.htm.

961 See NHRA \ 41(1) juncto NHRA \ 2 (xxix)(d) juncto NHRA \3(s)(g). Cf.: Deacon, H.J. / Deacon, J., 1999, pp. 196-197; Seidemann, R.M., 2004, pp. 566-567.

962 The United States of America and Tasmania.

963 Cf.: Palmer, N., 2000b, p. 345.

964 Zimmerman, L.J. / Clinton, R.N., 1999, p. 219. See more in general on the employment of the mass media and the raising of dramatic cases at law (even when the case is expected to be lost) as consciousnessraising techniques to awaken dormant values: Price III, H.M., 1991, p. 19.

965 The reference to global village is not meant to evoke Marshall McLuhan's understanding of the phrase in his book the Gutenberg Galaxy but is used in it current general understanding as a metaphor to describe the Internet and the World Wide Web. 
collections. In the following we will first address the relationship between international, cross-border claims for the repatriation of human remains with the existing legal framework on the restitution of cultural objects under public international law as outlined in Chapter 1 above. Such demarcation contributes to a better understanding of the present claims and the reactions and initiatives by the international community in the form of principles, resolutions and declarations that will be addressed subsequently.

\section{THE CASE OF HUMAN REMAINS FROM THE LEGAL PERSPECTIVE}

\section{PUblic International LaW TOUCHING EXPLiCITLY ON HUMAN REMAINS}

In Chapter 1 we have analysed in how far public international law is relevant for the return and restitution of cultural objects. The analysis distinguished between the following categories: the protection of cultural objects in times of war $(\mathbb{\Omega} 1)$, the protection of cultural objects in time of peace $(\mathbb{S} \& \& 3)$; the restitution of cultural objects to private individuals $(\S 4)$, as well as to a people $(\$ 5)$. Different from Nazi spoliated art, these categories are of indirect relevance only for current claims for the return of human remains from public collections. This must not surprise as the constellations analysed aim at the restitution of cultural property. However, despite the fact that the frameworks do not seek to provide for the restitution of human remains as human remains, i.e. as the remains of once sentient human remains, the analysis nevertheless revealed instances in which the restitution of human remains was explicitly addressed in two instances. Before reflecting upon the relevance of this finding, let us recall and further elaborate upon these instances.

The first international binding provision to explicitly touch upon human remains is Art. 246 of the Treaty of Versailles:

"Within six months from the coming into force of the present Treaty, Germany will restore to His Majesty the King of the Hedjaz the original Koran of the Caliph Othman, which was removed from Medina by the Turkish authorities and is stated to have been presented to the ex-Emperor William II.

Within the same period Germany will hand over to His Britannic Majesty's Government the skull of the Sultan Mkwawa which was removed from the Protectorate of German East Africa and taken to Germany. The delivery of the articles above referred to will be effected in such place and in such conditions as may be laid down by the Governments to which they are to be restored".

The above analysis of the article, especially its second provision, revealed that the obligations of Art. 246 had been included in the treaty in response to British lobbying and strictly speaking did not constitute a form of reparations. Instead of constituting part of the German reparations to the British for the losses and damage sustained in the First World War the inclusion of the provision on the skull's return clearly served the British in their political aspirations in Tanganyika. In the following, we will further analyse the second provision of Art. 246 of the Treaty of Versailles against its historical and political context, as well as its perception in the literature. 
Sultan Mkwawa of Uhehe was a tribal chief who had fought against the Germans during their occupation of East Africa. ${ }^{966}$ In 1898, after a seven-year fight, his rebellion failed when he died of exhaustion or committed suicide. ${ }^{967}$ His body was found by a German soldier called Merkl. Most likely, Merkl had ordered for the cutting of the head as proof to claim the reward that had been promised on the capture of Mkwawa.968 Different accounts exist on what happened with the head after Merkl had delivered it to the German Governor Tom von Prince. Whether the head / skull had indeed been taken to Germany as assumed in Art. 246 of the Versailles Treaty has never been established. ${ }^{969}$ Germany held that the head had never been taken to Germany. ${ }^{970}$ In any

966 The (German) East African territory, which corresponds to present-day Rwanda and Burundi, the continental portion of Tanzania, and a small section of Mozambique, was first penetrated by German commercial agents in 1884. German claims to the territory were recognized by the other European powers in the period 1885-94. In 1891 the German imperial government took over administration of the area from the German East Africa Company. German East Africa (2008). In Encyclopædia Britannica. Retrieved May 15, 2008, from Encyclopædia Britannica Online, http://www.search.eb.com/eb/article-9036569. See further on the German imperialism, the Bushiri's rebellion and the rule of Mkwawa: Winans, E.V., 1994, pp. 224-233.

967 Winans, E.V., 1994, p. 225.

968 Ibid., pp. 228-229. The report written after the Second World War by the then British Governor of Tanganyika in his search for the skull contains the following quotation from a report filed by SergeantMajor Merkl on the death of Mkwawa: "On July 14, 1898, a native brought news that Mkwawa had been here during the past few days. I received orders to proceed by forced marches with 15 askaris (Arabic word for soldier K.L.) and a few Hehe and, if possible, to capture him... I had halted in the bush to await the remaining askaris who had been sent out to scour the country, when I saw a boy coming down the hillside. The boy fled as soon as he had seen us. We caught him and found that he was Maw's boy. He stated that Mkwawa lay sick in the bush three hours away, at a place where, on the evening before he had shot his last companion for fear of betrayal. He, the boy, had run away that morning. Without waiting for my caravan I immediately started with one corporal, two soldiers and one Hehe, guided by the boy. After half an hour we heard a distant shot in a south-westerly direction. The boy thought that that was Mkwawa shooting game for him. At last he said we were near the camp. We took off our boots and kit and crawled on our stomachs to a baobab which I climbed, but I could see nothing. We crawled on over the stony ground to a dry watercourse, where we saw the camp at a hundred yards distance, and from there we crawled on to within 30 yards of the camp. We now saw two figures apparently asleep, one of whom the boy said was Mkwawa himself. As we could not proceed over the stoned unnoticed, we aimed, fired, and ran on. Both figures were dead, and we judged that the one identified by the boy as Mkwawa had been dead for about an hour or so. Mkwawa had clearly killed himself with the shot which we had heard and the muzzle of his carbine was burst and the rifle was charred by the fire beside him... The caravan soon caught us up; the Hehe immediately recognized Mkwawa and remained for long in silence" (Merkl report quoted by: Twining, E., 1954. The Twining report is quoted by: Winans, E.V., 1994, p. 228. Research into the availability of the Twining report conducted by the Royal Library of the Netherlands revealed that none of the German, English, American or Australian catalogues contained a reference to the report. According to Winans' interpretation the cutting off of the head was done for mere practical reasons - to serve as proof to claim the reward (p. 230).

969 That Merkl did deliver the head to Prince and received the reward is accounted in the published diary of Prince's wife: Prince, M.v., 1908, p. 179 where she reports of Merkl bringing the head of the dead Mkwawa (Quawa) to her husband, the governor. She also gives a precise description of the head. See on various explanations of what had happened with the head subsequently: Engstler, L., 1964, p. 127; Winans, E.V., 1994, p. 230 referring to: Department of State Publication 2724, Conference Series 92, The Treaty of Versailles and After, Annotations of the text of the Treaty, Washington 1947, p. 524); Hollander, B., 1959, p. 32; Baer, M., 2001, pp. 195-197. 
event, the head was not returned within the six month time-frame provided for in the Article. ${ }^{971}$

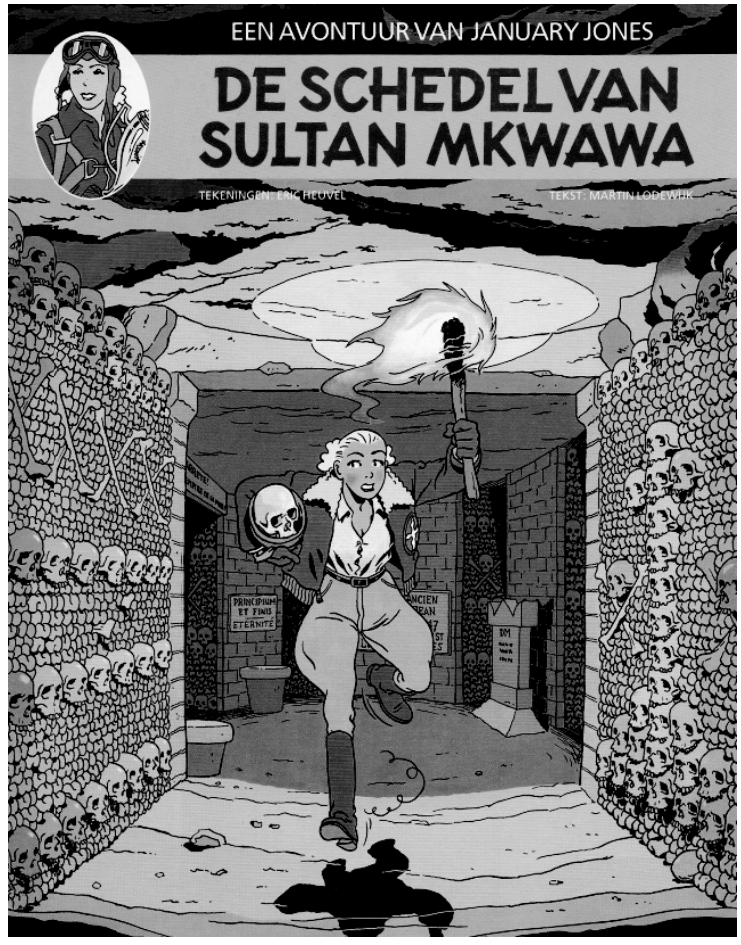

The skull of Mkwawa figures in one of the episodes of the comic 'Avonturen van January Jones' by Eric Heuvel: 'De schedel van sultan Mkwawa', 1990, published in Heemstede by Big Balloon. CRedhill V.O.F.

According to Moffett, the British administrator of Tanganyika Territory Sir Horace Byatt had asked the British Secretary of State immediately after the armistice in 1918 to

970 Germans Can't Return Sultan Makaua's Head; Say African Trophy Was Retaken Years Ago, 10 September 1920.

${ }^{971}$ Ibid. It is possible that the skull had been kept at the Völkerkundemuseum (Überseemuseum) in Bremen and that it was returned to the Hehe in June 1953. Cf.: http://www.mkwawa.com/vincent/return.asp (last visited 19 June 2009). The website also reports that a later inquiry in 1988 in the Überseemuseum whether the skull was indeed the skull of Mkwawa and whether it was returned to the Hehe had been answered rather evasive by its director Dr. Herbert Ganslmayr: "As I had not been at the Überseemuseum in 1954 I tried to get more information from still living collaborators about the return of the skull. In the meantime it has been confirmed that the information in 'The Times British Colonies Review autumn 1954' is correct. Further information or documentation are not to be found in the archives of the Oversee Museum." (KL: the reference to the 'The Times British Colonies Review autumn 1954' refers to: Twining, E., 1954. As mentioned already above none of the Dutch, German, English, American or Australian catalogues contained a reference to the report). 
negotiate about the return of the skull to the people of Uhehe. ${ }^{972} \mathrm{He}$ also reports that the wish of the Uhehe to have the skull returned had been voiced "almost [as] the very first request $(. .$.$) when the British assumed administrative charge at Iringa". { }^{973}$

Winans, a scholar investigating the question as to why a British high-ranked administrator placed such priority on the Uhehe's request suggests that the British "merely engaged in a political charade intended to establish good relations with the $[$ U]Hehe". 974 Winans comes to the conclusion that "the British did see the skull as an object but (...) the [U]Hehe were more concerned about their dead chief as a person". ${ }^{975}$ Put differently, the skull was not requested by the British as the remains of a once sentient human being but as a convenient object to enforce their political powers.

What might be even more interesting than the British motivation for including the provision in the Treaty of Versailles is the perception of the provision in academic literature. While the above analysis revealed that Art. 246 received only little academic attention it is nevertheless interesting to reflect upon the way the literature treated the request for the return of the skull of Mkwawa. Where Art. 246 is mentioned in the literature, it is in the context of Art. 245 and Art. 247 as articles "providing for the restitution of works of art"976 or "cultural property" 977 respectively as articles holding "specific obligation for Germany concerning cultural property".978 The literature does not hesitate to qualify Art. 246 as an article dealing with cultural objects. In fact, the literature review did not identify any publication reflecting upon the human quality of the skull. This is true both for older publications and publications written subsequent to the present rise in claims for the restitution of human remains as ancestral remains.

The second instance in which the above analysis touched upon the restitution of human remains concerns the case of the "Broken Hill" Skull. Strictly speaking the Broken Hill Skull does not qualify as "human remains" as it has been placed under the species name Homo Heidelbergensis which thus constitutes the last step before contemporary man in the imaginary evolutionary scheme. ${ }^{979}$ The fossilized skull was

\footnotetext{
${ }^{972}$ Moffett, J.P., 1958, pp. 61-62.

973 Ibid., p. 61. The British had attempted to invade German East Africa in 1914 but were repulsed. The change in power between Germany and Great Britain over the territory was confirmed in Art. 119 of the Versailles Treaty in which "Germany renounces in favour of the Principal Allied and Associated Powers all her rights and titles over her oversea possessions". The name of the territory was changed to Tanganyika. Cf.: German East Africa (2008). In Encyclopædia Britannica. Retrieved May 15, 2008, from Encyclopædia Britannica Online, http://www.search.eb.com/eb/article-9036569.

974 Winans, E.V., 1994, p. 235. See more in general on the motivation underlying returns of cultural objects: Savoy, B., 2009, p. 93.

975 Winans, E.V., 1994, p. 235. Cf.: McGuire, T., 1990, pp. 41-42 who characterises the skull as "a trophy signifying Britain's new dominion over the former German colony".

976 See, e.g.: Hollander, B., 1959, p. 32.

977 See, e.g.: Gattini, A., 1996, p. 5; Birov, V.A., 1998, p. 209; Keane, D., 2004, pp. 7-8.

978 Engstler, L., 1964, p. 126; Jenschke, C., 2005, p. 139; Odendahl, K., 2005, p. 164. An exception is Siehr who discusses only Artt. 245 and 247 but does not mention Art. 246: Siehr, K., 1993, pp. 116-117.

${ }^{979}$ Many researchers believe that the Homo beidelbergensis is the common ancestor of both Neanderthals and modern man, with the transition from $H$. heidelbergensis to $H$. sapiens having occurred in Africa between
} 
found in 1921 near the town of Kabwe, Zambia (formerly Broken Hill, Northern Rhodesia) in 1921. At that point Zambia was still a colony of the United Kingdom. 980 The skull was donated to the British Museum of Natural History where it remains until today. ${ }^{981}$

In 1972, the Zambian Government requested the British Government to have the skull returned. The request was turned downed with reference to the British Museum Act, which would not allow the disposal of the skull from the museum's collection. ${ }^{982}$ The British Government suggested providing Zambia with a replica. ${ }^{983}$ The Town Council of Kabwe, the city where the skull had been discovered and the Zambian Government insisted that the original skull was to be returned to Zambia. In 1974, the British Government reiterated its stand that the British Museum Act debarred the return of the skull. ${ }^{984}$

In 1991, Zambia requested the help from UNESCO's Intergovernmental Committee for Promoting the Return of Cultural Property to its Countries of Origin or its Restitution in case of Illicit Appropriation to have the skull returned from the United Kingdom. ${ }^{985}$ While the case was never officially filed with the Intergovernmental Committee this was not due to the fact that the claim concerned a fossilised skull rather than cultural property in the classical sense. Instead, the Intergovernmental Committee requested Zambia to first (re-) enter into bilateral negotiations with the United Kingdom. 986 While the documentation available does not clarify the result of these negotiations or why the request was never officially filed with the Intergovernmental Committee, the reaction of the Intergovernmental Committee is nevertheless instructive as to the perception of the claim. By requiring Zambia to explore the bilateral

300,000 and 200,000 years ago. See further: Homo heidelbergensis (2009). In Encyclopædia Britannica. Retrieved April 1, 2009, from Encyclopædia Britannica Online, http://www.search.eb.com/eb/article9040898; Kabwe cranium. (2008). In Encyclopædia Britannica. Retrieved December 9, 2008, from Encyclopædia Britannica Online,

http://www.search.eb.com/eb/article-9044260;

http://piclib.nhm.ac.uk/piclib/www/image.php?search=cat_1\&getprev=51522 (last visited 9.12.2008).

980 Zambia became an independent republic in 1964.

981 Mulongo, A.H., 1992, p. 103. See for the catalogue entry and image of the skull:

http://piclib.nhm.ac.uk/piclib/www/image.php?search=cat_1\&getprev=51522 (last visited 9.12.2008). The literature does not report on when and how the skull entered the collection.

982 Ibid. The British Museum Act applies also to the British Museum of Natural History (See s. 8(3) of the British Museum Act 1963 according to which "Sections 2 to 7 of this Act and the First Schedule thereto shall apply in relation to the Natural History Museum and the Trustees thereof as they apply in relation to the British Museum and the Trustees thereof (...)") See for an extensive analysis of the restrictions on the disposal of objects in public collections in the United Kingdom in chp. 3.\$2.II.

983 Greenfield, J., 1989, p. 159; Mulongo, A.H., 1992, p. 103.

984 Mulongo, A.H., 1992, p. 103.

985 Cf.: Report by the Intergovernmental Committee for promoting the return of Cultural Property to its Countries of Origin or its restitution in case of illicit appropriation on its Activities (1991-1993), 27 C/102, para. 5; Greenfield, J., 1989, p. 159.

986 Cf.: Report by the Intergovernmental Committee for promoting the return of Cultural Property to its Countries of Origin or its restitution in case of illicit appropriation on its Activities (1991-1993), 27 C/102, para. 5. 
negotiations first, UNESCO's Intergovernmental Committee indirectly acknowledged that the disputed skull qualified as cultural property as defined in Art. 3 of its Statute.987 Whether the fact that the fossilised skull was in fact the skull of a pre-modern Homo, and not from a modern Homo sapiens did play a role in the Intergovernmental Committee's considerations cannot be established. Its official report does not make mention of the age or attribution of the skull but speaks of skull without any further qualifications. ${ }^{988}$ Secondary literature discussing the request for the return of the Broken Hill Skull also discusses the case as a case dealing with the return of cultural property. ${ }^{989}$

Further to these two cases the general framework on the protection of cultural property is also relevant for human remains with regard to preventive protection against destruction and damage, as well as removals in the future. In the analysis above, we have seen that the definitions of cultural property employed by the 1954 Hague Convention and its protocols, as well as by the 1970 UNESCO Convention and the 1995 UNIDROIT Convention are extremely broad and subjective in that importance is to be defined by a State Party. Consequently, human remains may enjoy protection under these conventions. This point becomes clearer by reflecting upon the definitions of cultural property employed by the conventions.

\section{RELEVANCE OF CULTURAL PROPERTY LAW FOR HUMAN REMAINS: HUMAN REMAINS = CULTURAL PROPERTY?}

In order to reflect upon the question whether human remains qualify as cultural property we first need to recall the characterisation of cultural property this study relies on. As stated in the introduction, this study relies on Odendahl's characterisation (rather than definition) of cultural property. ${ }^{990}$ Based on her study on the multi-level system of the protection of cultural property, Odendahl arrived at the following characterisation of cultural property:

"[o]bjects qualifying as cultural property are corporeal objects, movable or immovable, either unique or consisting of collections / ensembles, which have been either created, changed or formed by human effort or which represent human cultural development, and which are accorded historical, artistic, scientific, architectural, archaeological or any other cultural value of different dimensions". 991

\footnotetext{
987 Goy, R., 1979, p. 969; Schulze, D., 1983, p. 26; Walter, B., 1988, p. 15 \& 96.

988 Cf.: Report by the Intergovernmental Committee for promoting the return of Cultural Property to its Countries of Origin or its restitution in case of illicit appropriation on its Activities (1991-1993), 27 C/102, para. 5.

989 See, e.g.: Walter, B., 1988, p. 14 who states that the "skull of the Broken Hill Man thus qualifies as cultural property". Greenfield, J., 1989, p. 159 speaks of a "paleontological claim". An exception is Engstler, L., 1964, p. 216 who states that human remains do not fall under "other archaeological objects" but does not motivate his statement.

${ }^{990}$ See above in the Introduction (\$2.III.2). Odendahl, K., 2005, p. 386.

991 Ibid., p. 387.
} 
Essentially, the characterisation consists of two elements: an anthropocentric element and a subjective element expressing an appreciation of the object concerned. With the designation "created, changed or coined by human effort or which represent human cultural development", the characterisation makes clear that cultural property cannot exist without an anthropocentric element. In other words, the object must have a link with human kind. In most cases, the relationship consists in the fact that the object has been created by a human being. This is, however, not a necessary condition. ${ }^{992}$ It is sufficient that an object has been changed by a human being (e.g. Palaeolithic Cave paintings) or has been formed by a human being (e.g. a natural science collection). Even an object that has not been created, changed or formed by a human being may represent human cultural development. This is in particular true for archaeological finds of organic origin, provided they allow the drawing of conclusions on the cultural development of human history. ${ }^{993}$

While any object that fulfils the requested anthropocentric element has the potential of qualifying as cultural property, the item must also be accorded "historical, artistic, scientific, architectural, archaeological or any other cultural value of different dimensions". ${ }^{994}$ According to Odendahl, the accordance of value to an object by a society (rather than a single human being) constitutes the most important element in the definition of cultural property. ${ }^{995}$ Consequently, the crucial criterion as to whether or not an object qualifies as cultural property is not an inherent characteristic of the object as such but is externally imposed. ${ }^{996}$

As an external subjective process, the accordance of cultural value to an object may be subject to change: an object can at one point in time be a simple tool and at a later stage qualify as cultural property of eminent value.997 Likewise, the cultural value accorded to an object can diminish over time. By referring to "culture value of different dimensions", Odendahl clarifies that it is irrelevant for the qualification as cultural property whether an object is of value (only) for a certain group of the population, a people, a continent or humanity as a whole. Neither is it crucial for the qualification of an object as cultural property that it is of outstanding cultural relevance: cultural property may be of outstanding, special, extraordinary or any other cultural value.998

\footnotetext{
992 Cf.: Schönenberger, B., 2009, p. 49.

993 Odendahl, K., 2005, pp. 387-388.

994 The same approach has been adopted by UNESCO in its Recommendation for the Protection of Movable Cultural Property as adopted by the UNESCO's General Conference on 28 November 1978. According to its first paragraph, “'movable cultural property' shall be taken to mean all movable objects which are the expression and testimony of human creation or of the evolution of nature and which are of archaeological, historical, artistic, scientific or technical value and interest (...)".

995 Odendahl, K., 2005, p. 388.

996 Cf.: Schönenberger, B., 2009, pp. 48-51. Schönenberger discusses a number of elements, such as age, origin, uniqueness, authenticity, aesthetic or financial value and comes to the conclusion that none of these elements can serve as defining element singling out cultural property from other goods.

${ }^{997}$ Cf.: Jenschke, C., 2005, p. 31 gives the example of an antique goblet.

998 Cf.: Müller-Katzenburg, A., 1996, p. 140 This interpretation is also supported by the analysis of O'Keefe on the definition of cultural property under the 1954 Hague Convention for the Protection of Cultural
} 
Consequently, territorial and qualitative dimensions are irrelevant to the qualification of an object as cultural property. They become relevant when it comes to the question of whether an object falls under the scope of application of a specific legal norm.999

Comparing the characterisation of cultural property as formulated by Odendahl with the characteristics of human remains in public collections, it becomes clear that human remains satisfy the two main criteria of cultural property: the presence of an anthropocentric element and the subjective element of possessing "historical, artistic, scientific, architectural, archaeological or any other cultural value of different dimensions". The anthropocentric element of human remains in public collections does not lie in the fact that the remains themselves are of human origin. Rather, the anthropocentric element is given by the changing of the remains by another human being; its inclusion in a collection is a reflection of the cultural development of humanity. ${ }^{1000}$ With regard to worked human remains such as a Tibetan skull cup (kapala), an Egyptian mummy or a preserved, tattooed head of Maori origin (Toi Moko), the identification of the anthropocentric element is evident: not only have these remains been changed by the skilful work of other human beings, they have also been included in collections where they give evidence of human beliefs and developments. ${ }^{1001}$ While most human remains in public collections have to some extent been "worked" in the sense of having been preserved against decay, it is less obvious to qualify non-worked human remains, e.g. skeletal remains, as cultural property. However, also non-worked human remains reflect the cultural developments of humankind and possess a cultural value ranging from historical to scientific or archaeological value. ${ }^{1002}$ In contrast to worked human remains, such as a mummy, which reflects the cultural values and mythology of the ancient Egyptians, unworked human remains mainly reflect the cultural values of those who acquired them. They bear witness to historical

Property in the Event of Armed Conflict. While its first Article seems to introduce a rather high standard by requiring an object to be of "great importance to the cultural heritage of every people"998, O'Keefe came to the conclusion "that the Convention applies to all movable (...) property considered by each respective state to form part of its national cultural heritage". O'Keefe, P., 1999b, p. 36.

999 Odendahl, K., 2005, p. 388.

1000 Cf.: Ibid.

1001 Mummies are the most frequently cited example of human remains qualifying as cultural property. See, e.g.: Hipp, A., 2000, pp. 10-11; Odendahl, K., 2005, p. 388. See also the Recommendation for the Protection of Movable Cultural Property as adopted by the UNESCO's General Conference on 28 November 1978, para. 1 (a) (iii) where mummies are explicitly listed as 'movable cultural property'. Disagreeing: Engstler, L., 1964, p. 216 who states that human remains such as Egyptian Mummies and remains from Pompeii constitute very important witnesses of the past but do not fall under "other archaeological objects" with regard to the 1954 Hague Convention. While he expresses his regret from the point of protection, he does not provide reasoning to support his conclusion. In theory, Engstler's understanding of a cultural object as an "individual creative activity by a human being, as well as any object from the hand of humans that are historically relevant" (p. 13) does not preclude human remains, at least those remains that have been modified by human skill and effort.

1002 Odendahl, K., 2005, pp. 387-388. Consenting: Fraoua, R., 1985, p. 10; Greenfield, J., 1989, p. 159; Prott, L.V., 1989, p. 225; Prott, L.V. / O'Keefe, P.J., 1992, pp. 307-308; Schorlemer, S.v., 1992, pp. 51 \& 82; Fechner, F.G., 1998, p. 380. 
developments such as colonialism and scientific theories, such as physical anthropology. Moreover, their (continued) presence in public collections bears witness to Western perceptions of death and the human body or what remains of it many years after a person's death. ${ }^{1003}$

The finding that human remains fall under the notion of cultural property is confirmed in secondary literature. This is not only the case with regard to the literature discussing (other) specific cases of requests for the return of human remains ${ }^{1004}$; is also true for more general discussions of the concept of cultural property. ${ }^{1005}$ The perception of human remains in public collections as cultural property does, however, not exclude other perceptions. Just like the accordance of cultural value to an object is subject to changes in time ${ }^{1006}$ it does not exclude multiple perceptions of an object at any point in time: while human remains qualify as cultural property from a Western perception; they may at the same time qualify as ancestral remains or simply the remains of a once sentient person.

The finding that human remains can represent various values while at the same time constituting cultural property brings us to the following conclusive remarks and questions: first, rather than giving rise to obligations to repatriate human remains, the various constellations of public international law are relevant for human remains in public collections in that they protect them against destruction and damage in times of war as well as against removal from the collections. Consequently, claimants seeking the repatriation of human remains cannot rely on rights to restitution under the traditional framework but rather have to face the fact that the framework(s) are reinforcing the status quo. It is, however, possible that one of the instruments adopted more or less recently at the international level has introduced a new legal basis for the return of human remains. Whether this is indeed the case will be scrutinised in the following section.

1003 "How to treat dead bodies may appear to be a trivial moral question compared with al the seemingly vital problems that confront the living. But, from a theoretical point of view, few are as illuminating of our self-conception and self-understanding", Kass, L.R., 1985, p. 24.

1004 See, e.g. the return by the museum of Archaeology and Ethnology at Cambridge, of the embalmed penis and testicles of Kabaka Mutesa I of Buganda to Uganda when that country became independent. See further: Daniel, G., 1982, p. 4; Prott, L.V. / O'Keefe, P.J., 1989, p. 885. Daniel speaks of the "rather special objects relating to the Kabaka of Buganda".

1005 See, e.g.: Prott, L.V. / O'Keefe, P., 1984, para. 454; Prott, L.V. / O'Keefe, P.J., 1989, chp. 16; Greenfield, J., 1996, pp. 132-135; Jenschke, C., 2005, p. 32. Cf.: Schönenberger, B., 2009, p. 47. Implicitly agreeing: Müller-Katzenburg, A., 1996, pp. 139-140. See further, by means of examples, the following articles published in journals dedicated to the subject of cultural property law and to the subject of arts antiquities and the law: O'Keefe, P., 1992; Zimmerman, L.J. / Clinton, R.N., 1999; Woodhead, C., C., 2004; Shelbourn, C., 2006; Bristow, M., 2008; Frigo, M., 2008. Cf.: also Marc-André Renold during his lecture at the Seminar for advanced Studies in Public and Private International law at the Hague Academy on the International Protection of Cultural Property on 12 February 2008, in which he discussed the return of human remains as "cultural property but not in classical form".

${ }^{1006}$ Cf.: Odendahl, K., 2005, p. 388. 


\section{RECENT DEVELOPMENTS: PRINCIPLES, RESOLUTIONS AND DEClaRATIONS ADOPTED BY THE INTERNATIONAL COMMUNITY IN REACTION TO THE RE- EMERGENCE OF THE DEBATE ON HUMAN REMAINS}

In this section we will address the developments at the international level since the beginning of the 1990s in response to the emergence of claims for the repatriation of human remains. In the light of the result of the analysis of public international law according to which claimants cannot rely on rights to restitution or return as they presently exist under the frameworks, the accords, codes and declarations that have been agreed upon at the international level in response to the emergence of claims are even more important when compared to the principles that have been adopted with regard to Nazi spoliated art. After all, one of the main problems for claimants of Nazi spoliated art is the passage of time as a consequence of which they can no longer rely upon the restitution rights once granted to them under public international law. With regard to human remains no such rights have been recognised in the past. Consquently, the main focus of the following analysis is whether the instruments introduced at the international level introduce legally enforceable rights for the return of human remains.

\section{The Vermillion Accord on Human Remains}

The first instrument dealing with human remains at the international level was the Vermillion Accord on Human Remains. ${ }^{1007}$ The Vermillion Accord, which has been shortly introduced above, was adopted in 1989 by the World Archaeological Congress. ${ }^{1008}$ As an instrument dealing with the treatment of human remains by archaeologists, the Vermillion Accord is not directly relevant for claims for the return of human remains from public collections. However, as the first instrument adopted with regard to the treatment of human remains and given its relevance in tilting the debate on the treatment of human remains from the intra-national to the international level, it is nevertheless included in this overview.

The Vermillion Accord consists of six paragraphs asking for respect for different interests with regard to the treatment of human remains. According to the first principle, respect for human remains shall be granted to all, irrespective of origin, race, religion, nationality, custom and tradition. The following three principles seek respect for the wishes of the dead with regard to disposition, for the wishes of the local community and of relatives and for scientific research. Consequently, the Vermillion Accord not only stresses the need to respect mortal remains and the wishes of the local communities during and after archaeological excavations; it also recognises the value of scientific research. The fifth principle then brings the previous four together in stating that agreement on the disposition of human remains must be the result of mutual

1007 Cf.: Working Group on Human Remains, 2003, p. 176.

1008 See above chp. 2.\$2.II.2. 
respect for the interests of the communities, as well as the interests of science and education. The last paragraph, rather than introducing a new principle, expresses the hope that agreements found on mutual and express recognition of the different interests will lead to acceptable agreements for all parties that will be honoured in the future. ${ }^{1009}$

The fact that the Vermillion Accord not only stresses the need to respect the dead and the interest of local communities but instead balances these interests with scientific ones stems from the fact that it was adopted by the World Archaeological Congress as a non-governmental organisation. While membership of the World Archaeological Congress is open to the general public it is first and foremost an organisation representing the interests of archaeologists. The appeal of the Vermillion Accord to respect certain interest groups with regard to human remains is hence in first instance directed at archaeologists. However, by stressing also the need for respect for scientific research the Vermillion Record also seeks to appeal to local communities.

With regard to the present analysis of principles applicable to the repatriation of human remains from public collections we should recall the fifth principle according to which agreement on the disposition of human remains must be based on respect for the interests of local communities, as well as for the interests of science and education. While the fifth principle deals with the disposition of human remains its relevance with regard to the disposal or repatriation from public collections is more indirect than might appear at first sight. After all, the decision upon disposition of human remains in the archaeological context of the Vermillion Record is relevant for the inclusion of human remains in public collections rather than their disposal: in the past, the inclusion of excavated human remains, especially indigenous ones, in public collections occurred rather automatically. It is at this point that the fifth principle becomes relevant in that it requires mutual agreement on the treatment of human remains subsequent to excavation and (possibly) research. Only where local communities and archaeologists agree that the disposition of the remains should consist of housing them in a public collection will the remains be included in a collection, at least in as far as the Vermillion Accord is observed. Consequently, the Vermillion Accord allows local communities to veto the inclusion of human remains in a public collection. While one could argue that the disposition of human remains already included in public collections, i.e. their disposal, should also be based upon mutual agreement between scientists and local communities, such a proposal would not take into account that the remains were in most cases included in the collections without consent in the first place. Also, the power to veto a decision would not lie with local communities but would shift to scientists.

1009 See further on the Vermillion Accord: Bulmer, S., 1991; Hubert, J., 1992, pp. 110-113; Watkins, J., et al., 1995. 


\section{MataAtua Declaration}

The Mataatua Declaration on Cultural and Intellectual Property Rights of Indigenous Peoples (hereinafter: "the Mataatua Declaration") was adopted as the result of the First International Conference on the Cultural and Intellectual Property Rights of Indigenous peoples. The conference was hosted in June 1993 by nine iwi of the Mataatua (Bay of plenty Region of Aotearoa New Zealand).

The Mataatua Declaration deals with various issues, including cultural property, but essentially asks members of the United Nations to recognize the rights of indigenous peoples to control in all respects their cultural intellectual property and to be the inherent beneficiaries of such property. ${ }^{1010}$ It is founded on the understanding that national laws failed to protect their property. Instead, national laws should recognise that property rights are multigenerational, that there is a need for retroactive action to be taken to protect "historical as well as contemporary works" and that biological and botanical knowledge requires specialized treatment. ${ }^{1011}$

In the section holding recommendations to states, national and international agencies, the Mataatua Declaration contains two provisions that are relevant with regard to the repatriation of objects from public collections. Recommendation 2.12 states that: "[a]ll human remains and burial objects of indigenous peoples held by museums and other institutions must be returned to their traditional areas in a culturally appropriate manner". If one compares the recommendation on human remains to Recommendation 2.14 dealing with indigenous cultural objects it becomes evident that the return of human remains is accorded greater importance: whereas the recommendation with regard to the return of human remains is formulated uncompromisingly Recommendation 2.14 dealing with cultural objects only states that they must be offered back to their traditional owners. ${ }^{1012}$ The appeal to return all human remains from museums and other institutions and to offer other cultural objects is complemented with Recommendation 2.13 according to which: "[m] useums and other institutions must provide, to the country and indigenous peoples concerned, an inventory of any indigenous cultural objects still held in their possession".

In recommending the return of all human remains of indigenous peoples held by museums and other institutions to their traditional areas, the Mataatua Declaration adopted a very comprehensive and uncompromising approach that starts from the mere existence of human remains in public collections rather than from requests made for the return of specific remains. The Mataatua Declaration has been presented to the United Nations Working Group on Indigenous Peoples (11 th session).

1010 Cf.: Ziff, B.H. / Pratima, V.R., 1997, p. 247.

1011 Cf.: Ibid.

1012 Recommendation 2.14 reads: "Indigenous cultural objects held in museums and other institutions must be offered back to their traditional owners". 


\section{THE ICOM CODE}

The ICOM Code of Professional Ethics (hereinafter: the ICOM Code) was adopted unanimously by the 15th General Assembly of ICOM (The International Council of Museums) in Buenos Aires, Argentina on 4 November 1986. It was amended by the 20th General Assembly in Barcelona, Spain on 6 July 2001, retitled ICOM Code of Ethics for Museums, and revised by the 21st General Assembly in Seoul, Republic of Korea on 8 October 2004. As an instrument adopted by a non-governmental organisation, the ICOM Code cannot bind national Governments. In can, however, serve as guideline for museums in as far as the behaviour recommended is in line with the national laws applicable to public collections.

With regard to the recommended treatment of human remains, the original 1986 version of the ICOM Code touched upon their acquisition, housing, research and display. According to para. 6.7:

"[w]here a museum maintains and /or is developing collections of human remains and sacred objects, these should be securely housed and carefully maintained as archival collections in scholarly institutions, and should always be available to qualified researchers and educators, but not to the morbidly curious. Research on such objects and their housing and care must be accomplished in a manner acceptable not only to fellow professionals but also to those of various beliefs, including particular members of the community, ethnic or religious groups concerned. Although it is occasionally necessary to use human remains and other sensitive material in interpretative exhibits, this must be done with tact and with respect for the feelings for human dignity held by all peoples".

What is striking about the 1986 ICOM Code, compared with the later amendments is that it does not contain any reference to the return of human remains. Also, it does not emphasize the beliefs and feelings of the members of the community, ethnic or religious groups concerned but mentions them secondary to the beliefs of museum professionals / researcher and as part of various beliefs only.

When the ICOM Code was amended in 2001, the paragraph on human remains was complemented with an additional sentence explicitly dealing with the removal of human remains from display and requests for the return of human remains. According to the renumbered paragraph 6.6, last sentence:

"[r] equests for removal from public display of human remains or material of sacred significance from the originating communities must be addressed expeditiously with respect and sensitivity. Requests for the return of such material should be addressed similarly. Museum policies should clearly define the process for responding to such requests".

While paragraph 6.6 explicitly addresses claims of the return of human remains it does not take a stand on whether or not the remains must be returned. All it asks museums to do is to address such claims with respect and sensitivity and to define their policy as to how they will react to such claims. In the present version of the ICOM Code, as amended in 2004, references with regard to the acquisition, housing, research, display and return of human remains are split over four paragraphs: Para. 2.5; para. 3.7; 
para. 4.3 and para. 4.4. Furthermore, a section has been introduced dealing with respect for source communities (paras. 6.5-6.8). Paragraph 2.5 deals with the acquisition of human remains and makes acquisition subject to appropriate housing of the remains:

"[c]ollections of human remains and material of sacred significance should be acquired only if they can be housed securely and cared for respectfully. This must be accomplished in a manner consistent with professional standards and the interests and beliefs of members of the community, ethnic or religious groups from which the objects originated, where these are known".

While paragraph 2.5 still mentions professional standards first, it does single out the interests and beliefs of members of the community, ethnic or religious groups from which the objects originated rather than subsuming them under "various beliefs" as it was done in the 1986 and the 2001 versions. However, the consideration of the beliefs of the source community are not absolute in that they have to be taken into account only "where known". The same principle applies to researching human remains (para. 3.7):

"[r]esearch on human remains and materials of sacred significance must be accomplished in a manner consistent with professional standards and take into account the interests and beliefs of the community, ethnic or religious groups from whom the objects originated, where these are known".

With regard to the displaying of human remains paragraph 4.3 again reiterates that professional standards and the interests and beliefs of the source community must be taken into account. Furthermore, the provision alludes to "feelings of human dignity held by all peoples":

"[h] uman remains and materials of sacred significance must be displayed in a manner consistent with professional standards and, where known, taking into account the interests and beliefs of members of the community, ethnic or religious groups from whom the objects originated. They must be presented with great tact and respect for the feelings of human dignity held by all peoples".

Interestingly, paragraph 4.4 dealing with requests to remove human remains from public display or to have them returned does not emphasise the interests and beliefs of the source community but speaks more vaguely of respect and sensitivity:

"[r] equests for removal from public display of human remains or material of sacred significance from the originating communities must be addressed expeditiously with respect and sensitivity. Requests for the return of such material should be addressed similarly. Museum policies should clearly define the process for responding to such requests".

Consequently, if one compares the provisions on human remains of the 2004 version of the ICOM Code with the 2001 version one realises that greater attention is paid to the interests of source communities. This tendency is furthermore confirmed if one compares the provision with the general provision on the return of cultural property as 
contained in para. $6.2^{1013}$ and by the inclusion of a new section titled 'Respect for Communities served'. According to its paragraph 6.7 the interests of contemporary communities should be taken into account in the use of collections:

"[m]useum usage of collections from contemporary communities requires respect for human dignity and the traditions and cultures that use such material. Such collections should be used to promote human wellbeing, social development, tolerance, and respect by advocating multisocial, multicultural and multilingual expression".

In conclusion, since its introduction in 1986 and over its course of amendments, the ICOM Code has developed towards greater emphasis of the interests and beliefs of source communities. However, with regard to the treatment of human remains these interests are not the only ones that inform the decision making process. The ICOM Code also takes into account professional standards of the museum world. With regard to the actual return of human remains paragraph 4.4 of the ICOM Code is less explicit in recognising the interest of source communities but speaks more vaguely of responding with respect and sensitivity.

\section{Convention for the Safeguarding of the Intangible Cultural Heritage}

In 2003 UNESCO adopted the Convention for the Safeguarding of the Intangible Cultural Heritage. ${ }^{1014}$ The convention entered into force on 20 April 2006.1015 While the convention does not deal with the return of human remains as such, it is nevertheless relevant in the present context as will be set out in the following.

The notion of intangible cultural heritage (ICH) emerged in the 1990s to counterbalance the normative efforts that had so far mainly focused on the protection tangible aspects of culture, both movable and immovable. According to Art. 2 of the convention the "intangible cultural heritage" means the practices, representations, expressions, knowledge, skills - as well as the instruments, objects, artefacts and cultural spaces associated therewith - that communities, groups and, in some cases, individuals recognize as part of their cultural heritage. This intangible cultural heritage, transmitted from generation to generation, is constantly recreated by communities and groups in response to their environment, their interaction with nature and their history, and provides them with a sense of identity and continuity, thus promoting respect for cultural diversity and human creativity. For the purposes of this Convention, consideration will be given solely to such intangible cultural heritage as is compatible

1013 Para. 6.2 on the return of Cultural Property reads: "Museums should be prepared to initiate dialogues for the return of cultural property to a country or people of origin. This should be undertaken in an impartial manner, based on scientific, professional and humanitarian principles as well as applicable local, national and international legislation, in preference to action at a governmental or political level".

1014 Convention for the Safeguarding of the Intangible Cultural Heritage, Paris, 17 November 2003, UNESCO Doc.MISC/2003/CLT/CH/14.

1015 Ibid., Art. 34. As of 2 November 2008, the Convention had 104 State Parties. 
with existing international human rights instruments, as well as with the requirements of mutual respect among communities, groups and individuals, and of sustainable development.

One of the domains in which the intangible cultural heritage manifests itself concerns social practices, rituals and festive events (Art. 2 (2) (c)). Amongst these social practices and rituals are burial ceremonies and funeral rituals. ${ }^{1016}$ The recognition of certain burial ceremonies and funeral rituals as ICH and their safeguarding under the convention does not result in the repatriation of all human remains belonging to the source community. It does, however, add authority to the relevance of protecting social practices, including burial ceremonies by ensuring greater viability of ICH by documenting and promoting it, in particular by means of a listing system. ${ }^{1017}$

\section{United nations Declaration on the Rights of Indigenous Peoples}

The UN Declaration on the Rights of Indigenous Peoples was adopted by the General Assembly on 13 September 2007.1018 It had taken more than a decade to reach the required consens. ${ }^{1019}$ The adoption of the declaration, which consists of 46 Articles including one article dealing with the repatriation of human remains, took so long due to the polarization between indigenous and state positions, particularly with regard to the question for self-determination, collective rights and territorial rights. ${ }^{1020}$ With regard to the provision dealing with the repatriation of human remains consensus was not so difficult to reach. ${ }^{1021}$ According to Art. 12:

"1. Indigenous peoples have the right to manifest, practice, develop and teach their spiritual and religious traditions, customs and ceremonies; the right to maintain, protect, and have access in privacy to their religious and cultural sites; the right to the use and control of their ceremonial objects; and the right to the repatriation of their buman remains.

\footnotetext{
1016 See: http://www.unesco.org/culture/ich/index.php?pg=55 (last visited 15.12.2008). 1017 See: Art. 2(3).

1018 United Nations Declaration on the Rights of Indigenous Peoples, 13 September 2007, (A/RES/61/295). The Declaration on the Rights of Indigenous Peoples was adopted by the General Assembly by a a majority of 144 states in favour, 4 votes against (Australia, Canada, New Zealand and the United States) and 11 abstentions (Azerbaijan, Bangladesh, Bhutan, Burundi, Colombia, Georgia, Kenya, Nigeria, Russian Federation, Samoa and Ukraine).

1019 The UN Working Group on Indigenous Populations had agreed on the final text of the draft UN Declaration on the Rights of Indigenous Peoples Approved on 26 August 1994, UN Doc.E/CN.4/Sub.2/Res/1994/56. Cf.: Vrdoljak, A.P., 2008, p. 73.

${ }^{1020}$ Cf.: Chernela, J., M., 2006, p. 487; Vrdoljak, A.P., 2008, pp. 73-74.

1021 See: Report of the working group established in accordance with Commission on Human Rights resolution 1995/32 of 3 March 1995 on its eleventh session (E/CN.4/2006/79 - 22 March 2006), 2006, pp. 6-7. Cf.: Vrdoljak, A.P., 2008, p. 76.
} 
2. States shall seek to enable the access and/or repatriation of ceremonial objects and human remains in their possession through fair, transparent and effective mechanisms developed in conjunction with indigenous peoples concerned." ${ }^{1022}$

Art. 12 explicitly mentions the 'right to the repatriation of their human remains'. The fact that this is remarkable becomes evident if one compares the wording of the article with that of Art. 11 dealing with cultural traditions and customs. According to the final version of the article as adopted:

"1. Indigenous peoples have the right to practise and revitalize their cultural traditions and customs. This includes the right to maintain, protect and develop the past, present and future manifestations of their cultures, such as archaeological and historical sites, artefacts, designs, ceremonies, technologies and visual and performing arts and literature.

2. States shall provide redress through effective mechanisms, which may include restitution, developed in conjunction with indigenous peoples, with respect to their cultural, intellectual, religious and spiritual property taken without their free, prior and informed consent or in violation of their laws, traditions and customs".

While Art. 11 mentions the right to "past manifestations of indigenous cultures, such as artefacts" as well as the introduction by States of "effective mechanisms, which may include restitution" the article does not speak of a right to restitution. While the reference to such a right had been included in the 1993 Draft UN Declaration ${ }^{1023}$ it was removed from the provision due to resistance of former metropolitan powers and market states. ${ }^{1024}$

In a similar fashion, Art. 12 does not provide for a right to the restitution of the right to the use and control of their ceremonial objects but makes mention only of the "right to the use and control of their ceremonial objects". ${ }^{1025}$ With regard to human remains, however, the attempts of some States to compromise the "right to the repatriation of their buman remains" with protection of third-party rights of scientists or public collections were unsuccessful. ${ }^{1026}$ Art. 12 clearly speaks of a right to the repatriation of human remains.

The finding that the UN Declaration on the Rights of Indigenous Peoples explicitly speaks of a right for the repatriation of human remains must of course be squared with the fact that the declaration is not legally binding. However, the long drafting period of

\footnotetext{
1022 (Emphasis added).

1023 Ex-Art. 12, 1993 Draft UN Declaration reads: "Indigenous peoples have the right to practise and revitalize their cultural traditions and customs. This includes the right to maintain, protect and develop the past, present and future manifestations of their cultures, such as archaeological and historical sites, artifacts, designs, ceremonies, technologies and visual and performing arts and literature, as well as the right to the restitution of cultural, intellectual, religious and spiritual property taken without their free and informed consent or in violation of their laws, traditions and customs" (Emphasis added).

1024 Cf.: Vrdoljak, A.P., 2006, p. 268.

1025 Cf.: Ibid.

1026 See: UN Doc. E/CN.4.2002/98, para. 51; UN Doc. E/CN.4/2004/81, para. 54. Cf.: Ibid.
} 
the declaration and the tug-of-war with regard to the formulation of the provisions, in the present context with regard to rights to repatriation and restitution are good indications that the declaration nevertheless influences legal and political reality as will be further addressed below.

\section{INTERMEDIARY CONCLUSIONS ON THE CASE OF HUMAN REMAINS}

In the previous section four instruments have been discussed that touch upon the question of the repatriation of human remains from public collections. None of the five instruments introduces new legal rights for the return of human remains. The first three instruments were all adopted by actors that do not have the capacity to agree binding legal treaties under international law. Despite the fact that public international law has come to recognise a broader concept of international legal personality than equating it with state actors only, the privilege of concluding treaties is still reserved to states and to a lesser extent to international organisations in the sense of inter-state organisations. Non-governmental organisations as the World Archaeological Congress and the International Council of Museums (ICOM) or indigenous peoples in case of the Mataatua Declaration cannot conclude treaties under public international law.

The UN Declaration on the Rights of Indigenous Peoples and the Convention for the Safeguarding of the Intangible Cultural Heritage do not create rights that exist directly under international law either. While the United Nations is an international organisation rather than an NGO and possesses, in the form of the Security Council, an organ that can create binding legal rules, declarations adopted by the General Assembly are not legally binding. ${ }^{1027}$ Consequently, different from the intra-national solutions adopted in the United States and the state of Tasmania the instruments adopted at the international level do not introduce legally enforceable rights for the repatriation of curated human remains. ${ }^{1028}$ As for the Convention for the Safeguarding of the Intangible Cultural Heritage, it requires its State Parties to undertake necessary measures to ensure the safeguarding of the intangible cultural heritage present in its territory. It does not create legally enforceable rights, let alone provide for rights pertaining to the return of human remains.

Further to this finding with regard to the legal status of the instruments, the chronological analysis of these instruments also revealed the following two trends: first, the analysis revealed that the instruments accord greater weight and legitimacy to the

1027 Cf.: Malanczuk, P. / Akehurst, M.B., 1997, p. 107.

1028 An interesting question exceeding the scope of the present thesis but meriting further research is whether a right to the repatriation of human remains might be construed as part of the right to selfdetermination. For a long time cultural (human) rights have attracted much less attention and conceptual elaboration compared with other human rights. See further on human rights, minorities' rights, and most importantly with regard to the repatriation of human remains, self-determination, e.g.: Wyss, M.P., 1992, p. 192; Sjouke, P.S., 1999; Pritchard, S., 2001; Chamberlain, K., 2003; Odendahl, K., 2005, p. 204-208; Francioni, F., 2008, p. 1. 
return of human remains in comparison to the restitution of cultural objects. Whereas the instruments remain somewhat reserved with regard to the restitution of cultural property, both the Mataatua and the UN Declaration on indigenous Rights state the right to the return of human remains in an uncompromised manner. From this follows the treatment of human remains and cultural property in separate provisions. ${ }^{1029}$

Secondly, the analysis revealed a polarisation with regard to the question whether the repatriation of human remains should be subject to the recognition rights of third parties such as scientists or curators. The Mataatua Declaration and the UN Declaration of indigenous Rights chose for an uncompromising approach not taking third party interests into account. While this is not surprising with regard to the Mataatua Declaration as a declaration by indigenous peoples this is to some extent remarkable with regard to the UN Declaration on indigenous Rights as product of an intergovernmental forum. The Vermillion Accord and the ICOM Code, on the other hand, do acknowledge third party rights, i.e. the interests of their drafters being archaeologists respectively museum professionals.

\section{§. CONCLUSIONS FOR CHAPTER 2}

\section{THE STATUS AND RELEVANCE OF SOFT LAW}

In the previous two sections dealing with Nazi spoliated art and human remains respectively we have seen that an array of declarations, principles, resolutions, accords etc. have been adopted that deal with the return of these objects to former owners, heirs, indigenous peoples or other groups of claimants. All of the instruments discussed share that they are not legally binding and as such do not introduce new legal rights and obligations to claim / return cultural objects.

The fact that the instruments do not create legally binding rules does not mean that they constitute merely "legal surrealism". ${ }^{1030}$ In order to understand the impact nonbinding instruments can have, it is instructive to first consider the reasons for countries to opt for non-binding insturments rather than binding legal agreements. ${ }^{1031}$ First, nonbinding agreements allow countries to gradually become familiar with the proposed

1029 Cf.: Thornberry, P., 2002, pp. 25-26 \& 370-376; Vrdoljak, A.P., 2006, p 267.

1030 Frigo, M., 2004, p. 70. Also: Alda, K., 2006: "Although none of the above acts and declarations formally goes beyond the borders of what is commonly defined as "soft law", it would not be wise to underestimate their value and effects on both diplomatic and judicial practice in many respects". Another indication of the relevance of non-legally binding instruments is the impact of the 1943 London Declaration as discussed in chp. 1.\$1.V. In fact, the London Declaration was not only referred to in the context of the restitution following WWII but was used as authority also in the debate on the return of cultural objects to their territories of origin. Cf.: below in chp. 1. 33.I where the UNESCO Resolution 3.428 is discussed.

${ }^{1031}$ It should be pointed out that the following statements apply first and foremost to instruments that have been adopted at the intergovernmental level. While non-binding instruments adopted by non-governmental organisations or interest groups can also affect the legal and political realm, their impact is even more indirect. 
standards before being confronted with the adoption of enforceable rules. Consequently, non-binding agreements allow for a greater basis for negotiation and achieving consensus on issues that are particularly complex or sensitive. ${ }^{1032}$ Secondly, these instruments do not require formal ratification, therewith having a more direct and rapid influence on the practice of states than treaties. ${ }^{1033}$ Thirdly, non-binding agreements can have legitimising effects for government action and can prepare the grounds for national legislative action. This is particularly true in the globalised society we live in and where documents are easily spread by media, especially the Internet. At the same time, these aspirational non-commitments often capture the imagination of citizens, NGOs, organisations treat these instruments as if they were legally binding instruments. In turn, this reception again impacts Governments who need to observe the wishes of citizens. ${ }^{1034}$ Where a Government wishes to deviate from the principles it must justify its choice. ${ }^{1035}$ This last aspect is in fact already an explanation for the effectiveness of instruments like declarations, principles, and resolutions. In spite of not being legally binding and having a more indirect effect these instruments nevertheless require signatory states to show a certain level of moral and political commitment.

Non-binding principles, resolutions, and declarations are often characterised as "soft law". ${ }^{1036}$ From a legal perspective the term "soft law", as distinct from binding "hard law" is not very helpful. ${ }^{1037}$ As of today there exists controversy on the existence of "soft law" and on how to define it. Legal scholars have tried to grasp the concept of soft law as the "linkage of a subject of international law to a norm, which it has created or supported. This linkage resembles a legally binding effect, but does not posses any binding effect itself", 1038 or as an "emerging patterns of behaviour". ${ }^{1039}$ Another attempt seeks to distinguish soft law from gentlemen's agreements, inter-agency agreements, and rules within treaties that are too vague to impose a legally binding effect and therefore only serve as explanatory of the binding rules. ${ }^{1040}$

\footnotetext{
1032 Cf.: Andorno, R., 2007.

1033 Bothe, M., 1980, pp. 91-92; Guzman, A.T., 2005, p. 592. any case dealing with spoliated art and as an argument for full physical restitution.

1035 Jayme, E., 2002, p. 248. See further: Dunné, J.M.v., 1996, pp. 263-264. 384.

${ }^{1037}$ Malanczuk, P. / Akehurst, M.B., 1997, p. 54; Meyer, T., 2008, p. 6.

1038 Ipsen, K., 2004, p. 251.

1039 Hillgenberg, H., 2004, p. 499.

1040 Cassese, A., 2005, p. 196.
}

1034 Cf.: Bothe, M., 1980, p. 91. From my working experience in the art market, especially in the segment dealing with restitution claims I can confirm the effect that non-binding principles give rise to expectations and trigger a certain pressure for compliance especially with regard to the Washington Principles. The Washington Principles are frequently cited as argument that a work of art must be restituted. Interesting to see was also that the practice developed its own understanding and scope of application of the principles: rather than restricting their referencing to cases of Nazi-confiscated works of art the principles were cited in

1036 Cf., with regard to the Washington Principles,: Rascher, A.F.G., 1999, p. 341; Frigo, M., 2004, p. 70. Cf., with regard to Resolution 1205, the Vilnius Declaration as well as the resolution of the European Parliament dated 17 December 2003,: Hartung, H., 2005, pp. 102-124; Selle, C.v. / Szchunke, U., 2006, p. 
This digest of definitions and concepts of soft law clearly shows that there exist different understandings of the characteristics and roles of soft law. In particular one can distinguish two different concepts of soft law within the various definitions: first, soft law as a term referring to rules of international law that are normative rules of law, but whose content is flexible and vague. Instead of establishing clear-cut norms the rules that fall under this first concept of soft law introduce incremental obligations to undertake certain extertions or relative obligations. Areas of law where this concept of soft law can be frequently denoted are non-traditional areas of international law, such as the protection of the environment and human rights. ${ }^{1041}$

Under the second concept, soft law is understood as a description of "values, guidelines, ideas and proposals that may develop into rules of international law but have not yet done so". ${ }^{1042}$ The crucial difference between the two concepts is that the former are normative rules whereas the latter are only principles de lege ferenda. ${ }^{1043}$ Rather than stating where the law currently stands, instruments that fall under the second concept of soft law suggest what the law may or should be in the future. The qualification of the prinicples as being de lege ferenda does not exclude the possibility that they can harden into legal rules. This "hardening" of soft law into hard law may happen via two different mechanisms: first, the non-binding rule can constitute the first step towards a treatymaking process in which reference will be made to the principles already stated in the declaration. Secondly, non-binding rules may lead to the creation of customary law. ${ }^{1044}$

The instruments we analysed in the present chapter with regard to the return of Nazi spoliated art and human remains respectively, fall under the second concept of soft law: they denote "values, guidelines, ideas and proposals that may develop into rules of international law but have not yet done so".1045 Consequently, while they require signatory states to show a certain level of moral and political commitment, they do not impose any legal obligations on states to act in a particular way or even to provide for the return of the objects. Put differently, these instruments do not limit the states' capacity to act in any way but serve as guidance on how states can react to the developments at the international level more in general and in specific cases of requests. In the following we will categorise the solutions proposed to facilitate the subsequent analysis of the national regimes.

\footnotetext{
1041 Dixon, M., 2007, p. 50. Dixon quotes Art. 2 of the Convenant on Economic, Social and Cultural Rights 1966 as an example of such a normative rule with vague content. The provision obliges the state parties to "take steps, individually and through international assistance (...) with a view to achieving progressively" the rights recognised in the treaty.

1042 Ibid.

1043 Ibid. Cf.: Malanczuk, P. / Akehurst, M.B., 1997, p. 54.

1044 Cf.: Szasz, P., 1992, p. 68; Cassese, A., 2005, p. 491; Andorno, R., 2007.

1045 Cf.: Dixon, M., 2007, p. 50.
} 


\section{SOLUTIONS PROPOSED BY THE INSTRUMENTS TO FACILITATE THE RETURN OF NAZI SPOLIATED ART AND HUMAN REMAINS}

The solutions proposed by the instruments discussed in the present chapter may be devided in two categories: solutions that seek to provide for or facilitate the return of the objects concerned by legal reforms and solutions that accept the present state of the law and seek to facilitate the return of cultural objects by different means. ${ }^{1046}$

\section{LEGAL SOLUTIONS}

Solutions pertaining to changing the law can be subdivided into the creation of a new basis for a claim on the one hand and the revival or strengthening of already existing legal norms on the other hand. The creation of a new basis for a claim has been realised and proposed with regard to the return of human remains. The ultimate example of a solution introducing new legally enforceable rights for the return of human remains is the Native American Graves Protection and Repatriation Act ("NAGPRA"). ${ }^{1047}$ The federal act introduced legally enforceable procedures that allow Indian tribes to recover human remains and funerary objects from federally funded museums. ${ }^{1048}$ Where human remains or associated objects are requested by a lineal descendant or a culturally affiliated tribe, federally funded museums are legally required to repatriate. At the international level, no comparable instruments exist. While Art. 246 of the Treaty of Versailles also created a legal obligation for Germany to return human remains, it is a provision dealing with one specific case, i.e. the skull of Sultan Mkwawa only. As for the instruments adopted in reaction to the rise in claims for the return of human remains we have already seen that due to their legal nature none of the instruments can create legally enforceable rights on their own. The suggestion to recognise / create such rights at the national level is, however, made by theMataatua Declaration on Cultural and Intellectual Property Rights of Indigenous Peoples ("the Mataatua Declaration") and by the UN Declaration on the Rights of Indigenous Peoples. ${ }^{1049}$ As for the UN Declaration it must be pointed out that it is somewhat ambiguous. While Art. 12 recognises on the one hand the right of indigenous peoples to the repatriation of their human remains, its second paragraph limits the absolute formulation by asking states to enable the repatriation of ceremonial objects and human remains "through fair, transparent and effective mechanisms developed in conjunction with indigenous peoples concerned". Consequently, while the first paragraph of Art. 12 suggests the creation of legally enforceable basis for a claim, the second paragraph limits this approach by referring to mechanisms that do not necessarily require the introduction of legal rights.

1046 Cf.: Schönenberger, B., 2009, pp. 240-284.

1047 Native American Graves Protection and Repatriation Act; Public Law 101-601; 25 U.S.C.3001 et seq.

104825 U.S.C. 3005 (2004).

1049 See Recommendation 2.12 of the Mataatua Declaration. 
With regard to Nazi spoliated art, the analysis did not reveal any instruments providing for or seeking the creation of a legal basis for a claim. Instead, more emphasis is put on the "revival" of already existing norms and the facilitation of returns by legal means. "Reviving" existing norms is necessary where the passage of time has the effect that an original title or claims right can no longer be relied upon due to good faith acquisition, prescriptive acquisition or extinctive prescription. The facilitation of returns consists in getting rid of any legal obstacles preventing or complicating the return of an object, such as rules preventing disposal and export regulations. The technique to support the return of spoliated objects by not recognising a later acquired title and by excluding extinctive prescription has already been applied by instruments discussed in Chapter 1 (\$4.II). Law No. 59 on the 'Restitution of Identifiable Property' in the U.S. occupied zone explicitly stated that a right to restitution could not be invalidated by the interests of a good faith purchaser. ${ }^{1050}$ The (First) Protocol of the 1954 Hague Convention goes even a step further. ${ }^{1051}$ According to Art. I 3, the obligation to return cultural property at the close of hostilities to the competent authorities of the formerly occupied territory is neither subject to any prescription, nor does it recede from any rights that might have been acquired after the export by a bona fide purchaser.

Of the instruments discussed in the present chapter, the only insturment explicitly advocating the revival of existing norms and of facilitating return by legal means is Resolution 1205 of the Council of Europe. According to paragraph 13, national parliaments should consider to extend or remove statutory limitation periods, restrictions on alienability, as well as the waiving of export controls. Furthermore, in paragraph 15 (sub c), Resolution 1205 recommends to annul later acquired titles. While the Vilnius International Forum was supposed to further elaborate upon the call for legal reform from Resolution 1205, the final Vilnius Forum Declaration had abondoned the call for a legislative reform.

\section{ALTERNATIVE SOLUTIONS}

Further to solutions that seek to provide for or facilitate the return of the objects concerned by legal reforms, our analysis revealed that a number of instruments accept the current state of the law and propose solutions alternative to legal reform. The following proposals have been identified.

First, a number of instruments made suggestions pertaining to facilitating the production of evidence. With regard to Nazi spoliated artworks, and in view of the difficulties of claimants to provide sufficient evidence of their original title and the circumstances of loss, the suggestions range from facilitating public access to historical

1050 Military Government for Germany, U.S. Are of Control, Law No. 59: 'Restitution of Identifiable Property', Military Government Gazette (Germany. U.S. Zone. Issue G) No. 10, November 1947, Art. 2. See for a discussion of the act more in detail above in chp. 1. \$4 III.

1051 Protocol for the Protection of Cultural Property in the Event of Armed Conflict, signed May 1954, 249 U.N.T.S. 358. See for a discussion of the protocol more in detail above in chp. 1.\$1.VI.2. 
records and archives (Principle II 1998 Washington Principles, paragraph 4 of 2003 European Parliament Resolution), to supporting the research with technical and human resources (Principles III, X, XI 1998 Washington Principles, paragraph 4 of 2003 European Parliament Resolution), to adopting a lenient stand with regard to the evidence that must be produced. According to Principle IV of the 1998 Washington Principles "[i]n establishing that a work of art had been confiscated by the Nazis and not subsequently restituted, consideration should be given to unavoidable gaps or ambiguities in the provenance in light of the passage of time and the circumstances of the Holocaust era". The leniency pertaining to the evidence to be provided is not a res nova. It has already been relied upon in the post WWII restitution laws. Art. 3 of Law No. 59 on the 'Restitution of Identifiable Property' in the U.S. occupied zone provided for the presumption that all transactions made in the period 1933-1945 by a person belonging to a persecuted group qualify as an act of confiscation. ${ }^{1052}$ Another international legal instrument employing an assumption of illegal loss is the First Protocol of the 1954 Hague Convention. According to its Art. I 3 any cultural property exported during a period of occupation must be returned.

With regard to facilitating the return of human remains only one of the instruments discussed explicitly stipulated the difficulties of claimants of making a claim. According to Recommendation 2.13 of the Mataatua Declaration "[m]useums and other institutions must provide, to the country and indigenous peoples concerned, an inventory of any indigenous cultural objects still held in their possession”. While the call for inventories is slightly different in nature than the proposals made in the context of Nazi spoliated art it nevertheless belongs to the categories of suggestions seeking to facilitate the production of evidence.

A second solution proposed as alternative means to legal reform is the creation of alternative dispute resolution mechanisms. This solution has been proposed only with regard to Nazi spoliated art (principle XI of the 1998 Washington Principles; paragraph 16 of Resolution 1205). More specifically, emphasis is put on the establishment of committees or other bodies with a balanced membership that can hear and decide cases without being limited to positive law applicable (principle X of the 1998 Washington Principles).

Before we can scrutinise the solutions adopted at the national level we will first discuss the national legal frameworks applicable to cultural objects in public collections in view of their disposal and export. Such an analysis serves a better understanding and assessment of the solutions adopted at national level in cases of requests for the return of cultural objects. Furthermore, from a more practical point of view, a clear understanding of what is achievable within the present confines of the law is important

1052 See, e.g.: Military Government for Germany, U.S. Are of Control, Law No. 59: 'Restitution of Identifiable Property', Military Government Gazette (Germany. U.S. Zone. Issue G) No. 10, November 1947. See further above in chp. 1S4.II. 
as it takes away insecurities both at the side of the holding collections and the claimants and therewith contributing to informed communication and understanding. ${ }^{1053}$

1053 Cf.: Working Group on Human Remains, 2003, para. 280 where the effects of legal uncertainty are addressed. The legalistic approach which has been witnessed in the United Kingdom with regard to questions of return is in part accorded to the confusion and insecurities about the legal position of the museums. See also: Seidemann, R.M., 2004, p. 562. 


\section{CHAPTER 3}

\section{Comparative Overview of National Legal Frameworks applicable to Cultural Objects in Public Collections in view of their Disposal and Export}

The present chapter explores the legal regimes applicable to public collections in the Netherlands, the United Kingdom (especially England) and France. ${ }^{1054}$ The finding from the two previous chapters that public international law does not provide for legally enforceable claims does not mean that the law is irrelevant for the return of cultural objects from public collections. In fact, the legal rules applicable to objects in public collections may hamper or even prevent a return. Obstacles could consist in the law applicable to the disposal of objects from public collections as well as the law applicable to the export of cultural objects. ${ }^{1055}$ Consequently, the aim of this chapter is to extrapolate the general law applicable to disposal and export of objects from public collection in the various jurisdictions and to identify potential obstacles.

The law applicable to the de-accessioning of objects from public collections is strictly national in nature. In scrutinising the national law attention must be paid to various fields of law: specific statutes under public law, administrative law, civil law, and trust law. Given the great variety in the national approaches on the regulation of public collections and the national idiosyncrasies, the structures of the country reports naturally vary.

With regard to export regulation, the analysis also needs to address European law. With all countries discussed in this chapter being Member States of the European Community their respective export regulations of cultural objects are to some extent shaped by European Community Law. A centralized discussion of the applicable EC

1054 See further on the choice of jurisdictions above in the Introduction ( $(2 . I)$.

1055 Cf.: $\int 13$ d) of the Council of Europe Resolution 1205 (1999) on Looted Jewish cultural property that also mentions export controls as obstacle to restitutions. Resolution 1205 has been discussed in detail in chp. 2.S1.III.2. 
law provides for a better fundament and therewith understanding of the national export controls. Consequently, before turning to the national jurisdictions, the relevant EC law with regard to export restrictions on objects of cultural relevance will be introduced. The subsequent country reports are represented in order of the extent of restrictions put on the disposal and export of objects from public collections starting with the country with the least stringent restrictions: first, the Netherlands, as a country with a very liberal approach towards the protection of cultural property, including export control will be analysed before turning to the law applicable in the United Kingdom, in particular England. The French legal framework is brought up to the rear.

\section{§1. EUROPEAN COMMUNITY LAW ON THE EXPORT OF NATIONAL TREASURES}

From the outset of the European integration the creation of a common or internal market was one of the main aims pursued. ${ }^{1056}$ In accordance with Art. 14 of the EC Treaty, the internal market is an area without internal frontiers in which the free movement of goods, persons, services and capital is ensured. With regard to the present subject, the movement of art works across national borders, the relevant fundamental freedom to be addressed is the free movement of goods. The applicability of this principle to works of artistic or cultural value has been confirmed by the European Court of Justice (hereinafter: "the ECJ") as early as 1968. In the case, which has become known as the "Italian Art Treasure Case"1057, the ECJ held that the principle of free movement of goods applies to any "products which can be valued in money and which are capable, as such, of forming the subject of commercial transactions".1058 In other

1056 Cf.: Art. 2 EU Treaty, Art. 2 and Art. 14 EC Treaty. Cf.: Craig, P. / De Búrca, G., 2008, p. 604. While the articles speak of 'common market' respectively 'internal market' the literature generally agrees that there exists no fundamental difference between the two concepts. See, e.g.: Borries, R.v. / Zacker, C., 2002, p. 124.

1057 Case 7/68 Commission v. Italy [1968] ECR 423. The case dealt with the admissibility of an Italian law (Law no. 1089 of 1 June 1939, in particular Art. 37) according to which a special export tax was charged on works of art and other cultural objects. The Commission brought an action under Art. 226 EC Treaty (exArt. 169) alleging that the tax was in breach Art. 25 EC Treaty (ex- Art. 16, which has been repealed but whose substance is now covered under Art. 25). Art. 25 prohibits duties and charges of equivalent effects on exports. Italy argued that the cultural objects did not qualify as goods for the purpose of the rules on the customs union and that furthermore the tax was levied to protect the national heritage. The Court rejected these arguments and held that the cultural objects covered by the export tax can be valued in money and are cable of forming the subject of commercial transactions and therewith qualify as goods for the purposes of EC Law. The argument of the Italian State that the tax was levied to protect its national heritage as a justification of the measure could not bite: where a tax is caught by Art. 25 EC Treaty, it is per se unlawful. The attempted justification with reference to Art. 30 EC Treaty (ex- Art. 36) by Italy is only available as defence in relation to quantitative restrictions as caught by Art. 28 EC Treaty (ex- Art. 30). Cf.: Craig, P. / De Búrca, G., 2008, pp. 639-640.

${ }^{1058}$ Case 7/68 Commission v. Italy [1968] ECR 423; Psychogiopoulou, E., 2008, p. 19. 
words, it is the economic character of an object that is determinative for the application of Community law. ${ }^{1059}$

With the principle of free movement of goods applying to the trade in cultural objects, the trade has to act in conformity with the prohibition of quantitative restrictions on imports and exports and all measures having equivalent effect (Artt. 28 and $29 \mathrm{EC}$ ). Measures having an effect equivalent to quantitative restrictions have been defined by the ECJ in Dassonville as:

"[a]ll trading rules enacted by Member States which are capable of hindering, directly or indirectly, actually or potentially, intra-Community trade are to be considered as measures having an effect quivalent to quantitative restrictions". 1060

While the Dassonville case dealt with the question whether a Belgian law was in violation of Art. $28 \mathrm{EC}$ (ex-Art. 30), it has since been recognised that quantitative restrictions have the same meaning for Art. 29 as for Art. 28. ${ }^{1061}$ While in general Art. 28 EC prohibiting restrictions on imports is the more important provision, it is of little relevance with regard to cultural objects as none of the EC Member States introduced any import restrictions for these objects. In principle, no state opposes to the import of cultural objects. ${ }^{1062}$ By subjecting the export of cultural objects to the requirement of obtaining an export licence, States can exercise control over which objects are exported and which are not. The subjection of exports to the requirement of an export licence qualifies as a measure having equivalent effect in the sense of Art. 29 EC.1063

However, measures having equivalent effect are not per se unlawful. Instead, the broad interpretation of measures having equivalent effect is to some extent balanced by the justifications available under Art. 30 EC. According to the article:

1059 See for a discussion of EC case law in respect of the cultural field and grounds accepted by the court as justifications for restrictions to the free movement rules: Psychogiopoulou, E., 2006, p. 580 and especially: Craufurd Smith, R., 2004, pp. 28-40.

1060 Case 8/74 Procureur du Roi v. Dassonville [1974] ECR 837, para. 5.

1061 European Commission, I.M.D., 2001, p. 18, http://ec.europa.eu/enterprise/regulation/goods/docs/art2830/guideart2830_en.pdf.

1062 Cf.: Berndt, J., 1998, pp. 140-141; Peya, A., 2002, pp. 57-58; Odendahl, K., 2005, p. 211. There do, however, exist jurisdictions that impose import restrictions on certain cultural objects: US Statute on the Importation of Pre-Columbian Monumental or Architectural Sculpture or Murals, 19 USCA \2091-2095 (1976). See further: Nafziger, J.A.R., 1982, p. 191; Siehr, K., 1993, pp. 172-176. Cf.: above chp. 1.\$2.IX.1. The reference in some publications (Fraoua, R., 1985, p. 89, fn. 57; Uhl, A.-K., 1993, p. 94, fn. 340; Bila, J., 1997, p. 54) to a Dutch act prohibiting the import of cultural objects worth more than fl. 1000 without the presentation of an important license declaring that the object had been legally exported is incorrect. Such an act never existed in the Netherlands. Cf.: Email from Marja van Heese, State Inspectorate for Cultural Heritage, Ministry of Education, Culture and Science dated 9.10.2008 on file with the author.

1063 Cf.: Case 68/76, Commission v. French Republic [1977] ECR 515.; Cases 51-54/71, International Fruit Company v. Produktschap voor Groenten en Fruit (No 2) [1971] ECR 1107; Schwarze, J., 1994, pp. 112-113; Müller-Graff, 1997a, para. 25. See further on the application of Art. 29 EC to the export of cultural goods: Peya, A., 2002, pp. 58-64. 
"[t]he provisions of Articles 28 and 29 shall not preclude prohibitions or restrictions on imports, exports or goods in transit justified on grounds of public morality, public policy, or public security; the protection of health and life of humans, animals or plants; the protection of national treasures possessing artistic, historic or archaeological value; or the protection of industrial and commercial property. Such prohibitions or restrictions shall not, however, constitute a means of arbitrary discrimination or a disguised restriction on trade between Member States" (emphasis added).

The ratio of Art. $30 \mathrm{EC}$ is to provide Member States with a certain discretion under national law to compensate for the absence in protection at the community level. ${ }^{1064}$ Justifing trade rules for certain policy aims, including the protection of national cultural treasures that would otherwise breach Artt. 28 and 29 EC, Art. 30 must be interpreted restrictively. ${ }^{1065}$ For a national rule to be saved by Art. $30 \mathrm{EC}$ it must be justified by one of the listed categories and must pass a test of proportionality: only where the Court is satisfied that the discriminatory measure is the least restrictive possible to attain the aim in view can the rule be justified by Art. 30 EC. 1066

The literature has noted a number of questions on the interpretation of the article and its application. ${ }^{1067}$ In particular, discussion exists on the community concept of 'national treasures' and the criteria of "artistic, historic or archaeological value". 1068 Despite the lack of clarity with regard to the interpretation of Art. $30 \mathrm{EC}$, it is generally accepted that the article allows for the persistence of national legislation foreseeing in the control of the export of cultural objects. ${ }^{1069}$

The protection of national treasures by national legislation could, however, function only for as long as the export of cultural objects was controlled at the national borders.

1064 Cf.: Müller-Graff, 1997b, para. 1.

1065 The ECJ already held in the Italian Art Treasure Case that Member States must observe the limitations imposed by Art. 30 EC Treaty (ex-36 EEC Treaty) with regard to the objective to be attained and the nature of the means employed in order to profit from the exception to the principle of the free movement of goods (Case 7/68 Commission v. Italy [1968] ECR 423). The finding was confirmed in: 46/67 Baubuis v. Netherlands [1977] ECR 5. Cf.: Maurer, C.H.M., 1997, p. 49; Müller-Graff, 1997b, para. 14; Peya, A., 2002, p. 79 .

1066 Cf.: Craig, P. / De Búrca, G., 2008, p. 696.

1067 See, e.g.: Uhl, A.-K., 1993, p. 115-137; Schmahl, S., 1996, p. 43 ff; Bila, J., 1997, p. 120- 132; Berndt, J., 1998, p. $142 \mathrm{ff.}$.

1068 Cf.: Odendahl, K., 2005, p. 211. As of today, no case has been brought to the ECJ requiring for the interpretation of the provision. Prott, L.V. / O'Keefe, P.J., 1989, p. 486, para. 942 reports of an incident where the consistency of the Waverley Criteria with Art. 30 EC was raised: the case concerned a silver plaque by Paul van Vianen, which had been purchased in 1979 the Dutch Rijksmuseum. When the export of the plaque from the UK was prevented for reason of qualifying as a national treasure in the sense of Art. 30 EC (ex-36 EEC), the Rijksmuseum argued that, although the article allows for restrictions on ground of the protection of national treasures possessing artistic, historic or archaeological value, the protection of cultural objects on grounds of their aesthetic significance or importance to scholarship, i.e. the second and third Waverley criterion, did not fall within that exemption. The Reviewing Committee rejected this view and concluded that the plaque could properly be considered as part of the United Kingdom's national heritage and therefore within the scope of Art. 30 EC, given that it met two of the Waverley criteria. The matter was apparently not taken any further. Cf.: The Reviewing Committee on the Export of Works of Art \& Objects of Cultural Interest (RCEWA), 1979-1980.

${ }^{1069}$ Cf.: Odendahl, K., 2005, p. 211. 
With the progressing integration consisting of the completion of the internal market in December 1992 as "an area without internal frontiers in which the free movement of goods, persons, services and capital is ensured", and the gradual abolition of systematic border controls under the Schengen Agreement ${ }^{1070}$ the national export restrictions could no longer bite: without the existence of internal border controls, national treasures could be freely moved within the European Community in spite of national rules banning their export. Once removed from the territory where the object was protected under national legislation the object could be easily exported to a third country as the national legislation or the state of origin would not apply after the object's removal from its jurisdiction ("cultural drain"1071). ${ }^{1072}$

Against this background and in order to reconcile the fundamental principle of European Community Law of the free movement of goods with the protection of objects classified as "national treasures possessing artistic, historic or archaeological value" in the sense of Art. $30 \mathrm{EC}$, the European Community adopted two measures: Council Regulation (EEC) No 3911/92 of 9 December 1992 on the export of cultural goods (hereinafter: "the Regulation") and Council Directive 93/7/EEC of 15 March 1993 on the return of cultural objects unlawfully removed from the territory of a Member State (hereinafter: "the Directive"). ${ }^{1073}$ The two measures are complementary to one another in that the Regulation provides for EC wide uniform export controls at the external borders in order to prevent the unregulated export of cultural objects, whereas the Directive introduced domestic obligations in all Member States to return cultural objects unlawfully removed from another Member State. ${ }^{1074}$ In the context of the present chapter looking into restrictions on disposal of objects from public collections and their export, we will concentrate on the Regulation. ${ }^{1075}$

\footnotetext{
1070 The Schengen Agreement consists of two treaties: the 1985 Agreement between the Governments of the States of the Benelux Economic Union, the Federal Republic of Germany and the French Republic on the gradual abolition of checks at their common borders (Official Journal L 239, 22/09/2000 P. 0013 0018) also known as Schengen I, and the 1990 Convention implementing the Schengen Agreement of 14 June 1985 between the Governments of the States of the Benelux Economic Union, the Federal Republic of Germany and the French Republic on the gradual abolition of checks at their common borders (Official Journal L 239, 22/09/2000 P. 0019 - 0062), also known as Schengen II or CIS.

1071 Siehr, K., 1993, p. 226.

1072 Cf.: Odendahl, K., 2005, p. 212.

1073 Council Regulation (EEC) No 3911/92 of 9 December 1992 on the export of cultural goods, OJ No L 395, 31.12.1992, p. 1, as amended by information of 27 March 1993, OJ No L 74, 27.3.1993, p. 80; Council Directive 93/7/EEC of 15 March 1993 on the return of cultural objects unlawfully removed from the territory of a Member State, OJ No L 74, 27.3.1993, p. 74.

1074 Siehr, K., 1993, p. 232.

1075 See further on the Directive above in chp. 1.\$2.VI.
} 


\section{Council Regulation No. 3911/92 0N The Export of Cultural Goods}

The Regulation, which entered into force in 1993, introduced a uniform system of controls of cultural objects at the external Community borders. ${ }^{1076}$ Where a cultural object is exported within the Community, the export is not affected by the Regulation. ${ }^{1077}$

Any object that falls under the scope of application of the Regulation may only be exported to a third country subject to the presentation of a valid Community export license (Art. 2(1)). ${ }^{1078}$ Rather than providing for a definition of cultural good ${ }^{1079}$, the Regulation's scope of application is set out in an annex. The annex employs a system of categories of objects that are squared with financial thresholds. In total, there exist fourteen categories of objects and five ranges of financial values:

1076 Cf.: COM Doc. (91)447, SYN 382, 10 Feb. 1992, 2 according to which the Regulation aims at: "supplementing the protection afforded by (divergent) national rules with a common system of protection at Community level (...) Member States will have to play their part in protecting the national treasures of the other Member States, through harmonized export control at the external frontiers and machinery for returning cultural objects unlawfully removed". In order to facilitate uniform controls, the Regulation introduces an EU wide system of export licenses for the export of cultural goods outside the customs territory of the Community. The system of export licenses is further outlined in Commission Regulation (EEC) No 752/93 of 30 March 1993. See also: Siehr, K., 1993, pp. 225-240; Vitrano, V.J., 1994; Polonsky, M. / Canat, J.-F., 1996, p. 558; Odendahl, K., 2005, p. 213-214.

1077 The fact that intra-community export is not governed by the Regulation does not mean that it is irrelevant for intra- Community trade. The national export controls, as measures having equivalent effect, must fulfil the requirements of Art. 30 EC. Furthermore, the regulation is indirectly relevant for intracommunity exports. According to Art. 1(2) of Council Directive 93/7/EEC of 15 March 1993 on the return of cultural objects unlawfully removed from the territory of a Member State unlawful removal in the sense of the Directive includes removal in breach of EEC Regulation No 3911/92. See further on the Directive and its interaction with the Regulation above in chp. 1.\$2.VI.

1078 The provisions necessary for the implementation of the Regulation, in particular with regard to the forms to be used, are outlined in Commission Regulation (EEC) No 752/93 of 30 March 1993 laying down provisions for the implementation of Council Regulation (EEC) No 3911/92 on the export of cultural goods.

1079 Note that the Regulation speaks of "cultural goods" while the Directive speaks of cultural objects. The difference in terminology has been criticised but it is generally assumed that there exists no material difference between the objects covered by the two instruments. See, e.g.: Odendahl, K., 2005, p. 215. 


\begin{tabular}{|c|c|}
\hline Table representing the categories of the Annex with the threshold applicable & \\
\hline Category of cultural good & Threshold value (in $€^{1080}$ ) \\
\hline $\begin{array}{l}\text { 1. Archaeological objects more than } 100 \text { years old which are the products of: } \\
\text { excavations and finds on land or under water } \\
\text { archaeological sites } \\
\text { archaeological collections } 1081\end{array}$ & Regardless of the value \\
\hline $\begin{array}{l}\text { 2. Elements forming an integral part of artistic, historical or religious } \\
\text { monuments which have been dismembered, of an age exceeding } 100 \text { years }\end{array}$ & Regardless of the value \\
\hline $\begin{array}{l}\text { 3. Pictures and paintings executed entirely by hand, on any medium and in } \\
\text { any material (and which are not included in category } 3 \mathrm{~A} \text { or } 4)^{1082}\end{array}$ & $\geq 150,000$ \\
\hline 3A. Water-colours, gouaches and pastels 1082 & $\geq 30,000$ \\
\hline $\begin{array}{l}\text { 4. Mosaics other than those in categories } 1 \text { or } 2 \text { and drawings executed } \\
\text { entirely by hand, on any medium and in any material } 1082\end{array}$ & $\geq 15,000$ \\
\hline $\begin{array}{l}\text { 5. Original engravings, prints, serigraphs and lithographs with their respective } \\
\text { plates and original posters } 1082\end{array}$ & $\geq 15,000$ \\
\hline $\begin{array}{l}\text { 6. Original sculptures or statuary and copies produced by the same process as } \\
\text { the original }{ }^{1082} \text {, other than those in category } 1\end{array}$ & $\geq 50,000$ \\
\hline 7. Photographs, films and negatives thereof 1082 & $\geq 15,000$ \\
\hline $\begin{array}{l}\text { 8. Incunabula and manuscripts, including maps and musical scores, singly or } \\
\text { in collections }{ }^{1081}\end{array}$ & Regardless of the value \\
\hline 9. Books more than 100 years old, singly or in collections 1081 & $\geq 50,000$ \\
\hline 10. Printed maps more than 200 years old & $\geq 15,000$ \\
\hline $\begin{array}{l}\text { 11. Archives, and any elements thereof, of any kind or any medium which are } \\
\text { more than } 50 \text { years old }\end{array}$ & Regardless of the value \\
\hline 13. Means of transport more than 75 years old & $\geq 50,000$ \\
\hline $\begin{array}{l}\text { 14. Any other antique items not included in categories A.1 to A.13 } \\
\text { (a) between } 50 \text { and } 100 \text { years old: } \\
\text { toys, games, glassware, articles of goldsmiths' or silversmiths' wares, furniture, } \\
\text { optical, photographic or cinematographic apparatus, musical instruments, } \\
\text { clocks and watches and parts thereof, articles of wood, pottery, tapestries, } \\
\text { carpets, wallpaper, arms } \\
\text { (b) more than } 100 \text { years old }\end{array}$ & $\geq 50,000$ \\
\hline
\end{tabular}

Where an object falls within one of the fourteen categories and the applicable financial thresholds it may not be exported to a third country without a valid

1080 The Regulation originally referred to ECU but was amended to incorporate the introduction of the Euro: Council Regulation (EC) No 974/2001 of 14 May 2001 amending Regulation (EEC) No 3911/92 on the export of cultural goods.

1081 Collections were defined by the Court of Justice in its judgment C- 252/84 Collector Guns v Hauptzollamt Koblenz [1985] ECR 3387 as: "Collectors` pieces within the meaning of heading $\mathrm{N}^{\circ} 97.05$ of the Common Customs Tariff are articles which possess the requisite characteristics for inclusion in a collection, that is to say, articles which are relatively rare, are not normally used for their original purpose, are the subject of special transactions outside the normal trade in similar utility articles and are of high value".

1082 The cultural goods must furthermore be older than 50 years and may not belong to their originators. 
Community export license (Art. 2(1)). ${ }^{1083}$ The decision whether or not to grant an export license depends on national legislation. With different national regimes of protection, ranging from very liberal regimes to very restrictive ones, the crucial question is which national legislation is applied to decide whether or not to grant an export license. According to Art. 2(2), it is the national legislation of the Member State in whose territory the cultural object in question was lawfully and definitively located on 1 January 1993 that is decisive for the granting of the export license. In those cases where an object is no longer located in the same jurisdiction where it was located as of 1 January 1993, the law of the new jurisdiction will only be applied if the export from the 1993 jurisdiction was lawful and definitive.

In 1996, an exception was introduced to the general rule that any object falling under the Regulation's annex may only be exported subject to a licence. Member States were granted the possibility to waive the need for export licences for archaeological objects of limited archaeological and scientific interest ${ }^{1084}$. Art. 2(2) second subparagraph, provides that no export licenses may be required for the following objects: archaeological objects where the objects are more than 100 years old and are the products of excavations and finds on land or under water and of archaeological sites outside of the territory of the Member State. Furthermore, the objects must be of limited archaeological or scientific interest and their presence on the market must be lawful. ${ }^{1085}$

The aim of this provision, which has been called a "de minimis clause"1086, is to exclude less important objects from the obligation of an export license. ${ }^{1087}$ The clause has been criticized for being difficult to enforce as its application requires expertise that is generally not present with the custom authorities. ${ }^{1088}$

The Regulation hence does not supersede national export regimes but complements them (or: rather allows for their effectuation) in order to allow for an effective protection regime in spite of absent border controls within the European Community. Given the broad scope of the Regulation's annex the theoretical possibility that an object that is protected under national legislation is not covered by the annex and

\footnotetext{
1083 The provisions necessary for the implementation of the Regulation, in particular with regard to the forms to be used, are outlined in Commission Regulation (EEC) No 752/93 of 30 March 1993 laying down provisions for the implementation of Council Regulation (EEC) No 3911/92 on the export of cultural goods.

${ }^{1084}$ Cf.: Peya, A., 2002, p. 147.

1085 The relevant passage of Art. 2(2) reads: "However, without prejudice to paragraph 4, the Member State which is competent in accordance with the two indents in the first subparagraph may not require export licences for the cultural goods specified in the first and second indents of category A.1 of the annex where they are of limited archaeological or scientific interest, and provided that they are not the direct product of excavations, finds and archaeological sites within a Member State, and that their presence on the market is lawful".

1086 Cf.: Peya, A., 2002, p. 147; Weber, M., 2002, p. 247 (with further references).

1087 Peya, A., 2002, p. 147.

1088 See, e.g.: Hipp, A., 2000, p. 270; Peya, A., 2002, pp. 147-148.
} 
therewith will slip through the export controls and into the "cultural drain" can be neglected. 1089

\section{Relevance of the Regulation in light OF REQUeStS For the RETURN OF CULTURAL OBJECTS}

While the Regulation aims first and foremost at the art market and privately owned cultural objects, rather than objects held in (permanent) public collections, it applies indiscriminately to any cultural object which falls under the annex' categories. Consequently, the Regulation and its requirement for the presentation of an export license for the export of a cultural object to a third country apply also to object originating from a public collection, where the object concerned falls under the scope of the annex.

The following steps must be taken to establish whether or not a return of a cultural object to a country not being an EC Member State must be supported by an export license in the sense of Art. 2 of the Regulation: 1090 first, it must be established whether the object concerned belongs to one of the categories outlined in the Regulation's annex. Given the broad scope of the annex, this is rather likely to be case. Where the object to be returned falls in one of the categories and meets the respective threshold in value, the object can only be exported subject to a valid export license.

It can be concluded here that EC law as such does in no way prevent any returns but does under certain circumstances require the return to an entity outside the EC territory to be accompanied by a Community export license. As to whether or not a Community export license is granted depends on national law, which will be addressed in the following sections. The country reports will first discuss potential restrictions to disposal before turning discussing the rules on export control.

\section{$\S 2$. NATIONAL LAW}

\section{THE NETHERLANDS}

The Dutch legal system for the protection of cultural heritage is of rather recent date compared with other European countries. ${ }^{1091}$ At the end of the $19^{\text {th }}$ century, the absence of any government intervention on cultural matters was challenged when Victor de Stuers, a high ranking official and politician published his article 'Holland op zijn smalst' which one might translate as 'Dutch frugality'. ${ }^{1092}$ In the article, which caused a

\footnotetext{
1089 Cf.: Odendahl, K., 2005, pp. 213-214.

1090 Where the export is to another EC Member State it is governed by national export controls (which must comply with Art. 30 EC Treaty).

1091 See on the history of the emergence of national regimes on the protection of tangible cultural heritage: Odendahl, K., 2005, p. 41.

1092 Stuers, V.E.L.d., 1873.
} 
stir, de Stuers criticised the neglect of the Dutch cultural heritage by the Government and pleaded for more governmental intervention. In response to de Stuers' accuse a Government Department for the Arts and Sciences was set up. In 1918, it was turned into a full-fledged Ministry for Education, the Arts and Sciences (Ministerie Onderwijs, Kunsten en Wetenschappen). ${ }^{1093}$ It took several decades until the adoption of the first legal instruments on the protection of cultural objects it would take several more decades. The first act on the protection of cultural heritage adopted was the Monuments Acts (Monumentenwet) in 1961.1094 The first act to apply to the protection of movable cultural heritage, the Cultural Heritage Preservation Act (Wet tot behoud van cultuurbezit) followed in 1984.1095 In the following we will introduce the main characteristics of the act and will discuss whether and in how far the act is relevant for the de-accessioning of objects in public collections. This question is important in that the act is generally considered to apply only to objects in private collections. ${ }^{1096}$ Once we have clarified whether there exist general restrictions to disposal we will turn to the more specific case where the object concerned has been acquired by donation or testamentary disposition. While there exists no general ban on disposal of objects acquired by donation or testamentary disposition ${ }^{1097}$, such a ban may arise from the obligations as stipulated by the donor or the testator. Subsequently, we will shortly elaborate on the question who is the competent actor to decide upon the deaccessioning of objects in public collections, before rounding off the Dutch country report with an analysis of potential export restrictions.

\footnotetext{
1093 Please note that for reasons of simplification we only refer to the Minister of Culture in the main text and do not distinguish between the Minister and the State Secretary. In some government terms there exist an additional State Secretary for Culture to support the Minister of Education, Culture and Science. Given that the final responsibility lies with the Minister we do not think it necessary to make the distinction. However, in the footnote references, we distinguish between them. Also, it should be noted that the name changed from Ministry for Education, the Arts and Sciences (Ministerie van Onderwijs, Kunsten en Wetenschappen) to Ministry for Culture, Recreation and Welfare (Ministerie voor Cultuur, Recreatie en Maatschappelijk Werk) to Ministry of Education, Culture and Sciences (Ministerie van Onderwijs, Cultuur en Wetenschappen) to Ministry of Education, Culture and Science (Ministerie van Onderwijs, Cultuur en Wetenschap). Again for reasons of simplification we only refer to the Ministry of Culture.

1094 Wet van 22 juni 1961 houdende voorzieningen in het belang van het behoud van monumenten van geschiedenis en kunst, Stb. 200 replaced by Wet van 23 december 1988 tot vervanging van de Monumentenwet, Stb. 638 and recently amended by Wet van 21 december 2006 tot wijziging van de Monumentenwet 1988 en enkele andere wetten ten behoeve van de archeologische monumentenzorg mede in verband met de implementatie van het Verdrag van Valletta (Wet op de archeologische monumentenzorg), Stb. 2007, 42.

1095 Wet van 1 februari 1984 houdende vaststelling van de Wet tot behoud van cultuurbezit, Stb. 1984, 49.

1096 See, e.g.: http://www.erfgoedinspectie.nl/page/collecties/de_wet_tot_behoud_van_cultuurbezit (last visited 21.6.2009).

${ }^{1097}$ Cf.: Quaedvlieg, A.A., 1991b, p. 124.
} 


\section{Cultural Heritage Preservation act (Wet tot behoud van CULTUURBEZIT)}

The Cultural Heritage Preservation Act (Wet tot behoud cultuurbezit) (hereinafter: "the CHP Act") was adopted and entered into force in 1984.1098 Since then, it has undergone several revisions. The most notable amendments were made in 1995, for the purpose of harmonizing the CHP Act with European Community Law. ${ }^{1099}$ The main goal of the CHP Act is the prevention of the loss of objects that are significant to Dutch cultural history, and it is specifically concerned with the loss of access to the objects through export. ${ }^{1100}$ To achieve this end, the CHP Act makes any transfer or relocation of protected objects subject to notification of the State Inspectorate for Cultural and permission of the Minister of Culture. ${ }^{1101}$

To receive protection under the CHP Act, an object must be deemed both irreplaceable and indispensable for Dutch cultural heritage. ${ }^{1102}$ An object is deemed irreplaceable when there are no similar objects present in the Netherlands. ${ }^{1103}$ An object is deemed indispensable if it fulfils a symbolic function, a "linking function", or a "reference function." 1104 An object has a symbolic function if it serves as memory of historically important persons or events. ${ }^{1105}$ An example is the "Portrait of Jan Six" by Rembrandt. ${ }^{1106}$ The other two alternative criteria for judging indispensability are formulated rather cryptically and are party overlapping: a "linking function" (in Dutch: schakelfunktie) is explained as the "functioning of an object or collection as an essential element in a development that is of great importance for the exercise of scholarly work, including cultural science studies".1107 An object is considered to have a "reference function" (in Dutch: ijkfunctie) if it "served as a starting point for the development for other scientific or artistic objects." 1108

\footnotetext{
1098 Wet van 1 februari 1984 houdende vaststelling van de Wet tot behoud van cultuurbezit, Stb. $1984,49$.

1099 See further below in chp. 3. 2 2.I.4 on the changes to the CHP Act in the context of the implementation of Council Directive 93/7/EEC where we discuss potential export restrictions applicable to objects in public collections.

1100 Art. 7 CHP Act.

1101 Art. 7 juncto Art. 1(f). Transfers that do not affect the presence of the object in the Netherlands only need to be notified but do not require permission.

1102 Art. 2.

1103 Art. 2(2).

1104 Art. 2(3).

1105 Art. 2(3)(a).

1106 See further on this particular painting, e.g.: Mak, G.L., 2005.

1107 Art. 2(3)(b). See also: Memorie van Toelichting, 27812, nr. 3, p. 8 para. 7. An example of an object listed for its "linking function" is a stone sculpture of a standing triumphing Jesus Christ. The sculpture dates from the Roman period and is one of very few similar sculptures that are present in the Netherlands. The sculpture is thus important for the studying of stone sculptures in the Maas area. Cf.: Raad voor Cultuur, 2001.

1108 Art. 2(3)(c). See also: Memorie van Toelichting, 27812, nr. 3, p. 8 para. 7. An example of an objects listed for its 'reference function' is the 'Portret van Jan Govertsen' by Hendrick Goltzius. The oeuvre of
} 
The exact scope of these functions is nowhere elaborated upon - neither in the legislative history nor in case law. While the criteria were discussed during an evaluation of the CHP Act in 1998 and 1999, no further light was shed on the meaning of the "linking function" or the "reference function." Instead the discussion centered on the merits of including additional cumulative or supportive criteria in the CHP Act. In the end, the Council for Culture, as the main advisory body for the Dutch Government on cultural policy matters, confirmed the existing criteria of the CHP Act and held that there was no need to introduce further criteria such as "artistic value" or "presenting value". 1109

Where an object fulfils the criterion of irreplaceability, and one of the three criteria stipulating its indispensability, it can be designated as a protected object under the CHP Act. ${ }^{1110}$ While any citizen can suggest the granting of protection to an object by writing a letter to the Ministry of Education, Culture and Science, it is the Minister of Culture, advised by the Netherlands' Council for Culture, who ultimately decides whether protection is granted or not. ${ }^{1111}$ Currently, 270 individual objects and 31 collections are listed in the specific inventory to be maintained by the Minister under the CHP Act (the so-called Cultural Heritage Protection list). ${ }^{1112}$ The Dutch State Inspectorate for Cultural Heritage estimates that the total number of single objects, plus objects from the designated collections, ranges from 60,000 to 70,000 objects ${ }^{1113}$ At present, all objects registered under the CHP Act are objects from private collections. In the following, we will discuss the relevance and application of the CHP Act to objects in public collections.

a) Cultural Heritage Preservation Act and objects in public collections: applicable to objects in public collections?

When the CHP Act was adopted in 1984, the Dutch Government did not think it necessary to bring cultural objects in public collections under the scope of the act.1114 With regard to the protection of objects held in public collections, the Dutch Government stated that public authorities and government-controlled museums were expected to "possess sufficient sense of responsibility to counter the disappearance of

paintings by Goltzius is limited. The painting is the only signed and dated portrait by Goltzius and thus forms an important starting point for studying the oeuvre. Cf.: Ibid.

1109 See also: Memorie van Toelichting, 27812, nr. 3, pp. 8-9, para. 7. "Artistic value" and "presenting value" as additional criteria were rejected for they were too difficult to define and their evaluation would depend too much on subjective factors and the zeitgeist.

1110 Art. 1.

1111 Art. 2(1) for single objects \& Art. 3 in respect of collections junto Art. 3c specifying the registration of the objects in the list.

1112 Art. 3c. See for the discussion in Parliament: Memorie van Toelichting, 27 812, no. 3, pp. 19-20.

1113 Source: Email from Margot Llompart, Ministerie van Onderwijs, Cultuur en Wetenschap dated 11.9.2008 on file with the author.

1114 See on the relevance of the Cultural Heritage Preservation Act with regard to the export of objects owned by the state or lower authorities, in particular its Art.14a, further below (chp. 3. \$2.I.4). 
really important works of art they themselves hold". The argument continued that "one may reasonably expect that the government bodies will not act irresponsibly with regard to cultural objects in their care". ${ }^{1115}$

The State Council in its reading of the act adopted a more pessimistic attitude with regard to the protection of cultural objects in public property. According to the State Council, the argument that public authorities possess sufficient sense of responsibility is not persuasive. Furthermore, the State Council referred to the existence of statutes dealing with immovable cultural objects in public ownership, such as the Monuments Act as an argument to provide for protection of movable cultural objects in public ownership. 1116 Despite the criticism of the State Council, the CHP Act was passed without any changes providing explicitly for the protection of objects of cultural relevance in public collections. ${ }^{1117}$ Within three years from the adoption of the CHP Act, the disposal of objects from a collection owned by a public authority became subject to extensive discussion when the city of Hilversum wanted to sell a Mondriaan painting from its collection.

1115 Memorie van Toelichting, Kamerstukken II 1980/1981, 16 749, p. 10. The relevant passage reads: "Van de overheid en de daaronder ressorterende musea zal men in het algemeen mogen vertrouwen, dat zij voldoende verantwoordelijkheidsbesef hebben om het verdwijnen van een eigen werkelijk belangrijk kunstbezit tegen te gaan". Cf.: Boll, J., M., 1989, p. 130; Quaedvlieg, A.A., 1991a, p. 49. See for a critical discussion of the exclusion of publicly owned cultural objects: Advies van de Raad van State, 1980-1981, 16 749, B, p. 14.

1116 Advies van de Raad van State, 1980-1981, 16 749, B, p. 14.

1117 In response to the State Council the Minister of Culture stated: "the acquisition of cultural objects by the Government is generally driven by the aim to introduce the acquired objects into public collections. The motives for including the objects in public collections are generally of cultural-historical, scientific, artistic and educational character. The pending proposal is of no relevance for the realisation of these motives with regard to objects in public collections. The further argumentation in favour of including objects from public collections on the list, i.e. the early warning system of a potential loss is not valid with regard to cultural objects owned by public authorities. Consequently, I do not see the necessity to reconsider this passage in the memory of explanation". While the Minister of Culture refers to the motivation of public authorities to acquire and include cultural objects in their collections, he does not elaborate as to how this acquisition policy relates to the question of disposal of such objects from the public collections or even prevents it (Nader Rapport, 1980-1981, 16 749, C). In Dutch: “Ten aanzien van de plaatsing van overheidsbezit op de lijst zegt de Raad niet overtuigd te zijn door het in de memorie van toelichting geleverde betoog, dat onder meer het voornemen kenbaar maakt om overheidsbezit bij voorkeur niet op de lijst te plaatsen. De motivering, dat van de overheid in het algemeen voldoende verantwoordelijkheidsbesef mag worden verwacht om het verdwijnen van werkelijk belangrijk kunstbezit tegen te gaan (met eventuele vormen van preventief en repressief toezicht als mogelijk correctiemiddel), spreekt de Raad kennelijk niet aan. Ik mag in dit opzicht in de eerste plaats op wijzen, dat de aankoop van cultuurbezit door de overheid in het overgrote deel van de gevallen de opneming in een museumverzameling ten doel heeft. De overwegingen, die aan deze opneming ten grondslag liggen zijn meestal van cultuurhistorische, wetenschappelijke, artistieke en educatieve aard. Het wetsvoorstel heeft voor de verwezenlijking van deze overwegingen ten aanzien van overheidsbezit geen betekenis. Het argument voorts voor plaatsing op de lijst, namelijk het vroegtijdig signaleren van het gevaar voor verlies voor het nationale cultuurbezit, komt voor cultuurbezit in overheidshand te vervallen. Ik acht daarom een heroverweging van de desbetreffende passage van de toelichting op dit punt niet noodzakelijk". 
b) The Mondriaan Case

Starting point for the discussion was the decision of the city council ${ }^{1118}$ of Hilversum from 8 April 1987 to sell the painting "Composition with two lines" by Mondriaan. ${ }^{1119}$ The painting had been given to the city in 1932.1120

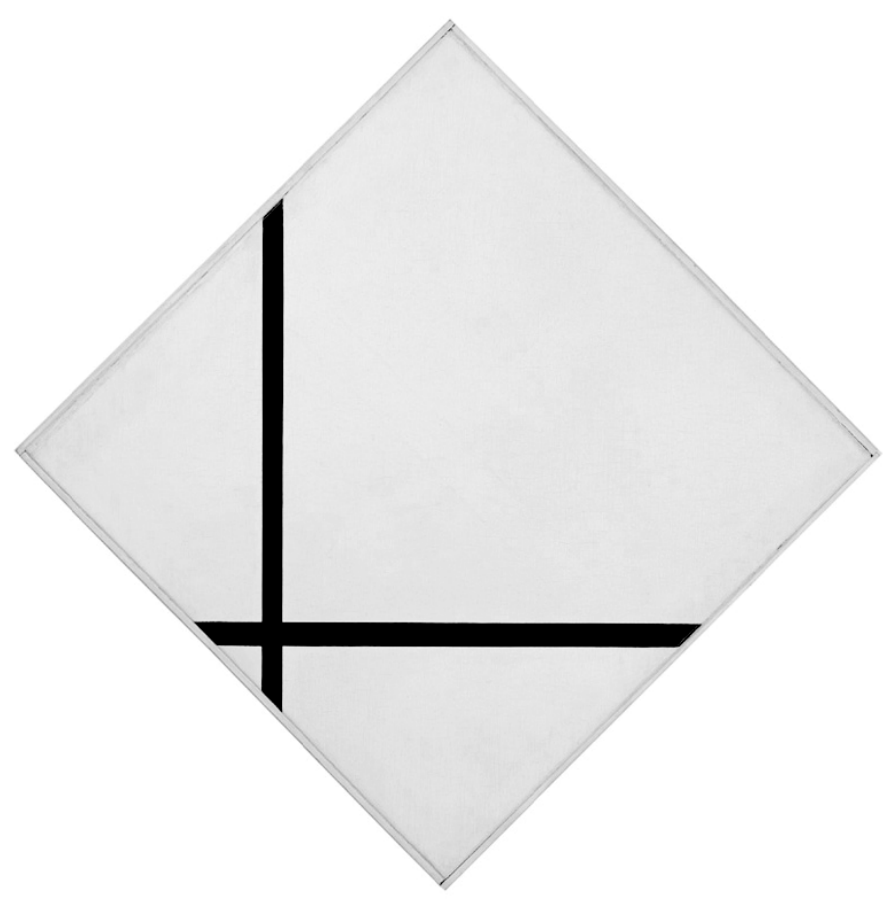

Piet Mondriaan, 'Compositie met twee lijnen', 1931, oil on canvas, diagonal 112 X $112 \mathrm{~cm}$. Signature monogrammed and dated, lower left: P.M.'31. CMondrian/Hotzman Trust c/o HCR International.

The city council wanted to use the sales proceeds to fund the restoring of the Gooilandtheater. The intended sale of the painting would have meant the loss of the painting to a buyer outside of the Netherlands. In order to preserve the painting for the Dutch cultural heritage, the Minister of Culture had a royal decree adopted that

1118 Prior to the entry into force of the Act on Dualism (Wet van 28 februari 2002 tot wijziging van de Gemeentewet en enige andere wetten tot dualisering van de inrichting, de bevoegdheden en de werkwijze van het gemeentebestuur" (Wet Dualisering Gemeentebestuur) in 2002, the city council was indeed the correct organ to decide upon legal acts under private law of the municipality. See further below (chp. 3. \$2.I.3) on the current regime where such decisions rest with the executive consisting of the Mayor and Aldermen.

1119 See further on the case and the motivation of the Stedelijk Museum to sell the painting: Timmer, P.M.Y. / Gubbels, G.J., 2007, pp. 25-27.

1120 See for the facts: President District Court The Hague, 14 July 1987, KG 1987-315. 
suspended the resolution of the City Council.1121 The royal decree stated that "the painting was of such great relevance for the Dutch cultural heritage that it satisfies the criteria employed by the CHP Act for the listing of cultural objects" and that "public authorities can be generally expected to preserve objects belonging to the Dutch cultural heritage satisfying these criteria". ${ }^{1122}$

The city of Hilversum initiated summary proceedings at the District Court in The Hague for the invalidation of the royal decree providing for the suspension of the City Council's resolution. ${ }^{1123}$ The District Court sided with the State and confirmed the city's responsibility to protect the national cultural heritage. The appeal of the city of Hilversum was dismissed by the Appeal Court The Hague. ${ }^{1124}$ According to the Appeal court, the decision of the city of Hilversum to dispose of the painting ignored the "special character of the right of ownership of government bodies with regard to works of art". 1125

With the confirmation of the suspension of the City Council's decision to sell the painting, any disposal of the painting was barred until further research would show whether the decision could be rescinded. ${ }^{1126}$ While the painting was in the end preserved for the Dutch cultural heritage by purchase of the city of Amsterdam, the case was reason for the Minister of Culture to consider the introduction of clearer guidelines or legislation on the disposal of objects from state-owned collections. ${ }^{1127}$ To this day, no such guidelines or legislation have been adopted. ${ }^{1128}$ This leaves us with the question as

${ }^{1121} \mathrm{~KB} 17$ juni $1987 \mathrm{nr}$ 7, Stb. 344 houdende schorsing van het besluit van de gemeenteraad van Hilversum tot verkoop van een schilderij (KB 17 juni $1987 \mathrm{nr}$ 7, Stb. 344). See further on the case: Boll, J., M., 1989; Quaedvlieg, A.A., 1991b, p. 51. It would be interesting to see where a similar case arose today whether the Minister of Culture would make use of the emergency procedure granted to him since 1 June 2002 (Wet van 7 maart 2002 tot wijziging van de Wet tot behoud van cultuurbezit in verband met een evaluatie van die wet, Stb. 2002, 145). According to Art. 3a and 3b the Minister can place objects under the protection of the Cultural Heritage Preservation Act without first having heard the owner and the Council for Cultural Matters (Raad voor het Cultuurbeheer).

$1122 \mathrm{~KB} 17$ juni $1987 \mathrm{nr}$ 7, Stb. 344 houdende schorsing van het besluit van de gemeenteraad van Hilversum tot verkoop van een schilderij.

1123 President District Court The Hague, 14 July 1987, KG 1987-315.

1124 Appeal Court The Hague, 26 November 1987, KG 1988, 72.

1125 Ibid. In Dutch: "Hilversum miskent het eigen-aardige karakter van het eigendomsrecht van overheidslichamen op kunstvoorwerpen (...)".

1126 Cf.: KB 17 juni 1987 nr 7, Stb. 344 houdende schorsing van het besluit van de gemeenteraad van Hilversum tot verkoop van een schilderij. See further on the possibility to annul or suspend decisions by Royal Decree: Art. 132(4) of the Dutch Basic Law, Art. 10:35 General Administrative Code, Art. 268 of the Act on Municipalities. Cf.: Boll, J., M., 1989; Versteden, C.J.N., et al., 2008.

1127 Quaedvlieg, A.A., 1991a, pp. 46 \& 51.

1128 While the Minister of Culture asked the State Commission for the Museums (Rijkscommissie voor de Musea) to advice on the matter, the latter's recommendation was not brought into effect in the form of a statute or guidelines. Advies of the State Commission for the Museums, 21 November 1989, ref. MR/III89-482. Reproduced in: Ministerie van Welzijn Volksgezondheid en Cultuur, 1990, Annex 3. According to the Commission any plan to sell or trade objects from the State-owned collections was acceptable only in very exceptional cases and should be brought before the Council for Cultural Matters (Raad voor het Cultuurbeheer). Cf.: Quaedvlieg, A.A., 1991a, p. 51. In 1995 the Council for Cultural Matters (Raad voor het 
to the relationship between the CHP Act and objects in public collections. That the CHP Act is relevant for objects in public collections became evident from the Mondriaan case. However, the case did not clarify whether the CHP Act was directly applicable to the painting or of indirect relevance only.

c) The CHP Act and objects in public collections: extensive interpretation?

From the legislative history of the CHP Act it appears that the Dutch Government and the State Council did not consider the act to apply to objects in public collections. ${ }^{1129}$ This understanding is reflected in the wording and structure of the act: while the CHP Act does not explicitly rule out the registration of objects in public collections, ${ }^{1130}$ its wording and the procedures that are relied on for the registration of an object clearly show that the act does not apply to objects in public collections. ${ }^{1131}$ Consequently, an extensive interpretation of the CHP Act to include also objects in pubic collections would conflict with a literal and historical interpretation. It is only a teleologic interpretation, which differs from the historical one in that it may take into account new facts and situations that were not taken into account at the drafting stage, that pleads for an extensive interpretation of the CHP Act. However, the fact that the legislator did discuss and refuse the application of the act to objects in public collections prevents such an interpretation. Consequently, we must conclude that the CHP Act is not directly relevant for the de-accessioning of objects from public collections. ${ }^{1132}$

\section{d) Analogous application of the criteria of the CHP Act}

Regardless of the fact that the CHP Act does not directly apply to cultural objects in public collections it is nevertheless relevant in the context of the discussion of disposal from public collections: where Dutch law limits private property rights for the safeguarding of cultural objects of outstanding cultural-historical or scientific value for the Dutch public interest, the underlying ratio and logic of the CHP Act analogously

Cultuurbeheer) became the Dutch Council for Culture (Raad voor Cultuur). The Commission for the Museums has been integrated in the Council of Culture (Raad voor Cultuur), department museums.

1129 See above.

${ }^{1130}$ See Artt. 1-2 of the Cultural Heritage Preservation Act. Cf.: MvT, Kamerstukken II 1993/94, 23657, nr. 3, pp. 4-5. The Flemish Topstukkendecreet on the other hand explicitly includes both objects and collections in private collections as well as objects and collections owned by public authorities (Art. 5. $\int 1$ ). Cf.: Draye, A.M., 2007, p. 390.

1131 Cf.: Art. 3 of the Cultural Heritage Preservation Act. According to this provision it is the Minister of Culture who decides upon the granting of protection of a cultural object under the Cultural Heritage Preservation Act. The article stipulates that the Minister has to hear both the owner and the Council for Cultural Matters (Raad voor het Cultuurbeheer) before taking the final decision. The fact that the provision stipulates that the Minister has to hear the owner is an indication that state-owned property was not intended to fall under the protection of the act. After all it is the Minister of Culture who has been accorded responsibility for the management of the public collections and the cultural objects in state ownership. See further below on the relevant provision of the Government Accounts Act (Comptabiliteitswet 2001) below in chp. 3.\$2.I.3.

1132 See for a different opinion: Vlies, I.C.v.d., et al., 2009, p. 85. 
demands the same from Dutch public authorities. ${ }^{1133}$ Consequently, although the deaccession of objects is generally not prohibited, public authorities may not part from an object that satisfies the criteria of irreplaceability and of indispensability of the CHP Act as outlined above.

This view on the management and disposal of objects from public collections was also adopted by the Minister of Culture in 1990-1991 in the policy note 'Opting for Quality'. ${ }^{1134}$ In the policy note, the Minister of Culture sketches the principles that should guide the management of public collections. Starting point of the policy note is that the quality of the Dutch collections and the access of the public are the predominant aims to be pursued. With regard to the disposal of collection items, these aims are translated into a literally conservative attitude. ${ }^{1135}$ While disposal is to be approached in a reserved manner, it is not subjected to a general ban. The question whether or not disposal of a specific object is allowed should be measured against the parameters of the CHP Act. ${ }^{1136}$ Put differently, where an object satisfies the criteria of irreplaceability and of indispensability, it shall not be disposed of.

In order to allow for a better assessment of an object's irreplaceability, the policy note introduced the notion of the 'Collectie Nederland'. ${ }^{1137}$ The 'Collectie Nederland', which in English would translate as 'the Netherlands Collection' may be defined as the aggregate of all publicly accessible collections in the Netherlands for which society is prepared to take responsibility. ${ }^{1138}$ Comparing a specific object against all objects comprised in the 'Collectie Nederland' allows for a more substantiated decision on an object's irreplaceability for the Dutch cultural heritage. The 'Collectie Nederland' therewith functions as an added framework for policy decisions, including decisions to dispose of objects. ${ }^{1139}$

As stipulated in the introduction to the Dutch country report there may exist further restrictions to the de-accessioning of objects from public collections that have been acquired by donation or testamentary disposition. In the following, we will further

1133 Cf.: Boll, J., M., 1989, p. 131; Ministerie van Welzijn Volksgezondheid en Cultuur, 1990, p. 24. See also the royal decree suspending the sale of the Mondriaan painting. The royal decree stated that "the painting was of such great relevance for the Dutch cultural heritage that it satisfies the criteria employed by the Cultural Heritage Preservation Act for the listing of cultural objects" and that "public authorities can be generally expected to preserve objects belonging to the Dutch cultural heritage satisfying these criteria". KB 17 juni $1987 \mathrm{nr}$ 7, Stb. 344 houdende schorsing van het besluit van de gemeenteraad van Hilversum tot verkoop van een schilderij. See on a comparable situation where provisions on the protection of privately owned nature reserves were held applicable also to public nature reserves by their "external effect" respectively analogy: ARRS 8 juni 1994, AB 1995/25, m.nt. Chris Backes.

1134 Ministerie van Welzijn Volksgezondheid en Cultuur, 1990, p. 24.

1135 The note considers disposal only in the sense of the selling of collection items. It does not mention disposal in the context of a case where the return / restitution of an object has been requested.

1136 Act of 1 February 1984, Stb. 1984, 49.

1137 Ministerie van Welzijn Volksgezondheid en Cultuur, 1990, p. 10.

1138 Cf.: Kuyvenhoven, F., 2001, p. 6.

1139 Cf.: the non-binding guidelines on de-accession prepared by the Netherlands Institute for Cultural Heritage: Instituut Collectie Nederland, 2006. 
reflect upon this specific category as claims for the return of an object may very well affect an object that has been acquired in this way.

\section{RESTRICTIONS FROM DONATIONS AND TESTAMENTARY DISPOSITIONS}

While the above analysis of the regulation of public collections showed that there exist no formal rules restricting the de-accession of objects from public collections except where the public destination of the collection calls for the analogue application of the CHC Act, restrictions may nevertheless exist where an object has been acquired by donation or testamentary disposition. ${ }^{1140}$ While there exists no general ban on disposal of objects acquired by donation or testamentary disposition ${ }^{1141}$, such a ban may arise from the obligations as stipulated by the donor or the testator. E.g. the donor or the testator might have stipulated that the objects concerned must remain exhibited in a particular museum ${ }^{1142}$, that the objects donated must always remain together ${ }^{1143}$, or that the collection donated may never be given in loan or exhibited outside of a certain institution ${ }^{1144}$. In the following we will address the question how Dutch law treats such conditions that might stand in the way of disposal, i.e. whether they constitute absolute bans or whether and if so how they can be amended. Both the inheritance law and the law applicable to donations changed recently: on 1 January 2003 the new rules on donations and inheritance law were introduced. Given the relevance of donations in acquisitions of public collections we will first address donations before turning to testamentary dispositions. ${ }^{1145}$

\section{a) Donations}

The specific legal regime applicable to donations is outlined in Title 3 of Book 7 of the Dutch Civil Code (DCC). ${ }^{1146}$ Furthermore, with donations qualifying as agreements ${ }^{1147}$, the general law of obligations as codified in Book 6 DCC is applicable. While Title 3 of Book 7 DCC dealing specifically with donations does not contain any rule or procedure with regard to amending restrictive conditions, there exists a provision in the general rules on obligations that allows for the amendment of conditions under certain circumstances. Art. 6:258 DCC contains the so-called 'imprévision-rule' according to which Dutch courts may, at the request of one of the parties, modify the effects of an agreement, or may wholly or partially set aside an agreement if due to unforeseen

\footnotetext{
1140 Cf.: Ministerie van Welzijn Volksgezondheid en Cultuur, 1990, p. 24.

1141 Cf.: Quaedvlieg, A.A., 1991b, p. 124.

1142 Cf.: the condition by Dr. A. Bredius in the so-called Bredius case: Hoge Raad 16 maart 1990, NJ 1991, 575. See for wording of the condition: Forder, C., 1993, p. 117.

1143 Cf.: Hoge Raad 30 januari 1976, NJ 1976, 564 on the collection of Adriaan van der Hoop.

1144 Cf.: Hoge Raad, 4 oktober 1996, NJ 1998, 397 on the collection Waller.

1145 According to a survey dating from 1988 donations constitute the most important source of acquisitions for $67 \%$ of museums of cultural-historical character. Cf.: Bevers, A.M. / Halbertsma, M.E., 1991.

1146 Artt. 7:175- 7:188 DCC.

1147 See Art. 7:175(1) DCC.
} 
circumstances the co-contracting party may, according to criteria of reasonableness and equity, not expect that the contract be maintained in an unmodified form. ${ }^{1148}$

Consequently, where "unforeseen circumstances" occurred after the conclusion of a donation, which the parties have not taken into account when concluding the contract, modification or annulment of the agreement is possible. "Unforeseen circumstances" are circumstances that have not been factored in by the parties, rather than circumstances that could not have been foreseen. ${ }^{1149}$ However, a court will order the alteration or annulment of contractual terms only in exceptional circumstances. It will not give such an order when the change of circumstances is considered to fall within the risk of the party requesting it, taking into account the nature of the contract and common opinion.

Applying the foregoing to a case in which an institution wishes to return / restitute an object that has been donated subject to conditions that restrict its disposal it seems likely that the court will alter or annul the terms prohibiting the disposal: ${ }^{1150}$ where not factored in by the parties a request for the return / restitution may qualify as unforeseen circumstances. In case of a pending request for the return or restitution of a cultural object the criteria of reasonableness and equity would command the alteration or annulment of the terms thus allowing for the disposal. Different from testamentary dispositions discussed in the following section, no case law exists on the alteration of conditions of donations to public collections. ${ }^{1151}$

\section{b) Testamentary dispositions}

Until 2002, there existed specific regulation on the alteration of obligations arising from testamentary dispositions in the form of the Museum Act (Museumwet). ${ }^{1152}$ The Museum Act provided for a very stringent regime under which stipulations in testamentary dispositions could be changed. ${ }^{1153}$ An application to the Supreme Court could only be made after more than 40 years had lapsed since the death of the testator.

\footnotetext{
1148 Art. 6:258 DCC reads in Dutch: "1. De rechter kan op verlangen van een der partijen de gevolgen van een overeenkomst wijzigen of deze geheel of gedeeltelijk ontbinden op grond van onvoorziene omstandigheden welke van dien aard zijn dat de wederpartij naar maatstaven van redelijkheid en billijkheid ongewijzigde instandhouding van de overeenkomst niet mag verwachten. Aan de wijziging of ontbinding kan terugwerkende kracht worden verleend. 2. Een wijziging of ontbinding wordt niet uitgesproken, voor zover de omstandigheden krachtens de aard van de overeenkomst of de in het verkeer geldende opvattingen voor rekening komen van degene die zich erop beroept. 3. Voor de toepassing van dit artikel staat degene op wie een recht of een verplichting uit een overeenkomst is overgegaan, met een partij bij die overeenkomst gelijk".

1149 Cf.: Baan, E. / Valk, W.L., 2008, para. 19.11.

${ }^{1150}$ In the absence of case law on the alteration of conditions of donations to public collections (Schiphof, T., 2000, p. 214) it is difficult to draw generally applicable conclusions. In the end each case has to be analysed in its own right with due regard for the specific nature of the agreement and its terms.

${ }^{1151}$ Cf.: Ibid.

1152 Wet van 1 mei 1925 tot herziening in het algemeen belang van bij erfstelling of legaat gemaakte bedingen, Stb. 174.

${ }^{1153}$ Kolkman, W.D., 2006, p. 151.
} 
Furthermore, the possibility to amend conditions was not unlimited. Instead only the following conditions could be amended:

a. the place where, and the manner in which, artefacts or objects of historical or scientific value (including documents), must be kept in a collection which is accessible to the public; or

b. the extent to which, and under which conditions, the public must be afforded access to view or use the objects;

c. the object to which money bequeathed for artistic or research purposes should be applied. ${ }^{1154}$

In weighing the application, the Supreme Court had to decide in accordance with public interests and the wishes of the testator.

With the introduction of new inheritance legislation in $2003^{1155}$, the Museum Act became redundant. ${ }^{1156}$ The new inheritance legislation introduced two provisions that are relevant for the changing of conditions that might be applicable to objects bequeathed to public collections. Before further scrutinising the relevant Artt. 4:123 and 4:134 DCC a few words must be said on the types of testamentary disposition according to which public collections may receive objects from the estate of a deceased. The most relevant scenario is that where a museum or public body receives a bequest. ${ }^{1157} \mathrm{~A}$ bequest is a "testamentary disposition by which a deceased grants one or more persons a right of claim". ${ }^{1158}$ A bequest concerns one ore more specific objects. ${ }^{1159}$ The second possibility is that an institution or public body is appointed as heir and therewith shares in the entire estate of a deceased. ${ }^{1160}$

Both types of testamentary dispositions - bequest and the appointment of heirs - can be subject to certain conditions as mentioned already above. Such conditions may take

1154 Art. 1. The translation of the conditions is based on: Forder, C., 1993, p. 120. For more information on this act see: Luijten, E.A.A., 1994a; Luijten, E.A.A., 1994b; Pitlo, A., et al., 1997, p. 248 ff; Hartkamp, A.S., 1999; Schiphof, T., 2000. See for relevant case law e.g.: the 'Bredius Case' (Hoge Raad 16 maart 1990, NJ 1991, 575) which has been discussed in the literature especially by private international law scholars for the interesting question it raised on the choice of law rules given the Monegasque nationality of the testator. Cf.: Forder, C., 1993; Boele-Woelki, K., et al., 2004, pp. 208-209.

1155 Wet van 18 April 2002 tot vaststelling van de Invoeringswet Boek 4 en Titel 3 van Boek 7 van het nieuwe Burgerlijk Wetboek, vierde gedeelte (aanpassing van de wetgeving aan het nieuwe erfrecht en schenkingsrecht), Stb. 230.

1156 Cf.: MvT, Kamerstukken II 2000/01, 27 245, nr. 3 p. 25-26.

1157 See for examples of objects acquired by legacy the cases listed in fn. 1154.

1158 Art. 4:117 DCC. Translation based on: Sumner, I. / Warendorf, H.C.S., 2005, p. 49. In Dutch Art. 4:117 (1) DCC reads: "Een legaat is een uiterste wilsbeschikking waarin de erflater aan een of meer personen een vorderingsrecht toekent".

1159 Cf.: Schiphof, T., 2000, p. 207.

1160 See Art. 4:115 DCC on the appointment of heirs according to which "[a]n appointment of an heir is a testamentary disposition pursuant to which a deceased leaves his or her entire estate or a share therein to one or more persons who are thereby designated". Translation based on: Sumner, I. / Warendorf, H.C.S., 2005. In Dutch Art. 4:115 DCC reads: "Een erfstelling is een uiterste wilsbeschikking, krachtens welke de erflater aan een of meer daarbij aangewezen personen zijn gehele nalatenschap of een aandeel daarin nalaat". 
the form of a testamentary obligation. ${ }^{1161}$ In the following two paragraphs we will scrutinise Art. 4:123 DCC, which provides for the possibility to alter obligations arising from a bequest, as well as Art. 4:123 DCC on the alteration of testamentary obligations. Both articles bear resemblance to Art. 6:258 DCC discussed above concerning the amending of conditions of donations. While testamentary dispositions differ from donations in that they are unilateral in character ${ }^{1162}$, the travaux preparatoires of the new inheritance law nevertheless considered the Artt. 4:123 DCC and 4:123 DCC as lex specialis to the 'imprévision-rule' codified in Art. 6:258 DCC. 1163

Art. 4:123 DCC introduces a general procedure under which the legatee or the person burdened with the bequest may request the court to alter or terminate the obligations. Such alteration is only possible on the ground of circumstances that occurred after the death of the deceased and which are of such a nature that the other party, according to standards of reasonableness and equity, may not expect these obligations to remain in effect without alteration. In deciding upon the request, the court will take the intentions of the deceased into account as much as possible. ${ }^{1164}$ Whether this excludes the possibility to dispose of objects from public collections will be discussed after Art. 4:134 DCC has been introduced.

Art. 4:134 DCC introduces a procedure to alter or discharge testamentary obligations resting upon the heirs or legatees. Different from Art. 4:123 DCC concerning obligations arising from bequests, the possibility to seek for the alteration of testamentary obligations is not only granted to the person charged with the testamentary obligation but is also accorded to the Public Prosecutor. The underlying ratio for including the Public Prosecutor lies in the fact that the testamentary obligations may be in the interest of the general public. ${ }^{1165}$ Furthermore, Art. 4:134 DCC provides for a greater variety of situations in which testamentary obligations may be changed. The first

1161 Art. 4:130 (1) DCC states that "A testamentary obligation is a disposition by last will whereby the deceased imposes an obligation on the joint heirs or on one or more determinate heirs or legatees not consisting in the execution of a bequest". Translation based on: Ibid. In Dutch Art. 4:130(1) reads: "[e]en testamentaire last is een uiterste wilsbeschikking waarin de erflater aan de gezamenlijke erfgenamen of aan een of meer bepaalde erfgenamen of legatarissen een verplichting oplegt, die niet bestaat in de uitvoering van een legaat".

1162 Cf.: Art. 4:42(1) DCC.

1163 MvA I, Parl Gesch. (Inv. Boek 4), p. 2018.

1164 Translation based on: Sumner, I. / Warendorf, H.C.S., 2005. In Dutch Art. 4:123 DCC reads: "1. De rechter kan op verzoek van de legataris of van hem die met het legaat belast is, de verbintenissen uit een legaat wijzigen of geheel of gedeeltelijk opheffen op grond van na het overlijden van de erflater ingetreden omstandigheden welke van dien aard zijn, dat de andere partij naar maatstaven van redelijkheid en billijkheid ongewijzigde instandhouding van die verbintenissen niet mag verwachten. 2. Bij een wijziging of opheffing neemt de rechter zoveel mogelijk de bedoeling van de erflater in acht. 3. De artikelen 258 leden 1, tweede zin, 2 en 3 van Boek 6 en 260 leden 1 en 2 van Boek 6 zijn van overeenkomstige toepassing". This third paragraph of the article declares the application mutatis mutandis of Art.s 258(1), second sentence, (2) and (3) of Book 6 and 260(1) and (2) of Book 6. These provisions concern the possibility to grant retrospective effect to alterations, that the alterations are applicable also to legal successors and that the court will not change the conditions where the changes in circumstances are caused or attributed to the requesting party.

1165 Cf.: Luijten, E.A.A. / Meijer, W.R., 2003, p. 178. 
situation is similar to the situation covered by Art. 4:123 DCC: the occurrence of circumstances after the death of the testator, which are of such a nature that the unaltered maintenance of the obligation would be unjustified having regard to the personal and societal interests involved. ${ }^{1166}$ The court may, upon request, also alter testamentary obligations where an obligation has become cumbersome or impossible to execute as a result of the abatement or reduction of the obligation or of the testamentary disposition to which it is connected ${ }^{1167}$ and in the case the obligation became incumbent pursuant to Art. 4:123 on a person other than the persons on whom the obligation was imposed by the testamentary disposition. ${ }^{1168}$ In all three situations, the court will bear in mind the intentions of the deceased as much as possible. ${ }^{1169}$

The literature discussing the introduction of the new inheritance legislation emphasises that the possibility to alter conditions and testamentary obligations is much broader compared with the old regime applicable under the Museum Act. ${ }^{1170}$ While this finding is certainly true for conditions or obligations concerning objects that did not fall under the scope of the Museum Act, which was limited to objects of the "arts, history or science"1171, the finding is also true with regard to situations that were previously governed by the Museum Act.

Under the current regime as introduced by Art. 4:123 DCC and Art. 4:134 DCC, there exists no minimum period of time that must have lapsed before conditions or obligations can be altered. ${ }^{1172}$ The current regime is also broader in that it does not list and thereby limit the conditions / obligations that may be altered or terminated. Different from the Museum Act, which exclusively listed three categories of conditions,

\footnotetext{
1166 Art. 4:134(1)a) DCC.

1167 Art. 4:134(1)b) DCC.

1168 Art. 4:134(1)b) DCC.

1169 Art. 4:134(2) DCC. The third paragraph of the article declares the application mutatis mutandis of Artt. 258(1), second sentence, (2) and (3) of Book 6 and 260(1) and (2) of Book 6. These provisions concern the possibility to grant retrospective effect to alterations, that the alterations are applicable also to legal successors and that the court will not change the conditions where the changes in circumstances are caused or attributed to the requesting party. Translation based on: Sumner, I. / Warendorf, H.C.S., 2005. In Dutch Art. 4:134 DCC reads: “1. De rechter kan op verzoek van degene op wie de last rust of van het openbaar ministerie de last wijzigen of geheel of gedeeltelijk opheffen: a. op grond van na het overlijden van de erflater ingetreden omstandigheden welke van dien aard zijn dat de ongewijzigde instandhouding van de last uit een oogpunt van de daarbij betrokken persoonlijke en maatschappelijke belangen ongerechtvaardigd zou zijn; b. op grond dat de last door inkorting of vermindering van de last, of van de making waaraan hij is verbonden, bezwaarlijk of onmogelijk uitvoerbaar is geworden; c. in geval de last ingevolge artikel 132 op een ander is komen te rusten dan degenen aan wie hij bij de uiterste wilsbeschikking is opgelegd.

2. Bij een wijziging of opheffing neemt de rechter zoveel mogelijk de bedoeling van de erflater in acht.

3. De artikelen 258 leden 1, tweede zin, 2 en 3 van Boek 6 en 260 leden 1 en 2 van Boek 6 zijn van overeenkomstige toepassing".

1170 Cf.: Luijten, E.A.A., 1994b, p. 138; Asser, C. / Perrick, S., 2002, para. 148; Luijten, E.A.A. / Meijer, W.R., 2003, pp. 175-176; Huijgen, W.G., 2005; Kolkman, W.D., 2006, p. 151.

1171 Cf.: Art. 1 of the Museum Act.

1172 The only reference to time under the current regime lays in the requirement that alteration or termination of obligations can only be requested where unforeseen circumstances occurred after the death of the testator. This requirement is, however, logic as the parties could otherwise renegotiate the conditions.
} 
the current regime starts with a general approach under which the conditions / obligations in a specific case must be weighed against the standards of reasonableness and equity. According to Art. 3:12 DCC "[i]n determining what reasonableness and equity require, reference must be made to generally accepted principles of law, to current juridical views in the Netherlands, and to the particular societal and private interests involved". 1173 In a case where the disposal of an object from a public collection is required in the context of returning / restituting the object to a third party the derogating effect of the standards reasonableness and equity could allow for the altering or termination of the conditions otherwise preventing the disposal. ${ }^{1174}$

In conclusion to this section scrutinising the possibilities to alter or terminate conditions or obligations originating from a donation or testamentary disposition preventing the disposal of an object it should first be repeated that there exists no general ban on disposal of objects acquired by donation or testamentary disposition. It is only where the donor or the testator stated explicit conditions or obligations stipulating e.g. that the object may never be removed or lent or that a collection must remain intact that the articles discussed in this section - Art. 6:258 DCC with regard to donations, Art. 4:123 DCC with regard to bequests and Art. 4:134 DCC with regard to testamentary obligations - become relevant. While it is one thing to amend conditions / obligations to allow an object to be moved from one museum to another it is a different matter to fully erase the obligation to preserve and object and therewith allow for its disposal. Only few cases have been tried since the introduction of the new legislation with regard to inheritance law and donations and none provide insight into whether disposal be allowed in a case where it is motivated by the wish to return / restitute the object concerned.1175 The derogatory effect of the standards of reasonableness and equity suggests that in cases of return / restitution disposal would be possible. It is also likely that the donor or the testator would have (had) sympathy for this cause.

After having discussed potential obstacles and restrictions to the de-accessioning of objects from public collections, we will now address the question who is competent to act on behalf of a public authority under private law.

\section{COMPETENCY TO DECIDE ON DiSPOSAL}

The question as to which organ of the legal personalities concerned has competences under private law is regulated in public law. While the State, the provinces, and the municipalities all possess legal personality (cf.: Art. 2:1, first paragraph General Administrative Code (Awb)), they are abstract constructs that cannot take concrete decisions but must be represented.

\footnotetext{
1173 Translation based on: Haanappel, P.P.C. / MacKaay, E., 1990.

1174 See further on the derogating effect of the standards of reasonableness and equity, e.g.: HR, 20 mei 1994, NJ 1995, 691, noot Brunner; Hesselink, M.W., 1999, pp. 166-172.

1175 None of the cases touch upon objects in public collections.
} 
At the national level, the relevant provision is provided for under the Government Accounts Act (Comptabiliteitswet 2001). ${ }^{1176}$ As a general rule, it is the Minister of Finances who is responsible for the management of movable and immovable things in state property (Art. 32(2) Government Accounts Act). ${ }^{1177}$ With regard to the management under private law of the public collections and the cultural objects in state ownership, however, the responsibility has been accorded to the Minister of Culture. ${ }^{1178}$ Consequently, it is the Minister of Culture who represents the State as owner of the public collections in decisions involving the management of public collections, including the disposal of collection items. It is foreseeable that the Minister of Culture will introduce more specific regulation on the management of the state's public collections in the near future: According to a proposal currently pending in the First Chamber, the Government Accounts Act should be amended to grant the Minister of Culture greater powers to adopt regulations on the management of cultural objects in state property. ${ }^{1179}$

At decentralised level, the competences to act on behalf of a municipality respectively province rest with the municipal executive, consisting of the Mayor and Aldermen, respectively with the provincial executive (gedeputeerde staten). ${ }^{1180}$ Decisions by provinces and municipalities are subject to control by the Dutch Government. ${ }^{1181}$

1176 Comptabiliteitswet 2001 (Government Accounts Act): Wet van 13 juli 2002 tot vaststelling van de Wet inzake het beheer van de financiën van het Rijk, Stb. 2002, 414.

1177 See: Ibid., Art. 32(2).

1178 See Wet van 24 juni 1993, houdende de verzelfstandiging van de rijksmuseale diensten, Stb. 1993, 398, Art. 4 juncto Art. 1. Art. 4 of this Act providing for the privatisation of the national museums reads: "Onze Minister is belast met het privaatrechtelijk beheer van de museale verzamelingen of museale voorwerpen die eigendom zijn van de Staat dan wel aan de zorg van de Staat zijn toevertrouwd".

1179 Tweede Kamer, 2004-2005, 29 833, nr. 6, Wijziging van de Comptabiliteitswet 2001 houdende bepalingen inzake een nadere splitsing van de Rijskbegroting (Tweede wijziging van de Comptabiliteitswet 2001). According to the proposal a new paragraph 3 shall be added to Art. 38 of the Comptabiliteitswet that allows the Minister of Culture to introduce specific regulation on the management of the state's public collections. See also: Letter from the State Secretary to the Second Chamber from 1 July 2005 with the subject "rijkscollectiebeheer", ref. no.: DCE/05/25372. The delegation of powers to adopt further regulation will not, however, affect the general rules with regard to the management of the collections under private law.

1180 See Art. 160 (e) of the Act on Municipalities according to which the municipal executive, consisting of the Mayor and Aldermen are "in any event competent to decide upon legal acts under private law of the municipality" (In Dutch: "Het college is in ieder geval bevoegd tot privaatrechtelijke rechtshandelingen van de gemeente te besluiten"). Where a decision has far-reaching implications for the municipality the executive is required by Art. 169 (4) to hear the city council. There exists great insecurity about the interpretation of this provision but it is generally accepted that the decision must have significant financial consequences for the municipality concerned. Prior to the entry into force of the Act on Dualism, decisions under private law were taken by the city council. Cf.: Kortmann, S.C.J.J., et al., 1999, p. 532. See the Mondriaan case above for an example of a decision of the city council to dispose of an object. See for another example the case study on the West Frisian Eskimo in chp. 4.\$2.I.1. See Art. 158 (e) of the Provinces Act according to which the provincial executive (gedeputeerde staten) are "in any event competent to decide upon legal acts under private law of the province" (In Dutch: "Gedeputeerde staten zijn in ieder geval bevoegd tot privaatrechtelijke rechtshandelingen van de provincie te besluiten"). Where a decision has far-reaching implications for the province the provincial executive is required by Art. 167 (4) to hear the provincial council. The competences to act on behalf of a municipality resepectively province have 


\section{EXPORT RESTRICTIONS}

The first legal restrictions on the export of cultural objects from the Netherlands were based upon the 1945 Exchange control regulation (Deviezenorder 1945). ${ }^{1182}$ According to the rules, which had been adopted with the aim to improve the Dutch currency market, any painting whose value exceeded $f 20.000$ and any other cultural object whose value exceeded $f 80.000$ could only be exported with a licence issued by the Minister of Culture. The 1945 Exchange control regulation proved to be a meagre legal basis and in the late 1950s, a ministerial committee was established to make recommendations on how to regulate the export of cultural objects. The report of the Committee Röell, named after its chairman, the director of the Rijksmuseum D.C. Röell, to subject any export of an object of a certain value to a ministerial license was, however, not put into practice. ${ }^{1183}$

In 1969, a new committee of experts was installed, this time under the chairmanship of D.F.W. Langelaan, then chairman of the Rembrandt Foundation. While the recommendations of the committee Langelaan to ban only the export of certain listed objects, respectively to subject their export to a license form the basis of the current system on export control, it would take several more years before the CHP Act would be adopted. According to the explanatory report of the act, the reason for the delay was the need to further study the effects of the increasing liberalisation of the international trade and the dwindling possibilities to control the export. ${ }^{1184}$

As a consequence of the delay, there was a gap in export protection between 1981 when the 1945 Exchange control regulation expired and 1984, when the CHP Act entered into force. ${ }^{1185}$ During its first decade the export restrictions of the CHP Act applied only to certain designated cultural objects in private ownership. It was only in

recently been changed in the context of an operation seeking to enhance the transparency of lower public authorities and in particular to strengthen the balance of power by re-organising ("dualising") the tasks and competencies of the administration and the representatives of the people. Cf.: Stuurgroep Evaluatie Dualisering Gemeentebestuur, 2004, para. 2.2.. At municipal level, the changes were introduced by the Act on Dualism (Dualiseringswet) that entered into force in March 2002: Wet van 28 februari 2002 tot wijziging van de Gemeentewet en enige andere wetten tot dualisering van de inrichting, de bevoegdheden en de werkwijze van het gemeentebestuur" (Wet Dualisering Gemeentebestuur). At provincial level, the operation of dualising the tasks and competences between the administration and the representation of the people was introduced by the Act on Dualising Provincial Administration. Wet van 16 januari 2003 tot wijziging van de Provinciewet en enige andere wetten tot dualisering van de inrichting, de bevoegdheden en de werkwijze van het provinciebestuur (Wet dualisering provinciebestuur).

1181 See further on the possibility to annul or suspend decisions by Royal Decree: Art. 132(4) of the Dutch Basic Law, Art. 10:35 General Administrative Code, Art. 268 of the Act on Municipalities. See above for an example the Mondriaan Case.

1182 Deviezenorder 1945, Stb. F 222.

1183 Cf.: Sjouke, P.S., 2007, p. 13.

1184 MvT, Kamerstukken II 1980/1981, 16 749, p. 7.

1185 The exchange control regulation expired with the entry into force of the Act on financial relations of foreign character: Wet van 28 mei 1980, Stb. 321 (Wet inzake de financiële betrekkingen met het buitenland). 
1995, in the context of the implementation of Council Directive 93/7/EEC (hereinafter: the Directive) ${ }^{1186}$, that the Netherlands introduced export restrictions for objects from public collections by amending the CHP Act accordingly. ${ }^{1187}$

Above we have already introduced the CHP Act, its parameters with regard to the listing of cultural objects from private collections as Dutch national treasures and its analogous application to the de-accessioning of objects in public collections. In the following we will not further touch upon the aspect of de-acessioning, but will focus on export restrictions applicable to objects from public collections as introduced in the context of the implementation of the Directive. ${ }^{1188}$ In the light of the aim of the present chapter we will also not discuss export restrictions of cultural objects in private collections.

As discussed above in Chapter 1 (\$2.VI) the Directive introduced domestic obligations in all Member States to return cultural objects unlawfully removed from another Member State. ${ }^{1189}$ One of the constellations that constitute unlawful removal in the sense of the Directive is removal in breach of national laws. ${ }^{1190}$ For an object to qualify as 'cultural object' in the sense of the Directive it must fulfil two requirements. First it must be "classified (...) among the 'national treasures possessing artistic, historic or archaeological value' under national legislation or administrative procedures within the meaning of Art. 36 of the Treaty" (Art. 1(1) Directive). Secondly, it must either belong to one of the categories listed in the Annex or must form an integral part of "public collections listed in the inventories of museums, archives or libraries' conservation collection" (Art. 1(2) Directive). ${ }^{1191}$

In order to profit from the protection granted by the Directive for the return of objects removed from the Dutch territory, the Dutch legislator had to provide for national legislation foreseeing in "administrative procedures within the meaning of Art. 36 of the Treaty". This was achieved by introducing Art. 14a to the CHP Act, which bans the export of an object from a Dutch public collection without prior written declaration by the object's owner, or where not available by the Minister of Culture. ${ }^{1192}$

\footnotetext{
1186 Council Directive 93/7/EEC of 15 March 1993 on the return of cultural objects unlawfully removed from the territory of a Member State. See further on the implementation and the effects on Dutch private law: Salomons, A.F., 2007.

${ }^{1187}$ MvT, Kamerstukken II 1993/94, 23657, nr. 3, pp. 1-3. Cf.: Sjouke, P.S., 2007, p. 23.

1188 See for a critical assessment of the implementation of the Directive into Dutch law more in general: Bollen, C.J.M. / de Groot, G.R., 1995.

1189 Siehr, K., 1993, p. 232.

1190 Art.1(2) Directive.

${ }^{1191}$ See further on the Directive above in chp. 1.\$2.VI.

1192 Art. 14a Cultural Heritage Preservation Act: 1. Het is verboden een roerende zaak die integrerend deel uitmaakt van een openbare collectie die vermeld staat in de inventarislijst van een museum, een archief of een vaste collectie van een bibliotheek, en waarvan de Staat of een ander openbaar lichaam eigenaar is, buiten Nederland te brengen zonder dat de eigenaar daartoe schriftelijk toestemming heeft gegeven. Indien de eigenaar zich te dier zake niet verklaart, kan zijn toestemming op verzoek van een belanghebbende worden vervangen door een vergunning van Onze Minister. 2. Het verbod, bedoeld in het eerste lid, geldt eveneens ten aanzien van een roerende zaak die integrerend deel uitmaakt van:
} 
The ban of Art. 14a CHP Act is not limited to cultural objects in public collections that are owned by the Dutch State and lower public authorities (Art. 14a(1) CHP Act). It also applies to those objects that are owned by the Dutch State but which are not part of any museum collection (Art. 14a(2)(c) CHP Act). ${ }^{1193}$ Furthermore, the ban may also apply to objects from the collections of a museum, archive or library, which owned by a legal person under private law but whose financing depends significantly on subsidies of the Dutch State or other public authorities. For the ban to apply the Minister of Culture must have designated the collection as falling under the ban and the object concerned must be listed in the institute's inventory (Art. 14a(2)(b) CHP Act). Finally, the ban applies to objects that belong to collections of cultural-historical or scientific relevance that are owned by a religious institution (Art. 14a(2)(a) CHP Act);

The administrative procedure introduced by the Dutch legislator concerning the export of public collections has correctly been characterised as very light regime that corresponds to the general attitude towards the protection of cultural objects in public collections. ${ }^{1194}$ In coherence with the disposal of objects from public collections emphasis is put on the discretion of the owner. Consequently, where an object from a Dutch public collection is to be exported from the Netherlands, also in a case of return or restitution, permission by the owner respectively the Minister of Culture is required.

Where the export is to a third country outside of the territory of the European Community, the obtaining of permission from the owner is not sufficient. Further to the permission of the owner an export license in the sense of Council Regulation (EEC) $\mathrm{N}^{\circ} 3911 / 92$ is required (Art. 14b CHP Act). Art. 14b(2) CHP Act grants the Minister the power to introduce the exception provided for under Art. 2(2) second subparagraph of the Regulation for archaeological objects of limited archaeological and scientific interest. The Minister has so far not used this power. ${ }^{1195}$

The competent Dutch authority to oversee the granting of export licences for exports outside of the territory of the European Union is the State Inspectorate, in

a. een inventarislijst van roerende zaken van cultuurhistorische of wetenschappelijke betekenis waarvan een kerkgenootschap, een zelfstandig onderdeel daarvan, of een ander genootschap op religieuze grondslag eigenaar is; b. een openbare collectie die vermeld staat in de inventarislijst van een museum, een archief of een vaste collectie van een bibliotheek, en waarvan de eigendom berust bij een privaatrechtelijke rechtspersoon die in overwegende mate wordt gefinancierd door subsidie, die door de Staat of een ander overheidslichaam wordt verstrekt en die door Onze Minister voor de toepassing van dit verbod is aangewezen; c. de inventarislijst die door Onze Minister wordt bijgehouden van roerende zaken van cultuurhistorische of of wetenschappelijke betekenis. (...).

1193 These more than 100.000 objects are managed by the Netherlands Institute for Cultural Heritage ((Instituut Collectie Nederland (ICN)) and can be assessed via a database available at: http://www.icncollectie.nl/ (last visited: 7 April 2009). The Institute, which falls under the responsibility of the Ministry of Culture has three more tasks further to managing this collection: consulting on management and preservation of collections, performing research, and disseminating and sharing knowledge. See further: http://www.icn.nl/en (last visited: 7 April 2009).

1194 Sjouke, P.S., 2007, pp. 25-26.

1195 Email from Marja van Heese, State Inspectorate for Cultural Heritage, Ministry of Education, Culture and Science dated 8.4.2009 on file with the author. 
cooperation with the Tax Authorities and Customs. Given the light regime of protection, such a licence will be granted in the great majority of the cases.

\section{UNITED KINGDOM}

In this section an overview will be given of the restrictions on the disposal of objects in public collections in the United Kingdom with an emphasis on England, as well as of potential export restrictions from the United Kingdom. It is difficult to categorise the many different museums in the United Kingdom but one can broadly distinguish between the following categories: local authority museum, university museums, national collections, charities, and collections vested in trustees pursuant to the terms of a trust obligation. Public collections can in be a number of these categories at the same time. As a consequence, various layers of law may apply simultaneously to a certain public collection.

The following analysis will focus on the interplay between the various layers of law with regard to disposal from national museums. While local authority museums and university museums will not be further discussed, the elaborations of restrictions arising from trust and charity law are also true for these two categories of museums. As for local authority museums, these layers may be the only layers of law restricting disposal as they are generally not subject to statutory restraints on disposal. ${ }^{1196}$ With regard to university museums, they may be subject to rules against disposal depending on their governing instruments (royal charters and foundation deeds).

Given the relevance accorded under Common law to the institute of the "trust", which is unique to Common Law, restrictions on disposal arising from trust law must first be considered. Subsequently, the existing statutory restrictions on disposal of

1196 Cf.: Palmer, N., 2000b, p. 348. The Public Libraries and Museums Act 1964 (c.75), London: The Stationery Office, which governs most local authority museums, gives local authorities the power to provide and maintain museums and art galleries (s. 12) but does not restrict local authorities' powers of disposal of items in their collections (ss. 12-26). There exists, however, the possibility that local authority museums are subject to statutory restrictions on disposal of objects from their collections under Local Acts (Public Libraries and Museums Act 1964 (c.75), London: The Stationery Office, s. 23 on Local Acts). To illustrate this point, reference can be made to the Greater Manchester Act 1981, London: The Stationery Office and the County of Lancashire Act 1984, London: The Stationery Office. According to section 149 of Manchester Act, the Manchester Council has to hold "all works or other objects of art" on trust for the benefit of the citizens of Manchester. While the Council may dispose of any object from the collection, this may only be done for a consideration, i.e. in the form of a sale or exchange. The power to dispose of objects for district councils subject to the Lancashire Act is more restrained: disposal in the sense of parting not only with possession but also ownership is limited to those cases where an object is given to another institution in Lancashire (museum, art gallery or library) which is more suitable for the object's suitable for exhibition or use. The disposal may be without consideration (County of Lancashire Act 1984, s. 58). Cf.: Department for Culture Media and Sport, 2006b, para. 2.13. What the examples of the Greater Manchester Act 1981 and the County of Lancashire Act 1984 indicate is that while the Public Libraries and Museums Act 1964 as such does not provide for a statutory restriction on disposal, this does not mean the absence of any statutory restrictions. Instead, one has to take into account of the respective Local Act. See further on local authorities: Palmer, N., 2000a, pp. 30-35. 
objects from the National collections, respectively the powers available for disposal will be scrutinised. In doing so, attention must also be given to the question how the law treats the disposal of objects acquired by gift or testamentary dispositions.

After the regime with regard to the disposal of objects from public collections have been scrutinised, the analysis will turn to the question in how far restitutions might be affected or restricted by the existence of export restrictions. These restrictions focus on the individual object and hence apply irrespective of the public collection the object belongs to. Put differently, the layer of export control applies to all categories of public collections.

\section{TRUST AND CHARITY LAW}

Trusts are a creation of equity consisting of a relationship based on fiduciary confidence between one person (or persons), known as a trustee and another person (or persons), known as a cestui que trust (or, more commonly, a "beneficiary"). ${ }^{1197}$ A trust may apply to any sort of property. Created by legal instrument, a trust vests legal title to the property in the trustee(s) who is/are bound to administer the property for the benefit of cestui que trust, that is to say an identifiable beneficiary, in accordance with the terms of the trust and usually without personal benefit to the trustee. ${ }^{1198}$ Trustees can be individuals or a body corporate.

For a trust to be enforceable at law there must be certainty about the beneficiary of the trust. In other words there must be someone capable to demonstrating to a court his or her right to benefit under the trust. Where there is no certainty as to the beneficiary the trust will fail.1199 Charity law provides an exception to this rule. Following the passing of the Statute of Charitable Uses, also known as the Statute of Elizabeth there gradually emerged a set of public interest purposes for which a trust could be said to exist as a matter of charity law, even though an individual could not be identified as its beneficiary. ${ }^{1200}$ As the law developed, the Sovereign's Attorney-General became the guardian of the beneficial interests in charitable trusts, and during the twentieth century his role has been largely subsumed into that of the Charity Commissioners.

In the eighteenth century, trust corporations were being created by Act of Parliament or Royal Charter for the foundation of institutions whose purpose was the public good (in the charitable sense) rather than personal gain for their members. Early examples included Sir Thomas Coram's Foundling Children's Hospital and of course the British Museum.

Trusts have been called "the guardian angel of the Anglo-Saxon, accompanying him everywhere, impassively, from the cradle to the grave". ${ }^{201}$ They sure follow him into the

\footnotetext{
1197 Cf.: Rutherford, L. / Bone, S., 1993, p. 332.

1198 Prott, L.V. / O'Keefe, P.J., 1989, para. 403.

1199 E.g.: Ramjohn, M., 2008, p. 54.

1200 Stat. 43 Eliz. 1, c4 (1601).

1201 Lepaulle, P., 1932, p. 113.
} 
museum premises with the national museums and galleries being established by statute and whose Trustees hold the collections in trust for the (education of the) public. ${ }^{1202}$ While the national museums and galleries are exempt from the mandatory provisions of the 1993 Charities Act under which charities are required to register with an account to the Charity Commissioners for England and Wales ${ }^{1203}$, there are nevertheless certain requirements of charity law that these institutions must conform to. ${ }^{1204}$

As starting point, any museum which is a charity cannot dispose of its charitable assets other than in its interest pursuant to its own charitable trusts and pursuant to the powers and duties set out in the Charities Acts 1993-2006.1205 This does not mean, however, that trustees may only dispose of charitable assets where they have been granted explicit powers to do so. Therefore, before we will scrutinise the powers explicitly granted to the trustees of the national collections under statutory law, we will shortly reflect upon the situation where the Trustees wish to make an application of property of the charity where they have not been provided with such a power. This question was addressed in $\mathrm{R} e$ Snowdon.1206 In his judgment Cross $\mathrm{J}$ held that the Attorney-General had the power to authorise "a payment (...) out of charity funds

1202 Cf.: Forder, C., 1994, p. 146. The statutory powers of a local authority are not confined to charitable purposes, and accordingly, items in the collection of a local authority museum are not necessarily subject to charitable trusts. Where the collection originally passed to a local authority from a learned society or other charity, for example, the items comprised in the collection at that date may well be subject to special charitable trusts, but subsequent acquisitions by the authority for the purposes of its museum may not be, depending on the terms on which the item was acquired. So, for example, Glasgow City Council was able to transfer title in a Lakota Ghost Dance Shirt in the collection of the Art Gallery and Museum in Kelvingrove to the Wounded Knee Survivors Association in 1999. The shirt had been donated to the Glasgow museum at the end of the $19^{\text {th }}$ century together with a number of other items. As no legal conditions were attached to the donation, there existed no legal obstacles to returning the Lakota Ghost Dance Shirt. See Memorandum from Glasgow City Council to the Select Committee on Culture, Media and Sport, April 2000, published with the minutes of evidence to that Committee in volume 2 of the Report of Cultural Property Return and Illicit Trade (HC 371-II).

1203 See Schedule 2 of the Charities Act 1993 (c. 10).

1204 Seventh Report of the House of Commons Select Committee on Culture Media and Sport, Cultural Property: Return and Illicit Trade, 2000, para. 138.

1205 It is fair to say that any public museum in the UK that operates for public benefit is either exempt, registered or entitled to register as a charity today. But for a number of local authority museums most public museums have done so.

1206 Snowden, decd, In re [1970] Ch 700. The circumstances of In re Snowden were as follows: there were two summonses before Cross J, one relating to the will of Norman Snowden, the other concerning the will of Florence Henderson. In the case of the will of Norman Snowden, due to sales made in his lifetime, bequests of his shareholdings in specific companies had been adeemed but, in consequence, pecuniary legacies and bequests of shares of residue were much greater than the testator could have contemplated. The pecuniary and residuary legatees were six charities. They agreed, if the Attorney General had no objection, that various sums should be paid to the specific legatees. In the case of the will of Florence Henderson a manuscript but unattested addition to the will was omitted from probate. Under the will, as proved, the residue after payment of various pecuniary legacies was left to charity generally. The administrators sought the approval of the court, if the Attorney General consented, to give effect to the manuscript alteration. Thus, in each case, approval was sought for a transaction in which charity would forego money to which it was entitled. Cf.: The High Court judgement of 24th May 2005 [2005] EWCH 1089 (Attorney-General v. Trustees of the British Museum), para. 17. 
which is motivated simply and solely by the belief of the trustees or other persons administering the funds that the charity is under a moral obligation to make the payment". ${ }^{1207}$ The judgment of Cross J has since been enshrined in statute. Section 27 of the Charities Act 1993 gives the designated authority power to authorise the trustees of the charity to "make any application of property of the charity (...) in a case where the charity trustees (...) have no power to do so, but in all the circumstances regard themselves as being under a moral obligation to do so". Hence, further to any explicit disposal powers granted to the trustees, they may make an application to the designated authority (the Charity Commission, the Attorney-General or the courts) to seek approval to part with property. ${ }^{1208}$

While In Re Snowdon and Section 27 of the Charities Act provide for the situation that there exists no statutory powers for disposal, they do not address the question whether an application the designated authorities can also be made in those cases where the trustees regard themselves as being under a moral obligation to dispose of objects but are prohibited by statute from doing so. Put differently, could Section 27 of the Charities Act be relied upon - not in the absence of any statutory provisions providing for a power of disposal - where such a disposal was explicitly prohibited by statute? This question was addressed in the Attorney-General v. Trustees of the British Museum (The Feldmann case).

a) Attorney-General v. Trustees of the British Museum (the Feldmann case) 1209

The Feldmann Case concerned a claim advanced in 2002 by the Commission for Looted Art in Europe on behalf of the heirs of the late Dr Feldmann for restitution of four old master drawings held by the British Museum. The drawings ${ }^{1210}$ had been seized in March 1939 by the Gestapo from Dr Feldmann's house in Brno when the Nazis invaded Czechoslovakia. Three of the drawings later entered the museum's collection through a sale at Sotheby's in 1946, while the fourth was part of a bequest to the museum in 1949. The British Museum's trustees agreed that the four drawings ought to be returned to the heirs of Arthur Feldmann as they felt they had a moral obligation to do so given the "exceptional atrocities committed during the 1933-1945 era". ${ }^{1211}$ In the light of the statutory restrictions on disposal of the British Museum Act 1963, according to which the Trustees may not dispose of objects vested in them otherwise than in a

\footnotetext{
1207 Snowden, decd, In re [1970] Ch 700, p. 710.

1208 Cf.: Seventh Report of the House of Commons Select Committee on Culture Media and Sport, Cultural Property: Return and Illicit Trade, 2000, para. 138.

1209 The High Court judgement of 24th May 2005 [2005] EWCH 1089 (Attorney-General v. Trustees of the British Museum).

1210 The Holy Family, by Niccolo dell'Abbate; An Allegory on Poetic Inspiration with Mercury and Apollo, by Nicholas Blakey; Virgin and Infant Christ adored by St Elizabeth and the Infant St John, by Martin Johann Schmidt; St Dorothy with the Christ Child, by a follower of Martin Schongauer.

1211 The High Court judgement of 24th May 2005 [2005] EWCH 1089 (Attorney-General v. Trustees of the British Museum), para. 5.
} 
number of very limited circumstances ${ }^{1212}$, the Attorney-General instituted proceedings to resolve the question whether the express restrictions prevented a disposal of the drawings under the Snowden principle. ${ }^{1213}$ According to the Trustees of the British Museum, who argued analogue to Re Snowden, the Attorney-General had the power to authorise the Trustees, notwithstanding the express terms of the statute restricting the British Museum's powers of disposal, to transfer the drawings to the claimants on the grounds that they were under a moral obligation to do so. The Attorney-General was unsure about the extent of his powers and had brought the matter before the ViceChancellor of the High Court to resolve the question.

The Vice-Chancellor held that "no moral obligation can justify a disposition by the Trustees of an object forming part of the collections of the museum in breach of section 3(4) of the 1963 Act". ${ }^{1214}$ Different from the Re Snowden ${ }^{1215}$, which confirmed the power to authorise trustees to make payments out of charity funds on moral grounds ${ }^{1216}$, the disposition of an object cannot be based on moral obligations contrary to statutory restrictions. ${ }^{1217}$ Consequently, the paintings could not be returned to the Feldmann heirs on moral grounds but remained in the collection of the British Museum.

The case Attorney-General v. Trustees of the British Museum therewith clearly stated the hierarchy between the possibility to apply to the designated authorities under section 27 of the Charities Act in favour of a disposal and statutory prohibitions on such disposal: where there exist statutory prohibitions on disposal of an object they can not superseded by the reliance on section 27 of the Charities Act. ${ }^{1218}$ For this reason, the subsequent paragraphs will analyse the powers and restrictions with regard to disposal as provided for in the individual constitutions of the national museums and galleries. ${ }^{1219}$

\section{The English National COLlections: Statutory powers and Restrictions ON DISPOSAL}

All national collections in England are subject to statutory restrictions on the disposal of items within their collection but vary in the degree of restrictedness in their

\footnotetext{
1212 See further below for an analysis of the exceptions available to the ban on disposal of s. 3(4) of the British Museum Act 1963, London: The Stationery Office (chp. 3.§2.II.2).

1213 Snowden, decd, In re [1970] Ch 700.

1214 The High Court judgement of 24th May 2005 [2005] EWCH 1089 (Attorney-General v. Trustees of the British Museum), para. 45.

1215 Snowden, decd, In re [1970] Ch 700.

1216 “(...) a payment (...) out of charity funds which is motivated simply and solely by the belief of the trustees or other persons administering the funds that the charity is under a moral obligation to make the payment" (para. 4).

1217 The High Court judgement of 24th May 2005 [2005] EWCH 1089 (Attorney-General v. Trustees of the British Museum), para. 45.

1218 See chp. 4.\$1.II.1 discussing the work of the Spoliation Advisory Panel as to the final settlement of the case.

1219 Seventh Report of the House of Commons Select Committee on Culture Media and Sport, Cultural Property: Return and Illicit Trade, 2000, para. 138.
} 
disposal powers. ${ }^{1220}$ Most but not all collections have also been granted powers to dispose of objects in their collections. In the following, the applicable statutory regimes of the national collections will be scrutinised with regard to the restrictions and powers provided for in the governing statutes.

At first, the restrictions and powers to disposal applicable to the British Museum, as primus inter pares, will be analysed before turning to the restrictions on and powers of disposal as they apply to the other national collections.

\section{a) British Museum and Natural History Museum}

The British Museum is governed by the British Museum Act 1963.1221 According to section 8(3) of the British Museum Act, the Natural History Museum is subject to the same restrictions as the British Museum with regard to questions of disposal.1222 Consequently, the following elaborations on the British Museum (Act) are true also for the Natural History Museum.

According to section 3(1) of the British Museum Act 1963, "it shall be the duty of the Trustees of the British Museum to keep the objects comprised in the collections of the Museum within the authorised repositories of the Museum (...)". Temporary removals of objects from the collection are only allowed for administrative reasons or the management of the collection, or in the form of loans for public exhibition (whether in the United Kingdom or elsewhere). ${ }^{1223}$ Section 3 (4) of the British Museum Act complements the positive duty of the Trustees to keep the objects from the collection within the authorised repositories of the museum with the explicit prohibition of disposing of any objects vested in them otherwise than in accordance with section 5 and 9 of that Act, or section 6 of the Museums and Galleries Act 1992.

Under section 5(1), the British Museum may dispose of items vested in the Trustees if:

\footnotetext{
a. the object is a duplicate of another object, or

b. the object appears to the Trustees to have been made not earlier than the year 1850, and substantially consists of printed matter of which a copy made by photography or a process akin to photography is held by the Trustees, or
}

\footnotetext{
1220 As far as Scotland is concerned, there are no statutory restrictions on disposals from collections in the governance arrangements for Scottish museums. Similarly there are no statutory restrictions on disposals from the collections of the National Museums and Galleries of Wales. The National Museums and Galleries of Wales are governed by Royal Charter, and are not therefore subject to statutory restrictions on disposal. Cf.: Department for Culture Media and Sport, 2006b, paras. 1.12 \& 12.11.

1221 British Museum Act 1963, London: The Stationery Office. British Museum Act 1963, London: The Stationery Office

${ }^{1222}$ See s. 8(3) of the British Museum Act 1963 according to which "Sections 2 to 7 of this Act and the First Schedule thereto shall apply in relation to the Natural History Museum and the Trustees thereof as they apply in relation to the British Museum and the Trustees thereof (...)".

${ }^{1223}$ Sec. 3(1) and sec. 4 of the British Museum Act 1963. See also further below (chp. 3.\$2.II.4) discussing export restrictions on Open Individual Export Licences (OIELs).
} 
c. in the opinion of the Trustees the object is unfit to be retained in the collections of the Museum and can be disposed of without detriment to the interests of students:

Provided that where an object has become vested in the Trustees by virtue of a gift or bequest the powers conferred by this subsection shall not be exercisable as respects that object in a manner inconsistent with any condition attached to the gift or bequest."

The powers conferred sub a) and b) apply to specific, well-defined situations: duplicates and objects that have been printed after 1850. The scope of the third power granted, according to which an object that is considered "unfit" and whose disposal is without detriment to the interests of students" may be disposed (sub c) is less clear. The general interpretation of this clause is that an object qualifies as unfit "if no reasonable person would want the Museum to keep it because, for example, it is a forgery or was wrongly identified and is for that reason, in the Trustees' reasonable opinion, without merit or value". ${ }^{1224}$

However, even if the object concerned fits any of these three categories (i.e. it is a duplicate, printed matter dating from 1850 onwards or is unfit to be retained), it may only be disposed of if it is not subject to any non-statutory restrictions. The British Museum Act does not lift the Trustees' obligation to observe non-statutory restrictions in the situations set out in section 5(1). To the contrary, non-statutory restrictions are explicitly entrenched by the proviso that

"where an object has become vested in the Trustees by virtue of a gift or bequest the powers conferred by this subsection shall not be exercisable as respects that object in a manner inconsistent with any condition attached to the gift or bequest".

Consequently, all three powers to disposal can be effected only where they do not contravene with any conditions attached to an object that has been received as a gift or bequest. This is different for the power granted in section 5(2). According to this section, Trustees are granted the power to dispose of any object vested in them if they are satisfied that it has become "useless for the purposes of the Museum by reason of damage, physical deterioration, or infestation by destructive organisms". In this case, disposal can be affected regardless of the question whether the objects had been acquired in form of a gift or bequest. Consequently, section 5(2) provides trustees with the power to override trust and other non-statutory conditions.

${ }^{1224}$ Cf.: Seventh Report of the House of Commons Select Committee on Culture Media and Sport, Cultural Property: Return and Illicit Trade, 2000, para. 139. It has been suggested that "unfitness" of an object might "extend to moral unfitness or the shame of continued retention". Such moral unfitness has never been argued or accepted as of today. Cf.: Palmer, N., 2000a, pp. 24-25; Palmer, N., 2000b, p. 349. However, even if one accepted that unfitness could be construed on moral grounds, the test in s 5(1)(c) is two fold: further to unfitness, disposal is subject to the requirement that it is without detriment to the interests of students. In the Feldmann Case discussed above the Trustees did not suggest that they were "unfit" by virtue of their provenance in the sense of s 5(1)(c) of the British Museum Act 1963. Cf.: The High Court judgement of 24th May 2005 [2005] EWCH 1089 (Attorney-General v. Trustees of the British Museum), para. 22. 
Further to the disposal powers granted in section 5 of the British Museum Act, the Trustees might also be allowed to transfer an object from their collection to another public collection. Under section 9 of the British Museum Act ${ }^{1225}$ and section 6 of the Museums and Galleries Act 1992 Trustees are granted the power to transfer an object other approved museums as specified in Part I of Schedule 5 to the Museums and Galleries Act 1992.1226 For objects that have been acquired subject to a trust or condition, transferors are required to hold the object subject to the same trust or condition (s. 6(4)). Where a transfer of an object subject would be inconsistent with a trust or condition, the transfer is only possible after the person who first imposed the trust or condition or his personal representatives have consented (s. 6(3)).

\section{b) Other National Museums}

In the following, the restrictions on and powers to disposal of objects from the other national museums will be discussed. Against the analysis of the restrictions applicable to the British Museum (and the Natural History Museum), the respective regimes can be classified in three categories: first, museums that are subject to similar statutory restrictions as the British Museum. Secondly, museums that are subject to stricter restrictions on disposal than the British Museum and thirdly, museums that are subject to less stringent restrictions. In the following we will first discuss the collections that are subject to similar restrictions as the British Museum before turning to the category that is subject to greater restrictions and the category of more liberally regulated museums.

\section{National museums with statutory restrictions on disposal similar to the British Museum}

A number of national collections are subject to similar statutory restrictions as applicable to the British Museum. First, there are the collections of the Victoria \& Albert Museum, the Science Museum, the Armouries and the Royal Botanic Gardens, Kew. All four collections are governed by the National Heritage Act 1983. According to section 6(3) of the Act, the Board of Trustees of the Victoria and Albert Museum may not dispose of an item which is vested in them and comprised in their collections unless:

a. the disposal is by way of sale, exchange or gift of an object which is a duplicate of another object the property in which is so vested and which is so comprised, or

1225 S 9 reads "[a]ny movable property vested in the Trustees of either Museum [the British Museum and the Natural History Museum, K.L.] may be transferred by them to the Trustees of the other Museum”.

1226 The following collections can be both transferors and transferees: The Board of Trustees of the Armouries, The British Library Board, The Trustees of the British Museum, The Trustees of the Imperial War Museum, The Board of Governors of the Museum of London, The Board of Trustees of the National Gallery, The Board of Trustees of the National Galleries of Scotland, The Board of Trustees of the National Library of Scotland, The Trustees of the National Maritime Museum, The Board of Trustees of the National Museums and Galleries on Merseyside, The Board of Trustees of the National Museums of Scotland, The Board of Trustees of the National Portrait Gallery, The Trustees of the Natural History Museum, The Board of Trustees of the Science Museum, The Board of Trustees of the Tate Gallery, The Board of Trustees of the Victoria and Albert Museum, The Historic Buildings and Monuments Commission for England. 
b. the disposal is by way of sale, exchange or gift of an object which in the Board's opinion is unsuitable for retention in their collections and can be disposed of without detriment to the interests of students or other members of the public, or

c. the disposal is an exercise of the power conferred by section 6 of the Museums and Galleries Act 1992 (i.e. to an approved museum), or

d. the disposal (by whatever means, including destruction) is of an object which the Board are satisfied has become useless for the purposes of their collections by reason of damage, physical deterioration, or infestation by destructive organisms.

With regard to the question in how far the power of disposal granted to the Trustees may be exercised contrary to non-statutory restrictions, section 6(5) explicitly foresees in this possibility with regard to disposal of an object that has become useless (s. 6(3)(d)). In case an object has become useless in the sense of section 6(3)(d) it may be disposed notwithstanding a trust or condition. ${ }^{1227}$

The same options of disposal are available to the Science Museum, the Armouries and the Royal Botanic Gardens. ${ }^{1228}$ With regard to the National Museums and Galleries on Merseyside ${ }^{1229}$, Art. 6 of the Merseyside Museums and Galleries Order 1986 also provides for the same restrictions. ${ }^{1230}$

\section{National museums with more stringent statutory restrictions on disposal}

In the following, four national museums subject to stricter restrictions on disposal will be discussed in ascending order according to the degree of restrictedness. While all four museums, the National Portrait Gallery, the Tate, the National Gallery, and the Wallace Collection, are governed by the Museums and Galleries Act 19921231, the applicable statutory restrictions and power to disposal vary.

The Trustees of the National Portrait Gallery may dispose of works from their collection by transfer to another approved museum, of duplicates, and of objects that have become useless for the collections by reason of damage, physical deterioration or infestation by destructive organisms. In the latter case, disposal may be affected despite any trusts or conditions prohibiting the disposal of the object. Compared with the British Museum and the other national museums discussed above, the National Portrait Gallery misses the option to dispose of an object that is considered "unfit to be retained". The Trustees of the National Portrait Gallery have, however, been granted a

1227 S 6(5) reads: "An object may be disposed of as mentioned I subsection (3)(d) notwithstanding a trust or condition (express or implied) prohibiting or restricting the disposal of the object".

1228 Ss 14(3), 20(3) and 27(2) of the 1983 Act respectively. As for the Board of Trustees of the Royal Botanic Gardens, it does not have the power under s 6 of the Museums and Galleries Act 1992 (c. 44), London: The Stationery Office to transfer items in their museums to approved museums.

${ }^{1229}$ The Liverpool Museum, the Museum of Liverpool Life, the Merseyside Maritime Museum, the Walker Art Gallery, the Lady Lever Art Gallery, Sudley House, the National Conservation Centre and the World Museum Liverpool.

${ }^{1230}$ Merseyside Museums and Galleries Order 1986, (as amended by the Museums and Galleries Act 1992), London: The Stationery Office.

${ }^{1231}$ See for an in-depth discussion of the Act and the legal situation of the galleries prior to the Act: Forder, C., 1994. 
"sui-generis" disposal power, which mirrors the mission of the museum as National Portrait Gallery: in cases where the identification of the sitter of a portrait has been discredited, the Board of Trustees may dispose of the portrait by whatever means (!). ${ }^{1232}$

The Trustees of the Tate may transfer an object to an approved museum, may dispose of an object considered unsuitable for retention, which can be disposed of without detriment to the interests of students or other members of the public and may dispose of an object which has become useless for the purposes of their collections by reason of damage, physical deterioration, or infestation by destructive organisms. ${ }^{1233}$ Squared with the possibilities of disposal granted to the Trustees of the British Museum, the Trustees of the Tate miss the option to dispose of a duplicate. Furthermore, they are not granted the power to override any trust or other non-statutory restriction. In contrast with the power granted to a number of other national collections ${ }^{1234}$ according to which they may dispose of an object notwithstanding any trust or condition restricting such disposal where the object has become "useless", section 4(4)(c) of the Museums and Galleries Act explicitly provides with regard to the collection of the Tate that "this subsection is without prejudice to any trust or condition (express or implied) prohibiting or restricting disposal of the relevant object".

The National Gallery is barred from disposing any item in its collection unless by way of transfer (by sale, gift or exchange) to an approved museum. ${ }^{1235}$ The Board of Trustees of the Wallace Collection, finally, has no power at all to dispose of objects in the collection. ${ }^{1236}$

National museums subject to less stringent restrictions than the British Museum

The group of national museums that are subject to a less stringent regime with regard to disposal is formed by the Imperial War Museum, the National Maritime Museum and the Museum of London, each of which are governed by their own museum act.

According to the Imperial War Museum Act 1920, the trustees of the Imperial War Museum may dispose of any duplicate. Non-duplicate objects, which are considered unfit to be preserved or no longer required for the museum's purposes may be disposed with the consent of the Secretary of State. ${ }^{1237}$ Furthermore, the museum may transfer objects to other approved museums. The Imperial War Museum Act contains no provision exempting the Trustees from observing non-statutory obligations.

\footnotetext{
1232 Museums and Galleries Act 1992 (c. 44), London: The Stationery Office, s 4(5). The terminology by "whatever means" suggests that this includes destruction. Cf.: Forder, C., 1994, p. 144.

${ }^{1233}$ Museums and Galleries Act 1992 (c. 44), London: The Stationery Office, s 4(4).

1234 British Museum under s 5(2) of the British Museum Act 1963, the Victoria \& Albert Museum, the Science Museum, and the Royal Botanic Gardens, Kew under s 6(3), respectively s 14(3) and s 27(3) of the National Heritage Act 1983, London: The Stationery Office.

1235 Museums and Galleries Act 1992 (c. 44), London: The Stationery Office, s 4(3). Cf.: Palmer, N., 2000a, p. 26.

1236 Museums and Galleries Act 1992 (c. 44), London: The Stationery Office, s 4(6).

${ }^{1237}$ Imperial War Museum Act 1920 (c.16), London: The Stationery Office, s 2(1)(c).
} 
The powers granted to the Trustees of the National Maritime Museum under the National Maritime Museum Act 1934 are similar. ${ }^{1238}$ On top of these powers, the Board may also transfer objects to any institution which receives monies provided by Parliament and which would be designated to hold the object. Similar to the Trustees of the Imperial War Museum, the powers of the Trustees of the National Maritime Museum are subject to any condition attached to a gift or bequest vesting the object in the Board for the purposes of the Museum. Different to the Imperial War Museum Act, the National Maritime Museum Act 1934 entrenches this general obligation in an explicit provision. ${ }^{1239}$

The Governors of the Museum of London, may dispose of duplicates and of objects which "for any other reason are not required for retention in those collections". ${ }^{1240}$ This power does not, however, supersede any restrictions originating from a trust or condition attached to the object. ${ }^{1241}$

\section{c) Restrictions applicable to public collections in Scotland, Wales and Nothern-Ireland}

As far as Scotland is concerned, section 8 of the National Heritage (Scotland) Act 1985 restricts the disposal of objects from the national museums of Scotland. ${ }^{1242}$ The National Museums and Galleries of Wales, to the contrary, are governed by Royal Charter, and are not subject to statutory restrictions on disposal. As belonging to the charitable assests of a registered charity, however, objects from the collection of the National Museums and Galleries of Wales may not be disposed of other that in the interests of the charity having regard to the charitable powers and duties of its trustees. ${ }^{1243}$ As for Northern-Ireland, the Museums and Galleries (Northern Ireland) Order 1998 restricts the disposal of objects under section 5. According to section $5(2)(b) \&(e)$, however, the national museums in Northern Ireland are grantd to the authority to de-accession from its collections, subject to the consent of the Department of Culture, Arts and Leisure. ${ }^{1244}$

\footnotetext{
1238 National Maritime Museum Act 1934 (c.43), London: The Stationery Office, s 2(3)(b).

1239 Ibid., s 2 reads: "(3) The Board shall have the general management and control of the Museum and for that purpose may - (b) exchange, sell or otherwise dispose of any duplicate objects vested in them for the purposes of the Museum, and with the consent of the Lord President of the Council exchange, sell or otherwise dispose of any objects so vested which the Board consider to be not required for the purposes of the Museum (...). Provided that the powers conferred by this section of selling or otherwise disposing of, or lending or transferring, any object, shall not be exercised in any manner inconsistent with any condition attached to any gift or bequest by virtue or in consequence of which that object was vested in the Board for the purposes of the Museum (Emphasis added). Cf.: Department for Culture Media and Sport, 2006b, para. 2.11.

1240 Museum of London Act 1965 (c. 17), London: The Stationery Office, s 5(2).

1241 Ibid., s 5(4).

1242 See for the text of s 8:

http://www.statutelaw.gov.uk/content.aspx?LegType=All+Primary\&PageNumber=39\&NavFrom=2\&par entActiveTextDocId=1298640\&ActiveTextDocId=1298651\&filesize $=6098$ (last visited: 6 July 2009).

1243 Cf.: Department for Culture Media and Sport, 2006b, paras. 1.12 \& 12.11.

1244 See for the text of s 5 :

http://www.statutelaw.gov.uk/content.aspx?LegType $=$ All+Legislation\&title $=$ Museums + and + Galleries +(

Northern+Ireland $)+$ Order $+1998 \&$ searchEnacted $=0 \&$ extentMatchOnly $=0 \&$ confersPower $=0 \&$ blanketAme
} 


\section{RESTRICTIONS ON DISPOSAL FROM DONATIONS AND TESTAMENTARY DISPOSITIONS}

Further to the statutory restrictions on disposal discussed above, disposal may be barred on the grounds of non-statutory restrictions. The most relevant non-statutory restrictions arise from the situation where an object has been acquired in the form of a gift or testamentary dispositions subject to explicit or implied terms preventing disposal. ${ }^{1245}$ By means of example, the reader may referred to Attorney-General $v$ Trustees of the British Museum ${ }^{1246}$ discussed above, which concerns four drawings from the collection of the British Museum, one of which had been acquired by bequest in 1949. While the fact that the drawing had been given to the museum by bequest was of no further relevance in the present case as disposal was barred already by statute, it might have been crucial in the absence of statutory limitations.

In those cases where a museum is not prevented from disposal by statutory provisions, it may nevertheless not be able to part from an object or collection vested in the trustees pursuant to the terms of a trust obligation, usually contained in a will of a deed of gift. ${ }^{1247}$ Where the donee museum accepted a gift or bequest subject to a private restriction, the limitation is recognized by the law. ${ }^{1248}$ However, the mere fact that an object has been received as a gift or testamentary disposition does not necessarily mean that it is subject to restrictive conditions. ${ }^{1249}$ Instead, a case-by-case analysis must establish the exact conditions attached to a bequest or gift and whether these bar disposal and transfer of the object.

In a limited number of cases disposal will be possible even if the conditions attached to the bequest or gift provide against disposal. This is, however, only the case where the governing statutes of the national collections explicitly provide for this option. The analysis of statutory powers above revealed that a number of national collections have been granted the power to override trust and other non-statutory conditions under certain circumstances. ${ }^{1250}$ Disposal in the context of a restitution case is, however, not amongst these circumstances. Rather, this power to dispose of an object in contravention of non-statutory restrictions is first and foremost granted where an object has become useless for the purpose of the collection by reason of damage, physical

ndment $=0 \&$ sortAlpha $=0 \&$ TYPE $=$ QS\&PageNumber $=1 \&$ NavFrom $=0 \&$ parentActiveTextDocId $=1012840$ \&ActiveTextDocId $=1012849 \&$ filesize $=2946$ (last visited: 6 July 2009).

1245 Above, the limitations on disposal under charity law have already been discussed.

1246 The High Court judgement of 24th May 2005 [2005] EWCH 1089 (Attorney-General v. Trustees of the British Museum).

${ }^{1247}$ Examples are the Wallace Collection or the Burrel Collection. See on the latter: Spoliation Advisory Panel, 2004 below in chp. 4.\$1.II.1).

1248 Jessup, P.C.J., 1991, p. 71.

1249 Cf.: Palmer, N., 2000a, p. 25.

1250 The National Portrait Gallery, the British Museum, the Royal Botanic Gardens, the Science Museum and the Victoria and Albert Museum. The British Library, the Museum of London, the National Maritime Museum, the Tate Gallery and the Merseyside Museums and Galleries have no power to override trusts and other conditions prohibiting disposal in any circumstances. 
deterioration or infestation by destructive organisms. In all other cases, i.e. where an object has not become useless, it may not be disposed of in contravention of nonstatutory restrictions. This situation can of course be changed by changing the governing statute. Inspiration could, e.g. be drawn from existing legislation at lower administrative level. The Greater Manchester Act 1981 and the County of Lancashire Act 1984, e.g. ensure that the extent to which the powers of disposal conferred on local authorities may be restricted by obligations to respect any condition attached to a gift or bequest is limited to a period of 21 years (in the case of Manchester) and 35 years (for Lancashire) from the date in which the object became vested in the local authority concerned. ${ }^{1251}$ There exists, however, resistance amongst the Trustees of the national museums to extent the possibilities to dispose of gifts and bequest for fear of sending wrong signals to potential future donors and testators. ${ }^{1252}$

The wish not to disencourage donations and gifts might also be an explanation for the fact that some statutes entrench ${ }^{1253}$ non-statutory restrictions by explicitly stating that any power of disposal granted to the institution is subject to any trust or other condition which might restrict the disposal of a particular item. ${ }^{1254}$

In the following section, the UK export control will be discussed and scrutinised with regard to the question in how far it applies to restitution cases.

\section{EXPORT RESTRICTIONS}

Until 1939, no legal controls on the export of cultural objects existed in the United Kingdom. In reaction to the outbreak of World War II and in order to conserve national resources in general, the Import, Export and Customs Powers (Defence) Act 1939 was enacted by Parliament, as well as the Defence (Finance) Regulations. Both legal instruments sought to ensure that the export of any good outside of the Sterling Area occurred only where the goods had earned their proper quota of foreign exchange. In 1940, antiquities and works of art were brought under the licensing system. ${ }^{1255}$

After the revival of the art trade in the post-war years, the export licensing regime became subject to controversy when a number of owners had been refused export

1251 Cf.: Department for Culture Media and Sport, 2006b, para. 2.20.

1252 Cf.: Forder, C., 1994, pp. 150-151 who reports of the wish of the National Gallery of Scotland to have its disposal powers restricted as it felt that the absence of such limitations put them in a comparative disadvantage to other national collections with regard to gifts and bequests. See also: National Museum Directors' Conference, 2003, p. 12.

1253 Cf.: Department for Culture Media and Sport, 2006b, para. 3.39.

1254 See, for example, the British Library Act 1972 (c.54), London: The Stationery Office, Schedule, paragraph 11(15); Museum of London Act 1965 (c. 17), London: The Stationery Office, s 5(4); National Maritime Museum Act 1934 (c.43), London: The Stationery Office, s 2(3)(e); Museums and Galleries Act 1992 (c. 44), London: The Stationery Office, ss 4(4) \& 4(5); British Museum Act 1963, London: The Stationery Office, s 5(1).

1255 Cf.: Department for Culture Media and Sport, 2007, p. 80. See further on the history of export controls in the UK: Maurice, C. / Turnor, R., 1992. 
licences without any corresponding purchase offer. ${ }^{1256}$ In reaction to this controversy a committee was appointed in 1950 to review the functioning of the export control system and to make recommendations for changes of the administrative arrangements. ${ }^{1257}$ The recommendations of the committee, named after its chairman Viscount Waverley, have shaped the UK export rules ever since ${ }^{1258}$ and are observed under the current export regime, which is derived from the Export Control Act 2002 and the Export of Objects of Cultural Interest (Control) Order 2003.1259

The Export Control Act 2002 as primary legislation replacing the 1939 Act, was adopted after the Scott Inquiry ${ }^{1260}$, which had identified a number of limitations in the 1939 Act, including the lack of parliamentary scrutiny of secondary legislation made under the Act and the absence of any indication of the purposes for which export controls may be imposed. ${ }^{1261}$ In accordance with Section 1(1) of the Export (Control) Act 2003, the Secretary of State is provided with order-making powers to introduce controls on the export of any goods (...). The Export of Objects of Cultural Interest (Control) Order 2003, which entered into force in May 2004, is based on this provision.

As a general rule under the Export (Control) Order 2003, all objects of cultural interest, which were manufactured or produced more than 50 years before the date of exportation may only be exported under the authority of a licence granted by the Secretary of State (S. 2 juncto Schedule 1, Art. 1). By requiring objects to be "manufactured or produced", the UK export control does apply exclusively to man made items and does not affect natural items. ${ }^{1262}$ Applications for an export licence must be addressed to the Export Licensing Unit of the Museums, Libraries and Archives Council.1263 In order to reduce the administrative burden of the Licensing Unit, as well as of exporters, a number of exceptions and blanket permissions have been introduced.

Excepted from the requirement to obtain an export licence are postage stamps and other articles of philatelic interest, as well as personal papers and goods exported by

\footnotetext{
1256 Cf.: Maurice, C. / Turnor, R., 1992, p. 275. Cf.: Waverley Committee, 1952, para. 22.

1257 Cf.: Prott, L.V. / O'Keefe, P.J., 1989, p. 457, para. 906.

1258 Maurice, C. / Turnor, R., 1992, p. 275; Department for Culture Media and Sport, 2007, p. 80. See further below in chp. 3.\$2.II.4 on the so-called Waverley criteria.

1259 Export Control Act 2002 (c. 28), London: The Stationery Office; The Export of Objects of Cultural Interest (Control) Order 2003, London: The Stationery Office; Department for Culture Media and Sport, 2007 , p. 80. Until recently, the UK export regime relied upon

1260 Sir Richard Scott's Report of the Inquiry into the Export of Defence Equipment and Dual-Use Goods to Iraq and Related Prosecutions in February 1996. See further: United Kingdom Parliament, 2002. 1261 Ibid.

1262 Cf.: Department for Culture Media and Sport, 2003, p. 31 where it is recommended to bring individual fossils of material value within the UK export control. In its response to the recommendation published on 16 December 2004, the Department for Culture Media and Sport agreed to further consider this. Department for Culture Media and Sport, 2004b, p. 5. As of today the wording of the Export (Control) Order 2003 has not been amended to include (a definition of) fossils. 1263 Museums Libraries and Archives Council Notice, 2008, p. 4.
} 
their maker or his or her spouse, widow or widower (Schedule 1, Art. 1 Export (Control) Order 2003).

Further to the exceptions stated in law, the Secretary of State introduced blanket permissions in the form of an 'Open General Export Licence' (OGEL) as well as Open Individual Export Licences (OIELs) which permit the export of certain specified objects, even if over 50 years, without the need to obtain a licence. ${ }^{1264}$ The OGEL covers temporary exports of certain objects and largely includes those exported under an EU licence or objects that do require an EU export licence. ${ }^{1265}$ Examples of items that fall under the OGEL are musical instruments or motor vehicles, as well as permanent exports of objects below a certain monetary threshold, e.g. any painting in oil or tempera of a value below $£ 180,000$ (about $€ 227.234$ ). ${ }^{1266}$

OIELs are available to specific authorised individuals and institutions for the following categories: licences for goods imported less than 50 years ago; licences for regular exporters of manuscripts, documents, archives and photographs; licences for temporary (1-2 year) export of objects owned or under the care of museums; licences for certain other art objects approved specifically approved by the Secretary of State, exported on a regular bases and if imported less than 50 years ago. ${ }^{1267}$ The existence of OIELS stresses that the UK export control aims at private owners but generally applies to any person or institution wishing to export an objects of cultural interest in the sense of the Export (Control) Order 2003. ${ }^{1268}$

Where objects are neither excluded from the export controls, nor fall under the OGEL or an OIELs, an export licence must be obtained. Straightforward cases are decided by the Staff of the Export Licensing Unit of the Museums, Libraries and Archives Council. More complex cases are referred to an expert adviser. ${ }^{1269}$ Where the expert adviser finds that the object to be exported is of national importance, he or she may object to the granting of the export licence. The assessment of an object's (national) importance is based on three criteria promulgated by the Waverley Committee:

1. Is the object so closely connected with our history and national life that its departure would be a misfortune?

2. Is it of outstanding aesthetic importance?

\footnotetext{
1264 The current OGEL is the Open General Export Licence dated 1st May 2004, which was granted by the Secretary of State in exercise of powers conferred by Art. 2 of the Export of Objects of Cultural Interest (Control Order 2993). The OGEL does not apply to embargoed destinations.

1265 Cf.: McAndrew, C. / O'Hagan, J., 2000, p. 4.

1266 See for a list of objects, manufactured more than 50 years before the date of exportation, which may be exported from the UK under the Open General Export Licence dated 1st May 2004:

http://www.mla.gov.uk/what/cultural/export/ /media/Files/pdf/2004/elu_open_general_exp_lic_2004 0501.ashx.

1267 Cf.: McAndrew, C. / O'Hagan, J., 2000, p. 4.

1268 Cf.: Barr-Smith, A., 1991, pp. 147 \& 150-151; Museums Libraries and Archives Council Notice, 2008, p. 7.

${ }^{1269}$ See for a list of the export advisers: Department for Culture Media and Sport, 2003, p. 41, Appendix D.
} 
3. Is it of outstanding significance for the study of some particular branch of art, learning or history?

Since the "Waverley criteria" have been introduced in 1952, their wording has been unchanged. Their interpretation, however, has been broadened to some extent. ${ }^{1270}$ Currently, the Waverley criteria are interpreted and applied as follows: ${ }^{1271}$

The first criterion, asking whether an object is so closely connected with the history of the UK and national life that its departure would be a misfortune, refers to national treasures whose export would constitute a loss for the country for the object's outstanding artistic, historical, or archaeological value. For an object to qualify under the first criterion it is not required that is has been created in the UK. What is crucial is the object acquired national importance by association with an important person, location or event. Under the original interpretation, this criterion referred to objects of truly national relevance only, such as the "Alfred jewel" and the manuscript of Gray's Elegy. Under the revised interpretation, however, also items that are of major importance for local history, items that have been part of collections which are of great historical significance, or objects which are associated with significant historical events, people or places can qualify under the first Waverley criterion. ${ }^{1272}$

The second criterion, investigating whether an object is of outstanding aesthetic importance, is a subjective one. It is not restricted to great works of art only but is applied also to other objects, e.g. an exquisite snuff box. The assessment whether an object is of outstanding aesthetic importance is judged on a case by case basis even where it concerns work by great artists. It is not the case that any work by a great artist is outstanding in the sense of the second Waverley criterion. Instead, the assessment includes also the condition as well as the quality of the work in question, as well as the extent of damages and restorations. ${ }^{1273}$

The third Waverley criterion, looking at an object's significance for the study of some particular branch of art, learning or history, assesses whether the object is

1270 The broadening of the interpretation of the Waverley criteria was discussed in the 2003 Quinquennial Review of the Reviewing Committee on the Export of Works of Art and Objects of Cultural Interest. The role of the Reviewing Committee in the UK export control will be discussed further below (Ibid., pp. 4445). The recommendation to broaden the interpretation of the Waverley criteria was published on 8 December 2003 and was subsequently accepted by the Department for Culture Media and Sport: Department for Culture Media and Sport, 2004b, p. 5.

${ }^{1271}$ Department for Culture Media and Sport, 2003, pp. 44-45.

1272 Examples of the first Waverley Criterion under the broadened interpretation cited by the Reviewing Committee are: the deposit from the 'royal' ship burial from Sutton Hoo, the Middleham jewel, the Lutterell psalter, the Dog of Alcibiades, a portrait miniature of Henry Stuart, Lord Darnley, the archive of manuscripts relating to the editing of Newton's Principia Mathematica, decorations awarded to Sir William Carnegie in connection with the battle of Trafalgar, Lewis Carroll's photographs of Alice Liddell, the Royal Standard belonging to Sir Ernest Shackleton and Captain Scott's sledging flag. Ibid., p. 44.

1273 Examples of the second Waverley Criterion are: Titian's 'Venus and Adonis'; Fra Bartholomew's 'the Holy Family with the Infant St John', a pair of George II open armchairs by William and John Linnell, Henry Moore's sculpture 'Bird Basket', a George III mahogany commode attributed to Tomas Chippendale, the drawing 'A Peasant Family going to market' by Gainsborough, as well as a watercolour by Van Gogh: 'Harvest in Provence'. Ibid. 
outstanding in significance either on its own account or in connection with a person, place, event, archive, collection or assemblage. The value of retaining such an object within the UK lies in its service as benchmark for the assessment of other items. Under the revised interpretation of the Waverley criteria "learning" in relation to culture covers a wide number of disciplines, such as art history, archaeology, ethnography, anthropology, palaeontology, science, engineering, architecture or literature. ${ }^{1274}$

There exists no hierarchy between the Waverley criteria. ${ }^{1275}$ If the export adviser comes to the conclusion that any one or more of the "Waverley criteria" is met and for this reason objects to the granting of a license, the application is referred to the Reviewing Committee on the Export of Works of Art and Objects of Cultural Interest (hereinafter: "the Reviewing Committee").

The Reviewing Committee is a non-statutory independent body whose role is to advise the Secretary of State on all cases where refusal of an export licence for an object of cultural interest is suggested on grounds of national importance. ${ }^{1276}$ The Committee consists of a chairman and seven experts in the relevant fields (paintings, furniture, etc.) who are appointed by the Secretary of State. ${ }^{1277}$ After a case has been referred to the Reviewing Committee from the expert adviser, the Reviewing Committee will institute a hearing. ${ }^{1278}$ If the Reviewing Committee concludes that an item meets one or more of the Waverley criteria, its recommendation is passed on to the Secretary of State. The Reviewing Committee also advises the Secretary of State about the object's condition and quality.

Where the Secretary of State upholds the decision that the object qualifies as national treasure, the export licence is not refused outright. Instead, a period of delay is given to allow the state or a public institution to raise sufficient funds to make an offer to the

1274 The Reviewing Committee stressed that this list is illustrative and not comprehensive. Cf.: Ibid. With regard to concrete examples of the third Waverley criterion, the Reviewing Committee referred to: a lady's secretaire by Thomas Chippendale, mathematical instruments associated with Charles, Earl Stanhope, ledgers and account books of Messrs Fribroug and Treyer, three albums comprising photographs of Indian architecture and scenery by Samuel Bourne, Shepherd and Roberson c. 1870, a $13^{\text {th }}$ century gold and sapphire clasp, a Hutton Racing car, and the Swan Roll manuscript. Department for Culture Media and Sport, 2003, p. 44.

1275 Cf.: Department for Culture Media and Sport, 2007, p. 22. Prott, L.V. / O'Keefe, P.J., 1989, p. 486, para. 942 reports of an incident where the Dutch Rijksmuseum challenged the validity of the second and third Waverley criteria: in 1979 the Dutch Rijksmuseum had purchased a silver plaque by Paul van Vianen. When the plaque's export was prevented for reason that it satisfied the second and third Waverley criteria, the Rijksmuseum argued that the second and third Waverley criteria did not describe objects qualifying as a national treasure in the sense of Art. 30 EC (ex-36 EEC). The Reviewing Committee rejected this view and concluded that the plaque could properly be considered as part of the United Kingdom's national heritage and therefore within the scope of Art. $30 \mathrm{EC}$ given that it met two of the Waverley criteria. The matter was apparently not taken any further. Cf.: The Reviewing Committee on the Export of Works of Art \& Objects of Cultural Interest (RCEWA), 1979-1980.

1276 See Terms of references of the Reviewing Committee on the Export of Works of Art and Objects of Cultural Interest: Museums Libraries and Archives Council Notice, 2008, p. 30, Appendix D.

1277 Cf.: Department for Culture Media and Sport, 2007, p. 81.

1278 See further on the hearing: Maurice, C. / Turnor, R., 1992, p. 285. 
owner to buy the work at the price which the Reviewing Committee recommends as the "fair market price". ${ }^{279}$ In case an offer is made and accepted by the owner, the application for the export licence lapses.

In those cases where the state or the public institutions do not succeed in raising the necessary funds by the end of the deferral period, which is generally between 2-6 months an export license will be granted, despite the fact that the object is considered as national treasure. ${ }^{1280}$ It is only where the owner refuses an offer at fair market value that an export licence will be refused. ${ }^{1281}$

Overall, the UK export control, with the Waverley system functioning as a tripwire rather than a mandatory right of pre-emption ${ }^{1282}$ qualifies as a very liberal regulation of exports of cultural objects from the UK. ${ }^{283}$ The interpretation of the Waverley criteria and their application in practice result in regime in which government approval is only required for the export of very valuable and important man-made objects of cultural relevance and in which export prohibitions are very rare. ${ }^{1284}$

\section{FRANCE}

France has a long history of protecting objects of cultural relevance. The idea of museums as comprehensive collections of valuable cultural objects took flight during the French Revolution (1789-1799). ${ }^{1285}$ It would take, however, some time before the idea found expression in law. At the beginning of the $20^{\text {th }}$ century, after the first protection measures on cultural heritage had focused solely on immovable objects ${ }^{1286}$ and cultural objects in state ownership ${ }^{1287}$, the Act on Historical Monuments from 31 December 1913 introduced a broader realm for the protection of immovable and

\footnotetext{
1279 Cf.: Ibid., p. 286; McAndrew, C. / O'Hagan, J., 2000, p. 3. See further on the calculation of the fair market value: Polonsky, M. / Canat, J.-F., 1996, p. 567; Weber, M., 2002, p. 340; Museums Libraries and Archives Council Notice, 2008, pp. 13-14. See the latter at pp. 12-13 on the decision on the length of the deferral period.

${ }^{1280}$ Cf.: McAndrew, C. / O'Hagan, J., 2000, p. 3; Cohan, A., 2004, p. 54.

1281 Cf.: Polonsky, M. / Canat, J.-F., 1996, p. 567.

1282 Cf.: Department for Culture Media and Sport, 2007, p. 19.

1283 Cf.: Weber, M., 2002, p. 355.

1284 McAndrew, C. / O'Hagan, J., 2000, p. 18; Weber, M., 2002, p. 355.

1285 Odendahl, K., 2005, p. 19 (with further references). See also: Jenschke, C., 2005, pp. 123-124.

1286 Odendahl, K., 2005, p. 26 (with further references).

${ }^{1287}$ Loi du 30 mars 1887 relative à la conservation des monuments et object d'art ayant un intérêt historique et artistique, JO, 31 mars 1887, Bull. $\mathrm{n}^{\circ}$ 17739. The act was adopted in reaction to a case in which the French State failed to revindicate the sarcophagus of the French politician Philippe Pot, which had been acquired by a private person in good faith. Richard de Vesvrotte v. l'État Dijon, Decision of 3.3.1886, D.P. 1887, II, 253. Cf.: Prott, L.V. / O'Keefe, P.J., 1989, p. 238, para. 405; Weidner, A., 2001, p. 30. Had the object belonged to the domaine public, such acquisition had not been possible. The notion of domaine public is discussed in the following section.
} 
movable cultural objects both in public and private ownership. ${ }^{1288}$ The Act is considered as the fundament of the current French system of protecting cultural property. ${ }^{1289}$

Since the adoption of the Act on Historical Monuments, a whole range of laws and regulations have been adopted for the protection of cultural property. ${ }^{1290}$ As a result, a complex and compartmentalised system, involving different national services responsible for the protection of cultural property had emerged. ${ }^{1291}$ In 2004, in the context of a greater operation of the French Government to simplify the law ${ }^{1292}$, the Cultural Heritage Code (Code du Patrimoine) was adopted. ${ }^{1293}$ The Cultural Heritage Code (hereinafter: "the $\mathrm{CHC}$ ") unifies and regroups the previously scattered laws dealing with tangible cultural heritage. Before discussing the $\mathrm{CHC}$ in view of restrictions to disposal and export of cultural objects, we will first introduce the notion of the domaine public as another relevant aspect of the French legal system of the protection of cultural objects.

\section{DOMAINE PUBLIC}

The notion of the domaine public constitutes a specific regime of protection under French law for part of the public property, which is not limited to objects of cultural relevance. ${ }^{1294}$ It differs between two categories of state property (domaine de l'Etat): the domaine public and the domaine privé. The domaine public consists of those objects that are considered as indispensable for the fulfilment of public tasks. ${ }^{1295}$ Objects that are merely useful but not crucial for the functioning of the state and the public authorities fall in the domaine prive. ${ }^{1296}$ This dichotomy with regard to objects in state ownership and the criteria that determine as to whether an object falls in the domaine public have been developed in case law ${ }^{1297}$ and doctrine ${ }^{1298}$ from the $19^{\text {th }}$ century onwards. ${ }^{1299}$ The exact

1288 Loi du 31 décembre 1913 sur les monuments historiques, JO 1 janvier 1914, p. 129. Cf.: Prott, L.V. / O'Keefe, P.J., 1989, p. 455, para. 904; Weber, M., 2002, p. 76-77.

1289 Cf.: El-Bitar, J., 2006, p. 30; Cornu, M., 2008.

1290 See, e.g.: Loi du 1 mai 1920 prohibant l'exportation des objets d'art et ameublement anciens et soumettant à des droit de sortie ceux des ces objets dont l'exportation aura été autorisé; Loi du 23 juin 1941 relative à l'exportation des oeuvres d'art, JO 19 juin 1941;Loi n 92-1477 du 31 décembre 1992 relative aux produits soumis à certaines restrictions de circulation et à la complémentarité entre les services de police, de gendarmerie et de douane, disposition relatives aux biens culturels, JO 5 janvier 1993, p. 198; Loi no 95-877 du 3 août 1995 portant transposition de la directive 93/7 du 15 mars 1993 du Conseil des Communautés européennes relative à la restitution des biens culturels ayant quitté illicitement le territoire d'un État membre de la Communauté européenne, JO 4 août 1995, p. 11664.

1291 Cf.: Cornu, M., 2008. Traditionally, the Ministry of Culture consisted of sub-sections dedicated to books and libraries, the museums, the fine arts, the national heritage and historical monuments and archives.

${ }^{1292}$ Loi n²003-591 du 2 juillet 2003 habilitant le Gouvernement à simplifier le droit du 2 juillet 2003, JO 3 juillet 2003, p. 11192, p. 11192.

1293 Code du Patrimoine. Available online at: http:/ /www.legifrance.gouv.fr/ (last visited: 15.09.08).

${ }^{1294}$ Cf.: Weber, M., 2002, p. 64.

${ }^{1295}$ Cf.: Weidner, A., 2001, p. 47.

1296 Cf.: Ibid. See further on the distinction between the domaine public and the domaine prive: Boulet-Sautel, M., 1995, pp. 100-102.

1297 The notion of the domaine public referred initially only to immovable objects. Since the first half of the $1^{\text {th }}$ century, however, it has been accepted that the notion also comprises movable objects of cultural 
scope of the domaine public remains unclear. The Code of State-owned property $(C o d e d u$ domaine de l'Etat) ${ }^{1300}$ does not define its boundaries. For some objects, their belonging to the domaine public is inherent to their nature. ${ }^{1301}$ Other objects require a dedication to the public cause. This dedication can take the form of an explicit order or can be implied. ${ }^{1302}$ With regard to public collections of cultural objects, which serve the public cause of preserving and exhibiting cultural objects on behalf of the public ${ }^{1303}$, their belonging to the domaine public is generally accepted. ${ }^{1304}$ However, not all cultural objects in state ownership fall in the domaine public: those objects, which do not strictly serve the public cause, e.g. cultural objects decorating or antique objects furnishing the buildings of the public authorities, fall in the domaine privé. 1305

Further to (cultural) objects from the domaine prive of the state, privately owned objects do not qualify as domaine public either. ${ }^{1306}$ The domaine public is, however, not limited to state property (not falling in the domaine prive) but extends also to objects owned by the departments, cities, as well as other corporations and corporations under public law or public bodies. ${ }^{1307}$

Once an object has become part of the domaine public it keeps its status even when no longer relevant to the public cause. The status can only be revised by means of an

relevance: Cour de Cassation, 10.8.1841 (Cousin c. la liste civile et les héritiers de Mallié), p. 1841, I, 742, Bull.civ. 1841, no. 104. See further on the development of the domaine public in case law e.g.: Hervé, B., 1993; Weber, M., 2002, pp. 69-75.

1298 The publication of the treaties by Victor Proudhon is generally considered as the hour of birth of the modern theory on the domaine public: Proudhon, V., 1833.

1299 Cf.: Chatelain, J. / Chatelain, F., 1990, p. 18; Chatelain, F., 1991, p. 109. While Art. 538 of the French Civil Code of 1804 refers to the "domaine public", it must not be confused with the notion of the domaine public as it would develop from the $19^{\text {th }}$ century onwards. The "domaine public" as referred to in Art. 538 does not distinguishes between different modalities in which the State can own property, which is the decisive criterion for the decision as to whether an object is held in the domaine public or domaine privé. Art. 538 reads: "Les chemins, routes et rues à la charge de l'Etat, les fleuves et rivières navigables ou flottables, les rivages, lais et relais de la mer, les port, les havres, les rades, et généralement tous les portions du territoire français qui ne sont pas susceptibles d'une propriété privée, sont considérés comme des dépendances du domaine public".

1300 The Code du domaine de l'État is based on décret n ${ }^{\circ} 57-1336$ du 28 décembre 1957 porte réforme des règles de gestion et d'alienation des biens du domaine national et codification sous le nom de code du domaine de l'État des textes legislatifs applicables à ce domaine and décret nº 62-298 du 14 mars 1962.

1301 E.g.: streets and rivers. Cf.: Weidner, A., 2001, p. 48.

1302 Aubry, C.M.B.A., et al., 1961, \169, no. 141; Ferid, M. / Sonnenberger, H.J., 1986, p. 525, para. 523 A 541.

1303 Cf.: Chatelain, J. / Chatelain, F., 1990, p. 18.

1304 Cf.: Chatelain, F., 1991, p. 109; Cornu, M., 1996, pp. 476-477; Weidner, A., 2001, p. 49; Cornu, M., 2008. Cf.: Cour de Cassation, decision of 2.4.1963, AJDA 1963, p. 486: "Les biens des établissements publics sont partie du domaine public dès lors que (...) leur conservation et présentation au public sont l'objet même du service public". Cf.: Chatelain, J. / Chatelain, F., 1990, p. 18.

1305 Cf.: Chatelain, J. / Chatelain, F., 1990, p. 19 with examples.

1306 Weber, M., 2002, p. 80.

1307 See for the relevant case law: Trib. de Montlucon, Decision of 29.9.1965, D.S. 1965, p. 774 ff; Conseil d'Etat, Decision of 21.3.1984, D.S. 1984, p. 510 (Guy Mansuy). See further: Weidner, A., 2001, p. 49; Weber, M., 2002, pp. 65-66, with further references in fn. 366. 
explicit legal act of de-classification. ${ }^{1308}$ While de-classification from the domaine public is regularly effected for consumer goods and other mass-produced goods of utilitarian character, which loose their value over time, e.g. military equipment, it is "very exceptional and in practise inexistent" with regard to objects in public museum collections. ${ }^{1309}$ The understanding of cultural objects belonging to the domaine public as "inalienable in perpetuity"1310 might explain the absence of a specific legal procedure for the de-classification of cultural objects from the domaine public. Different from declassification of ecclesiastical objects, which is outlined in a special law ${ }^{1311}$ the declassification of cultural objects from the domaine public is not regulated in a specific law. ${ }^{1312}$ However, as will be discussed further below, a specific procedure for declassification of objects from the Musées de France, has recently been introduced. This declassification procedure is relevant only to a certain portion of the domaine public. For cultural objects that belong to the domaine public but are not owned by a public collection designated as Musées de France, the general rules on de-classification from the domaine public apply.

According to the general rules on de-classification (or desaffection) from the domaine public, which have been developed in case law and legal doctrine, the de-classification must be an explicit administrative act ${ }^{1313}$ and may not coincide with the sale of the object concerned. ${ }^{1314}$ The form of the de-classification (act, executive order, or a decision) must correspond with the form of the classification. ${ }^{1315}$ As a result of the declassification, the object concerned no longer belongs to the domaine public but instead belongs to the domaine privé. 1316 The domaine privé is not subject to restrictions on disposal.

In 2006, with the introduction of the General Code Regarding the Property of Public Entities 1317 (hereinafter: “GCPPP”), certain aspects of the notion of the domaine public have been codified. The GCPPP entered into force on 1 July $2006 .{ }^{1318}$ Of relevance with

1308 Cf.: Dufau, J., 1993, p. 265; Weidner, A., 2001, p. 48; Weber, M., 2002, pp. 87 \& 92. See Conseil d' État 9.5.1958 (Delort), AJDA 1958, II, 331; Conseil d’État 17.2.1932 (Commune de Barran), D. 1933, III, 49 for relevant case law. Whereas the de-classification of ecclesial objects is outlined in a special law (Loi du 9 décembre 1905 concernant la séparation des Églises et de l'État, JO 11 décembre 1905) the de-classification of cultural objects is not regulated by law. This has recently been changed to some extend for a specific category of public collections. See further below on the details with regard to the procedure for declassifying objects belonging to the so-called Musées de France. Chatelain, F., 1991, p. 110.

${ }^{1309}$ Chatelain, F., 1991, p. 110.

1310 Ibid.

1311 Loi du 9 décembre 1905 concernant la séparation des Églises et de l'État, JO 11 décembre 1905.

1312 Weber, M., 2002, p. 92.

1313 Conseil d'État 9.5.1958 (Delort), AJDA 1958, II, 331. See also Art. L. 2141-1 GCPPP.

1314 Conseil d’État 17.2.1932 (Commune de Barran), D. 1933, III, 49. Cf.: Weber, M., 2002, p. 92.

1315 Cf.: Ibid. See further on this principle of the analogy of forms: Cornu, M. / Mallet-Poujol, N., 2006, p. 275.

1316 Chatelain, F., 1991, p. 110 ; Weber, M., 2002, p. 92.

1317 Code général de la propriété des personnes publiques. The Code was established by Ordonnance 2006460 of 21 April 2006.

1318 See further: Sorbara, J.-G., 2007. 
regard to cultural objects is Art. L. 2112-1 GCPPP. The Article confirms the status of several (collections of) movable cultural objects as belonging to the domaine public by stating that they are "part of the movable public domain of the public entity owning property with a public interest from the perspective of history, art, archaeology, science or technology". 1319

Having outlined the notion of the domaine public, we can now discuss the Cultural Heritage Code in view of the disposal and export of cultural objects.

\section{The Cultural Heritage Code (CHC)}

The Cultural Heritage Code (CHC) was established by Order 2004-1781320 and entered into force on 20 February 2004. The main aim of the CHC is to simplify the law applicable to the French cultural heritage by integrating previously dispersed acts and regulations. ${ }^{1321}$ But for minor changes, which were required for the coherence and legibility of the new code, the substance of the protection applicable to the different categories of cultural objects was not affected and will be outlined in the following.

\section{a) The structure and protection of the Cultural Heritage Code (CHC)}

The framework of the $\mathrm{CHC}$ consists of one introductory article that sets out the code's scope of application and seven books that integrate the previously existing laws and regulations. According to the introductory Art. L. 1 CHC, French cultural heritage in the sense of the $\mathrm{CHC}$ consists of the totality of immovable and movable goods, both in public or private property that are of historical, artistic, archaeological, esthetical, scientific or technical interest. ${ }^{1322}$ The notion of cultural heritage is naturally very broad to comprise the respective realms of protection outlined in the books of the $\mathrm{CHC}$ for

1319 Art. L. 2112-1 GCPPP reads: "Sans préjudice des dispositions applicables en matière de protection des biens culturels, font partie du domaine public mobilier de la personne publique propriétaire les biens présentant un intérêt public du point de vue de l'histoire, de l'art, de l'archéologie, de la science ou de la technique, notamment: (...) $6^{\circ}$ Les objets mobiliers classés ou inscrits au titre du chapitre 2 du titre II du livre VI du code du patrimoine ou situés dans un immeuble classé ou inscrit et concourant à la présentation au public de parties classées ou inscrites dudit immeuble; (..); $8^{\circ}$ Les collections des musées; $9^{\circ}$ Les œuvres et objets d'art contemporain acquis par le Centre national des arts plastiques ainsi que les collections d'œuvres et objets d'art inscrites sur les inventaires du Fonds national d'art contemporain dont le centre reçoit la garde; $(\ldots)$ ". The wording of the article follows the wording of the Code du Patrimoine. The Code du Partrimoine defines the French patrimony as the "ensemble des biens, immobiliers ou mobiliers, relevant de la propriété publique ou privée, qui présentent un intérêt historique, artistique, archéologique, esthétique, scientifique ou technique" (Emphasis added). Cf.: Cornu, M., 2008.

1320 Ordonnance $\mathrm{n}^{\circ} 2004-178$ du 20 février 2004 relative à la partie législative du code du patrimoine, JO 24.2.2004.

1321 E.g.: Loi du 31 décembre 1913 sur les monuments historiques, JO 1 janvier 1914, p. 129 and Loi n²002-5 du 4 janvier 2002 relative aux musées de France, JO 5 janvier 2002, p. 305. Cf.: El-Bitar, J., 2006, p. 30; Cornu, M., 2008.

1322 Le patrimoine s'entend, au sens du présent code, de l'ensemble des biens, immobiliers, ou mobiliers, relevant de la propriété publique ou privée, qui présentent un intérêt historique, artistique, archéologique, esthétique, scientifique ou technique. 
the different categories of cultural objects. ${ }^{1323}$ Quintessentially, the $\mathrm{CHC}$ distinguishes between cultural objects that qualify as national treasures (trésors nationaux) and cultural objects that do not. National treasures are objects that belong to the collections of the specifically designated Musées de France or other public collections owned by the State or lower public authorities, objects classified as historical monument and classified archives. Furthermore, objects that are not comprised in any of the former subcategories but which are of significant relevance for the national heritage from the perspective of history, art or archaeology can be qualified as national treasure. ${ }^{1324}$ Before turning to these realms of protection, it must be pointed out that so far, only the socalled "partie legislative" of the Code has been adopted. These legal norms, which originate from the previously existing acts and regulations, need subsequent implementation in the form of regulations. Until this has been achieved, a number of regulatory rules predating the $\mathrm{CHC}$ remain in force. All other earlier laws, whose provisions on the protection of cultural property have been incorporated into the $\mathrm{CHC}$, have been repealed. ${ }^{1325}$

The first book (Book I) holds provisions that apply to the totality of the cultural heritage, in particular with regard to the export of cultural objects. ${ }^{1326}$ The following five books are dedicated to different categories of cultural property: Book II deals with archives, Book III deals with libraries, Book IV deals with collections designated as Musées de France, Book V is dedicated to archaeology and Book VI deals with historical monuments and protected sites. ${ }^{1327}$

1323 It has been pointed out that the definition does not refer to intangible cultural heritage despite the French ratification of the 2003 UNESCO Convention for the Safeguarding of the Intangible Cultural Heritage. Cf.: Cornu, M., 2008. This is, however, of no further relevance in the context of the present study. 1324 Art. L. 111-1 CHC: "Les biens appartenant aux collections publiques et aux collections des musées de France, les biens classés en application des dispositions relatives aux monuments historiques et aux archives, ainsi que les autres biens qui présentent un intérêt majeur pour le patrimoine national au point de vue de l'histoire, de l'art ou de l'archéologie sont considérés comme trésors nationaux".

1325 See: Ordonnance $\mathrm{n}^{\circ}$ 2004-178 du 20 février 2004 relative à la partie législative du code du patrimoine, JO 24.2.2004, Art. 7 The following laws were repealed: Loi du 31 décembre 1913 sur les monuments historiques, JO 1 janvier 1914, p. 129; Loi nº79-18 du 3 janvier 1979 sur les archives, JO 5 janvier 1979, p. 43; Loi n²002-5 du 4 janvier 2002 relative aux musées de France, JO 5 janvier 2002, p. 305 ; Loi n $92-$ 1477 du 31 décembre 1992 relative aux produits soumis à certaines restrictions de circulation et à la complémentarité entre les services de police, de gendarmerie et de douane, disposition relatives aux biens culturels, JO 5 janvier 1993, p. 198; Loi no 95-877 du 3 août 1995 portant transposition de la directive 93/7 du 15 mars 1993 du Conseil des Communautés européennes relative à la restitution des biens culturels ayant quitté illicitement le territoire d'un État membre de la Communauté européenne, JO 4 août 1995, p. 11664.

1326 Book I integrates the previous Loi $\mathrm{n}^{\circ}$ 92-1477 du 31 décembre 1992 relative aux produits soumis à certaines restrictions de circulation et à la complémentarité entre les services de police, de gendarmerie et de douane, disposition relatives aux biens culturels, JO 5 janvier 1993, p. 198; Loi no 95-877 du 3 août 1995 portant transposition de la directive 93/7 du 15 mars 1993 du Conseil des Communautés européennes relative à la restitution des biens culturels ayant quitté illicitement le territoire d'un État membre de la Communauté européenne, JO 4 août 1995, p. 11664 ; Loi n 92-546 du 20 juin 1992 relative au dépôt légal, JO 23 juin 1992, p. 8167 ; Loi du 31 décembre 1921 portant fixation du budget général de l'exercice.

${ }^{1327}$ Book VII deals with the application of the $\mathrm{CHC}$ in the French departments overseas. 
In the following, Book IV dealing with the Musées de France and Book VI dealing with historical monuments will be further outlined as the two most relevant sources for the protection of public collections, next to the application of the concept of the domaine public. In the final part of this section, Book I of the $\mathrm{CHC}$ will be scrutinised and discussed with regard to the applicable law for export restrictions.

\section{b) Book IV of the Cultural Heritage Code (CHC) on the Musées de France}

Book IV of the CHC outlines the protection available to museum collections, in particular those museums that have been designated as Musées de France. The protection corresponds with the protection previously granted by Law No. 2002-05 relating to French Museums. ${ }^{1328}$ The Law relating to French Museums had for the first time codified the protection of public collections whose protection previously depended on the notion of domaine public. Furthermore, it extended the protection available to certain collections in private ownership. With the integration of its provision into the CHC, the Law relating to French Museums as separate law has been repealed. ${ }^{1329}$ Only a few provisions of the Law remain in force until they will have been replaced by further regulations as provided for under the $\mathrm{CHC}$.

In the following, the CHC's provision with regard to the designation of museums as Musées de France will be introduced, as well as the scope of protection granted to the collections of the museums with this label and the possibility of revocating the label.

\section{c) The designation as "Musée de France"}

According to Art. L. 441-1 CHC, the label "Musée de France" can be granted to national museums, as well as to museums belonging to other legal entities under public law or legal entities under private law with a charitable cause. ${ }^{1330}$ Different from the domaine public outlined above which consists only of objects in public ownership (notincluding objects in the domaine privê), the label "Musée de France" can also be granted to entities under private law with charitable cause. Any collection that is put forward for designation must, however, be of permanent character and must be comprised of objects whose conservation is in the public interest and which is managed for the knowledge, education and entertainment of the general public (Art. L. 410-1 CHC).

\footnotetext{
${ }^{1328}$ Loi nº2002-5 du 4 janvier 2002 relative aux musées de France, JO 5 janvier 2002, p. 305. The Law relating to French Museums was adopted to replace an earlier order whose application to museums of fine arts was considered too limited: Ordonnance ${ }^{\circ} 45-1546$ du 13 juillet 1945 modifiée portant organisation provisoire des musées des Beaux-Arts. Cf.: El-Bitar, J., 2006, p. 43; Recours, Rapport Nº3036 from 3 May 2001 of the Commission des Affaires Culturelles, Familiales et Sociales of the Assemblée Nationale, p. 5.

1329 Ordonnance $n^{\circ}$ 2004-178 du 20 février 2004 relative à la partie législative du code du patrimoine, JO 24.2.2004, Art. 7.

1330 Art. L. 441-1 CHC reads: "L'appellation "musée de France" peut être accordée aux musées appartenant à l'Etat, à une autre personne morale de droit public ou à une personne morale de droit privé à but non lucratif'.
} 
A number of museums have automatically been designated as "Musée de France" by Art. L. 442-2 CHC. According to this provision, the national museums ${ }^{1331}$, classified museums (musées classés) ${ }^{1332}$, as well as state museums whose status has been determined by executive order, qualify as "Musée de France" as of 5 January 2002.1333

Other museums have to follow the designation procedure as outlined by Art. L. 422$1 \mathrm{CHC}$ : as first step, the legal entity owning the collections has to make a formal application. The requirements that must be fulfilled are more stringent for collections owned by legal entities under private law with charitable cause in order to compensate for the lesser influence on the collection management by public authorities. ${ }^{1334}$ The subsequent step consists of hearing the High Council (Haut Consei) of the French Museums ${ }^{1335}$. The hearing of the High Council is mandatory. ${ }^{1336}$ The ultimate decision power lies with the Minister of Culture.

The designation of a museum as "Musée de France" is permanent but can be revoked. There exist two grounds on which the label can be withdrawn: first, in those cases where the conservation of the collection and its presentation to the public is no longer of public interest. If the absence of such public interest has been confirmed by the High Council, the Minister of Culture can revoke the designation. ${ }^{1337}$ The second situation in which the designation can be revoked is where the legal entity, which had applied for the designation in the first place, seeks for reversal of the designation. For the entity to be able to revise the designation, a number of conditions must be fulfilled. First, the revocation is possible only after a period of four years since the designation. Furthermore, should the museum have received financial aid from public funds, the decision to revoke the designation requires prior approval by the High Council and can only be affected after the objects, which had been acquired by means of public funds or

1331 National Museums are defined by Décret $n^{\circ} 45-2075$ du 31 août 1945 portant application de l'ordonnance relative à l'organisation provisoire des musées des beaux-arts, JO 14 juin 1945, p. 4343, Art. 3 and have been listed in: Décret n86-1370 du 30 décembre 1986 fixant les dispositions statutaires applicables à certains emplois de la direction des musées de France, JO 1 janvier 1987, p. 65. There are in total 32 National Museums including the Musée du Louvre, the Musée d'Orsay, the Picasso Museum.

1332 The so-called musées classées are listed in Executive Order n ${ }^{\circ}$ 46-1702 from 26.7.1946.

1333 State Museums (Musée de l'Etat) are those museums that have been founded by ministerial order and reside under one of the ministerial departments.

1334 Art. L. 442-1 second paragraph CHC reads: Lorsque la demande émane d'une personne morale de droit privé à but non lucratif, l'attribution de cette appellation est subordonnée à la présentation d'un inventaire des biens composant les collections, à la justification de l'absence de sûretés réelles grevant ces biens et à la présence, dans les statuts de la personne en cause, d'une clause prévoyant l'affectation irrévocable des biens acquis par dons et legs ou avec le concours de l'État ou d'une collectivité territoriale à la présentation au public, conformément à l'article L. 451-10. La décision attribuant l'appellation ainsi que l'inventaire joint à la demande font l'objet de mesures de publicité définies par décret en Conseil d'Etat.

1335 Art. L. 430-1 CHC outlines the general composition of the High Council. Further details on the composition, as well as on the election of its members must be determined by executive Order (Art. L. 430$2 \mathrm{CHC})$.

1336 The High Council must not be confused with the National Scientific Commission of Museum Collections of France further introduced below.

1337 Or where applicable another minister. 
as result of the exercise of the right of pre-emption, have been transferred to another public collections in accordance with Art. L. 451-8 CHC. 1338

\section{d) Legal Consequences of the designation of a collection as "Musée de France"}

With regard to the applicable legal rules on the protection of objects in collections designated as Musées de France and their impact on the possibility to dispose of an object from such a collection, one must distinguish between collections in public ownership and collections owned by legal entities under private law with charitable cause. While the provisions of Book IV of the $\mathrm{CHC}$ as originally introduced by the Act relating to French Museums did extent the regime of protection to collections owned by legal entities under private law with charitable cause, the protection of these collections in the form of restrictions of the owner's bundle of rights cannot correspond to those applicable to collections in public property for it would constitute too great an infringement of private property. ${ }^{1339}$ Consequently, while the principle of imprescriptability applies both to objects in pubic and private collections, the principle of inalienability applies only to objects in collections owned by the French State and other legal entities under public law.

Imprescriptability refers to the owner's right of revindication. If an object qualifies as imprescriptable, its owner can at all times seek revindication of the object. According to Art. L. 451-3 of the CHC, the collections of the Musées de France are imprescriptable. ${ }^{1340}$ Consequently, legal title to an object from the collection cannot be acquired by a good faith purchaser by means of legal transaction nor as a result of adverse possession. ${ }^{1341}$ On top of that, the action to revindication is not subject to any extinctive prescription period. 1342 The owner of the collection designated with the label "Musée de France", regardless of whether it is held in public or private property, can at all times recover the object. Therewith, imprescriptability prevents involuntary loss of title, even against a purchaser in good faith. ${ }^{1343}$

\footnotetext{
1338 Art. L. 451-8 CHC reads: "Une personne publique peut transférer, à titre gratuit, la propriété de tout ou partie de ses collections à une autre personne publique si cette dernière s'engage à en maintenir l'affectation à un musée de France. Le transfert de propriété est approuvé par décision de l'autorité administrative, après avis du Haut Conseil des musées de France. Les dispositions du présent article ne sont pas applicables aux biens remis à l'État en application des articles 1131 et 1716 bis du code général des impôts”.

1339 Weidner, A., 2001, p. 36.

1340 Art. L. 451-3 CHC reads: "Les collections des musées de France sont imprescriptibles".

${ }^{1341}$ Cf.: El-Bitar, J., 2006, p. 35.

1342 Cf.: Cornu, M. / Mallet-Poujol, N., 2001, p. 148 See, e.g. the case where the export licence for a fragments of the column Vendôme was denied for the reason that the object belonged to the domaine public. The column had disappeared in the 19th century but nevertheless the then possessor of the column could not have acquired legal title to the fragment due to the object's imprescriptability. Tribunal administratif de Paris, 9 avril 2004.The decision of the Administrative Tribunal of Paris was confirmed in appeal by CAA Paris, 4 avril 2006. Cf.: Schmitt, J.-M., 2004; Cornu, M., 2008.

1343 Cf.: Debbasch, C., et al., 1994, p. 121; El-Bitar, J., 2006, p. 35. See for a critical discussion of the weak position of a good faith purchaser: Carducci, G., 1997, p. 64; Chatelain, F., et al., 1997, p. 34; Weber, M., 2002, pp. 91-92.
} 
Another possibility of granting protection to collection items is by rendering the objects inalienable. Inalienability means that an object cannot be sold or otherwise be transferred by any legal transaction. ${ }^{1344}$ Any transfer of an inalienable object is void. ${ }^{1345}$ Given the fact that the rendering of an object as inalienable constitutes a significant interference with property rights, it applies only to objects from collections owned by the state or other legal entities under public law but does not apply to objects in privately owned collections. ${ }^{1346}$

With regard to objects from collections owned by legal entities under private law with charitable cause, the restrictions on disposal are less far-reaching: as a general rule objects from privately owned collections can be disposed. It is only with regard to objects that have been acquired by donations, legacies or by public monies, that disposal is limited with regard to the transferee: objects thus acquired may only be transferred to another Musée de France provided that the High Council of French Museums agrees with such transfer.

With regard to objects held in publicly owned collections, the interference with property rights does not constitute a hindrance for the full application of the rule on inalienability. According to the first sentence of Art. L. 451-5 CHC "objects constituting collections of the museums of France, and belonging to a legal personality under public law, are in the domaine public and are hence inalienable (...)".1347 The provision contributes to legal security by clearly stating that objects from the collections of publicly owned Musées de France cannot be sold or otherwise transferred by any legal transaction. ${ }^{1348}$ It does not, however, change or extend the protection that had already been granted to the objects under the notion of the domaine public. ${ }^{1349}$ Together, the traits of inalienability and imprescriptability render an object that belong to the domaine public (res) extra commercium. 1350 It is only after its de-classification from the domaine public that an object is no longer inalienable and imprescriptable and can be legally transferred. ${ }^{1351}$

\footnotetext{
1344 Cf.: Weidner, A., 2001, p. 10. See for relevant case law: Cour de cassation 2.4.1963 (Sieur Montagne c. Réunion des Musées de France et autres), AJDA 1963, II, 486 which concerned the sale of a sketch by Georges Seurat that had been donated to the Louvre. Cf.: Weber, M., 2002, p. 85.

1345 Cf.: Conseil d' État 30.10.1936 (Cotteraux), D.H., 1937, 55; Conseil d' État 25.1.1984 (Ville de Grasse c. Montlaur et autres), R.D.S. 1985, 466. Cf.: Weber, M., 2002, p. 84 ; Debbasch, C., et al., 1994, p. 122.

1346 Cf.: Weidner, A., 2001, p. 36. See above fn. 13396.

1347 Art. L 451-5 CHC first sentence reads in French: "Les biens constituant les collections des musées de France appartenant à une personne publique font partie de leur domaine public et sont, à ce titre, inaliénables". See also Art. L. 451-4 of the CHC according to which "every cession of all or part of a collection of a museum of France contrary to the provisions of this section is null. Actions or claims to nullify can be exercised at any time by the State or by any legal personality that is the proprietor of the collection". Cf.: Art. L. 3111-1 GCPPP confirms the general rule with regard to objects in the domaine public, i.e. that these objects are "inalienable and imprescriptable".

1348 See above on the meaning of inalienability.

1349 Cf.: also with Art. L. 2112-1 (sub 8) GCPPP that also certifies museums owned by public persons to belong to the domaine public.

1350 Cf.: Weidner, A., 2001, p. 9.

${ }^{1351}$ Cf.: Debbasch, C., et al., 1994, p. 101.
} 
The circumstances under which objects from public collections that carry the title Musée de France can be declassified (and hence disposed of) are set out in Art. L. 451-5 $\mathrm{CHC}$. This provision constitutes a novelty from the previous regime by explicitly setting out the procedure to be followed for de-classification of an object. According to the provision, the decision to declassify an object from public collections qualifying as Musée de France can only be taken in accordance with the assent of a scientific body, the composition and functionality of which are to be fixed by executive order. ${ }^{1352}$

Strictly speaking, the novelty of the explicit de-classification procedure was not introduced under the $\mathrm{CHC}$ but under the Law relating to French Museums of January 4, 2002. ${ }^{1353}$ Prior to the adoption of the Law relating to French Museums of January 4, 2002, which is now incorporated into Book IV CHC, no specific rules with regard to cultural objects (not being ecclesiastical objects) did exist. ${ }^{1354}$ Rather, the general procedure of de-classification by means of an explicit legal act had to be followed and has to observe the rule of parallism of forms. ${ }^{1355}$ With the introduction of Art. 11(II) of the Law relating to French Museums (now: Art. L. 451-5 CHC ), the de-classification of objects from public collections of the Musée de France has been explicitly recognised and framed in legal provisions and in procedure. This formal recognition of the possibility to declassify objects from the collections of the Musée de France is the more important given the unique feature of cultural objects of (often) increasing in value over time. ${ }^{1356}$

The details of the de-classification procedure, in particular the establishment and consultation of a "National Scientific Commission of Museum Collections of France" (hereinafter: "the National Scientific Commission"), were further outlined in an executive order from 25 April 2002 and will be outlined in the following. ${ }^{1357}$

\section{e) De-classification via the National Scientific Commission of Museum Collections of France}

The National Scientific Commission of Museum Collections of France has been established by Art. 16 of the executive order of 25 April, 2002 as provided for under the Law relating to French Museums. ${ }^{1358}$ According to Art. 22 of the executive order, the National Scientific Commission consists of twenty members, the majority of which are

\footnotetext{
1352 "Toute décision de déclassement d'un de ces biens ne peut être prise qu'après avis conforme d'une commission scientifique dont la composition et les modalités de fonctionnement sont fixées par décret".

1353 See Art. 11(II) of the Law relating to French Museums of January 4, 2002.

1354 See further with regard to the de-classification of ecclesial objects: Loi du 9 décembre 1905 concernant la séparation des Églises et de l'État, JO 11 décembre 1905. Cf.: Weber, M., 2002, p. 92.

1355 See further on the rule of analogy of forms: Cornu, M. / Mallet-Poujol, N., 2006, p. 275. Cf.: Dufau, J., 1993, p. 265; Weidner, A., 2001, p. 48; Weber, M., 2002, pp. 87 \& 92. See Conseil d' Etat 9.5.1958 (Delort), AJDA 1958, II, 331; Conseil d'État 17.2.1932 (Commune de Barran), D. 1933, III, 49 for relevant case law.

1356 Chatelain, F., 1991, p. 110. With regard to the situation as it existed prior to the explicit legal recognition to declassify cultural objects, Chatelain stated that "the museum collections are in fact unalienable for eternity or at least for as long as the concept of the museum as it exists for more than two centuries does not change".

${ }^{1357}$ Décret n²002-628 du 25 avril 2002 modifié pris pour l'application de la loi 2002-5 du 4 Janvier 2002 relative aux musées de France, JO 28 avril 2002, p. 7742.

1358 Ibid.
} 
representatives from the national or public museums or of the French Government. ${ }^{1359}$ Decisions on de-classification must be taken by the full National Scientific Commission (Art. 22(II)) and require a three quarter majority (Art. 23).

The provisions outlining the composition and modalities of the National Scientific Commission are essentially procedural in character. They do not provide for the criteria on the basis of which a decision on de-classification has to be assessed. Until today, the National Scientific Commission has never met and thus did not elaborate upon the criteria. ${ }^{1360}$ This leaves question whether the Commission will decide solely from the interest of preserving the collections or whether it will include other interests in the decision making-process presently unanswered. In the former case, which seems the more likely scenario given the name and the composition of the National Scientific Commission, the situations in which de-classification is possible will be very limited given the fact that different from most other objects, cultural objects do not loose but instead increase their value over time. ${ }^{1361}$ However, even if the National Scientific Commission is able to declassify objects for reasons not purely related to the preservation of public collections (e.g. interests of claimants seeking the return of an object), the involvement of the commission in the first place, the fact that it has never convened so far, its composition and modalities of its decision-making makes that declassification remains an absolute exception and in practice inexistent. ${ }^{1362}$

While the possibility to dispose of an object is thus very limited in general some objects may not be declassified at all. According to Art. L. 451-7 CHC, objects that have been acquired by donation or legacy, or - where it concerns public collections not in State property - objects that have been acquired with financial public support cannot be

1359 Ibid., Art. 22 - I reads as follows: La Commission scientifique nationale des collections des musées de France est présidée par le directeur des musées de France. Elle comprend en outre:

$1^{\circ}$ Des membres de droit: a) Le chef de l'inspection générale des musées, vice-président; b) Le chef de l'inspection générale de l'architecture et du patrimoine; c) Le chef de la mission permanente d'inspection, de conseil et d'évaluation de la création artistique; d) Le président du musée du Louvre; e) Les chefs des grands départements mentionnés à l'article 2 du décret du 31 août 1945 susvisé; f) Le directeur du Musée national d'art moderne; g) Le directeur des collections au Muséum national d'histoire naturelle; h) Le directeur du musée national des techniques du Conservatoire national des arts et métiers; i) Le directeur des collections à la Bibliothèque nationale de France; j) Le chef du centre de recherche et de restauration des musées de France;

$2^{\circ}$ Cinq membres désignés par le directeur des musées de France parmi les professionnels siégeant dans les commissions régionales ou interrégionales;

$3^{\circ}$ Un membre désigné par le directeur des musées de France parmi les spécialistes siégeant dans les commissions régionales ou interrégionales;

$4^{\circ}$ Quatre personnalités qualifiées désignées en raison de leurs compétences scientifiques par arrêté du ministre chargé de la culture: a) Un conservateur du patrimoine, conseiller pour les musées dans une direction régionale des affaires culturelles; b) Une personnalité désignée sur proposition du ministre chargé de la recherche; c) Une personnalité désignée sur proposition du ministre de la défense; d) Une personnalité désignée sur proposition du ministre chargé de la jeunesse et des sports.

1360 Cf.: Email by Marie Cornu with the subject 'Re: question en concernant la Commission scientifique national e des collections des musées de France' dated 1.4.2009 (on file with the author).

1361 Cf.: Poli, J.-F., 1996, p. 283.

1362 Cf.: Chatelain, F., 1991, p. 110; Cornu, M., 2008. 
declassified. ${ }^{1363}$ The inability to declassify these objects is motivated by the wish not to disencourage future donations and legacies. ${ }^{1364}$ This inability of declassifying an object from the domaine public constitutes a full ban on the object's disposal from the collection.

The protection of gifts goes so far that they may not even be transferred to other Musées de France under the procedure outlined in Art. L 451-8 CHC. According to this article, cultural objects from collections designated as Musée de France ${ }^{1365}$ may be transferred between these collections provided that the future conservation of the objects transferred is guaranteed. The reason that objects that have been acquired by gift or legacy or in accordance with the provisions of the French Tax Code (Code Général des Impôts) ${ }^{1366}$ may not be transferred between the collections of the Musées de France lies again in the inclination not to disencourage future gifts and legacies.

The above analysis of the CHC, the notion of the domaine public as recently codified in the GCPPP as to their relevance for the disposal of cultural objects from public collections revealed that disposal from a collection would only be possible after the object has been declassified from the domaine public. As long as the object belongs to the domaine public, it cannot be disposed of due to its inalienability. With regard to privately owned collections designated with the label Musée de France there exists no such limitation to disposal. In the following section on Book VI CHC, a different source of protection for certain cultural objects will be discussed that has the effect of restricting the alienability of the objects concerned.

\section{f) Book VI of the Cultural Heritage Code ("Act on Historical Monuments")}

Book VI of the Cultural Heritage Code (CHC) hosts the provisions that originate from the Act on Historical Monuments (Loi sur les monument historiques) from 31 December 1913.1367 The Act on Historical Monuments has been crucial in laying the fundament of the current regime of protection of cultural objects in France. ${ }^{1368}$ While its provisions (as codified in the $\mathrm{CHC}$ ) are first and foremost relevance for the protection of immovable cultural heritage ${ }^{1369}$, the scope of the Act also comprises movable objects.

The provisions that are relevant for the protection of movable cultural objects are comprised in the second Chapter of Book VI (Artt. L. 622-1 - L. 622-21 CHC). The

\footnotetext{
1363 Art. L. 451-7 CHC reads: "Les biens incorporés dans les collections publiques par dons et legs ou, pour les collections ne relevant pas de l'Etat, ceux qui ont été acquis avec l'aide de l'État ne peuvent être déclassés".

1364 Cornu, M., 2008.

1365 Art. L. 451-8 CHC reads: "Une personne publique peut transférer, à titre gratuit, la propriété de tout ou partie de ses collections à une autre personne publique si cette dernière s'engage à en maintenir l'affectation à un musée de France. Le transfert de propriété est approuvé par décision de l'autorité administrative, après avis du Haut Conseil des musées de France. Les dispositions du présent article ne sont pas applicables aux biens remis à l'État en application des articles 1131 et 1716 bis du code général des impôts".

1366 See in particular Artt.1131 and 1716 bis du code général des impôts.

${ }^{1367}$ Loi du 31 décembre 1913 sur les monuments historiques, JO 1 janvier 1914, p. 129.

1368 Cf.: El-Bitar, J., 2006, p. 30; Cornu, M., 2008.

${ }^{1369}$ Cf.: Cornu, M., 2008.
} 
chapter is subdivided in two sections each representing a separate regime of protection. Section 1 on the classification of movable objects (Artt. L. 622-1 - L. 622-19 CHC) contains the more important and elaborate regime of protection. Section 2 allows for the inscription of objects that do not qualify for classification under section 1 in a special inventory (Artt. L. 622-20 - L. 622-21 CHC).

\section{Classification as historical monument}

According to Art. L. 622-1 CHC, movable objects whose preservation is of public interest with regard to history or the arts, the sciences, or technical developments, can be classified as historical monument. ${ }^{1370}$ The classification as historical monument is available to cultural objects both in public and private ownership. ${ }^{1371}$ Against the scope of the present study, the following elaboration will focus on cultural objects from public collections, both belonging to the State (Art. L. 622-2 CHC) and lower public authorities (Art. L. 622-3 CHC). ${ }^{1372}$

The classification of cultural objects as historical monuments is done by the respective administrative authority. ${ }^{1373}$ From the moment the administrative authority notified the owner of the object concerned about its classification as historical monument, the objects can no longer be freely transferred or disposed of.

With regard to historical monuments that are in State ownership, Art. L. 622-14 CHC declares them to be inalienable. ${ }^{1374}$ Historical monuments that are owned by a lower public authority or public corporation are not subjected to a full ban on their alienability. However, they can only be transferred to a limited circle of recipients

1370 Art. L. 622-1 CHC reads: "Les objets mobiliers, soit meubles proprement dits, soit immeubles par destination, dont la conservation présente, au point de vue de l'histoire, de l'art, de la science ou de la technique, un intérêt public peuvent être classés au titre des monuments historiques par décision de l'autorité administrative. Les effets du classement subsistent à l'égard des immeubles par destination classés au titre des monuments historiques qui redeviennent des meubles proprement dits". The expression "immovible par destination" refers to the legal fiction of Art. 524 CC according to which "[a]nimals and things that the owner of a tenement placed thereon for the use and working of the tenement are immovable by destination". Thus, (...) all movables which the owner has attached to the tenement perpetually are also immovables by destination". See further for examples of cultural objects falling under the fiction of "immovable by destination": Frier, P.-L., 1997, pp. 430-431.

1371 See Artt. L. 622-2 - L.662-4 CHC.

1372 See further on the classification of privately owned objects e.g.: El-Bitar, J., 2006, pp. 32-33.

1373 See Art. L. 622-1 CHC in combination with the Artt. L. 622-2 - L.662-3 CHC. In case of classification of objects owned by lower public authorities, Art. L.611-1 CHC on the involvement of the 'Superior Commission of Historical Monuments' applies. See further on the classification procedure and the different regimes that apply depending on whether the owner agrees or disagrees with the classification: El-Bitar, J., 2007, pp. 31-33.

1374 Art. L. 622-14 CHC reads: "Les objets classés au titre des monuments historiques appartenant à l'État sont inaliénables. Les objets classés au titre des monuments historiques appartenant à une collectivité territoriale ou à un établissement public ou d'utilité publique ne peuvent être aliénés qu'avec l'accord de l'autorité administrative et dans les formes prévues par les lois et règlements. La propriété ne peut en être transférée qu'à l'Etat, à une personne publique ou à un établissement d'utilité publique". See further on the meaning of inalienability above. 
consisting of the state, public corporations or an institution for the public benefit. Furthermore, their transfer is subject to assent by the public authority.

The rule on the historical monuments' inalienability is complemented by their imprescriptability, which, according to Art. L. 622-13 applies indiscriminately to all movable historical monuments whether they are owned by the State or a lower public authority. ${ }^{1375}$

For as long as an object is classified as historical monument, it cannot be disposed of. Objects in State ownership cannot be disposed of at all, whereas objects owned by lower public authorities can only be transferred to certain recipients, mainly other public collections. The classification as historical monument, is, however, not irreversible. According to Art. L.622-6 CHC, de-classification is possible where the administrative authority explicitly provides for the de-classification of a classified object either exofficio or on demand by the object's owner. ${ }^{1376}$ As a result of the de-classification, the object is no longer classified as historical monument. Consequently, the provisions of Book VI will no longer prevent the object's disposal.

The de-classification as historical monument does, however, not automatically mean that the object can be disposed. While the provisions of Book VI may no longer prevent the object's disposal, it may still be prohibited under the rules applicable to the domaine public. ${ }^{1377}$ Where the two regimes with regard to historical monuments and the domaine public collide, rules with regard to domaine public are granted priority. ${ }^{1378}$

\section{Registration of non-classified movable heritage in a special inventory}

Section 2 of the second Chapter of Book VI introduces the possibility for the registration of movable objects in a special register (Art. L. 622-20 CHC). ${ }^{1379}$ The

\footnotetext{
1375 Art. L. 622-13 CHC reads: "Tous les objets mobiliers classés au titre des monuments historiques sont imprescriptibles". See further on the meaning of imprescriptability above.

1376 Art. L. 622-6 CHC reads: "Le déclassement d'un objet mobilier classé au titre des monuments historiques peut être prononcé par l'autorité administrative soit d'office, soit à la demande du propriétaire. Il est notifié aux intéressés".

1377 See in this regard Art. L. 2112-1 GCPPP. While the article lists (only) "les objets mobiliers classés ou inscrits au titre du chapitre 2 du titre II du livre VI du code du patrimoine ou situés dans un immeuble classé ou inscrit et concourant à la présentation au public de parties classées ou inscrites dudit immeuble", it is nevertheless feasible that also objects not or no longer classified as historical monuments or registered in an inventory referred to in Art. L. 622-20 belong to the domaine public. See above on the rules on the domaine public. See further Chatelain, J. / Chatelain, F., 1990, p. 49, note 13 who laments the impreciseness of the legal terminology with regard to the de-classification of historical monuments and from the public domain. Chatelain proposes to speak of "desaffectation" with regard to the domaine public Chatelain, J. / Chatelain, F., 1990, p. 49, note 13. Cf.: Weidner, A., 2001, p. 51, fn. 50. See above on the rules on the domaine public.

1378 Weidner, A., 2001, pp. 50-52.

1379 Art. L. 622-20 CHC: "Les objets mobiliers, soit meubles proprement dits, soit immeubles par destination, appartenant à l'Etat, aux collectivités territoriales et aux établissements publics ou aux associations cultuelles et qui, sans justifier une demande de classement immédiat, présentent, au point de vue de l'histoire, de l'art, de la science ou de la technique, un intérêt suffisant pour en rendre désirable la préservation, peuvent, à toute époque, être inscrits sur un inventaire supplémentaire à la liste des objets mobiliers classés au titre des monuments historiques".
} 
decision to register an object can be taken by the administrative authority (Art. L. 62221CHC). ${ }^{1380}$ This registration is available to those movable objects that do not qualify for classification as historical monument under section 1 discussed above. The legal consequences of registration are less far-reaching than that of classification under section 1: registered objects are neither inalienable nor imprescriptable. ${ }^{1381}$ Instead, the protection granted to the registered objects consists of their owners' obligation to inform the administrative authorities in advance about any change in location (one month prior to envisaged change) and any plans to dispose of the object or to modify it in any sense (two month notification). This obligation of prior notice allows the administrative authorities to take further protective measures, such as the classification of the object under section 1 if deemed necessary under the applicable circumstances.

In the previous sections, various regimes applicable to French cultural heritage from public collections have been discussed with regard to the question in how far they allow for the disposal of an object. As outlined in the introduction to this chapter the restitution of an object abroad not only requires the object's disposal but also presupposes its export. The export of cultural objects is often subject to conditions or restrictions. Export restrictions seek to prevent the removal of an object outside of a country's territory and therewith have the potential of further hampering envisaged restitution. For this reason, the French export rules with regard to cultural objects will be scrutinised in the following.

\section{EXPORT RESTRICTIONS: BOOK I CHC}

The French regime with regard to export restrictions was significantly revised in reaction to Council Regulation (EEC) No 3911/92 of 9 December 1992 on the export of cultural goods (hereinafter: "the Regulation"). The French regime as it existed prior to the Regulation since 1941 had relied to a great extent on tariff regulation. ${ }^{1382}$ With the

1380 Art. L. 622-21 CHC: “Cette inscription est prononcée par décision de l'autorité administrative. Elle est notifiée aux propriétaires, aux gestionnaires, aux détenteurs, aux affectataires et aux dépositaires et entraîne pour eux l'obligation, sauf en cas de péril, de ne procéder à aucun transfert de l'objet d'un lieu dans un autre sans avoir informé, un mois à l'avance, l'administration de leur intention et l'obligation de ne procéder à aucune cession à titre gratuit ou onéreux, modification, réparation ou restauration de l'objet, sans avoir informé, deux mois à l'avance, l'administration de leur intention. Un décret en Conseil d'État détermine les conditions d'application du présent article".

1381 Unless of course the registered object is State property. Cf.: Art. L. 2112-1 GCPPP: "Sans préjudice des dispositions applicables en matière de protection des biens culturels, font partie du domaine public mobilier de la personne publique propriétaire les biens présentant un intérêt public du point de vue de l'histoire, de l'art, de l'archéologie, de la science ou de la technique, notamment: (...)

$6^{\circ}$ Les objets mobiliers classés ou inscrits au titre du chapitre 2 du titre II du livre VI du code du patrimoine ou situés dans un immeuble classé ou inscrit et concourant à la présentation au public de parties classées ou inscrites dudit immeuble".

1382 Cf.: Frier, P.-L., 1997, pp. 464 ff. \& 470-471; El-Bitar, J., 2006, p. 56. See, e.g. on the old system: Mercillon, H., 1990. 
abolition of systematic border controls, the revision of the French export regime had become indispensable. ${ }^{1383}$

The new export regime is based upon Act No. 92-1477 of 31.12.19921384 and Executive Order No. 93-124.1385 With the adoption of the CHC in 2004, the newly introduced export regime was incorporated in Book I CHC. Book I holds provisions that apply to the totality of the cultural heritage, in particular with regard to the export of cultural objects. ${ }^{1386}$

The current export regime distinguishes between three categories of cultural objects: national treasures, cultural objects of historical, artistic or archaeological interest and finally those cultural objects that do not fall in any of the two previous categories.

National treasures as the first category are defined in Art. L. 111-1 CHC as those object that either belong to public collections owned by the State or lower public authorities, the collections of the Musées de France, objects classified as historical monument (as well as classified archives), as well as other objects of significant relevance for the national heritage from the perspective of history, art or archaeology. ${ }^{1387}$ The reference to objects from public collections and collections of the Musées de France is rather straight forward. All cultural objects that belong to the domaine public qualify as national treasures. With regard to classified objects, these are also clearly delineated by Book II CHC with regard to archives and by Book VI with regard to historical monuments. Less clear is the reference to "other objects of significant relevance for the national heritage from the perspective of history, art or archaeology". ${ }^{1388}$ It is a category that is not defined a-priori to the application for an export licence. Instead, whether an objects falls in this category is determined only in the procedure following the application for an export licence and depends on the

\footnotetext{
1383 Cf.: Poli, J.-F., 1996, pp. 75.

1384 Loi n $92-1477$ du 31 décembre 1992 relative aux produits soumis à certaines restrictions de circulation et à la complémentarité entre les services de police, de gendarmerie et de douane, disposition relatives aux biens culturels, JO 5 janvier 1993, p. 198.

1385 Décret de 29.1.1993 relatif aux biens culturels soumis à certaines restrictions, JO 30 janvier 1993, p. 1600. The executive order was revised by two further executive orders: Décret no 95-24 du 9 janvier 1995 modifiant le décret no 93-124 du 29 janvier 1993 relatif aux biens culturels soumis à certaines restrictions de circulation, JO 11 janvier 1995 and Décret n²001-894 du 26 septembre 2001, JO 29 septembre 2001, p. 15393.

1386 Book I also contains the provisions of the Act No 95-877 of 3.8.1995 implementing Council Directive 93/7/EEC of 15 March 1993 on the return of cultural objects unlawfully removed from the territory of a Member State which is not further discussed here (Loi n ${ }^{\circ}$ 95-877 du 3 août 1995 portant transposition de la directive 93/7 du 15 mars 1993 du Conseil des Communautés européennes relative à la restitution des biens culturels ayant quitté illicitement le territoire d'un État membre de la Communauté européenne, JO 4 août 1995, p. 11664).

1387 Art. L. 111-1 CHC: "Les biens appartenant aux collections publiques et aux collections des musées de France, les biens classés en application des dispositions relatives aux monuments historiques et aux archives, ainsi que les autres biens qui présentent un intérêt majeur pour le patrimoine national au point de vue de l'histoire, de l'art ou de l'archéologie sont considérés comme trésors nationaux".

1388 Cf.: El-Bitar, J., 2006, p. 58 ; Weber, M., 2002, p. 295.
} 
appreciation of the administration. ${ }^{1389}$ The necessity of allowing for such a vague ad-hoc "promotion" of objects to national treasures has been explained with reference to the undesirability of an exhaustive definition of what constitutes national treasures given the evolving character of the notion of cultural heritage and the little awareness of the French administration of the cultural heritage in private hands. ${ }^{1390}$

While the category of national treasures remains an open ended category given the administrative's discretionary power to declare objects of significant relevance national treasures, the legal consequence of the qualification is clear: cultural objects that qualify as national treasures may not be exported. ${ }^{1391}$ While the wording of Art. L. 111-4 CHC suggests that the license that is required for export "may" be refused for national treasures ${ }^{1392}$, there exists general agreement in the literature that the provision is badly drafted and that, in accordance with its legal history, must be understood as prohibiting the granting of an export licence to national treasures rather than only providing the possibility for doing so. ${ }^{1393}$

The prohibitive interpretation of Art. L.111-4 is furthermore supported by the scope of Art. L. 111-7 CHC which explicitly provides for four situations in which a national treasure may be temporarily exported. The existence of this provision, which allows for temporary export of a national treasure for reasons of restoration, the obtaining of expertise, for exhibition purposes and as loan to a public collection ${ }^{1394}$ can only be explained against the general ban on national treasures' export. Consequently, cultural objects that qualify as national treasures cannot be exported unless it concerns a temporary removal for one of the specified aims.

1389 Art. L. 111-2 CHC: "L'exportation temporaire ou définitive hors du territoire douanier des biens culturels, autres que les trésors nationaux, qui présentent un intérêt historique, artistique ou archéologique et entrent dans l'une des catégories définies par décret en Conseil d'État est subordonnée à l'obtention d'un certificat délivré par l'autorité administrative. (...)". Cf.: El-Bitar, J., 2006, p. 59 ; Poli, J.-F., 1996, p. 78.

1390 Marché, J.-P., pp. 19 ff. quoted by: Poli, J.-F., 1996, pp. 78-79.

1391 Cf.: El-Bitar, J., 2006, pp. 30 \& 34.

1392 Art. L. 111-4 CHC: "Le certificat ne peut être refusé qu'aux biens culturels présentant le caractère de trésor national. Aucune indemnité n'est due du fait du refus de délivrance du certificat. Il est accordé aux biens culturels licitement importés dans le territoire douanier depuis moins de cinquante ans. S'il existe des présomptions graves et concordantes d'importation illicite, l'autorité administrative peut exiger la preuve de la licéité de l'importation du bien et, en l'absence de preuve, refuser la délivrance du certificat. Le refus de délivrance du certificat ne peut intervenir qu'après avis motivé d'une commission composée à parité de représentants de l'État et de personnalités qualifiées et présidée par un membre du Conseil d'Etat. Un décret en Conseil d'État fixe les modalités de désignation de ses membres et les conditions de publication de ses avis" (emphasis added).

1393 Cf.: Poli, J.-F., 1996, p. 78 ;Weber, M., 2002, p. 295. According to Poli it would have been preferable had the provision stated that the certificate "devait être refusé aux bien culturels qui sont des trésors nationaux" rather than stating that the certificate "pouvait être refusé".

1394 Art. L. 111-7 CHC: "L'exportation des trésors nationaux hors du territoire douanier peut être autorisée, à titre temporaire, par l'autorité administrative, aux fins de restauration, d'expertise, de participation à une manifestation culturelle ou de dépôt dans une collection publique. Cette autorisation est délivrée pour une durée proportionnée à l'objet de la demande. A l'occasion de la sortie du territoire douanier d'un trésor national mentionné à l'article L. 111-1, l'autorisation de sortie temporaire doit être présentée à toute réquisition des agents des douanes. 
As for those cultural objects that do not (or after de-classification no longer) qualify as national treasures, the current export regime differs between objects that are of historical, artistic or archaeological interest and which also fall in one of the categories as defined by executive order and those objects that do not.

As for cultural objects of historical, artistic or archaeological interest Art. L. 111-2 $\mathrm{CHC}$ provides that their export is subject to the requirement of a certificate granted by the administrative authority. ${ }^{1395}$ The details with regard to the application to obtain a certificate and the procedure followed by the administrative authority to decide upon the application are outlined in Executive Order 93-124. ${ }^{1396}$ While the procedure will not be further elaborated ${ }^{1397}$, it should be pointed out that it is during this procedure that the administrative authority will determine whether the object concerned qualifies as an "object of significant relevance for the national heritage from the perspective of history, art or archaeology" and therewith constitutes a national treasure in the sense of Art. L. 111-1 CHC. Where the administrative authority finds that the object is indeed of significant relevance for the national heritage, the object - as national treasure - may not be exported. This possibility to prevent an export aims at the safeguarding of objects from private collections and is therefore of little relevance in the present study.

Where the administrative authority comes to the conclusion that the object does not represent an object of significant relevance it can be exported without an export license. Only where such an object is exported to a non-EC Member State is the export subject to an export license, provided that the objects falls in one of the categories of the EEC Regulation's annex.

\section{§3. CONCLUSIONS FOR CHAPTER 3}

This chapter scrutinised national jurisdictions for the existence of legal barriers to the restitution of cultural objects from public collections. The analysis split in two parts: the analysis of the national regimes first addressed the law applicable to the disposal of objects from public collections before turning to export controls, therewith following the chronological sequential of a restitution case. It revealed that while all national regimes know restrictions, there exist great variety in the degree of restrictions as well as in the form of the technique employed that prevents disposal. While a minimalist

\footnotetext{
1395 Art. L. 111-2 CHC: "L'exportation temporaire ou définitive hors du territoire douanier des biens culturels, autres que les trésors nationaux, qui présentent un intérêt historique, artistique ou archéologique et entrent dans l'une des catégories définies par décret en Conseil d'État est subordonnée à l'obtention d'un certificat délivré par l'autorité administrative. (...)". The categories defined by décret by the Conseil d'État correspond to the categories of the EEC Regulation's Annex. Cf.: Weber, M., 2002, p. 296, fn. 344; ElBitar, J., 2006, p. 61.

1396 Décret $\mathrm{n}^{\circ} 93-124$ du 29 janvier 1993 relatif aux biens culturels soumis à certaines restrictions de circulation, JO 30 janvier 1993, p. 1600 as modified by Décret n²001-894 du 26 septembre 2001 modifiant le décret $\mathrm{n}^{\circ}$ 93-124 du 29 janvier 1993 relatif aux biens culturels soumis à certaines restrictions de circulation, JO 29 septembre 2001, p. 15393.

1397 See further on the details of the procedure, e.g.: El-Bitar, J., 2006, pp. 62-64.
} 
summary of the Dutch regime would be: "no restriction on disposal but...", the English system comes down to "no disposal but...". With regard to the French system the letter of the law could be characterised as "no disposal except where de-classification from the public domaine is possible" but in practice boils down to "no disposal". As to the techniques of restricting disposal the systems either chose to restrict the owners' rights to disposal or to declare objects as res extra commercium.

Dutch law prevents disposal of objects from public collections in a limited number of scenarios by restricting the owners' rights to disposal. While the analysis of the Dutch regime revealed that there exists no formal restriction to the disposal of an object from a public collection, the collection's public destination may nevertheless prohibit the public authorities from disposing of the object where it satisfies the criteria of the CHP Act of irreplaceability and indispensability. Further to objects being considered as irreplaceable and indispensable, objects that have been acquired by means of donation or testamentary disposition require specific attention. While there exists no prohibition on the disposal of objects thus acquired as such, the donation or testamentary disposition might include conditions or obligations that prevent disposal explicitly or implicitly. However, even where this is the case it seems likely that the conditions can be altered in a legal procedure.

Different from the Dutch regime that starts from the possibility that objects can be freely disposed from the public collections, the English and the French regime are characterised by a general ban on the disposal of objects from the majority of public collections. The analysis of restrictions on disposal of objects in UK, in particular from English public collections revealed extensive restrictions on disposal due to the interplay of trust law and statute law. As general stating point of trust law trustees may not dispose of any collection items except where provided for in their governing statute or in the Charities Acts 1993-2006. The analysis of the powers granted for disposal revealed that these are essentially limited to duplicates, unfit or useless objects. Disposal in order to return / restitute an object from a national collection is thus impossible unless the object concerned is a duplicate, unfit to be retained or otherwise useless. Further restrictions may emerge for objects that have been acquired by bequest or as a gift. Where the conditions attached to the bequest or gift stipulate that and object may not be disposed off, disposal is only possible if the statutory powers granted to the trustees explicity allow for the overriding of trust and other non-statutory conditions. It is thus not exaggerated to state that disposal is unavailable for restitution cases.

Different from the Dutch and the UK system, the French system is based on res extra commercium legislation. ${ }^{1398}$ Res extra commercium is a legal concept that originates from Roman law. ${ }^{1399}$ Where an object qualifies as res extra commercium, it can neither be

\footnotetext{
1398 Two reasons can be listed for the UK not having opted for the technique of rendering objects in public collections res extra commercium: the nemo dat principle and the Anglican Church.

1399 Roman law knew the following categories of res extra commercium: res communes, res divini iuris, and res publica. The first category refers to objects belonging to everyone, such as the air we breathe. Cf.: Vliet, L.P.W.v.,
} 
transferred under private or property law, nor can it be subject to acquisitive prescription. ${ }^{1400}$ Put differently, the object is inalienable and imprescriptable. What is characteristic of res extra commercium is the fact that the limitations on the object's marketability is inherent to the object itself. It is an intrinsic characteristic of the object, rather than a restraint of the owner's capacity to act or his entitlement to dispose of his property. ${ }^{1401}$

The analysis of the French law above revealed that with regard to objects in public collections and historical monuments both the component of inalienability and imprescriptability are given, therewith rendering them res extra commercium. ${ }^{1402}$ However, the fact that a cultural object is presently res extra commercium does not exclude its reintroduction to trade. The analysis revealed the possibility of de-classification as a consequence of which the object is no longer inalienable. Consequently, the statement that res extra commercium is an intrinsic characteristic of the object must to some extent be nuanced in that the inherence of the characteristic is not permanent but can be changed by means of de-classification. De-classification is, however, perceived as an option that is rarely available, which is expressed by the very arduous procedure recently introduced with regard to objects belonging to the collections of the Musées de France. The declassification of objects not belonging to this circle of collections must follow the general rules on de-classification. According to the general rules, de-classification can take the form of a law, executive order or a decision. With regard to objects that have been acquired by means of donation or testamentary disposition or - where it concerns public collections not in State property - objects that have been acquired with financial public support that disposal is completely ruled out.

\section{Export restrictions}

Given that all countries addressed in this chapter are Member States of the European Community and therewith have to abide to Community law the analysis first addressed Council Regulation (EEC) No 3911/92 of 9 December 1992 on the export of cultural goods (hereinafter: "the Regulation") ${ }^{1403}$ before turning to the national export regimes.

2007. The res divini iuris, which can be further divided into res sancrae, res religiosae and res sanctae, consists of objects dedicated to the gods. The res publicae, finally, are those objects that belong to the property of the state. Another possibility to subdivide the categories is to start with only two categories, the res divini iuris and the res publicae and to subgroup the res communes under the latter. See, e.g.: Weber, M., 2002, p. 5. One will, however, look in vain for reference to the expression res extra commericum in the Roman legal sources. Instead, they refer to "res quia commercium eius non est" (Marc. Dig. 20, 3, 1 \ 2), to "res quarum commercium non est" (Inst. 2, 20 \ 4, Pomp. Dig. 18, 1, 6 pr.); or to "res nullius in bonis" (Inst. 2, 1, 7; Gai. Dig. 1, 8, 1 pr.). Cf.: Weidner, A., 2001, p. 14. See for a treaties of the legal history of the legal concept res extra commercium: Weidner, A., 2001, pp. 14-32; Weber, M., 2002, pp. 5-7.

1400 Weidner, A., 2001, p. 15.

1401 Ibid., p. 9.

1402 Cf.: Art. L. 2112-1 GCPPP and Art. L. 3111-1 GCPPP; Art. L. 451-3 CHC and Art. L. 451-5 CHC; Art. L. 622-13 CHC and Art. L. 622-14 CHC.

1403 The Regulation was complemented by Council Directive 93/7/EEC of 15 March 1993 on the return of cultural objects unlawfully removed from the territory of a Member State (hereinafter: "the Directive"). The 
The analysis of the Regulation revealed that the Regulation as such does not prevent any restitution. It is, however, not completely irrelevant in the context of restitutions in that it results in the requirement of a Community export licence where an object, which falls in one of the categories and accompanying financial thresholds as set out it its annex, is to be exported outside of EC territory. The decision as to whether the Community export licence will be granted is not decided by EC law but is a matter of the national export controls.

The analysis of export controls under Dutch, UK, and French law leads to a different clustering of countries than with regard to restrictions to disposal from the national collections. With regard to export controls, the Dutch and English regime side together as very liberal regimes whereas the French system imposes greater restrictions to the export of objects from public collections.

As for the Netherlands, Art. 14a CHP Act requires a written declaration by the object's owner, or where not available by the Minister of Culture. Consequently, the export control does not provide for extra restrictions. Instead, the permission to export stands and falls with the decision on disposal, therewith constituting a very liberal export regime. Where an object is to be exported to a non-EC Member State, the written declaration must be accompanied by an EC Export Licence to be issued by the State Inspectorate. There exist no further criteria, next to the permission of the owner, that are tested by the State Inspectorate.

The English export control is equally liberal in degree but employs the so-called Waverley criteria to determine whether or not an object of cultural relevance may be exported. Given the very selective character of the Waverley criteria only few objects would be prevented from export. With regard to restitution cases involving human remains, it can be concluded that they are not affected by the UK export control at all. With Section 2 juncto Schedule 1, Art. 1 speaking of "manufactured or produced" objects of cultural relevance the export control does not cover human remains, except for objects produced from human material. ${ }^{1404}$ In all cases that fall under the scope of application of the export control,

In contrast to the Dutch and English system, France has chosen for a very restrictive export regime with regard to objects in public collections. ${ }^{1405}$ According to Art. L. 111-1

Directive introduced domestic obligations in all Member States to return cultural objects unlawfully removed from another Member State. In the context of the present chapter looking into restrictions on disposal of objects from public collections and their export, the Directive is irrelevant. See further on the Directive above in chp. 1.\$2.VI.

1404 As an example of an object produced from human material one may cite a drinking cup made from a human skull or a flute made of human fermur bone. Cf.: Department for Culture Media and Sport, 2003, p. 31 where it is recommended to bring individual fossils of material value within the UK export control. In its response to the recommendation published on 16 December 2004, the Department for Culture Media and Sport agreed to further consider this. Department for Culture Media and Sport, 2004b, p. 5. As of today the wording of the Export (Control) Order 2003 has not been amended to include (a definition of) fossils.

${ }^{1405} \mathrm{An}$ interesting question but one that exceeds the scope of this study is the question whether the French export control is in conformity with EC Law. France could argue two ways to defend its legislation: it could 
$\mathrm{CHC}$ all objects that either belong to public collections, objects classified as historical monument (as well as classified archives), and objects of significant relevance for the national heritage from the perspective of history, art or archaeology ${ }^{1406}$ qualify as national treasures that may not be permanently exported. ${ }^{1407}$ With regard to restitution cases, this ban on export is, however, less relevant than it might seem at first sight. Given that the export ban is linked to the objects presence in a public collection or designation as historical monument, they stand and fall with the objects' inclusion in a collection / designation. Consequently, de-classification will not only allow for an object's disposal from a collection but will at the same time release the object from the ban on export.

In conclusion, different from the rules applicable to disposal of objects from public collections, restitution cases will not be hindered by export restrictions. The export will however be subject to administrative requirements such as the presentation of national export licences (or as far as the Netherlands is concerned written declarations) and where an export is to an entity outside of EC territory an EC export licence must be presented.

Having analysed the law applicable to objects in public collections, especially in view of the possibility of disposing and export, we can now assess the way in which the countries chose to react to claims for the return of Nazi spoliated art and human remains.

argue à Keck that its regulation with regard to public collections does not affect inter state trade and that its rules are not prima facie unlawful. Alternatively, if one accepted that the rules constitute a measure having equivalent effect under Art. 29 EC Treaty France could plead that the rules are justified by Art. 30 EC Treaty. France would have to show that the rules seek the protection of national treasures possessing artistic, historic or archaeological value and that there exists no less restrictive measure to achieve this end. According to Maurer who analysed the national export control of the EC 15, all national legislation is in conformity with Art. 30. Maurer, C.H.M., 1997.

1406 Art. L. 111-1 CHC: "Les biens appartenant aux collections publiques et aux collections des musées de France, les biens classés en application des dispositions relatives aux monuments historiques et aux archives, ainsi que les autres biens qui présentent un intérêt majeur pour le patrimoine national au point de vue de l'histoire, de l'art ou de l'archéologie sont considérés comme trésors nationaux".

1407 Cf.: El-Bitar, J., 2006, pp. 30 \& 34. 



\section{CHAPTER 4}

\section{Solutions Adopted for the Return of Nazi Spoliated Art and Human Remains at the National Level}

In the present chapter we will explore the solutions adopted at the national level with regard to claims for the return of Nazi spoliated art (\$1) and human remains $(\$ 2)$. From the analysis in Chapter 2 we know that public international law does not dictate the return of Nazi spoliated art and human remains. The soft-law character of the instruments analysed does not mean, however, that they are irrelevant to present day returns of Nazi spoliated art and human remains. Possessing a certain moral and political authority, the instruments certainly have an influence on the national solutions adopted. One must also not forget the mere practical relevance of these instruments in offering a number of solutions, be it legal or non-legal in character, to allow for the return of the objects concerned. ${ }^{1408}$

In analysing the countries' reactions to the increase in claims for the return of Nazi spoliated art and human remains this chapter seeks to provide insights about the nature of the policies implemented in the different countries. This is an important question as there often exists confusion about the nature of the policy and its contents. ${ }^{1409}$

Further to sketching the relevant national policies, the following specific points will be addressed: with regard to Nazi spoliated art the role and relevance accorded by the national solutions to potential financial compensation received during the post WWII period will be addressed. This question emerged fom the finding of Chapter 1 according to which the post-war restitution efforts put great emphasis on financial compensation where physical restitution was not possible and the finding of Chapter 2 that the soft law instruments adopted by different institutions and fora at the international level do not touch upon the relevance of financial compensation. With regard to human remains, we will look out for signs that confirm the tendency of the international soft law

1408 See above chp. 2.\$3.

${ }^{1409}$ See, e.g.: Kuitenbrouwer, F., 18 April 2002; Rijghard, R., 7 February 2006. 
instruments to accord greater priority to the return of human remains in comparison to other cultural objects.

Where countries have not (yet) adopted legislation and / or administrative policies, we will conduct case studies. Case studies are frequently relied upon in the museum sector and in the field of cultural property law. ${ }^{1410}$ It is important to note from the outset that while case studies allow us to extrapolate common patterns and principles they are first and foremost studies of a singular case only: "[c]ase study is the study of the particularity and complexity of a single case, coming to understand its activity within important circumstances". ${ }^{1411}$ In the present context of the return of cultural objects from public collection case studies are not only important to understand how and why a particular case developed the way it did - they are also crucial in that they constitute important records for history and thus to some extent remedy the loss of a tangible object for a collection and the falsification of history. In documenting an irreversible process, case studies ensure the archival integrity of collections even where the actual object concerned is no longer part of the collection.

After having analysed the national solutions we can come full circle by reflecting upon the relevance of the national initiatives on rules of international law on the return of Nazi spoliated art and human remains. As outlined in Chapter 2, one of the mechanisms in which soft law may turn into hard law is the creation of customary law. ${ }^{1412}$ By taking an inductive approach analysing the solutions adhered to at the national level we can assess whether there exists sufficiently extensive and convincing state practice. ${ }^{1413}$ In the final Chapter 5, we can then reflect upon the relevance of the developments with regard to Nazi spoliated art and human remains for the return of cultural objects from public collections more in general.

\section{$\S 1$. NAZI SPOLIATED ART}

\section{THE NETHERLANDS: THE INTRODUCTION OF A LIBERALISED GOVERNMENT POLICY AND THE WORK OF THE RESTITUTIONS COMMITTEE}

In the Netherlands the initiative to investigate the provenance of art works in public collections started in 1997. The main reason for doing so was the critical assessment in the local and foreign media of how the Dutch post-war restitution regime had been shaped and implemented. ${ }^{1414}$ One of the aspects that were particularly

\footnotetext{
1410 See, e.g.: Seligman, T.K., 1999; Timmer, P.M.Y. / Gubbels, G.J., 2007; http://www.culturalpropertyadvice.gov.uk/public_collections/case_studies (last visited 8 June 2009). 1411 Stake, R.E., 1995, p. xi.

1412 See above chp. 2.\$3. See further on the constitutive elements of a rule of customary, state practice and opinio iuris, above in chp. 1.\$1.VIII.

1413 Case Concerning Delimitation of the Maritime Boundary in the Gulf of Maine Area (Canada/United States of America), ICJ Reports, 1984, p. 246, para. 111.

1414 Cf.: Palmer, N., 2000a, p. 130; Muller, E. / Schretlen, H., 2002, p. 6; Commissie Ekkart, 2006, p. 9; Schnabel, G. / Tatzkow, M., 2007, p. 144.
} 
discussed in the media was the way in which the Netherlands Art Property Foundation (Stichting Nederlandsch Kunstbezit (SNK)) had fulfilled its task of re-uniting former owners or their heirs with artworks that had been restored from Germany. ${ }^{1415}$

At first, the Dutch Government initiated a pilot project looking into the provenance of some hundred works of art in the so-called Netherlands Art Property Collection (Nederlands Kunstbezit-collectie, hereinafter: NK Collection). ${ }^{1416}$ The NK Collection is part of the Dutch National Art Collection and consists of some 4000 works of art that had been recuperated after the war from West-Germany but could not or have not been given back to the original owners. The pilot revealed irregularities about the research that had formed the basis for decisions under the restitution policy from that period and concluded that there was a need to carry out a more extensive investigation into the provenance of the works in the NK Collection. ${ }^{1417}$ As a consequence the Origins Unknown Agency (Bureau Herkomst Gezocht) was established on 1 September 1998. The work of the Origins Unknown Agency was put under the supervision of a committee referred to as the 'Ekkart Committee' after its chairman Dr. R.E.O. Ekkart. ${ }^{1418}$.In the following we will summarise the main findings of the Origins Unknown Agency on the functioning of the Netherlands Art Property Foundation.

\section{THE RESULTS OF THE INVESTIGATIONS OF THE POST-WAR RESTITUTION REGIME WITH REGARD TO ART WORKS RECOVERED FROM GERMANY}

In reaction to the results of the pilot study, which had revealed serious lack of knowledge of the provenance of works of art in the NK Collection, as well as of the functioning of the post-war restitution regime the Ekkart Committee recommended further research into the legal framework and the working methods of the Netherlands Art Property Foundation (SNK). ${ }^{1419}$ The aim of this research was two-fold: to lift the veil of secrecy and speculations with regard to the functioning of the SNK in returning recuperated art works from Germany to their former owners and secondly, to provide the Ekkart Committee with the information required for formulating new policy recommendations for the Government. ${ }^{1420}$

The Netherlands Art Property Foundation (SNK) had been established on 11 June 1945. One of its main purposes was to recuperate artworks from abroad (primarily from

\footnotetext{
1415 Cf.: Muller, E. / Schretlen, H., 2002, p. 6. In Dutch the Netherlands Art Property Foundation is referred to as Stichting Nederlands Kunstbezit. In the following we will refer to the foundation as Netherlands Art Property Foundation (SNK).

1416 Palmer, N., 2000a, p. 130; Commissie Ekkart, 2006, p. 9.

1417 Letter [in Dutch] from the State Secretary for Education, Culture and Science to the House of Representatives dated 20 May 1998, parliamentary year 1997-1998, 25013, nr. 23; Herkomst Gezocht / Origins Unknown, 1998; Commissie Ekkart, 2006, p. 9.

1418 Besluit van de Staatssecretaris van Onderwijs, Cultuur en Wetenschappen tot instelling van een tijdelijk adviescollege, 20 September 1999, WJZ/1999/31477 (8091).

${ }^{1419}$ Cf.: Muller, E. / Schretlen, H., 2002, p. 7.

${ }^{1420}$ Cf.: Ibid.
} 
Germany) and to arrange for their return to their lawful owners. ${ }^{1421}$ When the Council for the Restoration of Rights (Raad voor Rechtsherstel) was inaugurated on 20 August 1945 with the task of the restoration of the pre-war legal system, the Netherlands Art Property Foundation (SNK) became part of the Council's Administrative Department (Nederlands Beheersinstituut (NBI)). ${ }^{1422}$ The NBI was charged with the task of tracking down, administering and liquidating both enemy and collaborationist assets, as well as assets of absent and unknown owners. ${ }^{1423}$ The Netherlands Art Property Foundation (SNK) thus became a specific organ of the NBI dealing exclusively with art works.

With regard to the task of repatriating spoliated art works from Germany the Netherlands Art Property Foundation (SNK) closely cooperated with the Monuments, Fine Arts and Archives Branch (MFA\&A) of the Allied Forces. ${ }^{1424}$ As to the restoration of the art works to their original owners within the Netherlands the work of the Netherlands Art Property Foundation (SNK) was based on the provisions of the Decree Recovery Legal Relations (Besluit Herstel Rechtsverkeer (Stb. E 100)) as adopted by the Dutch Government in exile on 17 September 1944. ${ }^{1425}$ In the research as instigated by the Ekkart Committee on the legal framework and the working methods of the Netherlands Art Property Foundation (SNK) the wide discretion of this Decree E 100 was identified as one of the reasons for the incoherence and arbitrariness of how the restitution of art works had been effected by the Netherlands Art Property Foundation $(\mathrm{SNK}) \cdot{ }^{1426}$

The Decree E 100 was one of the most important measures to implement Decree Occupation Measures (Besluit Bezettingsmaatregelen (Stb. E 93)), which foresaw in rules dealing with regulations that had been adopted by the occupying power. ${ }^{1427}$ The Decree E 100 introduced open standards and emphasised 'reasonability' as main norm for evaluating claims, therewith granting discretion to the judiciary in considering the various interests on a case by case basis. ${ }^{1428}$ The wide discretion on the part of the judiciary, the Judicial Division of the Council for the Restoration of Rights, necessarily led to a certain degree of randomness and unpredictability of its decision, if not

1421 Cf.: Ibid., pp. 7-8. The other main task of the Netherlands Art Property Foundation was to manage art works from enemy assets situated in the Netherlands in accordance with the Decree Enemy Property (Besluit Vijandelijk Vermogen (Stb. E 133))

1422 Further to the Administrative Department the Council for the Restoration of Rights consisted of a Judicial Division (Afdeling Rechtspraak), a Securities Division (Afdeling Effectenregistratie); a Division on Provisions for Absentees (Afdeling Voorzieningen voor Afwezigen); a Division on Legal Persons (Afdeling Rechtspersonen) and a Division for immovable property (Afdeling Onroerende Goederen). Cf.: Art. 4 Decree Recovery Legal Relations (Besluit Herstel Rechtsverkeer (Stb. E 100)).

1423 The latter first and foremost concerned the property of Jewish citizens that had been deported and murdered. Cf.: Veraart, W., 2005, p. 68.

${ }^{1424}$ For the Netherlands, the most important Collecting Points were in Munich and Offenbach.

1425 Muller, E. / Schretlen, H., 2002, p. 16. See for a detailed analysis of the decree and the activities of the Dutch Government-in-exile: Michielsen, J., 2004; and especially: Veraart, W., 2005.

1426 Cf.: Muller, E. / Schretlen, H., 2002, p. 259; Veraart, W., 2005, p. 87.

1427 Veraart, W., 2005, pp. 60-61; see further on the decree E 100: Meijer, K., 2008.

1428 Cf.: Ibid., pp. 62-64 \& 547. 
injustices. ${ }^{1429}$ Another characteristic of the Decree E 100 is the fact that it protected the interests of good faith purchasers over the interests of those who had lost their possession. ${ }^{1430}$ While good faith was not presumed but had to be demonstrated ${ }^{1431}$, this reversal of the burden of proof changed little about the fact that many original owners could not recover their property. ${ }^{1432}$ In these cases, the former owners could only seek financial compensation from the German State or the private party who had knowingly and deliberately sold the object concerned. ${ }^{1433}$

Faced with the wide discretion of Decree E 100, the Netherlands Art Property Foundation (SNK) had repeatedly asked for official guidelines on how to organise its tasks with regard to the management and restitution of art works. ${ }^{1434}$ The absence of such official guidelines is an indication of the little relevance that was accorded in the past to the restitution of art works at the ministerial level and the Dutch Parliament. ${ }^{1435}$ In effect, the restitution of art works to their original owners was considered of secondary relevance compared to the interest in safeguarding and re-establishing the national cultural patrimony. ${ }^{1436}$ The latter was considered essential for the greater good of the Dutch nation and its people. ${ }^{1437}$ As a consequence lesser efforts were made with regard to the restitution of spoliated art works to dispossessed individuals.

In those cases where works of art were returned to private individuals, the process was not without conditions. Claimants had to pay an administrative charge of $2.75 \%$ of the value of the object. ${ }^{1438}$ Also, where the original owner had received some form of remuneration, e.g. in case of a forced sale, restitution of the object depended on the paying of the respective sum to the Dutch State. ${ }^{1439}$ Further to these financial conditions for return, the research also revealed that the policy of the Netherlands Art Property Foundation (SNK) was inconsistent. While some private individuals were given the option to re-purchase their property after restitution had been denied, which was often financially more attractive than restitution ${ }^{1440}$, others were denied this possibility. On top

\footnotetext{
${ }^{1429}$ Cf.: Ibid., p. 547.

1430 See Art. 27 sub 1 Decree E 100.

1431 See Art. 32 Decree E 100.

1432 Cf.: Veraart, W., 2005, p. 547. See further on the possibilities to seek compensation from the German state above in chp. 1. $\int 4$

1433 Cf.: Ibid.

1434 Cf.: Muller, E. / Schretlen, H., 2002, p. 259 referring to the following documents: C.M. Van der Does, 'proces-verbaal relaterende het onderzoek naar onregelmatigheden door de Raad van Beheer van de Stichting Nederlands Kunstbezit, t.a.v. van een geschenk aan Prof. Vorenkamp', verklaring van J.K. van der Haagen, 22 september 1948. Ministerie van Financiën, archief Directie Bewindvoering, inv. Nr. 277.

1435 Cf.: Ibid.

1436 Cf.: Ibid., pp. 257-258.

1437 Cf.: Ibid., p. 257.

1438 Cf.: Ibid., p. 264.

1439 Cf.: Art. 27 sub 5 Decree E 100. Cf.: Ibid; Campfens, E., et al., 2006, p. 417.

1440 As mentioned above restitution was made subject to the repayment of any renumeration received and an administrative fee. Given the collapse of the art market and therewith the prices after the war it was often financially more attractive to pay the post-war market value than repaying the higher renumeration
} 
of that the conditions made for the re-purchase varied per case. ${ }^{1441}$ Few claimants, however, made use of the possibility to appeal to the Judicial Department of the Council for the Restoration of Rights, which served as court of appeal for decisions taken by one of the other departments. ${ }^{1442}$

While some of the flaws in the functioning of the Netherlands Art Property Foundation (SNK) appeared only from the research as instigated by the Ekkart Committee in the late 1990s, some irregularities had been known as early as the late 1940s when the director Arie Bob de Vries and one of his close employees were arrested respectively convicted for fraud and personal unjustified enrichment. ${ }^{1443}$ As a result of the mismanagement, the Netherlands Art Property Foundation (SNK) not only received a new director, J. Jolles, but the tasks of the foundations were also transferred to the Office for Reparation Payments and Restitution of Property (Bureau Herstelbetalingsen Recuperatiegoederen in short and hereinafter: Hergo) as of 1 July 1950. ${ }^{1444}$ In July 1951 the period for the submission of an application for claims lapsed. ${ }^{1445}$ However, the situation was not only problematic with regard to cases in which claimants had not filed their claim in due time, but also with regard to cases that had been filed but were not dealt with by the Netherlands Art Property Foundation (SNK) respectively Hergo before the Dutch Government concluded the process of the restoration of rights. In a report dated 1 July 1951 Jolles remarked that hundreds of claims had not been dealt with. ${ }^{1446}$ While the restitution of art works had significantly improved under his direction the task could not be completed under the time-pressure as imposed by the Ministry for Finance. The Ministry, which had proven to be the most influential of all ministries in the implementation of the restoration of rights ${ }^{1447}$, was wary about the costs of the restoration framework and sought to dismantle the process as quickly as possible. ${ }^{1448}$ It is in this context some 4000 artworks, including ca. 1700 paintings were

received when the market was still flourishing plus $2.75 \%$ of the object's value. Cf.: Muller, E. / Schretlen, H., 2002, p. 264.

1441 Ibid; Veraart, W., 2005, p. 87, fn. 85.

1442 Campfens, E., et al., 2006, p. 417. See for a case in which the claimants did appeal to the Judicial Division of the Council of Restoration of Rights the Gutmann case below.

1443 See further: Muller, E. / Schretlen, H., 2002, pp. 17-18.

1444 Before August 1948, HERGO had existed under a different name: the "War loot department" (Oorlogs buit). The War loot department had been founded in December 1945 to take over the task to collect, administer, distribute and sell all goods that had been captured form the German armed forces from a comparable department under the Military Authority that had been founded almost a year earlier in January 1945. In November 1946, recuperation of goods removed from the Netherlands and compensation payments were also assigned to the "War loot" department. This task would soon take up most of the department's time and work, which is reflected in the change in designation: in August 1948, the department was changed into Bureau Herstelbetalings- en Recuperatiegoederen, which might be translated as Office for Reparation Payments and Restitution of Property. The SNK was officially disabanded on 1 November 1952.

1445 Cf: Campfens, E., et al., 2006, p. 417.

1446 Rapport inzake de stand der werkzaamheden van het Bureau Herstelbetalings- en Recuperatiegoederen.

1447 Veraart, W., 2005, p. 83.

1448 Cf.: Muller, E. / Schretlen, H., 2002, p. 263. 
sold in auction. ${ }^{1449}$ The possibility to sell objects that had not been claimed within a certain time period was granted in Art. 113 sub 2 of Decree E $100 .{ }^{1450}$ Research into the practice of Hergo revealed that the provision was interpreted rather extensively: not only objects that had not been claimed were sold in auction; the same was true for artworks whose former owners were known but did not qualify for restitution (e.g. where the transaction was considered voluntary in nature) or refrained from making a claim. ${ }^{1451}$ It is estimated that objects (then) worth $f 2$ million had been sold in auction on behalf of the Dutch treasury. ${ }^{1452}$

Custodianship for artworks that were not sold in auction but were not restituted either was transferred from the Ministry of Finance to the State Art Collections Service at the Ministry of Education, Arts and Sciences in 1952. Hergo was dissolved on 1 February 1953; its activities were transferred to the Administration Directorate at the Ministry of Finance. As of May 1988, the responsibility for the restoration of art works was also transferred to the Ministry of Welfare, Health, and Culture, now the Ministry of Education, Culture and Sciences, by Royal Decree 233 of April 20, 1988. ${ }^{1453}$

\section{The Development of a liberalised Return policy in a dialogue between THE GOVERNMENT AND THE EKKART COMMITTEE}

Next to supervising the provenance work of the Origins Unknown Agency, the Ekkart Committee was asked to advise the Minister of Education, Culture and Science ${ }^{1454}$ on a future policy with regard to the return of art works from the NK Collection. ${ }^{1455}$ In the following we will analyse the recommendations made by the Ekkart Committee to the Government and the Governmental reactions in order to subsequently distil the current policy pursued by the Minister of Education, Culture and Science with regard to the return of artworks from the Dutch State collection respectively Dutch public collections.

\footnotetext{
1449 Cf.: Ibid., p. 255.

1450 Art. 133 sub 2 Decree E 100 reads in Dutch: "Voor het geval de eigenaar binnen een nader door Ons te bepalen termijn niet is opgekomen, zullen de zaken, die niet reeds eerder zijn verkocht te gelde worden gemaakt en zullen de opbrengsten van alle zaken, elke ingevolge het bepaalde in dit hoofdstuk door den Raad zijn beheerd, worden aangewend tot een nader door Ons bepalen doel.“

1451 Cf.: Muller, E. / Schretlen, H., 2002, p. 237.

1452 Cf.: Ibid., p. 255. See for an extensive discussion of the sale of artworks in auctions under Hergo: Muller, E. / Schretlen, H., 2002, pp. 236-256.

1453 Besluit herindeling ministeriële taak recuperatie weggevoerde kunstvoorwerpen, Stb. 233.

1454 Please note that for reasons of simplification we only refer to the Minister of Culture in the main text and do not distinguish between the Minister and the State Secretary. In some government terms there exist an additional State Secretary for Culture to support the Minister of Education, Culture and Science. Given that the final responsibility lies with the Minister we do not think it necessary to make the distinction. However, in the footnote references, we distinguish between them.

1455 See Besluit van de Staatssecretaris van Onderwijs, Cultuur en Wetenschappen tot instelling van een tijdelijk adviescollege, 20 September 1999, WJZ/1999/31477 (8091), Art. 1 sub a with regard to the supervision of the Origins Unknown Agency and Art. 1 sub b with regard to the policy recommendations.
} 
In reaction to the investigations of the functioning of the Netherlands Art Property Foundation $(\mathrm{SNK})$ in general and the provenance research of objects in the NK Collection the Ekkart Committee issued a number of recommendations to the Dutch Government. In light of the claimants' advanced age the Ekkart Committee sought it desirable to publish recommendations with regard to claims from private individuals at the earliest moment possible. ${ }^{1456}$ Therefore, the Ekkart Committee dropped the initial idea to await the final outcome of the research of the Origins Unknown Agency in favour of a phased issuing of recommendations.

The first set of recommendations of the Ekkart Committee focusing on art works spoliated from private collections was published in April 2001. In January 2003, the second set of recommendations dealing with art works from dealers' trading stocks followed. The final set of recommendations, which is more general in nature, dates from September 2004.

Before addressing these three sets of recommendations, reference should be made to a government memorandum on restitution and recuperation of cultural objects dating from 14 July 2000.1457 The memorandum, which dates from after the establishment of the Ekkart Committee but predates its first set of recommendations, was adopted in reaction to a request by the standing Committee for Education, Culture and Science in respect of Resolution 1205 (1999) on Spoliated Jewish cultural property by the Council of Europe. ${ }^{1458}$ It contains information on the state of affairs regarding the restitution of Jewish cultural objects by the Dutch Government and sets out provisional policy rules for the handling of individual applications for the restitution of works of art in anticipation of the recommendations of the Ekkart Committee. ${ }^{1459}$

The memorandum refers back to policy rules that had been formulated by the Minister of Culture in his letter to the House of Representatives dated 20 May 1998, which accompanied the report of the pilot study on the NK Collection. ${ }^{1460}$ According to these policy rules applications for the restitution of cultural objects from the Dutch NK Collection should be dealt with only where it concerned new applications or where new

1456 The Ekkart Committee explicitly chose to deviate from the initial intention to include the restitution policy recommendations to the Government in its final report, as it considered it "extremely desirable to speed up the restitution policy advisory process". See: Ekkart Committee (Supervisory committee Origins Unknown/Herkomst Gezocht), 2001, p. 5; Commissie Ekkart, 2006, p. 28.

1457 Brief en regeringsnotitie inzake restitutie en recuperatie van cultuurgoederen (letter and government memorandum in respect of restitution and recuperation of items of cultural value) d.d. 14 juli 2000, Tweede Kamer, vergaderjaar 1999-2000, 25 839, nr. 16.

1458 By adoptiong this memorandum the Dutch Government reacted to the appeal of paragraph 10 of Council of Europe Resolution 1205 asking national parliaments to "give immediate consideration to ways in which they may be able to facilitate the return of spoliated Jewish cultural property". See further on Resolution 1205 above in chp. 2.\$1.III.2.

1459 Cf:: Advisory Committee for Restitution Applications for Items of Cultural Value and the Second World War, 2003b, para. 2.3 on the 'Government position on second World War Assets', 21 March 2000. 1460 Letter [in Dutch] from the State Secretary for Education, Culture and Science to the House of Representatives dated 20 May 1998, parliamentary year 1997-1998, 25013, nr. 23. See further above on the pilot study. 
facts have become available. ${ }^{1461} \mathrm{New}$ applications were understood as applications that had not been settled previously by means of a decision by an authorised body for the restoration of property rights or by means of amicable restoration of property rights. According to the memorandum of 20 July 2000 these policy rules were also held applicable to works that are not part of the NK Collection but which belong to other parts of the Dutch national art collection. ${ }^{1462}$ The policy rules laid down in the memorandum dealt only with the eligibility of a claim for (re-) consideration. It did not lay down new criteria for the allowance or rejection of an application on substantive grounds. Instead, it stressed that until the Ekkart Committee had recommended otherwise, the assessment of a claim would be based on the rules as laid down by the post-war restoration of property rights. ${ }^{1463}$ In its first set of recommendation, the Ekkart Committee reacted to the policy as laid down in the memorandum.

\section{a) First series of recommendations of the Ekkart Committee, April 20011464}

On 26 April 2001 the Ekkart Committee presented its first set of recommendations to the Minister of Culture. ${ }^{1465}$ The general tone of the recommendations was that the

1461 Brief en regeringsnotitie inzake restitutie en recuperatie van cultuurgoederen (letter and government memorandum in respect of restitution and recuperation of items of cultural value) d.d. 14 juli 2000, Tweede Kamer, vergaderjaar 1999-2000, 25 839, nr. 16; Advisory Committee for Restitution Applications for Items of Cultural Value and the Second World War, 2003b, para. 2.4, p. 12.

1462 Advisory Committee for Restitution Applications for Items of Cultural Value and the Second World War, 2003b, para. 2.4, p. 12.

1463 Ibid.

1464 Commissie Ekkart, 2006, pp. 28-29 \& Appendix 27.

1465 Ekkart Committee (Supervisory committee Origins Unknown/Herkomst Gezocht), 2001. The Recommendation reads as follows:

1. The committee recommends that the notion of "settled cases" be restricted to those cases in which the Council for the Restoration of Property Rights or another competent court has pronounced judgment or in which a formal settlement was made between the lawful owners and the bodies which in hierarchy rank above the SNK.

2. The committee recommends that the notion of new facts be given a broader interpretation than has been the usual policy so far and that the notion be extended to include any differences compared to judgments pronounced by the Council for the Restoration of Property Rights as well as the results of changed (historic) views of justice and the consequences of the policy conducted at the time.

3. The Committee recommends that sales of works of art by Jewish private persons in the Netherlands from 10 May 1940 onwards be treated as forced sales, unless there is express evidence to the contrary. The same principle should be applied in respect of sales by Jewish private persons in Germany and Austria from 1933 and 1938 onwards, respectively.

4. The Committee recommends that the sales proceeds be brought into the discussion only if and to the extent that the then seller or his heirs actually obtained the free disposal of said proceeds.

5. The Committee recommends that for the purposes of applying this rule the rightful claimants be given the benefit of the doubt whenever it is uncertain whether the seller actually enjoyed the proceeds.

6. The Committee recommends that whenever it is necessary to couple a restitution to the partial or full repayment of the sales proceeds, the amount involved be indexed in accordance with the general priceindex figure.

7. The Committee recommends that the authorities, when restituting works of art, refrain from passing on the administration costs fixed by the SNK at the time. 
Dutch Government should not hide behind the decisions taken in the post-war period and instead should introduce a more generous restitution regime. ${ }^{1466}$ The recommendations focus on the following five aspects: the question of what constitutes a settled case and new facts (nova) ${ }^{1467}$; the question of what constitutes a forced sale and how one should deal with the proceeds a claimant may have received in the transaction ${ }^{1468}$; the requirements with regard to proof of title ${ }^{1469}$; the settling of administration costs incurred by the Dutch Government ${ }^{1470}$; and the possibility for repurchase of objects that do not qualify for restitution ${ }^{1471}$.

\section{Settled cases and new facts (nova)}

With regard to the definition of a settled cases and new facts (nova) the Ekkart Committee reacted to the policy as laid down in the Government memorandum from 14 July 2000. With regard to the question which cases should be considered as "settled" the Ekkart Committee held that only cases that had ended in a court ruling or in a formal settlement between the claimant and the Council for the Restoration of Rights or the Council's Administrative Department (Nederlands Beheersinstituut (NBI)) should be considered as settled. Furthermore, later formal settlements between the Dutch State and claimants should qualify as settled cases. Settlements between claimants and the Netherlands Art Property Foundation (SNK), however, should not qualify as settled cases in the eyes of the Ekkart Committee. Put differently, cases concluded with a settlement with the SNK should be eligible for reassessment.

With regard to the question of what constitutes a new fact (novum) the Ekkart Committee argued for a broad understanding. Rather than limiting the concept of nova to new, hard facts about the provenance of a works of art, differences between judicial judgments and decisions by the Netherlands Art Property Foundation (SNK) should also be considered as new facts. ${ }^{1472}$ This latter point requires some further explanation: the research into the work of the Netherlands Art Property Foundation (SNK) had revealed that only in a few cases where restitution had been refused, claimants had appealed to the Judicial Division of the Council for the Restoration of Rights. The research furthermore revealed a qualitative difference in how the Judicial Division and the Netherlands Art Property Foundation (SNK) had interpreted the provisions of

8. The Committee recommends that a work of art be restituted if the title thereto has been proved with a high degree of probability and there are no indications of the contrary.

9. The Committee recommends that owners who did not use an earlier opportunity of repurchasing works of art be reafforded such opportunity, at any rate insofar as the works of art do not qualify for restitution without any financial compensation according to other applicable criterions.

1466 Cf.: Schrage, E.J.H., 2007, p. 45.

1467 Recommendations 1-2.

1468 Recommendations 3-6.

1469 Recommendation 8.

1470 Recommendation 7.

1471 Recommendation 9.

1472 Commissie Ekkart, 2006, p. 78. 
Decree E $100 .{ }^{1473}$ The Judicial Division was more lenient towards the claimants in its interpretation of the provisions. E.g. in a case focusing on the question whether a sale qualified as involuntary loss, the Judicial Division held, in deviation from the practise of the Netherlands Art Property Foundation (SNK), that a sale "under the influence of the special circumstances of the war" also qualified for annulment. ${ }^{1474}$ Consequently, the notion of nova should include differences between judgments pronounced by the Council for the Restoration of Property Rights and decisions of the Netherlands Art Property Foundation (SNK). Finally, the results of changed (historic) views of justice and the consequences should also be considered as nova.

\section{Forced sales}

A significant part of the recommendations dealt with the question of what constituted a forced sale. According to the research instigated by the Ekkart Committee this question pinpoints the most frequently occurring practical problem in the post war restitution practice. ${ }^{1475}$ The Ekkart Committee recommended that all sales of art works from private Jewish collections in the Netherlands from 10 May 1940 onwards should be considered as forced sales, unless there is clear evidence to the contrary. In fact, this recommendation came down to a reversal of the burden of proof compared to the restitution practise under the Netherlands Art Property Foundation (SNK). The Ekkart Committee furthermore argued for the application of the same principle in respect of sales by Jewish private persons in Germany and Austria from 1933 and 1938 onwards, respectively.

With regard to the question of the repayment of sales proceeds, the Ekkart Committee held that different from the policy in the past the repayment should only be considered in cases where the claimant could freely dispose of the proceeds. In those cases where it cannot be established whether the claimant could freely dispose of the proceeds he should be given the benefit of the doubt.

\section{Evidence of ownership}

Further to the reversal of the burden of proof with regard to the possibility to dispose of sale proceeds in forced sales the Ekkart Committee suggested a lenient approach towards the requirements for proof of title to an artwork. Given the circumstances of war and the long time period that has passed since, it should be sufficient for a claimant to prove his title with a high degree of probability where there are no indications to the contrary.

\footnotetext{
1473 Ibid., pp. 77-78.

1474 Ibid., p. 78. See further on the treatment of transactions concluded under the circumstances of war below in chp. 4.\$1.3.a) discussing the Gutmann case.

1475 Ibid., p. 28.
} 


\section{Administration costs occurred by the Dutch Government}

With regard to the past practise of the Netherlands Art Property Foundation (SNK) to pass on the costs of custodianship to the claimants, the Ekkart Committee held that the future policy should refrain from passing on the administration costs to the claimants.

\section{Repurchasing}

The evaluation of the functioning of the Netherlands Art Property Foundation (SNK) had revealed that in a number of cases former owners were offered to buy back art objects that had been restituted to the Netherlands. For reasons such as the conditions stated for the repurchasing or for lack of financial resources not all former owners did make use of this possibility. The Ekkart Committee recommended that previously unused opportunities to buy back art works that had been denied during the post war practice should be re-opened for claimants.

b) Reaction of the Dutch Government to the first series of recommendations of the Ekekart Committee

The response of the Government to the first Ekkart recommendations is stretched over two letters of the Minister of Culture to the House of Representatives. In the first, initial letter dated 29 June 2001 the Minister of Culture reported that the Government planned to follow the main points of the recommendation: ${ }^{1476}$

With regard to the question of what constitutes a settled case the Minister of Culture accepted the view of the Ekkart Committee, including (after some further exchange of information with the Ekkart Committee ${ }^{1477}$ ) the view that decisions by the Netherlands Art Property Foundation (SNK) do not constitute settled cases. With regard to the question what constitutes a "formal settlement" between the Dutch State and a claimant, the Minister of Culture elaborated that a case is settled where a claim resulted either in a conscious and deliberate settlement or when a claimant expressly renounced his claim for restitution.

With regard to the interpretation of the concept of nova the Government generally endorses a broad interpretation of the concept. It agrees with the Ekkart Committee that greater relevance must be accorded to the criterions as formulated by the Judicial Division of the Council for the Restoration of Property Rights. With regard to the role that these criterions should play, however, the Government differs from the opinion of the Ekkart Committee: rather than understanding these criterions as nova as the Ekkart Committee suggested the Government they should be used for the substantive examination of restitution claims. Put differently, rather than playing a role in the

1476 Letter [in Dutch] from the State Secretary for Education, Culture and Science to the House of Representatives dated 29 June 2001 in respect of recommendations made by the Ekkart Commitee, parliamentary year 2000-2001, 25839 , nr. 26.

1477 Ibid; Commissie Ekkart, 2006, p. 29. 
decision as to whether or not a case should be re-accessed these criteria should become relevant only after it has been established that a case must not be considered as settled case. With regard to the suggestion to include changed (historic) views of justice and the consequences in the broader notion of nova, the Government postponed its definite answer and limited its first letter to making a preliminary reservation.

The recommendation of the Ekkart Committee to consider in principle all sales by Jewish owners as forced sales was approved by the Government. The Government announced that it wanted to further study the implications of applying the principle also to sales by Jewish private persons in Germany and Austria from 1933 and 1938 onwards, respectively. Furthermore, the Government wanted to study whether it was advisable and feasible to restrict the recommendation to Jewish private property or whether it should be extended to other population groups as well.

With regard to the repayment of sales proceeds the Government states that the recommendation to relax the rules and to demand repayment only in cases were it has been proven that the former owner or his heirs could freely dispose of the proceeds is in line with the policy as already endorsed by the Government. The Government furthermore endorses the principle not to charge any administration costs in case of restitution.

With regard to the required proof of title the Government accepts that documentary proof is difficult to produce and accepts the recommendation of the Ekkart Committee that art works should be restituted if title has been proven with a high degree of probability and in absence of indications to the contrary.

With regard to the question of granting claimants the possibility to repurchase their works of art the Government states that it wishes to seek further advice on the implications of this recommendation.

Further to its reaction to the specific recommendations of the Ekkart Committee, the Government also announced its plan to establish a committee with the task to advise the Minister of Culture on individual applications for the restitution of art works from the NK Collection. In reaction to the recommendation of the Ekkart Committee, and in the light of the Washington Principles and developments in France and the United Kingdom the Government considered a restitution committee as the most appropriate form to shape the future restitution policy based on a "more policy-based approach" rather than on a "purely legal approach". 1478

\section{c) The more detailed reaction followed by letter dated 16 November 2001}

On 16 November 2001 the Minister of Culture sent a second letter to the House of Representatives holding the definitive reaction of the Government with regard to the liberal interpretation of the notion of nova to include also changed (historic) views of justice; the extension of the reversal of the burden of proof with regard to forced sales from Jewish claimants to claimants from other population groups, and the re-opening of

1478 See on the Restitutions Committee below. 
the possibility to repurchase works of art, which had not been purchased at an earlier occasion. ${ }^{1479}$

With regard to the question in how far changed (historic) views should qualify as nova the Government upheld its reservation expressed in its first letter. As to the reversal of the burden of proof in cases involving forced sales the Government held that the principle should be applicable also to sales by Jewish private persons in Germany and Austria from 1933 respectively 1938 onwards and to other persecuted groups of the population, such as Sinti and Roma. With regard to the ninth recommendation of the Ekkart Committee, i.e. to reafford owners with the opportunity of repurchasing works of art, the Government declares that it cannot endorse it as it would introduce a situation in which the restoration of property rights would be repeated in a number of cases and therewith would collide with the general government position that the restoration of property rights should not be repeated.

Finally, the second letter was supplemented with the decree establishing the 'Advisory Committee on the Assessment of Restitution Applications for Items of Cultural Value and the Second World War'. ${ }^{1480}$

d) Second series of recommendations of the Ekekart Committee, January 20031481

On 28 January 2003 the Ekkart Committee presented its second series of recommendations that focus on the restitution of artworks from art dealers' trading stocks. The Ekkart Committee was plain about the fact that it was harder to formulate clear and cohesive recommendations with regard to the art trade in comparison to objects from private collections. The following factors were identified as complicating the subject matter: first, the inherent interest of art dealers to sell works of art as a consequence of which one cannot assume that all sales in the period 1940-1945 constituted forced sales. Secondly, where a so-called Verwalter had been appointed by the German occupying authorities it was difficult to draw the line between a sale by a Jewish art dealer and the Verwalter. Finally, the growing number of occasional art dealers that entered the business during the booming years of the art market during the war, next to long-established art galleries.

Despite these factors preventing an integral application of the principles developed with regard to privately owned artworks the Ekkart Committee nevertheless declared six principles $(1,4,5,6,7$, and 8$)$ of the 2001 recommendation to equally apply to works of

1479 Letter [in Dutch] from the State Secretary for Education, Culture and Science to the House of Representatives dated 16 November 2001 in respect of recommendations made by the Ekkart Commitee, parliamentary year 2001-2002, 25 839, nr. 27.

1480 Decree issued by the State Secretary for Education, Culture and Science, F. van der Ploeg, establishing a committee to advise the government on the restitution of items of cultural value of which the original owners involuntarily lost possession due to circumstances directly related to the Nazi regime and which are currently in the possession of the State of the Netherlands, 16 November 2001 (Reference WJZ/2001/45374(8123). See further below in chp. 4.\$1.I.3 on the characteristics and work of this Restitutions Committee.

1481 Ekkart Committee, 2003; Commissie Ekkart, 2006, Appendix 10. 
art from dealers' trading stocks. ${ }^{1482}$ Consequently, only cases in which the Judicial Division of the Council for the Restoration of rights or another competent court had issued a judgement or in which a formal settlement had been reached between claimant being an art dealer and a body higher in hierarchy than the Netherlands Art Property Foundation (SNK) are to be considered as settled cases. In case of a forced sale the sales proceeds only have to be repaid if the art dealer or his heirs had been able to freely dispose of them. In evaluating the question whether the sales proceeds could have been freely disposed the benefit of the doubt must be given to the art dealer. No administrative costs should be charged to the claimant and finally, with regard to the proof of valid title a high probability of such title and the absence of evidence to the contrary should be sufficient.

The second principle of the 2003 recommendation extends the scope of application of the principles to the loss of property or transactions by Jewish dealers in Germany as of 1933 and in Austria as of 1938 onwards rather than applying only to the loss of property or transactions by Jewish dealers in the Netherlands.

The third principle of the 2003 recommendation deals with the possibility that an art work could have belonged to an art dealer's private collection rather than his trading stock. The Ekkart Committee recommends that where there are enough indications that an artwork did belong to a dealer's private collection, the restitution claim should be dealt with in accordance with the standards for privately owned artworks.

Principles 4, 5 and 6 of the 2003 recommendation all deal with the required proof as to the evaluation whether a loss from an art dealer's stock constituted theft respectively confiscation, voluntary or involuntary sale. The Ekkart Committee suggested that where a first-hand statement of the art dealer or his heirs, i.e. in the form of a declaration form filled in after the war, is available the statement should be taken at face value, provided that there exists no evidence to the contrary. In the absence of a declaration form clues that provide for theft or confiscation must be accorded great relevance in considering restitution. ${ }^{1483}$ With regard to involuntary sales the recommendation lists a number of clues indicating the involuntary character of the transaction where a declaration form is missing: the treat of reprisal and the promise of the provision of passports or safe

1482 The first principle of the November 2003 Recommendations reads: "The committee recommends using the same points of departure for the art trade with regard to private art property".

1483 The fourth principle of the November 2003 Recommendations reads: "The committee recommends that if in a declaration form after the war the transfer of artworks from the property of an art dealer has been qualified as theft or confiscation, and nothing has been discovered which refutes this, the qualification concerned should be accepted. If no declaration form was made or there is only an internal declaration form, clues which make it highly probable that the case concerns theft or confiscation must be considered a reason for restitution, whereby with regard to Jewish art dealers the threatening general circumstances must be taken into account".

The fifth principle of the November 2003 Recommendations reads: "The committee recommends viewing the qualification binding in all cases in which the art dealer himself, his heirs or and immediate representative appointed by him or his heirs has filled in 'voluntary sale' unless very clear clues are submitted which make it probable that a mistake was made when the form was filled in or that the filling in of the form took place under disproportionately burdening circumstances". 
conduct as part of the transaction. Furthermore sales by Verwalters or other managers not appointed by the owner from the stocks under their management in as far as the original owners or their heirs have not fully benefited from the transaction and have explicitly waived their rights after the war". 1484

If one squares the principles of this second set of recommendations with the first set it becomes evident that the Ekkart Committee did declare the majority of principles of the first set equally applicable to the restitution of works from art dealers' stock. The two sets of recommendations differ, however, with regard to the presumption of a forced sale and with regard to the interpretation of new facts (nova). Whereas the Ekkart Committee did explicitly state that the principle of the presumption of a forced sale was not valid with regard to art dealers whose intrinsic business it is to sell works of art, it did not reflect upon or explicitly mention that it did not declare the broader notion of "nova” equally applicable to works from dealers' trading stocks. ${ }^{1485}$

\section{e) Reaction of the Dutch Government to the second series of recommendations of the Ekekart Committee}

The reaction of the Government to the second set of recommendations of the Ekkart Committee was communicated to the House of Representatives on 5 December 2003.1486 In the government reaction the Minister of Culture endorsed all six recommendations of the Ekkart Committee. With regard to the fourth and six recommendations dealing with forced respectively involuntary sales the Government states that these recommendations apply not only to Jewish art dealers but also to art dealers from other persecuted groups.

\footnotetext{
1484 The sixth principle of the November 2003 Recommendations reads: "In all cases in which after the war the party involved, his heirs or his immediate representative appointed by him or his heirs have filled in the qualification 'involuntary sale' on a declaration form and there are no indications that contradict this qualification, such a qualification should be accepted. In all cases in which such a declaration form is missing, clues - which make it highly probable that coerced sale took place - serve as the point of departure for the restitution policy. Clues indicating involuntary sale in any case include the treat of reprisal and the promise of the provision of passports or safe conduct as part of the transaction. Involuntary sales are also taken to mean sales by Verwalters or other managers not appointed by the owner from the stocks under their management in as far as the original owners or their heirs have not fully benefited from the transaction and have explicitly waived their rights after the war".

1485 Ekkart Committee, 2003. See also: Advisory Committee for Restitution Applications for Items of Cultural Value and the Second World War, 2003b, p. 29, fn. 16. The Restitutions Committee characterises this omission as "striking". See for an analysis of how the Restitutions Committee deals with claims concerning the restitution of works from a dealer's trading stock below under the analysis of the Goudstikker case.

1486 Letter [in Dutch] from the State Secretary for Education, Culture and Science to the House of Representatives dated 5 December 2003 in respect of the second series of recommendations made by the Ekkart Commitee, parliamentary year 2003-2004, 25 839, nr. 34.
} 


\section{f) Final recommendations of the Ekkart Committee, September 2004}

On 30 September 2004 the Ekkart Committee presented its final recommendations to the Government. ${ }^{1487}$ At that point, its recommendations also took into consideration the experience of the Restitutions Committee in applying the liberalised return policy based on the previous two sets of recommendations and the respective government reactions. The Ekkart Committee did not consider it necessary to come back or amend any of its earlier recommendations or to comment upon their application by the Restitutions Committee. Instead, the Ekkart Committee focused on the conclusion of the period of liberalised restitution regime, the treatment of unjustly recuperated objects and how the Government should deal with the impression that it had been unjustifiably enriched.

With regard to the finalisation of the period of the liberalized restitution policy the first, second and ninth principles of the recommendations are relevant. In the first principle the Ekkart Committee recommends to end the period in which claims for the restitution of works of art from the NK Collection can be made under the liberalised policy two years from the Government reaction to this final set of recommendations. In the eyes of the Ekkart Committee such a cut-off point was justified on two grounds: first, the liberalisation of the restitution policy had been intended as a temporary measure from the beginning. Secondly, with the ever greater passage of time and the death of the last eye witnesses it is considered unlikely that further successful claims will emerge. Principle 2 seeks to balance the cut-off point by advising the Government to widely publicize the impending lapse of this opportunity one year prior to the termination of the period. The ninth principle deals with the preservation and making available of the documentation compiled during the Origins Unknown Agency's research. According to the Ekkart Committee this documentation should be preserved permanently and as complete as possible and be lodged in the National Archives where it should be made accessible to all interested parties.

The second focus of the final recommendations is on artworks that were (possibly) unjustly recuperated to the Netherlands after the war. The principles suggested by the Ekkart Committee foresee both in the situation that an artwork is claimed by a foreign private individual and by a foreign state. According to the third principle claims from foreign private individuals should be dealt with conform the claims of (the heirs) of owners who lost works of art within the Netherlands. ${ }^{1488}$ With regard to claims by another state the fourth principle states that these claims should not be submitted to the Restitutions Committee but should be dealt with on the basis of bilateral consultations with the Government of the country concerned.

\footnotetext{
1487 Ekkart Committee, 2004.

1488 See, e.g. for a recommendation by the Restitutions Committee dealing with an artwork that had not been lost within the Netherlands: Recommendation RC 1.71, 3 July 2008. The recommendation is available online at: http://www.restitutiecommissie.nl/en/rc_1.71/advies_rc_1.71.html (last visited 19.01.2009).
} 
The remaining principles of the final recommendations make suggestions on how to deal with the situation of artworks that cannot be returned and on how to prevent or remedy the impression of unjustified enrichment by the Dutch State. With regard to artworks in the NK Collection, which were definitely or most certainly stolen, confiscated or lost to their original Jewish owners by forced sale and for which no legally entitled parties can be indicated the fifth principle states that these works should remain in the NK Collection and should be exhibited only in companionship of a plate commemorating their provenance. Furthermore, the corresponding financial value of these works should be donated in equal shares to the Jewish cultural charities mentioned in the seventh principle: the Cultural Heritage Foundation of the Portuguese-Israeli Community and the Jewish Historical Museum. Further to the donation based on unreturnable artworks still present in the NK Collection the sixth principle states that an indexed percentage of the proceeds of the recuperated works of art sold up until 1952 should also be made available to these two Jewish cultural charities. Finally, according to principle 8 any possible incoming repayments for the restitution of works of art (i.e. in case where claimants had been able to freely dispose of sales proceeds) should also be allocated to these two Jewish cultural charities.

With the presentation of its final recommendations the Ekkart Committee concluded its task of making recommendations to the Government.

\section{g) Reaction of the Dutch Government to the final recommendations of the Ekeart Committee}

The reaction of the Government to the final set of recommendations of the Ekkart Committee was communicated to the House of Representatives on 8 March 2005. ${ }^{1489}$ The Minister of Culture integrally endorsed the final set of recommendations of the Ekkart Committee.

h) Putting the Ekekart Recommendations and the Government Reactions together: the current policy of the Dutch Government regarding restitution of cultural property spoliated during the Second World War

The current Dutch Government policy regarding restitution of cultural property spoliated during the Second World War is the result of a dialogue between the Dutch Government and the Ekkart Committee during the period 2000-2005. For reasons of transparency and legal certainty it would have been desirable if the policy as agreed had been summarised in a single document. This is particularly true with regard to claims concerning objects from previously private collections where the policy must be extrapolated from the provisional government memorandum from 14 July 2000, the first set of recommendations of the Ekkart Committee and two government reactions. With regard to objects from art dealers stock, respectively the final recommendations of

1489 Letter [in Dutch] from the State Secretary for Education, Culture and Science to the House of Representatives dated 8 March 2005 in respect of the final recommendations made by the Ekkart Commitee, parliamentary year 2004-2005, 25 839, nr. 36. 
the Ekkart Committee on the conclusion of the period of liberalised restitution and measures addressing the impression of enrichment by the Dutch State the Government endorsed all recommendations by the Ekkart Committee. ${ }^{1490}$ For this reason, we will focus on summarising the valid principles with regard to private collections.

General starting point of the liberalised return policy is that the restoration of property rights should not be repeated. Consequently, claims for the restitution of objects presently in the Dutch NK Collection or State Collection will only be considered if they qualify as new applications.

A claim can qualify as a new application if it does not qualify as settled case. A settled case is understood as a case that had ended in a court ruling or in a formal settlement between the claimant and the Council for the Restoration of Rights or the Council's Administrative Department (Nederlands Beheersinstituut (NBI)). Furthermore, later formal settlements between the Dutch State and claimants could also qualify as settled cases where a claim resulted either in a conscious and deliberate settlement or when a claimant expressly renounced his claim for restitution.

Settled cases can only be reassessed where new, relevant facts have become available. ${ }^{1491}$ With regard to new facts (nova) both the Ekkart Committee and the Government endorse a broad(er) understanding of what constitutes new facts: next to new insights into the provenance of an art work the case law of the Judicial Division of the Council for the Restoration of Rights is accorded a greater role under the notion of nova: where cases have been decided by the stricter interpretation of the provisions of Decree E 100 by the Netherlands Art Property Foundation (SNK), the more lenient interpretation by the Judicial Division of the Council for the Restoration of Rights of the same provisions should be considered as a new fact and allow for a reconsideration of the case. Changed (historical) insights in respect of the justice and consequence of the policy pursued at that time were not accepted as nova. ${ }^{1492}$

\footnotetext{
1490 The only material difference between the second recommdation of the Ekkart Committee and the reaction by the Government lies in the fact that with regard to the fourth and six recommendation dealing with forced respectively involuntary sales the Government extended the principles from Jewish art dealers to art dealers from other persecuted groups.

${ }^{1491}$ Brief en regeringsnotitie inzake restitutie en recuperatie van cultuurgoederen (letter and government memorandum in respect of restitution and recuperation of items of cultural value) d.d. 14 juli 2000, Tweede Kamer, vergaderjaar 1999-2000, 25 839, nr. 16; Advisory Committee for Restitution Applications for Items of Cultural Value and the Second World War, 2003b, para. 2.4, p. 12.

1492 Commissie Ekkart, 2006, pp. 28-29 \& Appendix 7; Letter [in Dutch] from the State Secretary for Education, Culture and Science to the House of Representatives dated 29 June 2001 in respect of recommendations made by the Ekkart Commitee, parliamentary year 2000-2001, 25 839, nr. 26, Letter [in Dutch] from the State Secretary for Education, Culture and Science to the House of Representatives dated 16 November 2001 in respect of recommendations made by the Ekkart Commitee, parliamentary year 2001-2002, 25 839, nr. 27. See for a different opinion: Vlies, I.C.v.d., et al., 2009, p. 102 who states that the State accepted the inclusion of changed historical insights as nova. The author of the present study was not able to find any information on the acceptance in the database Opmaat (http://opmaatnieuw.sdu.nl/opmaat/l/pages/opmaat/landingpage.xml).
} 
With regard to the question of forced sales there exists a presumption that sales of works of art by Jewish private persons or from other persecuted groups in the Netherlands from 10 May 1940 onwards were forced sales. The same presumption applies in respect of sales by Jewish private persons or persons from other persecuted groups in Germany from 1933 and in Austria from 1938 onwards. Sales proceeds only have to be repaid (in accordance with the general price-index figure) where it has been proven that the former owner or his heirs could freely dispose of the proceeds. The proceeds are not paid into the Dutch treasury but are forwarded in equal shares to the Cultural Heritage Foundation of the Portuguese-Israeli Community and the Jewish Historical Museum. ${ }^{1493}$ No administration costs will be charged in case of restitution.

With regard to the required proof of title it is sufficient that title has been proven with a high degree of probability and in absence of indications to the contrary.

\section{THE ROLE AND wORK OF THE 'Advisory COMmitTe on the Assessment OF Restitution Applications for items of Cultural Value and the Second WORLD WAR'}

In reaction to the first set of recommendation by the Ekkart Committee the Minister of Culture announced the plan to establish a committee with the task to advice on individual applications for the restitution of art works from the NK Collection. ${ }^{1494}$

Four month later, by decree of 16 November 2001 the "Advisory Committee on the Assessment of Restitution Applications for Items of Cultural Value and the Second World War" (hereinafter: the "Restitutions Committee") was established. ${ }^{1495}$ It took up its work on 22 December 2001. The task of the Restitutions Committee is twofold: first and as main task the Restitutions Committee has to advise the Minster for Education, Culture and Science on decisions to be taken concerning applications for the restitution of items of cultural value of which the original owners involuntarily lost possession due to circumstances directly related to the Nazi regime and which are currently in the possession of the State of the Netherlands. ${ }^{1496}$ The second task of the Restitutions

\footnotetext{
1493 Cf.: Ekkart Committee, 2004, principle 8.

1494 Letter [in Dutch] from the State Secretary for Education, Culture and Science to the House of Representatives dated 29 June 2001 in respect of recommendations made by the Ekkart Commitee, parliamentary year 2000-2001, 25 839, nr. 26.

1495 Besluit van de Staatssecretaris van Onderwijs, Cultuur en Wetenschappen, dr. F. van der Ploeg, houdende Instelling van een commissie die adviseert over verzoeken om teruggave van cultuurgoederen waarover de oorspronkelijke eigenaar door omstandigheden die direct verband hielden met het nazi-regime onvrijwillig het bezit heeft verloren en die zich thans in bezit van de Staat der Nederlanden bevinden (Besluit adviescommissie restitutieverzoeken cultuurgoederen en Tweede Wereldoorlog) WJZ/2001/45374(8123) 16 November 2001, . The Restitutions Committee is often referred to as the Polak Committee after its first chairman mr. J.M. Polak.

1496 Cf.: Decree issued by the State Secretary for Education, Culture and Science, F. van der Ploeg, establishing a committee to advise the government on the restitution of items of cultural value of which the original owners involuntarily lost possession due to circumstances directly related to the Nazi regime and
} 
Committee concerns disputes about works of art that are not in the possession of the Dutch State. At the request of the Minister of Culture and provided that both parties to the dispute agree, the Restitutions Committee issues recommendations on the restitution of these cultural objects. ${ }^{1497}$

The Restitutions Committee's advisory framework with regard to the restitution claims for objects in possession of the Dutch State, both in the NK Collection and in the other state-owned collections consists of the policy as adopted by the Government in reaction to the recommendations by the Ekkart Committee (as outlined above). ${ }^{1498}$ The recommendation of the Restitutions Committee can consist of recommending the Minister of Culture to reject a claim or to return a claimed object. ${ }^{1499}$ In the latter case, the Restitutions Committee can also recommend to make the return subject to certain conditions. E.g. where the object had been lost due to forced sale, and the former did receive the payment and could freely dispose of it, the Restitutions Committee can recommend to state a condition that the sales proceeds must be returned.

Recommendations by the Restitutions Committee are not binding upon the State Secretary. However, so far the Minister of Culture followed all recommendations, albeit the motivation might have differed. ${ }^{1500}$ Decisions by the Minister of Culture can be challenged in a civil procedure. ${ }^{1501}$

In cases involving art works that are not in the possession of the Dutch State the Restitutions Committee has to base its decision on the principles of reasonableness and fairness but may apply the liberalised policy in analogy. 1502

In agreement with the first and second principle of the final recommendations of the Ekkart Committee ${ }^{1503}$ the Dutch Government announced on 4 April 2005 that the final

which are currently in the possession of the State of the Netherlands, 16 November 2001 (Reference WJZ/2001/45374(8123), Art. 2 sub 1.

${ }_{1497}$ Cf.: Ibid., Art. 2 sub 2 juncto sub 3. See below the analysis of the binding advice given by the Restitutions Committee concerning the dispute over the restitution of A Prayer before Supper by Jan Toorop from the estate of E. Flersheim, currently in the possession of the Zeeuwse Museum Foundation (Binding Advice RC 3.45).

1498 Cf.: Ibid., Art. 2 sub 4.

1499 Cf.: Palmer, N., 2005, para. 21.

${ }^{1500}$ See in this respect below the Goudstikker case in chp. 4.\$1.I.3.b).

1501 Cf.: Uitspraak op het hoger beroep van de Staatssecretaris van Onderwijs, Cultuur en Wetenschap, thans de Minister van Onderwijs, Cultuur en Wetenschap, appellant, tegen de uitspraak in zaak no. AWB 04/4576 van de rechtbank Amsterdam van 7 juni 2006 (200605289/1), para. 2.4.

1502 Cf.: Decree issued by the State Secretary for Education, Culture and Science, F. van der Ploeg, establishing a committee to advise the government on the restitution of items of cultural value of which the original owners involuntarily lost possession due to circumstances directly related to the Nazi regime and which are currently in the possession of the State of the Netherlands, 16 November 2001 (Reference WJZ/2001/45374(8123), Art. 2 sub 5. See further below in chp. 4.81.I.c) on the Regulations on binding recommendation procedure in the section discussing Binding Advice RC 3.45 concerning a painting by Toorop.

1503 See above. 
deadline for the filing of new restitution claims was 4 April 2007.1504 At that point in time it was estimated that the Restitutions Committee would need one year from the cut-off point to make recommendations on all submitted requests. Given the significant increase of requests in reaction to the announcement of the cut-off point, however, the Restitutions Committee's mandate was renewed until the end of $2010 .{ }^{1505}$

With regard to the question of how claims would be treated that had been made only after that cut-off point, the Minister had originally indicated that recourse would be taken to the restitution policy as it was pursued prior to the liberalised policy as adopted by the Government in reaction to the recommendations of the Ekkart Committee. ${ }^{1506}$ However, this plan was eventually abandoned due to international pressure and the number of claims received after the cut-off point. ${ }^{1507}$ More than twenty claims had been received after 4 April 2007 and have been referred to the Restitutions Committee. ${ }^{1508}$

\section{Cases}

By the end of 2007 the Restitutions Committee had received a total of 91 requests for recommendations. ${ }^{1509}$ Three cases have been referred to the Committee that did not concern objects in the possession of the Dutch State but instead concerned any case where the present holder is not the Dutch State.

An analysis of all these cases and recommendations would exceed the scope of the present study. However, we nevertheless feel the need to discuss the cases to reflect upon how the Restitutions Committee applies the Government policy in practice. For the following reasons, we have chosen the Gutmann case, the Goudstikker case and the Toorop case: the Gutmann case was the first case decided by the Restitutions Committee and is crucial for the understanding of how the Restitutions Committee

\footnotetext{
1504 The following announcement was published in the Government Gazette on 4 April 2007 and in many national and foreign newspapers: "As of today, claimants have another two years in which they can seek to reclaim art spoliated by the Nazis. This is revealed in a government response to the final recommendations of the Ekkart Committee published today in this gazette. With the Committee, the Government recognises that a period of two years is necessary to gather the information required to submit a claim. Nevertheless, both the Government and the Committee consider a period longer than two years inappropriate because it is becoming ever more difficult to gather first and second-hand information about the situation during the Second World War". Government Gazette, 4 April 2005, no. 64, p. 13.

1505 Amendment of the Decree establishing the Advisory Committee on the Assessment of Restitution Applications for Items of Cultural Value and the Second World War, 8 November 2007.

1506 Cf.: Advisory Committee for Restitution Applications for Items of Cultural Value and the Second World War, 2007, pp. 17-18. Amendment of the Decree establishing the Advisory Committee on the Assessment of Restitution Applications for Items of Cultural Value and the Second World War, 8 November 2007. Cf.: E-mail dated 27 January 2009, reference no. 96339 from Postbus 51 Informatiedienst. 1507 Cf.: Ibid., p. 5

1508 Interview with Inge van der Vlies, Professor for Administrative Law at the UvA and member of the Restitutions Committee on 6 March 2009.

${ }^{1509}$ In fact, a total of 94 requests had been referred to the Restitutions Committee: two of the requersts were deferred and one was combined with a request field later. Cf:: Advisory Committee for Restitution Applications for Items of Cultural Value and the Second World War, 2007, p. 7. The annual report for 2008 was not published by July 2009 when this research was finalised.
} 
applied the broader notion of new facts (nova). ${ }^{1510}$ As for the category dealing with objects from art dealers' trading stocks we will discuss the Goudstikker case. The Goudstikker case is without any doubt the most prominent case in the Netherlands and set the ball rolling. It was the first case decided by the Restitutions Committee where the Committee had to apply the principles specifically aiming at art dealer cases. The case is furthermore interesting in that it opens the door to restitution even where cases qualify as settled under the liberalised restitution policy. As to the third category concerning items of cultural value that are not in possession of the Dutch State but of a private individual, a foundation or a provincial or municipal government institution we will discuss the binding advice given by the Restitutions Committee concerning the dispute over the restitution of a painting by Jan Toorop from the Zeeuwse Museum Foundation to the estate of E. Flersheim

\section{a) The Gutmann Case}

On 24 January 2002 the Minister of Culture referred the request from the Gutmann family for the restitution of artworks formerly in the Gutmann collection from the $\mathrm{NK}$ Collection to the Restitutions Committee. The request for restitution concerned those artworks from the collection that had been sold during the war to the German art dealers Böhler and Haberstock. ${ }^{1511}$ After the war many of the objects sold to Böhler and Haberstock had been recovered from Germany. The children of Gutmann, who had survived the war, sought the restitution of these objects from the Netherlands Art Property Foundation (SNK). After a dispute between the heirs and the SNK regarding the question whether the sale had been voluntary the matter was referred to the Judicial Division of the Council for the Restoration of Rights. ${ }^{1512}$

In 1952 the Judicial Division ruled that while the sales had not been made under duress they had nevertheless been made "under the influence of special circumstances". For this reason, the Judicial Division held that the sale should be rescinded. ${ }^{1513}$ The Judicial Division ordered the Netherlands Art Property Foundation (SNK) to release the objects but added a reservation based on Art. 27 sub 5 Decree E 100 to the effect that the sales price of the object had to be refunded to the Netherlands Art Property Foundation (SNK). ${ }^{1514}$ The heirs of Gutmann stated that their father had never received the sales price and refused to refund the monies. Consequently, the objects remained in the possession of the Dutch State until their inclusion in the NK Collection was challenged by the heirs under the liberalised restitution policy.

\footnotetext{
1510 http://www.minocw.nl/english/doc/persbericht25.doc.

1511 See further on the loss and restitution of further objects from the collection especially in Paris: Goodman v. Searle, No. 96-C-6459 (N.D. Ill., filed Sept. 24, 1996); Feliciano, H., 1997, p. 188; Buomberger, T., 1998, p. 24; Aalders, G., 1999, pp. 90-91; Harclerode, P. / Brendan, P., 1999, p. 266; Weil, S., 1999, pp. 294-295.

1512 Campfens, E., et al., 2006, p. 428.

1513 See Art. 23 of the Decree E 100.

1514 Cf.: Veraart, W., 2005, pp. 101-102.
} 


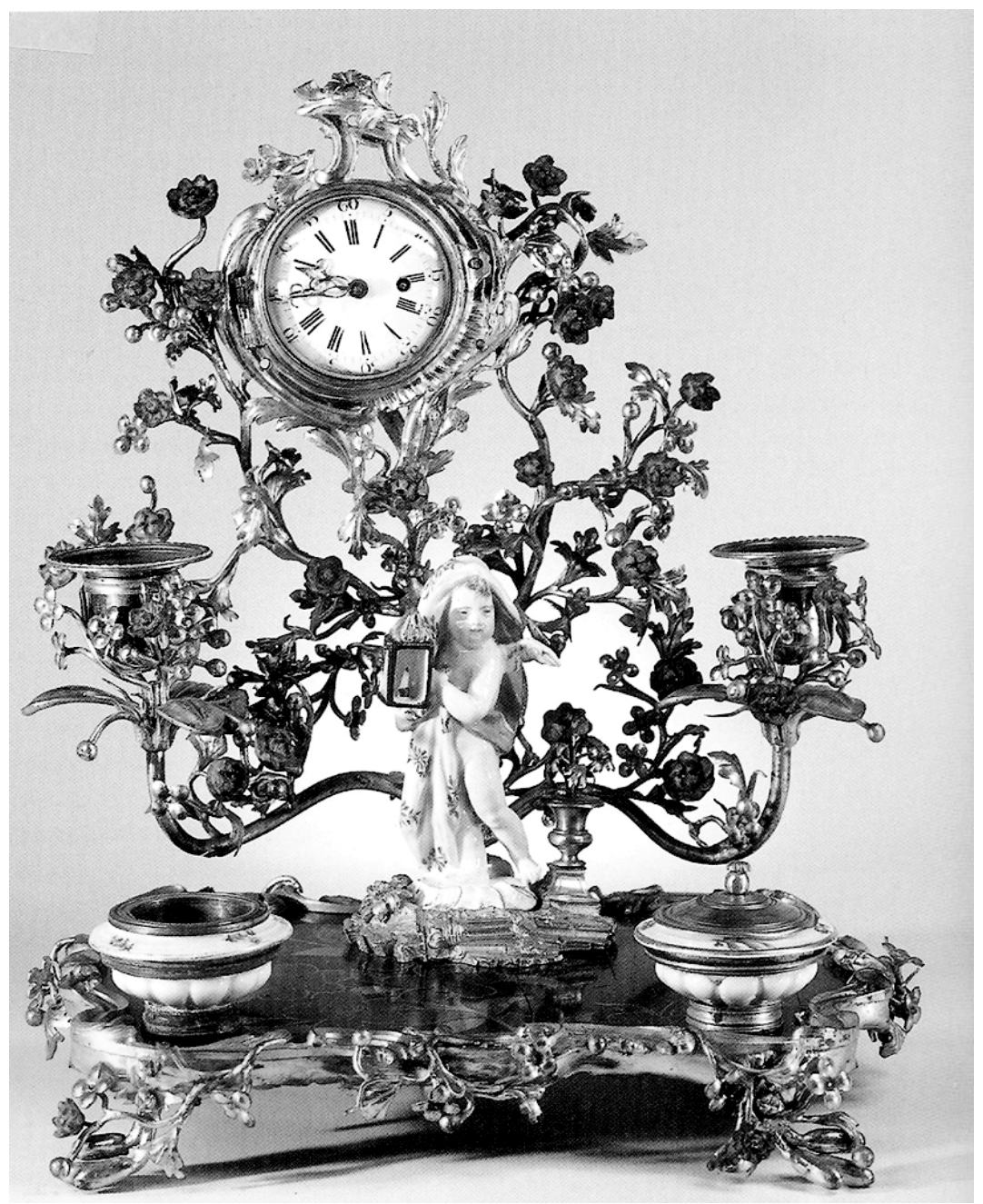

One of the objects returned to the Gutmann heirs was this inktstand with integrated clock from ca. 1750, bronze and porcelain, 28 × 26 × 21 cm. Photo: Muller / Schretlen, 2002, p. 174. 
In its "Advice concerning the application for restitution of the Gutmann collection" the Restitutions Committee started by stating four general considerations that would be recited in all subsequent recommendations: 1515

a. The Committee has drawn up its opinion with due regard for the relevant lines of policy as issued by the Ekkart Committee and the Government, as referred to in the Decree establishing the Advisory Committee on the Assessment of Restitution Applications.

b. The Committee asked itself whether it is acceptable that an opinion to be issued is influenced by its potential consequences for decisions in other cases. The Committee resolved that such influence cannot be accepted, save cases where special circumstances apply, since allowing such influence would be impossible to justify to the applicant concerned.

c. The Committee then asked itself how to deal with the circumstance that certain facts can no longer be traced, that certain information has been lost or has not been retrieved, or that evidence can no longer be otherwise compiled. On this issue the Committee believes that, if the problems that have arisen can be attributed at least in part to the lapse of time, the associated risk should be borne by the Government, save cases where exceptional circumstances apply.

d. Finally, the Committee believes that insights and circumstances which, according to generally accepted views, have evidently changed since the Second World War should be granted the status of new facts.

In particular the last consideration (sub d) concerning the treatment of changed insights and circumstances as new facts (nova) is interesting: the analysis of the Ekkart recommendations and the government reactions revealed that the Government explicitly refused to consider changed (historical) insights in respect of the justice and consequence of the policy pursued at that time as nova.1516 Consequently, with consideration sub d) the Restitutions Committee amended the policy according to its own views.

In the Gutmann case consideration d) or rather the question of the qualification of new facts played a decisive role. The Restitutions Committee based its recommendation that the art works should be returned on the finding that the reservation stated by the Judicial Division in 1952, according to which the artworks were to be released upon refunding of the sales price to the State of the Netherlands, has become unacceptable in

1515 As of 12 November 2007 the general considerations had to some extent been amended in reaction to the recommendations with reagard to the art trade published by the Ekkart Committee in 2003 and the reponse of the Government. Cf.: Advisory Committee for Restitution Applications for Items of Cultural Value and the Second World War, 2007, p. 16. See further on the general considerations in art trade cases below in chp. 4.\$1.3.a) discussing the Goudstikker case.

1516 Commissie Ekkart, 2006, pp. 28-29 \& Appendix 7; Letter [in Dutch] from the State Secretary for Education, Culture and Science to the House of Representatives dated 29 June 2001 in respect of recommendations made by the Ekkart Commitee, parliamentary year 2000-2001, 25 839, nr. 26, Letter [in Dutch] from the State Secretary for Education, Culture and Science to the House of Representatives dated 16 November 2001 in respect of recommendations made by the Ekkart Commitee, parliamentary year 2001-2002, 25 839, nr. 27. 
view of the present government policy. ${ }^{1517}$ The Restitutions Committee refers to the recommendation of the Ekkart Committee to give a more liberal interpretation to the concept of nova than has been the case under the policy practice so far, such that the concept also covers deviations from the judgements issued by the Council for the Restoration of Rights, as well as the results of changed (historical) insights regarding the justification and consistency of the policy pursued at the time. ${ }^{1518}$ With regard to the sale and restitution of the objects from the Gutmann collection the Restitutions Committee states that "new facts have been presented. In view of the special circumstances in which the sales transactions took place, it cannot be assumed that the heirs would be unlawfully enriched by the restitution if they did not refund the sales proceeds". 1519

While it is true that the Ekkart Committee did recommend in principle 2 of its first recommendation to accept changed (historical) insights in respect of the justice and consequence of the policy pursued at that time as nova ${ }^{1520}$ this interpretation was refused by the Government in its reactions from June and November 2001.1521

Consequently, it is doubtful whether the Gutmann case should actually have been reassessed by the Restitutions Committee: if one sticks to the government policy according to which changed historical insights do not constitute a valid novum the Gutmann case was reassessed in spite of the existence of a new fact. The fact that under the liberalised return policy sales proceeds only have to be repaid were it has been proven that the former owner or his heirs could freely dispose of the proceeds this principle is not a novum that allows for the reconsideration of a case. Rather it is a principle on the treatment of claims that have not been settled or where new facts have emerged.

On 18 April 2002, the Minister of Culture announced the return of 233 works of art from the Gutmann Collection. ${ }^{1522}$

\section{b) The Goudstikeker Case}

The Goudstikker Case was the first case submitted to the Restitutions Committee that concerned the restitution of art works from the trading stock of an art dealer. The case concerned those works of art that had been part of the trading stock of the prominent art gallery of Jacques Goudstikker in May 1940. Goudstikker, his wife, and

\footnotetext{
1517 Cf.: Advisory Committee for Restitution Applications for Items of Cultural Value and the Second World War, 2002.

1518 Cf.: Ibid.

1519 Cf.: Ibid.

1520 Ekkart Committee (Supervisory committee Origins Unknown/Herkomst Gezocht), 2001.

1521 Letter [in Dutch] from the State Secretary for Education, Culture and Science to the House of Representatives dated 29 June 2001 in respect of recommendations made by the Ekkart Commitee, parliamentary year 2000-2001, 25 839, nr. 26; Letter [in Dutch] from the State Secretary for Education, Culture and Science to the House of Representatives dated 16 November 2001 in respect of recommendations made by the Ekkart Commitee, parliamentary year 2001-2002, 25 839, nr. 27.

${ }^{1522}$ Van der Ploeg volgt advies commissie. Oorlogskunst uit rijksbezit naar erven, 18 April 2002.
} 
his son left the Netherlands when the German Army invaded the Netherlands. During the boat journey to the United States Goudstikker lost his life in an accident. ${ }^{1523}$

After the agent whom Goudstikker had authorised to take care of the art gallery in his absence had died unexpectedly in May 1940, the gallery was left behind without management. ${ }^{1524}$ Consequently, two employees of the Goudstikker NV ${ }^{1525}$, A.A. ten Broek and J. Dik, Sr., took on the management of the gallery. During an extraordinary general meeting of shareholders in June 1940, which was attented by the mother of Goudstikker who stayed in the Netherlands during the war, Ten Broek was named company director. Almost immediately after the capitulation of the Netherlands, Alois Miedl, a German banker and businessman living in the Netherlands, joined the art business and took over the actual management of the gallery. ${ }^{1526}$

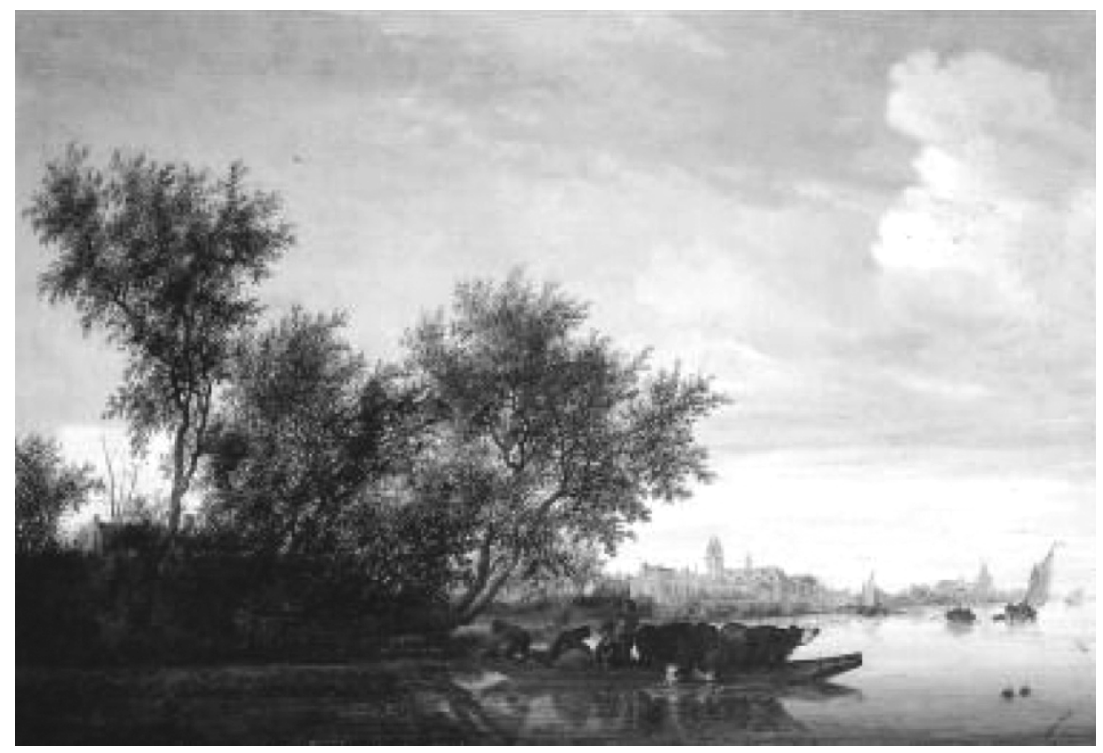

One of the returned paintings is this painting by Salomon van Ruysdael, Ferry boat with cattle on the river Vecht near Nijenrode, Oil on panel, 58 x $84 \mathrm{~cm}$. CTim Koster/ICN.

By contract dated 1 July 1940, Miedl purchased all immovable and movable assets of the gallery, as well as the trading name. The contract was amended when Hermann

${ }^{1523}$ For historical account of the Goudstikker "empire", his families attempt to flee to the US and his death caused by his fall into a hold on the ship, see: Hollander, P.d., 1988; Advisory Committee for Restitution Applications for Items of Cultural Value and the Second World War, 2005b.

1524 Advisory Committee for Restitution Applications for Items of Cultural Value and the Second World War, 2005a, para. 5.

1525 Naamloze vennootschap (usually abbreviated NV) is the Dutch term for a public limited liability company that is owned by shareholders.

1526 Advisory Committee for Restitution Applications for Items of Cultural Value and the Second World War, 2005a, para. 5. 
Göring indicated his interest in the Goudstikker stock. As a result, on 13 July 1940, Ten Broek as company director sold part of the trading stock for $f 550,000$ to Miedl, (hereafter: the "Miedl-Transaction"), and the other part for $f$ 2,000,000 to Göring (hereafter: the Göring-Transaction). ${ }^{1527}$ Appearantly, Miedl pledged himself to grant protection to the mother of Goudstikker. ${ }^{1528}$ Whether this pledge was written down in the agreement or was communicated only verbally is not clear. What is known is that Désirée Goudstikker as widow and heir of Jacques Goudstikker refused to grant permission for the sale of the trading stock (she represented 334 of the 600 shares, partly on behalf of her underage son) there was little she could do to prevent the sale in her absence due to the circumstances of the war.

On 14 September 1940, Miedl founded the 'Gallery formerly known as J. Goudstikker NV' (Kunsthandel voorheen J. Goudstikker NV) and on 2 October 1940 the Goudstikker NV was liquidated. ${ }^{1529}$ During the war years, Mield's gallery flourished; he sold many works from the trading stock of Goudstikker NV, especially to German buyers, acquired new paintings for the stock and sold them again. Towards the end of the war, when the influence of Göring started to decline and Miedl, his Jewish wife and children no longer felt comfortable in the Netherlands and fled to Spain. ${ }^{1530}$ Miedl knew to smuggle out some 200 paintings. Amongst these paintings was the Penitent Magdalene depicted on the cover of this book. ${ }^{1531}$

As a result of the sale to Göring, Miedls active selling during the war years, especially to German buyers, and his export of paintings to Spain a great number of art works from the stock of the Goudstikker NV was no longer present in the stock of the former Goudstikker NV at the end of the war. However, a significant amount of works was restored to the Netherlands at the end of the war and came under the administration of the Netherlands Art Property Foundation (SNK). ${ }^{1532}$

After the war, Goudstikker NV, represented by the widow of Goudstikker, now operating by the name of her second husband von Saher, sought for the restoration of rights. The liquidation of the Goudstikker NV was reversed with retroactive effect on 26 February 1947. From the beginning the restoration of rights focussed on the art

\footnotetext{
1527 The Penitent Magdalene depicted on the cover was part of the Miedl-transaction. Together with some 200 other paintings it was smuggled to Spain in 1944 by Miedl where it was kept in the Free Port of Bilbao.

1528 Cf.: Advisory Committee for Restitution Applications for Items of Cultural Value and the Second World War, 2005a, p. 5. During the war, Miedl, who was married to a Jewish woman, helped Jewish families. Cf.: Advisory Committee for Restitution Applications for Items of Cultural Value and the Second World War, 2005a, p. 6.

1529 Cf.: Advisory Committee for Restitution Applications for Items of Cultural Value and the Second World War, 2005a, p. 5.

1530 See further on the details of the flight: Harclerode, P. / Brendan, P., 1999, pp. 148-153.

${ }^{1531}$ Cf.: Ibid., p. 153.

1532 Cf.: Advisory Committee for Restitution Applications for Items of Cultural Value and the Second World War, 2005a, p. 12. See further on the process of the restoration of rights by the Allies in chp. $1 . \$ 1 \&$ $\$ 4$.
} 
works that had been part of the Miedl and Göring transactions. ${ }^{1533}$ With regard to the works of art delivered to Miedl, von Saher signed a settlement agreement with the Administrative Department of the Council of Restorations of Rights (Nederlands Beheersinstituut (NBI)) on 1 August 1952. In this agreement von Saher waived the ownership rights to the objects delivered to Miedl. In the preamble of the settlement von Saher explicitly states that the reasons for agreeing with the settlement: the uncertain political situation and the possibly time-consuming litigation. She explicitly states she considers herself deeply deprived and that she does not acknowledge any of the other party's statements. ${ }^{1534}$

That part of the collection that had been purchased by Göring did not become part of the settlement agreement and no other attempt to annul the agreement with Göring was made. 1535 Consequently, the paintings that had been covered by the Göring transaction remained in the NK Collection' (Netherlands Art Property Collection). One must not disregard the fact, however, that from the sales proceeds of the transactions to Göring and Miedl (together $f$ 2,550,000) $f$ 1,363,752.33 had remained as assesst of the Goudstikker NV and as such available to the heirs to the Goudstikker NV.1536

On 9 January 1998, i.e. prior to the introduction of the liberalised restitution policy, the heirs of Goudstikker requested the Minister of Culture to return all objects from the former Goudstikker collection from the NK-Collection, i.e. both works that fell both under the Miedl- and the Göring-Transaction. By decision dated 25 March 1998, the

1533 Advisory Committee for Restitution Applications for Items of Cultural Value and the Second World War, 2005b, p. 12.

1534 In Dutch: "dat partij ter andere zijde deze beëindiging slechts wenst, in verband met de tijd, die met de procedure gemoeid kan zijn; (...) dat genoemde Mevrouw von Saher (Desirée Goudstikker remarried August E.D. von Saher) tot haar diepe teleurstelling moet ervaren, dat zij, om datgene te bereiken, hetgeen zij als rechtsherstel beschouwt, daarvoor misschien nog jaren zal moeten procederen, thans besloten heeft om zich, in verband met het vorenstaande en mede in het licht van de onzekere polititieke toestand, in te laten met een schikking; dat partij ter andere zijde derhalve zelfs bereid is, zich daarvoor opofferingen te getroosten, die zij als uitermate onredelijk beschouwt en dat zij uitdrukkelijk wenst vast te leggen, dat zij geen der door de wederpartijen in de voormelde procedure vastgelegde argumenten erkent en dat zij zich ten zeerste benadeeld acht, doordat zij onder meer generlei vergoeding subsidiair schadevergoeding heeft verkregen of verkriigt voor door genoemde Alois Miedl en /of Miedl N.V. met het bedrijf van Goudstikker N.V. gemaakte winsten en voor het verliezen der goodwil van Goudstikker N.V.". Cf.: Schoordijk, H., C.F., 2006, pp. 745-746; Velten, A.A.v., 2006a, pp. 242-243.

1535 See Memorandum by Goudstikker's lawyer M. Meyer dated November 10, 1949 and the report by A.E.D. von Saher (Goudstikker's lawyer and second husband) from April 1952. Cf.: Velten, A.A.v., 2006b, p. 263. The Göring-Transaction had been mentioned in Art. 1.5 of a draft from June 1952 of the settlement agreement. A July draft and the final settlement agreement no longer contained the reference to the waiver of the rights to the works covered by the Göring-Transaction. Art. 1.6 of the final settlement agreement still contains a reference to the Göring Transaction. "Overigens is en blijft de partij Goudstikker gerechtigd om goederen en rechten die niet vallen onder de overeenkomsten die op 1 juli 1940 en op 13 juli 1940 met Alois Miedl en op 13 juli 1940 met Hermann Göring werden aangegaan op de vorderen". It is not clear whether the parties, especially the lawyer of von Saher simply forgot to remove the mentioning of the Göring Transaction at this place when the reference to the Göring-Transaction was removed from Art. 1.4 on the waiver of the ownership rights.

1536 Cf.: Kuitenbrouwer, F., 7 February 2006. 
Minister of Culture rejected the application for the return of the Goudstikker Collection from the NK-Collection. The motivation was that the immediate post-war restoration of rights had been carefully settled, also when measured by current standards. Therefore, the Minister of Culture continued, there was no reason not to invoke the lapse of the limitation period.

The heirs to the Goudstikker NV appealed the decision of the Minister of Culture before the Court of Appeal in The Hague. Together with their appeal the heirs submitted an application for the restoration of rights for the Göring-Transaction ${ }^{1537}$. The reason for not including the Miedl-Transaction was that the two transactions had been treated differently during the immediate post-war restitution procedures at the end of the 1940s and 1950s.

By ruling dated 16 December 1999 the Court dealt with the appeal and the application for the restoration of rights in three different ways. In the first place, regarding the appeal against the decision of the State Secretary, the Court declared that it had no competence to hear the matter: while the Court acknowledged its function as successor of the Judicial Division of the Council of Restoration of Rights ${ }^{1538}$, a decision by the Minister of Culture does not qualify as a decision of a department of that Council. ${ }^{1539}$ Therefore, the appeal was turned down on procedural reasons. As second step, the court dealt with the application for the restoration of the ownership rights regarding the works of art covered by the Göring-Transaction. The application was based on the Decree E $100 .{ }^{1540}$ The Court found the application inadmissible, as the application had not been submitted within the application period that had expired on 1 July 1951. Thirdly, the Court examined whether compelling reasons allowed for an official granting of the restoration of rights. 1541 The Court did not follow the heirs of Goudstikker's argument that von Saher had been misled during the 1950s by the Netherlands Art Property Foundation (SNK) and the Council's Administrative Department (Nederlands Beheersinstituut (NBI) to the effect that the Göring transaction had been voluntary in nature and with regard to the value of the paintings concerned. The Court held that the heirs of Goudstikker NV had been free, regardless of the position of the Netherlands Art Property Foundation (SNK) to submit a request

1537 Gerechtshof Den Haag, eerste civiele kamer, 16 december 1999, req. nr. 98/298. Siehr, K.G., 2005

1538 The Council of Restoration of Rights was disabanded in 1967.

1539 The Minister of Culture is the successor of the Stichting Nederlandsch Kunstbezit (SNK). The SNK was a special post-war organisation assigned with the task of recuperating works of art from abroad. It was not a department of the Council of Restoration of Rights.

1540 Art. 21 (1): "De bevoegdheden, in de volgende artikelen van dit hoofdstuk aan den Raad toegekend, kunnen worden uitgeoefend op grond van een schriftelijk verzoek daartoe, door of namens een belanghebbende ingediend".

1541 Art. 21 (3) Decree on Restoration of Legal Transactions, E 100 from 1944 provides a discretionary power to allow for the restoration of rights in case of compelling reasons that is available to the Court even after 1 July 1951: "De den Raad in de volgende artikelen van dit hoofdstuk toegekende bevoegdheden kunnen ook ambtshalve, zelfs na afloop van den ingevolge het vorige lid vastgestelden termijn, door den Raad worden uitgeoefend". 
for restitution to the Council for the Restoration of Rights (Raad voor Rechtsherstel) whatever the position of the Netherlands Art Property Foundation (SNK) and the Council's Administrative Department (Nederlands Beheersinstituut (NBI) might have been. Furthermore, the Court held that von Saher had expert legal advisers who could have contested the voluntary nature of the transaction and who could have requested a counter appraisal of the paintings by independent experts. Consequently, the court held that von Saher had deliberately decided against seeking restoration of rights in respect of the Göring-Transaction. ${ }^{1542}$ The Court furthermore motivated its decision against an official granting of the restoration of rights as follows: first, the Court pointed out that more than fifty years had passed since the end of the application period for claims under the Decree on Restoration of Legal Transactions. The application for the restoration of rights regarding the Göring-Transaction, the second point the court dealt with, had been held inadmissible for the same reason. While this is a long period from a legal point of view the argument does not necessarily rule out the granting of restoration rights as the decree did not limit the restoration of rights in time. ${ }^{1543}$

The ruling of the Court of The Hague with the twofold declaration of inadmissibility, and the declaration that no compelling reasons existed for the use of the Court's discretionary power for an official granting of the restoration of rights was not the only legal procedure that had been initiated by the heirs of Goudstikker NV.1544 However, the other procedures were equally unsuccessful ${ }^{1545}$, or were stayed in the light of an application filed on 26 April 2004 that would result in the return of a total of 202 paintings to the heirs on the basis of the liberalised restitution policy.

On 26 April 2004, the Heirs of Goudstikker NV1546 filed an application for the return of a total of 276 works of art with the Minister of Culture who referred the application to the Restitutions Committee for advice. ${ }^{1547}$

\footnotetext{
1542 The Court referred to a memorandum of the lawyer of von Saher dated 10 November 1949, and a report by von Saher's second husband A.E.D. von Saher dated April 1952: Gerechtshof Den Haag, eerste civiele kamer, 16 december 1999, req. nr. 98/298, para. 20.

1543 Art. 21 (3) of that Decree allows for the restoration of rights in case of compelling reasons "even after 1 July 1951".

${ }^{1544}$ By letter dated 22 April 1998 the heirs had appealed against the decision of the State Secretary from 25 March 1998 at a special committee for appeal within the Ministry of Education, Culture, and Science. See for a similar case, in which a decision by the State Secretary was appealed and the decision of the State Secretary not to deal with the appeal as the original decision did not qualify as decision in the sense of the Dutch General Administrative Code was unsuccesfully challenged in court: Minister wint zaak Koenigscollectie, 1 February 2007; Uitspraak op het hoger beroep van de Staatssecretaris van Onderwijs, Cultuur en Wetenschap, thans de Minister van Onderwijs, Cultuur en Wetenschap, appellant, tegen de uitspraak in zaak no. AWB 04/4576 van de rechtbank Amsterdam van 7 juni 2006 (200605289/1). Further to the appeal, the Heirs of Goudstikker NV had initiated a civil procdure at the Rechtbank Den Hag 10 januari 2001.

${ }^{1545}$ See for the civil procedure: Rechtbank Den Haag 10 januari 2001.

1546 Technically speaking the applicant was the "Amsterdamse Negotiatie Compagnie NV". It was the new name given to the former Gallery J. Goudstikker NV in 1952. As of 14 December 1955 until 28 February 1960, the assets of the company were liquidated. On 31 March 1998, by order of the Amsterdam District Court, the liquidation was reopened.

1547 Letters dated 10 June 2004 and 20 September 2005.
} 
In order to fulfil its task to advise the Minister of Culture the Restitutions Committee first ordered to undertake further research on the facts and the background of the claim. The findings are written down in a report that forms an integral part of the final recommendation. The report deals with the following relevant historical developments: first, the loss of the works of art at the beginning of the war when J. Goudstikker and his family fled the Netherlands, and when the Gallery's movable and immovable property was sold to Alois Miedl and Hermann Göring. Secondly, the report sets out the negotiations between the widow Goudstikker and the Dutch authorities on the restoration of rights in the post-war era (1947-1954), which resulted in two settlement agreements between von Saher and the administrators who were appointed on behalf of the Council's Administrative Department (Nederlands Beheersinstituut (NBI) $)^{1548}$. The first settlement concerned the Gallery's immovable property. ${ }^{1549}$ The second agreement concerned the movable property of the Gallery, i.e. the works of art. The settlement reached on 1 August 1952, however, did not cover all works of art that had belonged to the Goudstikker NV trading stock in May 1940. Subsequently, the report deals with earlier attempts undertaken by the heirs of Goudstikker NV for restitution: the 1998 application to the State Secretary, and the ruling of the Court of Appeal The Hague in 1999. The last chapter of the report deals with the provenance of the works of art in order to verify whether the objects in stock were indeed the property of the Goudstikker NV at the time of the transactions to Miedl and Göring.

Once the preparatory research had been conducted, the Restitutions Committee, in its final advise to the Minister of Culture on the decision regarding the return of the works of art, addressed the following questions: first, whether the transactions to Miedl and Göring must be regarded as involuntary. ${ }^{1550}$ Different from losses by private individuals the presumption of an involuntary sale does not apply to losses by art dealers. ${ }^{1551}$ The Committee concluded that the loss of possession must be considered involuntary under the current restitution policy, as the widow Goudstikker had explicitly refused her permission for the transactions to Miedl and Göring, and secondly, the new director who arranged for the sale of the objects had not been properly elected.

The next question the Restitutions Committee addressed was whether the application to return the works of art was admissable. Only cases that qualify as new applications, or where new facts have emerged, may be assessed by the Restitutions Committee. According to the liberalised return policy a case has been settled when it

\footnotetext{
1548 The Netherlands Property Administration Institute.

1549 Ekkart Committee (Supervisory committee Origins Unknown/Herkomst Gezocht), 2001.

1550 See: Art. 2 of the Decree of 16 November 2001 on the tasks and responsibilities of the Restitutions Committee: "(...) for the restitution of items of cultural value of which the original owners involuntarily lost possession (...)". Note that the Committee first established whether an application concerns an involuntary loss of possession before dealing with the question whether an application is admissible.

1551 See further above in chp. 4. 1 1.I.2 on the principles developed by the Ekkart Committee and as adoted by the Dutch Government that deal specifically with the return of artworks from art dealers' trading stock. See in particular principles 4-6.
} 
had ended in a court ruling or in a formal settlement between the claimant and the Council for the Restoration of Rights or the Council's Administrative Department (Nederlands Beheersinstituut (NBI)). Furthermore, later settlements between the Dutch State on the one hand and claimants on the other hand could also qualify as settled cases where a claim resulted either in a conscious and deliberate settlement or when a claimant expressly renounced his claim for restitution. ${ }^{1552}$

With regard to the settlement agreement with the Council's Administrative Department (Nederlands Beheersinstituut (NBI)) signed by von Saher on 1 August 1952 regarding the works delivered to Miedl the Restitutions Committee first verified whether the agreement constituted a valid formal settlement. The Restitutions Committee held that the settlement was valid. ${ }^{1553}$ The Committee was not "convinced by legal arguments that the agreement should not be deemed valid" because it came about under coercion and deception. ${ }^{1554}$

Having concluded that the "Miedl settlement" is legally valid, the Committee subsequently held that the settlement must be regarded as definitive and the claim as settled: the settlement consisted of a solution agreed upon by parties that had formerly been in disagreement. The Restitution Committee furthermore held that different from a court ruling that is imposed from above, a settlement is the result of an active agreement. Also, the Committee held that there is a difference between the mere decision not to submit an application for the restoration of rights and the waiving ownership rights as Goudstikker had done in the agreement in the eyes of the committee. ${ }^{1555}$ Due to the definitive nature of the waiving of the ownership rights, the Committee concluded that the Miedl settlement constituted a "settled case" and was not admissible.

As for the Göring transaction, the Committee set out that it was not covered by the 1952 formal settlement. While a draft version of the Miedl settlement did mention the Göring transaction, the reference was later scratched and was absent in the final version. Consequently, and different from the Miedl settlement the decision by the Heirs of Goudstikker NV with regard to the Göring transaction qualifies as "mere decision not to submit an application". The application could however be barred by the ruling handed down by the Court of Appeals of The Hague on 16 December 1999. In that ruling, the Court of Appeal had denied the existence of compelling reasons to officially grant restoration of rights as the Company had "intentionally and deliberately decided

\footnotetext{
1552 Brief en regeringsnotitie inzake restitutie en recuperatie van cultuurgoederen (letter and government memorandum in respect of restitution and recuperation of items of cultural value) d.d. 14 juli 2000, Tweede Kamer, vergaderjaar 1999-2000, 25 839, nr. 16; Advisory Committee for Restitution Applications for Items of Cultural Value and the Second World War, 2003b, para. 2.4, p. 12.

1553 Advisory Committee for Restitution Applications for Items of Cultural Value and the Second World War, 2005a, pp. 27-31.

1554 Ibid., p. 9 .

1555 Ibid.
} 
against seeking restoration of rights" in respect of the 'Göring transaction'. 1556 However, different from the Court the Restitutions Committee concluded that an intentional and deliberate decision not to seek restoration of rights, does not "automatically mean that the Applicant's actual rights to the Göring collection have been surrendered". ${ }^{1557}$ The Committee accepted that various reasons could have existed for Von Saher to decide against seeking restoration of rights without at the same time surrendering the ownership rights. ${ }^{1558}$ Further support for this argumentation was derived from the fact that the reference to the Göring collection had been removed from the 1952 Miedl Agreement. ${ }^{1559}$ On top of that, the Committee stressed that the 1999 court ruling predated the coming into existence of the liberalised return policy and thus could not have taken account of it. All taken together, the Restitutions Committee reached the conclusion that the application for restitution of the works of art delivered to Göring was admissible. Once the hurdle of admissibility had been taken, and in the light of its earlier finding that the loss of possession must be regarded as involuntary, the Committee came to the conclusion that the application for the return of the works covered by the Göring transaction should be granted. 1560

In reaching this conclusion the Restitutions Committee shortly reflected about the question whether, in light of the quantity and quality of the paintings involved, there could be a public interest that should be weighed as part of this recommendation. The Restitutions Committee held that when a collection or objects qualifies as irreplaceable and indispensable under Art. 2 of the Cultural Hertage Protection Act (Wet tot Behoud Cultuurbezit) this could constitute a matter of public interest to keep them permanently within the Netherlands. ${ }^{1561}$ However, the Restitutions Committee does not verify whether any of the objects involved qualifies as irreplaceable and indispensable for the following reason. According to the Restitutions Committee the establishing of a public

\footnotetext{
1556 Gerechtshof Den Haag, eerste civiele kamer, 16 december 1999, req. nr. 98/298, para. 20.

1557 Advisory Committee for Restitution Applications for Items of Cultural Value and the Second World War, 2005a, p. 10.

1558 An example given by the Committee is that the authorities responsible for restoration of rights wrongfully created the impression that Goudstikker's loss of possession of the trading stock did not occur involuntarily.

1559 Art. 1.5 of the draft version from June 1952 contained the surrender of ownership rights both for the Miedl and the Göring transaction. The July 1952 draft version no longer contained the reference to the Göring transaction. Art. 1.4 of the final settlement from August 1952 on the surrendering of ownership rights referred only to the Miedl transaction. Note that Art. 1.6 of the final settlement did contain a reference to the Göring transaction: “(...) Goudstikker remains the right to seek restoration of goods and rights that are not covered by the settlements dated 1st July 1940, 5th of July 1940, and 13th July 1940 concluded with Alois Miedl and the settlement dated 13 July 1940 with Hermann Göring." See also: Gerechtshof Den Haag, eerste civiele kamer, 16 december 1999, req. nr. 98/298. Verweerschrift landsadvocaat van de Staat, quoted in: Advisory Committee for Restitution Applications for Items of Cultural Value and the Second World War, 2005b, p. 36, para. 34.33.32 'Argumenten Staat'.

1560 The same is true for the so-called "meta-paintings": paintings Goudstikker co-owned with others and the "Ostermann painings" that were sold by the gallery's staff to the German W. Lüpps in May 1940 before Miedl took over the gallery but after the Goudstikker family had left the Netherlands.

1561 The Cultural Heritage Protection Act (CHP Act) is discussed in detail above in chp. 3.\$2.I.1.
} 
interest must be based on the situation of 1940, prior to the loss of possession, rather than on a present evaluation. ${ }^{1562}$ Given the fact that the CHP Act dates only from 1984, the Restitutions Committee holds that no public interest could be present. Furthermore, the Committee also states that any any post-war shift in the appreciation of the works of art cannot and should not have any influence on the recommendation to restore the art to the claimant. 1563

On 19 December 2005, the Restitutions Committee communicated its recommendation to the State Secretary. On 6 February 2006, the Minister of Culture announced the decision to return a total of 202 paintings to the heirs of the Goudstikker NV.1564 While the decision concluded almost a decade of conflict between the Dutch State and the heirs of Goudstikker, it did not end the controversy around the case.

Following the announcement of the Restitutions Committee's recommendation and the State Secretary's decision to return the paintings that had been covered by the Göring transaction, commentators dicusssed whether the decision collided with the starting point of the liberalised return policy that the restoration of property rights should not be repeated. After all, restitution had been denied by the Court of Appeals of The Hague on 16 December 1999. Further to this first point that focussed on the Göring transaction, there was also debate on whether or not the Restitutions Committee had been correct in characterising the restoration of rights with regard to the Miedl transaction as settled case. In the following, we will first discuss the criticism regarding the Miedl case before discussing the return of the paintings form the Göring transaction in the greater context of the liberalised restitution policy.

As outlined above, Von Saher had signed a settlement agreement with the Administrative Department of the Council of Restorations of Rights (Nederlands Beheersinstituut (NBI)) on 1 August 1952 concerning the works of art covered by the Miedl-transaction. According to this agreement, Von Saher waived the ownership rights to the objects delivered to Miedl. A reading of the preamble of the settlement reveals that Von Saher agreed to the settlement only with great resentment. ${ }^{1565}$ The applicant's authorised representatives claimed that the settlement is null and void because it came about under coercion and deception. The Restitutions Committee, however, dismissed this argumentation in according greater weight to the fact that the widow Goudstikker signed the agreement than to the circumstances under which she signed. ${ }^{1566}$ According to the Restitutions Committee:

1562 Advisory Committee for Restitution Applications for Items of Cultural Value and the Second World War, 2005a, p. 14.

1563 Ibid., p. 13-14.

1564 See: 'Rijk retourneert Goudstikkers', 4 February 2006; Gollin, R. / Schoonenboom, M., 9 February 2006; Velten, A.A.v., 2006b, p. 262. Different from its general practice the recommendation was not published before the annunciation of the decision of the State Secretary.

1565 See above where we summarise and cite the considerans.

1566 Advisory Committee for Restitution Applications for Items of Cultural Value and the Second World War, 2005a, p. 9. 
"the circumstance that she signed the settlement despite this disappointment indicates that she opted for the lesser of (what she considered to be) two evils. In legal terms, this cannot be termed coercion, and no compelling arguments to support the accusation of deception have been submitted nor found by the Committee". ${ }^{1567}$

The decision by the Restitution Committee to consider the agreement as a valid settlement has been criticised, in particular by Schoordijk.1568 According to Schoordijk the situation is comparable to the situation of a ship in distress at sea, which he characterises as prime example of an agreement concluded under undue influence. According to the old Commercial Code a ship could renegotiate an agreement concluded with another ship while in distress in view of being saved (the so-called "hulploonovereenkomst"). ${ }^{1569}$ Similar to a ship in distress Von Saher could only choose between two evils - the lengthy unsure legal procedure or the waiving of ownership rights. If one agrees with this argumentation the settlement was not valid respectively should have been invalidated by the Restitutions Committee. While we cannot definitively answer the question whether or not the settlement is the result of undue influence, it is certainy possible.

When the Minister of Culture announced the decision to return the paintings covered by the Göring transaction it was emphasised that while the recommendation of the Restitutions Committee to return the paintings was followed, its reasoning was not shared by the Government. ${ }^{1570}$ The Minister of Culture was keen to stress that different from the view expressed by the Restitutions Committee the Government considered the restoration of rights in respect of the Göring transaction as a settled case: after all, the Court of Appeals of The Hague had given a definitive ruling in this case on 16 December 1999. The Minister of Culture continued that while the case consequently fell outside the scope of the present restitution policy, there were nevertheless special reasons, such as circumstances of the involuntary sale of the paintings and the deficiencies of the restoration of rights during the post war era to nevertheless follow the recommendation of the Restitutions Committee to return the objects. ${ }^{1571}$ The reason for the Government's wariness to follow the reasoning of the Restitution Committee might not so much lay in the Goudstikker case itself but in the potential effect such deviation from an earlier court decision could have for other cases. ${ }^{1572}$ The Government fears that the case could lead to the challenging of more settled cases, whether related to Nazi spoliated art or not and that it could impeach the credibility of the judiciary. ${ }^{1573}$

Therefore the Government stated that the Göring transaction qualifies as settled case: according to the liberalised return policy a settled case is a.o. a case that had ended

\footnotetext{
1567 Ibid.

1568 Schoordijk, H., C.F., 2006, pp. 745-746.

1569 See Art. 555 of the old Commercial Code. Ibid., p. 746.

1570 See, e.g.: Borg, L.t. / Rottenberg, H., 2006; Rijghard, R., 7 February 2006.

${ }^{1571}$ De staatssecretaris van Onderwijs Cultuur en Wetenschap, 2006; Kuitenbrouwer, F., 7 February 2006.

1572 Cf.: Kuitenbrouwer, F., 7 February 2006.

1573 Gollin, R. / Schoonenboom, M., 9 February 2006; Rijghard, R., 7 February 2006.
} 
in a court ruling in which the Judicial Division of the Council for the Restoration of rights or another competent court had issued a judgement. ${ }^{1574}$ The Court of Appeal not only functions as successor of the Judicial Division of the Council of Restoration of Rights, it was also the competent court to hear the case in 1998/1999. Consequently, the State Secretary's decision not to follow the argumentation of the Restitutions Committee was not an exaggerated measure of precaution to prevent corrosion of the judiciary but results from the framework of the liberalised restitution policy.

Why, then, did the Government choose to follow the recommendation of the Restitutions Committee to return the paintings rather than rejecting the claim on the basis that it did not fall under the scope of the liberalised policy? The reason lies in the order of events in this case which distinguishes it from many other cases. ${ }^{1575}$ The Goudstikker case is special in that there exists a court ruling as late as 1999. In most other cases involving a judicial ruling the ruling dates from the 1950 s. ${ }^{1576}$ In the Goudstikker case, the ruling of the Court of Appeal dates from 1999, i.e. less than two years before the liberalised return policy had been introduced. 1577 While in 1999, when the Court of Appeal rendered its judgment, it was already known that the restoration of right during the post war era by the Netherlands Art Property Foundation (SNK) had not been flawless, it was not until the year 2000 that the whole extent of the irregularities and flaws in the functioning of the Netherlands Art Property Foundation (SNK) had been made known. ${ }^{1578}$ Had the Court of Appeal heard the case after the publication of the reports by the Origins Unknown Committee and the introduction of the liberalised policy on the restitution of rights it would have been unlikely that the court had held that there were no compelling reasons to grant restoration of rights. Consequently, in view of the chronology and presumably also in reaction to international pressure exerted, the Dutch Government decided to return the paintings despite the fact that the restoration of rights of the Göring transaction was strictly speaking settled. ${ }^{1579}$

The previous paragraphs discussed the decision of the Dutch Government to accept the recommendation of the Restitutions Committee to return the paintings covered by

1574 Ekkart Committee (Supervisory committee Origins Unknown/Herkomst Gezocht), 2001, Recommendations 1-2; Letter [in Dutch] from the State Secretary for Education, Culture and Science to the House of Representatives dated 29 June 2001 in respect of recommendations made by the Ekkart Commitee, parliamentary year 2000-2001, 25 839, nr. 26

1575 See, e.g. above the Gutmann case where the ruling of the Judicial Division of the Council for the Restoration of Rights dates from 1952.

1576 Ibid.

1577 See above on the introduction of the liberalised policy in dialogue between the Ekkart Committee and the Government.

1578 Herkomst Gezocht / Origins Unknown, 1998; Herkomst Gezocht / Origins Unknown, 1999; Herkomst Gezocht / Origins Unknown, 2000; Herkomst Gezocht / Origins Unknown, 2002; Muller, E. / Schretlen, H., 2002, pp. 6-8.

1579 While it is difficult to obtain information about pressure exerted, we can quote by means of example a fax sent by Alfonse M. D'Amato, United States Senator to the Ministry of Foreign Affairs of the Netherlands, dated 10 May, 1998 (on file with the author). 
the Göring transaction albeit on a different motivation and outside of the existing liberalised restitution policy. This interpretation of the Government was considered as based on the terms and conditions of the restitutions policy, in particular the understanding of what constitutes a settled case in the sense of the liberalised return policy. However, by presenting the decision to return the paintings as falling outside off the present framework of the reuturn policy, the Government effectively recognised an avenue of returning artworks next to the liberalised return policy as adopted in 2001 . Consequently, also cases that qualify as settled under the liberalised return policy may nevertheless give rise to return.

The analysis of Goudstikker case as a claim for the restitution of an art dealer's stock furthermore showed how the Restitutions Committee applied the slightly different policy framework with regard to losses by art dealers rather than losses private individuals: the involuntary nature of the loss had to be proven and the Restitutions Committee did not elaborate upon the possibility of reopening the settlement with regard to the Miedl transaction on the basis of nova.

\section{c) The Toorop Case: the estate of E. Flersheim against the Zeeuws Museum in Middelburg}

The case concerning the painting 'A Prayer before Supper' (1907) by Jan Toorop is different from the previous two cases discussed in that it is not owned by the Dutch State. Instead, the painting belongs to the collection of the Zeeuws Museum. As a foundation that is significanty subsidized by public money, the Zeeuws Museum collections qualifies as a public collection in the sense of this thesis. ${ }^{1580}$

While the Restitutions Committee was first and foremost established to advise the Minster for Education, Culture and Science on decisions to be taken concerning applications for the restitution of items of cultural value of which the original owners involuntarily lost possession due to circumstances directly related to the Nazi regime and which are currently in the possession of the State of the Netherlands ${ }^{1581}$ the Restitutions Committee may also give binding advice in disputes relating to art works that are not owned by the Dutch State. ${ }^{1582}$

Regulations of the Restitutions Committee in dealing with claims concerning objects not in possession of the Dutch State

Before discussing the claim concerning 'A Prayer before Supper' by Toorop and the binding advice given by the Restitutions Committee we will outline the regulations the

\footnotetext{
1580 See: Annual Report of the Zeeuws Museum. See above on the use of terminology in the present study in the Introduction (\$2.III.1)

1581 Cf.: Decree issued by the State Secretary for Education, Culture and Science, F. van der Ploeg, establishing a committee to advise the government on the restitution of items of cultural value of which the original owners involuntarily lost possession due to circumstances directly related to the Nazi regime and which are currently in the possession of the State of the Netherlands, 16 November 2001 (Reference WJZ/2001/45374(8123), Art. 2 sub 1.

1582 Cf.: Ibid., Art. 2 sub 2 \& 3.
} 
Restitutions Committee adopted in 2007 that further define the procedure for such claims. ${ }^{1583}$ The regulations provide rules governing the admissibility of applicants, the authority of the Restitutions Committee, and the hearing of disputes by the Restitutions Committee. According to these regulations the Restitutions Committee will only provide binding advice where a joint request of both parties has been referred to it by the Minister of Culture and on the precondition that both parties involved have signed an agreement stating that they accept the advice at issue as binding. ${ }^{1584}$ Where these preconditions have been fulfilled the Restitutions Committee will comply with its advisory task by giving a binding advice or by promoting a settlement between the parties. 1585 The binding advice falls within the meaning of a settlement contract ("vaststellingsovereenkomst") of Art. 7:900 Dutch Civil Code. ${ }^{1586}$ In formulating the binding advice the Restitutions Committee must follow the imperative of the requirements of reasonableness and fairness. ${ }^{1587}$ Furthermore, the Restitutions Committee may take aspects into consideration such as:

a. the Government's line of policy concerning the restitution of stolen works of art in so far as they apply by analogy;

b. the circumstances in which possession of the work was lost;

c. the extent to which the applicant has endeavoured to trace the work;

d. the circumstances in which the owner acquired the work and the inquiries the owner made when acquiring it;

e. the significance of the work for the applicant;

f. the significance of the work for the owner;

g. the significance for the public art collection. ${ }^{1588}$

In fact, this list of aspects, which is not exclusive, spells out aspects that need to be taken into consideration in defining the requirements of reasonableness and fairness. The fact that the restitution policy may only be applied in analogy must not surprise: the framework was drafted in view of the post war era restitution as effected by the

1583 Regulations on binding recommedation procedure under Art. 2, paragraph 2 and Art. 4, paragraph 2 of the Decree establishing the Advisory Committee on the Assessment of Restitution Applications for Items of Cultural Value and the Second World War (hereinafter: "the Regulations").

1584 Art. 3 of the Regulations.

1585 Art. 2, para. 2 of the Regulations.

1586 Art. 7:900 DCC reads: “1. Bij een vaststellingsovereenkomst binden partijen, ter beëindiging of ter voorkoming van onzekerheid of geschil omtrent hetgeen tussen hen rechtens geldt, zich jegens elkaar aan een vaststelling daarvan, bestemd om ook te gelden voor zover zij van de tevoren bestaande rechtstoestand mocht afwijken.

2. De vaststelling kan tot stand komen krachtens een beslissing van partijen gezamenlijk of krachtens een aan één van hen of aan een derde opgedragen beslissing.

3. Een bewijsovereenkomst staat met een vaststellingsovereenkomst gelijk voor zover zij een uitsluiting van tegenbewijs meebrengt.

4. Deze titel is niet van toepassing op de overeenkomst van arbitrage". See for an analysis in detail of Art. 7:900 DCC: Snijders, M.Y. / Meier, G.J., 2002, pp. 341-359.

1587 Art. 4 Regulations.

1588 Art. 4 Regulations. 
Netherlands Art Property Foundation (SNK) and as a result of which many objects remained in the NK Collection. Different from these objects, potentially disputable objects now in possession of other institutions did not necessarily pass through the hands of the Netherlands Art Property Foundation (SNK). Depending on the outcome of the assessment of the requirements of reasonableness and fairness the Restitutions Committee may recommend that:
a. the work be returned to the applicant;
b. the work be returned on payment by the applicant to the owner of a sum of money to be determined;
c. the work be returned to the applicant subject to further provisions;
d. the owner pay the applicant a sum of money to be determined, while the item remains in the owner's possession;
e. the work be exhibited, stating its provenance and the part played by the (heirs of the ) original owner;
f. the application for restitution be denied, subject to further provisions, where applicable.1589

According to Art. 18 of the Regulations the Restitutions Committee's recommendation may only be reversed by an ordinary court, provided it has been submitted within two months after it has been sent to the parties. After two month, the recommendation becomes irreversible. Having outlined the most important provisions of the Regulations concerning the binding advice procedure we can now turn to the specific case concerning Toorop's 'A Prayer before Supper'. ${ }^{1590}$

The Facts: the Flersheim Collection, the loss of the painting during the war era and the acquisition by the Zeeuwse Museum Foundation

The painting 'A Prayer before Supper' by Toorop (hereinafter: "the painting”) had belonged, at least from 1909 onwards to Ernst Flersheim (1862-1944). ${ }^{1591}$ Ernst Flersheim lived in Germany until 1937 when he fled the Nazi regime to the Netherlands due to his Jewish descent. His wife followed him in 1938 and two of his three daughters fled to London and Brussels respectively. In May 1937, a substantial part of the family Flersheim art collection, was auctioned in Frankfurt. The painting was not included in the list of works, predominantly be German artists that were offered. Objects by nonGerman artists had been stored with the international export firm 'Dellihausen' in Frankfurt. According to a statement made by Edith Eberstadt - Flersheim, the only family member that survived the war, to the Chamber of Reparation of the District Court of Frankfurt am Main (Wiedergutmachungskammer des Landgerichts) a number of artworks from the collection had been confiscated by the Gestapo around 1938, including the artworks that had been put into storage. According to her post war

\footnotetext{
1589 Art. 12 Regulations.

1590 The facts oulined in the following are derived from the Binding Advice of the Restitutions Committee itself unless otherwise indicated.

1591 See further on the family Flersheim, as well as their relationship with the painter Toorop: Vloten, F.v., 2001.
} 
statement, the painting was one of the confiscated objects. Except for Edith Eberstadt Flersheim's statement no further evidence concerning any such confiscations exists.

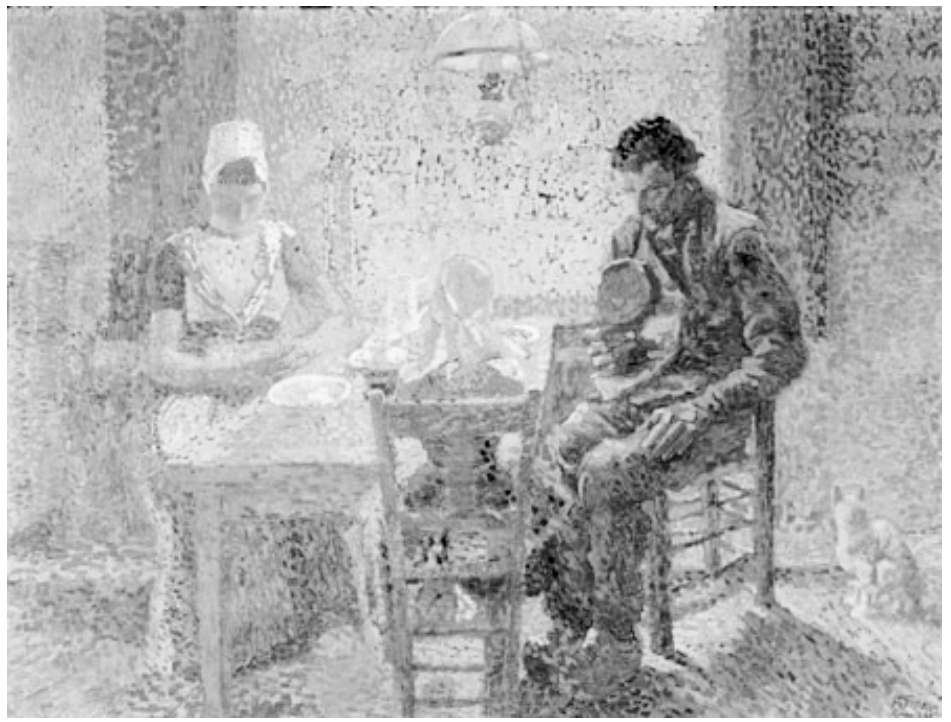

Jan Toorop, 'A prayer before Supper', oil on canvas, 73,5 x $98 \mathrm{~cm}$, signed and dated lower right: J.Th.

Toorop 1907 CRKD.

While it cannot be established what happened to the painting in the period 1938 1942, it reappeared in November 1942 in the hands of the art dealer H.E. d'Audretsch. Stickers on the back of the painting suggest that it had been included in a number of Dutch collections. ${ }^{1592}$ In 1973, the painting was acquired by the art dealer Ivo Bouwman, who declared to have bought the painting from the estate of the d'Audretsch. In 1981, Bouwman sold the painting to the Zeeuwse Museum Foundation in Middelburg, which acquired it for $f$ 150,000 with financial support of the Rembrandt association (Vereniging Rembrandt).

In January 1999 the Zeeuws Museum received an application for the restitution of the painting by the sole surviving heirs of Ernst Flersheim, Walter A. Eberstadt and his sister. The Zeeuwse Museum Foundation stressed in its first preliminary reaction that it did not wish to restitute the painting for its great relevance for the collection and the fact that it had been acquired in good faith. Before taking a definitive stand on the application for restitution, the museum foundation sought advice from the Ethical Code

1592 Lables and stickers on the back of the painting suggest that the painting had been included in Dutch collections including those of 'G. Oudshoorn (Rotterdam Bank) The Hague' and 'Collection of Mr. W.A.M., Nijmegen'. The painting also has a sticker on the back with the name 'Mr W.M.A. Weitjens', who played a key role in dealing with the Nazis during the Second World War. 
Committee of the Dutch Museum Association (Nederlandse Museumvereniging (NMV)). ${ }^{1593}$

\section{The Recommendation by the Ethical Code Committee of the Dutch Museum Association in 2000}

The Dutch Museum Association dates back to 1926 when it was founded as think tank of and for museum directors. Since then it developed into the umbrella organisation for the museum sector with tasks such as lobbying and development of policies. In 1991 it introduced the first Dutch version of the ICOM Code of Professional Ethics for Museums. ${ }^{1594}$ The same year the 'Ethical Code Committee' (hereinafter: NMV Ethical Code Committee) was founded to advise museums about the Dutch ICOM Code and to hold their behaviour against the Dutch ICOM Code. ${ }^{1595}$ The Dutch ICOM Code has been revised several times to reflect the changes made in the international ICOM Code. ${ }^{1596}$

In analysing the question whether or not the Zeeuwse Museum Foundation should return the painting the NMV Ethical Code Committee focused on three aspects:

1. whether it has been established that the painting had belonged to the collection Flersheim and that it has been confiscated;

2. whether the museum acted carelessly when acquiring the painting in 1981;

3. what are the ethical imperatives on how a Dutch museum should react to the claim from the family Flersheim according to present perceptions and which aspects must be taken into consideration?1597

With regard to the first aspect, the NMV Ethical Code Committee reached the conclusion that while the painting had certainly belonged to the Collection Flersheim its confiscation could not be established with certainty. However, given the great probability of this course of events and given the post war declaration by Edith Eberstadt - Flersheim the NMV Ethical Code Committee accepted that the painting had been confiscated.

With regard to the second aspect, the conduct of the museum in 1981 when it acquired the painting, the NMV Ethical Code Committee held that the museum did not act carelessly in acquiring the painting without conducting further provenance research: in 1981 the museum could not / ought not to have known that the provenance of the

\footnotetext{
${ }^{1593}$ Letter dated 7 December 1999 from the Chairman of the Foundation of the Zeeuws Museum to the director of the Dutch Museum Association. At this point the Restitutions Committee had not yet been established.

${ }^{1594}$ See further on the international ICOM Code above in chp. 2.\$2.IV.3.

1595 http://www.museumvereniging.nl/defaultaspx?id=327 (last visited 6 July 2009). The NMV Ethical Code Committee was originally called in Dutch the 'Commissie Museale Gedragslijn'. In 2007 the name was revised to "Ethische Codecommissie voor Musea".

1596 The last revision took place during 2004-2006 in response to the revised ICOM Code as adopted in Seoul in 2004. The integral text of the code can be found at:

http://www.museumvereniging.nl/files/Ethische\%20Code\%20_versie\%2020\%20nov\%202006_\%20_2_.p df (last visited 6 July 2009).

${ }^{1597}$ Commissie Museale Gedragslijn, 2000.
} 
painting was problematic. The NMV Ethical Code Committee reached this conclusion on the basis of the following aspects: the museum relied on the reputation of Ivo Bouwman as an art dealer and his information according to which he had acquired the painting in the 1970s from the estate of the art dealer d'Audretsch. Furthermore, the date of acquisition preceded the increase in information available about the involvement of various actors in the spoliation of art works during the war, as well as the introduction of the first ethical codes for museums and the shift in the perception within the museum world on how to deal art works that had changed owners during the Nazi regime.

With regard to the third aspect, dealing with the present ethical imperatives of how a Dutch museum should react to a claim such as from the family Flersheim the NMV Ethical Code Committee stresses that consequently great relevance must be accorded to the fact that the grandparents of the claimants had been murdered in Bergen Belsen and the emotional value of the painting for the claimants. However, the NMV Ethical Code Committee lists a number of aspects that must also be taken into consideration. Some of these aspects add further weight to restitution of the painting whereas other support the retention of the painting by the museum. For a number of criteria it is not evident how they impact the final balancing in that the NMV Ethical Code Committee confined itself to listing the aspects without explicitly balancing them.

The fact that it has been sufficiently established that the painting had not been the object of a voluntary sales transaction is an aspect speaking in favour of restitution. Aspects speaking against restitution are the fact that the museum was not required to instigate further provenance research, as well as the relevance of the painting within the museum collection. The NMV Ethical Code Committee accepts that the painting being painted in Zeeland, depicting a family from Zeeland in traditional costume, and being the only painting from Toorop owned by the Zeeuwse Museum Foundation, belongs to its core collection.

Aspects mentioned by the NMV Ethical Code Committee whose weight in the balancing is not evident are the financial compensation of 3,000 DM granted to Edith Eberstadt-Flersheim in 1956 and the state of conservation of the painting. With regard to the financial compensation, which corresponds to the market value of the painting in 1956 the NMV Ethical Code Committee states that it did not take away the validity of the current claim. In as far as the painting's state of conservation is concerned it is noted that the condition of the painting, which is painted on card board was poor when acquired in 1981 but has nevertheless not been restored for lack of financial resources of the museum. Another aspect mentioned by the NMV Ethical Code Committee, which does not explicitly speak for or against restitution is the suggestion that in view of the sales price of $f 150.000$ that was paid by the Museum with support of the Vereniging Rembrandt in 1981 the claimants should compensate the museum in case of restitution.

Having listed these aspects the NMV Ethical Code Committee comes to the conclusion that the Zeeuws Museum does not act unjust by not returning the painting. 
It does, however, suggest that the parties look further for an alternative just and fair solution that do justice both to the relevance of the painting for the claimant and for the museum collection. ${ }^{1598}$

As result of the recommendation by the NMV Ethical Code Committee from May 2000 the painting remained in the Zeeuws Museum. ${ }^{1599}$ The recommendation did not, however, solve the dispute between the heirs and the museums. Consequently, when the Restitutions Committee was established in November 2001 with one of its tasks being to give binding advice with regard to disputes of spoliated art works not in the possession of the Dutch State, the two parties decided, albeit not until 2006, to submit a joint request to the Minister for Culture to have the dispute settled by the Restitutions Committee.

\section{The binding advice by the Restitutions Committee from 2008}

The report published by the Restitutions Committee on 7 April 2008, which includes the binding advice to the parties starts out with an overview of the facts and background of the dispute, starting from Ernst Flersheim's art collection, the fate of the family and their art collection during the war, the post-war restoration of rights, and the recommendation issued by the NMV Ethical Code Committee. The report subsequently sets out both the claimants' position and the position of the Zeeuwse Museum Foundation as outlined already above, before describing the assessment of the facts and the formulation of the binding advice.

The followings aspects were highlighted by the Restitutions Committee as relevant in formulating the binding advice: the circumstances in which the possession of the work was lost, the extent to which the party requesting restitution has exerted itself to retrieve the work, as well as the period and the circumstances in which the current owner acquired the work and the investigation carried out by the current owner before the work was acquired. Further aspects are the respective importance of the work for both parties and for the public art collection. In the following we will shortly summarise the view of the Restitutions Committee on these aspects before discussing how the Restitutions Committee finally balanced them.

With regard to the circumstances of loss, the Restitutions Committee assumes that the painting was confiscated by the Gestapo around 1938. ${ }^{1600}$ As for the extent to which the Flersheim heirs have exerted themselves to retrieve the work the Restitutions Committee is satisfied with the attempts of the heirs. ${ }^{1601}$ The Restitutions Committee subsequently addressed the diligence of the Zeeuwse Museum Foundation when acquiring the painting in 1981. It rejects the argument of the claimants that the foundation did not act in good faith and endorsed an expert opinion of Prof. R.E.O.

\footnotetext{
1598 Cf.: Schrage, E.J.H., 2007, pp. 54-59.

1599 Cf.: Heyting, L., 29 May 2000.

1600 Advisory Committee for Restitution Applications for Items of Cultural Value and the Second World War, 2008, Assessment of the facts in the dispute, para. 5.

1601 Ibid., Assessment of the facts in the dispute, para. 6.
} 
Ekkart, the chairman of the Ekkart Committee, according to which museums and art dealers were not in the habit of researching whether or not works of art acquired had a war history in the beginning of the 1980s. Furthermore, Ekkart's expert opinion states that the manner in which art works were traded in the past cannot be judged with the hindsight of the present knowledge and awareness. Consequently, the Museum did not act negligently by not instigating a special investigation into the painting's provenance between 1933 and 1945 before acquiring it in 1981.1602

Subsequently, the Restitutions Committee evaluated the importance of the painting for both parties. With regard to the claimants' position, the Restitutions Committee emphasises that the painting belonged to their grandparents' art collection and that it was one of several paintings the family had bought from the painter whom they personally knew from and befriended during their frequent holidays in Zeeland. ${ }^{1603}$ The Restitutions Committee recognises that the claimants attach great emotional value to the painting. With regard to the importance of the painting to the Zeeuws Museum, the Restitution Committee quotes the museum's statement that

"the loss of the work [would] constitute a huge loss for the museum. It is an important piece for the province of Zeeland because it links an international artistic movement (luminism; painting with light) with a local theme. It is a family portrait of Toorop's friends from Domburg, the Louwerse family. In addition, it is a portrait that represents the painter's glorification of piety of the citizens of Zeeland. In sweeping brushstrokes, the painting depicts the divine glow that surrounds the family during their evening prayer". ${ }^{1604}$

Having set out these aspects, the Restitutions Committee first ascertained the legitimacy of the claimants and that the claim had not been settled previously. The Restitutions Committee found no evidence of a court ruling concerning restitution of the painting or of an explicit waiver of rights. With regard to the compensation of DM 3,000 received by Edith Eberstadt-Flersheim the Restitutions Committee does not deem it an impediment in the current application for restitution. ${ }^{1605}$ Subsequently, the Restitutions Committee turned to the balancing of the aspects and the formulation of the binding advice.

With regard to the evaluation of the facts, the Restitutions Committee held that different from the argument made by the claimants, the Government's line of policy concerning the restitution of spoliated art works does not directly apply to the present case but may be applied in analogy. ${ }^{1606}$ Another aspect to be taken into account in balancing the aspects is the fact that the Zeeuwse Museum Foundation did not wish to invoke the prescription of Flersheim' heirs' claims. ${ }^{1607}$

\footnotetext{
1602 Ibid., Assessment of the facts in the dispute, para. 7.

1603 See further on the relationship between the family Flersheim and Toorop: Vloten, F.v., 2001.

1604 Advisory Committee for Restitution Applications for Items of Cultural Value and the Second World War, 2008, Assessment of the facts in the dispute, para. 8.

1605 Ibid., Assessment of the facts in the dispute, paras. $3 \& 4$.

1606 Ibid., Assessment of the facts in the dispute, para. 1.

1607 Ibid., Assessment of the facts in the dispute, para. 2.
} 
Balancing the aspects on the grounds of reasonableness and fairness the Restitutions Committee reached the conclusion that the Zeeuwse Museum Foundation should return the painting to the heirs of Flersheim upon payment by the heirs of EUR 121,500 to the Zeeuwse Museum Foundation. ${ }^{1608}$ Should the heirs decide to sell the work within the next ten years, they will be obliged to offer it for sale to the Museum first. Furthermore, the heirs are obliged to cover the costs of insuring and transporting the painting from the moment of transfer from the Museum and to indemnify the Museum against thirdparty claims to the painting.

The following aspects outweighed the museum's interest in keeping the painting, which the Restitutions Committee did also recognise as considerable interest: first, the involuntary loss of the painting by Flersheim precipitated by the Nazi regime, secondly, the emotional importance of the painting to the claimants, thirdly, the willingness of the heirs to compensate the museum financially and finally the fact that even though the Museum cannot be reproached for acting carelessly when acquiring the painting there are elements in the provenance of the work that point to dubious dealings. ${ }^{1609}$ However, the Restitutions Committee's binding advice does not only stipulate that the museum must return the painting: the requirements of reasonableness and fairness require that the duty on behalf of the museum is matched with duties on behalf of the claimants: claimants have to reimburse the museum for the sale price $(f 150,000)$ indexed according to the general price index (EUR 121,500). Furthermore, claimants have to cover the costs of insurance and transport and have to guarantee the museum the right of first refusal where the painting is resold within ten years. ${ }^{1610}$

As a result of the binding advice of the Restitutions Committee the painting 'A Prayer before Supper' by Toorop was returned to the heirs of Ernst Flersheim. However, half a year later the painting returned to the museum: the heirs had offered the museum to buy back the painting for EUR 380,000. Almost one third of the amount was paid by the sum paid by the heirs to the museum. ${ }^{1611}$

In the previous paragraphs we have discussed the binding advice of the Restitutions Committee concerning the dispute between the heirs of Ernst Flersheim and the Zeeuwse Museum Foundation. According to the Restitutions reasonableness and fairness dictate the museum to return the painting to the heirs while the heirs must refund the sales price paid by the museum in 1981. The Restitutions Committee consequently arrived at a different conclusion from the NMV Ethical Code Committee, which had decided in 2000 that the museum was not required to return the painting. An aspect that might explain the opposed findings of the two committees is the fact that the Zeeuwse Museum Foundation had explicitly stated when accepting the authority of the Restitutions Committee that it did not wish to invoke the prescription of Flersheim'

\footnotetext{
1608 Ibid., Assessment of the facts in the dispute, para. 9.

1609 Ibid.

1610 Ibid.

1611 Toorop terug naar Zeeuws Museum, 28 November 2008.
} 
heirs' claims. ${ }^{1612}$ However, the decision of the museum not to invoke the defense of prescription was not listed amongst the aspects that have been highlighted by the Restitutions Committee as outweighing the museum's interest in keeping the painting. ${ }^{1613}$ Instead, the Restitutions Committee had stressed the involuntary loss of the painting by Flersheim precipitated by the Nazi regime, the emotional importance of the painting to the claimants, the willingness of the heirs to compensate the museum financially and finally the fact that even though the Museum cannot be reproached for acting carelessly when acquiring the painting that there are elements in the provenance of the work that point to dubious dealings. Consequently, whether the decisive difference between the findings of the two committees can be explained by the waiver of the defence of the prescription by the museum remains subject to speculation. Another explanation could be that public opinion and awareness about how to deal with spoliated art had shifted after the recommendation of the NMV Ethical Code Committee in 2000 but before the binding advice of the Restitutions Committee in 2008. ${ }^{1614}$ From our analysis above on the introspection of the restoration of right during the post war era by the Netherlands Art Property Foundation (SNK) we know that by the year 2000 the whole extent of the irregularities and flaws in the functioning of the Netherlands Art Property Foundation (SNK) had been made known. ${ }^{1615}$ While the case of the Toorop is unrelated to this chapter of Dutch post war history in that the painting had not been dealt with by the Netherlands Art Property Foundation (SNK) we can assume that by 2000 there was general awareness about the problem of Nazi spoliated art, for sure amongst the members of the NMV Ethical Code Committee. On the other hand, the recommendation of the NMV Ethical Code Committee preceded the first recommendation by the Restitutions Committee, which dates from March 2002. Consequently, one could also argue that while factual knowledge had been present full awareness about the consequences had not yet been developed. We will not further speculate about the explanation for the different results of the two committees, but focus on two other interesting aspects from comparing the exercising of the Restitutions Committee in giving binding advices from its other task of making recommendations with regard to objects from the SNK Collection.

Different from making recommendations with regard to objects in the SNK Collection the Restitution Committee does not base its binding advices on the liberalised return policy as adopted by the Government in 2001. Instead, its main parameters are the requirements of reasonableness and fairness. It does, however, apply

1612 Advisory Committee for Restitution Applications for Items of Cultural Value and the Second World War, 2008, Assessment of the facts in the dispute, para. 2.

1613 See above and Ibid., Assessment of the facts in the dispute, para. 9.

1614 See above where we discuss this possibility with regard to the decision of the Court of Appeal in the Goudstikker case.

1615 Herkomst Gezocht / Origins Unknown, 1998; Herkomst Gezocht / Origins Unknown, 1999; Herkomst Gezocht / Origins Unknown, 2000; Herkomst Gezocht / Origins Unknown, 2002; Muller, E. / Schretlen, H., 2002, pp. 6-8. 
the liberalised return policy in analogy. In the present case of the Toorop, e.g. we saw that the Restitutions Committee was prepared to accept the involuntary loss of the painting without conclusive evidence. While the Restitutions Committee did not go as far as to fully apply the presumption of involuntary loss as applied under the liberalised return policy in full, it did adopt a lenient approach towards the burden of proof of the claimants.

Another interesting aspect we wish to comment on is the financial compensation received by Edith Eberstadt-Flersheim in the post war era for the loss of the painting. Both the recommendation of the NMV Ethical Code Committee and the binding advice of the Restitutions Committee mentioned the fact that the sole surviving heir of Ernst Flersheim did receive financial compensation of 3,000 DM in 1956. ${ }^{1616}$ It is furthermore stated that this amount corresponds to the 1956 market value of the painting. Both the NMV Ethical Code Committee and the Restitutions Committee state that the compensation received does not constitute an impediment in the application for restitution. Neither committee further incorporates the fact in its decision making process or in the formulation of a just and fair solution.

As of today, the Restitutions Committee has given a binding advice only in a very limited number of cases. However, it is possible that this number will increase in light of the start of an initiative researching the provanance of works acquired by museums in the period 1933-1939. ${ }^{1617}$ Given the time period, this research is irrelevant with regard to the NK Collection but might identify objects in other public collections.

\section{INTERMEDIARY CONCLUSIONS FOR THE NETHERLANDS}

In the present section we have summarised the main findings of the Origins Unknown Agency on the functioning of the Netherlands Art Property Foundation (SNK) during the post war era and analysed the liberalised return policy as introduced on the basis of recommendations by the Ekkart Committee in 2001 by the Dutch Government. The liberalised return policy applies to objects from the NK Collection and other national collections. It may, however, be applied in analogy to disputes concerning objects not held by the Dutch State where the parties involved agree.

A crucial aspect of the liberalised return policy is the understanding of new facts 'nova'. Only cases that qualify as new applications, or where new facts have emerged, may be assessed by the Restitutions Committee. While the Government endorsed a broader interpretation of nova it did not follow the suggestion of the Ekkart Committee

1616 Unfortunately, neither the recommendation of the NMV Ethical Code Committee nor the binding advice of the Restitutions Committee elaborate on the legal basis of the restitution. Generally speaking, the Federal Restitution Law (BRüG) would be the appropriate law. However, it was adopted only 1957 whereas both the NMV Ethical Code Committee and the Restitutions Committee speak of 1956 as the year in which Edith Eberstadt-Flersheim was granted compensation. See further on the BRüG above in chp. 1.S4.IV.

${ }^{1617}$ Museumonderzoek Museale Verwervingen 1933-1940 en 1948-heden, 2009. The results are expected to be published in 2013 . 
to include changed (historic) views of justice. ${ }^{1618}$ The Restitutions Committee, however, which was established to advise the Government on the basis of the liberalised restitution policy, chose to apply the broader notion as originally suggested by the Ekkart Committee. According to the Restitutions Committee, changed insights and circumstances should be granted the status of new facts. Consequently, the Restitutions Committee amended the liberalised return policy with regard to the interpretation of nova according to its own views. As result they extented the scope of cases that qualify for reassessment and to a certain extent undermine the general starting point of the Government that the restoration of rights should not be repeated.

An alternative to subsuming settled cases under the liberalised return policy by a more extensive interpretation of nova, as the Restitutions Committee did in the Gutmann case, was introduced with regard to the Goudstikker case. When the Minister of Culture announced the decision to return the paintings covered by the Göring transaction it was emphasised that while the case fell outside the scope of the present restitution policy for having been settled in the past, there were nevertheless special reasons to follow the recommendation of the Restitutions Committee to return the objects on moral grounds. ${ }^{1619}$ Put differently, the Government chose to return the objects from the Goudstikker collection despite the fact that the Göring transaction qualified as settled case on the grounds of the 1999 ruling of the Court of Appeal. Consequently, the Government recognised the existance of an additional avenue, next to the liberalised restitution policy, that allows for the restitution of objects from already settled cases.

Our analysis furthermore revealed that in assessing claims for the return of objects from the NK Collection on the grounds of the liberalised return policy, the Restitutions Committee accords little weight to the relevance an object may have for the public interest. ${ }^{1620}$ Where it discussed the public interest of the Goudstikker collection - given its quantity and quality the Restitutions Committee somewhat intricately argued that the public interest should be assessed on the basis of the objects' relevance in 1940, prior to the loss of the objects rather than according to the present relevance. In 2007, and according to the Restitutions Committee due to reports about a legal dispute between the heirs of the Goudstikker NV and their lawyers and the auctioning off of Goudstikker works that had been returned in 2006, questions emerged about the legitimacy of returning spoliated items of cultural value and the relevance that should be accorded to preserving valuable or unique items of cultural value in public art collections in the Netherlands. ${ }^{1621}$ The Restitutions Committee noted that the debate touches on the core of restitution policy but did not further elaborate.

\footnotetext{
1618 See for a different opinion: Vlies, I.C.v.d., et al., 2009, p. 102.

${ }^{1619}$ De staatssecretaris van Onderwijs Cultuur en Wetenschap, 2006; Kuitenbrouwer, F., 7 February 2006.

1620 Cf.: Kuitenbrouwer, F., 7 February 2006.

1621 Advisory Committee for Restitution Applications for Items of Cultural Value and the Second World War, 2007, pp. 9-10.
} 
Different from cases dealing with objects in the NK collection, the Restitutions Committee seems to accord greater weight to the public interest in cases dealing with objects that are not held by the Dutch State. According to the regulations adopted by the Restitutions Committee in 2007 with regard to the issuing of binding advice concerning disputes over objects not in the NK collection, the Restitutions Committee may take the significance of the object for the public art collection into consideration. ${ }^{1622}$ In our analysis of the case of the painting by Toorop, we have seen that the relevance of the painting for the museum and the general public is acknowledged by the Restitutions Committee but was outweighed by a number of other aspects.

Little discussion can also be noted with regard to question of the relevance of financial compensation received during the post war era. From the cases we discussed, only the Toorop case mentioned financial compensation received by the (heir of the) original owner. Interestingly, the fact that the (heir of the) original owner had received financial compensation representing the market value of the missing painting, was not taken into account when assessing the validity of the claim or in deciding on a just and fair solution.

\section{UNITED KINGDOM}

In the United Kingdom the scrutinising of public collections for art works dispossessed during the period 1933-1945 started in 1998 with the initiative of the National Museum Directors' Conference (NMDC) to formulate a 'Statement of Principles and Proposed Action'. ${ }^{1623}$ The NMDC is a UK wide voluntary association of 26 national cultural institutions receiving funding from the central government and including 20 museums, the three national libraries, the Royal Botanical Gardens in Kew and Edinburgh and the Public Record Office. ${ }^{1624}$ The Statement of Principles provides as follows:

“i) NMDC recognises and deplores the wrongful taking of works of art that constituted one of the many horrors of the Holocaust and World War II.

ii) NMDC members support the principle outlined in the Museums Association Code of Practice for Governing Bodies dated 1994 which states that "Collections Management Policy should ensure, through the appropriate documentation, that the museum does not acquire or exhibit any stolen or illegally exported works and that it acquires legal title to items accessioned to its collections".

iii) NMDC is committed to working with other institutions and organisations both within the UK and internationally to increase awareness and understanding of the facts surrounding the spoliation of works of art by the Nazis and others during the Holocaust and World War II period.

1622 Art. 4 Regulations, sub g.

1623 Cf.: Bailey, M., 2005, p. 58; Schnabel, G. / Tatzkow, M., 2007, p. 172.

1624 Cf.: National Museum Directors' Conference (NMDC), 1998, para. 1.2. 
iv) NMDC is committed to giving prompt and serious consideration to claims to title for specific works in their collections.

v) In line with its members' general policies for and commitment to increasing public access to information about their collections, NMDC advocates a practical approach to reviewing and making accessible information relating to the provenance of their collections, taking into account the nature and size of the collections concerned and the resources available.

vi) NMDC advocates a process of reviewing, reporting and researching the issue of works of art wrongfully taken which respects the dignity of all parties and the complexity of the issue. Each claim represents a unique situation which must be reviewed thoroughly on a case by case basis taking into account both the interests of individuals and the statutory and legal responsibilities of the institutions".

In a nutshell the statement by the NMDC stresses that the associated institutions share the concern for Nazi spoliated art and calls for transparency and dialogue while observing the legal framework, including legal obstacles to disposal. ${ }^{1625}$ The Statement of Principles also states that "for the purposes of interpreting this document, wrongful taking shall mean any act of theft or other deprivation, the legality of which is open to reasonable challenge, and which was committed during the Holocaust and World War II period". With regard to the mechanism of how claims should be solved the NMDC assumed that this would be done by each institution individually, albeit in conjunction with the Department of Culture, Media and Sport. ${ }^{1626}$

In reaction to the NMDC initiative and international developments with regard to the restitution of Nazi spoliated art the Department of Culture, Media and Sport considered it desirable to establish an independent body that could examine claims and propose solutions. ${ }^{1627}$ On 13 April 2000, the Spoliation Advisory Panel was established. Before outlining the Panel's constitution and terms of reference we will shortly reflect upon the UK situation which is different from the situations in the Netherlands and France. Different from these two countries in continental Europe neighbouring Germany, the UK had not been occupied during World War II. While it was attacked and fought the Axis forces ${ }^{1628}$ as one of the Allied Forces, it had never been occupied by the Nazis. Consequently, there had not been any losses of works of art by UK citizens comparable to those by French or Dutch citizens, first and foremost Jews. This means that most objects in UK public collections are the result of acquisitions or donations during or after the Nazi regime. Given the relevance of the UK art market the number of objects spoliated in Continental Europe that were at some stage traded in the UK might not be insignificant. Further to transactions of objects sold after having been spoliated, the strength of the UK art market also resulted in a number of forced sales

1625 See in particular principles 2. 4; 2.5; 2.6 and 5.4 of the Ibid. Cf.: Palmer, N., 2000a, p. 27. See for a more detailed discussion of the 'Statement of Principles and Proposed Action': Range, D., 2004, pp. 665-667.

1626 Cf.: National Museum Directors' Conference (NMDC), 1998, para. 5.4.

1627 Cf.: Bailey, M., 2005, p. 58.

1628 The major Axis powers, next to Germany, were Italy and Japan. 
being effected in the UK. E.g. the collection of Italian Maiolica from the Pringsheim Collection was sold at Sotheby's, London on 7-8 June and on 19-20 June 1939 in accordance with the terms of the German Office for Foreign Exchange Control: ${ }^{1629}$ the collection was to be exported to London and to be auctioned at Sotheby's in order to raise foreign currency for the German treasury. Of the net benefit to the German State, Pringsheim should receive only $40 \%{ }^{1630}$

Consequently, while the strenth of the UK art market certainly attracted spoliated art works that may still be part of the public collections, the UK does not have an equivalent to the Dutch NK-Collection or the French MNR-Collection. ${ }^{1631}$ For this reason the introspective aspect of the initiatives in the Netherlands and France with regard to the post-war restoration of rights is missing in the UK. The first policy measurement was taken over fifty years after the end of WWII, when the UK Government established the Spoliation Advisory Panel.

\section{The Spoliation advisory Panel}

The UK Spoliation Advisory Panel (hereinafter: "the Panel”) was established in 2000 to consider claims from people, or their heirs, who "lost possession" of a cultural object during the years 1933-1945 where that object is now in the possession of a UK national collection or in the possession of another UK museum or gallery established for the public benefit. ${ }^{1632}$ The mandate of the Panel is therefore not limited to claims by (heirs of) former Jewish owners, nor is it limited to cases of outright confiscation by the Nazis or forced sales but applies to any form of loss. ${ }^{1633}$ The Panel may also advise on claims between two private parties provided that there has been a joint request by the

1629 See file from the Munich State Archive: WB I a 2407. Later internal communication between different agencies of the Reich spoke, however, of different a allocation of the net proceeds with only $20 \%$ of the net proceeds up to $f, 20,000$ and $30 \%$ thereafter to be accorded to Pringsheim. But even this intention was not kept. Communication of 8 November 1938 - O1729/1896/38 B III b Ja/St Re: maiolica collection of Councillor Pringsheim, Munich, translated and published in: Falke, O.v., 1994, p. 96.

${ }^{1630}$ See export report by Otto von Falke, undated, certifying that the Pringsheim maiolica Collection could be removed from the German list of national treasures and suggesting England and the United States as best markets for the sale. He mentions the donated objects: "the donation of some especially valuable maiolicas (...) and two silver goblets by the famous $16^{\text {th }}$ century silver smith Ludwig Krug, which are depicted in Pantheon 1933, volume XI, p. 191.

1631 See further below in chp. 4.\$1.III on the MNR-Collection.

1632 Spoliation Advisory Panel, Constitution and Terms of Reference, s 2. Note that while the content of the Panel's Constitution and Terms of Reference did not change the numbering was revised in 2007. Our references are to the most recent manner of numbering. Examples of "another UK museum or gallery established for the public benefit" are the Courtauld Institute of Art and the art collection owned by the Glasgow City Council. Cf.: Spoliation Advisory Panel, 2004, para. 3; Spoliation Advisory Panel, 2007a, para. 2.

1633 See e.g. the Benevento Missal Case where the Spoliation Panel decided that a missal currently in the collection of the British Library should be returned to despite the fact that it could not be proven when, whether, and if by whom the manuscript was spoliated in what form whatsoever (confiscation, sale, sale at an undervalue, etc). Spoliation Advisory Panel, 2005. 
parties. ${ }^{1634}$ The Panel advises the Secretary of State on what action should be taken regarding a specific claim as well, where it deems it appropriate, on general issues raised by a case.

Claimants can make a claim by submitting the claim in writing to the Panel, having gathered a comprehensive amount of evidence to support themselves (comprising of witness statements and documents) which the institution in possession of the claimed cultural object must reply to within six weeks. ${ }^{1635}$ The Panel is supported by a secretariat and can consult independent legal advisors. ${ }^{1636}$ The Panel is charged with evaluating a claim both to the legal force, and the moral quality. ${ }^{1637}$ The Panel is construed as an alternative to litigation, not as process of litigation. ${ }^{1638}$ The paramount parameter of the Panel is to find solutions that are fair and just both to the claimant and to the institution, respectively to both private persons where a dispute concerns private property. ${ }^{1639}$ For this purpose the following concrete steps are listed:

(a) make such factual and legal inquiries, (including the seeking of advice about legal matters, about cultural objects and about valuation of such objects) as the Panel consider appropriate to assess each claim as comprehensively as possible;

(b) assess all information and material submitted by or on behalf of the claimant and the institution or any other person, or otherwise provided or known to the Panel;

(c) examine and determine the circumstances in which the claimant was deprived of the object, whether by theft, forced sale, sale at an undervalue, or otherwise;

(d) evaluate, on the balance of probability, the validity of the claimant's original title to the object, recognising the difficulties of proving such title after the destruction of the Second World War and the Holocaust and the duration of the period which has elapsed since the claimant lost possession of the object;

(e) give due weight to the moral strength of the claimant's case;

(f) evaluate, on the balance of probability, the validity of the institution's title to the object;

(g) consider whether any moral obligation rests on the institution taking into account in particular the circumstances of its acquisition of the object, and its knowledge at that juncture of the object's provenance; take account of any relevant statutory provisions, including stipulations as to the institution's objectives, and any restrictions on its power of disposal;

(i) take account of the terms of any trust instrument regulating the powers and duties of the trustees of the institution, and give appropriate weight to their fiduciary duties;

(j) where appropriate assess the current market value of the object, or its value at any other appropriate time, and shall also take into account any other relevant circumstance affecting compensation, including the value of any potential claim by the institution against a third party;

(k) formulate and submit to the claimant and to the institution its advice in a written report, giving reasons, and supply a copy of the report to the Secretary of State, and

(l) formulate and submit to the Secretary of State any advice pursuant to paragraph 4 in a written report, giving reasons, and supply a copy of the report to the claimant and the institution. ${ }^{1640}$

1634 Spoliation Advisory Panel, Constitution and Terms of Reference, s 3.

1635 Spoliation Advisory Panel, Rules of Procedure, s 1 and s 2.

1636 Spoliation Advisory Panel, Constitution and Terms of Reference, s 2; s 12 (a).

1637 Ibid, s 5 \& 6; s 12 (d-g).

1638 Ibid, s 6.

${ }^{1639}$ Ibid, s 11.

${ }^{1640}$ Ibid, s 12. 
Where the Panel reaches the conclusion on the basis of the aforementioned steps that a claim should be upheld it can choose between a number of remedies: it may recommend the return of the claimed object, the payment of compensation to the claimant, or the payment of an ex gratia payment by the Government. With regard to the later two remedies which imply that the object concerned stays in the public collection the Panel may also recommend a commemorative notice on the provenance of the object to be exhibited alongside the object. ${ }^{1641}$ In as far as the amount of a compensation payment is concerned it is for the Panel to decide, taking into account all relevant circumstances including the current market value, but not tied to that current market value. The recommendations issued by the Panel are not legally binding on any of the parties involved. ${ }^{1642}$ However if the claimant accepts the recommendation of the Panel and the recommendation is implemented then the claimant is expected to accept this as "full and final settlement of his claim". ${ }^{1643}$

From the outline of the Panel's terms above it appears that while the Panel will consider legal issues relating to title to the object its recommendations are based upon a broader assessment of claims beyond merely legal rights. Instead, the Panel also takes into account the "moral strength of the claimant's case" and the "moral obligations" that may rest on a holding institution. The Panel's Constitution and Terms of Reference do not further explicate what is meant by moral strength or moral obligations. Consequently, the Panel enjoys a certain margin of appreciation as to what constitutes moral strengths and obligations. In order to get a better understanding of how the Panel applies these notions we will have to look at the cases for which the Panel has already issued recommendations.

Until the end of 2008 the Panel, which has been referred to as being “(...) without doubt one of the most elegant organisms ever created by government"1644, had completed reports into nine claims to objects held in the following collections: the Tate, the British Library, the Glasgow City Council (as part of the Burrell Collection), the Ashmolean Museum, the British Museum, the Courtauld Institute of Art and the Fitzwilliam Museum. ${ }^{1645}$ In the following, we will shortly summarise the Panel's

\footnotetext{
1641 Spoliation Advisory Panel, Constitution and Terms of Reference, s 13.

$1642 \mathrm{Ibid}, \mathrm{s} 7$.

1643 Ibid, s 8.

1644 Select Committee on Culture, Media and Sport Minutes of Evidence Examination of Witnesses (Questions 320-329), Q322 (Chairman).

1645 Report of the Spoliation Advisory Panel in respect of a painting now in the possession of the Tate Gallery, 18 January 2001 (hereinafter: Spoliation Advisory Panel, 2001); Report of the Spoliation Advisory Panel in respect of a painting now in the possession of Glasgow City Council, 24 November 2004 (hereinafter: Spoliation Advisory Panel, 2004); Report of the Spoliation Advisory Panel in respect of a 12th century manuscript now in the possession of the British Library, 23 March 2005 (hereinafter: Spoliation Advisory Panel, 2005); Report of the Spoliation Advisory Panel in respect of a painting held by the Ashmolean Museum in Oxford, 1 March 2006 (hereinafter: Spoliation Advisory Panel, 2006a); Report of the Spoliation Advisory Panel in respect of four drawings now in the possession of the British Museum, 27 April 2006 (hereinafter: Spoliation Advisory Panel, 2006b); Report of the Spoliation Advisory Panel in
} 
recommendations before seeking to extract common grounds, in particular with regard to Panel's interpretation of moral strength and obligations.

\section{a) The case of 'A View of Hampton Court Palace' by Jan Griffier the Elder' claimed from the Tate Gallery}

In this case, the heirs of a Jewish couple laid claim to a picture that had been in the collection of the Tate Gallery since its donation in 1961 by the Friends of the Tate. The painting by Griffier had been sold in 1939 by the mother of the claimants for very little money, next to other paintings from the family's collection in order to finance her basic necessities as a Jewish refugee in hiding in Belgium after her husband had been shot. After the war, she sought and was awarded compensation from the German Government for three painting allegedly stolen in transit. The Panel was informed that the compensation files do not make any reference to the Griffier painting. ${ }^{1646}$

The Panel examined the factual evidence produced by the claimants, most of which was based on the claimants' recollection or on information derived from their deceased mother. In line with their principle of generous interpretation of evidence - given the difficulties of proof after the destruction of WWII and the duration of the period which has elapsed since - the Panel accepted the evidence regarding the family's original ownership and loss of the painting in a forced sale.

As next step the Panel addressed the question who presently holds title to the painting. In order to evaluate the validity of the Tate's title at that moment the Panel examined all transfers, starting with the forced sale in Brussels until the final transfer when the Friends of the Tate acquired the painting in 1961. The Panel found that in accordance with the Limitation Act 1939 the claimant's title was extinguished in 1967, clothing the Friends of the Tate and thereafter the Tate with an unassailable title. Consequently, the claimants do not have a valid legal claim to the picture.

respect of three drawings now in the possession of the Courtauld Institute of Art, 24 January 2007 (hereinafter: Spoliation Advisory Panel, 2007a); Report of the Spoliation Advisory Panel in respect of three Rubens paintings now in the possession of the Courtauld Institute of Art, London, 28 November 2007 (hereinafter: Spoliation Advisory Panel, 2007b); Report of the Spoliation Advisory Panel in respect of pieces of porcelain now in the possession of the British Museum, London and the Fitswilliam Museum, Cambridge, 11 June 2008 (hereinafter: Spoliation Advisory Panel, 2008). The claim for the return of porcelain from the former Rothberger Collection from Vienna against the British Museum and the Fitzwilliam Museum were dealt with by the Panel in one single report, explaining that the number of cases (9) exceeds the number of published reports (8). On 24 June 2009, after the research in the context of this thesis was closed, the Panel published its 9th Report (Spoliation Advisory Panel, 2009), on eight drawings now in the collection of the Courtauld Institute of Art in London.The Report concludes that, whilst the predominant reason for the sale of the drawings in 1933 by the owner, Professor Dr Curt Glaser, was Nazi oppression, the moral claim was insufficiently strong to warrant the transfer of the drawings. In reaching this conclusion, the Panel took account of the fact that the sale prices achieved at the time were reasonable and that Dr Glaser's widow had received compensation from the German compensation authorities after the War. See for the report: http://www.culture.gov.uk/images/publications/429961_HC757_PROOF.pdf (last visited 30 June 2009). For reasons of timing, the recommendation could not be integrated in this study but will be discussed in the epilogue.

1646 Spoliation Advisory Panel, 2001, paras. 8-9. 


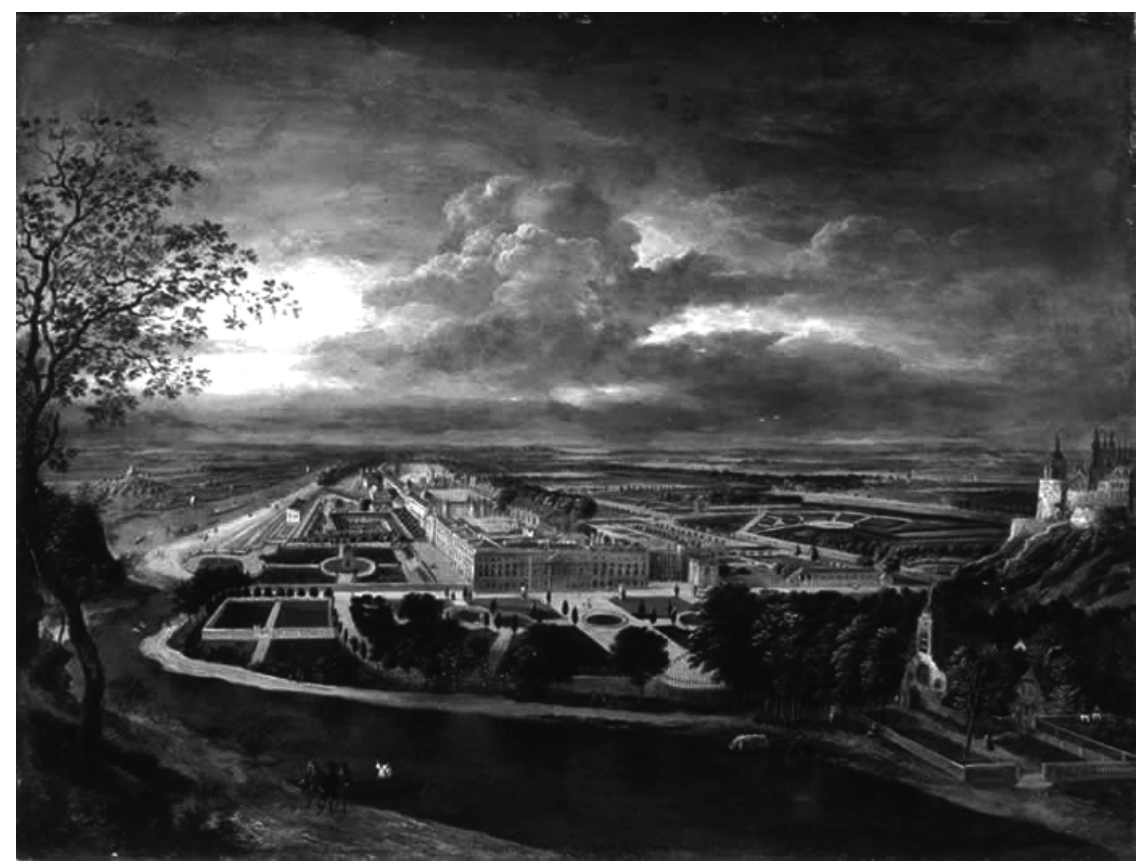

Jan Griffier the Elder, View of Hampton Court Palace, oil on copper, 38 x $51 \mathrm{~cm}$. Photo: Tate Gallery, London/Art Resources NY.

Having discussed the legal dimension of the case, the Panel then turned to the moral issues. Referring to the 1943 London Declaration and the warning expressed therein that the signatory countries had the right to declare invalid any transaction within an occupied territory, regardless of the circumstances of the transaction, the Panel held that the present case, where the painting was sold by a "Jew struggling to survive in a hostile environment, and faced with the thread of starvation" falls under the scope of the London Declaration. ${ }^{1647}$ The Panel continued that if the mother were the claimant, it would be persuaded by the moral strength of her case. Given the mother's death in 1968 the Panel addressed the question whether her heirs were in a weaker position. First, it disussed whether the relevance of the fact that the claimants had waited nine years since first identifying the painting in the Tate before making their claim known. The Panel held that the passiveness did not diminish the strength of the claim for reasons that it was only towards the end of the 1990s that a favourable public attitude had developed towards Nazi spoliated art claims.

The Panel subsequently assessed whether any moral obligation rested on the Tate. It refers in particular to the circumstances under which the institution acquired the object

1647 Ibid., para. 43. See further on the 1943 London Declaration above in chp. 1.\$1.V. 
and their knowledge of its provenance at that point as possibly giving rise to moral obligations. The Panel recognised that the Tate had investigated the provenance of the work by writing to previous dealers and archives but nevertheless asked the question of whether the Tate should have done more provenance research. In answering this, the Panel held that the question must be judged by the standard of the times, i.e. the 1960s when "museum buyers were characteristically concerned with the history and importance of the picture rather than with any considerations of spoliation". ${ }^{1648}$ Consequently, the Panel did not find any grounds for criticising the conduct of the Tate in moral terms.

Having upheld the claim, the Panel addressed the question as to the appropriate remedy. In principle, the first option would be to recommend the return of the pictures to the claimants. Nevertheless, the Panel decided to award an ex gratia payment of $£ 125,000$ calculated as to reflect the current market value of the painting, deducted by the costs borne by the holding institution for insurance, and restoration. The amount was furthermore balanced by the benefit derived by the holding institution from the possession of the work of art.

While it clearly motivated its choice against compensation in being inappropriate given the absence of a legal claim, the Panel did not explicitly state the decisive reasons for preferring an ex gratia payment to be paid by the Government over restitution. It did mention that the claimants did not seek its return and that the return would be debarred in any case under the present statute. The Panel also recommended displaying the picture in the future with a plaque commemorating its history and provenance.

b) The case of 'Still Life' formerly attributed to Jean-Baptist-Siméon Chardin claimed from the Glasgow City Council

The heirs of former Jewish shareholders of an art gallery in Munich claimed a 'Still Life' formerly attributed to Chardin from the City of Glasgow. The painting, which until recently was believed to be an authentic Chardin had been part of the stock of the Munich gallery, which had been forced to auction its entire stock in 1936. A few days after the auction, the painting had been resold to Sir William Burrell who donated his entire art collection to the City of Glasgow in 1944. The claimants held that the gallery was forced to liquidate its stock to satisfy an extortionate tax demand which they had to pay in order to be allowed to emigrate from Germany. The claimants contended that they had received the tax demand shortly after a new tax officer with Nazi sympathies had been appointed. Consequently, the claimants case centred on the fact that they had been deprived of their freedom to retain or dispose of their property as they wished to.

They referred to the restitution principles adopted by the Allied Forces after the war, which presumped that all transactions made in the period 1933-1945 by a person belonging to a persecuted group qualify as an act of confiscation. Only if positive evidence was provided according to which the transfer would also have taken place in

1648 Ibid., para. 50. 
the absence of National Socialism or resulted in the successful protection of a property interest of the original owner could the presumption be refuted. ${ }^{1649}$

The Panel accepted the claimants' evidence that the Jewish shareholders of the gallery had been confronted with an extortionate tax demand and that the auctioning of its stock was a direct consequence. Squared with the restitution principles of the Allied Forces and the 1943 London Declaration the Panel recognised a strong moral case in the claimant's favour.

With regard to the moral position of the City of Glasgow, the Panel looked at the steps taken in 1944 when it took possession of the collection of Sir William Burrell. The City of Glasgow contended that Sir William Burrell had recorded everything he knew about his collection in his purchase book and when the city took over the collection they missed man-power to conduct further provenance research. Taking the size of the collection as well as the missing resources into account, the Panel did not find the City of Glasgow under a moral obligation.

Having recognised a "sufficiently robust moral case to justify the award of a remedy" on behalf of the claimants the Panel first discussed the fact that the Jewish shareholders had been paid DM 75,000 by the German Government as compensation for their loss on the sale. While the report refers only to the "Federal Compensation Act" the compensation was presumably based on the Federal Restitution Law (BRüG) as adopted in 1957.1650 The Panel remarks that it had been informed that the sum received represented an overall payment for the entire loss of which only a fraction would be attributable to the painting. It does not reflect upon the consequences of compensation received, i.e. the impact of compensation payments on the remedy determined but turns immediately to establishing the current market value of the painting and the appropriate remedy. ${ }^{1651}$ The Panel also did not further elaborate upon the fact that since the compensation payments, the painting is no longer considered as a Still Life by Chardin, but would realise a price of approximately $£, 7,500$ when sold in auction.

The Panel notes that the claimants seek either the return of the painting or an $e x$ gratia payment, while the City of Glasgow pleads for an ex gratia payment funded by the Government for being debarred from granting restitution under the terms of the memorandum of agreement with Sir William Burrell. The memorandum stipulated that "the donnees shall not be entitled on any pretext whatever to sell or donate or exchange any item or part of the Collection once it has formed part of the Collection (...)".1652 Despite this contractual rather than statutory impediment the Panel reached the final conclusion that the "just and fair solution in the present case is restitution of the picture to the claimants". ${ }^{1653}$ It lists a number of reasons that it considered as speaking against

\footnotetext{
1649 See further on the restitution principles above in chp. 1. $\$ 4$.

${ }_{1650}$ Bundesrückerstattungsgesetz (BRüG) 19 July 1957, BGBl. I-734. See further on the BrüG above in chp. 1. $4 . I V$.

1651 Spoliation Advisory Panel, 2004, para. 24.

1652 Ibid., para. 22.

1653 Ibid., para. 36.
} 
an ex gratia payment: first, it mentions the discrepancy in value between 1936 when the painting fetched a generous price as a genuine Chardin and the current market value as an attributed work. Secondly, the Panel refers to the compensation payments received from the German Government and states that while it would be prepared to disregard the "tiny fraction" received, it would need to make allowance for the expenses (insurance and conservation) which the claimants would have incurred had they retained possession. Consequently, the amount of an ex gratia payment would be restricted to an amount representative of the claimants' loss of their right of disposal plus some allowance in recognition of the public benefit derived from the painting having been exhibited all these years. The Panel concludes that it would not "shrink from proposing a figure if this were the only course available, we doubt whether such an assessment would seem fair to either side". ${ }^{1654}$ Instead, but without further motivation, the Panel decided for full restitution of the painting as just and fair solution.

\section{c) The case of the 'Beneventan Missal' claimed from the British Library}

The claim was brought by the city of Benevento in Italy for the return of a manuscript originating from the Chapter Library in Benevento, now in the possession of the British Library. The claimants held that it lost possession of the manuscript between 1943 and 1944. The exact circumstances of when and under which conditions the claimants had lost the manuscript were unknown. In fact, the case did not have a direct Nazi connotation, as a consequence of which the Panel first had to decide whether the case came within its jurisdiction.

As outlined above the Panel can hear claims from people, or their heirs, who "lost possession" of a cultural object during the years 1933-1945 where that object is now in the possession of a public UK institution. ${ }^{1655}$ While the terms of reference do not require that the loss of possession is a direct result of Nazi intervention the loss must have occurred during the years of the Nazi reign. Whereas the claimants held that this was the case, this was disputed by the British Library. In evaluating the arguments made by both sides concerning proof of the manuscripts' presence in the Chapter Library until the outbreak of WWII and its loss before the end of the war the Panel took into account the difficulties of proof after the Destruction of WWII and the duration of the period which has elapsed since. The Panel came to the conclusion that the circumstantial evidence relied upon by the claimants is "sufficiently robust" to support their claim that the manuscript was spoliated between 1943 when the city of Benevento was bombed and 1944, when the missal was discovered by an English captain in a bookshop in Naples. ${ }^{1656}$ Consequently, the case fell into the jurisdiction of the Panel, which turned as next step to evaluate the moral positions of the parties. As for the legal

1654 Ibid., para. 28.

1655 Spoliation Advisory Panel, Constitution and Terms of Reference, s 2. Note that while the content of the Panel's Constitution and Terms of Reference did not change the numbering was revised in 2007. Our references are to the most recent manner of numbering.

1656 Spoliation Advisory Panel, 2005, para. 52. 
title to the manuscript it was accepted from the outset that the British Library's title is impregnable under the Limitation Acts. ${ }^{1657}$

In evaluating the moral positions of the parties, the Panel first explicated two instruments that inform its duty to give weight to moral considerations: the 1943 London Declaration, which had been referred to also in the two previous cases heard by the Panel and the National Museum Directors' Conference's (NMDC) 'Statement of Principles and Proposed Action' introduced above. ${ }^{1658}$ The reason for explicitly referring to the NMDC Principles could have been that in 2000, under the auspices of the NMDC, the British Library published a "List of works with incomplete provenance during the period 1933 to 1945 ", which includes the missal. The entry significantly states that "the manuscript was not identified directly by research, but may have been spoliated during the Nazi period". 1659

Concerning the claimants' moral position the Panel accepts as "central pillar of their case" vindicating their moral claim for the manuscript's return the argumentation of the claimants that as an object of war time looting, the subsequent acquisition of the manuscript by the English captain in Naples in 1943 was both unlawful and immoral and falls within the scope of the 1943 London Declaration. ${ }^{1660}$ The Panel dismissed the British Library's argument that the long period of inactivity on behalf of the Chapter Library in seeking the return of the manuscript dismissed their moral claim. ${ }^{1661}$

The Panel then discussed the British Library's moral position. Given the fact that the moral discussion focuses on the acquisition of the manuscript and the knowledge about its provenance at that point it is important to note that the missal was originally acquired by the British Museum in 1947 and was transferred to the British Library on the latter's foundation under the terms of the British Library Act 1972. Consequently, the discussion of a moral obligation necessarily focuses on the behaviour of the British Museum in the late 1940s rather than on the British Library. In evaluating the conduct of the British Museum in acquiring the manuscript the Panel held that under the circumstances applicable the British Museum should have made further attempts to investigate its provenance. Crucial for its decision to criticise the British Museum's behaviour was the fact that when the British Museum was contacted by the English Captain who had acquired the manuscript in Naples for an evaluation in 1946, its deputy keeper explicitly informed the captain that the manuscript could have been spoliated property. Despite this awareness, when the manuscript came up in auction at Sotheby's only a year later, the British Museum acquired the object without further provenance research. Regardless of the fact that the standards of provenance research were less

\footnotetext{
1657 Spoliation Advisory Panel, 2004, para. 3.

1658 Cf.: Bailey, M., 2005, p. 58; Schnabel, G. / Tatzkow, M., 2007, p. 172.

1659 Spoliation Advisory Panel, 2004, para. 62.

1660 Ibid., paras. 62 \& 66.63.

1661 Ibid., paras. $64 \& 66.63$
} 
rigorous back then, the Panel criticises the conduct of the British Museum from a moral point of view.

Having established that "the claimants have made good their moral claim" the Panel then turns to the appropriate remedy. ${ }^{1622}$ The Panel follows the wish of the claimants to have the manuscript returned and to recommend to the Government the introduction of appropriate legislation to enable the manuscript to be returned. ${ }^{1663}$ Consequently, the Panel recommends that legislation should be introduced to amend not only the British Library Act 1972, but also the British Museum Act 1963 and the Museums and Galleries Act 1992 to permit restitution of objects lost in the period 1933-1945. Until such legislation would be realised the manuscript should be returned to Benevento on the basis of a loan agreement. ${ }^{1664}$

d) Portrait of a Young Girl in a Bow window, attributed to von Landshut claimed from the Ashmolean Museum

In 2002, the heirs of the Jewish German banker Jakob Goldschmidt sought the return of the 'Portrait of a Young Girl in a Bow window', attributed to von Landshut from the collection of the Ashmolean Museum. The painting had been sold at auction in Germany in 1936 after Goldschmidt had already left the country for the United States. In evaluating the claim, the Panel had to establish whether or not the sale of the painting was forced or whether the sale was the result of financial problems Goldschmidt had occurred already prior to the Nazi rise to power. The Danatbank, which had been founded by Goldschmidt, encountered significant problems in result to the 1929 world financial crisis and had to declare bankruptcy in July 1931. In reaction to this, Goldschmidt concluded a number of agreements with the Danatbank in 1931 and with its successor the Dresdner Bank and Thyssen in 1932. Having analysed these agreements the Panel reached the conclusion that by the end of 1931 Goldschmidt had transferred all assets from his households, including the painting in dispute as security for his debt to the Donatbank. Consequently, at that point in time ownership of the painting had been transferred to the Donatbank. In a number of agreements in 1932 between Goldschmidt, the Dresdener Bank and Thyssen it was subsequently agreed the whole art collection of Goldschmidt that had been kept in his house in Berlin would be secured in favour of Thyssen. In light of these agreements the Panel reached the conclusion that the 1936 sale at Hugo Helbing was not forced by the demands of the Nazi regime but instead had to meet the debt to Thyssen. As additional supportive evidence of its finding the Panel mentions the fact that in 1936 Goldschmidt had already emigrated to the United States and that the sale proceeds were directly paid to Thyssen. ${ }^{1665}$ The Panel furthermore verified that the painting had not been sold at an

\footnotetext{
1662 Ibid., para. 72.

1663 Ibid., paras. $73 \& 79$.

1664 Ibid., para. 80.

1665 Spoliation Advisory Panel, 2006a, para. 35.
} 
undervalue. It concluded its analysis of Goldschmidt's position with the finding that it would involve too many speculative steps to conclude that he could have been able to repay his debts by 1936 if the Weimar Republic had continued in existence. Translating the findings into the moral force of the case the Panel qualified it as weak. ${ }^{1666}$

With regard to the legal and moral position of the Ashmoleon Museum, the Panel held that its legal title to the painting is impregnable and that the museum behaved in an entirely appropriate manner when it acquired the painting by means of bequest in 1967.1667 Having reached the conclusion that the Ashmoleon Museum had unassailable legal title to the painting and was under no moral blame whatsoever while the moral force of the claimant was weak the Panel rejected the claim. ${ }^{1668}$

\section{e) Four drawings claimed from the British Museum}

The case, in which heirs of the late Dr Arthur Feldmann claimed four drawings from the collection of the British Museum, has already been introduced above in Chapter 3 (\$2.II.1.a)) where we discussed the case Attorney-General v Trustees of the British Museum. ${ }^{1699}$ The case was advanced in 2002 on the ground that the drawings ${ }^{1670}$ had been seized in March 1939 by the Gestapo from Dr Feldmann's house in Brno when the Nazis invaded Czechoslovakia. Three of the drawings had entered the museum's collection through a sale at Sotheby's in 1946, while the fourth was part of a bequest to the museum in 1949. The British Museum's trustees agreed that the four drawings ought to be returned to the heirs of Arthur Feldmann as they felt they had a moral obligation to do so given the "exceptional atrocities committed during the 1933-1945 era".1671 However, in the light of the statutory restrictions on disposal of the British Museum Act 1963 and the findings of the Vice-Chancellor in the High Court judgment that "no moral obligation can justify a disposition by the Trustees of an object forming part of the collections of the museum in breach of section 3(4) of the 1963 Act"1672, the claimants and the British Museum had made a joint submission to the Panel proposing as "preferred solution" that the paintings remains in the collection of the British Museums and that the claimants should be awarded full financial compensation. ${ }^{1673}$

In evaluating the claim the Panel does not further consider the legal title of the British Museum, presumably as it had been confirmed already by the Vice-Chancellor

\footnotetext{
1666 Ibid., paras. 42 \& 48 (vii).

1667 Ibid., para. 47.

1668 Ibid., para. 49.

1669 The High Court judgement of 24th May 2005 [2005] EWCH 1089 (Attorney-General v. Trustees of the British Museum). See further on the case above in chp. 3.\$2.II.1.a).

1670 The Holy Family, by Niccolo dell'Abbate; An Allegory on Poetic Inspiration with Mercury and Apollo, by Nicholas Blakey; Virgin and Infant Christ adored by St Elizabeth and the Infant St John, by Martin Johann Schmidt; St Dorothy with the Christ Child, by a follower of Martin Schongauer.

1671 The High Court judgement of 24th May 2005 [2005] EWCH 1089 (Attorney-General v. Trustees of the British Museum), para. 5.

1672 Ibid., para. 45.

${ }^{1673}$ Spoliation Advisory Panel, 2006b, para. 4.
} 
and directly addressed the moral issues involved. For the first time, the Panel explicitly mentioned the 1998 Washington Declaration as international instrument giving weight to moral considerations next to the 1943 London Declaration. While the 1998 Washington Declaration had been annexed to all earlier recommendations the Panel had never chosen to refer to it before in its report. The Panel limited itself to pointing out that the declaration "stresses the need to achieve a just and fair solution". 1674

With regard to the claimants position the Penal held that the loss of the drawings by gross act of spoliation by the Gestapo, furnishes an unassailable moral strength to the claim. ${ }^{1675}$ As for the position of the British Museum, the Panel held that the lack of investigation at the time the drawings were acquired is "with hindsight regrettable" and would "by modern standards be unacceptable" but cannot justify criticising the museum given the less rigorous standards previously applicable.

In determining the appropriate remedy the Panel respects "preferred solution" of the two parties and hence does not recommend the return of the drawings. Instead, the Panel recommends an ex gratia payment. The Panel held that given the continued profit of scholars and the public and given the fact that no legal liability or moral blame rested on the British Museum an ex gratia payment borne by the Government was more appropriate than compensation paid by the museum. As for the amount of the ex gratia award, it was based on the valuation of the drawings, balanced by the expenses the claimants would have had occurred had they retained the drawings. In the present case, these were only insurance costs and potential sale expenses, suggesting a final payment of $£, 175,000$ to the claimants.

\section{f) Three drawings claimed from the Courtauld Institute of Art}

The claim for three drawings from the collection of the Courtauld Institute of Art was also made by the heirs of the late Dr Arthur Feldmann. ${ }^{1676}$ According to the heirs the drawings had been seized, together with the rest of Dr Feldmann's art collection in March 1939 by the Gestapo from Dr Feldmann's house in Brno. ${ }^{1677}$ Consequently, the underlying fact on which the claimants rely are similar to those considered in the case concerning the four drawings in the collection of the British Museum discussed above and will not be further discussed here. ${ }^{1678}$ In fact, the drawings had been included in the same sale at Sotheby's on 16 October 1946 as three of the drawing in the collection of the British Museum. The drawings were acquired by an art dealer who sold them the same day to Sir Robert Witt (1872-1952). In 1952, the drawings were part of the Witt

\footnotetext{
1674 Ibid., para. 33.

1675 Ibid., para. 34.

1676 See above the case concerning four drawings claimed from the British Museum.

1677 "A lion", attributed to Carl Ruthart (1630-1703), black chalk, brown wash, watercolour, heightened with white; "A dog lying down", attributed to Frans Van Mieris the elder (1635-1681), black and red chalk, brown wash, pen and ink; "An architectural capriccio", attributed to Giuseppe Bibiena (16961756), black chalk, pen and brown ink, brown and blue wash.

1678 See further: Spoliation Advisory Panel, 2006b; Spoliation Advisory Panel, 2007a, paras. 5-10.
} 
bequest to the Courtauld Institute of Art, University of London. In 2002, the Courtauld Institute acquired independent legal status. In as far as the legal title of the Courtauld Institute to the three drawings is concerned, it is impregnable.

With regard to the moral issues, the Panel referred to the terms of the 1943 London Declaration and the 1998 Washington Declaration. As for the claimants' position the Panel repeated its earlier finding from the case involving the British Museum that the claim of the heirs had an unassailable moral strength given the deprivation of the drawings by a gross act of spoliation by the Gestapo. ${ }^{1679}$ With regard to the moral position of the Courtauld Institute, the Panel mentioned the fact that there is no evidence of any provenance research at the time of acquisition. However, in the light of the less rigorous standard at that time and the fact that the drawings were part of an enormous bequest the Panel reached the conclusion that it would not be fair to criticise the Courtauld Institute of Art, University of London and the present Courtauld Institute as its successor. ${ }^{1680}$

Having established valid legal title but no moral blame on the side of the Courtauld Institute and a claim of unassailable moral strength on behalf of the claimants, the Panel then addressed the question of appropriate remedy. Similar to the British Museum case, the parties had made a joint request that they would prefer the solution in which the drawings remained in the collection of the Courtauld Institute whereas the claimants would be offered an ex gratia award. Different from the British Museum case, there exists no statutory bar on the disposal of objects from the collection of the Courtauld. Consequently, return of the object was also a realistic option and in the end the remedy considered most appropriate by the Panel. From the report it appears that the decisive reason to decide in favour of restitution and against an ex gratia award was not simply the fact that restitution was legally feasible. Instead, the Panel held that the poor quality of two of the drawings could not justify the paying of an ex gratia award from the tax payers' money as the public benefit derived from the drawings was negligible. Consequently, the Panel recommended restitution as the most appropriate remedy in the present case. ${ }^{1681}$

g) Three Rubens paintings claimed from the Courtauld Institute of Art1682

In 2006, the Trustees of the Samuel Courtauld Trust received a claim from Ms Christine Koenigs for the return of three oil sketches by Peter Paul Rubens currently in the possession of the Courtauld Institute of Art (hereinafter: "the Courtauld"). ${ }^{1683} \mathrm{Ms}$

\footnotetext{
1679 Spoliation Advisory Panel, 2007a, para. 21.

1680 Ibid., para. 22.

1681 Ibid., paras. 28-29.

1682 Spoliation Advisory Panel, 2007b.

1683 St. Gregory the Great with Ss. Maurus and Papianus and St. Domitilla with Ss. Nereus and Achilleus. 1606-1607, oil on panel, 62.9 x 46.7 cm; The Conversion of St. Paul, c.1610-1612, oil on panel, 57.4 x 80.2 $\mathrm{cm}$; The Bounty of James I Triumphing Over Avarice, for the ceiling in the Banqueting House, Whitehall, c.1632-1633, oil on panel, 46.2 x $30.8 \mathrm{~cm}$.
} 
Koenigs is the granddaughter of Franz W. Koenigs, a German businessman who acquired Dutch nationality in 1939. In the beginning of 1940 he lost his art collection of Old Master drawings when he was living in the Netherlands. The recommendation of the Panel centred on the question whether the loss of the collection was precipitated by the Nazi reign or whether it was a loss suffered for commercial reasons. Only in the former case could the request of the claimant have any moral strength. In as far as the legal title to the oil sketches is concerned the Panel held that the Courtauld's legal title is impregnable. ${ }^{1684}$

In evaluating the moral issues of the case, the Panel analysed the following facts: in 1935 Koenigs lent his collection of Old Master drawings and paintings to the Boymans Museum in Rotterdam. The same year he took out a loan from the Lisser \& Rosenkranz Bank in Hamburg, under an agreement formalising an earlier loan made in 1931. The collection of Old Master drawings at the museum was provided as collateral to secure the loan. While Koenigs himself was not Jewish, the proprietors of the bank were for the most part Jewish. In the face of the Nazi oppression of the Jewish people in Germany the bank had moved to the Netherlands. On 2 April 1940, about a month before the German invasion of the Netherlands, the Bank went into voluntary liquidation and exercised its right to call in the loan. The liquidators contacted the Museum with the intention to realise their security by taking possession of the works of art, with the knowledge of Koenigs. Part of the collection, including the three oil sketches in question, were acquired in May 1940 by Count Antoine Seilern who subsequently bequeathed them to the Home House Society in 1978 as part of the Princes Gate Bequest. ${ }^{1685}$

Having heard the claimant's case and the response of the Courtauld and having sought further expert evidence, the Panel reached the view that the claimant's grandfather was deprived of his art collection as a result of the bank calling in the loan and realising its security, rather than by theft, forced sale or by sale at an undervalue. The bank had had the right to sell the collection because of the loan agreement entered into by Koenigs in 1935, making the loss suffered by Koenigs one of commercial reasons and not as result of Nazi spoliation or any form of duress. While the Panel held that this finding was already sufficient to resolve the case in the Courtauld's favour, it furthermore held that the claimant could not have a moral claim as there was no evidence that Koenigs ever intended to leave his art collection to his heirs.

Denying the claimant's case any moral strength and emphasising that no criticism attaches to the Courtauld in respect of the manner and circumstances of its acquisition

1684 Spoliation Advisory Panel, 2007b, para. 32.

1685 The facts are also discussed in: Koenigs, C.F., 1997; Leistra, J., 1997. 
of the oil sketches, the Panel issues the recommendation that the claim should be rejected. 1686

\section{h) Pieces of porcelain claimed from the British Museum and the Fitrwilliam Museum ${ }^{1687}$}

In these two cases the claimant, the sole heir of Heinrich Rothberger contested rare and distinctive objects of porcelain in the collection of the British Museum and the Fitzwilliam Museum. ${ }^{1688}$ According to the claimant, Mrs Gutmann, the objects had been seized by the Gestapo from her uncle's house in Vienna in 1938. Given the overlap between the two cases the Panel decided to consider them jointly.

The Panel accepted the evidence that the porcelain dish and the monteith formed part of Rothberger's collection prior to 1938 and were amongst the family assets that had been seized by the Gestapo in 1938.1689 Due to this clear evidence of spoliation the Panel held that the claimant had a strong moral claim both to the porcelain dish in the collection of the British Museum and to the monteith in the collection of the Fitzwilliam Museum. ${ }^{1690}$ Both holding institutions were attested impregnable legal title ${ }^{1691}$ and the Panel did not wish to criticise their behaviour at the time of acquisition on moral grounds for the fact that the standard of provenance research was raised only recently to the current standards. ${ }^{1692}$

Despite this great overlap between the cases, the Panel held different remedies appropriate. With regard to the porcelain dish in the collection of the British Museum the Panel respected the solution that had been jointly proposed by the two parties: to award Mrs Gutmann an ex gratia award reflecting the value of the dish to be established in the light of independent valuations while the dish remains in the collection of the British Museum, which will, whenever the dish is published or exhibited, acknowledge that it once belonged to the collection of Heinrich Rothberger and rehearse the circumstances of its expropriation and sale by the Nazis, and the generous goodwill of the heir of Heinrich Rothberger in agreeing that it should remain in the British Museum. ${ }^{1693}$ The Panel motivated its choice for an ex gratia payment by the fact that restitution of the dish is debarred under section 5 of the British Museum Act 1963 and that despite its earlier recommendation in the British Library case no action had been undertaken to remove the legal bar to de-accession and thus return. In this light and

\footnotetext{
1686 Cf.: the recommendation of the Dutch Restitutions Committee with regard to the Koenigs Collection: Advisory Committee for Restitution Applications for Items of Cultural Value and the Second World War, $2003 a$.

1687 Spoliation Advisory Panel, 2008.

1688 A Viennese (Du Paquier) dish of handpaste porcelain and a Sèvres seau crennelé or monteith used for cooling glasses.

1689 The Rothberger collection is discussed in Sophie Lillie's book on Vienna's plundered art collections: Lillie, S., 2003, pp. 990-997.

1690 Spoliation Advisory Panel, 2008, paras. 13 \& 28-29.

1691 Ibid., paras. $12 \& 28$.

1692 Ibid., paras. 6\& 25.

1693 Ibid., para. 23 juncto para. 20.
} 
given the little likeliness that the law will be changed within due time the Panel held that it would not be realistic or fair to the claimant to defer their decision in the present case. Consequently, the Panel recommended that the Government should make an ex gratia payment of $£ 18,000$ to the claimant. The Panel furthermore reflected upon the future public benefit of the dish, which legitimised the burdening of the tax payer to fund the agreement.

As to how exactly the Panel arrives at setting the amount of the award, is not clear. The report quotes three valuations:

\begin{tabular}{|c|c|}
\hline Sotheby's: & $£ 12-£, 18,000$ (on behalf of the claimant) \\
\hline Bonhams: & $£ 16.000$ (on behalf of the British Museum) \\
\hline Manners: & 20,000 (on behalf of the Panel) \\
\hline
\end{tabular}

The Panel subsequently states that "taking the three valuations into account, and bearing in mind that if the dish had remained in the family's possession they would probably have incurred insurance expenses, we have concluded that a fair valuation is $f_{18,000 " .}{ }^{1694}$ Not only does the Panel mix up the valuation with the subsequent balancing of aspects that must be distracted from the award, such as costs incurred by the holding institution which would have otherwise been born by the claimant (insurance and conservation cost, selling costs), it is also not clear how the Panel decided that $f_{18,000}$ (or even a higher amount given the Panel already balanced it by potential insurance expenses) was the correct valuation. Different from its earlier recommendations of an ex gratia award the Panel did not reflect about the setting of the amount. 1695

No statutory bar prevented the restitution of the monteith from the collection of the Fitzwilliam Museum. Consequently, and in line with the wish of the claimant the Panel recommended that restitution is the appropriate remedy. ${ }^{1696}$

i) Analysis of the cases and recommendations

Until the end of 2008, the Panel has made recommendations in nine cases. In seven cases the Panel found the claim valid. All seven cases have in common that the holding institution had valid legal title and that the claimant had a strong moral claim. In all cases, except for the case of the Benevento missal in the possession of the British Library, the Panel furthermore held that the holding obligation was under no moral obligation, despite the fact that the conduct of some institutions was considered regrettable by current standards. However, the Panel decided that the conduct cannot be criticised for being in accordance with the less rigorous standards previously applicable. With regard to the British Library case, the Panel did criticise the conduct in acquiring the missal in the years 1946-1947. Under the circumstances in which the British

\footnotetext{
1694 Ibid., para. 20.

1695 Cf.: Spoliation Advisory Panel, 2001; Spoliation Advisory Panel, 2006b.

1696 Spoliation Advisory Panel, 2008, para. 36.
} 
Museum [sic] acquired the missal it should have made further attempts to investigate its provenance for the possibility that the missal had been spoliated. ${ }^{1697}$ However, with regard to the remedy accorded, the absence of any moral obligation or criticism in the majority of the cases proved immaterial. Presumably, the criticism of a holding institution on moral grounds would matter in cases where the Panel would decide between compensation to be borne by the museum itself and an ex gratia award paid by the Government. In the case of the Benevento Missal the criticism of the British Museum's behaviour did not have any measurable effect, except for the public naming and shaming, in that the Panel decided for restitution.

In four of the cases in which the Panel had upheld the claim, it recommended that the claimed object should be returned to the claimant: in the case involving a painting previously attributed to Chardin in the possession of Glasgow City Council; in the case of the Beneventan Missal in the collection of the British Library; in the case of three drawings now in the possession of the Courtauld Institute of Art, and finally in the case of a piece of porcelain now in the possession of the Fitzwilliam Museum. The fact that the Panel recommended the return of the objects does not necessarily mean that the holding institutions are legally able to do so. In fact, only the Courtauld Institute of Art and the Fitzwilliam Museum are presently able to live up to the recommendation of the Panel. The Glasgow City Council and the British Library are debarred from returning the objects concerned for reasons of contractual terms of a donation agreement, respectively statutory provisions. ${ }^{1698}$

In the other three cases where the Panel upheld the claim, it awarded an ex gratia payment: the case of a painting now in the possession of the Tate Gallery; the case of four drawings now in the possession of the British Museum and in respect of a piece of porcelain now in the possession of the British Museum. Compensation in the legal sense was not considered a just and fair solution seeing that the claimants did not have a legal claim. Different from compensation to be borne by the holding institution an ex gratia payment is paid by the Government, i.e. by the tax payers' money. In two of the cases the Panel carefully calculated the amount of the ex gratia award on the basis of the current market value of the painting, deducted by the costs borne by the holding institution for insurance, restoration, safekeeping etc. The amount is furthermore balanced by the benefit derived by the holding institution from possessing and exhibiting it. In the case of the porcelain dish in the possession of the British Museum the Panel's calculation of the award was less thoroughly motivated.

With regard to the painting in the Tate Gallery and the piece of porcelain from the British Museum collection the recommendation furthermore stipulated that future

1697 Spoliation Advisory Panel, 2005, para. 69.61-62. The missal was originally acquired by the British Museum in 1947 and was transferred to the British Library on the latter's foundation under the terms of the British Library Act 1972.

1698 The developments in order to broaden the power of national museums to allow for disposal in cases involving Nazi spoliated artworks will be discussed in chp. 4.\$1.II.2. 
exhibition of the object should be accompanied by a display commemorating the object's history and provenance during and since the Nazi era. As to why such a commemorative agreement was not considered or recommended in the British Museum case is not known but regrettable. Commemorative plaques are a powerful reminder and instructor to the general public of the story of those who suffered at the hands of the Nazis. ${ }^{1699}$

In comparing the four cases where the Panel considered restitution an appropriate solution with the three cases in which the Panel recommended ex gratia payment it is interesting to pose the question whether one can detect a pattern as to which aspects are decisive for the panel's choice of recommendation. Given the fact that the Panel opted for restitution in two cases where the holding institutions were (and still are) legally debarred from disposing of the object the legal feasibility is not decisive. Where the claiming party seeks restitution and the Panel upheld the claim it has always recommended the restitution of the object concerned. The Panel has only opted for an ex gratia payment in those cases where the claiming party had indicated that it would prefer or accept financial compensation. However, the Panel does not automatically recommend an ex gratia payment where the claiming party asks for it. In two cases, concerning the drawings from the Feldmann collection in the collection of the Courtauld Institute and the 'Still Life' attributed to Chardin in the collection of the Glasgow City Council, the Panel decided against the claimant's wish to endorse an ex gratia payment. In the case of the Feldmann drawings, the following two aspects were decisive in the Penal's decision to recommend restitution rather then an ex gratia payment: the fact that restitution was not legally debarred and the quality of the drawing could not justify the burdening of the tax payer for the payment of an ex gratia award for the public benefit derived from the drawings was too minimal. ${ }^{1700}$ In this respect the case of the Feldmann drawings in the Courtauld Institute diametrically opposes the constellation in the case of the porcelain dish from the Rothberger collection, now in the collection of the British Museum: in the latter case the Penal listed the following reasons for deciding in favour of an ex gratia payment: first, that the restitution of the porcelain dish was legally debarred and that for this reason the claimant preferred compensation of restitution and secondly, that the object was of considerable importance for the collection of the British Museum, which justified the reliance on public money.

In the case involving the 'Still Life' in the collection of the Glasgow City Council, the argumentation of the Panel as to why it preferred restitution over financial compensation is less apparent. The Panel listed the following aspects as speaking against an ex gratia payment: first, the discrepancy in value between 1936 when the painting realised a generous price as a genuine Chardin and the current market value as an attributed work. Secondly, the Panel refers to the compensation payments received from

1699 Messer, K., 1008, p. 19.

1700 Spoliation Advisory Panel, 2007a, paras. 28-29. 
the German Government and states that while it would be prepared to disregard the "tiny fraction" received, it would need to make allowance for the expenses (insurance and conservation) which the claimants would have incurred had they retained possession. Consequently, the amount of an ex gratia payment would be restricted to an amount representative of the claimants' loss of their right of disposal plus some allowance in recognition of the public benefit derived from the painting having been exhibited all these years. The Panel concludes that it would not "shrink from proposing a figure if this were the only course available, we doubt whether such an assessment would seem fair to either side". ${ }^{1701}$ Unfortunately, the Panel does not elaborate upon its doubts as why such an assessment would not be fair and why in the given situation restitution was fairer to both sides than a financial compensation taking account of the facts that the 1936 sale did fetch a generous price (especially if one takes into account that the painting is currently no longer accepted as a genuine work by Chardin) and the original owners had received some compensation from the German Government for the loss based on the 1936 sales price.

Leaving out the reasoning of the Panel in the case of the attributed Still Life the following pattern in the hierarchy of remedies emerges (provided of course that the Panel upholds a claim and that there exists no legal claim): where the claimant seeks restitution the Panel will recommend restitution regardless of the current legal feasibility of the object's disposal. ${ }^{1702}$ The Panel will also recommend restitution - even against the preference of the claimants and the holding institution - where the quality of an object cannot justify the reliance on public money. However, where the quality of an object can justify the payment of an ex gratia payment for being of sufficient public benefit and the claimant prefers or accepts payment instead of restitution the Panel will recommend an ex gratia payment.

In two cases, the Panel recommended to reject the claim: the case of a painting held by the Ashmolean Museum in Oxford and the case of three Rubens paintings now in the possession of the Courtauld Institute of Art. In both cases the Panel reached the conclusion that the loss of the artwork concerned was for commercial reasons and not precipitated by the Nazi reign. The cases, especially the Koenigs case, are an indication of the difficulty of where to draw the line. In the case of the Benevento missal in the collection of the British Library the Panel had adopted a very lenient approach in accepting that the loss of an object was precipitated by the Nazi regime. In the cases of Goldschmidt and Koenigs, it held that it would involve too many speculative steps to consider what would have happened had the Weimar Republic continued in existence (such as the questions what would have happened if proprietors of the bank where Koenigs had taken out the loan had not been Jewish or whether the bank not have gone

\footnotetext{
1701 Spoliation Advisory Panel, 2004, para. 28.

1702 See below on the discussion of the Panel's general recommendation to the Secretary of State to amend legislation to allow for disposal in restitution cases and its increasing frustration about the long period of inactivity.
} 
into voluntary liquidation just before the Nazi invasion of the Netherlands and would it not have exercised its right to call in the loan).

Having analysed the cases in which the Panel has issued recommendations we can now turn to the question how the Panel has used the margin of appreciation it is granted as to what constitutes "moral strength of the claimant's case" and "moral obligations" that may rest on a holding institution. As explained above, the Panel's Constitution and Terms of Reference do not further explicate these notions.

In further defining its moral framework, the Panel chose to refer to the following instruments: the 1943 London Declaration or in full the 'Inter-Allied Declaration against Acts of Dispossession committed in territories under Enemy Occupation or Control'; the restitution principles adopted by the Allied Forces after the war, the National Museum Directors' Conference's (NMDC) 'Statement of Principles and Proposed Action' and the 1998 Washington Declaration. According to the London Declaration, which we discussed in detail in Chapter $1(\$ 1 . \mathrm{V})$, the signatory countries had the right to declare invalid any transaction within an occupied territory, regardless of the circumstances of the transaction. ${ }^{1703}$ With regard to the possibly affected transactions the London Declaration adopted a broad approach ranging from outright confiscations, to forced sales, forced donations and abandonments. ${ }^{1704}$ The London Declaration is referred to in all cases where the Panel upheld the claim, except in the recommendation concerning the 'Still Life' in the collection of the Glasgow City Council, presumably for the reason that the loss had occurred within Germany rather than in an occupied territory, and as such does not fall under the scope of the London Declaration. Instead, in this case the Panel referred to the restitution principles adopted by the Allied Forces after the war with regard to the restoration of rights within Germany. The principles were based on the presumption that all transactions made in the period 1933-1945 by a person belonging to a persecuted group qualify as an act of confiscation. Only if positive evidence was provided according to which the transfer would also have taken place in the absence of National Socialism or resulted in the successful protection of a property interest of the original owner could the presumption be refuted. ${ }^{1705}$

The NMDC Statement of Principles is only referred to in the case of the Benevento Missal. Why the Panel chose to refer to the NMDC Statement of Principles is not so evident at first sight. While it stresses that the associated institutions share the concern for Nazi spoliated art and call for transparency and dialogue, it recognises the legal

${ }^{1703}$ The London Declaration refers to "any transfers of, or dealings with, property, rights and interests of any description whatsoever which are, or have been situated in the territories which have come under the occupation or control, direct or indirect, of the Governments with which they are at war, or which belong, or have belonged to persons (including juridical persons) resident in such territories". The London Declaration is not numbered; hence no specific reference to the quoted passage can be given.

${ }^{1704}$ Cf.: Schwarz, W., 1974, p. 15.

${ }^{1705}$ See further on the Allied restitution principles above in chp. 1.\$4. 
framework, including legal obstacles to disposal. ${ }^{1706}$ However, the Statement of Principles also states that "for the purposes of interpreting this document, wrongful taking shall mean any act of theft or other deprivation, the legality of which is open to reasonable challenge, and which was committed during the Holocaust and World War II period". Another reason for the Panel to explicitly refer to the NMDC Statement of Principles could have been that in 2000, under the auspices of the NMDC, the British Library published a "List of works with incomplete provenance during the period 1933 to 1945 ", which includes the missal. The entry significantly states that "the manuscript was not identified directly by research, but may have been spoliated during the Nazi period". 1707

The 1998 Washington Declaration, which we discussed in detail in Chapter 2 (\$1.III.1) has been explicitly referred to since the case of the Feldmann drawings in the British Museum. However, the Panel limited itself to pointing out that the declaration "stresses the need to achieve a just and fair solution". ${ }^{1708}$ For the sake of completeness it should be mentioned that the 1998 Washington Declaration had been annexed to all earlier recommendations.

While the Panel essentially limited itself to referring to or quoting a relevant passage from these documents, we can conclude from these references that the Panel wishes to apply a very broad notion as to transactions that may qualify for a remedy and that it will work with the presumption that all transactions made in the period 1933-1945 by a person belonging to a persecuted group qualify as an act of confiscation. From the analysis of the recommendations it becomes evident that the Panel recognises the existence of a moral claim in all cases where there existed a legal right that is no longer enforceable. In the understanding of the Panel, moral rights mirror legal claims as they existed after the war with the crucial difference that the moral claim is not subject to the lapse of limitation periods. Where a loss is not precipitated by demands of the Nazi regime but by commercial reasons, no moral force is recognised. ${ }^{1709}$

It must be admitted that the decision of the Panel to accept a moral claim on behalf of the City of Benevento for the return of the missal is difficult to fit into this dichotomy for the circumstances of the loss of the manuscript are not clear. Regardless of that, the Panel accepted as "central pillar of their case" vindicating their moral claim for the manuscript's return the claimants' argumentation that as an object of war time looting, the subsequent acquisition of the manuscript by the English captain in Naples in 1943 was both unlawful and immoral, and falls within the scope of the 1943 London Declaration. ${ }^{1710}$ While one could argue that the Panel applied the presumption of war-

1706 See in particular principles 2. 4; 2.5; 2.6 and 5.4 of the National Museum Directors' Conference (NMDC), 1998. Cf.: Palmer, N., 2000a, p. 27. See for a more detailed discussion of the 'Statement of Principles and Proposed Action': Range, D., 2004, pp. 665-667.

1707 Spoliation Advisory Panel, 2005, p. 62.

1708 Spoliation Advisory Panel, 2006b, para. 33.

1709 Spoliation Advisory Panel, 2006a, paras. 42 \& 48 (vii).

1710 Spoliation Advisory Panel, 2005, paras. 63 \& 66.63.. 
related loss to the Chapter Library, despite not belonging to the group of persecuted people, we cannot but conclude that the Panel might have overstretched its mandate in this case: 1711 the finding that the loss falls within the scope of the 1943 London Declaration is not correct in that the London Declaration warned the Axis powers and neutral countries that the signatory countries had the right to declare invalid any transaction within an occupied territory, regardless of the circumstances of the transaction (emphasis added). Italy was not an occupied territory but instead belonged to the Axis Powers.

Interestingly, the assessment of the moral strength of a claim is limited to the circumstances of loss in the years 1933-1945 and does not pay any regard to the developments in the post-war era. As outlined in Chapter $1(\$ 1 . \mathrm{V} / \$ 4)$, both the Allied Forces and Germany undertook great efforts with regard to external and internal restitution. The analysis revealed that where physical restitution was not an available option for the cultural object either being destroyed or lost, financial compensation was paid. Compensation for lost property was calculated according to the estimated replacement value at the time the compensation was granted. ${ }^{1712}$ While it would be naïve to assume that compensation has been paid in each case where physical restitution was not available, always corresponded to the market value or in all cases effectively reached the claimant, it is nevertheless a fact one could expect to be included in the discussion of what constitutes just and fair solutions. After all, compensation is paid with the intention to compensate the original owner for the loss. While one could argue that only physical restitution can remedy the loss of an art work, this is not the point of view adopted by the Panel, which recommended also ex gratia awards. Consequently, financial compensation is accepted as a form of "full and final settlement of claim". ${ }^{1713}$ If financial compensation awarded by the Panel is accepted as settling a claim, logic dictates that financial compensation received during the post-war period should also be taken into account. Unfortunately, the Panel has so far not reflected upon the relevance of compensation received in the past more in general. However, from the analysis of the Panel's recommendation it appears that financial compensation received in the past is considered of little relevance.

\footnotetext{
1711 See in this respect also the Consultation document discussed further below (chp. 4.\$1.II.2) on the introduction of legislation allowing for the disposal of objects spoliated in the Nazi era from national museums. DCMS also identifies the case of the Beneventan Missal as problematic as it would not fall under the definition of loss according to which it would be necessary for the claimants to demonstrate that the circumstances surrounding the loss were caused by the actions of the Nazis in the relevant period. DCMS mentions the option of introducing a separate provision to allow for the disposal of the missal. Department for Culture Media and Sport, 2006a, paras. 3.18-13.19.

1712 According to the BRüG, which was in particular relevant for those claims dealing with property that no longer existed or which had disappeared from either within or outside the German territory compensation for lost property was calculated according to the estimated replacement value as of April 1, 1956. See further on the BRüG above in chp. 1. J.4.IV.

1713 Spoliation Advisory Panel, Constitution and Terms of Reference, s 8.
} 
The aspect of financial compensation during the post war era was mentioned in three cases heard by the Panel. ${ }^{1714}$ In the case of the Griffier painting in the collection of the Tate Gallery and in the case of the 'Still Life' in the collection of the Glasgow City Council the Panel's reports mention that the original owner(s) of the painting had sought and been awarded compensation. In the case of the Griffier painting the Panel did not further investigate the compensation files, but was satisfied with the information that "the claim files do not make any reference to the Griffier painting". ${ }^{1715}$ In respect of the 'Still Life' formerly attributed to Chardin the Panel mentioned the fact that the Jewish shareholders had been paid DM 75,000 by the German Government as compensation for their loss on the sale. The Panel remarks that it had been informed that the sum received represented an overall payment for the entire loss of which only a fraction would be attributable to the painting and does not further reflect upon whether or not and if so to what extent such compensation should be taken into account in formulating just and fair solutions. ${ }^{1716}$ In two further cases the report suggests that the victimised family sought compensation after the war: the cases of the drawings from the Feldmann collection that were claimed from the British Museum respectively the Courtauld Institute.1717 However, the report does not further elaborate whether the claim was awarded and if so whether it included the drawings.

As for the cases in which no mention of past compensation payments was, we cannot exclude the possiblity that the claimants in the other cases might have received some form of financial compensation after the war. In order to establish this, a detailed analysis of the relevant archives, including the archives holding the files dealing with the restoration of rights under the German Federal Restitution Law BRüG, would be required.

Having discussed the fact that the moral strength of a claimant's case depends exclusively on the circumstances of loss in the period 1933-1945, we can now summarise how the Panel determines whether a holding institution is under any moral obligation. It appears from the recommendations that the moral obligation of the holding institution also focuses on the past, i.e. the moment when the institution

1714 After the main research of this study was closed in the beginning of June 2009, the Panel has issued its $9^{\text {th }}$ report, in which the Panel did take financial compensation payments received after the war into account. Spoliation Advisory Panel, 2009. According to the Panel, while the predominant reason for the sale of eight drawings now in the collection of the Courtauld Institute of Art in London in 1933 by the owner, Professor Dr Curt Glaser, was Nazi oppression, the moral claim was insufficiently strong to warrant the transfer of the drawings. In reaching this conclusion, the Panel took account of the fact that the sale prices achieved at the time were reasonable and that Dr Glaser's widow had received compensation from the German compensation authorities after the War. See further on the case in the epilogue.

1715 Spoliation Advisory Panel, 2001, paras. 8-9.

1716 Spoliation Advisory Panel, 2004, para. 24.

1717 Spoliation Advisory Panel, 2006b, para. 19; Spoliation Advisory Panel, 2007a, para. 10: "Heinrich Rosorius, the Nazi-appointed Trustee of the Feldmann estate, gave evidence in a compensation claim made in Germany that, when he took over in 1940 or 1941, the Gestapo had seized everything other than the villa itself and a briefcase containing some artistic drawings. Otherwise there is no evidence of the whereabouts of the collection until after the war". 
acquired the object. Depending on the circumstances of acquisition and the knowledge of the object's provenance at that moment in time, the Panel judges whether the institution lived up to the then applicable standards. In applying the standards the panel adopted a pragmatic account, taking into account also the amount of objects to be checked where the acquisition consisted of a greater group of objects (donation /bequest) and the resources available. Where the institution's provenance research failed to meet the applicable standards at the time of the acquisition, it is held to be under a moral obligation. Where an institution is held to be under no moral obligation, this does not mean that the institution will not have to return the disputed object concerned. Where the Panel accepts a moral claim on behalf of the claimant the object concerned will either be returned or the claimant will receive a financial payment. The question whether the institution is under any moral obligation is only relevant where the Panel has to decide upon the question who has to bear the costs of financial compensation. Where the museum is held to be under no moral obligation the Panel might opt for an ex gratia payment borne by the Government.

\section{Changing the law to extend the Possibility For museums to Dispose of OBJECTS THAT HAVE BEEN LOST DURING THE NAZI ERA?}

In five of the nine cases in which the Panel was asked to give a recommendation it was confronted with the situation that restitution was legally barred. ${ }^{1718}$ In the majority of cases the disposal of the disputed objects was prevented by statutory rules. Only in one case disposal was prevented by contractual impediments. ${ }^{1719}$ In fact, the need to broaden the power of national museums to allow for disposal in cases involving Nazi spoliated artworks had been pointed out by the UK Parliament at several occasions since 2000. In 2000, the Select Committee on Culture Media and Sport of the House of Commons concluded that the case for special treatment for cases of alleged wrongful taking during the period 1933 to 1945 had been convincingly established and that it would be absurd if restitution were not possible due to the dilatoriness of Ministers in DCMS. ${ }^{1720}$ At that point the Government thought about bringing legislation forward by an order under the Regulatory Reform Bill. ${ }^{1721}$ However, in 2003 during a follow up inquiry of the Culture, Media and Sport Committee of the British House of Commons it was recognised in dismay that no such order had been passed. ${ }^{1722}$ At that point the Government considered the need for legislative change to have evaporated. The

\footnotetext{
1718 Spoliation Advisory Panel, 2001; Spoliation Advisory Panel, 2004; Spoliation Advisory Panel, 2005; Spoliation Advisory Panel, 2006b; Spoliation Advisory Panel, 2008.

${ }^{1719}$ Spoliation Advisory Panel, 2004, para. 22.

1720 Seventh Report of Culture, Media and Sport Committee, Session 1999-2000, Cultural property: return and illicit trade, HC 371, para. 193.

1721 Cf.: Select Committee on Culture, Media and Sport Minutes of Evidence Examination of Witnesses (Questions 320-329), Q322 (Chairman).

${ }^{1722}$ First Report of Culture, Media and Sport Committee, Session 2003-04: Cultural objects: developments since 2000, December 2003 HC 59, paras. 59-62.
} 
expected flood of claims had not materialised and the Secretary of State had "come to rest on the absence of a recommendation of the Panel that its powers were inadequate to the task before them". ${ }^{1723}$

While the Secretary of State was correct in that the Panel had not made use of its power according to section 14 of its Terms of Reference to "recommend any action which they consider appropriate, and in particular (...) direct the attention of the Secretary of State to the need for legislation to alter the powers and duties of any institution" until 2003, the Panel did make such a recommendation two years later. In 2005, in its recommendation concerning the Benevento Missal in the collection of the British Museum, the Panel recommended to the Secretary of State that legislation should be introduced to amend the British Museum Act 1963, the British Library Act 1972, and the Museums and Galleries Act 1992 so as to permit restitution of objects in this particular category. ${ }^{1724}$

In July 2006, the Department for Culture, Media and Sport (DCMS) launched a consultation inviting views on how far a power to make restitution of objects lost during the Nazi era should extend, who should be responsible for taking decisions on restitution, and what continuing role the Panel should have. ${ }^{1725}$ One of the conclusions of the consultation was that there is great support for removing the statutory restrictions that stop museums from de-accessioning works of art lost during the Nazi era.

In response to the consultation, the UK government was planning on implementing legislation allowing for the disposal of Nazi spoliated artworks under moral grounds, claiming that "the Government are committed to introducing legislation as soon as possible to allow all national museums, that are currently prevented from doing so by the acts of parliament under which they are founded, to return works of art spoliated during the Nazi era."1726 The legislation was supposed to be a component of the Heritage Protection Bill. The Heritage Protection Bill was supposed to introduce a legislative framework for a unified and simpler heritage protection system. A draft of the Heritage Proctection Bill was published in April 2008. However, the draft was dropped in December 2008, apparently for the emergence of new priorities with the turbulence in the financial markets. ${ }^{1727}$

After the Heritage Protection Bill was dropped, the initiative to introduce legislation that allows for the de-accessioning of cultural objects from museums that are presently prevented from doing so was taken over by a Member of Parliament in the form of a

\footnotetext{
1723 Cf.: Select Committee on Culture, Media and Sport Minutes of Evidence Examination of Witnesses (Questions 320-329), Q321.

1724 Spoliation Advisory Panel, 2005, para. 77: “(...) we have come to the conclusion that it would be right to accede to the invitation of the Select Committee, and to recommend to the Secretary of State that legislation should be introduced to amend the British Museum Act 1963, the British Library Act 1972, and the Museums and Galleries Act 1992 so as to permit restitution of objects in this particular category".

1725 Department for Culture Media and Sport, 2006a.

1726 Copping, J., 18 October 2008.

1727 See, e.g.: http://www.english-heritage.org.uk/server/show/nav.20038 (last visited 18 May 2009).
} 
Private Member's bill. ${ }^{1728}$ The aim of the draft of this Holocaust (Stolen Art) Restitution Bill is to enable specified national museums to remove cultural objects spoliated between 1933 and 1945 from their collections and to return them to claimants when the return is recommended by an advisory body established by the Secretary of State and when the Secretary of State accepts that body's recommendation. Such an advisory body already exists in the shape of the Panel. The power to de-accession objects would apply only to those cases in which the Panel upheld the claim and recommended the return of the object, and in which the Secretary of State had accepted that recommendation. The Bill would not prescribe any return but would allow for de-accession with the final decision remaining with the museum trustees.

The Bill was presented to Parliament on 26 January 2009 for a First Reading. During a Second Reading on 15 May 2009 no Member of Parliament opposed it. ${ }^{1729}$ On 24 June 2009, the Government confirmed its backing for the Bill. The Bill is due to have its 3rd Reading and Report Stage in the Commons, where it was introduced, on Friday 26 June 2009. Given the Government support it is not unfeasible that the Bill will be adopted, thus finally enabling the national museums to remove cultural objects spoliated between 1933 and 1945 from their collections and to return them to claimants when the return is recommended by an advisory body established by the Secretary of State.

\section{INTERMEDIARY CONCLUSIONS FOR THE UNITED KINGDOM}

In the present section we have described the introduction of the Panel as an out of court mechanism to hear claims concerning objects lost during the Nazi reign. The Panel may make recommendations concerning objects in the possession of a UK national collection or in the possession of another UK museum or gallery established for the public benefit. Furthermore, the Panel may also make recommendations to private parties where both parties agree to the jurisdiction of the Panel (effectively committing themselves). In order to get a better understanding of the Panel's decisionmaking framework, in particular of the non-legal obligations to be taken into account, we took an inductive approach starting from the cases and recommendations of the Panel.

Our analysis revealed with regard to the timeframe/ situation of loss scrutinised by the Panel that it may assess all cases in which the loss of a cultural object occured during the years 1933-1945 and was to some extent precipitated by the Nazi reign. Where a transaction was the result of an economic situation, which had manifested itself prior to the year 1931, the Panel refused to recognise that the loss was precipitated by the Nazi reign. Furthermore, the assessment of the moral strength of a claim by the Panel does

\footnotetext{
$1728 \mathrm{http}: / /$ www.andrewdismoremp.com/uploads/3b30f5fe-4d99-49d4-c97f-c9a974611bc7.pdf (last visited 18 May 2009). See further on private Members' bills:

http://www.parliament.uk/about/how/laws/private_members.cfm (last visited 28 May 2009). 1729 http://services.parliament.uk/bills/2008-09/holocauststolenartrestitution.html (last visited 18 May 2009).
} 
not take into account the developments in the post-war era. Consequently, financial compensation received by claimants at an earlier stage is not taken into account when assessing the validity of a (moral) claim or the remedy to be accorded.

With regard to the balancing of the moral strength of a claim and the moral obligations that may rest on an institution, the analysis revealed that the crucial aspect is the moral strength of a claimant's case. Where the Panel accepts a moral claim on behalf of the claimant the object concerned will either be returned or the claimant will receive a financial payment, irrespective of whether or not the institution is found to have a moral obligation. An institution is held to be under a moral obligation when its provenance research at the time of acquisition did not live up to the standards applicable at that time. The question whether the institution has a moral obligation, is however relevant in view of the remedy chosen by the Panel.

The analysis of the remedies applied by the Panel revealed a preference of physical restitution of the object over compensation payments borne by the museum or the Government. The only situation where the Panel will decide against physical restitution (leaving aside rejected claims) is where the claimant explicitly opted for financial compensation and the object concerned is of sufficient quality and relevance to justify expenses by the institution or the Government. It is only in those cases where the museum is held to be under no moral obligation the Panel might opt for an ex gratia payment borne by the Government.

The emphasis on physical restitution has in a number of cases led to the situation that the remedy could not be provided for being prohibited in law. Whether the law, preventing the national museums from de-accessioning objects from their collections, will be changed in the near future, remains to be seen. Presently, all hopes are set on a Private Member's Bill. Should the bill fail, a slot would need to be found in the legislative programme of the Government. In any event, the legal changes as foreseen will not be compelling in nature; they would be limited to allowing for the implementation of the remedies as recommended by the Panel.

\section{FRANCE}

The investigation of the spoliation of Jewish people during World War II in France were triggered in particular by the publication of Hector Feliciano's book 'Le musée disparu' in 1995 criticising France's covert management of artworks spoliated by the Nazis. ${ }^{1730}$ The same year, the French Government took responsibility for the deportation of French Jews by the Vichy regime during World War II. ${ }^{1731}$ Also, at the end of 1995 a report by the French audit office (Cour des Comptes) criticised the French state and museum curators of failing to adequately publicise the existence of

${ }^{1730}$ Feliciano, H., 1995. In 1997, an English translation was published: Feliciano, H., 1997.

1731 Chirac, J., 1995. Cf.: Friedmann, E. / Weissberb, R., 2006, p. 135; Hershkovitch, C., 2006, p. 444. 
artworks recuperated after the war and to draw up a proper inventory. ${ }^{1732}$ In reaction to these developments, on 5 February 1997, the French Prime Minister established a committee with the task of:

"study[ing] the conditions in which movable and immovable property belonging to French Jews was confiscated, or more generally, obtained by fraud, under duress, or by misrepresentation, or by the occupying force as well as by the Vichy government, between 1940 and 1944". ${ }^{1733}$

The 'Study Mission on the Spoliation of Jews in France' is also known as the 'Mattéoli Committee', in reference to its chairman. ${ }^{1734}$

\section{The Mattéoli Committee}

In order to carry out its task the 'Mattéoli Committee' set up nine specialised study groups. One of the sub-groups focused on the looting of artworks (hereinafter: the 'Artworks Sub-Committee'). ${ }^{1735}$ This Artworks Sub-Committee studied the history and provenance of those artworks that had been recovered by France after the war and that were still under the custody of the French Museums. ${ }^{1736}$ This collection of works of art is known as Musées Nationaux Récupération (MNR).

The Artworks Sub-Committee established that after the war a total of 61,233 artworks had been recovered by France from the more than 100,000 artworks that had been spoliated during the occupation. ${ }^{1737}$ Put differently, almost 40,000 works had not been recovered after the war. Of the recovered works $74 \%$, i.e. 45,441 artworks had been returned to their original owners or their heirs by 1950.1738 With regard to the approximately museums remaining artworks a selection committee was appointed in 1949 to decide upon which of these artworks were of sufficient relevance and quality to be kept under French custody and which objects were to be sold. ${ }^{1739}$ Given the scarcity of sources documenting the work of this committee the criteria of the selection process

1732 Troisième Chambre de la Cour des Comptes, 1995. Cf.: Lichfield, J., 28 January 1997; Falconer, K.A., 2000, pp. 419-420.

1733 Mission-Mattéoli, 2000, p. 8.

1734 In French: la Commission pour l'indemnisation des victimes de spoliations intervenues du fait des législations antisémites en vigueur pendant l'Occupation.

1735 Cf.: Anglade, L., 2000, p. 150.

1736 Le Masne de Chermont, I. / Schulmann, D., 2000. Cf.: Anglade, L., 2000, p. 150.

1737 Le Masne de Chermont, I. / Schulmann, D., 2000, p. 34. Cf.: Anglade, L., 2000, p. 151; Hershkovitch, C., 2006, p. 443. The figures were confirmed by JP Bady in his presentation on 'The Policy of Compensation for Plundered Works of Art in France', London 18 October 2006, at the Conference on Dispute resolution and holocaust related art claims organised by the Institute of Art and Law. JP Bady is a member of the CIVS.

1738 Cf.: Ruzié, D., 2004, www.civs.gouv.fr/IMG/pdf/Livret_Ruzie_avril_07.pdf (originally published in: Liberté, justice, tolérance - Mélanges en l'honneur du Doyen Gérard Cohen-Jonathan (pp.1351-1370); Schnabel, G. / Tatzkow, M., 2007, p. 140.

1739 Décret $\mathrm{n}^{\circ}$ 49-1344 du 30 septembre 1949 relatif à la fin des opérations de la commission de récupération artistique (Journal officiel du 02.10.1949). Cf.: Anglade, L., 2000, p. 152. 
could not be retraced by the Artworks Sub-Committee. ${ }^{1740}$ From the roughly 16,000 objects, the selection committee selected less than 14\% (2,143 objects) to be kept under French custody. After having been exhibited from 1950-1954 in the National Museum of the Chateau de Compiègne, these artworks were spread over French museums where only their label on the stretcher 'MNR' as acronyum for Musées Nationaux Récupération identifies them as belonging to the collection of artworks recuperated after the war. The objects did, however, remain listed in the MNR inventory and did not become the property of the holding museums. ${ }^{1741}$ By decree, the museums were appointed to be "precarious holders" of the art works given into their custody, with the responsibility to preserve and exhibit them and to assist dispossessed collectors. ${ }^{1742}$ The 14,043 artworks that were considered of insufficient relevance or quality were auctioned off by the State Property Office. ${ }^{1743}$

As a result of the research of the Artworks Sub-Committee, whose main task it was to establish the provenance of each artwork of the MNR collection, 32 objects were returned to the (heirs of the) former owners. ${ }^{1744}$ The objects that could not be returned on the basis of the research of the Artworks Sub-Committee remained in the MNR Collection subject to supervision by the Directorate of the Musées de France. In view of future decisions to be taken for these artworks the Artworks Sub-Committee divided the works into three categories: first, objects for which there exist proof beyond reasonable doubt that they were spoliated by the Nazis. This category is the smallest one comprising only $10 \%$ of the objects from the MNR collection. The second and largest category consists of objects that had been bought by Germans on the Parisian art market. According to the research of the Artworks Sub-Committee this category accounts for $65 \%$ of the objects now in the MNR collection. The final category consisted of those remaining $25 \%$ of objects whose provenance and circumstances of loss could not be established. ${ }^{1745}$

The Artworks Sub-Committee did not make further recommendations as to future measures to be taken with regard to these three categories but left this to the Mattéoli Mission. Also, and in accordance with its mandate to focus on objects in the MNR Collection, the Artworks Sub-Committee did not elaborate upon the approximately

\footnotetext{
1740 Le Masne de Chermont, I. / Schulmann, D., 2000, p. 37. Cf.: Anglade, L., 2000, p. 152.

1741 Cf.: Country Reports of the conference "Spoils of War and Restitutions. The Destiny of French Works of Art During the Second World War", Paris, 17 November 1996, http://www.dhh3.de/biblio/bremen/sow3/crfrance.htm; Bourlet, M., 1997, pp. 113-114; Feliciano, H., 1997, pp. 214 \& 218-219; Falconer, K.A., 2000, p. 419.

1742 Décret $\mathrm{n}^{\circ}$ 49-1344 du 30 septembre 1949 relatif à la fin des opérations de la commission de récupération artistique (Journal officiel du 02.10.1949). Cf.: Falconer, K.A., 2000, p. 419

1743 Cf.: Anglade, L., 2000, p. 152.

1744 Cf.: Ibid., p. 153. See for a list of all objects that have been returned from the MNR Collection until June 2009:

http://www.culture.gouv.fr/public/mistral/mnrbis_fr?ACTION=CHERCHER\&FIELD_4=LOCA\&VA LUE_4=Restitu\%e9\&DOM=All\&REL_SPECIFIC=1 (last visited 25 June 2009).

${ }^{1745}$ Le Masne de Chermont, I. / Schulmann, D., 2000, pp. 60-69. Cf.: Anglade, L., 2000, p. 153.
} 
40,000 artworks that had not been recovered after the war and whose present locations are unknown. This category of spoliated artworks was, however, addressed in the final report of the Mattéoli Mission discussed in the following section.

\section{The REPORTS to THE PRIME Minister}

The Mattéoli Mission issued two interim reports in December 1997 respectively February 1999 before publishing its final report in April 2000. ${ }^{1746}$ In its second interim report the Mattéoli Mission proposed the creation of an indemnification commission do deal with financial wrongs that had not yet been addressed. ${ }^{1747}$

In its final report the Mattéoli Mission made nineteen recommendations on the future course of restoration of rights in France. The recommendations deal with the following aspects: access to and preservation of archives (recommendations no. 1-4), subjects on which future research is required (recommendations no. 5-7), the assessment of individual claims (recommendations no. 8-10), the establishment of a memorial foundation (recommendations no. 11-12), artworks (recommendations no. 13-17), as well as bank accounts and insurance policies (recommendations no. 18-19). ${ }^{1748}$

Further to recommendations 13-17 dealing specifically with artworks (mainly objects in the MNR Collection and to a lesser extent with artworks that had not been recovered and whose present locations are unknown), the recommendations dealing with archives, future research and the assessment of individual claims are also relevant for the treatment of claims dealing with spoliated art. In the following we will discuss the relevant principles starting with the more general ones.

With regard to archives, the Mattéoli Mission pleaded for better access to and indexing of public and private archives. ${ }^{1749}$ Furthermore, in view of future research, the Mattéli Mission stated the necessity of taking measures for the conservation of archival sources and of preserving its own research findings. ${ }^{1750}$ As to subjects requiring further research the Mattéoli Mission pointed to the provenance of artworks in the collections of the Musées de France. While the Mattéoli Mission recognised that much work had been undertaken in identifying works, whose provenance did not rule out the possibility of having been spoliated, it argued for continuation of this research. ${ }^{1751}$ Such research could not only contribute to identifying former owners of objects from the MNR Collection but could also result in the identification of artworks that had never been officially recovered by France but that had nevertheless found their way into the collections of the Musées de France.

\footnotetext{
1746 Cf.: Friedmann, E. / Weissberb, R., 2006, pp. 135-136.

1747 Mission d'étude sur la spoliation des Juifs de France: rapport d'étape: janvier - décembre 1998, 1999.

Cf.: Friedmann, E. / Weissberb, R., 2006, pp. 135-136.

${ }^{1748}$ Mission-Mattéoli, 2000, pp. 168-173.

${ }^{1749}$ Ibid., Recommandation no 1, p. 168. Cf.: Anglade, L., 2000, p. 156.

${ }^{1750}$ Mission-Mattéoli, 2000, Recommandation no 2-4, p. 168-169.

1751 Ibid., Recommandation no 5, p. 169.
} 
In light of the special situation of artworks from the MNR Collection compared to other spoliated objects or artworks whose present locations are unknown, the Mattéoli Mission issued a number of specific recommendations: artworks that were not spoliated by the Nazis should become the legitimate property of the French museums. ${ }^{1752}$ Artworks that were either spoliated with certainty or which have been the subject of forced sales should stay in the collections of the Musées de France for the present to allow for the pursual of a double objective consisting of the return of the objects and the education of the public. As specific measures to achieve these two aims, the Mattéoli Mission suggested to make the MNR catalogue widely and easily accessible to the public; to include information on the provenance when exhibiting the artworks and to launch a special MNR Internet site. ${ }^{1753}$ In order to allow for greater exposure, the Mattéoli Mission also recommended the exhibition of spoliated art works in museums in Jerusalem. ${ }^{1754}$ To encourage future commitment and to increase transparency the Mattéoli Mission recommended the publication of an annual report by the board of the Musées de France on their progress concerning restitution and the information of the public. ${ }^{1755}$

With regard to approximately 40,000 artworks that had not been recovered after the war the Mattéoli Mission proposed to intensify and to systematise the efforts to recover these objects. As concrete measure the Mattéoli Mission recommended the introduction of a new permanent body assigned with this task. While the Final Report does not elaborate upon the specific form of this body it suggested the following three tasks: to complete and update the inventory of all artworks that have been claimed and are still missing; to undertake research on these claimed and missing objects and to actively seek the recovery of these objects. With regard to the latter the Final Report stresses the need of international co-operation and suggested the establishment of crossborder governmental bodies with Russia, Austria and Germany. ${ }^{1756}$

With regard to the indemnification of individual claims for objects the Mattéoli Mission states as general principle that such loss must be compensated regardless of any lapse of prescription periods. ${ }^{1757}$ However, given the findings of the Mattéoli Mission that a great number of spoliated objects had either been restituted after the war or their loss had been compensated under French or German legislation the Mattéoli Mission

\footnotetext{
1752 Ibid., Recommandation n 13, p. 174. Cf.: Anglade, L., 2000, p. 155.

1753 Mission-Mattéoli, 2000, Recommandation n 14, pp. 171-172. Cf.: Anglade, L., 2000, p. 155. The third measure has been implemented at the following website:

http:/ /www.culture.gouv.fr/documentation/mnr/pres.htm\# (last visited 21.01.2009).

1754 Mission-Mattéoli, 2000, Recommandation $n^{\circ}$ 15, p. 172. In 2008, an exhibition "To whom do these canvases belong? French policy on seeking the provenance, custodianship and restitution of art works spoliated during World War II" was held at the Israel Museum in Jerusalem (February 19 to June 4) and at the Musée d'art et d'bistoire du Judaïsme in Paris (June 24 to September 28).

1755 Ibid., Recommandation $n^{\circ} 16$, p. 172.

1756 Ibid., Recommandation n 17, p. 172. Cf.: Anglade, L., 2000, p. 157.

1757 Mission-Mattéoli, 2000, Recommandation n 8, p. 170.
} 
stressed that compensation must be limited to those cases in which the rightholders had not been compensated in the past. ${ }^{1758}$

\section{COMMISSION POUR L'INDEMNISATION DES VICTIMES DE SPOLIATIONS INTERVENUES DU FAIT DES LÉGISLATIONS ANTISÉMITES EN VIGUEUR PENDANT L'OCCUPATION (CIVS)}

In reaction to the proposal of the Mattéoli Mission concerning the establishment of a non-adversarial claims resolution body the 'Commission pour l'indemnisation des victimes de spoliations intervenues du fait des législations antisémites en vigueur pendant l'Occupation' (in short and hereinafter: CIVS) was created in September 1999. ${ }^{1759}$ As the name indicates, CIVS hears claims that seek compensation for the spoliation resulting from anti-semitic legislation in force in France during the Occupation.

CIVS constitutes a new procedure created in law that functions outside the court system and whose frame of reference is not limited to the strict letter of the law. ${ }^{1760}$ CIVS is asked to adopt a pragmatic attitude and to seek solutions where courts actions are barred due to lapse of limitation periods. ${ }^{1761}$ The commission has a broad "jurisdiction" dealing with claims for material or financial spoliation, including the forced seizure of companies, looting of equipment, furniture, apartments, blocked bank accounts, insurance policies and other valuables including artworks. ${ }^{1762}$

\footnotetext{
1758 Ibid., Recommandation nº 9, p. 170 ; Ruzié, D., 2004, www.civs.gouv.fr/IMG/pdf/Livret_Ruzie_avril_07.pdf (originally published in: Liberté, justice, tolérance Mélanges en l'honneur du Doyen Gérard Cohen-Jonathan (pp.1351-1370).

1759 Decree No. 99-778 of 10 September 1999, establishing a Commission for the Compensation of Victimes of Spoliation under the anti-Semitic Legislation in force during the Occupation (Décret 99-778 du 10 Septembre 1999) avialable at:

http://www.legifrance.gouv.fr/affichTexte.do?cidTexte $=$ LEGITEXT000005628500\&dateTexte $=20090120$ (last visited: 20 January 2009). The recommendation to create such a body was made by the Mattéoli Mission in its second interim report: Mission d'étude sur la spoliation des Juifs de France: rapport d'étape: janvier décembre 1998, 1999. Cf.: Friedmann, E. / Weissberb, R., 2006, pp. 135-136.

1760 Palmer, N., 2000a, p. 104.

1761 Cf.: the Preamble of the Decree according to which "[i]t is not contemplated to create a body of a jurisdictional nature since [a judicial body] would often have to reject the claims. On the contrary, the Commission (...) shall proceed to the examination of the files by taking all of their aspects into account. It should try to reconcile the parties with a view to obtaining an agreement between the claimant and the relevant institution. In case it fails to reach such an agreement, the Commission may issue recommendations". Cf.: Anglade, L., 1999, p. 308 who interprets the edict as insisting, "that the new Commission must act in a pragmatic and efficient way in order to avoid the undue complications sometimes caused by legal formalism".

1762 According to Art. 1 of the Decree of 10 September 1999 the task of the CIVS is "[t]o examine individual claims emanating from victims of their families in order to indemnify them for the damages they have sustained as a result of the looting of properties which occurred by the operation of the anti-Semitic laws adopted during the Occupation by the [Germans] as well as by the Vichy authorities". Cf.: Ibid., p. 307; Palmer, N., 2000a, pp. 104; Friedmann, E. / Weissberb, R., 2006, p. 139.
} 


\section{Claims DEALING WITH ARTWORKS: SPLIT RESPONSIBILITY BY CIVS AND THE ARCHIVES DEPARTMENT OF THE Ministry OF Foreign AFFAIRS}

Where a claim deals with spoliated artworks an application to CIVS is not the only procedure available to claimants. CIVS is first and foremost concerned with the evaluation of claims for indemnification, i.e. claims dealing with objects that are lost or no longer exist. Where the claim concerns an object presently in the MNR Collection, the main responsibility to decide on and to order the return of an object lays with the Archives Department of the Ministry of Foreign Affairs (Direction des Archives du Ministère des Affaires étrangères). ${ }^{1763}$ The Archives Department cooperates with the Directorate of the Musées de France that is in charge of the MNR Collection. While CIVS may also make recommendations in claims seeking the physical return of objects from the MNR Collection ${ }^{1764}$, the final decision on returning the object remains with the Archives Department of the Ministry of Foreign Affairs. ${ }^{1765}$ CIVS may also make recommendations concerning claims for the return of an object from a public collection designated as Musée de France. ${ }^{1766}$ It is not competent to make recommendations in cases dealing with objects in private collections. ${ }^{1767}$

In order to submit a claim to the CIVS, victims or their heirs have to send an informal letter to the CIVS, accompanied by all relevant documentation. ${ }^{1768}$ Each claim will be assigned to a "rapporteur" who is responsible for the further investigation of the claim, for hearing parties and witnesses and for consulting experts. ${ }^{1769}$ After the stage of preliminary investigations, cases are passed to the decision-making panel (sitting in either plenary or restricted formation) for final examination. The final decision-making of CIVS is based on equitable principles. In the absence of absolute proof, CIVS will take the following aspects into account: the probability of the loss in the light of the circumstances during the Nazi reign, the sincerity of the claimant, the moment since when and the consistency in pursing the claim, as well as the absence of other competing claims. When CIVS reaches the conclusion that a claim is valid and should be acknowledged it can choose between the following measures: returning the object, compensation payments, or other measures of reparation. ${ }^{1770}$ The amount of the compensation payments is based of the value of the work at the date of plunder, as

\footnotetext{
1763 Commission pour l'indemnisation des victimes de spoliations intervenues du fait des législations antisémites en vigueur pendant l'Occupation' (CIVS), p. 18.

1764 Cf.: Ibid., p. 19.

1765 Cf.: Ibid., pp. 18-19; De Bastier, M., 2009, Re: questions en concernant le service de CIVS à propos la restitution / l'indemnification des objets d'arts. Email dated 23 June 2009 on file with the author.

1766 De Bastier, M., 2009, Re: questions en concernant le service de CIVS à propos la restitution / l'indemnification des objets d'arts. Email dated 23 June 2009 on file with the author.

1767 Ibid.

1768 Art. 4 of the Decree of 10 September 1999.

1769 Ibid.

1770 Art. 1 of the Decree of 10 September 1999.
} 
adjusted by the price index reflecting the average change in prices between the war years and the presence.

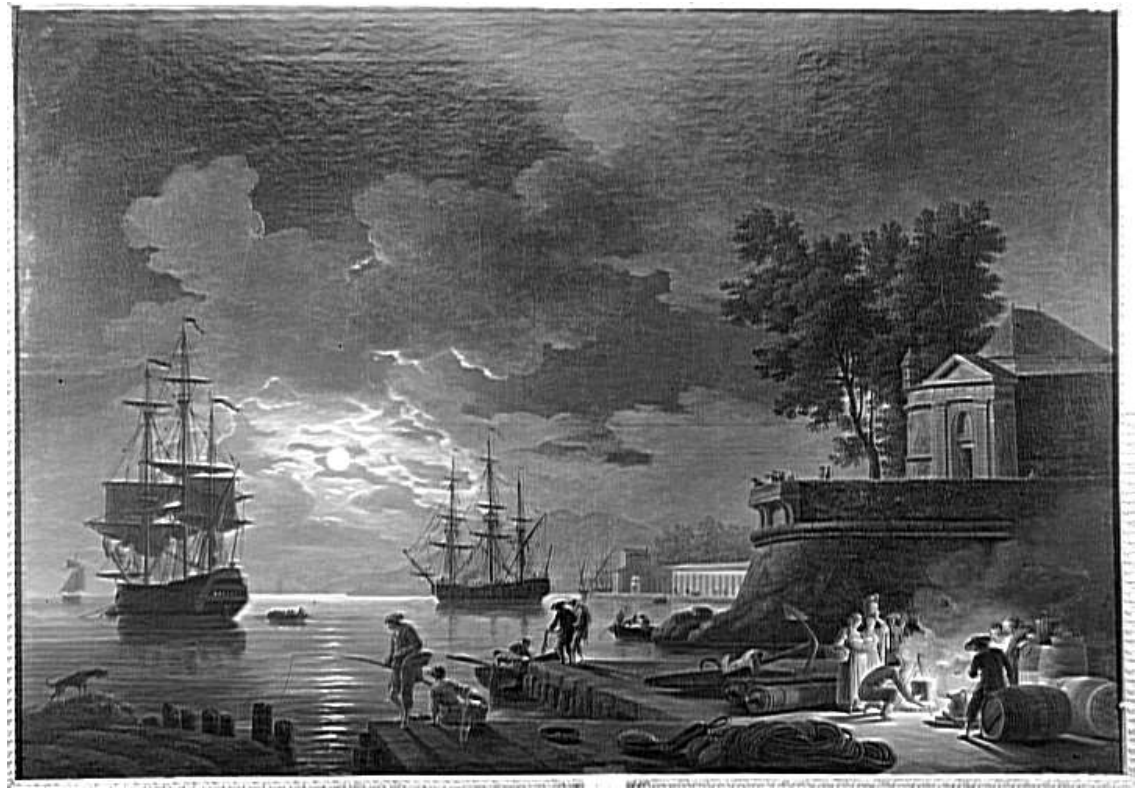

Joseph Vernet, Marine, clair de lune, oil on canvas, 115x $163 \mathrm{~cm}$. CRéunion des musées nationaux.

As part of its investigations, CIVS checks whether the claims submitted have not already been the subject of compensation by France under the 1946 Act on War Damage ${ }^{1771}$ or under the German Federal Restitution Law (BRüG). ${ }^{1772}$ For this purpose the CIVS operates an office in Berlin with the task to study the files on the application of the BRüG in view of possible applications for damages in the past. ${ }^{1773}$ In those cases where compensation had been received a claim is denied. Where only partial compensation was received, CIVS may order for supplementing the amount. ${ }^{1774}$ The

${ }^{1771}$ Law 46-2389 of October 28, 1946 (Loi n46-2389 du 28 octobre 1946 Réparation des Dommages) put forth the principle of full compensation for direct material damage caused by acts of war to personal property, real property and business assets. All victims of events occurring during World War II were eligible for this compensation. These measures therefore benefited both victims of anti-Semitic laws and other war victims. Claims under this act were administered by the Ministry of Reconstruction and Housing (M.R.L.). Source: http://www.civs.gouv.fr/spip.php?article580.

1772 Information Brochure: Commission for the Compensation of Victims of Spoliation Resulting from the Anti-Semitic Legislation in Force during the Occupation (CIVS), p. 3; Kalfon, L., 2006, p. 437. Given the destruction of relevant files in French archives in the years 1957-1970 the BRüG files also serve as important source on restitutions under French law as the files often bear information on damages paid by the French State. Cf.: Friedmann, E. / Weissberb, R., 2006, p. 139.

1773 See for a description of the BRüG above in chp. 1.\$4.IV.

1774 Kalfon, L., 2006, p. 439. 
files of the hearings and recommendations by CIVS are not available to the public. ${ }^{1775}$ For this reason, different from the previous sections discussing the Dutch and UK situation, no case studies are included.

Recommendations by the CIVS are non-binding with the final decision-making power resting upon the Prime Minister. ${ }^{1776}$ Where compensation payments are ordered they are paid by the department of the Prime Minister. The possibility for appeal is limited to the emergence of new facts or clerical error.

Since the establishment of the CIVS until the end of 2008, the CIVS had received 25,542 claims, all losses combined. ${ }^{1777} 1593$ files concern claims that deal with cultural objects in the broad sense, including furniture. 1253 of the files have been handeld so far. Of these files, 389 concern missing cultural objects. ${ }^{1778} 797$ cases dealt with missing furniture. In two cases CIVS recommended restitution. Both cases concerned objects in the MNR Collection. ${ }^{1779} 65$ claims were rejected as the claims did not fall under the jurisdiction of CIVS. ${ }^{1780}$

1775 De Bastier, M., 2009, Re: questions en concernant le service de CIVS à propos de la restitution / l'indemnification des objets d'arts. Email dated 23 June 2009 on file with the author.

1776 During a presentation in October 2006 it was reported that up until then all recommendations by the CIVS had been followed and implemented. Cf.: Presentation by JP Bady 'The Policy of Compensation for Plundered Works of Art in France', London 18 October 2006, Conference on Dispute resolution and holocaust related art claims organised by the Institute of Art and Law.

1777 Cf.: Commission pour l'indemnisation des victimes de spoliations intervenues du fait des législations antisémites en vigueur pendant l'Occupation' (CIVS), p. 17.

1778 The present numbers do not mention in how many cases CIVS recommended compensation payments. The numbers presented in the annual report of 2006 represented the following numbers: of the 107 files dealing with artworks in the narrow sense, CIVS approved 71 compensation payments. In ten of the cases the payments were supplementing earlier payments received under the BrüG. 34 claims were denied and in two cases restitution was recommended. Cf.: Commission pour l'indemnisation des victimes de spoliations intervenues du fait des législations antisémites en vigueur pendant l'Occupation' (CIVS), pp. 13-14.

1779 Both cases concerned paintings from the MNR collection: in the first case paintings by Vernet, "Marine, Clair de Lune" and Courtois, "Bataille contre les Turcs" were returned to the heirs of Maurice Lehamnn (http://www.culture.gouv.fr/public/mistral/mnrbis_fr?ACTION=RETROUVER\&FIELD_4=LOCA\&V ALUE_4=Restitu $\%$ e9\&NUMBER=8\&GRP=0\&REQ=\%28\%28Restitu $\%$ e9 $\% 29 \% 20 \% 3 \mathrm{aLOCA} \% 20 \% 29$ $\& U S R N A M E=$ nobody $\& U S R P W D=4 \% 24 \% 2534 P \& S P E C=1 \& S Y N=1 \& I M L Y=\& M A X 1=1 \& M A X 2=10$ $\&$ MAX3 $=50 \& D O M=$ All

http://www.culture.gouv.fr/public/mistral/mnrbis_fr?ACTION=RETROUVER\&FIELD_98=ATIT\&V ALUE_98 $=$ Marine $\& N U M B E R=9 \& G R P=0 \& R E Q=(($ Marine $) \% 20 \% 3$ AATIT $\% 20) \& U S R N A M E=$ nobody $\&$ USRPWD $=4 \% 24 \% 2534 \mathrm{P} \& S P E C=\& S Y N=1 \& \mathrm{IMLY}=\& \mathrm{MAX} 1=1 \& \mathrm{MAX} 2=1 \& \mathrm{MAX} 3=50 \& \mathrm{DOM}=\mathrm{All}$ (last visited 25 June 2009). The second case concerned the painting “Tête de femme" by Pablo Picasso. The painting originally belonged to Alphonse Kann. His art collection was spoliated by the German troops. In 1945 the painting was restored to France where it became part of the MNR Collection and was kept in the Musée Nationale d' Art Moderne (Centre Georges Pompidou). In 1998, the heirs of Kann sought the return of the painting. In May 2002, the CIVS recommended the return of the painting, which was effected in 2003. (http://www.culture.gouv.fr/public/mistral/mnrbis_fr?ACTION=RETROUVER\&FIELD_1=Caut\&VA LUE_1=picasso\&FIELD_2=Cdate\&VALUE_2=\&FIELD_3=Ctitre\&VALUE_3 $=$ tete\&FIELD_4=LOC A\&VALUE_4 $=\&$ FIELD_5 $=$ Ctexte\&VALUE_5 $=\& F I E L D \_6=$ Domaine\&VALUE_6 $=\&$ NUMBER $=1 \&$ GRP $=0 \& R E Q=\% 28 \% 28$ picasso $\% 29 \% 20 \% 3$ AAUTR $\% 2$ cAATT $\% 2$ cATTR $\% 2$ cECOL $\% 20 \% 20$ ET $\% 20 \% 2$ 0\%28\%28tete $\% 29 \% 20 \% 3$ aTITR $\% 2$ cATIT $\% 2$ cAUTI $\%$ 2cPTIT $\% 2$ cDENO $\% 2$ cDESC $\% 2$ cSUITE $\% 20 \% 29$ $\% 29 \& U S R N A M E=$ nobody $\& U S R P W D=4 \% 24 \% 2534 \mathrm{P} \& S P E C=9 \& S Y N=1 \& I M L Y=\& M A X 1=1 \& M A X 2$ 


\section{INTERMEDIARY CONCLUSIONS FOR FRANCE}

In the present section we have summarised the findings of the Mattéoli Committee with regard to the looting of art works from France and their recovery and have further analysed the CIVS as the non-adversarial claims resolution body, which was established by the French Government in reaction to the findings of the Mattéli Committee. CIVS is different from the bodies introduced in the jurisdictions discussed so far in that it does not deal solely with claims dealing with art works. Instead, works of art constitute only one category of assets dealt with by CIVS. In as far as claims dealing with artworks are concerned CIVS is first and foremost competent to deal with claims seeking compensation for missing art works. Where objects are presently held in the MNR Collection or a public collection designated as Musée de France, the most suited institution to contact is the Archives Department of the Ministry of Foreign Affairs.

The framework governing the decision-making of CIVS, or the 'doctrine' as CIVS refers to it in order to distinguish it from the judicature ${ }^{1781}$, takes a lenient approach towards the required proof with regard to former ownership of an object and with regard to the involuntary circumstances of the loss. Where no conclusive evidence can be provided, CIVS works on the basis of probabilities. Where the former ownership and loss of the object as result of the measures of the Vichy regime or the German occupation is probable, CIVS will recommend the return of the object or, where this is not possible, the payment of compensation. Where prior compensation has been received, a claim will be denied, or, where only partial compensation was received, supplementary compensation will be recommended.

\section{§2. HUMAN REMAINS}

\section{The Netherlands: VARIOUS FORMS OF SELF-gOVERNANCE AT MUSEUM LEVEL}

In the Netherlands no official policy on the return of human remains from public collections has been endorsed by the Dutch Government. Consequently, we will have to rely upon case studies to extrapolate the principles applicable to the return of human remains from Dutch public collections. At the time we collected the research material for the case studies only two cases involving requests for the return of human remains

=10\&MAX3=50\&DOM=All (last visited 25 June 2009). Cf.: Schnabel, G. / Tatzkow, M., 2007, p. 398 ; Presentation by JP Bady 'The Policy of Compensation for Plundered Works of Art in France', London 18 October 2006, Conference on Dispute resolution and holocaust related art claims organised by the Institute of Art and Law.

1780 De Bastier, M., 2009, Re: questions en concernant le service de CIVS à propos la restitution / l'indemnification des objets d'arts. Email dated 23 June 2009 on file with the author. Cf.: Commission pour l'indemnisation des victimes de spoliations intervenues du fait des législations antisémites en vigueur pendant l'Occupation' (CIVS), .

1781 Deutscher Bundestag (Ausschuss für Kultur und Medien), 2007, p. 11,

http://www.bundestag.de/ausschuesse/a22/anhoerungen/raubkunst/a22_Prot31.pdf. 
from a public collection in the Netherlands had been decided: the case of the "West Frisian Eskimo" from the collection held by the Westfries Museum in Hoorn and the case of the Toi Moko from the collection held in the National Museum of Ethnology (Rijksmuseum voor Volkenkunde) in Leiden. In reaction to these two cases and the developments abroad a third institution - the KIT Tropen Museum in Amsterdamdecided to not await an actual claim but to reflect upon its policy with regard to human remains in a pro-active manner. This initiative of the KIT Tropen Museum has been studied as a third case study.

More recently, a number of new claims have been received by Dutch public collections. While these cases will not be analysed for having occurred only after we concluded the gathering of material for case studies, we will shortly introduce them. Only one of the cases is international in character; the other one is an intra-Dutch claim: in 2007 an interest group consisting of Dutch citizens from the village of Urk requested the return of eight skulls presently in the collection of the University Museum in Utrecht. ${ }^{1782}$ The skulls had been removed for scientific research purposes from the local cemetery during the $19^{\text {th }}$ century. ${ }^{1783}$ Until the end of 2008, no agreement had been made between the interest group, seeking the reburial of the skulls and the University Museum, wishing to preserve them as important objects representing part of Dutch scientific history. The second case, which is international in character, concerns the head of the former Ghanaian King Badu Bonsu II. The head, preserved in formaldehyde had entered into the collection of Leiden University's Medical Laboratory in the second half of the $19^{\text {th }}$ century. It was discovered by Dutch writer Arthur Japin who started an initiative to return the head to Ghana on personal title. At some point, the Ghanaian Government officially took up the request for the return of the head. By the time we had finalised our research, the Dutch Government announced to return the head. The details of the return were yet to be discussed. ${ }^{1784}$

The case notes are presented in chronological order. Each case note starts with the summary of the main facts and then describes the discussions and developments with regard to the request for return, respectively repatriation of human remains more in general in the first case study. The case studies will be concluded with the identification of the main principles that governed the decision-making process. As conclusion of this section on the repatriation of human remains from Dutch public collections we will compare the principles thus identified with each other in order to see whether there

1782 See http://www.urkerschedels.blogspot.com/ (last visited 19 April 2009). Until 1939, when Urk became conntected to the mainland by a dyke, Urk was an island in the Zuidersee. This isolation made the study of its inhabitants of particular interest to Dutch physical anthropology. It was believed that the people of Urk represented the archaic inhabitant, the "Batavus genius" of the territory now constituting the Netherlands. Cf.: Lubina, K.R.M., 2007, p. 84. See, e.g.: Harting, P., 1853.

1783 The skulls were taken by J.F. van Hengel, a doctor from Hilversum in 1877. Having sent away the guard of the cemetary he exchanged the skulls with other skulls he taken along for this purpose.

1784 Leiden geeft hoofd Badu Bonsu II terug, 21 March 2009. The head was returned on 23 July 2009, after this research had been concluded. See, e.g.: Dutch return Ghana chief's severed head, 2009,

http://www.nrc.nl/international/Features/article2309332.ece/Dutch_return_Ghana_chiefs_severed_head. 
exists common grounds. The evaluation of the principles against the international developments will be presented at the end of the chapter, together with the principles to be extracted for the UK and French situation.

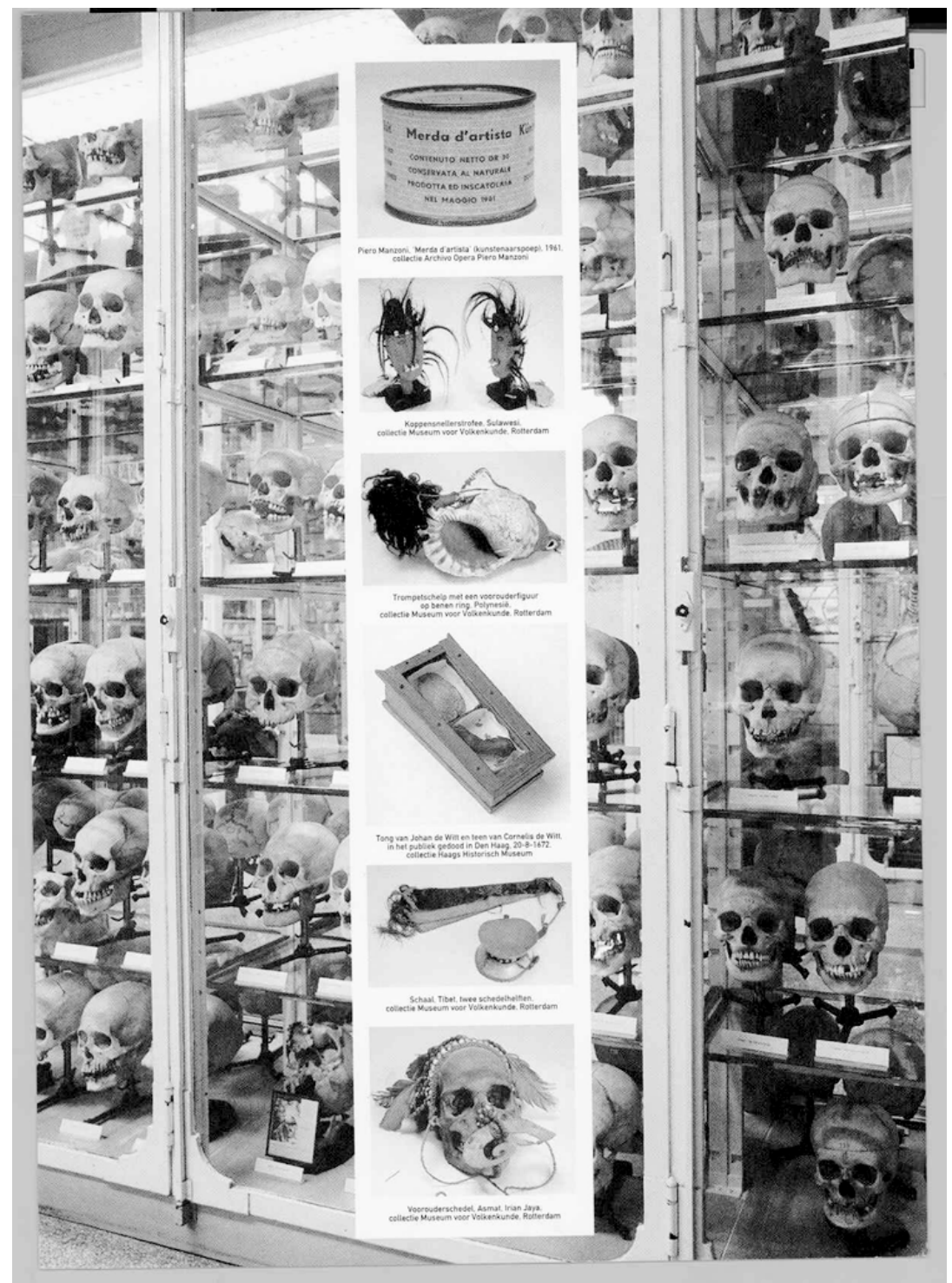

Flyer from the exhibition at the museum Kunsthal Rotterdam titled "Bone by Bone - human remains in museums", 7 November 1998 - 10 January 1999. The exhibtion gave an overview of human remains from Dutch public collections. See further on the exhibition in the section below discussing the case of the "West Frisian Eskimo". 


\section{The "WeSt Frisian ESKIMO" FROM the COLlection OF the WestFries MUSEUM IN HOORN}

a) The Facts

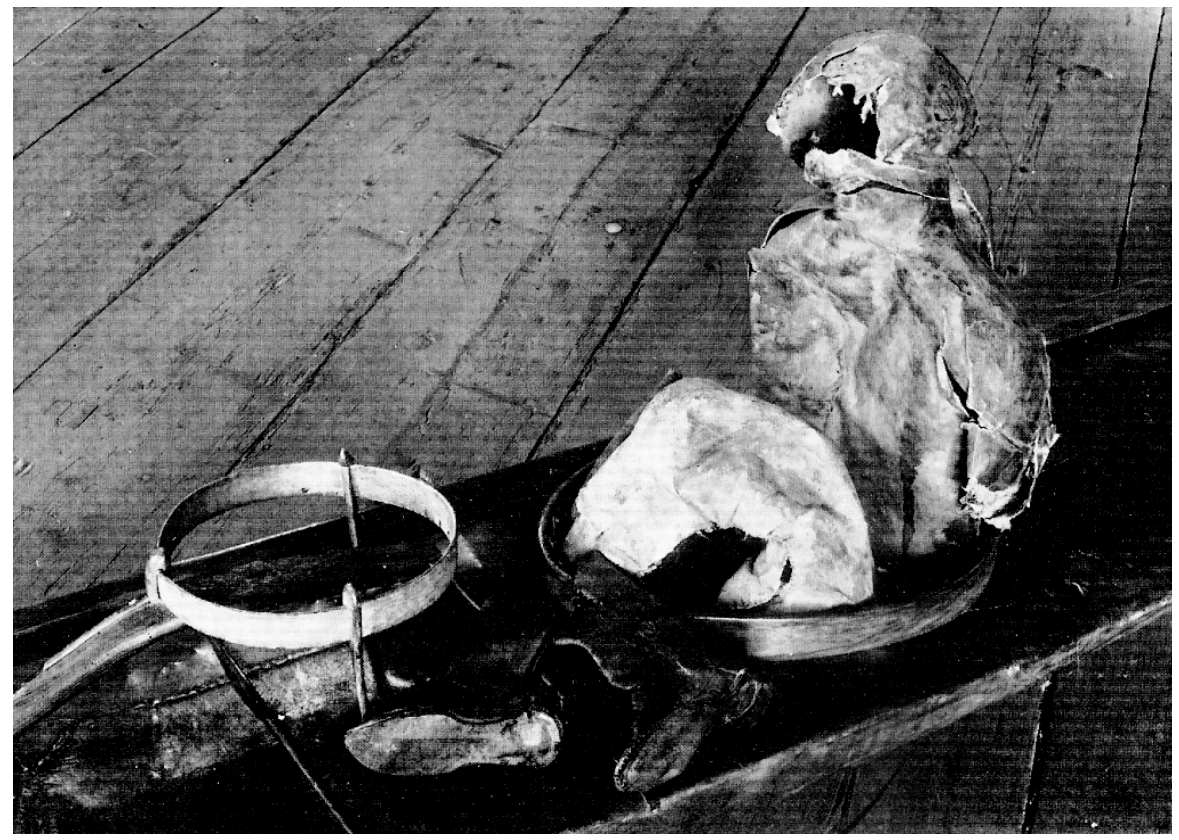

Photo of the remains and the kayak from G. Nooter's book on 'Old Kayaks in the Netherlands', 1971, p.

29.

In 1998, the Westfries Museum, which is situated in the city of Hoorn in the province of North Holland, was the first public institution in the Netherlands to receive a claim for the return of human remains. While the museum was the addressee of the claim, it is not the owner of the collection. Instead, the collection is owned by the city of Hoorn. The contested human remains were parts of the skin of an arm, hand, back, torso and head of a man. The provenance of the remains, as well as the exact circumstances of when and how they were introduced to the collection are unknown. According to oral tradition, the remains were that of a dead man in a kayak, which was found close to the Dutch shore probably in the early $19^{\text {th }}$ century. ${ }^{1785}$ Both the kayak

1785 In a study published in 1971 on "Old Kayaks in the Netherlands" the following information is provided on the kayak and the human remains: "In Hoorn not only the kayak but also the skin of the Greenlander found dead in the kayak at sea are to be seen" (Nooter, G., 1971, p. 7). With regard to the human remains the author continues: "It (...) seems difficult to explain the human skin kept with the kayak in Hoorn, which tradition says belonged to a man found in the kayak at sea, except by assuming that a man in his kayak had indeed approached close to the coast of The Netherlands" (p. 10). The fact that the earliest 
and the remains were part of the West Frisian museum's permanent exhibition and were presented to the public, in accordance with the style of the kayak, as being of "Eskimo origin".

While the presence of these alleged Inuit or Greenlandic remains in the Westfries Museum had been known to some representatives of Greenland since the beginning of the seventies ${ }^{1786}$, the official claim by Greenland for the return of the remains was made in 1998, after the matter had been discussed at the $8^{\text {th }}$ General Assembly of the Inuit Circumpolar Conference. ${ }^{1787}$

At the time when the Westfries Museum received the claim, it had just agreed to give the remains in loan for an exhibition on the subject of human remains in Dutch public collections. The exhibition at the museum Kunsthal Rotterdam titled "Bone by Bone human remains in museums" "1788 was scheduled from 7 November 1998 - 10 January

available report on the kayak, which dates from 1890, does not mention the human remains raises some doubts on the relationship between the remains and the kayak. The 1890 catalogue only mentions the "Eskimosche boot (kayak) van walvis ribben en zeehondvel vervaardigd, met pagaai en zitbank" Brouwer, D., 1890, p. 3. The 1891 catalogue, however, does mention the remains in connection with the kayak: “( ...) Het schijnt dat dit vaartuigje drijvende in zee werd aangetroffen met het lijk van een verdwaalde en van honger omgekomen man. Ouderen van dagen herinneren zich althans, dat zich een verdroogd in leder gekleed menselijk lichaam in het bootje bevond, (...). Dit menselijk lichaam is bij de verschillende verhuizingen langzaamerhand verdwenen (...)" Brouwer, D., 1891. Since then, the museum catalogue mentions the remains in connection with the kayak. E.g. the 1934 catalogue states: “(...) Het schijnt, dat dit vaartuig in zee drijvende werd aangetroffen met het lijk van een Eskimo er in. Niet zo lang geleden waren er nog menschen, die zich herinnerden, dat zich een verdroogd, in leder gekleed, menselijk lichaam in het bootje bevond, dat toen in één der zalen van de klinische school alhier was geplaatst. Ook de overblijfselen van den Eskimo zijn ondergebracht in het museum." With the museum catalogues not being conclusive on the question as to whether or not the remains were indeed those of the kayak's peddler, Nooter initiated investigations on the finger prints and for the determination of the hair typology. The investigations failed to provide a conclusive answer. While Nooter acknowledges the possibility that the remains were added to the kayak only at a later point, he concludes his analysis that "On the basis of the discussion in the introduction concerning the ways in which kayaks could have reached The Netherlands, with or without a paddler, it follows that this must certainly have been a Greenlander who escaped or was put over the side of a homeward-bound ship. The tradition cannot be verified, because the skin remnants did not permit exact determination". Nooter, G., 1971, p. 34

1786 The existence of the remains in the Westfries Museum was a.o. known as the Greenland National Museum and Archives closely cooperated with the Dutch anthropologist Gert Nooter, author of the 1971 study on "Old Kayaks in the Netherlands" who discussed the remains in his study (Source: Personal EmailCorrespondance with Claus Andreasen from the Greenland National Museum and Archives from 3 October 2007. On file with the author). Probably in reaction to Nooter's study, a group of Greenlanders visited the Westfries Museum in 1980. In 1993, an advisor on Greenlandic Affairs at the Danish Ministry of Foreign Affairs, Finn Lynge, visited the Westfries Museum. At that point, the remains were not exhibited but were kept in the deposit. It was not possible to get access to the remains in the deposit, but the inspection of the exhibited kayak revealed that what appeared at first sight as a kayak glove, were in fact the remains of the hand of the canoeist.

1787 The plan for repatriation was formulated at the 8th General Assembly of the Inuit Circumpolar Conference that took place in July 1998. (Source: Boekel, J.v. / Groot, G.d., 1998/1999, p. 1).

${ }^{1788}$ The original title in Dutch was: Botje bij Botje - Menselijke Resten in Musea. See above for the flyer of the exhibition. 
1999. When it became evident that the Westfries Museum wanted to go ahead with the loan developments accelerated.

Greenland fiercely opposed the inclusion of the remains in the exhibition. A meeting was called upon between the minister counsellor for Greenland to the EU, the Attaché of the Royal Danish Embassy ${ }^{1789}$, and 'Artic Peoples Alert'1790 on the one hand and the director of the Westfries Museum and other representatives from Dutch public collections ${ }^{1791}$ on the other. The meeting was cancelled at short notice when it became evident that the Westfries Museum was determined to go ahead with the loan. ${ }^{1792}$

After the meeting had been cancelled, representatives from other Dutch public collections - curators of the museum "Museon" in The Hague and the National Museum of Ethnology in Leiden sought to mediate between the parties and appealed to the Westfries Museum to refrain from the loan. After this proved not to have any effect, they appealed to the mayor of Hoorn, the Dutch State-Secretary of Culture, as well as the alderman of culture of the city of Rotterdam. But neither their efforts, nor efforts by the Dutch foundation Arctic Peoples Alert prevented the remains from being included in the exhibition that opened its doors to the public on 7 November 1998.

On 29 November 1998, the Danish Ambassador officially intervened on behalf of the Government of Greenland. ${ }^{1793}$ He requested the Dutch Minister of Foreign Affairs to persuade the Kunsthal to remove the Greenlandic human remains from the exposition. ${ }^{1794}$ On 20 January 1999, ten days after the exposition in the Kunsthal had ended, the Dutch Minister of Foreign Affairs informed the Danish ambassador that neither the Ministry of Education, Culture, and Science, nor the Ministry of Foreign Affairs had any responsibility for the collection held by the Westfries Museum, nor for the exposition policy of the Kunsthal Rotterdam: "[i]n the Netherlands, the Government is supposed to abstain from judging the independent and artistic content of art and culture". ${ }^{1795}$

1789 While Greenland has been granted self-government in 1979, its foreign affairs are exercised by Denmark, which explains the involvement of the Danish Embassy.

1790 Artic Peoples Alert is a Dutch foundation, which was established in January 1992. It had been asked by representatives from Greenland to locally support the repatriation claim. See e.g. letter from Emil Rosing, director of the Greenland National Museum and Archives to Artic Peoples Alert dated 9 November 1998 (on file with the author).

1791 The curator of the National Museum of Ethnology and the curator of the museum Museon.

1792 Fax by the director of the Westfries Museum, Ruud Spruit, to Peter Bettenhausen, conservator of the Museon Den Haag. Cf.: Bettenhaussen, P., 2000, p. VI.Bettenhaussen, P., 2000

1793 See above fn. 1789.

1794 Boekel, J.v. / Groot, G.d., 1998/1999, p. 1.

1795 Boekel, J.v. / Groot, G.d., 1999, p. 5: "Het is in Nederland gebruikelijk dat de regering zich onthoudt van het geven van meningen over de onafhankelijke en artistieke inhoud van kunst en cultuur". This quote is a direct reference to the so-called "Thorbecke principle". Thorbecke, who lived in the 19th century, was one of the most important Dutch politicians. As Minister of Internal Affairs he stated that "(...) the Government may make no judgement of the science and the arts". Handelingen Tweede Kamer, 1862/1862, Verslag p. 36. 
In the meantime, the Westfries Museum had announced that it was willing to consider returning the human remains to Greenland. While the ultimate decision lay with the city of Hoorn as the owner of the collection the attitude of the museum as holder of the collection was important in the decision-making process. In its deliberations, the Westfries Museum sought advice from the Dutch Museum Association (Nederlandse Museumvereniging (NMV)).

The Dutch Museum Association dates back to 1926 when it was founded as think tank of and for museum directors. Since then it developed into the umbrella organisation for the museum sector with tasks such as lobbying and development of policies. In 1991 it introduced the first Dutch version of the ICOM Code of Professional Ethics for Museums. ${ }^{1796}$ The same year an 'Ethical Code Committee' (hereinafter: NMV Ethical Code Committee) was founded to advise museums about the Dutch ICOM Code and to hold their behaviour against the Dutch ICOM Code. ${ }^{1797}$ The Dutch ICOM Code has been revised several times to reflect the changes made in the international ICOM Code. ${ }^{1798}$

When the Dutch Museum association received the request for advice by the Westfries Museum it referred the matter to the NMV Ethical Code Committee. However, the Director of the Dutch Museum Association saw it fit to ask the NMV Ethical Code Committee not only to advise on the specific case but to on the return of human remains more in general by appending the following questions:

1. Are there reasons speaking in favour of returning the remains of the so-called West Frisian Eskimo to Greenland?

2. Which requirements does a claim for repatriation have to meet?

3. Will the return of human remains be subject to conditions and which ones?

4. Does the decision to return human remains have to be considered as a precedent?

5. Does the problematic situation of this case justify the elaboration or revision of the Dutch ICOM Code?

6. What is the relationship between the return of human remains with that of cultural property in general? 1799

\footnotetext{
${ }^{1796}$ See further on the international ICOM Code above in chp. 2.\$2.IV.3.

$1797 \mathrm{http}: / /$ www.museumvereniging.nl/default.aspx?id=337 (last visited 27 March 2008). The NMV Ethical Code Committee was originally called in Dutch the 'Commissie Museale Gedragslijn'. In 2007 the name was revised to "Ethische Codecommissie voor Musea".

1798 The last revision took place during 2004-2006 in response to the revised ICOM Code as adopted in Seoul in 2004. The integral text of the code can be found at:

http://www.museumvereniging.nl/files/Ethische\%20Code $\% 20$ _versie $\% 2020 \% 20$ nov\%202006_\%20_2_.p df (last visited 27 March 2008).

1799 Letter from the Director of the Dutch Museum Association NMV to the NMV Ethical Code Committee dated 25 May 1999.
} 
b) The Recommendation by the NMV Ethical Code Committee

After the questions had been referred to the NMV Ethical Code Committee, the Committee met twice, in July and October 1999 before presenting its recommendation in December 1999. ${ }^{1800}$

The actual recommendation is preceded by a statement concerning the improper use of terminology when speaking of the remains of an "Eskimo" as a pejorative reference to part of a people that refers to itself as "Inuit". Furthermore, the reference to the remains as "Greenlandic Eskimo" gives a false impression by suggesting that the Greenlandic origin of the remains has been confirmed, which was not the case. Also, the NMV Ethical Code Committee did not consider the term "mummy" appropriate as the remains consisted only of parts of the skin, which must either have been tanned, or dissected, and which had been stuffed at some later point in time. They did, however, qualify as "human remains" in the eyes of the NMV Ethical Code Committee. According to the Committee human remains in the sense of the ICOM Code are "everything that once formed part of a human body and can be traced back to a specific individual". Against this background, the NMV Ethical Code Committee chose to speak of the "human remains of an Inuit" in its recommendation.

After the reflections upon terminology, the actual recommendation starts with the general view that the return of human remains should be treated as the return of cultural property in accordance with Art. 4.4. sub b of the Dutch ICOM Code (1999 version). ${ }^{1801}$ According to this provision:

"[i]n case of requests for the return of cultural property to the land of origin, museums should be prepared to initiate dialogues based on scientific and professional principles (in preference to action at a governmental or political level). The possibility of developing bilateral or multilateral cooperation with museums in countries that have lost a significant part of their cultural heritage should be explored". 1802

1800 Commissie Museale Gedragslijn, 1999. The original recommendation is available online at: http://www.museumvereniging.nl/files/2_ethiek_adv-eskimo.pdf (last visited 5 January 2009).

1801 The 1999 version was the second, revised translation of the ICOM Code. As outlined in chp. 2.\$2.IV.3, it was only in 2001 that a paragraph was added to the international ICOM Code dealing with the return of human remains (para. 6.6). Consequently, the Dutch 1999 ICOM Code did not include any provision dealing explicitly with requests for the return of human remains. The current version of the Dutch ICOM Code, which was adopted on 8 November 2006, and which is based upon the 2004 version of the internatioanal ICOM Code, does include a provision dealing with requests for the return of human remains (para. 4.4). Below, where we extrapolate the principles that guide the recommendation of the NMV Ethical Code Committee, we will take this development into account.

1802 Art. 4.4 sub b: "Als er verzoeken komen om de teruggave van cultureel bezit aan het land van oorsprong, dan behoren musea bereid te zijn een dialoog op gang te brengen op basis van wetenschappelijke en professionele principes (te verkiezen boven actie op overheids- of politiek niveau). Er behoort nagegaan te worden wat de mogelijkheden zijn om bilaterale of multilaterale samenwerkingsprogramma's te ontwikkelen om musea te helpen met het opzetten van goede museale infrastructuur in landen waarvan wordt aangenomen dat ze een belangrijk deel van hun cultureel erfgoed hebben verloren”. 
Hence, as a general starting point, a Dutch museum that receives a request for the return of human remains should be open to dialogue and the exploration of cooperation. The provision makes no case that the human remains would need to be returned.

Different from the starting point that human remains should be dealt with in accordance with Art. 4.4. sub b of the Dutch ICOM Code, the NMV Ethical Code Committee holds that some requests merit a different treatment. This is the case where the request for the return of the remains is motivated by the wish of (re-) burial respectively other funeral arrangements. In these cases the interest of the claimants $\underline{c a n}$ prevail over the interest of retaining the cultural property. ${ }^{1803}$

The following conditions were discussed by the NMV Ethical Code Committee as necessary (but not necessarily sufficient) conditions:

First, the request for the return of human remains for funeral arrangements has to be made by probable relative(s). Second, a close family link/next-of-kin relationship between the requesting party and the human remains must be established with the burden of proof resting upon the requesting party. Evidence of such a relationship can be given by means of genetic research (such as the testing of DNA) or can otherwise be documented. If the requesting party fails to establish a family link or kinship, the NMV Ethical Code Committee holds that there can be no specific interest in funeral arrangements and the request must be judged in accordance with Art. 4.4 sub b Dutch ICOM Code. On the other hand, a successful proof of family link or kinship does not necessarily lead to the return of the remains: in case of positive proof the NMV Ethical Code Committee states that the human remains in question may be returned. They do not have to be returned.

While the recommendation does not explicitly refer to the notion of the national heritage, it departs from the understanding that the status quo of public collections should be preserved in as far as possible and should only be compromised in very limited circumstances, i.e. only for the reburial of human remains. Such extensive protection can only be understood if the NMV Ethical Code Committee attaches great relevant to the preservation of the national heritage.

After outlining the conditions for the restitution of human remains, the NMV Ethical Code Committee dealt with the six questions submitted by the Director of the Dutch Museum Association. As to the first question, whether there were any reasons speaking in favour of returning the Inuit remains, the NMV Ethical Code Committee held that the claim as it then stood did not meet any of the established conditions. In the light of the negative answer to the first question, the NMV Ethical Code Committee did not further address the second question asking for requirements a claim for the return of human remains has to meet, nor did it further reflect upon the third question asking for further conditions a return could or should be subjected to. The fourth question, as to whether a decision to return human remains must be considered as a

1803 (Emphasis added). 
precedent, was negated by the NMV Ethical Code Committee referring to the stringed conditions it set in the recommendation.

In response to the fifth question, whether the return of human remains calls for a revision of the Dutch ICOM Code, the NMV Ethical Code Committee held that this was not the case. ${ }^{1804}$ The sixth and last question asking for the relationship between the return of human remains with that of cultural property in general is not directly answered. Instead, the NMV Ethical Code Committee referred back to its recommendation where it held that a special regime for human remains applies only if a specific interest in funeral arrangements exists, which, according to the Committee presupposes a direct link between the claimant and the remains in question. In the absence of such a link /interest the request must be judged in accordance with Art. 4.4 sub b Dutch ICOM Code. ${ }^{1805}$

The NMV Ethical Code Committee concludes its elaborations on the return of human remains more in general and the present case by advising the Westfries Museum to adapt the exhibition of the remains in accordance with Art. 6.7 of the Dutch ICOM Code which asks for the payment of respect ${ }^{1806}$ and to include in the information provided to visitors the insights concerning the unsure origins of the Inuit remains.

\footnotetext{
${ }^{1804}$ It might be interesting to know that in the past the Dutch ICOM Code had been revised only once. In 1998 one article was revised and a supplement was added. The latter regulates how to deal with "dead material of animals derived from zoos".

1805 The actual recommendation of the NMV Ethical Code Committee was numbered from 1-7. To answer the question of the relationship between human remains and cultural property, the Committee only stated that "The answer on the last question is provided for under point 6". In fact, the sixth point does not address this issue at all but only states that human remains can be returned if the requesting party succeeds in proving the family ties, provided that upon return the remains will be buried or otherwise disposed of. The cross-reference only makes sense and has been understood in the present analysis as referring to the seventh point instead where it is stated that in case kinship between the claimant and the human remains cannot be established, the specific interest in funeral arrangements does not apply and consequently, the only issue at stake is the cultural importance of the human remains, which is dealt with in article 4.4 sub b of the Gedragslijn.

1806 Art. 6.7 of the 1999 Dutch ICOM Code on human remains and objects of religious significance reads: a. In case a museum possesses or collects human remains and religious objects, it has to provide for secure storage and meticulous maintenance for them as objects of scientific collections in research institutions. The objects have to be available for competent researchers and educators at all times, but not for people with a sick curiosity.

b. Research on these objects and the storage and maintenance must be carried out in a manner that is acceptable to colleagues, and to people from different religions, in particular those of the religious or ethnic group concerned. While it will occasionally be necessary to exhibit human remains and other sensitive material in explanatory exhibitions, this must be done with respect to the feelings for human dignity of all peoples.

The original version in Dutch reads:

a Wanneer een museum collecties van menselijke resten en religieuze voorwerpen bezit of verzamelt, dan behoren deze veilig gehuisvest en zorgvuldig onderhouden te worden als studieverzamelingen in wetenschappelijke instellingen. Ze behoren altijd beschikbaar te zijn voor bevoegde onderzoekers en educatoren, maar niet voor mensen met een ziekelijke nieuwsgierigheid.

b Onderzoek van dergelijke voorwerpen en hun huisvesting en zorg behoort te geschieden op een manier die aanvaardbaar is voor vakgenoten,en ook voor mensen van verschillende religies, in het bijzonder leden
} 


\section{c) Developments after the recommendation}

In response to the recommendation by the NMV Ethical Code Committee, the requested remains from the Westfries Museum were subjected to a DNA- test by the Panum Institute in Copenhagen. ${ }^{1807}$

While the results of the DNA-analysis were pending, the Board of Trustees of the Westfries Museum advised the City Council of Hoorn, as the relevant decision making organ of the city of Hoorn ${ }^{1808}$ as owner of the collection, to return the remains to Greenland should the DNA-test provide that the remains were indeed of Greenlandic origins.

In line with the advice of the museum's Board of Trustees, the College of Mayor and Aldermen issued a proposal in favour of return should the DNA-research proof the Greenlandic origin of the remains. ${ }^{1809}$ On 11 July 2000, the proposal was adopted by the City Council of Hoorn. ${ }^{1810}$ The City Council of Hoorn did, however, make the (potential) return dependent on a guarantee that the human remains were not to be exhibited upon their return to Greenland but had to be given a last resting-place in conformity with the customs of Greenland. ${ }^{1811}$ The Council motivated this extra condition as to prevent a precedent. ${ }^{1812}$ The City Council also mandated the Mayor and Aldermen to deal with practical matters once the results of the DNA-research were known.

\footnotetext{
van de betreffende gemeenschap, etnische of religieuze groep. Hoewel het incidenteel noodzakelijk is om menselijke resten en ander gevoelig materiaal te gebruiken in verklarende tentoonstellingen,behoort dit met tact en respect voor de gevoelens voor menselijke waardigheid van alle volkeren gedaan te worden.)

1807 Whether this is the same institute that conducted the research documented in Nooter's Study on 'Old Kayaks in the Netherlands' is not known. Nooter wrote the following on the research: "I had hoped that an investigation performed for me in Copenhagen on the characteristics of the hair still present on the skin, would permit determination of whether this is indeed the skin of a Greenlander, but unfortunately no conclusions could be drawn on this point. (...) An investigation performed in Freiburg on the fingerprints of the skin belonging to the right hand also failed to supply an answer to the question of whether this is the skin of a Greenlander". Nooter, G., 1971, p. 34. In the documentation of available on the case of the Westfries Eskimo and in the final report on the DNA/ radiocarbon research (Institute of Forensic Medicine, 2001), no reference is made the investigations performed on behalf of Gert Nooter.

1808 Prior to the entry into force of the Act on Dualism (Wet van 28 februari 2002 tot wijziging van de Gemeentewet en enige andere wetten tot dualisering van de inrichting, de bevoegdheden en de werkwijze van het gemeentebestuur" (Wet Dualisering Gemeentebestuur) in 2002, the city council was indeed the correct organ to decide upon legal acts under private law of the municipality.

${ }^{1809}$ Raadsvoorstel nr. 12, 11 July 2000, Registratienummer: 99.01622: “...to return the Inuit to Greenland in the case of an affirmative result of the DNA-analysis provided that the Inuit shall not be exhibited in Greenland but shall be laid to rest. With this strict condition setting a precedent will be prevented." (...over te gaan tot teruggave van de Inuit aan Groenland indien middels DNA-onderzoek de Groenlandse herkomst bewezen is, waarbij als voorwaarde wordt gesteld dat de Inuit in Groenland niet als object van beschouwing of tentoonstelling zal dienen, maar daar een laatste rustplaats zal krijgen. Door deze strikte voorwaarden wordt precedentwerking voorkomen).

1810 Ibid.

1811 Ibid.

1812 Ibid.
} 
After the municipal decision making process had been finalised but before the completion of the DNA-research and the radiocarbon analysis, the Westfries Museum reconsidered its position on the return of the remains: given the fact that the Greenland National Museum also had mummies of Greenlandic origin in its collection and exhibition, the Board of Trustees of the Westfries Museum no longer considered it necessary to return the remains. ${ }^{1813}$ The City of Hoorn, however, did not find it necessary to revise its decision. While the mayor of Hoorn wrote a letter to the Danish ambassador asking for clarification of the facts, which was redirected to the Danish Ministry of Foreign Affairs ${ }^{1814}$, the City Council stood by its earlier decision.

On 29 March 2001, the Greenland Government announced the results of the DNA and radiocarbon analysis. According to the report by the Department of Forensic Genetics, it had been impossible to extract DNA from the specimens. ${ }^{1815}$ From the radiocarbon analyses, however, it appeared that the specimen presumably dated from a period around $1670 \mathrm{AD}$ or [sic] the latter part of the 18 th century. ${ }^{1816}$ It also indicated that the deceased must have had an almost exclusively terrestrial diet. This latter finding was crucial in the present case as the diet of Greenland Inuit consisted mainly of marine food intake. 1817 Consequently, it was concluded that the remains could not have been that of a Greenland Inuit. This negative conclusion was supported by the existence of an ear piercing, which has never been described for Thule Culture Eskimos. ${ }^{1818}$

With the finding that the human remains from the collection held by the Westfries Museum were not of Greenlandic origin the case came to a rest. The remains are still exhibited in the Westfries Museum. ${ }^{1819}$

\section{d) Extrapolation of principles}

The fact that the remains did not prove to be of Greenlandic origin does not mean that we cannot extrapolate the principles that underlie the decision-making process. This is the more the case in that the recommendation by the NMV Ethical Code Committee is meant to constitute general guidelines rather than applying only to the specific case. ${ }^{1820}$ In the following we will reformulate the recommendation by the NMV Ethical Code Committee in the form of principles.

\footnotetext{
1813 Coalitie blijft bij besluit over teruggeven mummie, 2000.

1814 'IJsbrand' nu op bordje Groenland, 23 September 2000.

1815 Institute of Forensic Medicine, 2001, p. 2.

1816 Ibid., p. 3.

1817 See further on the possibility of dietary reconstruction by isotope research: Larsen, C.S., 1997.

1818 Institute of Forensic Medicine, 2001, p. 3.

1819 Timmer, P.M.Y. / Gubbels, G.J., 2007, p. 191. Telephonic inquiry on 17 July 2009.

1820 Cf.: the terms of references of the NMV Ethical Code Committee: 'Reglement van de Commissie Museale Gedragslijn', para. $4 .^{1821}$ Cf.: Aarts, B., 2000, p. 82. In section 2(1) of NAGPRA cultural affiliation is defined as "a relationship of shared group identity which can be reasonable traced historically or prehistorically between a present day Indian tribe or Native Hawaiian organization and an identifiable earlier group”. 25 U.S.C.3001 (2) (2004). See further on NAGPRA above in chp. 2.\$2.II.2.
} 
The solution introduced by the NMV Ethical Code Committee does not accord greater weight and legitimacy to the return of human remains than to the return of cultural objects in general. In fact, the solution proposed by the NMV Ethical Code Committee does not distinguish between human remains on the one hand and cultural artifacts on the other but instead accords greater weight and legitimacy only to claims for the return of human remains that are motivated by the wish for reburial.

Furthermore, the wish for reburial will only be accepted where expressed by close family members or next-of-kin with the burden of proof of such relationship resting upon the claimants. According to one source the NMV Ethical Code Committee had considered to allow also for claims by culturally affiliated groups similar to the US federal legislation NAGPRA. ${ }^{1821}$ In its final recommendation, however, any reference to a broader group of claimants was dropped in order to avoid misunderstanding with regard to the historical relevance of human remains as witness of past views and practices. ${ }^{1822}$

The NMV Ethical Code Committee's approach is furthermore characterised by putting great emphasis on the interests of third parties: not only does it stress the need for conservation where human remains are not claimed with the underlying motive to bury them; even where this is the case and claimants have proven the required close family link, the retention of the remains can prevail over returning them.

In short, we can summarise the underlying principles as follows:

1. As a general principle, the return of human remains should be treated as the return of cultural property in accordance with Art. 4.4. sub b of the Dutch ICOM Code (1999 version): "[i]n case of requests for the return of cultural property to the land of origin, museums should be prepared to initiate dialogues based on scientific and professional principles (in preference to action at a governmental or political level). The possibility of developing bilateral or multilateral cooperation with museums in countries that have lost a significant part of their cultural heritage should be explored".

2. Where requests are motivated by the wish of (re-) burial respectively other funeral arrangements, reburial might outweigh the interests of the holding institution in retention.

3. For a request to qualify as being motivated by the wish of (re-) burial it must be expressed by relatives / next of kin who have provided proof of their relationship with the remains in form of DNA-testing or other form of documentation.

1821 Cf.: Aarts, B., 2000, p. 82. In section 2(1) of NAGPRA cultural affiliation is defined as "a relationship of shared group identity which can be reasonable traced historically or prehistorically between a present day Indian tribe or Native Hawaiian organization and an identifiable earlier group". 25 U.S.C.3001 (2) (2004). See further on NAGPRA above in chp. 2.\$2.II.2.

1822 C.f.: Ibid. Aarts' information is based on an interview with Renée van Kempen, then secretary of the NMV Ethical Code Committee. 


\section{THE CASE OF THE TOI MOKO FROM THE COLlection OF THE National Museum OF ETHNOLOGY ${ }^{1823}$}

a) The facts

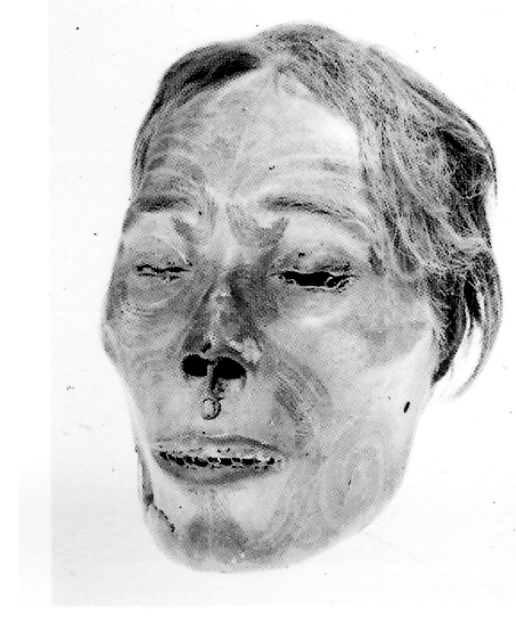

The Toi Moko. Photo: Timmer, P.M.Y. / Gubbels, G.J., Niets gaat verloren: twintig jaar selectie en afstoting uit Nederlandse museale collecties, (Amsterdam, Instituut Collectie Nederland, Boekmanstudies) (2007), p. 188.

The National Museum of Ethnology (Rijksmuseum voor Volkenkunde) in Leiden was the second public institution in the Netherlands to receive a request for the return of human remains and the first one to decide for their return. ${ }^{1824}$ In September 2002, the Museum of New Zealand Te Papa Tongarewa (hereinafter: "the Te Papa") made a formal application to the museum in Leiden for the return of human remains. ${ }^{1825}$ The claim concerned all Māori and Moriori ${ }^{1826}$ remains that are part of the collection held by

1823 The author wishes to thank Steven Engelsman for his willingness to provide information and documentation on this case.

1824 Cf.: Timmer, P.M.Y. / Gubbels, G.J., 2007, p. 188.

1825 The Museum of New Zealand Te Papa Tongarewa, 16 September 2002, Letter to Steven Engelsman with the subject "Repatriation - Human Remains". At that point, the Te Papa had already sought repatriation of Māori remains from the following institutions: Musée d'Ethograph, Geneva, Switzerland; Museum für Völkerkunde, Basel, Switzerland; Manchester Museum, United Kingdom; New Zealand High Commission, London, United Kingdom; Exeter City Museum \& Art Gallery, United Kingdom; Queensland Museum, Australia; Whitby Museum, Leeds, United Kingdom; University of Edinburgh, United Kingdom; Saffron Walden Museum, United Kingdom; National Museum of Denmark, Copenhagen, Denmark; University of Edinburgh, United Kingdom; National Museums of Scotland, United Kingdom, South Australian Museum, Australia. Source: The Museum of New Zealand Te Papa Tongarewa, 2001.

1826 Māori are the native Polynesian people of New Zealand. Moriori are the native inhabitants of the Chatham Islands of New Zealand. Cf.: Moriori (2009). In Encyclopædia Britannica. Retrieved April 17, 
the National Museum of Ethnology, but explicitly mentioned a tattooed and preserved head (Toi Moko) with inventory number RMV 360-5763.1827 The provenance of the Toi Moko, or rather the circumstances under which it had left New-Zealand were unknown.

During the eighteenth century expeditions under James Cook to New Zealand, a great number of objects were taken from New Zealand. It is therefore possible that the Toi Moko was amongst these objects. Captains, civil servants, and travellers brought these objects back home and traded them. Batavia, the main Eastern base of the Dutch trade, was at that time an important centre of the trade with Asia and the Southern hemisphere, and many Dutch citizens were sailing in the South Pacific Ocean. ${ }^{1828}$

The inventory numbering suggests that the Toi Moko entered the collection of Royal Collection of Rarities in The Hague between 1827 and 1876. ${ }^{1829}$ The Royal Cabinet had been founded by King William I (1772-1843) in 1816 in The Hague. ${ }^{1830}$ The cabinet contained three categories of object: objects from the royal family; items that referred to the Dutch history; and finally ethnographic objects that had been acquired on trading missions to the East Indies or had been donated. The ethnographic part of this Royal Collection later formed the basis for the current National Museum of Ethnology.

After the National Museum of Ethnology had received the request to return the remains from the Te Papa, it informed the Minister of Culture about the request. ${ }^{1831}$ As one of the former state museums that were converted from decentralised ministerial departments into independent legal entities in the $1990 \mathrm{~s}^{1832}$ the National Museum does not own the collection including the Toi Moko but holds it on behalf of the Dutch State - the owner of the collection. Consequently, it is the Minister of Culture who has the authority to decide upon the return of the Toi Moko. ${ }^{1833}$ As holder of the collection, the

2009 from Encyclopædia Britannica Online; Maori (2009), In Encyclopædia Britannica. Retrieved April 17, 2009, from Encyclopædia Britannica Online.

${ }^{1827}$ From the available documentation it appears that further to the Toi Moko the National Museum of Ethnology does not contain other human remains of Māori or Moriori origin. An internal document states that the National Museum of Ethnology collection contains "no more than 35 objects of Māori origin". While it does not explicitly state that these objects are not of human origin, the use of the word object ("voorwerp" in Dutch) suggests that there were no human remains amongst them. CB, 2002, Aan MT (Management Team). Betreft voorstel antwoord aan Te Papa en als aanhangsel de verschillende overwegingen die hieraan ten grondslag liggen. In Dutch the relevant passage reads: "Overigens omvat onze collectie van de Māori niet meer dan 35 voorwerpen".

1828 C.f.: Effert, R.A.H.D., 2005.

1829 C.f.: Ibid.

1830 See for an analysis of the history of the Royal Cabinet of Curiosities: Effert, R.A.H.D., 2003, pp. 15-63; Effert, R.A.H.D., 2008. The nucleus of the collection had been built by the father of King William I: Stadhouder prins Willem V (1748-1806). See further on his collection: Campen, J.v., 2000, pp. $202-221$.

1831 Engelsman, S., 23 October 2002, Letter to State Secretary of Culture Van Leeuwen.

1832 See for the Conditions of privatisation: Memoire van Toelichting van de Wet verzelfstandiging rijksmuseale diensten kamerstukken II 1991/1992, 22771, nr. 3 and art. 21 van de Comptabiliteitswet, wet van 8 december 1976, Staatsblad 1976, nr. 671, laatstelijk gewijzigd bij Wet van 24 juni 1992, staatsblad 1992 , nor. 351 .

1833 Engelsman, S., 23 October 2002, Letter to State Secretary of Culture Van Leeuwen. 
National Museum of Ethnology suggested to prepare a recommendation on behalf of the State Secretary. 1834

In the following, before turning to the recommendation submitted to the State Secretary, the internal deliberations amongst the curatorial staff of the National Museum of Ethnology shall be summarised as it allows for a view behind the curtains and provides an overview of the possible attitudes and arguments that can be expected to live within any public institution confronted with a claim for the return of human remains.

The preparation of a recommendation on behalf of the Minister of Culture started with an internal survey of opinions held by the curatorial staff working at the National Museum of Ethnology. The following arguments for retention respectively he return of the Toi Moko emerged from the internal discussions: ${ }^{1835}$

As arguments speaking against return were mentioned the insecurity as to whether the Te Papa qualified as legitimate stakeholder to claim the remains. Secondly, the relevance of the Toi Moko in the tradition of collecting and collections was emphasized. The head had entered the collection in the 1840s and consequently belongs to the nucleus of the collection held by National Museum of Ethnology. As one of the most senior objects from the collection, the Toi Moko has "become part of a European museum tradition, the preservation of which also should be recognized a highly serious responsibility (...)". ${ }^{1836}$ Furthermore, a return of the Toi Moko would harm the integrity of the collection and thereby would result in a "falsification of the history". ${ }^{1837}$ Finally, the loss of the Toi Moko for future research was mentioned. This aspect was considered far more important than the loss of the object for exhibition purposes.

The following aspects were brought forward as speaking in favour of return: in the first place returning the Toi Moko would contribute to good relationships with the Te Papa and the region. Furthermore, by returning the Toi Moko, the National Museum of Ethnology would "make history" and could serve as good example for other museums. Finally, reference was made to the ethical imperative. ${ }^{1838}$

Parallel to its internal deliberations the National Museum of Ethnology decided to seek external advice from an ethics committee, the (preparatory) 'SVCN Ethnological Ethics Committee'.

\footnotetext{
1834 Ibid.

1835 While a number of variations to retention on the one hand and return on the other were mentioned, the discussion soon focussed on the question as to whether or not return the remains. The following variations of how the National Museum of Ethnology could react to the request were not further considered: to limit itself to explaining its point of view and to guaranteeing that it continues to pay due respect to the Māori and Moriori culture. Alternatively, to invite the Te Papa to attend a ceremony during which the Toi Moko would be transferred to a special storage place within the National Musuem of Ethnology's deposit.

1836 CB, 2002, Aan MT (Management Team). Betreft voorstel antwoord aan Te Papa en als aanhangsel de verschillende overwegingen die hieraan ten grondslag liggen.

1837 Ibid.

1838 Ibid.
} 


\section{b) The recommendation of the (preparatory) 'SVCN Ethnological Ethics Committee'}

While the National Museum of Ethnology is a member of the Dutch Museum Association NMV, it did not turn to the NMV Ethical Code Committee that had issued the recommendation on the alleged Inuit remains held by the Westfries Museum. Instead, the National Museum of Ethnology sought advice from the ethics committee that was founded by the 'Foundation of Ethnological Collections in the Netherlands' (hereinafter: "Foundation of Ethnological Collections (SVCN)"). ${ }^{1839}$ This Foundation of Ethnological Collections represents eight institutions holding public collections of predominantly ethnological character. ${ }^{1840}$ The particular needs and questions that may arise from caring for ethnological collections is reflected in the aims and composition of the ethics committee as founded by the Foundation of Ethnological Collections (SVCN) (hereinafter the: SVCN Ethnological Ethics Committee): its main task is to advise Dutch Ethnological Museums on questions regarding human remains, potential illegal objects, and the repatriation of objects or collections. ${ }^{1841}$ As for the composition of the SVCN Ethnological Ethics Committee, it consists of representatives from the associated museums, a representative of the art trade, and an independent chairman. ${ }^{1842}$ In fact, the SVCN Ethnological Ethics Committee was officially established only in 2004. However, prior to the official establishment of the SVCN Ethnological Ethics Committee a preparatory committee had been appointed ("kwartiermakende commissie"). While its main task was to define the scope and procedural rules of the SVCN Ethnological Ethics Committee it also made a number of substantial recommendations, one of them being on the request to return the Toi Moko.

On 29 January 2003, the National Museum of Ethnology approached the (preparatory) SVCN Ethnological Ethics Committee for feedback on the aforementioned scenarios of responding to the request for the Toi Moko. The National Museum of Ethnology also sought advice on the two conditions it wanted to make: first, that the Toi Moko may never be destroyed as it is part of Dutch cultural property, and secondly that it would remain accessible for scientific research.

The (preparatory) SVCN Ethnological Ethics Committee dealt with the request for advice of the National Museum of Ethnology during its meeting of 3 April 2003. While it was the first time that the (preparatory) SVCN Ethnological Ethics Committee had to decide upon a case on the return of human remains it was not the first time that the treatment of human remains was discussed amongst members of the Foundation of Ethnological Collections (SVCN). In May 2002, a symposium on the treatment of human remains had been organised amongst the associated ethnological museums. ${ }^{1843}$ As a result of the symposium, a (draft) ethical code on the treatment of human remains

\footnotetext{
1839 In Dutch: Stichting Volkenkundige Collectie Nederland (SVCN).

1840 http:/ / www.svcn.nl/nieuws.asp?identifier=272 (last visited 27 March 2008).

1841 See: http:/ /www.svcn.nl/nieuws.asp?identifier=160 (last visited 27 March 2008).

1842 See: http://svcn.collectionconnection.nl/nieuws.asp?identifier=160 (last visited 17 April 2009).

1843 The SVCN Symposium on human remains was held on 13 May 2002 in Amsterdam.
} 
was formulated. ${ }^{1844}$ The code applies to the treatment of human remains ranging from their acquisition, management, research, presentation and restitution and refers to the ICOM Code as starting point:

Collections of human remains and material of sacred significance should be housed securely and respectfully, and carefully maintained as archival collections in scholarly institutions. It should be available for legitimate study on request. Research on such materials, its housing, care and use (exhibition, replication, and publication) must be accomplished in a manner consistent with professional standards and the interests and beliefs of the members of the community, ethnic or religious groups from which the object originated. When sensitive material is used in interpretive exhibits, this must be done with great tact and with respect for the feelings of human dignity held by all peoples. ${ }^{1845}$

From this provision of the ICOM Code the SVCN deducted a number of guidelines for the treatment of human remains by its associated institutions. With regard to the return of human remains paragraphs 2 and 6 are relevant.

According to paragraph 2 museums have to provide for registration and documentation of existing collections of human remains. Where source communities approach a museum with a request for information on human remains, museums must share their information with them. ${ }^{1846}$ Hence, the code does not foresee in a pro-active duty to provide source communities with information about human remains but requires the members of the Foundation Ethnological Collections (SVCN) to keep (or bring) their inventories and documentation up-to-date and to respond diligently to requests for information.

Paragraph 6 deals with various requests concerning human remains ranging from transfer of management responsibilities, research, exhibition and restitution. ${ }^{1847}$

1844 Legêne, S., et al., 2001. The code was officially adopted by the board of the Foundation Ethnological Collections on 27 June 2003 - shortly after the (preparatory) Ethnological Ethics Committee had issued its advise on the return of the Toi Moko. Presently, the SVCN Ethical Committee as officially established in 2004 is working on the drafting of guidelines on the repatriation of objects from their members' collection, including human remains. Cf.: Email by Annelies Valgaeren dated 1 April 2009, re: 'introductory text for the expert meeting of the SVCN, Friday 3th of April 2009' on file with the author.

1845 Interestingly, despite being adopted in 2003, the SVCN ethical code on the treatment of human remains refers to the 1986 version of the ICOM Code and not to the ICOM Code as amended in 2001, which includes an additional sentence explicitly dealing with the removal of human remains from display and requests for the return of human remains. However, given the non-binding character of the ICOM Code and the fact that the tone of the two versions of the ICOM Code did not change, this reliance on the outdated ICOM Code is of no further relevance. See further on the evolution of the international ICOM Code above in chp. 2.\$2.IV.3.

1846 Para. 2 reads in Dutch: "Ieder museum dient zorg te dragen voor registratie en documentatie van bestaande collecties menselijke resten en heeft daarover desgevraagd aan de betrokken gemeenschappen een informatieplicht. Indien de betreffende menselijke resten deel uitmaken van een grafvondst waaruit ook andere objecten in de collectie zijn opgenomen wordt dit expliciet gedocumenteerd".

1847 Para. 6 reads in Dutch: "Ieder museum gaat open en afgewogen ter werk bij eventuele verzoeken met betrekking tot overdracht van het beheer, tot onderzoek, tentoonstellen of restitueren van menselijke resten 
Museums are required to deal with such requests in an open and deliberate manner. The SVCN ethical code does not give any further guidance upon the criteria that may or should be taken into consideration when deciding upon a claim for the return of human remains. E.g. the wish for funeral arrangement, which plays a crucial role in the eye of the NMV Ethical Code Committee in its advice on the alleged Inuit remains, is not mentioned in the SVCN ethical code. Also, the code does not elaborate upon who qualifies as "legitimate representatives of the community concerned". The SVCN ethical code does, however, explicitly require the associated institutions to share with the requesting party the decisive criteria on which its decision on the request is based. This requirement indirectly contributes to the quality of the decision-making process by requiring the institution to explicitly formulate its criteria. The responsibility and discretion given to the associated institutions is to some extent mitigated by the fact that institutions may always consult the SVCN Ethnological Ethics Committee for further guidance.

In the present case dealing with the request for the return of the Toi Moko, the (preparatory) SVCN Ethnological Ethics Committee discussed the two scenarios that were put forward by the museum: to either "return" the Toi Moko in form of a loan and under the conditions that it may never be destroyed as belonging to Dutch cultural property, and that it remained accessible for scientific research or to fully and unconditionally return the Toi Moko. The (preparatory) SVCN Ethnological Ethics Committtee dismissed the claim that the object belonged to the Dutch cultural heritage as weak. Consequently, it came to the conclusion that the most appropriate solution was the full and unconditional transfer of the property to the Te Papa. ${ }^{1848}$

On the basis of recommendation of the (preparatory) SVCN Ethnological Ethics Committtee and its internal deliberations the National Museum of Ethnology drafted its recommendation to the State Secretary, which will be discussed in the following.

\section{c) Recommendation on behalf of the state secretary}

On 7 May 2003, the National Museum of Ethnology sent its recommendation to the Minister of Culture. As a general starting point, National Museum of Ethnology emphasizes that human remains must be considered as sensitive parts of the collection. ${ }^{1849}$ Consequently, any decision-making process involving human remains should take due account of the views of all stakeholders, including those from the country of origin. ${ }^{1850}$

\footnotetext{
aan legitieme vertegenwoordigers van de betrokken gemeenschap. De criteria die worden gebruikt om tot een eindoordeel te komen worden expliciet aangegeven".

1848 Verslag Ethische Commissie van de SVCN d.d. 3 april 2003 (on file with the author), .

1849 Engelsman, S., Letter by Steven Engelsman to State Secretary of Culture Van Leeuwen re: "Maorihoofd 360-555763", 7 May 2003.

1850 The recommendation sought to illustrate this point with reference to the case of the Westfries Eskimo. It stated that the National Museum of Ethnology would not have exhibited the remains of the so-called West Frisian Eskimo "as it is known that this is highly problematic for the Inuit". With exhibiting mummies
} 
With regard to claims for the return of human remains, the National Museum of Ethnology starts with the possibility of returning human remains. After recognising the de-accessioning and returning of human remains as realistic scenario, the recommendation reflects upon factors that are relevant for the decision-making process. One crucial question for the decision-making is whether the claiming party qualifies as direct stakeholder. With regard to the burden of proof of the relationship with the claimed remains it is held that it rested upon the claimant.

Having suggested the foregoing general parameters to the State Secretary, the recommendation by the National Museum of Ethnology applies them to the specific claim of the Toi Moko. It informs the Minister of Culture that it is sceptical whether the Te Papa qualifies as direct stakeholder. While it was recognised that the Te Papa was an institution acting in the interest of the Māoris', the National Museum of Ethnology suggested that one should only return the Toi Moko to the Te Papa after its mandate had been confirmed by the New-Zealand Government and the Māoris. ${ }^{1851}$ The National Museum of Ethnology nevertheless suggested dealing with the merits of the case in order not to give the impression that one was hiding behind procedural arguments.

Consequently, the National Museum of Ethnology advised the Minister of Culture to agree in principle with the return of the Toi Moko to the legitimate stakeholder. Furthermore it asked to be mandated to start negotiations with the Te Papa and to make binding agreements. According to the National Museum of Ethnology, one should aim in the present case at returning the Toi Moko under a loan agreement and preferably on the conditions that the Toi Moko would never be destroyed as it belongs to Dutch cultural property, and that it would remain accessible for scientific research. Only if a "return" in form of a loan and under the aforementioned conditions proved unfeasible, the property of the Toi Moko should be transferred, full and unconditional.

The Minister of Culture agreed with the recommendation as prepared by the National Museum of Ethnology. ${ }^{1852}$

\section{d) Stakeholder question}

While the advice of the SVCN Ethnological Ethics Committee clearly provided that the Toi Moko should be returned unconditionally, it did not take away the doubts voiced with regard to the question whether the Te Papa Museum could legitimately

originating from Peru not being problematic in Peru, the National Museum of Ethnology does not consider it problematic to exhibit Peruvian remains.

${ }^{1851}$ In the documentation that was submitted by the Te Papa with the official request, it was stated that "in regard to the repatriation of human remains, both the New Zealand Government and Māori tribes have agreed in principle to Te Papa's role in this work, but no policy direction has yet been defined by the Government". The Museum of New Zealand Te Papa Tongarewa, 2001.

1852 A copy of that confirmation is not included in the file; the letter by the state secretary is referred to in Engelsman, S., 2004b: “...in antwoord op mijn brief van 7 mei 2003 (...) heeft het Ministerie van OC\&W mij laten weten dat de Staatssecretaris akkoord gaat met de voorgestelde acties". (...in response to my letter dating 7 May, 2003, the Ministry of OC\&W has informed me that the State Secretary agreed with the proposed plan), 
claim the remains. In order to erase these doubts the National Museum of Ethnology sought advice from the Dutch Ambassador in New-Zealand. The Dutch ambassador discussed the matter with a leading Māori Chief, Darcy Nicholas, who is also general manager of the Museum Pataka in Porirua, New Zealand. ${ }^{1853}$ His reaction shows that the mission of the Te Papa is not uncontested: according to Nicholas, it was not for the Te Papa to claim the "guardianship" of Māori human remains: "We Māori are our own guardians!"1854 The Dutch Ambassador advised the National Museum of Ethnology to wait with the return of the Toi Moko until the iwis (Māori groups) ${ }^{1855}$ had adopted a common policy. ${ }^{1856}$

On 30 June 2004, the Te Papa sent a letter to the National Museum of Ethnology confirming that it "had been mandated by the New Zealand Government to undertake a repatriation programme for Māori and Moriori ancestral remains". 1857 The programme, titled 'Karanga Aotearoa Repatriation Programme', had formally been adopted in July 2003. The letter also stressed that as national museum of New Zealand, the Te Papa works closely together with Māori communities and tribal authorities.

After continued communication between the Dutch and the New Zealand institution ${ }^{1858}$, the Te Papa submitted further documents to endorse the official status of Te Papa's repatriation scheme: a letter from the Chief Executive of Te Manatu Taonga / Ministry for Culture and Heritage, dated 31 August 2004 on the "Repatriation of Koiwi Tangata Māori (Māori Ancestral Human Remains) ${ }^{1859}$, a briefing note prepared by Te Papa especially designed for overseas institutions on the role and status of the Te Papa in the repatriation of koiwi tangata ${ }^{1860}$; as well as a document entitled Te Papa Tongarewa and Repatriation.

By letter dating from 7 October 2004, the National Museum of Ethnology informed the Te Papa that it accepted the letter written by Chief Executive Matthews of Te Manatu Taonga / Ministry for Culture and Heritage as proof for the New Zealand Government's mandate for the Te Papa to implement a repatriation policy for koiwi tangata Māori. As far as the Māori support for the repatriation policy is concerned, however, the National Museum of Ethnology stated that: "it would be extremely helpful for our decision process to have an explicit statement in which the iwi express their

\footnotetext{
${ }^{1853}$ Nachenius, A.d.B., 18 February 2003, Letter to the Director of the Museum van Volkenkunde - subject: Maori head and Te Papa.

1854 Ibid.

1855 An "iwi" is defined as "the traditional Māori tribal hierarchy and social order made up of hapu (kin groups) and whanau (family groups), having a founding ancestor and territorial (tribal) boundaries." Retrieved April 5, 2005, from http://www.courts.govt.nz/Māorilandcourt/glossary.htm.

1856 Nachenius, A.d.B., 18 February 2003, Letter to the Director of the Museum van Volkenkunde - subject: Maori head and Te Papa.

${ }^{1857}$ Te Puni, J. / Nesus, C., 30 June 2004, Letter to the Director of the Museum van Volkenkunde - subject: Maori ancestral remains.

1858 Engelsman, S., 2004a.

1859 Matthews, M., 2004.

${ }^{1860}$ The Museum of New Zealand Te Papa Tongarewa, .
} 
support for Te Papa's repatriation policy. Such a document would be an elegant companion to the New Zealand Government's mandate". 1861

\section{The return of the Toi Moko}

While it does not appear from the available documentation whether an expicit statement by one of the Māori iwis was ever presented, or which other developments might have triggered the decision, by August 2005 the National Museum of Ethnology was ready to return the Toi Moko. By letter dating from 11 August 2005 the director of the National Museum of Ethnology asked the Secretary of Culture to be mandated to return the Māori head to the Te Papa. ${ }^{1862}$ By letter dating 14 September 2005, the Minister of Culture gave the mandate to the director of the museum, Steven Engelsman, to transfer the property of the Toi Moko. On 9 November 2005 the head was returned to representatives of the Te Papa during a small ceremony attended by curators, scientists, academics and journalists. ${ }^{1863}$

\section{Extrapolation of principles}

In the following we will extract the principles with regard to the return of human remains as proposed in the case of the Toi Moko by the National Museum of Ethnology (RMV) and as confirmed by the (preparatory) SVCN Ethnological Ethics Committee. ${ }^{1864}$ Before reformulating the analysis in a number of principles, we need to reflect upon the relevance accorded in the present case to the notion of cultural national heritage.

In the above analyse, the relevance of the Toi Moko for the Dutch cultural heritage was touched upon in several instances. On the one hand, the relevance of the Toi Moko for the Dutch cultural heritage was emphasised: as an item from the collection of Royal Collection of Rarities the head was held to have "become part of a European museum tradition (...)". 1865 The initial idea of the RMV to return the Toi Moko under a loan agreement and on the conditions that the Toi Moko would never be destroyed gives expression to this perception of the head as belonging to Dutch cultural heritage. The (preparatory) SVCN Ethnological Ethics Committee on the other hand dismissed the claim that the object belonged to the Dutch cultural heritage as weak. It did not motivate its finding. However, based on our analysis in Chapter 3 of the regulation of Dutch public collections we can now discuss the status of the Toi Moko for the Dutch cultural heritage more in depth.

\footnotetext{
${ }^{1861}$ Engelsman, S., 2004c, Letter to Mrs. Catherine Nesus - Repatriation Project Leader of the Te Papa.

1862 Engelsman, S., 2005.

1863 See, e.g.: Kaam, A.v., 9 November 2005.

1864 We will evaluate them, together with the principles extrapolated from the other case studies at the end of this section discussing the return of human remains from the Netherlands.

1865 CB, 2002, Aan MT (Management Team). Betreft voorstel antwoord aan Te Papa en als aanhangsel de verschillende overwegingen die hieraan ten grondslag liggen.
} 
From the analysis in Chapter 3 (\$2.I) we know that the Dutch perception of its national cultural heritage is very exclusive: only objects that are irreplaceable and indispensable in the sense of the Cultural Heritage Preservation Act (CHP Act) qualify as objects of the national cultural heritage. ${ }^{1866}$ While the CHP Act aims at the protection of cultural objects of national relevance in private collections, it applies analogously to objects in public collections. An object is irreplaceable if there are no similar objects present in the Netherlands. ${ }^{1867}$ While the Toi Moko might have been irreplaceable ${ }^{1868}$ it is doubtful whether it fulfils one of the functions (symbolic function; "linking function"; "reference function") stipulating indispensability. ${ }^{1869}$ It clearly does not have a symbolic function: being of unknown provenance it cannot serve as memory of historically important persons or events. ${ }^{1870}$ However, the Toi Moko might have a "linking function" (in Dutch: schakelfunktie). This notion of indispensability is explained as the "functioning of an object or collection as an essential element in a development that is of great importance for the exercise of scholarly work, including cultural science studies." 1871 While one could clearly argue that the Toi Moko is not irrelevant for scientific research and cultural science studies it seems unlikely that the object is of such great importance that it fulfils a 'linking function' and is thus indispensable.

Yet a different matter is the status of the Toi Moko as part of the greater collection of the Royal Collection of Rarities. This collection clearly satisfies the criteria of irreplaceability and indispensability. ${ }^{1872}$ Not only can the collection serve as memory of King William (1772-1843) as founder of the collection, which suggests a symbolic function; even more relevant is the collection's "linking function" and "reference function": the foundation of the collection is typical for the emergence of public collections out of private collections at the end of the $18^{\text {th }}$ century within Europe. ${ }^{1873}$ While the disposal of the Toi Moko cannot diminish the meaning and significance of the collection as such it is nevertheless important that its loss for the collection will be absorbed in as far as possible by documentation. Such documentation would reduce the harm done to the integrity of the collection and would counteract the fear of "falsifying

\footnotetext{
1866 Art. 2. CHP Act. See above in chp. 2.\$2.I.1 for a discussion of these criteria. 1867 Art. 2(2) CHP Act.

1868 The author is not aware of other Toi Moko's present in Dutch public collections.

1869 Art. 2(3) CHP Act.

1870 Art. 2(3)(a) CHP Act.

1871 Art. 2(3)(b) CHP Act. See also: Memorie van Toelichting, 27812, nr. 3, p. 8 para. 7. An example of an object listed for its "linking function" is a stone sculpture of a standing triumphing Jesus Christ. The sculpture dates from the Roman period and is one of very few similar sculptures that are present in the Netherlands. The sculpture is thus important for the studying of stone sculptures in the Maas area. Cf.: Raad voor Cultuur, 2001. See further on the relevance of the collection: Effert, R.A.H.D., 2003; Effert, R.A.H.D., 2008.

1872 See with regard to collections Art. 3 juncto Art. 2 sub 2 and 3.

1873 Cf: the motivation of designating the Bibliotheca Thysiana as protected collection on the list of the CHP Act. Raad voor Cultuur, 2001, available online at: http://www.minocw.nl/documenten/brief2k-2002doc-8733b.pdf (last visited 8 April 2009).
} 
history". ${ }^{1874}$ In conclusion, our reflection of the Toi Moko's relevance for the Dutch cultural heritage revealed that the head as such did not form part of the Dutch national cultural heritage but its de-accession should be accompanied by precise documentation to compensate for its loss for the Royal Collection of Rarities and thus to safeguard the collection's integrity.

Having "dismissed" the Toi Moko as object of crucial relevance for the Dutch cultural heritage we can now turn to the extrapolation of principles that were decisive in the decision-making process of the return of the Toi Moko:

1. Human remains must be considered as sensitive parts of the collection;

2. Any decision-making process involving human remains should take due account of the views of all stakeholders, including those from the country of origin;

3. the holding institution must share with the claimant the criteria that were decisive in the decisionmaking process;

4. While return in form of a loan must not be dismissed as an option, full and unconditional transfer of human remains is the most appropriate option where the remains do not form part of the Dutch cultural heritage;

5. In deciding upon requests for return collection holders must pay attention to the question whether the requesting party qualifies as appropriate stakeholder;

6. The requesting party has to provide proof of being the appropriate stakeholder. ${ }^{1875}$

\section{THE PRO-ACTIVE APPROACH OF THE KIT TROPENMUSEUM}

a) The facts

Different from the previous two case-studies the case study on the KIT Tropenmuseum ${ }^{1876}$ in Amsterdam does not deal with a specific claim for the restitution of human remains. Instead, it deals with the pro-active initiative taken by the KIT Tropenmuseum (hereinafter: the KIT) in studying and reflecting upon its collection of human remains. The decision of the KIT to deal with this subject matter was triggered by the return of a long-term loan and by the restitution claims that resonated in museums around the world. ${ }^{1877}$

The long-term loan concerned the physical anthropological collection of human remains, animal remains and plaster casts from the KIT that had been given to the University of Amsterdam's Museum Vrolijk in 1973. The loan had been meant to supplement the medical anatomical collection of the Vrolijk Museum at a time when the

1874 CB, 2002, Aan MT (Management Team). Betreft voorstel antwoord aan Te Papa en als aanhangsel de verschillende overwegingen die hieraan ten grondslag liggen.

1875 See further below for an update on the developments within the SVCN with regard to the drafting of guidelines on the return of human remains.

1876 The Tropenmuseum (literally: the "tropical museum" or the museum of the tropical) is part of the Royal Tropical Institute (Koninklijk Instituut voor de Tropen). The abbreviation KIT refers both to the museum and the institute. Cf.: Duuren, D.v., et al., 2007, p. 5

1877 Cf.: Ibid., pp. 6-7. 
KIT no longer conducted physical anthropological research. ${ }^{1878}$ The loan was designed as a long-term loan, with no termination date. In 2000, the Vrolijk Museum decided to return the loan. Given the developments challenging the status of human remains in (public) collections world-wide the KIT decided to take the return of the loan as starting point of researching the history of its Department of Physical Anthropology and to reflect upon its current policy with regard to (the restitution of) human remains. ${ }^{1879}$

The first phase of the research project consisted of an internal research in which the provenance of all objects from the returned physical anthropological collection was investigated. 1880 The internal research of the collection revealed that the collection of human remains had been brought together between 1915 and 1964. This core period of collecting human remains essentially stretches over the period of existence of the KIT's predecessor, the Colonial Institute. The Colonial Institute in Amsterdam had been established in 1910 as Dutch centre of expertise in a range of subjects relating to Dutch colonialism, including ethnology. Part of the Colonial Institute was the Colonial Museum, which had a bi-parte structure consisting of a section dealing with trade in tropical objects and an ethnographic section. As of 1915, physical anthropology occupied a prominent part in the scientific and public policy of the institute. ${ }^{1881}$ In 1964 , with the retirement of R.A.M. Bergman as director of the Colonial Institute, the era of physical anthropology came to an end. Since then, the activities in this field were confined to the keeping of the already assembled objects. ${ }^{1882}$

An exact calculation of the number of human remains in the collection is difficult to make. Often, a single inventory number designates some hundred bones and bone fragments. ${ }^{1883}$ Most of the human remains are so-called dry specimens (bones). This category splits into contemporary remains and much older, archaeological remains. ${ }^{1884}$ Only a comparatively small number of specimens is preserved in alcohol. ${ }^{1885}$

With regard to the geographical origin of the collection most of the human remains that had been acquired prior to World War II had a colonial provenance: most remains were obtained in the Dutch colonies, in particular the Dutch East Indies (Indonesia), and the former Dutch New Guinea (Papua). ${ }^{1886}$

With regard to the composition of the collection and the circumstances in which the remains had been acquired the research was not conclusive given the absence of any written collection or research policy in the available archival records. The lack of information stems to some extent from the fact that physical anthropologists rarely

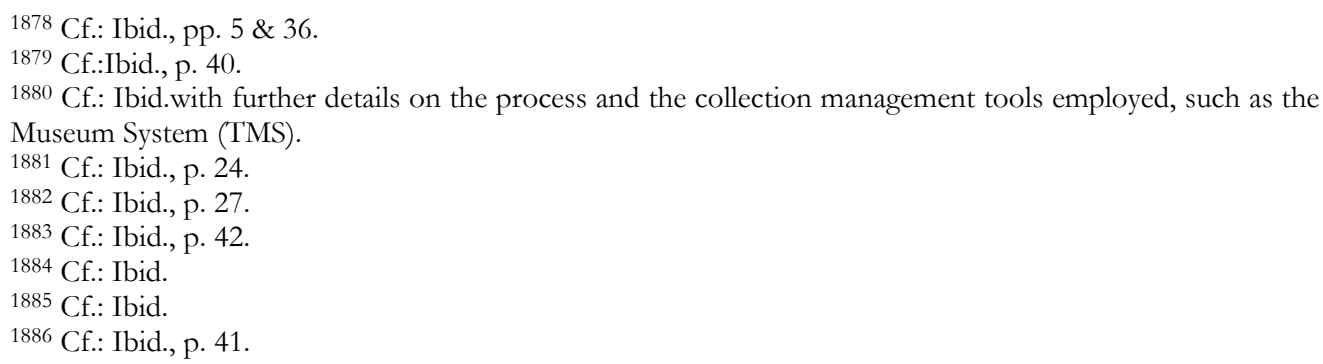


recorded the circumstances of acquisition of their material. ${ }^{1887}$ Consequently, little is known about the original relevance of the remains for source communities and the circumstances of acquisition. The fragmented and inbalanced composition of the collection (a "potpourri of rare ethnological, archaeological and recent human remains") ${ }^{1888}$ suggests donations as main means of acquisition. ${ }^{1889}$

On the basis of its research findings the KIT formulated a draft policy to be discussed with experts from different academic, museological, and national backgrounds. The draft policy differed between four categories of human remains:

A. Physical anthropological remains in the strict sense of the term;

B. Ethnographical remains;

C. Archaeological remains, at least two hundred years old plus worked human remains;

D. Recent historical remains from the World War II, found in Dutch New Guinea. ${ }^{1890}$

According to the draft policy, each of these categories merits different treatment: physical anthropological remains, i.e. dry specimen such as skulls, parts of skulls and bones and specimen preserved in alcohol should either be "destroyed" or be disposed. Destruction was understood as ranging from cremation and burial to donations for academic use. Given the poor conditions and anonymity of the remains cremation or burial were thought as the most obvious option. With regard to ethnographic remains, as well as archaeological remains, the draft policy stated that both categories required (further) re-evaluation as to their ethnographical, historical and cultural importance. With regard to the fourth category, consisting of skeletal remains of soldiers that had died in Dutch New Guinea during World War II, the policy recommended their repatriation. ${ }^{1891}$

The draft policy was discussed during an expert meeting that had been convened for this purpose by the KIT in February 2006. Experts from different academic, museological, and national backgrounds ${ }^{1892}$ had been invited to discuss the "past, present and future" of the collection of human remains of the KIT.1893

\footnotetext{
1887 Cf.: Ibid., p. 43.

1888 Cf.: Ibid., pp. 50 \& 40.

1889 Cf.: Ibid.

1890 Cf.: Lubina, K.R.M., 2007, p. 85.

1891 Cf.: Ibid.

1892 Dr. Laura van Broekhoven - National Museum of Ethnology Leiden, Dr. Andries van Dam, Museum of Anatomy Leiden, Dr. Katherine Goodnow - University of Bergen, Prof. Dr Ton Hol- Utrecht University, Einar Lund Jansen - National Museum of Denmark, Viktor Kasiepo - Representatie Papua community in The Netherlands, Prof. Dr. Sankot Marzuki - Eijkman Institute for Molecular Biology Jakarta, Prof. Dr. Norman Palmer, Dr. Laura Peers - Pitt Rivers Museum, Dr. Ciraj Rassool, University of the Western Cape, Drs. Laurens de Rooy - Museum Vrolijk, Dr. Hedley Swain - Museum of London. From the KIT: Indrea Bergval, Drs. Koos van Brakel, Drs. David van Duuren, Denise Frank, Prof. Dr Susan Legêne, Lejo Schenk, Drs. Pim Westerkamp. The morning session was attended by Riet de Leeuw, Ministry of Education, Culture and Science. The author was allowed to attend the meetings.

1893 The following summary of the expert meeting is based on: Lubina, K.R.M., 2007.
} 
As to the four categories proposed in the draft policy and the diverging treatment, the group of experts unanimously agreed that there exists no clear-cut distinction between the categories: the distinction between physical anthropological material and ethnographic material, as well as archaeological remains however is not as self-evident as it appears in the first place. In principle, ethnographical remains are physical anthropological material with a historic, local, and/or scientific context. Vice versa, ethnographical remains also qualify as physical remains. Neither does a clear-cut distinction with archaeological remains exist. Consequently, the group of experts held that all human remains in the collection of the KIT should be re-evaluated instead of limiting re-evaluation to ethnographical and archaeological remains. The re-evaluation should cover the original meaning of the remains to the source-community, their current meaning within the collection of the KIT, as well as their current meaning outside the KIT to source-communities and other institutions.

The experts pleaded for a more nuanced approach both with regard to the destruction and restitution of human remains: with regard to the KIT's original idea to destroy most physical anthropological objects it was stressed that the objects may very well have scientific value: the remains originated from parts of the world that are or may not be (well) represented in other collections and thus should not be automatically destroyed. With regard to the restitution of human remains, the discussions amongst the experts highlighted that restitution should not be done for the wrong reason: restitution should not be motivated by the wish to get rid of the material. On the other hand, restitution should not be understood as simply giving back material from one country to another: restitution is not about restitution of remains in the first place, but about the restitution of authority over these remains. In this understanding, restitution can also mean that the remains stay in the museum while ownership or the management is transferred. Also, restitution can mean that remains are given a specific status within, or even outside the museum collection (e.g. from owner to custodian with limited rights).

It was agreed during the expert meeting that until restitution in this broad sense could be realised, human remains were best taken care of by the KIT itself. In the meantime, the KIT should continue analysing its one own intellectual history and engage in new relationships with formerly colonized peoples. The latter requires more provenance research of the human remains. The research should be extended from the archives of the KIT to include also archives of private collectors who might have introduced the objects to the collection of the then colonial museum, as well as archives in other European countries. The experts pointed out that the identification of source communities could lead to the following paradox: with successful identification of source communities of human remains as necessary condition for any restitution, the scientific value of human remains increases. Put differently: with the increase in documentation and knowledge of the remains their scientific value increases as well. Until such information is found the remains from the anthropological collection have little significance for the KIT in its current understanding as ethnographic museum. 
However, by putting the remains in their historical, cultural and geographical context they may gain a new dimension of significance for scientific research. ${ }^{1894}$

Regardless of this potential conflict between restitution and scientific research the seeking of dialogues with source communities was stressed as an important, if not the most important next step for the KIT to take. It was expressed that the KIT should seek as much openness and transparency to allow for dialogue with source communities.

\section{Extrapolation of principles}

As a result of the expert meeting the KIT came to the conclusion that its attempt to formulate and implement a clear-cut policy making an a priori distinction between different categories of human remains in its collection was not sustainable. While its draft policy proved very valuable in initiating the process of reflecting upon the collection the KIT learned to approach the restitution of human remains as a process that could not be dealt with by the implementation of certain guidelines but as a process that had only been initiated and involved a broad understanding of restitution and greater understanding of the value of the collection as a whole. In agreement with the expert recommendations to strive for openness and transparency the KIT published its research findings on its physical anthropological collection in a special volume of its bulletin series. ${ }^{1895}$ With the publication of "Physical anthropology reconsidered - Human remains at the Tropenmuseum" the KIT signalled its willingness to engage in a dialogue with other stakeholders. Also, the KIT is currently cooperating with the Vrije Universiteit, Amsterdam and the Nederlands Instituut voor Oorlogsdocumentatie NIOD in a research project, investigating a.o. the origin of human remains, allegedly Japanese soldiers with the aim to repatriate them. ${ }^{1896}$

While the KIT came to the conclusion that it is not possible to define a clear-cut policy with regard to the treatment and repatriation of human remains we can nevertheless extract principles that guide the decision-making process:

1. Human remains must be treated with sensitivity bearing in mind their original meaning to the sourcecommunity, their current meaning within the collection of the KIT, as well as their current meaning outside the KIT to source-communities and other institutions;

2. The relevance of human remains for research should be assessed against a global context.

3. Repatriation is not only about the actual act of returning human remains:
a. motivation of the holding collection matters
b. repatriation is about the restitution of authority;

4. Repatriation can have various manifestations ranging from physical return to transferring ownership or management to granting the remains a specific status within, or even outside the museum collection;

\footnotetext{
1894 Cf.: Duuren, D.v., et al., 2007, p. 59.

1895 Ibid.

1896 See for a description of the project: 'Sites, Bodies and Stories - The dynamics of heritage formation in colonial and postcolonial Indonesia and the Netherlands':

http://www.onderzoekinformatie.nl/nl/oi/biza/d34000o/OND1331303/ (last visited 17 April 2009).
} 
5. Dialogue with source communities is essential.

\section{COMPARISON OF THE PRINCIPLES EXTRAPOLATED IN VIEW OF IDENTIFYING KEY ELEMENTS FOR A DUTCH POLICY ON THE REPATRIATION OF HUMAN REMAINS}

At the end of each case-study we have extracted the principles that underlie the decision-making in the respective case. In the following, we will compare these principles in order to see whether they allow us to formulate more general principles or to identify key elements with regard to the repatriation of human remains from Dutch public collections.

At first sight already, a comparison of the principles extrapolated in the case studies suggests that it is impossible to identify common ground in the principles extracted. While there exists significant agreement between the principles put forward by the National Museum of Ethnology (RMV) / (preparatory) SVCN Ethnological Ethics Committee and those underlying the pro-active reflection by the KIT there exists little if no overlap with the principles that underlie the recommendation of the NMV Ethical Code Committee. One of the principles that underlie both the decision-making by the National Museum of Ethnology (RMV) / (preparatory) SVCN Ethnological Ethics Committee and the reflection of the KIT is that all human remains must be treated with great sensitivity. In contrast, the NMV Ethical Code Committee expressed the principle that in principle human remains should not be treated any different from the return of other collection items. It is nevertheless correct to state that the principle that human remains should be considered as sensitive parts of the collection and should be treated with respect and sensitivity constitutes a general principle of Dutch policy on the repatriation of human remains: in 2006, the Dutch translation of the international ICOM Code has been updated. This change is relevant in that the Dutch ICOM Code form the basis of the recommendations of the NMV Ethical Code Committee. ${ }^{1897}$ While the 1999 version that underlies the recommendation with regard to the "West Frisian Eskimo" did not include any provision dealing explicitly with the return of human remains the present Dutch version dating from 2006 does contain such provision. Paragraph 4.4 of the Dutch ICOM Code (2006) is an accurate translation of the provision from the international 2004 ICOM Code:

Requests for removal from public display of human remains or material of sacred significance from the originating communities must be addressed expeditiously with respect and sensitivity. Requests for the return of such material should be addressed similarly. Museum policies should clearly define the process for responding to such requests. 1898

\footnotetext{
1897 http://www.museumvereniging.nl/default.aspx?id=327 (last visited 17 April 2009).

1898 In Dutch: 4.4 Verwijdering uit een openbare tentoonstelling: Verzoeken tot verwijdering van menselijke resten of objecten met een religieuze betekenis uit een openbare tentoonstelling, komende uit de betrokken
} 
With this provision dealing specifically with human remains and stressing the need of respect and sensitivity, the general starting point of the recommendation of the NMV Ethical Code Committee to treat requests for the return of human remains no different from any other request seeking the return of cultural property can no longer be upheld. Instead, paragraph 4.4. of the current version of the Dutch ICOM Code supports the general principle that 'human remains must be considered as sensitive parts of the collection and must be treated with respect and sensitivity'.

A second, however, irreconcilable difference between the three sets of principles concerns the motivation for which human remains may legitimately be claimed. Again, it is the policy as expressed by the NMV Ethical Code Committee that cannot be reconciled with the principles underlying the decision by the National Museum of Ethnology (RMV) / (preparatory) SVCN Ethnological Ethics Committee and the reflection of the KIT. According to the NMV Ethical Code Committee only requests motivated by the wish of (re-) burial respectively other funeral arrangements will be considered. The two other policies took a much broader perspective on repatriation and did not formulate any conditions on the treatment of remains after their return. In fact, while the National Museum of Ethnology (RMV) contemplated about including a condition prohibiting the burial of the Toi Moko, the (preparatory) SVCN Ethnological Committee stated that where an object does not qualify as belonging to Dutch cultural heritage, a return must be full and unconditional. The KIT's pro-active initiative does not make mention of any conditions for returns. Instead, it starts from the perception that repatriation is about the transfer of authority and that it can have various manifestations ranging from physical return to transferring ownership or management to granting the remains a specific status within, or even outside the museum collection. Both the (preparatory) SVCN Ethnological Committee and the KIT did not state any other substantial criteria that should guide the decision making process. Instead, both put more emphasis on the decision-making process. Before turning to this aspect we have to conclude that no general principle can be formulated with regard to substantial criteria: the emphasis the NMV Ethical Code Committee put on the motivation of reburial is not shared by the other two policies and no further substantial criteria have been provided.

In the absence of substantial criteria, the decision-making process becomes crucial. Both the National Museum of Ethnology (RMV) / (preparatory) SVCN Ethnological Ethics Committee and the KIT stress the relevance of dialogue between the holding institution and the claimants. While the policy of the NMV Ethical Code Committee is silent in this respect, it does not oppose dialogue and the sharing of the criteria on which its decision on the request is based with the requesting party. Consequently, we take the liberty to formulate as key element for a Dutch general policy that the decision-

gemeenschappen, worden met respect en gevoel behandeld. Voor verzoeken tot teruggave geldt hetzelfde. Voor de behandeling van dergelijke verzoeken worden heldere richtlijnen vastgesteld. 
making process should be characterised by dialogue. ${ }^{1899}$ As minimum measure institutions must share the decisive criteria with the requesting party.

The principle that the decision-making process should be characterised by dialogue presupposes a second party to discuss the matter. From the case notes, especially the note discussing the return of the Toi Moko, it became apparent that the identification and confirmation of the legitimate negotiating party or stakeholder is more complex than appears at first sight. Who should be accepted as legitimate stakeholder? The NMV Ethical Code Committee took a very restrictive approach as to whom to accept as stakeholder: only relatives / next of kin who have provided proof of their relationship with the remains in form of DNA-testing or other form of documentation are accepted as stakeholder. Such approach demonstrates a Euro-American conception of kinship: "a conception in which the notion of direct kin, or in fact the transmission of "blood" or genetic material, is considered the unambiguous and only determinant for a person's place in the network of relations". 1900 The Euro-American conception of kinship consequently does not pay any relevance to shared experiences or substances other than blood and genetic material in shaping the network of relations between people. However, since the mid-1990s, anthropology has adopted a broader perspective, encompassing "norms, roles, institutions and cognitive processes referring to all the social relationships that people are born into or create later in life, and that are expressed through, but not limited to, an etic biological idiom". ${ }^{1901}$ Consequently, under the current concept of kinship relatedness can be established through other means than blood and genetic material. ${ }^{1902}$ According to one source, the NMV Ethical Code Committee had considered to allow also for claims by culturally affiliated groups similar to the US federal legislation NAGPRA. ${ }^{1903}$ In its final recommendation, however, any

1899 Such principle would also be in line with the so-called polder model that is often stressed as being typical for Dutch mentality. The polder-model refers to the decision-making by consensus. The name polder-model is derived from one of the possible explanations of the emphasis put on consensus: according to this explanation the unique geography of the Netherlands, largely consisting of polders forced different societies to cooperate. Polders, land regained from the sea, require constant pumping and maintenance of the dykes. Consequently, even when different cities in the same polder were fighting each other, they still had to cooperate in taking responsibility for the dykes. See further on the polder-model: Bos, D., et al., 2007.

1900 Dousset, L., 2002, http://www.ausanthrop.net/research/kinship/kinship2.php (unnumbered document).

1901 Ibid., (unnumbered document); Stone, L., 2001, p. 2.

1902 Dousset gives the following examples of practices: "in New Guinea, two persons that regularly drink from the same cup and eat the same food become brothers. They share substance, they establish kinship through consubstantiality. Among the Inuit or Eskimos, you do not always have to hunt with or fish with your kin, but an unrelated hunting partner may well become close relatives, as if they were born by the same mother. Among Noongar (...) rearing up is an important mechanism in the establishment of kin ties. Of course, those who are reared up together do not have to be what Euro-American culture calls blood relatives". Dousset, L., 2002, http://www.ausanthrop.net/research/kinship/kinship2.php (unnumbered document).

1903 Cf.: Aarts, B., 2000, p. 82. In section 2(1) of NAGPRA cultural affiliation is defined as "a relationship of shared group identity which can be reasonable traced historically or prehistorically between a present day 
reference to a broader group of claimants was dropped in order to avoid misunderstanding and stress the historical relevance of human remains as witness of past views and practices. ${ }^{1904}$ As consequence, culturally affiliated groups cannot validly claim human remains according to the NMV Ethical Code Committee.

In contrast to the dated Euro-American conception of kinship as embraced by the NMV Ethical Code Committee the National Museum of Ethnology (RMV) / (preparatory) SVCN Ethnological Ethics Committee did not define or restrict the circle of legitimate stakeholders in advance. Instead, they limited themselves to emphasising the relevance for the holding institutions to pay attention to the question whether the requesting party qualifies as appropriate stakeholder. This question has to be decided case-by-case and on the basis of proof provided by the requesting party. In the present case the National Museum of Ethnology (RMV) accepted the Museum of New Zealand Te Papa Tongarewa ("the Te Papa") as "replacement" stakeholder in the absence of clarity as to which of the Māori communities (iwi) the Toi Moko should be returned to.

The KIT did not explicitly reflect upon the notion of stakeholder or who qualifies as legitimate party seeking the return of human remains. The absence of this reflection can be explained by the fact that the case of the KIT is an pro-active introspection rather than a reaction to a request made by another party. From the fact that the KIT does refer repeatedly to the interests of source communities we can nevertheless conclude that the KIT has a broad understanding of who can qualify as stakeholder.

Again, we have identified a situation in which the KIT and the National Museum of Ethnology (RMV) / (preparatory) SVCN Ethnological Ethics Committee expressed similar ideas with regard to whom may qualify as legitimate stakeholder. According to their approach the circle of legitimate stakeholders should not be limited in advance. Proof of a valid interest must be provided by the requesting party. The NMV Ethical Code Committee again represents a dissenting opinion starting from an Euro-American conception of who may qualify as legitimate stakeholder. In light of the developments in the field of anthropology since the mid-1990s, in particular the adoption of a broader perspective on kinship encompassing "norms, roles, institutions and cognitive processes referring to all the social relationships that people are born into or create later in life, and that are expressed through, but not limited to, an etic biological idiom"1905, we deem it appropriate to attach less value to the principle expressed by the NMV Ethical Code Committee. Consequently, the third and final general principle we were able to identify by comparing the sets of principles from the case studies is that 'great relevance must be paid to the question whether the requesting party qualifies as appropriate stakeholder.

Indian tribe or Native Hawaiian organization and an identifiable earlier group”. 25 U.S.C.3001 (2) (2004). See further on NAGPRA above in chp. 2.S2.II.2.

1904 C.f.: Ibid. Aarts' information is based on an interview with Renée van Kempen, then secretary of the NMV Ethical Code Committee.

1905 Dousset, L., 2002, http://www.ausanthrop.net/research/kinship/kinship2.php （unnumbered document); Stone, L., 2001, p. 2. 
This question has to be decided case-by-case and on the basis of proof provided by the requesting party'.

\section{INTERMEDIARY CONCLUSIONS FOR THE NETHERLANDS}

In the Netherlands no official policy on the return of human remains from public collections has been endorsed by the Dutch Government. Instead, institutions affected by a claim or wishing to adopt a pro-active attitude are essentially free to decide about whether or not to return human remains. The Dutch Government was, however, involved in the case of the Toi Moko claimed from the Museum of Ethnology in Leiden. As owner of the collection, the state, represented by the Minister of Culture had to agree with the de-accession of the object from the collection. ${ }^{1906}$ In the absence of government regulations, public collection have sought external advice from professional bodies advising museums about ethical problems or from an ad-hoc group of experts.

In the case of the alleged Inuit remains the West Frisian sought advice from the NMV Ethical Code Committee, which was founded to advise museums about the Dutch ICOM Code and to hold their behaviour against the code. ${ }^{1907}$ In the case of the Toi Moko from the collection of the National Museum of Ethnology a different committee was relied upon: the (preparatory) 'SVCN Ethnological Ethics Committee'. The committee was founded by the Foundation of Ethnological Collections (SVCN) in order to better represent the particular needs and questions that may arise from caring for ethnological collections. When the case of the Toi Moko was referred to the committee, it was not yet fully established. In fact, the SVCN Ethnological Ethics Committee was officially established only in 2004. Consequently, the case of the Toi Moko was heard by a preparatory committee, which had been appointed to define the scope and procedural rules of the SVCN Ethnological Ethics Committee but also made a number of substantial recommendations. The KIT, finally, did not seek advice from any of the two permanent professional bodies but instead invited a number of experts to seek feedback on its envisioned policy.

Our analysis of the recommendations of the professional ethics bodies / expert group revealed that it is difficult to arrive at one common set of ethical principles. Only three principles, essentially procedural in character, could be identified as principles of general validity:

1. Human remains must be considered as sensitive parts of the collection and must be treated with respect and sensitivity;

2. The decision-making process should be characterised by dialogue. As minimum measure institutions must share the decisive criteria with the requesting party;

1906 Cf.: chp. 3. \$2.I. on the management of cultural objects in ownership of the Dutch State.

1907 http:/ / www.museumvereniging.nl/default.aspx?id=337 (last visited 27 March 2008). The NMV Ethical Code Committee was originally called in Dutch the 'Commissie Museale Gedragslijn'. In 2007 the name was revised to "Ethische Codecommissie voor Musea". 
3. Great relevance must be paid to the question whether the requesting party qualifies as appropriate stakeholder. This question has to be decided case-by-case and on the basis of proof provided by the requesting party.

Consequently, while there exists some guidance for institutions in the Netherlands on how to deal with a claim for the return of human remains no clear-cut practice instructing the decision-making process from a substantive point of view could (yet) be identified. How must one evaluate the finding that with regard to the Dutch situation we have been able to identify only three principles of procedural character? At first sight this finding is clearly disappointing. However, they might very well be realistic. While we will postpone further evaluations until after we have extrapolated also the principles valid in the United Kingdom and France, we would like to make mention of the findings by an expert group with regard to the formulation of principles on repatriation. On 3 April 2009 the SVCN Ethical Code Committee (i.e. the now fully established successor of the preparatory SVCN Ethical Code Committee) convened an expert meeting on the drafting of guidelines with regard to the repatriation of objects, including human remains from the collections of their associated member institutions. ${ }^{1908}$ After having discussed international developments, philosophical aspects of repatriation and restitution, as well as case studies of various Dutch institutions ${ }^{1909}$ the meeting was concluded with emphasising the need of open-minded and transparent dialogue with requesting parties. Such dialogue should be facilitated by a list of aspects that could or should be discussed. Similar conclusions were also drawn for the jurisdiction of the United Kingdom, which will be discussed in the following section.

\section{UNITED KINGDOM}

In the United Kingdom, the introspection of its public collections and the reflection upon how to deal with human remains and future claims was triggered by two events in particular: the publication of a report by the Select Committee on Culture Media and Sport of the House of Commons (hereinafter: "the Select Committee") and a joint statement by the prime ministers of the UK and Australia.

In July 2000, the Select Committee published a report titled 'Cultural Property: Return and Illicit Trade'. ${ }^{1910}$ The report focused inter alia on policies and procedures of museums relating to the acquisition and return of cultural property which has been illicitly removed. The Select Committee touched upon human remains as one type of material that falls under the broad notion of "cultural property" as defined in the 1970

${ }^{1908}$ Email by Annelies Valgaeren dated 1 April 2009, re: 'introductory text for the expert meeting of the SVCN, Friday 3th of April' on file with the author.

1909 The case studies were not limited to human remains. As for human remains only the case of the Toi Moko was discussed.

${ }^{1910}$ Seventh Report of the House of Commons Select Committee on Culture Media and Sport, Cultural Property: Return and Illicit Trade, 2000. 
UNESCO Convention. ${ }^{1911}$ With regard contested cultural property, the Select Committee stated that the nature of the claims for the return varies: "[ $t$ ] material subject to claims are very diverse, from human remains, to works of art and domestic and religious objects". ${ }^{1912}$ During the process of the inquiry, the Select Committee became convinced that the category of return claims dealing with human remains deserved separate analysis. ${ }^{1913}$ Consequently, and based upon further insights gained during the inquiry, the Select Committee recommended further analysis, including a consultation exercise of claims dealing with human remains and the handling of human remains in public collections more in general. ${ }^{1914}$ The same year, in July 2000, UK Prime Minister Tony Blair and Prime Minister of Australia John Howard issued a joint statement according to which both governments were to increase efforts to repatriate human remains to Australian indigenous communities. ${ }^{1915}$

In response to this statement and the recommendations of the Select Committee and the Government of the United Kingdom established a working group to provide for a comprehensive analysis of the subject before undertaking a consultation exercise. ${ }^{1916}$

\section{The Working Group on Human Remains in Museum Collections}

The "Working Group on Human Remains in Museum Collections" (hereinafter: "WGHR") was established in May 2001, with the following terms of reference:

- $\quad$ to examine the current legal status of human remains within the collections of

- $\quad$ publicly funded museums and galleries in the United Kingdom;

- to examine the powers of museums and galleries governed by statute to

- deaccession, or otherwise release from their possession, human remains within

- their collections and to consider the desirability and possible form of legislative

- change in this area;

1911 Ibid., para. 124. The Select Committee stated that the concept of cultural property of the 1970 UNESCO Convention was "extremely broad and subjective, in that it is assumed that importance is to be defined by a State. Objects that can be subject to trading restrictions or prohibitions range from buman remains to postage stamps" (Emphasis added).

1912 Ibid.

1913 The Select Committee referred to developments in other countries, especially NAGPRA. Ibid., paras. 153-155. See for an outline of NAGRPA and its relevance for the internationalisation of claims seeking the return of human remains: chp. 2.\$2.II.2 / 3.

1914 Ibid., para. 199. The principal conclusions and recommendations stated in subsection xiv) - xvi) that there should be discussions with museum representatives, claimant communities, and governments to prepare a statement of principles and accompanying guidance relating to the care and safe-keeping of human remains and to the handling of requests for return of human remains; that access to information on holdings of indigenous human remains for all interested parties, including potential claimants, needs to be improved; and that the Department for Culture, Media and Sport should undertake a consultation exercise on the terms of legislation to permit the trustees of national museums to remove human remains from their collections.

1915 See for the full text of the statement: Working Group on Human Remains, 2003, para. 4.

1916 Ibid., para. 3: Hansard, HC, vol. 368, col. 115W, 8 May 2001, A. Howarth; and Hansard, HL., vol. 625, Part 75, col. WA240, 10 May 2001, Lord McIntosh of Haringey. 
- to consider the circumstances in which material other than, but associated with,

- human remains might properly be included within any proposed legislative

- change in respect of human remains;

- to take advice from interested parties as necessary;

- to consider the desirability of a statement of principles (and supporting guidance) relating to the care and safe keeping of human remains and to the handling of requests for return; if the Working Group considers appropriate, to draw up the terms of such a statement and guidance;

- to prepare a report for the Minister for the Arts and make recommendations as to proposals which might form the basis for a consultation document (to be used for consultation under the Regulatory Reform Bill). ${ }^{1917}$

In November 2003 the final report of the WGHR was published. ${ }^{1918}$ Within the twoand-a-half years of research the members of the WGHR carefully analysed questions such as the information and other gains to be expected from retention of human remains; the arguments for and circumstances favouring restitution or relocation; UK institutional treatment of contemporary human remains; alternatives to compelled physical relocation; and the volume (size and distribution of collections; measurement; resource implications) of the collections. ${ }^{1919}$ In its deliberations, the WGHR adopted the following definition of human remains:

1917 Ibid., pp. 1-2, para. 1.

1918 The report of the WGHR consists of thirteen chapters and an appendix of ten documents. chp. 1 sets out the establishment of the WGHR and its terms of reference. Chapters 2 and 3 provide background information on the volume and source of human material currently within the collections of English museums and other institutions. Chapter 4 summarises the written and oral evidence received by the WGHR of scientists, communities of origin and holding institution. Chapter 5 gives an account of modern developments concerning the return of human remains both by English museums and overseas national initiatives and discusses other cases of return, in particular the restitution of material spoliated during the period 1933-1945. Chapter 6 outlines the contemporary law applicable to human remains in England and Wales. Amongst the legal aspects addressed is the so-called no-property rule, which will be discussed more in detail below. Chapter 7 marks the first Chapter to discuss the future treatment of human remains in England by reflecting upon the notion of consent; in particular in how far its application with regard to human remains in museum collections should equal or parallel its relevance for the future acquisition, retention and use of bodily material by medical institutions. In Chapter 8 the WGHR made an attempt to pin down the notion of 'objects associated with human remains'. Chapter 9 sets out principles that the WGHR believes should inform the discussion of all future care, treatment and return of human remains in UK collections. Chapter 10 is a recapitulation of those aspects of law and practice discussed in the previous chapter that need to be improved. The process for the evaluation and decision making on claims for the return of human remains is outlined in Chapter 11, whereas Chapter 12 summarises all recommendations of the WGHR. Chapter 13 presents a statement of dissent by one of the members of the WGHR.

The appendix consists of the following documents: 1) Powers of disposal for museums; 2) Law on human remains in museum collections - a working survey; 3) Repatriation of Human Remains and the Human Rights Act; 4) Case summaries relating to human remains; 5) International Agreements; 6) Professional and Institutional Approaches to Human Remains; 7) Terms of reference; 8) Draft Code of Practice for the Treatment, Care and Safe Keeping of Human Remains in English Museums and Collections; 9) Working Group on Human Remains submissions; 10) The Native American Graves Protection and Repatriation Act (NAGPRA): A detailed analysis.

1919 Working Group on Human Remains, 2003, pp. 5-6, para. 17; Woodhead, C., C., 2004, pp. 179-180. With regard to the extent of holdings of human remains in England, the HRWG commissioned a survey. The results of this survey are published in: Weeks, J. / Bott, V., 2003. The survey is available online at: 
"human remains should be understood as including all forms of human material and should be specifically taken as including:

- osteological material (whole or part skeletons, individual bones or fragments of

- bones, teeth);

- $\quad$ soft tissue including organs, skin, hair, nails etc (preserved in spirit or wax or

- $\quad$ dried/ mummified);

- $\quad$ slide preparations of human tissue;

- $\quad$ artefacts made wholly or largely from any of the above". ${ }^{1920}$

In basing its definition on the human origin of the material, regardless of the later treatment of the remains, such as the processing of a skull into a drinking vessel or the processing of a fermur bone into a flute, the WGHR adopted a rather broad definition of human remains, excluding only human fossils and sub-fossils. ${ }^{1921}$

In the following, before summarising the conclusions drawn by the WGHR and the recommendations it issued, we would like to reflect upon one particular aspect of the report more in detail: the legal status of human remains, more in particular whether human remains in public collections may be subject to property rights. The reason for focusing on this aspect is that it is frequently discussed in English academic literature. In Chapter 6 outlining the contemporary law applicable to human remains in England and Wales, the WGHR discusses the so-called no-property rule. As the name indicates, the no-property rule holds that there can be no property in a corpse. The relevance of the rule for the return of human remains, should it apply also to human remains in museum collections lies in the fact that it would allow for the disposal of human remains regardless of the general ban outlined in above on disposal of objects from the national museums. This statement requires some further explaination: the analysis in Chapter 3 ( $\$ 2 . I I)$ on the regulation of the national museums in the UK revealed that objects vested in the trustees as part of the collections of the Museum shall not be disposed of by them except for in a number of very limited exceptions. ${ }^{1922}$ The term "vested" implies ownership. ${ }^{1923}$ Consequently, where the no-property rule applied to human remains in museum collection the ban on disposal may not be valid as the human remains have

http://www.culture.gov.uk/images/publications/ScopingSurveyWGHR.pdf (last visited 22 April 2009). See for a summary of the findings: Working Group on Human Remains, 2003, pp. 10-27, paras. 30-83; Woodhead, C., C., 2004, p. 180.

1920 Working Group on Human Remains, 2003, pp. 7-8, para. 19. Note that in subsuming artifacts, such as sculptural renderings of human beings, under the definition of human remains the WGHR differs from the perception of the Select Committee on Culture Media and Sport, which strictly distinguished between the remains of actual human beings and human remains which have been physically modified (Seventh Report of the House of Commons Select Committee on Culture Media and Sport, Cultural Property: Return and Illicit Trade, 2000, para. 163).

1921 The WGHR does not motivate its decision not to include human fossils and sub-fossils.

1922 See above in chp. 3. S2.II on the analysis of the regulation of English (national) museums, in particular the analysis of Section 3(4) of the British Museum Act 1963, sections 6(3) and 14(3) of the National Heritage Act 1983, sections 4(3), 4(4), 4(5), 4(6) of the Museums and Galleries Act 1992.

1923 Cf.: Working Group on Human Remains, 2003, pp. 110-111, para. 271. 
never been vested in the Trustees. ${ }^{1924}$ The rule, which as been established in case law, is, however, not without exceptions. In the following, we will shortly introduce the noproperty rule - the general common law rule that dead bodies (and separated materials) cannot be the subject of property rights - and the exception of the application of skillful work according to which most human remains in museum collections are capable of being property.

The first binding judicial pronouncement of the no-property rule dates back to the case R. v Sharpe from 1857.1925 According to Erle J the law applicable does not recognise property in a corpse. ${ }^{1926}$ Erle J. based himself on the ealier Hayne's case. The Hayne's case dates from 1614 and dealt with the theft of a burial shroud. ${ }^{1927}$ One of the questions that arose in this case was who was the owner of the winding sheets in which the dug up bodies had been wrapped. According to the judge, a corpse could not own property. Consequently, the taking of the sheets did not qualify as theft. While the judge did not state that the corpse could not qualify as property, the case was subsequently wrongly interpreted as stating exactly this. Consequently, in the case of R. v Sharpe, Erle J.'s obiter dicta that the law does not recognise property in a corpse was lacking a proper precedent. Subsequent case law followed the 'no-property' principle with its dubious historical origins. ${ }^{1928}$

In 1908, in the case Doodeward v Spencer, the no-property rule was qualified in view of the effects of lapse of time. ${ }^{1929}$ According to Griffith C.J. the incapability of human remains to being owned at their moment of death does not prevent them from loosing this status over time. Griffith C.J. referred to mummies and other anatomical and pathological specimens in support of his position. ${ }^{1930}$ The distinction between mere corpse and body which had been subjected to a process of preservation was confirmed in Dobson v North Tyneside Area Health Authority. ${ }^{1931}$ In this case the Court of Appeal accepted the proposition that there is no property in a corpse, but that the

\footnotetext{
1924 Note that the lawyers of the UK "Working Group on Human Remains in Museum Collections" (hereafter: "WGHR") that has been established by the Minister for the Arts in May 2001 all agreed that no legislation was necessary in order to allow for the de-accession of human remains (private conversation with Norman Palmer, Chairman of the UK WGHR on Thursday, April 2006). Cf.: also: Ibid., p. 111, para. 271.

1925 R v Sharpe (Sharpe's Case (1856-1857) Dears \& Bell 160; 169 ER 959. The case dealt with the removal of the remains of Sharpe's mother, a dissenter of Church of England, from unconsecrated grounds belonging to protestants. Sharpe pretended to bury his father's remains in his mother's grave but instead removed her body. Sharpe was charged for trespassing the licence by abusing it for a different purpose.

1926 Ibid., para. 163.

1927 Haynes's Case (1614) 12 Co Rep 113; 77 ER 1389.

1928 Forster v Dodd (1867) L.R. 3 QB 67, para. 77; R v Lynn (1788) 2 T.R. 733, 100 E.R. 394. Cf.: Hardcastle, R., 2007, chp. 2 \& 3.

${ }^{1929}$ Doodeward v. Spence (1908) 6 C.L.R. 406

1930 Ibid., para. 414.

${ }^{1931}$ Dobson v North Tyneside Health Authority [1997] 1 WLR 596 (CA). See for a case note: Palmer, N., 1996.
} 
principle is subject to the qualification the process or application of human skill can render a corpse the subject of property. ${ }^{1932}$

The process or application of human skill as an exception to the no-property rule was further explicated in the case R v Kelly. ${ }^{1933}$ The case arose after the artist Anthony Noel Kelly had asked the co-defendant Niel Lindsay, who worked at the Royal College of Surgeoens to provide him with some 40 human body parts. Kelly had paid Lindsay $£ 400$ for the body parts and used the parts to make casts. The Southwark Crown Court found Kelly and Lindsay guilty of theft and convicted them. ${ }^{1934}$ Kelly and Lindsay appealed to Divisional Court arguing a.o. that given the no-property rule they could not have commited a theft. The Court of Appeal confirmed the judgement of the Southwark Crown Court: while there had existed an English common-law rule of 'questionable' historical origins for over 150 years body parts were exceptionally capable of being property for the purposes of the Theft Act 1968, where "they have acquired different attributes by virtue of the application of skill, such as dissection or preservation techniques, for exhibition or teaching purposes". 1935

Leaving aside the "conspicuously dubious historical origins" of the no-property rule ${ }^{1936}$ we can conclude that the exception introduced in Doodeward v Spence and as further explicated in R.v Kelly according to which human body parts can become subject to property rights by by virtue of the application of skill applies to most human remains in public collection as these remains have undergone some form of preservation. ${ }^{1937}$ Consequently, with human remains in public collections being capable of ownership, they are vested in the trustees as part of the collections of the Museum and do not by their nature enjoy a broader range of de-accession possibilities.

\section{a) The main conclusions of the WGHR}

The WGHR identified two fundamental responsibilities of museums with regard to curated human remains: on the one hand, to respect the diversity of beliefs with regard to the significance of ancestral remains and how they should be treated; on the other hand, to recognize the relevance of human remains for scientific research. As to the coexistence of these two responsibilities the WGHR noted that at times they cannot be reconciled. ${ }^{1938}$ According to the WGHR, when assessing the responsibilities museums must be aware of the asymmetric sphere of influence in which they are operating: this sphere of influence consists of implications of cultural diversity, the relevance of scientific research, and the anger and pain that can be felt by source communities. In

\footnotetext{
1932 Cf.: Smith v Tamworth City Council (1997) 41 N.S.W.L.R. 680.

${ }^{1933}$ R v Kelly and another [1999] QB 621 (CA); Palmer, N., 1998a.

1934 Section 1(1) of the Theft act 1968 reads: "A person is guilty of theft if he dishonestly appropriates property belonging to another with the intention of permantently depriving the other of it".

1935 Per Rose L.J at pp 749-750; R v Kelly and another [1999] QB 621 (CA).

1936 Hardcastle, R., 2007, p. 28.

1937 Cf.: Woodhead, C., C., 2002, p. 320.

1938 Cf.: Department for Culture Media and Sport, 2004a, p. 23, para. 28.21.
} 
view of this asymmetric sphere of influence the WGHR identified the removal of legal barriers to repatriation as one of the most urgent steps in achieving even-handed solutions. ${ }^{1939}$ Without taking away the legal barriers to deaccession considerations to requests for return are missing the serious and constructive context they require. ${ }^{1940}$

Further to changing the law, the WGHR also concluded that there is a need for formal licensing and regulation of museums holding human remains to ensure the highest standards of care in the treatment and safe keeping of human remains. The WGHR referred to the anticipated bill with regard to the regulation of human tissue in the medical context and stated that similar regulation was needed in the museum context, if possible under the umbrella of the same act. ${ }^{1941}$ Similar to the treatment of human tissue in the medical context, the retention and treatment of human remains by museums should be based on consent. The WGHR's conclusions were inconclusive with regard to questions such as how to identify the person or community whose consent should be sought, how far the requirement for consent should be extended; and whether parties having a relationship other than one being based on genealogical ties should be in a position to give or withhold consent. ${ }^{1942}$ It did, however, express a strong view that the views of close family or direct genealogical descendants on the treatment or return of human remains should be regarded as paramount. Where such views clash with scientific interests, the former should be decisive. ${ }^{1943}$

As to the best practice in situations where close family or genealogical descendants cannot be identified, the opinions within the WGHR differed: according to the majority opinion, a person or group, which in its own culture or belief system enjoys a status or responsibility comparable to that which UK institutions would recognise as conferring authority to withhold consent, should be able to determine any future act in relation to the human remains in question. According to the minority opinion, however, the views of such persons or groups should not be understood as over-riding requirement for consent but should be taken into account, next to other factors such as the age of the remains and their relevance for scientific research. ${ }^{1944}$

With regard to question of how to resolve disagreement between claimants and holding collections the WGHR favoured alternative dispute resolution procedures over formal legal processes. ${ }^{1945}$ Possible alternative dispute resolution procedures could consist of panels set up within individual museums and the establishment of a national

\footnotetext{
${ }^{1939}$ See above chp. 3.\$2.II for an overview of the restrictions on the disposal of objects in public collections in the United Kingdom (UK), in particular in England.

1940 Cf.: Department for Culture Media and Sport, 2004a, p. 23, para. 28.23.

1941 Cf.: Ibid., p. 23, para. 28.24.

1942 Cf.: Ibid., p. 23, para. 28.25

1943 Cf.: Ibid., p. 23, para. 28.26

1944 Cf.: Ibid., p. 23, para. 28.27.

1945 Ibid., p. 23, para. 28.28.
} 
panel of independent experts. Such a "Human Remains Advisory Panel" could be inspired by the form and mandate of the Panel. ${ }^{1946}$

On the basis of its conclusions the WGHR issued a number of recommendations, which we will summarise in the following.

\section{The main recommendations of the WGHR ${ }^{1947}$}

While the conclusions were supported by all members of the WGHR, the recommendations were not unanimous. ${ }^{1948}$ We will first summarise the majority view before discussing the dissenting opinion, which proposed alternative recommendations. The statement of dissent was submitted by the Director of the Natural History Museum, Neil Chalmers.

The majority recommendations deal with the law, dispute resolution, regulation, and a number of additional issues ("other matters"). As far as the law is concerned the WGHR recommends the removal of the present legal restrictions on museums' ability to dispose of human remains. ${ }^{1949}$ While the WGHR considered recommending mandatory disposal and repatriation it did not deem it the most appropriate response. At present, permissive legislation supplemented by public regulation and a credible dispute resolution procedure would be a more appropriate response to the present situation. ${ }^{1950}$ While the WGHR had reviewed a number of possible forms of legislative provision to give effect to a power of disposal, it did not recommend a particular approach. However, in as far as possible the provisions permitting disposal to be enacted for all museums, including national museums, should be uniform. ${ }^{1951}$

With regard to dispute resolution, the WGHR had reached the conclusion that disputes between holding institutions and communities of origin should be dealt with by alternative dispute resolution methods rather than by formal legal procedures. As concrete recommendations the WGHR suggested that all museums should introduce a procedure for the determination of claims and controversies concerning the repatriation of human remains. The criteria by which museums assess a claim are to be published. ${ }^{1952}$ The WGHR furthermore made a number of recommendations concerning the establishment of advisory panels within individual museums to consider issues concerning the return or treatment of human remains. Such panels would need to have objective standards of independence, fairness, consistency and transparency. Also, the

\footnotetext{
1946 See further above in chp. 4. S1.II.1 the description of the Spoliation Advisory Panel. 1947 Department for Culture Media and Sport, 2004a.

1948 Cf.: Working Group on Human Remains, 2003, p. 177, paras. 171.171-171.172.

1949 See above in chp. 3.\$2.II.2 on the statutory restrictions on the disposal of items within the collections fo the national museums.

1950 Cf.: Department for Culture Media and Sport, 2004a, p. 25, para. 29.23.

1951 Cf.: Working Group on Human Remains, 2003, p. 161, paras. I-II.

1952 Cf.: Ibid., p. 162, para. IV.
} 
panels need to have appropriate representation drawn from outside the institution in question. ${ }^{1953}$

Next to the procedures at individual museum level the WGHR recommended the establishment of a national Human Remains Advisory Panel, consisting of independent experts. Such a panel should be accessible to all relevant parties but will give recommendation only where the reference is by common consent of the parties. The functions of the panel should be in broad conformity with the functions and powers of the Panel. ${ }^{1954}$

Further to changes in the law and dispute resolution the WGHR made recommendations on the regulation of human remains collections in museums. Inspired by the proposal for the Human Tissue Act, which foresees in licensing requirements for human tissue in the medical context, the WGHR recommended that similar licensing requirements should be introduced on the holding, return, treatment, handling and disposal of human remains from museum collections. ${ }^{1955}$ Under such regime, the licensing authority under the Human Tissue Act would have power to grant, withhold and withdraw licences, to impose conditions on the grant of licences, to direct the disposal of, and provide for the management of human remains, as well as investigating complaints. While the Human Tissue Authority would be able to set and enforce standards relating to the care of remains it would not have any power to give guidelines relating to, or arbitrate in, claims for repatriation. The Working Group rounded off its recommendations on licensing with the suggestion that institutions should be required to subscribe to a code of practice on the care and management of human remains. ${ }^{1956}$

One of the subjects discussed under the category of additional issues ("other matters") was the question of consent. The WGHR recommended that, in light of the relevance many communities of origin attach to human remains, no museum should keep human remains, or do research on them, where there is reason to believe that the original removal of the remains occurred without consent, and that the present treatment of the remains is without the consent of close family or direct genealogical descendants of the dead person. In this case, museums should try to identify family or descendants. With regard to the situation where no close family or descendants can be identified the opinions within the WGHR differed: a majority of the WGHR recommends that museums should then seek instructions from someone from the dead person's own religion or culture who has a status or responsibility comparable to that of close family or direct genealogical descendants for consent. A minority of the WGHR took the view that in this case decisions should be based on consultation, taking account of a wide range of interests, rather than on a requirement for consent. Rather, than

\footnotetext{
1953 Cf.: Ibid., p. 164, para. IV.

1954 Cf.: Ibid., p. 164, para. V.

1955 Cf.: Ibid., p. 165, para. VIII.

1956 Cf.: Ibid., pp. 165-168, para. VIII-XII. See for a draft code of practice, drawn up by the Working Group, in Appendix 4 of the report.
} 
seeking consent from parties (not being family or descendants) their interests with regard to the human remains should be factored in the decision-making process alongside factors such as scientific and social benefits of retention and research. ${ }^{1957}$

\section{b) Dissenting recommendations}

As stipulated above the WGHR was not unanimous in its recommendations. A statement of dissent was submitted the Director of the Natural History Museum, Neil Chalmers. In the following we will discuss his alternative recommendations for they agree significantly with the recommendations finally adopted by the UK Government. Chalmers identifies three main reasons for dissenting with the recommendations of the WGHR as summarised above: first, the recommendations do not arrive at a proper balance between the public benefits deriving from medical, scientific and other research on the one hand and the wishes of claimant communities on the other. ${ }^{1958}$ Secondly, he dismisses some of the recommendations as disproportionately complicated ${ }^{1959}$ or, as third reason as unworkable. ${ }^{1960}$

In as far as the proper balance between the public benefits deriving from retaining human remains and the wishes of claimant communities on the other is concerned, Chalmers supports the recommendation that return should be based on permissive rather than mandatory reason. He criticises, however, that this recommendation is lacking a fundamental, ethically-based reason and is instead based upon pragmatic reasons that favour permissive rather than mandatory return. ${ }^{1961}$ Chalmers' argumentation is somewhat slanted: while it is true that the reasons provided by the WGHR for preferring permissive rather than mandatory return are pragmatic in character, the majority opinion of the WGHR also mentioned a "fundamental, ethicallybased reason for coming to this conclusion". According to the majority opinion of the WGHR, the need to redress human remains in museum collections lies in the respect for and well-being of claimant communities: not granting authority to these communities about their ancestral remains confirms and prolongs the discriminatory treatment indigenous peoples have suffered since the era of Imperialism. Furthermore, the WGHR stresses that claimant societies must be enabled to fulfil their obligations towards their ancestors as it otherwise impairs their spiritual well-being. ${ }^{1962}$ Regardless of

\footnotetext{
1957 Cf.: Ibid., pp. 170-171, para. XV.

1958 This criticism aims at recommendations I-III of the majority opinion of the WGHR.

1959 This criticism aims at recommendations IV to XII and XIX of the majority opinion of the WGHR.

1960 This criticism aims at recommendations XV, XVI and XVIII (lxiv) of the majority opinion of the WGHR.

1961 Working Group on Human Remains, 2003, pp. 177-178, paras. 172.171-172.172. Chalmer refers to pp. 122-125, paras. 309-319 as the relevant sections listing the pragmatic reasons.

1962 " 1 . To many indigenous peoples the return of their ancestors to the homeland is essential to the health of the descendant community. Such a community should be allowed to decide for itself how its members are treated. Any derogation from this principle is a discriminatory subordination of indigenous peoples and a demeaning relegation of them and their concerns to inferior status. It also prevents them from fulfilling a solemn obligation, the neglect of which causes acute pain. There is little question that the original taking of
} 
the fact that the WGHR preferred permissive rather than mandatory repatriation the starting point of the WGHR's majority opinion is that human remains should be repatriated.

Chalmers, in his minority opinion, does not start from a general acceptation that human remains should be returned. Instead, his starting point is that there is no generally valid ethical imperative for repatriation of human remains in abstracto. Rather, he suggests to introduce a system in which in every case the benefits and disadvantages of repatriation or retention are compared, balancing a number of factors affecting the strength of the claim for repatriation and factors affecting public benefit, especially research, that arise from retention. Chalmers refers to the duty to show respect for persons, the duty to be sensitive to cultural differences and the duty not to exploit the vulnerable as principles to assess the benefits and disadvantages of repatriation. In some cases, the assessment will point to repatriation as the ethically right course of action; whereas in other cases the arguments for repatriation will not outweigh the profits of retention. ${ }^{1963}$ As second criticism of Chalmers of the balance between the wishes of claimant communities and public benefits deriving from retaining human remains deals with the WGHR's proposition to make the continued retention of human remains subject to consent from the claimant community. ${ }^{1964}$ According to Chalmers such a system would effectively introduce a mandatory regime to repatriate human remains. $\mathrm{He}$ states that a mandatory regime of repatriation, regardless of whether effected by means of legislation or by making consent by claimant communities as precondition for retention, would be unacceptable.

In light of his criticism Chalmers recommends to change the law affecting the holding of human remains in order to allow museums to return human remains. Such legislation, nor any other measures to be introduced (e.g. the requirement of consent) should result in a mandatory regime of repatriation. ${ }^{1965}$

Chalmer's second reason for dissenting with the recommendations of the WGHR is that he deems a number of recommendations as disproportionately complicated. First, Chalmer criticises that a system entailing not only the museums themselves, but also a new licensing authority, a purely advisory national panel, with the additional option of

these remains was often morally, if not legally, wrongful, that such dispossession would not be tolerated today, and that English museums will no longer acquire indigenous remains in violation of the wishes of their parent communities. Why, then, should it make any difference that particular remains are already in the possession of a museum?

2. Until this wrong is redressed, there will be no closure in respect of past injustices and an arguable enduring violation of fundamental human rights. The physical and psychological health, and indeed the social advancement, of indigenous communities are in consequence impaired. No other class of society finds its lack of consent overridden, its autonomy subverted, and its spiritual needs unilaterally subordinated to other interests in this way. Equality and justice demand the return of ancestral remains. People grieve and will continue to grieve until the spirits of their ancestors are at rest”. Cf.: Ibid., pp. 122-123, para. 311.

1963 Cf.: Ibid., p. 178, para. 172.173.

1964 Cf.: Ibid., pp. 170-171, para. XV.

1965 Cf.: Ibid., p. 179, paras. 173.173-173.176. 
local panels, and the possible intervention of the Minister for the Arts. A system involving this many participants would be excessively complicated and untransparent to claimant societies while at the same time not adequately protecting the public interest of research into human remains. ${ }^{1966}$ The Minority Report agrees with the recommendation that museums should be required to conform to procedures specified by the new licensing authority. However, different from the majority opinion, the licensing authority would not only specify standards with regard to the care of human remains in museum collections but would also specify procedures for dealing with requests for repatriation of human remains from claimant communities. ${ }^{1967}$ While the licensing authority would wake over museums to live up to high standards of care, the decision on repatriation of human remains should rest with the governing bodies of the museums themselves. Chalmers prefers each licensed museum setting up its own ethics committee rather than relying on a (national) Human Remains Advisory Panel and/ or ministerial intervention. ${ }^{1968}$

After having criticised a number of recommendations of the WGHR's majority's opinion as unbalanced and disproportionately complicated, Chalmer's final criticism is that a number of recommendations are unworkable, in particular the requirement for museums to seek consent of claimant communities and the requirement to consult overseas public authorities to seek guidance on unclaimed human remains. If implemented, these recommendations would effectively mean a halt on all research upon human remains from claimant communities, and consequently cannot be said to strike a fair and workable balance between the interest of claimant communities and the public benefits that arise from research. ${ }^{1969}$ As an alternative, Chalmers suggests the introduction of guidelines that would constitute an ethical framework for decisionmaking. Such guidelines should look at aspects, such as whether the identity and geographical or community origins of the deceased are known; how recently or far in the past the deceased lived; how closely the claimants are related to the deceased, and on the circumstances by which the deceased came into the museum's possession. Further to these aspects establishing the strength of a claim for repatriation, the guidelines must also take into account the relevance of the remains for research purposes. ${ }^{1970}$ Finally, Chalmers dismisses the recommendation that museums should proactively seek advise on the display, research and storage of human remains from the close family or direct genealogical descendants of deceased persons, respectively their community surrogates, or failing that all other concerned parties whose concerns are known to the museum as „disproportionate, unrealistic and unworkable“..1971

\footnotetext{
1966 Cf.: Ibid., p. 179, paras. 174.171.

1967 Cf.: Ibid., p. 179, paras. 174.172.

1968 Cf.: Ibid., p. 179, paras. 174.173-174.174.

1969 Cf.: Ibid., p. 182, para. 185.181.

1970 Cf.: Ibid., p. 182, para. 185.182.

1971 Cf.: Ibid., p. 182, para. 185.183.
} 
In comparing the recommendations of the minority opinion with those of the majority opinion, it becomes clear that they are based on different starting points. Whereas the majority opinion considers the wishes of the deceased as paramount and consequently should transcend the interests of science ${ }^{1972}$, the minority opinion does not accept a generally valid ethical imperative for repatriation of human remains in abstracto. Instead, the minority opinion puts great emphasis on the relevance of retention of human remains for public interest, in particular research, and accepts repatriation only in specific cases as ethically the right course of action. ${ }^{1973}$ In the following, we will discuss the developments since the publication of the WGHR's report and recommendations. We will first discuss the inclusion of section 47 in the Human Tissue Act, as direct result of the WGHR's report before discussing the 'Guidance for the care of Human Remains in Museums' as finally approved by DCMS.

\section{Human TISSUE ACT 2004 AND THE POWER TO DISPOSE OF HUMAN REMAINS}

Following the recommendations of the WGHR, the Government immediately moved to legislate to enable nine national museums to dispose of human remains from their collections.1974 At the time the WGHR presented its report in 2003 the Government was considering the introduction of new legislation on the question of human tissue and organs. Given the difficulty to find a place in the legislative programme, it was decided to subsume the legislative changes necessary for the disposal of human remains from public collections under the same legislation dealing primarily with the regulation of human organs and tissue in hospitals and medical research institutions. The need to legislate on the question of human tissue and organs had appeared from a number of revelations during 1999 and 2000 about the retention of human organs and tissue by hospitals and health authorities, in particular at Bristol Royal Infirmary, the Royal Liverpool Children's Hospital (Alder Hey). Inquires about the practices at the two hospitals revealed that organs and tissue from children who had died had been removed, stored and used without proper consent of the parents. ${ }^{1975}$ Further reports revealed a more general practice in the past of storing and using organs and tissue without proper consent. ${ }^{1976}$ These practices had occurred against the

1972 Cf.: Woodhead, C., C., 2004, pp. 192-193.

1973 Cf.: Steel, P., 2004, p. 22.

1974 See above chp. 3.\$2.II for an overview of the restrictions on the disposal of objects in public collections in the United Kingdom (UK).

1975 Cf.: Bristol Royal Infirmary Inquiry, Interim Report: Removal and Retention of Human Material (May 2000); The Royal Liverpool Children's Inquiry Report (The Stationery Office 2001) H.C. [Session 2000-1]; 112-II, . Cf.: Price, D., 2005, p. 798.

1976 The Royal Liverpool Children's Inquiry Report (The Stationery Office 2001) H.C. [Session 2000-1]; 112-II; Chief Medical Officer, Report of a Census of Organs and Tissues Retained by Pathology Services in England, January 2001, available online at:

http://www.dh.gov.uk/en/Publicationsandstatistics/Publications/PublicationsStatistics/DH_4006720;

Department of Health, Human Bodies, Human Choices: The Law on Human Organs \& Tissue in England \& Wales - A Consultation Report, (2002), . 
backdrop of the Human Tissue Act 1961. Under this act, the person lawfully in possession of a human body, i.e. the hospital wherein the person died, was permitted to authorise the removal and use of human material for the purposes of therapy, education and research where there was no reason to believe that either the deceased or any surviving spouse or relative objected to it. ${ }^{1977}$

The purpose of the Human Tissue Act 2004 is to introduce a legislative framework for all issues relating to the taking, storage and use of human organs and tissue that is based on 'informed consent' rather than an 'absence of objection'. Part I of the Human Tissue Act 2004 deals with obtaining 'appropriate consent' for the removal, storage and use of human organs and other tissue for a number of specified purposes. 'Appropriate consent' is defined in section 3 as the consent of the person whose remains are to be used. Where it concerns the tissue derived from a child and the child is not competent to give consent, 'appropriate consent' refers to the consent of the parents. By making the treatment of human tissue subject to the requirement of 'appropriate consent', the act aims to strike a balance between the rights and expectations of individuals and families, and the general interest, such as research, education, training, pathology and public health.

The Human Tissue Act 2004 was introduced into the House of Commons on 3 December 2003. On 29 June 2004 it was brought to the House of Lords. On 19 November 2004 it passed through the Upper House to receive Royal Assent on 15 November 2004. ${ }^{1978}$ The Act repeals in their entirety the Human Tissue Act 1961, as well as the Anatomy Act 1984 and the Human Organ Transplants Act 1989 (except with regard to Scotland), and the Human Tissue Act (Northern Ireland) 1962.1979 It entered into force in various stages as was specified in commencement orders.

As for human remains, sections 1, 9, 16 and 47 are relevant. ${ }^{1980}$ According to Section 1 , there exist a number of situations that are exempted from the general requirement to obtain 'appropriate consent'. Section 1(5) excludes imported bodies from this requirement, whereas Section 1(6)(c) excludes all material that came from the body of a person who has been dead for more than one hundred years (on a rolling basis). Also exempted from the requirement of 'appropriate consent' are human remains and tissue that have been held for the purposes now regulated by Part I of the Human Tissue Act 2004 prior of the entry into force of the Human Tissue Act 2004 (section 9). ${ }^{1981}$

Part 2 of the Human Tissue Act 2004 outlines the introduction and tasks of a Human Tissue Authority (sections 13-15). According to section 16, a licence of the Human Tissue Authority is required for purposes including the storage of anatomical

\footnotetext{
1977 Price, D., 2005, p. 799.

1978 Ibid., p. 798.

1979 Ibid.

${ }^{1980}$ In the context of this study we will focus on the relevance of the Human Tissue Act for the treatment of human remains in public collections. See further on the principal matters of the relating to human material in hospitals and medical research facilities, e.g.: Ibid; Hardcastle, R., 2007, chp. 4.

1981 Cf.: Shelbourn, C., 2006, pp. 188-189.
} 
specimens and the public display of human tissue or remains. Failure to comply with the requirement to obtain a licence or with the conditions stipulated in a licence constitutes an offence (section 25). However, similar to Sections 1(6)(c) and 9 discussed above, there is no need to obtain a licence from the Human Tissue Authority where the activities concern remains of persons who deceased more than one hundred years ago (on a rolling basis) or which had been held at the moment the Human Tissue Act 2004 entered into force (section 16(4)). ${ }^{1982}$ Also excluded from the licensing requirements of the Human Tissue Act 2004 are the use and storage of religious relics (section 40).

As a result of these exemptions with regard to the requirement to obtain 'appropriate consent' and of holding a licence, the activities of museums fall largely outside the application of the Human Tissue Act 2004. Different from the majority conclusions of the WGHR it does not impose a requirement to obtain consent for human remains in museum collections retrospectively to authorise continued storage and use of existing holdings. ${ }^{1983}$ Most of the human remains in public collection are either older than one hundred years or had been collected prior to the entry into force of the Human Tissue Act 2004. Also, human remains from people who deceased more than one hundred years ago (on a rolling basis) or which had been held at the moment the Human Tissue Act 2004 entered into force do not fall within the remit of the Human Tissue Authority and the licensing regime. ${ }^{1984}$ However, where museums wish to acquire new human material for their collections and this material is not imported and less than one hundred years old, the museum requires the consent of the donor and a licence from the Human Tissue Authority. The latter requirement applies also when the human tissue is imported. ${ }^{1985}$

1982 Cf.: Ibid., p. 189.

1983 Cf.: Department for Culture Media and Sport, 2004a, p. 19, para. 17.18.

1984 Cf.: Ibid., p. 20, para. 27.12.

1985 The exceptions that have been introduced for curated human remains already in possession of the museums at the time the Human Tissue Act 2004 entered into force corresponds to the preferences expressed in the consultation exercise of the Department for Culture, Media and Sport (DCMS): Ibid. The consultation document invited comments on the recommendations of the WGHR. The key areas of the consultation were: whether the museums sector should be brought fully under the remit of the Human Tissue Authority; what model of consent should be adopted in dealing with any claims for repatriation; whether the Government should establish a Human Remains Advisory Panel, to mediate claims for repatriation of human remains and whether a statement of principles should be published as guidance to museums? Forty-seven responses were received by DCMS ranging from UK national and non-national museums, archaeological groups as well as cultural and religious groups. As to the question whether the museums sector should be brought fully under the remit of the Human Tissue Authority, 29\% of respondents supported to bring all activities of museums under the licensing regime of the Human Tissue Authority. 53\% opposed this, including 12 respondents that would support licensing only for human remains less than 100 years old. Many museums indicated that regulation exceeding the regime to be introduced by the Human Tissue Act 2004 would lead to costs of compliance that would adversely affect operations. In particular, smaller provincial museums might not be able to sustain their collections under more restrictive regulation. With most human remains in UK collections being uncontentious licensing of all museum activities was perceived as disproportionate.

With regard to the question whether the treatment and retention of human remains by museums should be based on consent $72 \%$ of the respondents agreed that where close family or direct genealogical descendents 
Whereas the sections of the Human Tissue Act 2004 discussed so far do not change the status of human remains in museum collections, Section 47 does effectively change the situation of human remains in nine named museums. ${ }^{1986}$ According to this section, the Royal Armouries, the British Museum, the Imperial War Museum, the Museum of London, the National Maritime Museum, the National Museums and Galleries on Merseyside, the Natural History Museum, the Science Museum and the Victoria and Albert Museum:

"may transfer from their collection any human remains which they reasonably believe to be remains of a person who died less than one thousand years before the day on which this section comes into force if it appears to them to be appropriate to do so for any reason, whether or not relating to their other functions". ${ }^{1987}$

Section 47(2) grants the trustees or governors of the named museums the possibility to dispose of human remains. Consequently, different from all other objects in public collections human remains may be de-accessioned. Trustees or governors are never under an obligation to dispose of human remains. The regime introduced by section $47(2)$ is a permissive rather than mandatory one.

The power to dispose human remains is not unlimited: it applies only to human remains that are less than 1000 years old (on a rolling basis). Also, the power granted for de-accession does not affect any 'trust or condition' under which the trustees or governors may hold the human remains concerned and which might prevent them from disposing (Section 47(4)). ${ }^{1988}$ Parliament does not regard it as in the public interest to create powers to override the terms of gifts to museum collections. On the other hand, Section 47 does not limit the possibility of disposal to certain claimant groups (e.g. lineal descendants). In fact, the power granted under Section 47 is not limited to disposal motivated by a wish to repatriation but is available "for any reason". ${ }^{1989}$ Furthermore, Section 47(3) extends the power of disposal also to things that are mixed or bound up with human remains, provided that it is undesirable, or impracticable, to separate them.

could be identified, research of human remains should be subject to their consent. $48 \%$ of respondents held that where no direct genealogical descendents could be identified, the use and custody of human remains should require consultation rather than consent. While consultation with wider groups was supported, the notion of consent should not exceed family and direct descendents. With regard to the question of the duties of museums in identifying the remains respectively genealogical descendants there was general agreement that museums should allow for the identification by providing clear and open information over their collection holdings. The need to pro-actively seek out descendants was dismissed for being unreasonable.

1986 Section 47 entered into force on 3 October 2005: Human Tissue Act 2004 (Commencement No. 2) Order 2005/2632.

1987 Section 47(2).

1988 Cf.: Shelbourn, C., 2006, p. 190.

${ }^{1989}$ Cf.: Ibid. 
Examples of objects mixed or bound up with human remains are masks that include human hair or a bark canoe that is sewn around infant bones. ${ }^{1990}$

Whereas section 47 of the Human Tissue Act 2004 applies only to nine national museums, its relevance exceeds the removal of legal barriers in repatriating human remains from these museums. By passing section 47 the UK parliament took a stand in the debate on the repatriation of human remains in favour of repatriation and granted more authority to repatriation claims. ${ }^{1991}$

\begin{tabular}{|l|l|l|}
\hline \multicolumn{3}{|l|}{ Table summarising the main provisions of the Human Tissue Act 20041992 } \\
\hline $\begin{array}{l}\text { Section I: Storage and use of } \\
\text { human tissue for anatomical } \\
\text { examination or display }\end{array}$ & $\begin{array}{l}\text { Part II: Anatomical examination, } \\
\text { storage and public display of } \\
\text { human tissue }\end{array}$ & $\begin{array}{l}\text { Section 47: Power to de- } \\
\text { accession human remains (and } \\
\text { items intimately associated with } \\
\text { them) }\end{array}$ \\
\hline Consent of donor required & $\begin{array}{l}\text { Licence required from Human } \\
\text { Tissue Authority }\end{array}$ & $\begin{array}{l}\text { Permissive not mandatory - } \\
\text { where trustees consider it } \\
\text { appropriate for any reason' }\end{array}$ \\
\hline $\begin{array}{l}\text { Consent not required where the } \\
\text { human tissue has been imported }\end{array}$ & $\begin{array}{l}\text { Licence not required where the } \\
\text { human tissue is from a person } \\
\text { who died before the Act came } \\
\text { into force }\end{array}$ & $\begin{array}{l}\text { Power to de-accession given only } \\
\text { to 9 named museums }\end{array}$ \\
\hline $\begin{array}{l}\text { Consent not required where } \\
\text { human tissue is from a person } \\
\text { who died more than 100 years } \\
\text { ago (on a rolling basis) }\end{array}$ & $\begin{array}{l}\text { Licence not required where the } \\
\text { human tissue is from a person } \\
\text { who died more than 100 years } \\
\text { ago }\end{array}$ & $\begin{array}{l}\text { Power applies only to human } \\
\text { remains less than 1000 years old } \\
\text { (on a rolling basis) and material } \\
\text { bound up with it (where } \\
\text { practically not separable) }\end{array}$ \\
\hline $\begin{array}{l}\text { Consent not required where } \\
\text { human tissue is part of a museum } \\
\text { collection held before the Act } \\
\text { entered into force }\end{array}$ & $\begin{array}{l}\text { Licence not required to hold and } \\
\text { display human tissue which is a } \\
\text { religious relic }\end{array}$ & \multicolumn{2}{|l}{} \\
\hline
\end{tabular}

\section{3. 'Guidance for the Care of Human Remains in Museums'}

In 2005, DCMS approved the 'Guidance for the Care of Human Remains in Museums', which had been prepared by a drafting group. ${ }^{1993}$ The guidance is not

1990 Flessas, T., 2007, p. 4.

1991 Cf.: Shelbourn, C., 2006, p. 190.Department for Culture Media and Sport, 2004a

1992 The table has been developed by: Shelbourn, C., 2006, p. 191.

1993 Department for Culture Media and Sport, 2004a, available online at:

http://www.culture.gov.uk/images/publications/GuidanceHumanRemains11Oct.pdf (last visited 22 June 2009). The drafting group had been commissioned by DCMS in reaction to the positive feedback received during the consultation on the introduction of a code of practice. See further on the consultation above in footnote 1985 . Nearly $70 \%$ of the respondants were in favour of a code of practice. The consultation also identified a number of aspects that should be provided for in such a code: acknowledgement of the special nature of human remains both in human terms and for science; emphasis on good curation; differentiation 
statutory and therefore can only recommend what is considered as best practice rather than prescribing it. ${ }^{1994}$ It provides advice to museums and other institutions holding human remains (except collections kept purely for medical teaching) on how to curate and use human remains appropriately and, most importantly, on how to deal with claims for their repatriation. ${ }^{1995}$ 'The guidance understands 'human remains' as

"the bodies, and parts of bodies, of once living people from the species Homo sapiens (defined as individuals who fall within the range of anatomical forms known today and in the recent past). This includes osteological material (whole or part skeletons, individual bones or fragments of bone and teeth), soft tissue including organs and skin, embryos and slide preparations of human tissue". ${ }^{1996}$

Furthermore, human remains also include any of the above that may have been modified in some way by human skill and/or may be physically bound-up with other non-human materials to form an artefact composed of several materials. Another, but less frequently encountered category of material included within the understanding of human remains is that of artworks composed of human bodily fluids and soft tissue. Not included in the definition, in line with the Human Tissue Act 2004, are hair and nails, although it is acknowledged that some cultural communities do give these a sacred importance. ${ }^{1997}$

The guidance consists of three parts: Part 1 outlines the legal and ethical framework for the treatment of human remains; Part 2 deals with the curation and use of human remains, and Part 3 provides for a decision-making framework on how to deal with claims for the return of human remains.

\section{a) Part 1 of the Guidance: legal and ethical framework}

Part I consists essentially of a summary of the provisions of the Human Tissue Act 2004 that are relevant for the care and disposal of human remains in museums. In view of the situation that museums are encountering restrictions to disposal that are not remedied by Section 47 of the Human Tissue Act 2004, the guideline encourages them to remove any such restrictions from the constitution documents. As for the ethical framework, the guidelines take a unpretentious stand in admitting that the ethical issues raised by human remains in museums are complex and that consensus, if at all, will only emerge with time and experience. Consequently, the ethical framework proposed in the guideline is meant as starting point for the museums only. ${ }^{1998}$ The ethical framework

between different types of human remains (e.g. in respect of their origin from within and outside the UK); recognition of the multiple accountability of all institutions holding human remains; need for holding institutions to inventorise and know their collections in detail; emphasis on openness and communication in all discussions. Cf.: Department for Culture Media and Sport, para. 4.1.

1994 Cf.: Department for Culture Media and Sport, 2005, p. 7.

1995 Cf.: Lohman, J., 2006a, pp. 11-12.

1996 Cf.: Department for Culture Media and Sport, 2005, p. 9.

1997 Cf.: Ibid.

1998 Cf.: Ibid., p. 13. 
splits in two parts: the first part provides for a number of procedural principles that should be demonstrated in making decisions concerning the care of human remains, or in dealing with claims for their return. In handling human remains and claims relating to remains, museums should demonstrate:

- $\quad$ Rigour - act rationally with appropriate knowledge, skill and care and justify your decisions;

- Honesty and integrity - be worthy of trust by others; declare conflicts of interest; show honesty in communicating knowledge with all interested parties; act in a principled manner;

- Sensitivity and cultural understanding - show sensitivity and compassion for the feelings of individuals; show understanding of different religious, spiritual and cultural perspectives;

- Respect for persons and communities - show respect for individuals and communities; minimise any adverse affect on people and communities; respect privacy and confidentiality;

- Responsible communication, openness and transparency - listen, inform and communicate openly and honestly;

- Fairness - act fairly; give due weight to the interests of all parties; act consistently. ${ }^{1999}$

\section{b) Part 2 of the Guidance: guiding principles}

The second part of the ethical frameworks seeks to provide principles that may guide and instruct museums' thinking and decision-making concerning the handling and care of human remains, and with regard to claims relating to them:

- Non-maleficence - doing no harm;

- Respect for diversity of belief - respect for diverse religious, spiritual and cultural beliefs and attitudes to remains; tolerance;

- $\quad$ Respect for the value of science - respect for the scientific value of human remains and for the benefits that scientific inquiry may produce for humanity;

- Solidarity - furthering humanity through co-operation and consensus in relation to human remains;

- Beneficence - doing good, providing benefits to individuals, communities or the public in general.2000

A reading of this list of principles shows that some of the principles (may) collide with one another. First, this may be the case for the respect for diversity of beliefs and the respect for the value of science: the principle for diversity of beliefs requires decision-makers to give appropriate consideration to the cultural and historical backgrounds, beliefs and values relevant to all parties concerned, including source communities. In particular it would require a museum to recognise and respect that a community may place a different cultural or religious value on human remains that requires their reburial. While the beliefs of other communities, especially of indigenous peoples are not necessarily anti-science, past experience has shown that at times the belief system of claimants and the values of science did not coincide. ${ }^{2001}$

${ }^{1999}$ Cf.: Ibid., p. 14.

2000 Cf.: Ibid., pp. 14-15.

2001 See, e.g. the Kennewick Man Case discussed in chp. 2.\$2.II.2.a). Cf.: Steel, P., 2004, p. 25 who reports of case where indigenous peoples from Australia claimed the return of four Aboriginal skulls from the Manchester Museum. 
A second set of principles that may collide are the principle of non-malenficence and the principle of beneficence: while these two principles will in some cases act as two sides of a single coin differing more in appeal or tone concerning the activities of the acting person or institution, they may also be in conflict with one another. Both, the principle of non-maleficence - or put differently the principle of doing no harm and the principle of beneficence or of doing good looks at the interests of individuals, communities or the public in general. Consequently, it is possible, e.g. in respect of scientific medical research of human remains that the principle of non-maleficence speaks against conducting the research for it would do cause distress ot the familiy or community of origin of the remains whereas the principle of beneficence speaks in favour of conducting this research in the interest of the general public.

Where the principles of the respect for diversity of beliefs and the respect for the value of science, respectively the principles of non-malenficence and of beneficence collide, the principle of solidarity might become important. According to the guideline, the principle of solidarity:

"recognises that we all have a shared humanity and an interest in furthering common goals and tolerating differences that respect fundamental human rights. Mutual respect, understanding and co-operation promote solidarity by fostering goodwill and a recognition of our shared humanity. This principle emphasises the importance of rising above our differences to find common ground, co-operation and consensus. It would be reflected, for example, by seeking to find a consensus in relation to competing claims over human remains that all parties can accept". ${ }^{2002}$

In a sense the principle of solidarity constitutes an umbrella principle comprising the prinples for respect for diversity of beliefs, for the value of science, respectively the principles of non-malenficence and of beneficence. While striving for consensus in relation to competing claims over human remains is certainly noble, it is doubtful in how far the principle constitutes an additional value next to the more specific principles.

A final observation is that the principles may in themselves be contradictory or at least indecisive as to the ethically right way of acting. This is especially the case for the principle of beneficence, which may at the same time dictate that scientific research should be conducted in view of advancing knowledge that is of benefit to humanity and that human remains should be returned in view of respecting the wishes of an individual.

\section{c) Part 3 of the Guidance: framework for handling claims}

In the light of the unclearities and sometimes conflicting messages of the principles provided under the ethical framework in part 1 of the guideline, the framewok for handling claims for the return of human remains provided in part 3 of the guidelines

2002 Cf.: Department for Culture Media and Sport, 2005, p. 15. 
becomes more important. ${ }^{2003}$ While it applies in the first place to claims for the return of human remains originating from outside the UK, it should be veiwed as an overarching set of guidelines for claims regardless of their origin. ${ }^{2004}$ At the heart of this third part focusing solely on claims for the return of human remains is a list of criteria that museums should take into consideration when deciding upon a claim for return. Before discussing this list of criteria we will shortly address other relevant instructions to museums contained in part 3.

General starting point for museums is that requests should be dealt with as an open and constructive dialogue between the museum and the claimants. ${ }^{2005}$ In order to be prepared for the situation that a request for return is made, museums should prepare clear guidance on the criteria by which a claim will be assessed, the time span a request will take to be considered, the position of individuals within an organisation who will take responsibility for decision-making and communication and who will be consulted externally. Furthermore, the individual museum guidelines should set out who will be responsible for bearing the museum costs of processing a claim, although this should normally be the museum. The guidance should be prepared and be made public before any case for return is dealt with. Another preparation museums may wish to take is the establishment of an advisory panel of experts to provide support in dealing with claims. ${ }^{2006}$

Where a museum leaves the prepartory stage in having received a request for the return of human remains it can turn to the list of criteria that should be taken into consideration when deciding upon a claim for return.

The first criterion (A) addresses the status of those making the request and continuity with remains. Three possible claimant groups are identified: genealogical descendants, the cultural community of origin and the country of origin. Not suprisingly, the guideline accords most weight to claims by individuals who can demonstrate a direct and close genealogical link to the human remains. This is especially the case where the remains are less than 100 years old. The older the remains the more decendants they may have many from more than one community. As a consequence, genealogical descent is less evident to determine the outcome of the decision-making

\footnotetext{
2003 At this point we jump directly from Part I setting out the legal and ethical framework to Part 3 focussing on claims for the return of human remains. The reason for skipping Part 2 is that it is mainly concerned with how human remains should be cared for within institutions. It does, however, provide some guidance on how museums should deal with cases where they wish to de-accession human remains in situations where they did not receive a request for their return. In this case, the guideline instructs museums to pro-actively seek to establish whether there exist any genealogical or cultural decendatns who might wish to make claim for return or reburial. Where this is not the case, human remains may be disposed of, provided this is done in a safe and respectful manner. Cf.: Ibid., p. 18.

${ }^{2004}$ Cf.: Ibid., p. 23.

2005 Cf.: Ibid., p. 24.

2006 Cf.: Ibid. Cf.: above the procedural principles that should be demonstrated in making decisions concerning the care of human remains as provided under part 1 of the guideline.
} 
procedure. ${ }^{2007}$ Where a request is not based on genealogical descent but instead on cultural links, its assessment becomes more difficult for the concept of a community is difficult one to define. The guideline stresses the need for museums to verify that the group they are dealing with is the only potential claimant, or that, if it is not, the other potential claimants support them. Advice can be sought from the national government concerned or by looking for precedents for how a community has acted in the past. As minimum standards to consider a claim in the first place a continuity of belief, customs or language must be demonstrated between the claimants and the community from which the remains originate. Also relevant for the cultural relationship may be the location of the claimant community and the origin of the remains. A clear demonstration of a continuity of association between the claimant and the remains will be of great importance in dealing with any claim: where a claimant group does not either occupy the land from which the remains came, practice the same religious beliefs, share the same culture or language, or cannot not demonstrate why this is no longer the case museums are advised not to recognise the claim. ${ }^{2008}$ The final claimant group consists of countries of origin. In a number of cases a claim is excerted by a nation either on behalf of a particular community or for all of its nationals. The guideline recommends assessing such claims along similar lines to claims based on cultural community. ${ }^{2009}$

The second criterion (B) looks at the cultural, spiritual and religious significance of the remains. Demonstration of strong continuous cultural, spiritual or religious significance of the human remains concerned, will add weight to a claim. The cultural, spiritual or religious significance may consist in the relevance of correctly laying the remains to rest, in ending the feeling of grief amongst claimants where the continued holding of the remains may cause harm to the spiritual well-being to individuals or the community, or where the reamisn are from an important family or representing war dead, or victims of a particular event, such as a massacre.

Criterion $\mathrm{C}$ addresses the age of the human remains. Archaeological and historical research indicates that it is very difficult to demonstrate genealogical, cultural or ethnic continuity far into the past. For this reason it is considered that claims are unlikely to be successful for any remains over 300 years old, and are unlikely to be considered for remains over 500 years old. The suggested time spans correspond not only with the majority of claims that have been made for return of human remains so far; they also correspond with the period of European Imperialism and its subsequent effect on Indigenous peoples. An exception might be made for cultures that put more emphasis on association with land that has a cultural, spiritual or religious importance and less on relative age.

Further to the chronological age of the remains the circumstances of their removal may matter. Consequently, criterion D considers how the remains were originally

2007 Cf.: Ibid., p. 26.

2008 Cf.: Ibid.

${ }^{2009}$ Cf.: Ibid., pp. 26-27. 
removed and acquired. While there are cases where human remains have been removed and studied without dispute there are other instances, particularly during the 19th and early 20th century, where remains were removed against the will of individuals, families and communities, or at least outside its laws and normal practices. The latter will add more weight to a claim.

Criterion E turns away from the meaning of the remains for the claimants and focusses on the status of the remains within the museum. Next to ensuring the exact legal status of the remains within their collections and their right to make decisions over their fate, the museums should clarify why they are being held and how they have been, and are likely to be, used:

1. Are the remains fully documented and the information about them publicly available?

2. Do they have continued, reasonably foreseeable, research potential?

3. Do they form part of a documented access strategy?

4. Are they curated according to the very highest standards?

5. Are they curated in such a way as their long-term preservation is assured?

6. Can the long-term security of the remains be guaranteed within the museum?

The guideline does not further elaborate upon how these aspects translate into the weighing of the claim. One can assume that where the long-term preservation is not assured or the long-term security cannot be guaranteed this might speak in favour of return whereas the finding that the remains have further research potential might factor into the reasons against return. The relevance of the remains for science, education and the studying of history is more explicitly addressed in criterion $\mathrm{F}$.

According to criterion $\mathrm{F}$, the value of human remains for research, teaching and display must be accorded great relevance in the decision making process. It may override other factors in favour of return, such as the wishes and feelings of genealogical descendants or cultural communities. Criterion $G$, which suggests the scientific relevance human remains have had in the past as yard stick for their future scientific value does not constitute a genuine criterion on its own but is better characterised as sub-criterion to criterion F.

Criterion $\mathrm{H}$ then turns away from the past scientific value of human remains and focuses on the consequences that a return of the remains might have on future research, teaching or even display. The criterion seems to suggest that where claimants are prepared to keep the remains in such a way that their scientific and educational relevance will not be diminished; museums should be more readily prepared to return the remains.

Criterion I deals with the documentation of the remains. Where a record of the remains exists, or can be made before return, return is less drastic for a museum in that a "footprint" of the remains will continue to exist in its archive.

Under Criterion J museums are asked toexplore alternatives to the extreme options of retention and return. Where possible, an alternative or comprise where the remains 
would stay in the museum but the claimant group would be accorded a certain level of control over their future use is to be preferred over full return.

Criterion $\mathrm{K}$ draws the attention of museums to the legislation or policy as developed in the country of origin of the claimants. Museums are advised to consider how a claim would be resolved if made in the country of origin for this might give an indication of the expectations on the side of the claimant. Again the guideline does not take an explicit stand on how the findings concerning the legislation or policy of the country of origin must be factored in the evaluation of a claim pending in the UK; while it might be the case that the legislation or policy of the country of origin should be mirrored to some extend in the decision concerning the return from the UK this might be stretching the principle of sovereignty.

Criterion L finally asks museums to consider claims, irrespective of the fact that they will be dealt with on a case-by-case basis, in the greater line of past cases the museum might have received in the past and might yet receive in the future. While the pending case should not deviate from the outcome of claims of a similar kind; the museum should also consider the impact of the decision to be taken on any decision on future claims.

With the adoption of the non-binding 'Guidance for the Care of Human Remains in Museums' the developments in the United Kingdom with regard to the repatriation of curated human remains has come to a hold. The non-binding guidance essentially boils down to a framework guiding institutions in their decision-making process. While the guidance also lists a number of principles that may guide the institutions' decision making process, its value lies more in guiding and structuring institutions from a procedural point of view in defining the relevant questions and aspects that must be addressed. As for the material principles, the most important ones being the avoidance of harm and solidarity, are less suited to guide the institutions' behaviour in that they are difficult to translate into concrete measures.

Next to the adoption of the non-binding guidance, the process, which was initiated by the Government in 2000 resulted in the adoption of legislation allowing national museums previsouly prevented from doing so to de-accession human remains from their collections. The power to de-accession as granted in s 47 of the Human Tissue Act 2004 is not absolute in that it applies to human remains that are less than 1000 years old at the moment the decision to de-accession them is taken. Also, the power to deaccession does not affect any 'trust or condiction' under which the trustees or governors may hold the remains concerned. While the legislation was always inteded to be permissive rather than compelling the return of human remains our analysis of the process indicates that the current regime is less radical in its effect on holding collections than the regime as proposed by the WGHR (the majority opinion). In particular, the requirement of consent as proposed by the WGHR is an aspect that was not taken over in the Human Tissue Act 2004 or the guidance. Another aspect that was not adopted by the Government was the proposal to establish a national Human Remains Advisory Panel to mediate claims for the repatriation of human remains. In 
contrast to the general praise of the Panel dealing with Nazi spoliated art, the establishment of a comparable body for mediation in cases dealing with human remains was not supported. ${ }^{2010}$ Instead, individual institutions were left free to establish local advisory panels allowing them to keep more controle about the decision making process and the content of their collections.

\section{INTERMEDIARY CONCLUSIONS FOR THE UNITED KINGDOM}

The process in the United Kingdom to introspect their public collections and to reflect upon the treatment of human remains was iniatied by the Government in 2000. The process started with the establishment of a Working Group on Human Remains (WGHR) to allow for a comprehensive analysis of the matter and subsequently taken further in a consulation exercise. While the debate on the return of human remains and the opinion to radically change the rules applicable to human remains in public collections gained momentum at the beginning of the work of the WGHR, much of it was lost during the final report and the subsequent consultation exercise. Two concrete results can be mentioned, next to a general increase of awareness of the sensitivity of curated remains: first, the adoption of legislation enabling national museums previously prevented from doing so to de-accession human remains from their collections. Secondly, the Department for Culture, Media and Sport (DCMS) adopted a non-binding 'Guidance for the Care of Human Remains in Museums'. As a result the present situation in the UK is not much different from the situation in the Netherlands: as for s. 47 of the Human Tissue Act 2004, it enables the de-accessioning of human remains but does not compell it. While the guidance might enjoy more authority having been adopted by DCMS, it is non-binding. Furthermore, while it lists a number of principles that may guide the institutions' decision making process, its value lies more in guiding and structuring institutions from a procedural point of view in defining the relevant questions and aspects that must be addressed.

\section{FRANCE}

In France, no official policy on the return of human remains from public collections has been endorsed by the French Government. Consequently, and similar to the analysis of the Dutch situation we need to rely on case studies to see whether we can extrapolate principles applicable to the return of human remains. So far, two cases have emerged in France: the case of the remains of Sarah Baartman and the case of a Toi Moko presently in the collection of the Natural History Museum in Rouen.

2010 Steel, P., 2004, p. 25 on the other hand reports of a straw poll taken at a MA event attended by researchers, archaeologists and museum professionals that showed overwhelming support for an advisory panel for human remains. 


\section{1. 'VÉnus HotTentote': THE RETURN OF THE REMAins OF SARAH BaARTMan to SOUTH AFRICA}

The repatriation of the remains of Sarah Baartmans from the National Museum of Natural History in Paris, France to South Africa in 2002 was mandated by statute. The case of the 'Vénus hottentote', as the remains of Baartman are often refered to, is different from the other case studies in that the name and identity of the remains are known. It is for this reason that we will begin the case study with a biographical sketch of Sarah Baartman before further discussing the case, the drafting process and the content of the statute that ordered for the repatriation of her remains.

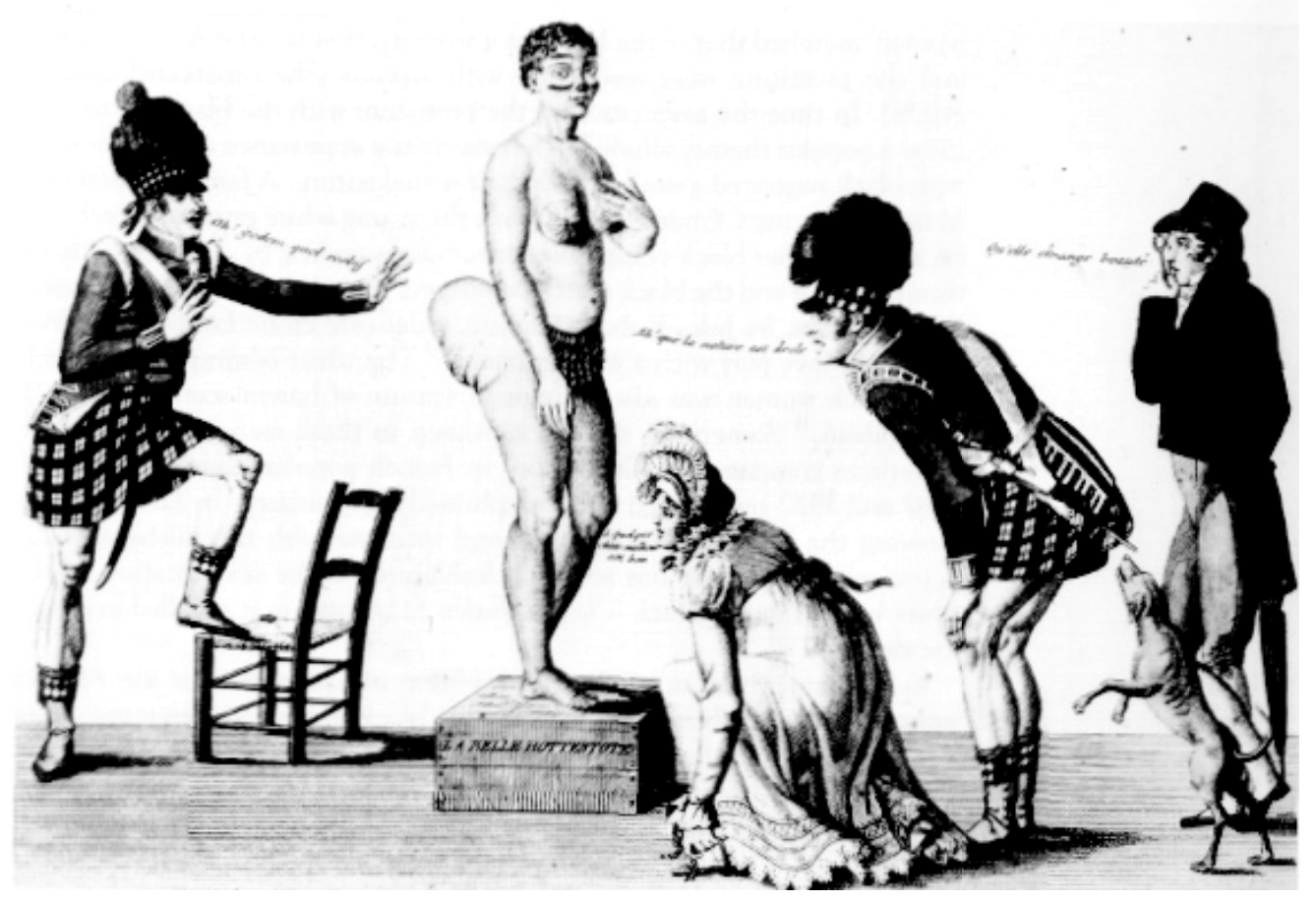

French cartoon 'Les curieux en extase ou les cordons de souliers', 1814, in which the French cartoonist pokes fun at the British fascination for the 'Venus hottentote'. (C) Bibliotheque Nationale, Paris. 


\section{Sarah Baartman's life 2011 :}

Sarah Baartman was born in the Gamtoos Valley in 1789. Under the present political system, the Gamtoos Valley belongs to the territory of South Africa. During Baartman's lifetime, South Africa did not exist as a political unit. In the mid-17th century, European settlement in the region started with the Dutch. In 1814, the region passed to Great Britain but was contested in the Boer War (1899-1902). Britain emerged as victorious party and took possession of the entire territory. The Union of South Africa was created in 1910. It was only in 1961 that South Africa declared its independence.

Different accounts exist as to the group membership of Baartman: some associate her with the San people (or Bushmen) 2012 , others with the Koehkhoe or Khoi-khoi people. ${ }^{2013}$ Others again come to the conclusion that her group membership cannot be recalled.2014 What is known about Baartman's early life is that her family had been massacred. Baartman was taken captive as a child, and worked as a slave for a Dutch farmer (Boers) close to the Cap. ${ }^{2015}$ In 1810, a British ship doctor, William Dunlop took Baartman to England. Fascinated by her physiognomy, in particular her buttocks and genitals Dunlop wanted to exhibit her to the "curiosity of the Europeans". 2016

Once in England, Baartman was presented to the public as the "Vénus Hottentote". Her display was, however, not uncontested: an African Association petitioned for her "release" and brought the case to court. ${ }^{2017}$ It is reported that when interrogated in court, Baartman stated that she came to England by free will, was under no restraint and had been guaranteed half the profits. ${ }^{2018}$

Little is known about her later years in England from her baptism in 1811 until she was sold to France in 1814. It is suggested that she was married and had two children. ${ }^{2019}$ Once in Paris, she was exhibited for several months, first by a man named Henry Taylor and then by an animal trainer under the name Reaux. The Musée National

\footnotetext{
2011 The exposé at hand is limited to the cornerstone dates of her life. For a more detailed description see, e.g.: Gordon, R., 2000; Tobias, P.V., 2002; Qureshi, S., 2004.

2012 Langaney, A., 2002, p. 377. The San people or Bushmen lived chiefly in Botswana, Namibia, and southeastern Angola. Bushmen is an Anglicization of boesman, the Dutch and Afrikaner name for them; saan (plural) or saa (singular) is the Nama word for "bush dweller(s)," and the Nama name is now generally favoured by anthropologists. Contrary to earlier descriptions, the San are not readily identifiable by physical features, language, or culture. In modern times, they are for the most part indistinguishable from the Khoekhoe or their Bantu-speaking neighbours. Nevertheless, a San culture did once exist and, among some groups, still exists. Source: San. (2005). In Encyclopædia Britannica. Retrieved December 14, 2005, from Encyclopædia Britannica Online, http://www.search.eb.com/eb/article-9065258.

${ }^{2013}$ Tobias, P.V., 2002, p. 107; Ferrus, D., 2004, p. 27 The Khoekhoe are not physically distinguishable from the San.

${ }^{2014}$ Gould, S.J., 1987, p. 293.

2015 Richert, P., 2002, p. 3.

${ }^{2016}$ The condition is called steatopygia. See: Gould, S.J., 1987, p. 297.

2017 Gould, S.J., 1987, p. 293. We were not able to find further information on the case, such as the case number.

${ }^{2018}$ The case has been mentioned in: Ibid., pp. 293-294; Gordon, R., 2000, p. 606.

${ }^{2019}$ Tobias, P.V., 2002, p. 107. However, no official reference number has been quoted.
} 
d'Histoire Naturelle expressed interest in observing her physiognomy. In a letter addressed to the mayor of Paris Etienne Geoffroy Saint-Hilaire expressed the wish of the museum to "profit from the possibility of the presence of a Bochimane Woman in Paris to further study the distinct features of this curious race". ${ }^{2020}$ In the spring of 1815 , Baartman was presented in the Jardin des Plantes to be observed by scientists and painters. ${ }^{2021}$

Sarah Baartman died on 29 December 1815.2022 As to the cause of her death, different explanations circulate: an inflammatory and eruptive sickness ${ }^{2023}$, an excess of alcohol $^{2024}$, pneumonia, or tuberculosis. ${ }^{2025}$ Upon her death, Etienne Geoffroy SaintHilaire asked the prefect of the police for permission to bring her corpse to the anatomical laboratory of the museum (...) to gain new insights on this singuliere race of humankind. A decree was granted to Saint-Hilaire allowing for the transport of the corpse to the faculty of Medicine and in the Hôpital de la Pitié. Upon her death Baartman's corpse was immediately moved, not by Saint-Hilaire but by a colleague of his, the scientist George Cuvier and to a different location, i.e. the laboratory of anatomy in the Musée National d'Histoire Naturelle. ${ }^{2026}$ Cuvier first made a plaster cast of her body, and then dissected it, removing the brain, and the genitals, which he preserved in glass jars. In 1817, Cuvier presented his observations to the l'Academie de mëdicine. ${ }^{2027}$

\section{The remains in the museum}

The skeleton and the cast of her body were exhibited in several Parisian museums for more than 150 years: first in the "Salle d'anatomie comparé" in the Musée National d'Histoire Naturelle, then in the Museum of Ethnography in the Palais du Trocadero, and finally in the Musée de l'Homme. The cast was exhibited until 1974; the skeleton until 1976. ${ }^{2028}$ The body cast was shown again to the public in 1994, in an exhibition entitled: "De la Vénus hottentote à la Tehura de Gauguin - Les dossiers du Musée d'Orsay". ${ }^{2029}$ Different accounts existed with regard to the whereabouts of the bottled brain and genitals. According to the anthropologist Steve J. Gould the bottled remains must have

${ }^{2020}$ Le Garrec, J., 2002, p. 7. See further on the person of Étienne-François Geoffroy: Geoffroy, ÉtienneFrançois (2005). In Encyclopædia Britannica. Retrieved October 18, 2005, from Encyclopædia Britannica Online, http://www.search.eb.com/eb/article-9036458.

2021 Gould, S.J., 1987, p. 294.

2022 Cuvier, G., 1817, p. 265. In the travaux préparatoires, the date of death is 1 January 1916. See: Assemblée Nationale, 2002, p. 31.

${ }^{2023}$ Cuvier, G., 1817, p. 262 ; Gould, S.J., 1987, p. 294.

2024 Cuvier, G., 1817, p. 263.

2025 Gordon, R., 2000, p. 607.

2026 See further on the person of Cuvier: Cuvier, Georges, Baron (2005). In Encyclopædia Britannica. Retrieved October 18, 2005, from Encyclopædia Britannica Online, http://www.search.eb.com/eb/article9028345.

2027 Cuvier, G., 1817.

${ }^{2028}$ It is unclear whether the skeleton was exhibited until 1974 or 1976: See e.g. Richert, P., 2002, pp. 3 \& 11.

2029 Ibid., p. 12. 
been in the depot of the Musée de l'Homme at least until his encounter with them sometime between 1979 and 1985.2030 The director of the Musée de l'Homme, Andre Langenay, denied that the bottled brains and genitals were contained in the collection. ${ }^{2031}$ Again others held that the bottled brain and genitals were accidentally destroyed when the shelves on which the bottles were kept collapsed in 1983 or 1984. ${ }^{2032}$ The bottled brain and genitals were rediscovered when the French legislative procedure to provide for the return of Baartman's remains had already reached the stage of the Senate. ${ }^{2033}$

\section{Requesting party?}

What is interesting about the case of the remains of Baartman is the fact that it is not entirely clear who actually requested their return. According to one view, the remains were officially requested by the South African Government. ${ }^{2034}$ This view is supported by the fact that then French Minister de la Coopération M. Jacques Godfrain and then South African Minister of Arts, Culture, Science, and Technology, Dr. Ngubane agreed in January 1996 to entrust a French and South African scientist with the task to find solution. ${ }^{2035}$ However, while the negotiations resulted in a set of recommendations ${ }^{2036}$,

\footnotetext{
2030 Gould, S.J., 1987, p. 292.

2031 Gordon, R., 2000; Davie, L., 2002, http://www.southafrica.info/about/history/saartjie.htm

2032 Richert, P., 2002, p. 3.

2033 Assemblée Nationale, 2002, p. 32; Sénat, 2002a, p. 4; Sénat, 2002b, p. 3. See further below for more details.

${ }^{2034}$ Le Garrec, J., 2002, p. 9; Tobias, P.V., 2002, p. 109. See also: Sénat, Questions, (2001), Journal officiel, p. 4659: M. Michel Duffour, State Secretary au Patrimoine et a la décentralisation culturelle stated that "des représentant de l'Afrique du Sud ont demande le retour des restes de miss Sarah Baartman conserves au Muséum national d'histoire naturelle ". Some sources state that in 1994 president Nelson Mandela stood up for the return of the remains. See, e.g.: Davie, L., 2002,

http://www.southafrica.info/about/history/saartjie.htm; Ferrus, D., 2004, p. 29; Bredekamp, J., 2006, p. 27. As yet another initiative on governmental level it was reported that the South African Embassy in Paris sent a letter to the French Minister of Foreign Affairs in October 2000. The letter dates 6 October 2000 and was probably inspired by the return of El Negro from Spain to Botswana. El Negro's remains were reburied
} in Tsholofelo Park in Gaborone, the capital of Botswana on 5 October, 2000.

2035 Le Garrec, J., 2002, p. 10.

2036 The persons entrusted with the negotiations were Henri de Lumley, Director of the Prehistory Laboratory of the National Museum of Natural History in Paris, and Philip Tobias, Professor of Anatomy and Human Biology at the University of the Witwatersrand Medical School. Their negociations resulted in the following recommendations:" 1 . The remains should be handed over directly to the South African government. 2. The South African government should consult all parties concerned before deciding on the disposition of the remains. 3. The remains should not be buried (in the ground) due to the loss to scientific and forensic analysis. It was pointed out that it might be important to determine the genetic relationship between Baartman's DNA and that of possible living descendants, or to confirm her age at death, or to verify that the returned bottled organs indeed belong to the same individual as did the skeleton, or to seek evidence bearing on the diagnosis of her final illness. It was proposed that, as an alternative, South Africa consider building a dignified tomb for housing the remains, designed as a shrine of remembrance open to visitors, with an illustrated account of Baartmans's life and death on the walls. It was further suggested that members of the Khoisan communities might be invited to serve as the custodians of the proposed Sarah Baarman memorial shrine“. 
they did not receive governmental support and the case came to a halt. ${ }^{2037}$ Other sources deny government intervention and instead refer to organisations representing the descendants of Khoisans and the Griqua National Conference of South Africa, a body that represents the interests of the Griquas since 1914, for having sought the return of Baartman's remains. ${ }^{2038}$ Another non-governmental organization that appearantly requested the French government for the repatriation of the female genitalia of Sarah Baartman in 1999 was the World Archaeology Congress. ${ }^{2039}$

At the time the return of Sarah Baartman was discussed in the French Senate, the official position of the French Government was that no official request had been received from the South African Government. It was observed that it was rather paradoxical that restitution would be based on a French initiative unsupported by South Africa. ${ }^{2040}$

The process of drafting legislation on the return of Baartman's remains: from integral object of the domaine public to human material incapable of being appropriated.

The case of Sarah Baartman was introduced into the French Senate by Senator Nicolas About on 12 October 2001.2041 About addressed the Minister of Culture and Communication and pleaded for the return of the remains of Baartman to South Africa. According to the joint reaction by the State Secretary for Cultural Heritage and Cultural Decentralisation and the Minister of Education dated 7 November 2001, it was stated that the remains had been conserved in a "correct and respectful manner, as all human remains in the collection of the Natural History Museum". As part of the national collection, the remains were inalienable under French law, which could only be overcome by means of a statute enacted by parliament. Furthermore, the reaction stressed the scientific value of the remains for the international community. ${ }^{2042}$

\footnotetext{
${ }^{2037}$ Le Garrec, J., 2002, p. 10. It is not specified whether these recommendations were ever discussed, and what the criticism was.

2038 Richert, P., 2002, p. 5 ; Concern over 'Hottentot Venus' of 1810: Griquas want to bury the remains of Khoi woman displayed in France as a freak, 13 December 1995. The Griqua are a 19th-century people, of mixed Khoekhoe and European ancestry, who occupied the region of central South Africa just north of the Orange River. In 1848 they were guaranteed some degree of autonomy by a treaty with the British governor of South Africa. Source: Griqua (2005). In Encyclopædia Britannica. Retrieved December 14, 2005, from Encyclopædia Britannica Online, http://www.search.eb.com/eb/article-9038148.

2039 Gordon, R., 2000, p. 606.

2040 "Aucune démarche officielle du gouvernement sud-africain n'a récemment attesté de la mobilisation de ces autorités sur ce dossier", et observe qu'il pourrait "sembler paradoxal que la restitution s'effectue sur la base d'une démarche française non relayée actuellement par l'Afrique du Sud".Richert, P., 2002, p. 6.

2041 Proposition de loi autorisant la restitution par la France de la dépouille mortelle de Saartjie Baartman, dite "Vénus hottentote" à l'Afrique du Sud, présentée par M. Nicolas About, Sénateur. It has been said that in 2001 he was busy preparing a proposition to change the law from 1850 holding that all objects in French museum are property of the French state when he got knowledge of the remains of Saartije Baartmans (through the poem by Diane Ferrus) Ferrus, D., 2004, pp. 29-30. He was contacted by Audrey van Zyl, parlementaire sud-africaine.

${ }^{2042} \mathrm{n}^{\circ} 1149$ (JO Débats du 12 octobre 2001) (p. 4026) - Ministère: Culture - Restitution à l'Afrique du Sud des restes de Sara Baartman - Réponse le 7 novembre 2001 (p. 4659).
} 
Senator About expressed his discontent with the answer and doubted the scientific relevance of the remains. However, following the reasoning of the State Secretary and the Minister of Education, he introduced the following proposal for a statute to provide for the return of the remains to South Africa on 4 December 2001:

"Par dérogation à l'article L.52 du code du domaine de l'État2043, il est procédé à la restitution par la France de la dépouille mortelle de Sarah Baartman, dite "Vénus hottentote", à l'Afrique du Sud". ${ }^{2044}$

As next step, a report was prepared on behalf of the Commission on Cultural Affairs. ${ }^{2045}$ The report addressed questions as to how the remains had become part of the national collection and why they had remained in the collection until the present day. Also, the report criticised the poor administration of the museums' inventories. The most important aspect however was the status of the remains within the national collection and the (im-)possibility of their de-accession. The report challenged the view that de-accession of the remains from the national collections is prevented by law. According to the report, Art. L. 52 on the inalienability and imprescribtability of objects from the domaine public must not be understand as fully preventing the possibility to declassify objects, in this case human remains, from the national collections. The report suggests that declassification could be legitimized by the remains' missing scientific importance, the necessity to end the "bad publicity", as well as the need to be able to answer to a request for return made by the country of origin. More in concrete, the report referred to Art. L. 69-1 of the Code of State-owned property (Code du domaine de l'Etat) as possible venue for de-accession. 2046 The article provides for a number of options in which objects whose value does not exceed a certain amount fixed by the Government may be donated to foreign states and organisations working for the good

2043 Art. L. 52 of the Code of State-owned property (Code du domaine de l'Etat) reads as follows: "Les biens du domaine public sont inaliénables et imprescriptibles".

2044 Proposition de loi de M. Nicolas About, autorisant la restitution par la France de la dépouille mortelle de Sarah Baartman, dite "Vénus hottentote", à l'Afrique du Sud, N 114 (2001-2002).

2045 Richert, P., 2002.

${ }^{2046}$ Les ventes mentionnées à l'article L. 68 ne peuvent être réalisées à un prix inférieur à la valeur vénale des biens cédés. Toutefois, les biens autres que les véhicules automobiles et dont la valeur n'excède pas un plafond fixé par arrêté du ministre chargé du domaine peuvent être cédés gratuitement à des Etats étrangers dans le cadre d'une action de coopération. De même, les biens meubles, autres que les véhicules automobiles, et dont la valeur unitaire n'excède pas un plafond fixé par arrêté du ministre chargé du domaine, peuvent être cédés gratuitement à des associations relevant de la loi du 1er juillet 1901 relative au contrat d'association visées au b du 1 de l'article 238 bis du code général des impôts et dont les ressources sont affectées à des oeuvres d'assistance, notamment à la redistribution gratuite de biens meubles aux personnes les plus défavorisées. Lesdites associations ne pourront procéder à la rétrocession, à titre onéreux, des biens ainsi alloués à peine d'être exclues du bénéfice des présentes mesures. De même, les services de l'Etat, les collectivités territoriales et leurs établissements sont autorisés à céder gratuitement les matériels informatiques dont ils n'ont plus l'emploi et dont la valeur unitaire n'excède pas 152 euros aux associations de parents d'élèves et aux associations de soutien scolaire. Ces associations s'engagent par écrit à n'utiliser les matériels qui leur sont cédés que pour l'objet prévu par leurs statuts, à l'exclusion de tout autre. Elles ne peuvent procéder à la rétrocession, à titre onéreux, des biens ainsi alloués, à peine d'être exclues du bénéfice de la présente loi. 
cause. Consequently, according to the Commission of Cultural Affairs there was no need to adopt a bill to allow for the return of the remains to South Africa.

The report also discussed the new stand that had been adopted by the Government with regard to the status of the Baartman's remains in the mean time. Different from its initial statement that the remains formed part of the national collections the Government referred to Art. 16-1 Civil Code and held that the remains could not be the object of a proprietary right in the first place. ${ }^{2047}$ Consequently, in this specific case the human remains could not constitute property of the museum, nor of the state and the decision to dispose of them was unrelated to the domaine public. Instead, the decision to dispose of the remains and to return them to South Africa rested with the administrative authorities. ${ }^{2048}$ The assumption by the Government that Art. 16-1 Civil Code applies to human remains in scientific collections is characterised by the report as "a little bit amazing, surprising". The report stresses that the "raison d'être" of the Bioethics Bill, which introduced Art. 16-1 Code Civil, was to outlaw insults or violations of human dignity, such as the selling of organs or parts of the human body of persons still alive or corpses. According to the drafters of the report the bill does not seek to define the legal status of human remains in scientific collections. Consequently, should the Government wish to adhere to the applicability of the 1994 Bioethics Bill to the present case, the consequences of such an extensive interpretation must be clarified. ${ }^{2049}$ In its final conclusion, the report stresses the urgency to stop the delay of the return of the human remains to South Africa. It concluded that no legislation was required to allow for the de-accession and transfer of Baartman's remains to South Africa as reliance on both Artt. L. 69.1 of the Code of State-owned property (Code du domaine de l'Etat) and 16-1 Civil Code could allow for their return without interaction of the legislator.

In spite of holding the proposed bill superfluous, the Commission of Cultural Affairs nevertheless did not advice to abandon the drafting process. Instead, only the wording of the article should reflect the new insights about the legal status of the remains:

“A compter de la date d'entrée en vigueur de la présente loi, les restes de la dépouille mortelle de la personne connue sous le nom de Sarah Baartman cessent de faire partie des collections de l'établissement public du Muséum national d'histoire naturelle.

L'autorité administrative dispose, à compter de la même date, d'un délai de deux mois pour les remettre à la République d'Afrique du Sud". 2050

2047 Art. 16-1 was introduced by Loi no 94-653 du 29 juillet 1994 relative au respect du corps humain. It reads: "Chacun a droit au respect de son corps. Le corps humain est inviolable. Le corps humain, ses éléments et ses produits ne peuvent faire l'objet d'un droit patrimonial". In English: Everyone has the right to respect for his body. The human body is inviolable. The human body, its elements and its products may not form the subject of a patrimonial right.

2048 Richert, P., 2002, p. 8.

2049 Ibid.

2050 In English: Act relating to the restitution by France of the remains of Sarah Baartman to South Africa. This Act will enter into force on 7 March 2002. As from the date of entry into force of this Act, the surviving remains of the person known as Sarah Baartman will cease to form part of the public collections 
The draft article as proposed by the commission no longer refers to Art. L. 52 of the Code of State-owned property (Code du domaine de l'Etat) and the domaine public. Also, the article no longer speaks of the de-accessioning or transfer of property or the restitution of the remains but instead simply states that the remains of Baartman leave the collection of the Musée National d'Histoire Naturelle and should be returned to South Africa within two month after the bill entered into force. ${ }^{2051}$

After having been discussed and unanimously adopted by the Commission on Cultural Affairs on 23 January, 2002, the report and draft bill were discussed in the French Senate on 29 January 2002. At that point, the bottled brains and genitals of Baartman that had been deemed missing or lost had been rediscovered. ${ }^{2052}$ The Research Minister (ministre de la recherche) defended the view that the remains of Baartman cannot be considered as part of the national patrimony for Art. 16-1 Civil Code would prevent any appropriation of the human body or corpse. He stressed that this understanding did not render the inclusion of human remains in museum collections illegal as it can be explained by scientific reasons. The minister did, however, recognise a need for the Government to reflect upon the status of (scientific) collections of human remains. He did not discuss the option that the remains might have become part of the domaine public and could be declassified by relying upon Art. 69 of the Code of State-owned property (Code du domaine de l'Etat). ${ }^{2053}$

With regard to the text of the proposed article, the Government suggested a number of amendments both to the title and the wording of the article itself but in the end the Senate adopted the article as proposed in the report of the Commission of Cultural Affairs with unanimity. ${ }^{2054}$

On 30 January 2002, the proposition was registered at the Assemblée Nationale. On 14 February 2002, the draft article was discussed within a sub-committee of the National Assembly. Despite emphasising the impact the draft article might have in creating a

of the National Museum of Natural History. The administrative authority has a time limit of two months, starting from the date of entry into force, within which to deliver the remains to the Republic of South Africa.

2051 Richert, P., 2002, p. 14.

2052 Sénat, 2002a, p. 4; Sénat, 2002b, p. 3; Assemblée Nationale, 2002, p. 32.

2053 Sénat, 2002a, p. 5.

2054 Sénat, 2002b. The first amendment suggested to change the title of the bill from "(...) relative à la restitution par la France de la dépouille mortelle de Sarah Baartman à l'Afrique du Sud” to "(...) relative au retour en Afrique du Sud de la dépouille mortelle de Sarah Baartman”. The second amendment proposed to amend the wording of the article as follows: "Les restes de le dépouille mortelle de la personne connue sous le nom de Sarah Baartman cessent d'etre placés sous la garde du Muséum national d'histoire naturelle et feront retour en Afrique du Sud. L'autorité administrative dispose d'un délai de six mois, a compter de la date d'entrée en vigueur de la présente loi, pour mettre en œuvre les dispositions du précédent alinéa". Hence, instead of the wording "ceasing to form part of the public collections of the National Museum of Natural History" the amendment suggests that the remains of Sarah Baartman" are no longer placed under the guardianship of the National Museum of Natural History". The amendment furthermore suggests to replace the verb "remettre" by the expression "feront retour" and to extend the period within which to act by four months. 
precedent for the restitution of "des monuments d'origine étrangère inscrits à notre patrimoine", the committee passed the bill with unanimous support to the full National Assembly. ${ }^{2055}$

The National Assembly discussed the proposal on 21 February 2002. In the discussion preceding the vote, the symbolic relevance of the statute was emphasized. It was explicitly held that from a legal point of view the adoption of the statute was superfluous given Art. 16-1 of the Code Civil: with human remains being excluded from appropriation they do not fall under the notion of the national patrimony, nor do the regulations concerning the domaine public apply. The only exception to this principle is where the remains are of scientific importance. In the absence of such scientific value, a statute providing for the de-classification of the remains and their return is redundant and the authority responsible for the collections could have decided about parting from the remains. Regardless of the fact that the draft article was presented as merely symbolic in character it was passed unanimously as the last statute adopted during the XI th legislative period. ${ }^{2056}$ In view of the question of creating a precedent, it was held that the specific character of the bill, drafted for a specific case should prevent its working as a precedent. ${ }^{2057}$

After the approval of the legislation on 21 February 2002, arrangements were made for the return of the remains to South Africa.

\section{The return to South Africa}

At the end of April 2002, a small delegation from South Africa arrived in Paris to accept the remains of Sarah Baartman on behalf of the South African Government. ${ }^{2058}$ On 3 May 2002, the remains arrived at Cape Town International Airport, packed in a crate draped in a South African flag and were taken to the Military State Mortuary. ${ }^{2059}$ On 9 August 2002 Sarah Baartman received a state burial near the city of Hankey on the

\footnotetext{
${ }^{2055}$ La commission des affaires culturelles, familiales et sociales, Travaux de Commission, débat au cours de sa séance du mercredi 30 janvier 2002, pp. 19-21.

2056 Assemblée Nationale, 2002, p. 31 ff. Loi n 2002-323 du 6 mars 2002 relative à la restitution par la France de la dépouille mortelle de Sarah Baartman à l'Afrique du Sud. (JO n 56 du 7 mars 2002 page 4265 texte $\mathrm{n}^{\circ} 2$ ). En vigueur depuis le 07 mars 2002. A compter de la date d'entrée en vigueur de la présente loi, les restes de la dépouille mortelle de la personne connue sous le nom de Sarah Baartman cessent de faire partie des collections de l'établissement public du Muséum national d'histoire naturelle. L'autorité administrative dispose, à compter de la même date, d'un délai de deux mois pour les remettre à la République d'Afrique du Sud. In English: Act relating to the restitution by France of the remains of Sarah Baartman to South Africa. This Act will enter into force on 7 March 2002.As from the date of entry into force of this Act, the surviving remains of the person known as Sarah Baartman will cease to form part of the public collections of the National Museum of Natural History. The administrative authority has a time limit of two months, starting from the date of entry into force, within which to deliver the remains to the Republic of South Africa. One member of the Assemblée Nationale, Mme Boisseau, initiatlly refused to vote on a statute that is redundant, not to attack the memories of Sarah Baartman, but to live up to her responsibilities as legislator.

2057 Assemblée Nationale, 2002, p. 31.

2058 Cf.: Bredekamp, J., 2006, p. 28.

${ }^{2059}$ Cf.: Ibid.
} 
bank of the Gamtoos river Valley in the Eastern Cape of South Africa. ${ }^{2060}$ In the mean time, the South African Government engaged in a campaign raising national awareness of the return of the remains. The campaign stressed that the return was the result of a request by the Khoisan people to former President Nelson Mandela, that Baartman had become a symbol of subjugation and humiliation of Khoisan women and an icon of restitution for people affected colonialism and that her burial at last confirmed the South African Government's negotiations skills in the international arena. ${ }^{2061}$

\section{Intermediary summary of the Sarah Baartman case}

The case of the return of the remains of Sarah Baartman addressed a number of interesting aspects: first, it is one of the few cases where not only the name and identity of the remains are known but historians are able to piece together a relatively coherent account of her life. ${ }^{2062}$ Secondly, it clearly highlights how perceptions of what constitutes valid scientific research can change in time. ${ }^{2063}$ Whereas Cuvier was a celebrated scientist during his lifetime and his lifework is still considered as marking a transition between the 18th-century view of nature and the view that emerged in the last half of the 19th century as a result of the doctrine of evolution, his ideas according to which humans are a single species but consisted of three physically distinguishable races, Caucasians, Ethiopians and Mongolian are now considered to be profoundly racist.2064

More concrete central aspects that emerged from the case study are the unclarities as to whether or at which point the South African Government actually claimed the remains and the uncertainty concerning the legal status of the remains. Little attention was paid to the question whether the remains of Baarman had been actively requested by the South African Government or another stakeholder. The return of the remains was discussed in the French Senate, despite the fact that (at least according to the official position of the French Government) no official request had been received from the South African Government. In this respect it is also interesting that no further research was conducted on possible genealogical descendants of Baartman. After all, some sources state that Baartman had married at a certain point and had two children. ${ }^{2065}$

During the process that the return of the remains were discussed in the French Parliament the status of the remains changed from inalienable object belonging to the national collections that could only be returned on the basis of specific legislation to

\footnotetext{
${ }^{2060}$ Ferrus, D., 2004, p. 32; Bredekamp, J., 2006, p. 29.

2061 Bredekamp, J., 2006, p. 29.

2062 Cf.: Qureshi, S., 2004, p. 249. This fact explains also the great number of articles published in various academic disciplines on Sarah Baartman. See, e.g.: Strother, Z.S., 1999; Gordon, R., 2000; Bennett, B., 2002; Ferrus, D., 2004. The life and death of Sarah Baartmans has also inspired a novel, theatre play and documentary: Parks, S.-L., 1997; Maseko, Z., 1998; Chase-Riboud, B., 2003.

2063 See also: Bristow, M., 2008, p. 216.

2064 Cf.: Qureshi, S., 2004, p. 243.

2065 Tobias, P.V., 2002, p. 107. However, no official reference number has been quoted.
} 
human tissue that could not be the subject to proprietary rights in the first place, and which could be disposed of and returned without intervention of the legislator. Despite this finding that the return did not require the intervention of the legislator, the National Assembly had decided not to discard the legislative proposal and to adopt it as being of mere symbolic character. The extensive interpretation of Art. 16-1 Civil Code to include also human remains in national collections was challenged in the second case dealing with the return of human remains from a French public collection, which will be discussed in the following.

\section{The Toi Moko from the Museum of natural history in Rouen}

The second case in which human remains were claimed from a French public collection deal with a tattooed and preserved head of Maori or Moriori origin (Toi Moko) in the collection of the Museum of Natural History, Ethnography, and the Prehistory in the City of Rouen. The Toi Moko had been given to the city of Rouen by an individual in 1875, appearantly as a gift, and has since been part of the municipal collection deposited in the Natural History Museum. ${ }^{2066}$ The Natural History Museum has been designated as "Musée de France" in 2003.2067 As explained above in Chapter 3 (\$2.III) objects in public collections qualifying as "Musée de France" are both inalienable and imprescriptable. ${ }^{2068}$

On 19 October 2007, in reaction to a request by the Museum of New Zealand Te Papa Tongarewa ("the Te Papa") the Municipal Council of Rouen unanimously decided that the Toi Moko should be returned to New Zealand. ${ }^{2069}$ Following the argumentation in the case of Sarah Baartman, according to which human tissue, including human remains in public collections could not be subject of property rights, the municipal council held that no declassifcation proceedings were required despite the museum's designation as "Musée de France". The resolution adopted by the council stated that

2066 Bel, M., et al., 2008, p. 225.

2067 Minister of Youth and Minister of Culture, A. September 17, 2003: Official Journal October 1, 2003. Cf.: Amiel, O., Ibid., p. 372 \& fn. 376; Bel, M., et al., 2008, p. 225. See further on the designation procedure according to Art. L. 422-1 Cultural Heritage Code above in chp. 3.\$2.III.

2068 See in particular Art. L. 451-5 and Art. L. 451-3 of the Cultural Heritage Code (Code du Patrimoine) (hereinafter: "CHC". According to Art. L. 451-3 CHC, the collections of the Musées de France are imprescriptable: "Les collections des musées de France sont imprescriptibles". According to the first sentence of L. 451-5 CHC "objects constituting collections of the museums of France, and belonging to a legal personality under public law, are in the domaine public and are hence inalienable (...)". (In French: "Les biens constituant les collections des musées de France appartenant à une personne publique font partie de leur domaine public et sont, à ce titre, inaliénables").

${ }^{2069}$ Amiel, O., 2008, p. 371. When exactly the museum had received a request by the Te Papa Museum does not appear from the documenation. From the judgment of the Administrative Tribunal of Rouen discussed below it appears that a request had been received: "Considérant que, répondant à la démarche de la Nouvelle-Zélande tendant au retour dans leur pays d'origine de restes humains Maori aux fins d'accomplissement des rites funéraires traditionnels, le conseil minicipal de la ville Rouen a autorisé (...). See for an English translation of the case: Bel, M., et al., 2008 (the quoted passage is on p. 224). 
"regarding human remains, Art. 16-1 Civil Code, enacted pursuant to the Bioethics Bill of July 29, 1994, as modified, stipulates that they cannot be objects of proprietary rights; consequently the principles of inalienability according to Art. L. 451-5 CHC do not apply.2070 A ceremony commemorating the return was scheduled for 23 October 2007. ${ }^{2071}$

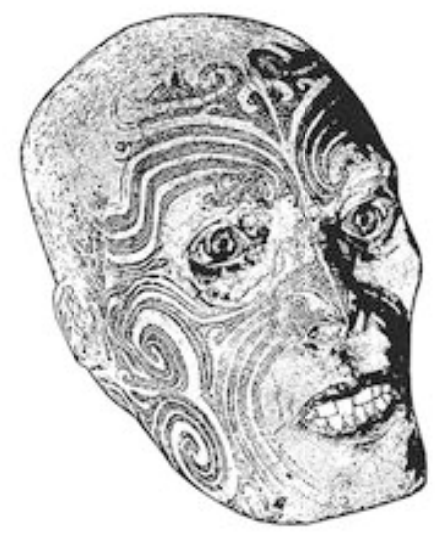

Image of the Toi Moko, (C)Agence France-Presse (AFP)

One day before the scheduled ceremony, on 22 October 2007, the prefect of SeineMaritime, who represents the national government at the local level, demanded the Administrative Tribunal of Rouen to annul the decision of the municipal council of Rouen from 19 October 2007.2072 The prefect held that Art. 16-1 Civil Code could not free the city of Rouen from the obligation to consult the National Scientific Commission of Museum Collections of France where it wishes to dispose of objects belonging to the collection of a museum classified as "Musée de France". 2073

In its ruling dated 27 December 2007, the Administrative Tribunal decided to annul the decision taken by the Municipal Council of the City of Rouen on 19 October 2007, which authorised the return of the Toi Moko to New Zealand, for being based on a procedural error. The tribunal had reached this conclusion by interpreting Art. 16-1 Civil Code. Under the terms of the article the "human body, its elements and its

2070 Municipal Council of Rouen, resolution nos. 2-8, October 19, 2007. Cf.: Amiel, O., 2008, p. 372 \& fn. 372.

2071 Muséum de Rouen, 2007. The effective transfer of the Toi Moko to New Zealand was planned for half November. Cf.: Amiel, O., 2008, p. 371.

2072 Cf.: Administrative Tribunal of Rouen, December 27th, 2007, no. 702737, Prefect of Seine-Maritime: Juris-Data no. 2007-350713.

2073 Cf.: Amiel, O., 2008, p. 372. The prefect referred to Art. L 451-3 and Art. 451-5 CHC. 
products cannot be the object of proprietary rights". ${ }^{2074}$ In order to establish whether human remains in museum collections, as the Toi Moko in the present case, must be considered as "human body, its elements and its products" in the sense of the provision the tribunal turned to the legislative history of the 1994 Bioethics Bill that had introduced Art. 16-1 into the Civil Code. ${ }^{2075}$ The tribunal held that the travaux préparatoires of the bill indicate that its provisions "constitute only one aspect of the superior principle of the protection of human dignity, and have as their object the prohibition of the appropriation of utilization of the human body and its elements and products, for the purposes of monetary gain". ${ }^{2076}$ The tribunal applied this finding to the case of the Toi Moko in the municipal collection of Rouen and held that their conservation in the collection is not contrary to Art. 16-1 Civil Code. The mere fact that the Toi Moko is of human origin does not suffice to subsume it under the scope of application of Art. 16-1 Civil Code and thereby to exclude it from the legal regime, in particular the provision on inalienability, applicable to objects in collections designated as "Musée de France". ${ }^{2077}$ Consequently, the city council of Rouen could not have decided to return the Toi Moko without the assent of the National Scientific Commission of Museum Collections of France as outlined in Art. L. 451-5 CHC on declassification.

As a result of the ruling the Toi Moko is still in the municipal collection of Rouen. However, both the city of Rouen and the Te Papa Museum of New Zealand have expressed their hope that the head will eventually return to New Zealand. ${ }^{2078}$

\section{INTERMEDIARY CONCLUSIONS FOR FRANCE}

In the present section two case studies have been presented on human remains in French public collections designated as Musées de France: the case of the remains of Sarah Baartman from the collection of the Natural History Museum and the case of a Toi Moko from the municipal collection of Rouen. Different from the UK but similar to the Dutch situation no official policy has so far been adopted in France with regard to the repatriation of human remains. Consequently, case studies are presently the only vehicle that may allow us to extrapolate common patterns and principles or at least help identifying the general problems, the actors involved, the interests at stake, and the solutions found.

Recalling the results of both case studies we can see that both cases struggled or touched upon the same general problem with regard to the legal status of human remains in museum collections designated as Musées de France, more in particular whether Art. 16-1 Civil Code was applicable to this category of human material. The applicability

\footnotetext{
2074 Art. 16-1 Code Civil: "Le corps humain, ses éléments et ses produits ne peuvent faire l'objet d'un droit patrimonial".

${ }^{2075}$ Law No. 94-653.

2076 Bel, M., et al., 2008, p. 225.

2077 Ibid.

2078 Ibid., p. 226.
} 
of this provision that had been introduced to the Civil Code by the 1994 Bioethics Bill was crucial in that it could undermine the general principle of inalienability that applies to all objects in collections designated as Musées de France. In the case of Sarah Baartman we have seen a shift from the intial understanding that the remains were part of the national collections and as such inalienable ${ }^{2079}$ to the perception that the remains fell under the scope of application of Art. 16-1 Civil Code with the result that the remains were excluded from appropriation and did not fall under the notion of the national patrimony and the regulations applicable. ${ }^{2080}$ It was explicitly stated in the Assemblee Nationale that the statute to be adopted on the return of the remains to South Africa was of symbolic relevance rather than a legal necessity. ${ }^{2081}$

If one squares this line of argumentation and the extensive interpretation of Art. 161 Civil Code as applied in the case of Sarah Baartman with the case fo the Toi Moko of the municipal collection in Rouen it becomes evident that the city council of Rouen in its decision to return the Toi Moko to New Zealand stricly followed the path as outlined in the legislative process in the French Sénat and Assemblée Nationale: according to the resolution adopted by the municipal council "Art. 16-1 Civil Code, enacted pursuant to the Bioethics Bill of July 29, 1994, as modified, stipulates regarding human remains that they cannot be objects of properietary rights; consequently the principle of inalienability according to Art. L. 451-5 CHC does not apply". ${ }^{2082}$ This extensive interpretation of Art. 16-1 Civil Code was, however, not supported by the Administrative Tribunal in Rouen. The tribunal held that the travaux préparatoires of the 1994 Bioethics Bill, which introduced Art. 16-1 to the Civil Code, stand in the way of interpreting the provision as applying to human remains in museum collections. According to the tribunal, the provisions of the bill "constitute only one aspect of the superior principle of the protection of human dignity, and have as their object the prohibition of the appropriaton of utilization of the human body and its elements and products, for the purposes of monetary gain". 2083

The decision of the Administrative Tribunal not only brought a halt to the return of the Toi Moko from the Natural History Museum in Rouen for the time being, it also undermines with hindsight the argumentation of the French legislator in the case of Sarah Baartman. While the finding does not invalidate the legislation on the return of Sarah Baartman, the bill may no longer be characterised as symbolic in character. In any event, the question emerges why the declassification procedure of Art. L. 451-5 CHC was not mentioned at all as an option in the case of Sarah Baartman. While no definitive answer can be given, the answer might lie in the chronology of events:

\footnotetext{
2079 n 1149 (JO Débats du 12 octobre 2001) (p. 4026) - Ministère: Culture - Restitution à l'Afrique du Sud des restes de Sara Baartman - Réponse le 7 novembre 2001 (p. 4659) - Musées

2080 Richert, P., 2002, p. 8; Sénat, 2002a, p. 5; Le Garrec, J., 2002, p. 11; Assemblée Nationale, 2002.

2081 Assemblée Nationale, 2002.

2082 Municipal Council of Rouen, resolution nos. 2-8, October 19, 2007. Cf.: Amiel, O., 2008, p. 372 \& fn. 372.

2083 Bel, M., et al., Ibid., p. 225.
} 
Senator About had introduced his proposal for a statute to provide for the return of the remains of Baartman to South Africa on 4 December 2001.2084 At that moment, the explicit declassification procedure now contained in Art. L. 451-5 CHC did not yet exist in law. ${ }^{2085}$ It was introduced only a month after the proposal for a statute had been launched by the Law relating to French Museums of January 4, 2002. ${ }^{2086}$ Consequently, the explanation as to why Art. 11(II) of the Law relating to French Museums (now: Art. L. 451-5 $\mathrm{CHC}^{2087}$ ) did not figure in the case of Sarah Baartman might lie in the fact that the declassification procedure was introduced only after the legislative procedure had already been started. Given the parliament's view that the remains fell under the scope of application of the 1994 Bioethics Bill there was no further incentive for the actors involved to study the new legislation introduced with regard to French Museums. The fact that there was not incentive or pragmatic reason to be aware of the changes in the law does not, however, take away that the legislator should have been aware of it. Had the legislator been aware of the relevance of the Law relating to French Museums for the declassification of objects from collections of the Musées de France, it could have cut down legislative costs, "activate" declassification procedure now contained in Art. L. 451-5 CHC and could have prevented the somewhat ironic situation of the decision of the municipal council of Rouen being characterised as marred by a procedural error where it followed the example set throughout the legislative procedure by the Research Minister, the Senate and the Assemblée Nationale in respect of the return of the remains of Baartman.

The future will have to show whether an eventual return of the Toi Moko of Rouen or other human remains will be based on the declassification procedure by the National Scientific Commission of Museum Collections in accordance with Art. L. 451-5 CHC or whether it will be based on a legal bill or on a combination of both. Before the National Scientific Commission will be able to decide upon the declassification of the Toi Moko from the municipal collection of Rouen, the criteria of the National Scientific Commission's assessment must be determined. As explained in Chapter 3 (\$2.III), the executive order from 2002 that establishes the National Scientific Commission does not

\footnotetext{
2084 Proposition de loi de M. Nicolas About, autorisant la restitution par la France de la dépouille mortelle de Sarah Baartman, dite "Vénus hottentote", à l'Afrique du Sud, n 114 (2001-2002).

2085 Prior to the adoption of this law, which is now incorporated in Book IV CHC, no specific rules with regard to cultural objects (not being ecclesiastical objects) existed. Rather, the general procedure of declassification by means of an explicit legal act had to be followed and has to observe the rule of parallism of forms. See further on the rule of analogy of forms: Cornu, M. / Mallet-Poujol, N., 2006, p. 275. Cf.: Dufau, J., 1993, p. 265; Weidner, A., 2001, p. 48; Weber, M., 2002, pp. 87 \& 92. See Conseil d' État 9.5.1958 (Delort), AJDA 1958, II, 331; Conseil d'État 17.2.1932 (Commune de Barran), D. 1933, III, 49 for relevant case law.

2086 See Art. 11(II) of the Law relating to French Museums of January 4, 2002.

2087 When the Cultural Heritage Code was adopted in 2004, the Law relating to French Museums as separate law has been repealed and its provision were integrated in the CHC. The CHC was established by Order 2004-178 and entered into force on 20 February 2004. See in particular Art. 7 of the order.
} 
provide for the criteria of assessment and until present the commission has not convened to define the criteria. 2088

In the absence of any criteria to guide the declassification procedure by the National Scientific Commission, it might be interesting to once again recall the case of Sarah Baartman as to the criteria or principles applied in this case. However, given the early choice to return the remains on the grounds that they could not be the museum's property for falling under the scope of application of Art. 16-1 Civil Code it is difficult to extrapolate criteria from the case of Sarah Baartman: throughout the case, her biography was stressed, i.e. the fact that her name and identity were known, as well as her exploitation as living display as the "Venus Hottentot". While these facts undoubtedly contributed to the need felt to return the remains it is not possbile to determine in how far the possiblity of identifying the remains, or the knowledge about her biography (should) qualify as criteria for future cases.

In order to stimulate debate on and the establisment of the criteria that will guide the assessment of the National Scientific Commission, senator Morin-Desailly, on 20 February 2008, introduced a proposal for a statute according to which all Maori heads were to be declassified from the collections designated as Musées de France:

“A compter de la date d'entrée en vigueur de la présente loi, les têtes maories conservées par des Musées de France cessent de faire partie de leurs collections".2089

Only two days later, the first public debate on the situation of human remains in museums was held in France: from 22-23 February 2008 the Musée du Quay Branley hosted a symposium on the subject 'From anatomic Collections to Objects of Worship: Conservation and Exhibition of Human Remains in Museums". ${ }^{2090}$ At present, the debate has not yet resulted in tangible results. The criteria of declassification to be applied by the National Scientific Commission are still not defined nor has the law applicable to Maori remains or human remains in collections of Musées de France been changed. At this point it is important to stress both options - declassification by the National Scientific Commission and the proposed law in its present wording will not be able to provide for the declassification of all human remains (irrespective of the fact that the proposal by senator Morin-Desailly is limited to "têtes maories"). From our analysis of the general legal framework applicable to French collections as outlined in Chapter 3 (\$2.III) it appeared that objects that have been acquired by donation or legacy, or where it concerns public collections not in State property - objects that have been acquired with financial public support cannot be declassified cannot be disposed of (Art.

2088 Décret 2002-628 du 25 Avril 2002 modifié pris pour l'application de la loi 2002-5 du 4 Janvier 2002 relative aux musées de France; Décret n ${ }^{\circ} 2002-852$ du 2 mai 2002 pris en application de la loi n ${ }^{\circ} 2002-5$ du 4 janvier 2002 relative aux musées de France.

2089 Proposition de loi visant à autoriser la restitution par la France des têtes maories présentée Par Mme Catherine Morin-Desailly, sénateur.

${ }^{2090}$ See for conference reports: Bristow, M., 2008; Frigo, M., 2008. 
L. 451-7 CHC). ${ }^{2091}$ The inability to declassify these objects from the domaine public is motivated by the wish not to disencourage future donations and legacies. ${ }^{2092}$ This inability constitutes a full ban on the object's disposal from the collection. One of the objects that cannot be disposed of under the current legal system is the Toi Moko in the collection of the municipal collection in Rouen: after all, it had been given to the city of Rouen by an individual in 1875, appearantly as a gift. Consequently, even after the declassification procedure as provided for in Art. L. 451-5 CHC has been awoken from its idle existence, the return of the toi moko from Rouen cannot be realised unless further legal changes have been undertaken.

\section{§3. CONCLUSIONS FOR CHAPTER 4}

Having analysed the developments in the Netherlands, the United Kingdom and France with regard to the return of Nazi spoliated art and human remains we can now draw conclusions on the nature and content of the policies implemented and the question in how far these policies might qualify as settled state practice testifying of the development of a rule in customary law. In fact, the first question concerning the content and the nature of the policies developed in the three countries has already been answered in detail in the respective country section. For this reason we will not repeat the findings but will limit ourselves to pointing out similarities and differences and to reflecting on how the solutions relate to the solutions proposed in the soft law instruments as elaborated in Chapter 2.

\section{NATURE AND CONTENT OF THE POLICIES WITH REGARD TO THE RETURN OF NAZI SPOLIATED ART AND HUMAN REMAINS}

\section{Nazi spoliated art}

The Netherlands, the United Kingdom and France all introduced non-adversarial claims resolution bodies in the form of the Dutch Restitutions Committee, the UK Panel and the French 'Commission pour l'indemnisation des victimes de spoliations intervenues du fait des législations antisémites en vigueur pendant l'Occupation' (CIVS). While the bodies have in common that they all give non-binding advice to their respective Government, their 'juridisctions', decision making frameworks, as well as the remedies they may recommend vary. Whereas the Dutch solution focusses in the first place on the stocks of objects that had been restored after the end of the war but also apply to other national collections, the French solution in the form of the CIVS also deals with claims of missing artworks. The UK Panel may issue recommendations in

\footnotetext{
2091 Art. L. 451-7 CHC reads: "Les biens incorporés dans les collections publiques par dons et legs ou, pour les collections ne relevant pas de l'Etat, ceux qui ont été acquis avec l'aide de l'État ne peuvent être déclassés".

${ }^{2092}$ Cornu, M., 2008.
} 
claims against a UK national collection or another UK museum or gallery established for the public benefit. ${ }^{2093}$

In as far as the decision-making framework of the reommendation bodies is concerned, the analysis revealed that all frameworks allow for a flexible approach exceeding purely legal aspects. In the Netherlands and France, the framework is to a certain extent defined by the Governments on the basis of the recommendations issued by the Ekkart Committee and the Mattéoli Mission. In contrast, the UK Government did not adopt an explicit policy concerning the return of artworks. Instead, and in line with the general characteristics of common law, i.e. lesser emphasis on codifications and a higher degree of judicial independence, the UK Government left it to the discretion of the Panel to define the meaning and relevance of 'non-legal aspects'. Our analysis of the recommendations issued by the Panel revealed that the Panel accords moral strength to a case in all situations where a cultural object was lost during the years 1933-1945 where the loss was precipitated by the Nazi reign, regardless of the actual form of transaction. In the end, however, our analysis revealed that there exists little difference between the policy-based approaches in the Netherlands and France and the UK case-based approach granting discretion to the Panel to translate the notions of non-legal obligations into a decision-making framework.

The three national solutions furthermore share that they take a lenient approach towards the proof required, taking account of the inherent difficulties given the war times circumstances and the passage in time to proof former ownership and the involuntary nature of a loss. ${ }^{2094}$

In as far as the range of available remedies is concerned, the Dutch Restitution Committee has the most limited range of remedies to its availabiltity. It can only decide between returning an object and denying its return. It cannot recommend the payment of financial compensation instead. It can, however, state conditions for the return of an artwork allowing for greater nuances in the remedies accorded. The Panel has been provided with a broad range of remedies ranging from recommending the return of an objects, to compensation payments and ex gratia payments, possiblity complemented with a commemorative notice reminding the public in future exhibitions of the history of the object and its former owners. As for France, CIVS has an additional remedy to its availability in the form of compensation payments for missing art works, corresponding

\footnotetext{
${ }^{2093}$ In this respect the statement by Schnabel and Tatzkow in their book 'Nazi spoliated art', p. 175 that the UK is bottom of the league for providing for the return of Nazi spoliated art is misleading. While the statement is correct in as far as the UK still has not amended the legislation preventing the return of works from the national collection, it does not pay due regard to the fact that the situation in the UK is different from the continental European countries in that it was never occupied. Consequently, different from the countries that had to provide for the restoration of rights after the war and where recent introspection of how the countries had fulfilled these tasks had led to a reconsideration, such incentive is absent in the case of the UK.

2094 According to Palmer, this leniency with regard to the burden of proof of the claimants is important in facilitating the return of objects to their former owers as laborious inquiries often keep victims and heirs from choosing for private litigation Palmer, N., 2000a, p. 53.
} 
to its greater jurisdiction dealing also with objects whose present location or existence are unknown.

If we compare the solutions implemented at the national level with the solutions proposed in the instruments disucssed in Chapter 2 it becomes evident that all three countries opted for the finding of solutions within the context of the existing law rather than introducing legal reforms as proposed by the Council of Europe in its Resolution 1205: the jurisdictions analysed did not introduce modern legislation compelling the return of spoliated art works. ${ }^{2095}$ Also, they did not change the law pertaining to good faith acquisition, extinctive or acquisitive prescription. ${ }^{2096}$ Instead, the national solutions essentially consist in the establishment of special committees that can hear and decide cases without being limited to the positive law applicable.

In analysing the national solutions adopted with regard to Nazi spoliated art, special attention was paid to the role and relevance accorded to potential financial compensation received in the past. The national solutions adopted in the Netherlands and the UK resemble the soft law instruments adopted at the international level in that they accord little relevance to the question of the relevance of financial compensation that might have been received in the context of the post war restoration of rights. The analysis of the cases heard by the Dutch Restitutions Committee and the UK Panel until the end of 2008 revealed that financial compensations received by the claimants were not taken into account in assessing the validity of a (moral) claim or in determing an appropriate remedy. ${ }^{2097}$

France, on the other hand, explicitly looks at potential compensation payments received by the claimants. In accordance with recommendation no. 9 of the Mattéli Mission, CIVS does not recommend compensation payments where the rightholders have already been compensated in the past. ${ }^{2098}$ Where only partial compensation has been received, CIVS may order to supplement the amount. Where a claimant seeks the return of an object from the MNR Collection rather than compensation, the return would depend on the repayment of the amount received. In order to assess whether

\footnotetext{
${ }^{2095}$ In fact, very few countries introduced modern legislation compelling the return of spoliated objects to victims of the Holocaust. Cf.: Palmer, N., 2001, p. 512. Exceptions are the Czech Republic with its Law no. 212/2000 of 23 June; see especially s. 3 para. 1 and Lithuania with its Law no. 212/2000 of 23 June; see especially s 3 para. 1. Cf.: Palmer, N., 2000b, p. 345. Austria adopted the 'Federal Law on return of Art Objects from the Austrian Federal Museums and Collections' (Bundesgesetz: Rückgabe von Kunstgegenständen aus den Österreichischen Bundesmuseen und Sammlungen) (NR: GP XX RV 1390 AB 1464 S. 146. BR: AB 5802 S. 646). Of these legal acts, only the Czech Act provides for a legally enforceable claims right. The Austrian and Lithuanian Acts enable return of Nazi spoliated art rather than prescribing it. Cf.: Schönenberger, B., 2009, p. 259.

2096 Schönenberger, B., 2009, p. 246.

2097 In 2009, the Spoliation Advisory Panel seems to have adopted a new attitude when it issued its 9th report:: http://www.culture.gov.uk/images/publications/429961_HC757_PROOF.pdf (last visited 30 June 2009).

2098 Mission-Mattéoli, 2000, Recommandation n 9, p. 170.
} 
claimants have been compensated in the past, CIVS operates an office in Berlin to consult files where compensation was previously awarded under the BRüG Law. ${ }^{2099}$

The finding that the solutions adopted in the Netherlands and the United Kingdom pay little regard to the question whether claimants might have received financial compensation in the past is interesting in two respects: first, a just and fair solution must consider compensation payments which already had been made according to post-war restitution laws. ${ }^{2100}$ While it could be argued that a just and fair solution demands the physical return of an object regardless of any compensation payments received, this cannot be presumed but must be discussed in public taking all relevant aspects, including past compensation payments, into account.

\section{Human remains ${ }^{2101}$}

With regard to the return of human remains from public collections, the analysis of the solutions adhered to in the Netherlands, the United Kingdom and France revealed that none of the countries introduced legislation comparable to the United States federal act NAGPRA. This might not be surprising if one considers the different political positions of the countries involved. Different from the United States and other countries discussed in Chapter 2.\$2.II.2, the Netherlands, the United Kingdom and France do not have a native population comparable to Native American Indians that is seeking the return of human remains. ${ }^{2102}$ Also, it should be emphazised that NAGPRA applies only to Native American remains, not to human remains in museum collections in general. The absence of the introduction of new legally enforceable rights for the return of human remains does not mean that the national solutions did not affect the law pertaining to human remains in public collections. This is, however, only the case for the United Kingdom, which adopted the 2004 Human Tissue Act.

The fact that the UK Government did introduce legislation positively discriminating human remains in comparison to other objects in their public collection in allowing for their de-accessioning, gives evidence of a certain commitment to the cause of returning human remains. With the introduction of s 47 of the 2004 Human Tissue Act the situation in the UK came closer to the legal situation in the Netherlands in that the trustees of national collections in the UK, which were previously prevented from

2099 Cf.: Presentation by JP Bady 'The Policy of Compensation for Plundered Works of Art in France', London 18 October 2006, Conference on Dispute resolution and holocaust related art claims organised by the Institute of Art and Law. In an interview in 2006, Prefet Kalfon, then director of the CIVS stated that until then no other country had expressed the wish to cooperate in this work (Kalfon, L., 2006, p. 436). 2100 Cf.: König, H.,

http://www.badv.bund.de/002_menue_oben/007_english/004_provenance/index.html.

2101 As stated above the reader may referred to the interim conclusions at the end of each section for a summary of the content and the nature of the policies developed in the three countries with regard to the return of human remains. In this section we will limit ourselves to pointing out similarities and differences. 2102 It should be mentioned that in the UK, the Council of British Druid Orders (CoBDO) has in a number of instances claimed the return of human remains. See, e.g.: Museen: Kontroverse um Kinderknochen, 2 February 2009. 
disposing of objects from their collections except in a limited number of exceptions, are now able to de-accession human remains if they wish to do so. By adopting legislation enabling de-accession of human remains the UK Government distanced itself from the opinion that human remains in public collections cannot be subject to property rights. Both, in the United Kingdom and in France, it was tried at a certain point to circumvent the ban on de-accession by relying on the no-property argument. The reference to the commons or anti-commons is a general strategy to change already owned things into an acquireable state. ${ }^{2103}$ In the end, however, the strategy of relying on the no-property rule was discarded in both countries: whereas the United Kingdom introduced legislation positively discriminating human remains in comparison to other objects in their public museum collections, France has returned to its initial starting point that human remains in collections designated as Musées de France cannot be de-accessioned unless by assent of the National Scientific Commission of Museum Collections of France as outlined in Art. L. 451-5 CHC. As for the Netherlands, the argument of the no-property role did not figure in any of the case studies. Dutch legal doctine generally affirms that ownership of human remains as present in museum collections is possible. ${ }^{2104} \mathrm{In}$ fact, the existence of human remains in museum collections and the trade in human remains is referred to as supportive evidence by the authors who argue that a corpse or in any event a human body after death can, at some point, become the object of property rights. ${ }^{2105}$ An explanation for the absence of the discussion in the Netherlands might be the fact that there exists no general ban on the de-accession of objects from Dutch national collections in the first place.

Except for the UK Human Tissue Act 2004, none of the national solutions adopted qualify as legal solutions in the sense of changing the law applicable to human remains in public collections. Instead, in the United Kingdom and in the Netherlands nonbinding guidelines were adopted. In the Netherlands, the policies were developed in a dialogue between the institutions affected by a claim for the return of remains, respectively adopting a pro-active attitude to meet future claims, and professional ethics bodies, respectively expert groups. The Dutch Government was not involved in the development of the policies. It did, however, in one case, indirectly confirm the policy relied upon by agreeing on the return of human remains that belonged to the national

\footnotetext{
2103 Cf.: Flessas, T., 2007, p. 19.

2104 Herten, J.H.S.v., 1984, p. 156 \& 160; Putten, W.G.H.M.v.d., 1993, p. 24; Steur, J.C.v.d., 2003, pp. 213214; Leenen, H.J.J., et al., 2007, p. 60; Vliet, L.P.W.v., 2007, p. 3.

2105 See, e.g.: Herten, J.H.S.v., 1984, p. 156; Putten, W.G.H.M.v.d., 1993, p. 24. There exists general agreement that throughout a person's lifetime, his or her body cannot be subject to property rights See in this respect: Petit, C., 1950, p. 431; Beekhuis, C.H., 1955, p. 854; Herten, J.H.S.v., 1984, p. 157; Steur, J.C.v.d., 2003, pp. 211-212; Boer, J.d., 2006, p. 51, nr. 58; Leenen, H.J.J., et al., 2007, pp. 47-59; Snijders, H.J. / Rank-Berenschot, E.B., 2007, p. 21, nr. 27. For a different opinion see advocate general Van Asch van Wijck in his conclusion in the Supreme Court case HR 25 June 1946, NJ 1946, 503 where he argued in favour of classifying the living body as the object in property owned by the living person as the right holder.
} 
collection. ${ }^{2106}$ As for the extrapolation of common principles, the analysis identified three principles. Essentially, these principles boil down to the need to treat human remains with respect and sensitivity; to be prepared for transparency and dialogue with the requesting party; and finally, less a principle but rather an aspect to be taken into account in the decision-making process, to verify the legimitate interest of the requesting party.

In the United Kingdom, the process of critically assessing the treatment of human remains in public collections and of developing guidelines was initiated by the Government. The final 'Guidance for the Care of Human Remains in Museums' is more extensive than the common policy we were able to extract for the Netherlands. It does not, however, differ in essence from the Dutch principles: while the guidance might enjoy more authority for having been adopted by the Department for Culture, Media and Sport (DCMS), it is non-binding. Furthermore, its main contribution lies in guiding and structuring the decision-making process of institutions with regard to the return of human remains by listing the relevant questions and aspects that must be taken into account. In as far as substantive principles are concerned the relevance of the guidance is limited.

As for France, no conclusions can yet be drawn with regard to the nature and content of any principles. While the case studies identified two possible mechanisms for the de-accessioning of human remains from French collections - by means of a legal statute or by following the declassification procedure involving the National Scientific Commission of Museum Collections - the present state of the cases does not provide insight on the nature and content of the principles that will govern the drafting of statutes or the de-classification procedure.

Different from the national solutions adopted with regard to Nazi spoliated art no recommendation committees were established to deal specifically with claims for the return of human remains as a form of alternative dispute resolution. If we compare the solutions adhered to at the national level with the soft law instruments discussed in Chapter 2 it becomes evident that the national solutions do not follow the soft law instruments in according greater priority to the return of human remains than to other cultural objects in public collections. While the developments in the three countries analysed, but especially in the United Kingdom and the Netherlands, give evidence of sympathy for the claimants and of willingness to return human remains, as embodied most prominently in s 47 of the Human Tissue Act 2004, they are not reflected in substantive principles compelling or at least effectively proposing the return. Instead, as summarised above, the principles are limited to procedural aspects of how to meet a request for return.

${ }^{2106}$ See above in chp. 4.\$2.I.2 for the analysis of the return of the Toi Moko from the collection of the National Museum of Ethnology to New Zealand. 


\section{TOWARDS RULES OF CUSTOMARY LAW ON THE RETURN OF NAZI SPOLIATED ART WORKS AND HUMAN REMAINS?}

One of the aims of the present chapter is to evaluate in how far the developments at the national level may be considered as expressions of (an emerging) rule of customary law. In Chapter 2, which focused on the principles, declarations and resolutions adopted at the international level, we came to the conclusion that the instruments presently constitute soft law principles de lege ferenda. Such principles may, however, develop into rules of international law. This "hardening" of soft law into hard law may happen via the creation of customary law. ${ }^{2107}$

Customary law, as an important source of international law next to treaty law, has been introduced in detail in Chapter 1. Consequently, we will not repeat the explanations concerning the two cumulative elements of customary law, opinio iuris and state practice, but will turn to the analysis whether the practices identified and discussed in the present chapter qualify as sufficiently extensive and convincing state practice. The following sources can give evidence of 'state practice': administrative acts, legislation, as well as decisions of courts. Furthermore, state practice may also be derived from activities on the international stage, such as treaty-making, resolutions in the United Nations General Assembly, comments made by governments on drafts produced by the International Law Commission, decisions of the international judicial institutions, decisions of national courts, treaties, and the general practice of international organisations. ${ }^{2108}$ In as far as the evidence that may be derived from the international stage is concerned, it has been scrutinised above in Chapter 2. Consequently, and in line with the content of the present chapter we can focus on the national dimension.

In Chapter 4.\$1 we have discussed the policies adopted in the Netherlands, the United Kingdom and France in reaction to claims seeking the return of Nazi spoliated art. The analysis revealed that none of the countries introduced legislation providing for the return of Nazi spoliated art. Instead, the Governments opted for the introduction of non-adversarial claims committees that may decide upon the return of art works, in particular from national and to a lesser extent from public collections not owned by the state. As for the Netherlands and France, the respective committees base their recommendations on Governmental policies. The UK Panel, on the other hand, has been granted carte blanche to interprete the meaning and relevance of 'non-legal aspects'. While the policies implemented by the three countries express sympathy for the course of returning Nazi spoliated art works and may not be undervalued for their effect in facilitating returns, they cannot satisfy the standards of uniformity and consistency that

2107 Cf.: Szasz, P., 1992, p. 68; Cassese, A., 2005, p. 491; Andorno, R., 2007.

2108 Shaw, M., N., 2008, p. 82. Cf.: Bossuyt, M.J.M. / Wouters, J., 2005, p. 108; Dixon, M., 2007 , p. 31. Bossuyt remarks that it is not entirely clear whether, in the eyes of the ICJ, the resolutions in the United Nations General Assembly provide evidence of state practice or of an opinio iuris (or both). 
are required to speak of state practice relevant for the emergence of a rule of customary law.

Even if our analysis had indicated uniform and consistent practice for the three countries scrutinised, the finding would not allow us to draw conclusions for the existence of a rule of custormary law. Such a conclusion would require the analysis of more jurisdictions. A review of secondary literature supports the conclusion that one cannot speak of a rule of customary law on the return of Nazi spoliated art. ${ }^{2109}$

The analysis of the national practices developed with regard to the return of human remains in Chapter 4. $\$ 2$ revealed even less consistency between the national solutions. Whereas the UK Government actively intervened and triggered the process of reflecting upon current practices and the need of returning human remains, no official policy was adopted. The Government did, however, relax the statutes applicable to the national collections in order to allow for the return of human remains where institutions wish to do so. In the Netherlands, no official Government intervention was identified, except for the granting of permission to return human remains from a national collection. While a connection between the state and public collections certainly exists, especially in as far state museums are concerned but including also public collections that are incorporated as foundations, trusts, or companies, which are indirectly held by the state and subsidized by public money 2110 , it would not be persuasive to argue that the decisions taken by the different public collections in the Netherlands can be accorded to the Dutch State as State actions. As for France, no coherent state practice could be detected either, with the two existing cases pointing in different differections.

Consequently, our analysis denies the existence of a rule of customary rule for the return of Nazi spoliated art respectively human remains. It does, however, reveal a general trend to facilitate returns both with regard to Nazi spoliated art and human remains. ${ }^{211}$ Different aspects facilitating the return have been identified in the present chapter: first, the removal of legal barriers to de-accession objects from public collections. This aspect emerged in particular in the context of returns from the United Kingdom as one of the jurisdictions characterised by limitations to the de-accessioning of objects from public collections. Whereas legislation enabling the return of human remains has already entered into force, the adoption of legislation allowing also for the return of Nazi spolitated art is currently pending. France, as the other country significantly limiting the de-accessioning of objects from public collections, especially from the Musées de France, is lagging behind with regard to the de-accessioning of human remains. While the de-accessioning of human remains from French public collections is not ruled out from the outset as was the case in the UK prior to the adoption of s 47 of the 2004 Human Tissue Act, France has not yet clarified the rules and conditions

2109 See, e.g.: Torsen, M.A., 2005, pp. 16-17, http://www.ejcl.org/94/art94-1.html (who analysed the national solutions adopted in the United States, Austria, France, and Russia); Garrett, R.L., 2000, p. 385.

2110 Siehr, K.G., 2005, p. 1086. Cf.: Schnabel, G. / Tatzkow, M., 2007, p. 197.

2111 Cf.: Schönenberger, B., 2009, p. 285. 
applicable to the declassification procedure by the National Scientific Commission of Museum Collections in accordance with Art. L. 451-5 CHC. However, the findings of the case study of the return of the remains of Saartje Baartmans nevertheless confirm the general tendency sympathetic to and faciliting the return of human remains.

Next to the relaxation of legal statutes preventing the return of human remains and Nazi spoliated art works the introduction of non-adversial claims committeees must be mentioned as another aspect facilitating the return. Not only do these committees constitute low-threshold procedures to claimants from a financial point of view and in view of the evidence required; they also allow for the assessment of claims not limited to strictly legal aspects. ${ }^{2112}$

The identification of a general return-friendly-tendency must neither be over- nor undervalued: the tendency is as of today not reflected in legal rules explicitly providing for the return of Nazi spoliated art respectively human remains. Put differently, returns depend on the good-will and the interests of the holding institution and state concerned. However, it would be myopic to consider only the interest of conserving an object for a collection. One must not disregard the inherent positive effect a return may have. This is particularly true for human remains: returns affected in the past have contributed to a better understanding of public collections, of colonial and post-colonial relationships and collecting practices. ${ }^{2113}$ Furthermore, they have resulted in new forms of agreements and cooperation between the former holding institutions and institutions in the country to which the remains have been returned: the repatriation of human remains has facilitated new discoveries about the collections, the provenance and original use of collection items, greater understanding of the cultures exhibited and has resulted in collaborative projects, such as joined exhibitions and research projects. ${ }^{2114}$ Next to internal reasons to return cultural objects, one must also not forget the influence of international media (pressure) and diplomatic channels.

\footnotetext{
2112 Cf.: Ibid., p. 265 \& 285.

2113 Vrdoljak, A.P., 2006, p. 15.

2114 Ibid. See for concrete examples of cases where the process of repatriation has had benefits both for the formerly holding institution: Simpson, M.G., 1996, pp. 233-234; Simpson, M.G., 2001, pp. 245-246.
} 



\section{CHAPTER 5}

\section{Conclusions}

The overall aim of this book is to take stock and analyse the present law and practice with regard to the return of cultural property from public (museum) collections through the lens of the cases of Nazi spoliated art and human remains. Time has come to draw some conclusions based on the research represented in the previous chapters. First, we will summarise the main research findings pertaining to the return of cultural objects $(\mathbb{1} 1)$. Subsequently, we will present the recommendations that can be made on the basis of the present research $(\$ 2)$, before briefly discussing the relevance of the developments in the cases of Nazi spoliated art and human remains for the return of cultural objects from museums more in general (\$3). A final reflection in the form of an epilogue will be dedicated to developments too recent to have been integrated in this study, but which might be of great relevance for the future course of the restitution debate.

\section{§1. SUMmaRY AND MAIN FINDINGS FROM THE PREVIOUS CHAPTERS \\ CHAPTER 1: FROM THE IUS PRAEDAE TO THE HERITAGE OF MANKIND: THE INCREASING PROTECTION OF CULTURAL OBJECTS AS CULTURAL PROPERTY, INCLUDING RESTORATIVE BUT NO RETROACTIVE PROTECTION}

In analysing public international law with regard to the protection and return of cultural objects, the following development became evident: starting from Ancient Times, where the looting of cultural objects was a well-established and recognised practice, there has been a gradual increase in recognising the obligation to restitute cultural objects.

The obligation to restitute cultural objects is most advanced in the law dealing with armed conflicts. The entry into force of the 1899 Hague Convention in 1900 marks a 
watershed in establishing a ban on the looting of cultural objects. ${ }^{2115}$ Hand in hand with the introduction of the ban on the looting of cultural objects emerged an obligation to restitute any objects looted in breach of the ban. This obligation is the result of a combination of the general principle of international law that any breach of an engagement involves an obligation to make reparation and the primacy of physical restitution over other forms of reparation where possible. The primacy of physical restitution, especially where it concerns an object of cultural relevance, was confirmed during the process of the restoration of rights after WWII. By the outbreak of the war in 1939 the ban on looting and the obligation to restitute looted cultural objects did not only apply to State Parties to the 1899 and 1907 Hague Conventions but qualified also as rules of customary law. Where cultural objects could not be physically restituted for having been destroyed or for being lost, compensation payments were granted. The emphasis on physical restitution and the payment of financial compensation where physical restitution was not an available option did not remain limited to external restitutions. The Allied Forces chose not to observe the principle of State sovereignty, according to which the internal restoration of rights would have been a matter of the German State only. Instead, they chose to extend the scope and principles of restitution to apply also to deprivations that had occurred within the German State since the Nazi's rise to power in 1933. By doing so they created new legal bases for the restitution of cultural objects. The new legally enforceable claim rights were construed in a way to allow victims to effectively reclaim their property: the internal restitution regime was based on a presumption that all transactions made in the period 1933-1945 involving a person belonging to a persecuted group qualified as an act of confiscation. Furthermore, the right to restitution also existed irrespective of any interest of a potential good faith purchaser.

In 1954, while the post-WWII process of the restoration of rights was still ongoing, the protection of cultural objects in times of armed conflicts made a leap forward with the adoption of the 1954 Hague Convention and its (First) Protocol. In particular the Protocol proved to be relevant for the restitution of cultural property: in the first place, the obligation to restitute cultural objects applies to all State Parties rather than only the aggressor state. Secondly, the obligation is not subject to any limitation periods. Finally, the obligation exists irrespective of any rights possibly acquired in the mean time by a bona fide purchaser. In this respect the obligation of the Protocol to restitute cultural property reflects the characteristics of the post WWII restitution regime. While the 1954 Hague Convention is less radical with regard to obliging State Parties to restitute cultural property, its relevance for the protection of cultural property must not be undervalued:

2115 The finding that it is the 1899 Hague Convention rather than the 1907 Hague Convention that constitutes the watershed in introducing a ban on looting and the corresponding obligation to restitute objects is not relevant from a practical point of view: during the ten years that lay between the entry into force of the two contentions in 1900 and 1910, no wars were waged between State Parties to the 1899 Hague Convention. See for a time chart of wars from 3000 BC to the present: Chandler, D.G., 2003. 
as the first international treaty to focus solely on the protection of cultural objects as cultural property, the 1954 Hague Convention added authority to the protection of cultural property more in general.

The protection of cultural property in times of peace in the form of international treaties started in the 1970s with the adoption of the 1970 UNESCO Convention. In 1995, the UNIDROIT Convention followed. While the 1970 UNESCO Convention requires State Parties to return cultural property stolen from a museum or a similar institution, it is not self-executing. Consequently, it cannot by itself create new legal rights to restitution. The 1995 UNIDROIT Convention, on the other hand, is selfexecuting and created new legally enforceable rights both with regard to the restitution of stolen cultural objects and illegally exported cultural objects. The provisions with regard to the return of illegally exported cultural objects are, however, significantly more limited in scope than the rights granted for the restitution of stolen cultural objects. Countries remain hesitant to grant special rights providing for the return of illegally exported cultural objects. However, this hesitation does not mean that states are lacking interest in the protection of another country's cultural property. While states refrain from enforcing another State's criminal or public laws, the analysis revealed a general support for the cause of returning cultural objects to the country from where they have been illegally exported. In particular, a tendency can be denoted to approach such cases as cases of stolen cultural property. ${ }^{2116}$

While the return of objects removed during the colonial era belongs strictly speaking to the category of objects removed in times of peace, specific attention was given to scrutinising the possible existence of specific rights providing for the return of these objects. The reason for doing so is two-fold: first, a number of authors have argued that a specific rule providing for the return of cultural objects removed from formerly colonised countries could have come into existence despite the general aversion of states to introduce retroactive obligations. ${ }^{2117}$ The second reason consists in the fact that there exists a coincidence of the era in which the fundaments of current public collections of human remains have been laid with the zenith of European dominion over the rest of the world. ${ }^{2118}$

The analysis addressed whether and in how far a legal basis for the return emerges from the resolutions adopted within the frameworks of UNESCO and from the rules on state succession. Also, it was verified whether the circumstances of acquisition during the colonial era allowed for the qualification as an international illegal act. None of the three approaches resulted in the identification of a legal basis providing for the return of cultural objects removed during the colonial era.

A final constellation analysed was the return of cultural objects to a people. The analysis did reveal a number of occasions in which cultural objects were returned to a

2116 Cf.: Schönenberger, B., 2009, pp. 215 \& 239.

2117 See further above in chp. 1.\$3.

2118 See further above in chp. 2.\$2.I. 
people. However, these returns were rather indirect in nature and cannot be seen isolated from the greater restoration of rights after WWII. There is not sufficient ground to speak of a general obligation to return cultural objects to a people.

In conclusion, explicit rights for the restitution of cultural objects are still mainly limited to situations qualifying as armed conflicts where they follow from the principle of reparations. Outside of armed conflicts, countries are wary to create or recognise legally enforceable rights for the return of cultural objects. This does not mean, however, that they are hostile to returning cultural objects.

\section{CHAPTER 2: THE GENESIS OF CURRENT CLAIMS AND THEIR LEGAL STATUS}

The findings of Chapter 1 concerning the wariness of States to create new legally enforceable rights for the return of cultural objects while sharing sympathy for the cause of returning cultural objects are also true for the two cases, Nazi spoliated art and human remains, that were addressed in detail.

\section{Nazi spoliated art}

With regard to Nazi spoliated art the analysis revealed that present claims can no longer rely on the post-war restitution rights. While objects may still be claimed back where the dispute is a matter between states, private individuals can no longer rely on the rights as they existed / were created after the end of WWII for the lapse of application periods. As for the principles, resolutions, and declarations adopted since the end of the 1990s with the 1998 Washington Principles as primus inter pares, the analysis revealed that the instruments, being of soft law character, did not create new legally enforceable rights. Consequently, the relevance of the instruments lies in the rising of awareness of the problem and in preparing the grounds for solutions to be adopted at the national level. The solutions proposed by the instruments may be grouped into two categories: the first category consists of solutions that seek to revive already existing legal norms. The solutions within this category seek to address the obstacles that prevent claimants from relying on already existing legal bases. In particular, they address legal institutions such as good faith acquisition, prescriptive acquisition and extinctive prescription. The instruments did not suggest the introduction of new legal bases for the return of Nazi spoliated art. Also belonging to this category of legal solutions that as such do not create legally enforceable rights are solutions that seek to abolish any rules preventing the disposal of objects from public collections or the objects' export. The second category of solutions proposed does not seek to improve the situation of claimants by means of legal reform but seeks to arrive at restitution by alternative means. In particular, they seek to improve the claimants' position in providing evidence supporting their claims and advocate the creation of alternative dispute resolution mechanisms. With regard to the latter, the instruments stress the creation of special committees that may hear claims and that may arrive at "just and fair" solutions that are not based solely on legal aspects. The question as to what must be understood by "just and fair" solutions is not further elaborated on. Against the findings of Chapter 1 it is 
noticeable that no reference is made to the possibility that financial compensation might have been received by (the heirs of) the former owner during the post WWII period.

\section{Human remains}

With regard to human remains the analysis indicated that human remains satisfy the characteristics of the notion of cultural property and thus fall under the protection granted by international treaties dealing with the protection of cultural property (Chapter 2.\$2.III.2). As a consequence, human remains, especially from public collections, are granted protection against theft and illegal export, including restorative protection in the sense that they must be returned to the country from where they had been illicitly removed. The existing legal framework of public international law does not, on the other hand, provide for any rights to reclaim human remains that have been acquired in the past. The same finding is also true for the instruments adopted by various fora dealing (in-) directly with the return of human remains. In fact, only the Convention for the Safeguarding of the Intangible Cultural Heritage could have provided for such a right. The Vermillion Accord on Human Remains, the Mataatua Declaration and the ICOM Code do not qualify as normative rules for not having been adopted by a forum with treaty-making authority, whereas the UN Declaration on the Rights of Indigenous Peoples as a declaration is missing the required will to be bound. Consequently, the relevance of the instruments lies essentially in proposing what the law may or should be in the future. Two paths have been suggested by the instruments for the solutions to be adopted at the national level: a strictly legal solution, consisting of the creation of legally enforceable rights similar to the US federal law NAGPRA and alternative solutions in the form of fair and transparent decision making mechanisms and in providing better inventories of the collection holdings. It can be noticed that the instruments attach greater importance to the necessity to return human remains than to return cultural property in general.

\section{Nazi spoliated art and human remains compared: similarities and differences}

If one compares the solutions proposed at the international level by the various fora with regard to recent claims for the return of Nazi spoliated art and human remains the following similarities and differences become evident. All instruments share that they do not create a new legal basis for the return of Nazi spoliated art and human remains respectively. As soft law instruments they can only denote "values, guidelines, ideas and proposals that may develop into rules of international law". ${ }^{2119}$ As far as the guidelines and proposals made with regard to the return of Nazi spoliated art and human remains, the instruments differ: whereas the instruments dealing with human remains stress in particular the necessity of creating new legal bases for the return of human remains, instrument dealing with Nazi spoliated art emphasize first and foremost alternative dispute mechanisms, and to a lesser extent legal reforms. Different from instruments

${ }^{2119}$ Cf.: Dixon, M., 2007, p. 50. 
dealing with human remains, however, the legal reforms do not seek to create new legal claim rights. Instead, they seek to reactivate past claim rights by addressing legal institutions that, through the passage of time, have invalidated past claim rights. Consequently, both alternative solutions and legal reforms pertaining to Nazi spoliated art seek for ways to circumvent the legal effects of the passage of time. Against the background of the legal framework as existing in public international law, the solutions proposed by the instruments for the two cases make sense: given the far-reaching efforts, including the introduction of new legal norms, to restitute spoliated art works during the period of the restoration of rights after the end of WWII, present attempts can take these past claim rights as anchor or starting point. With regard to human remains, such anchorage ground is missing, leaving the call for the creation of new legal bases for the return of human remains as the only available option.

\section{ChaPTER 3: THE CONFINES OF THE LAW}

The analysis in Chapter 3 of the rules applicable to public collection revealed that a return may be prevented by rules regulating the disposal of objects from a public collection. This is especially the case for UK and French public collections. Both the $\mathrm{UK}$ and the French regime are characterised by a general ban on the disposal of objects. However, whereas the ban on the disposal of objects from UK public collections originates from restraints on the owners' rights to disposition, the ban on the disposal of objects from French public collections results from res extra commercium legislation. Put differently, as for objects in UK public collections the ban is the result of an external factor whereas the inability to be transferred of objects in French public collections is an inherent characteristic of the objects themselves. However, this inherent characteristic is not absolute. It may be altered by following the de-classification procedure now provided for in Art. L. 451-5 CHC. Consequently, from a theoretical point of view the ban on the disposal of objects from French public collections is less absolute than the $\mathrm{UK}$ regulation in that it provides for a back door to revoke the ban on disposal. From a practical point of view, in the absence of any measures implementing the declassification procedure of Art. L. 451-5 CHC, the ban on the disposal of objects from French public collections is presently as impervious as the ban applicable to objects in UK collections. As for the Dutch situation, the analysis revealed that no formal restrictions exist to the disposal of an object from a public collection. However, in a limited number of cases disposal may be ruled out on the ground of application of the criteria of the CHP Act by analogy.

Further to the general rules on disposal, additional limitations may apply to objects that were acquired by donation or legacy. Again, it is the French system that is most radical in limiting the possibilities of disposing of an object. According to Art. L. 451-7 $\mathrm{CHC}$, objects that have been acquired by donation or legacy cannot be declassified. The inability to declassify these objects is motivated by the wish not to discourage future donations and legacies. While the Netherlands and the United Kingdom also know 
limitations on disposal of objects acquired by donations or legacies, additional limitations to the possibility of disposal will arise only where explicitly or implicitly stipulated by the terms of the donation or testamentary disposition. However, even when the terms of the agreement exclude or limit disposal they are not necessarily fatal for an intended return. As for the UK, the governing statutes of the national collection concerned may explicitly provide for the possibility to override trust and other nonstatutory conditions. As for the situation in the Netherlands, the so-called imprévisionrule' of Art. 6:258 DCC may provide for the possibility to dispose of objects acquired by donations. With regard to testamentary dispositions, the 2003 reform of the inheritance legislation broadened the possibility to alter applicable conditions and obligations, including limitations on disposal.

With regard to export regulation the analysis did not detect any fatal obstacles for an intended return of an object to a claimant or country abroad. Export regulations may, however, subject a return to certain administrative requirements such as the presentation of an export licence.

CHAPTER 4: NATIONAL SOLUTIONS PERTAINING TO THE RETURN OF NAZI SPOLIATED ART AND HUMAN REMAINS - DIFFERENT PERCEPTIONS ABOUT THE NEED TO RETURN

In Chapter 4 we summarised the nature and content of the national policies with regard to the return of Nazi spoliated art and human remains. In both cases, the solutions adhered to do not constitute legal reforms but provide for alternative solutions within the existing law. The only exception currently consists in the UK 2004 Human Tissue Act, in particular s 47. S 47 enables the disposal of human remains from the national collections, which was previously prevented by the trust and statutory rules applicable.

While the solutions adhered to in both cases mainly consist of alternative solutions respecting the present state of the law, they nevertheless differ in approach. The solutions introduced with regard to the return of Nazi spoliated art rely extensively on committees that have been specifically established to give advice on the return in individual cases. From the analysis it appeared that the committees have to a greater or lesser extent shaped the policy on the return of works of art. This is specifically true for the UK Panel whose terms of reference do not further explicate what is meant by "moral strength or moral obligations". While the margin of appreciation of the Dutch Restitutions Committee is considerably more limited in that it has to apply the liberalised policy as defined by the Government, the analysis revealed that the Committee nevertheless has considerable influence on putting the policy into practice.

In contrast to Nazi spoliated art, no advisory committee has been adopted to make recommendations on the return of human remains. Instead, the solutions developed with regard to human remains rely essentially on non-binding guidelines that serve institutions in their decision-making process. While the guidelines stress that human remains should be treated with respect and sensitivity the guidelines do not advocate 
that human remains must be necessarily returned. Instead, they offer stepping stones to ensure a well-informed and well-balanced decision making process.

Comparing the reliance on recommendation committees that have significant influence on the developments with regard to Nazi spoliated art on the one hand with the absence of such committees with regard to human remains and the introduction of merely non-binding procedural guidelines on the other hand, suggests the following underlying perception of the cases: with regard to Nazi spoliated art the return is recognised as a valid ethical imperative in abstracto. This imperative seems to go as far to include even cases in which the claimant has already received compensation payments in the past. In contrast to Nazi spoliated art, no such imperative to return human remains in abstracto has been recognised. The mere fact that the objects requested are the remains of once sentient human beings or the circumstances of their appropriation are not considered as imperative reasons to return. Instead, the solutions adhered to seek to allow for an optimal decision making process in concrete cases without tipping the scales necessarily towards return. Consequently, despite the "closer similarity, in terms of the need for sensitivity and recognition and respect between these two areas than between any two others" 2120 , the present developments with regard to the objects' return nevertheless rest on different underlying perceptions as to the imperative to return Nazi spoliated art and human remains respectively.

\section{$\S 2$. RECOMMENDATIONS}

Based on the research findings of this study the following recommendations can be formulated. The recommendations are presented in the order following from more specific to more general recommendations.

\section{I. (RE-) OPENING OF THE DEBATE ON JUST \& FAIR SOLUTIONS WITH REGARD TO NAZI SPOLIATED ART}

Since the (re-) emergence of the debate in the mid 1990s the case of Nazi spoliated art has come a long way: after awareness of the Nazi art looting was virtually inexistent during the 1970s and 1980s, there is now general awareness about the Nazi looting and the fact that works of art had been traded for decades without paying any attention to the objects' fate and potential title problems. However, the present analysis of the return of Nazi spoliated art in the past and present ${ }^{2121}$ indicates that there is not yet enough historical profundity: while the history of art works and the fate of their former owners prior and during WWII is well researched, little attention is granted to the developments during the post-war era. As a consequence, there still exists an imbalance of the relevance accorded to financial compensations payments. While the

${ }^{2120}$ Palmer, N., 2000a, p. 169; Woodhead, C., C., 2002, pp. 324 \& 346.

${ }^{2121}$ See above chp. 1.\$1.V / \$4; 2.\$1.III; 4.\$1. 
rules introduced after WWII on the restitution of spoliated art works provided for financial compensation payments in cases that physical restitution was impossible, this fact is not yet sufficiently acknowledged in the present debate on the return of Nazi spoliated art. Neither the instruments introduced by international fora such as the 1998 Washington Principles ${ }^{2122}$, nor the national solutions, with the exception of France, pay any regard to financial compensation payments that might have been received by the (heirs of the) former owners during the post-war period. Instead, the solutions proposed at the international level and as implemented in the Netherlands and the United Kingdom present a one-dimensional picture in that they address only the circumstances of loss during the years 1933-1945 but do not systematically take into account developments since the end of WWII. While it could be argued that a just and fair solution demands the physical return of an object regardless of any compensation payments received, this cannot be presumed but must be discussed in public taking all relevant aspects, including past compensation payments, into account.

One explanation for the little relevance accorded to the post-war restoration of rights can be found in the way that so-called provenance research is conducted nowadays. Provenance research of works of art is concerned with the history of ownership. ${ }^{2123}$ In the past, provenance research had served in the first place the research on the authenticity of a work: in the ideal case, a researcher succeeded to establish an unbroken chain between a current owner and the artist as the ultimate proof that the work was by the hands of the artist. While provenance research still contributes to research concerning a painting's authenticity, its focus has shifted to establish the fate of a work of art during the reign of the Nazis in 1933-1945.

While provenance research is conducted by well-trained art historians who go to great length in researching a painting's provenance, there are two problematic aspects about provenance research. As pointed out by one of the leading provenance researchers Sophie Lillie, provenance lacks a clear methodology and it is often conducted in a particular interest. ${ }^{2124}$ As a consequence, provenance research does not pay sufficient attention to reconcile the history of the painting during WWII with the restitution processes in the post-war era. While provenance researchers are well aware of files documenting the post-war restoration of rights and are keen to integrate them into their research as compelling proof that a work of art had indeed been looted ${ }^{2125}$, the research stops with the finding that an object has been looted.

\footnotetext{
2122 See for the relevant instruments above in chp. 2.\$1.III.

2123 Yeide, N.H., et al., 2001, p. 1.

2124 Presentation Sophie Lillie, Restitution Symposium organised by Sotheby's Amsterdam on 30 January 2008. See for a conference report: Lubina, K.R.M., 2008. Sophie Lillie is author of the book "Was einmal war", 2003.

2125 The German restitution files have been characterised as restitution records available to all provenance researchers as they could serve as "nearly perfect proof that an individual owned an object before the war and lost it due to persecution as the post-war German authorities were rigorous (...) in confirming a claim before compensating a Nazi victim for a loss”. Henry, M., 8 September 2007.
} 
Consequently, the first recommendation is to reopen the debate of what constitutes just and fair solutions and which relevance must be accorded to financial compensation payments received. Such reflection on the relevance of compensation payments received from the German Government after the war for current disputes involving works of art that had been looted during the war is of course not solely the tasks of provenance researchers. To the contrary, while provenance research might still be missing a clear methodology and is often exercised for specific interests, its aim is first and foremost to establish the (unbroken) chain of a painting's owners. Rather, such a reflection is the task of academics, as well as the media and the public.

Such a debate is not only important to prevent a later backlash undermining the legitimacy of the return policies, it would also constitute a chance to allow for a broadening the palette of remedies. A solution often praised as just and fair solution but less often implemented consists of paying the claimant financial compensation while leaving the object in the public collection where it reminds the public, by means of commemorative note, of its history and the fate of its former owners. ${ }^{2126}$ Commemorative plaques are a powerful reminder and instructor to the general public of the story of those who suffered at the hands of the Nazis. ${ }^{2127}$ Furthermore, they will continue to send out their reminder of the horrors of the Nazi reign and their warning about the inhumanity within the human species in the near and later future. At present, shortly after the end of the first decade of renewed interest into the return of Nazi spoliated art works, the level of public awareness is still high. However, one cannot foresee how this development will be remembered in the future. At a certain point no more art works will be claimed. With fewer claims and returns, there will be less media coverage and consequently awareness. In light of keeping up remembrance in the future, the feasibility of solutions allowing an object to remain available to the public and serving as an ambassador of history should be reassessed. ${ }^{2128}$

${ }^{2126}$ Messer, K., 1008, p. 19; Elmer, T., G., 2000; Hartung, H., 2005, p. 96. The case generally referred to and praised for having resulted in a settlement agreement including a commemorative plaque is the dispute between the heirs of Fritz and Louise Gutmann and the collector Daniel C. Searle concerning the ownership of the painting "Landscape with Smokestacks" by Degas. See for a short description of the case and the settlement above in chp. 2.\$1.I. The analysis above of the recommendations of the UK Spoliation Adivsory Panel showed that in two of the cases the Panel also recommended to leave the objects, her a painting and a piece of porcelain in the national or public collection where their future exhibition should be accompanied by a display commemorating the object's history and provenance during and since the Nazi era. Cf.: Spoliation Advisory Panel, 2001; Spoliation Advisory Panel, 2008.

2127 Messer, K., 1008, p. 19.

2128 At the point that we concluded this research the Terezin Declaration was adopted (30 June 2009). The Declaration devotes substantial attention to Holocaust education, remembrance and research, and to memorial sites, which will be the only physical witnesses to the Holocaust when the last survivors have died. See for the text of the Declaration: http://www.holocausteraassets.eu-files/20000021535d8ef1a36/Terezin_Declaration_Final.pdf. The Terezin Declaration will be shortly introduced and discussed in the epilogue. 


\section{Redrafting of the 1998 Washington Principles}

In the light of the foregoing and in order to stimulate public debate on what constitute just and fair solutions in cases of Nazi spoliated art we suggest a redrafting of the Washington Conference Principles on Nazi-Confiscated Art. ${ }^{2129}$ The reasons for opting for the 1998 Washington Principles rather than any other of the soft law instruments discussed in Chapter 2 are twofold: not only were the 1998 Washington Principles the first soft law instrument adopted with regard to Nazi spoliated art and marked the transition from the period in which awareness had been raised and information on the looting and the international and national restitution regimes had been gathered to a period in which the composition of public collections were actively challenged. ${ }^{2130}$ The 1998 Washington Principles also became the most prominent soft law instrument and have been recited almost as a mantra.

The redrafting of the 1998 Washington Principles a little bit more than a decade after their adoption should include at least the following changes: first, changing the title from 'Washington Conference Principles on Nazi-Confiscated Art' to 'General Principles on Nazi-Spoliated Art' therewith "codifying" present practice, which is not limited to cases dealing with art works confiscated by the Nazis but comprises also involuntary losses that must be considered as being precipitated by the Nazi Regime. ${ }^{2131}$ Secondly, the principles dealing with records and archives that may yield information on Nazi spoliated art works and also the resources and personnel that should be made available for researching the sources should refer to records and archives holding information on the post-war process of the restoration of rights. ${ }^{2132}$ Finally, the principles asking to arrive at just and fair solutions should call for an open-minded assessment of what constitutes a just and fair solution in a specific case, taking account

\footnotetext{
2129 The 1998 Washington Principles are discused in detail above in chp. 2.\$1.III.

2130 Of course, not only public collections were affected but also private collections. See, e.g. the case in which the heirs of Margarete Mauthner sought the return of a painting by Van Gogh from the collection of Elizabeht Taylor; the case Gerda Dorothea de Weerth vs Edith Marks Baldinger or the case of the heirs of Carlotta Landsberg vs Marilynn Alsdorf. See for a short summary of the cases and a list of further cases: Schnabel, G. / Tatzkow, M., 2007, part 2.

2131 Cf.: The Oxford English Dictionary. 2nd ed. 1989. OED Online. Oxford University Press: "spoliate, v." 2132 The relevant principles of the 1998 Washington Principles dealing with archival records and human resources to research the records are principles 2 and 3. They could be amended by the formulations in italics to include the reference to potential financial compensation payments received:

"2. Relevant records and archives, including those bolding information on the restoration of rights in the post-war years, should be open and accessible to researchers, in accordance with the guidelines of the International Council on Archives.

3. Resources and personnel should be made available to facilitate the identification of all art that had been confiscated by the Nazis and not subsequently restituted. Resources and personnel should also be made available to determine whether the loss of an object has been remedied by other means than physical restitution, including finacial compensation payments".
} 
of all facts and circumstances of a specific case, including past compensation payments received. 2133

\section{HUMAN REMAINS: OPEN DIALOGUE AND COMMON SENSE}

In contrast to the case of Nazi spoliated art works, no concrete recommendations can be given for the case of human remains on the basis of the current research. The practices and principles pursued in the various juridisdictions do not coincide and are vague in character themselves. The only conclusion that can be drawn on the basis of the present research is that open dialogue and common sense are the best advisors for public collections to deal with claims for the return of human remains. In dealing with claims, it is important to take claimants seriously and to be aware of the relevance of the whole process rather than only the final decision on whether or not human remains are returned. Ideally, claimants would be involved in defining the criteria on the basis of which the decision will be taken. This way the process would become a true dialogue and learning experience for both parties. The (re-) action of public collections should not be motivated by the fear of loosing a collection item but by the wish to learn more about the culture of the requesting party. While it is exaggerated to state that a claim for the return contributes to the safeguarding of intangible cultural heritage, as is pursued by the UNESCO Convention for the Safeguarding of the Intangible Cultural Heritage ${ }^{2134}$, an open dialogue with claimants will certainly contribute to better knowledge of burial ceremonies and funeral rituals. ${ }^{2135}$ The learning process does not have to be limited to the specific culture's attitude towards the dead but can go further in the form of future collaboration in research and exhibitions.

\section{III. "WALK THE TALK": LIVING UP TO RAISED EXPECTATIONS IN ENABLING RETURNS}

Squaring the findings of Chapters 3 and 4 dealing with the protection of cultural objects in public collections and the national solutions introduced in view of returning Nazi spoliated art and human remains, it becomes evident that there remains a gap

\footnotetext{
2133 The relevant principles of the 1998 Washington Principles dealing with just and fair solutions are principles 8 and 9 . They could be amended by the formulations in italics to include the reference to potential financial compensation payments received:

" 8 . If the pre-War owners of art that is found to have been confiscated by the Nazis and not subsequently restituted, or their heirs, can be identified, steps should be taken expeditiously to achieve a just and fair solution. In assessing what constitutes a just and fair solution in a specific case, an open-minded approach should be adopted, taking into account all facts and circumstances of a specific case, including past compensation payments received".

9. If the pre-War owners of art that is found to have been confiscated by the Nazis, or their heirs, can not be identified, steps should be taken expeditiously to achieve a just and fair solution. In assessing what constitutes a just and fair solution in a specific case, an open-minded approach should be adopted, taking into account all facts and circumstances of a specific case, including past compensation payments received".

2134 Convention for the Safeguarding of the Intangible Cultural Heritage, Paris, 17 November 2003, UNESCO Doc.MISC/2003/CLT/CH/14.

2135 See: http://www.unesco.org/culture/ich/index.php?pg=55 (last visited 15.12.2008).
} 
between the solutions introduced and the legal possibilities to realise the solutions. This finding is particularly true for the United Kingdom and France whose public collections are protected by a general ban on the disposal of objects. While the United Kingdom has provided for an exception enabling the return of human remains from the national collections by introducing s 47 of the 2004 Human Tissue Act, comparable legislation with regard to Nazi spoliated art is missing until today. As a consequence, recommendations of the Panel suggesting the return of cultural objects, cannot be implemented. All hopes are currently set on a Private Member's bill, which is due to have its $3^{\text {rd }}$ Reading when the present research was concluded. Should the 'Holocaust (Stolen Art) Restitution Bill' not be adopted, the UK Government is advised to take swift action to finally adopt legislation enabling the return of Nazi spoliated art in order to guarantee its integrity and that of the Panel.

As for France, the main point of recommendation concerns the de-classification procedure as introduced under the Law relating to French Museums from 2002. In the present context the procedure is especially relevant for the return of human remains from public collections designated as Musée de France. It is less relevant for Nazi spoliated art in that the works listed in the MNR inventory did not become the property of the holding museums. While the introduction of the de-classification procedure must be lauded in enabling returns of objects from the Musées de France, the analysis revealed that the procedure has not yet been put into practice. Consequently, France must work on the implementation of the de-classification procedure by defining the relevant criteria to effectively allow for the return of cultural objects. Furthermore, the French legislative should consider facilitating disposal in cases where objects have been acquired by donations or testamentary dispositions. While it is one thing not to discourage future donations a full ban on the disposal of such objects is disproportionate. A final recommendation with regard to the French situation concerns Nazi spoliated art works in French public collections that do not belong to the MNR-Collection. Current efforts focus either on the objects that have been officially recovered by France after the war and that now belong to the MNR-Collection or on those objects that were not recovered and are still missing. However, further to these two categories, it is conceivable that spoliated objects have unofficially entered the French public collections at some point after 1933. ${ }^{2136}$ After all, public awareness of the problem of Nazi spoliated art was raised only in the mid 1990s. This brings us back to the recommendation already made in view of the disposal of human remains, i.e. the need to make the declassification procedure under the $\mathrm{CHC}$ Act operative.

2136 Cf.: the situation of UK public collections. Cf.: also the scope of application of the Dutch liberalised return policy that applies not only to objects in the NK Collection but to objects in state-owned collections in general. 


\section{TAKE PROTECTION OF OBJECTS IN PUBLIC COLLECTIONS SERIOUSLY}

For the Netherlands, different recommendations apply. As a country characterised by a liberal regulation of its public collections, few problems exist with regard to the disposal of objects from public collections. To the contrary, while the UK and France must work on legislation enabling disposal, the Netherlands should consider strengthening the protection of its public collections. As has been analysed in Chapter 3 (\$2.I.1), the scope of application of the Cultural Heritage Preservation Act is limited to privately-owned cultural objects. As for objects in public collections, the CHP Act applies only in analogy. In the light of the Mondriaan case and increasing pressure on museums to act as cultural entrepreneurs, the Dutch legislator should consider extending the application of the Cultural Heritage Preservation Act to objects in public collections. ${ }^{2137}$ Inspiration could be drawn from the recent changes to the German Law for the Prevention of Export of Cultural Property. ${ }^{2138}$ Until the amendment brought about by the act implementing the 1970 UNESCO Convention in Germany ${ }^{2139}$, the law applied only to privately-owned objects. Since May 2007, the law has been extended to allow also for the listing of publicly-owned cultural objects. ${ }^{2140}$

Further to amending the CHP Act, a recommendation can be made concerning the work of advisory committees. This is a recommendation addressed to the museum sector rather than the legislature given the self-regulation of the Dutch museum sector. The analysis in Chapter 4. S2.I revealed that at present a number of advisory or ethics committees are active in the Dutch museum sector. The analysis furthermore revealed that the recommendations by these committees differ considerably and sometimes even oppose one another. Given the fact that the value of a recommendation of an advisory or ethics committee depends on its moral authority, conflicting recommendations by different committees are not desirable. Furthermore, the existence of more than one ethics committees diminishes the learning effect in that each committee will deal with lesser cases, thus having less opportunity to test and refine its recommendations. Consequently, the Dutch museum sector should consider merging the NMV Ethical

\footnotetext{
2137 Cf.: Vlies, I.C.v.d., et al., 2009, p. 86.

2138 Gesetz zum Schutz deutschen Kulturgutes gegen Abwanderung in der Fassung der Bekanntmachung vom 8 Juli 1999 (BGBl. I S. 1754). Another source of inspiration is the Flemish Topstukkendecreet (Decreet van 24 januari 2003 "houdende bescherming van het roerend cultureel erfgoed van uitzonderlijk belang“" (B.S. 14 maart 2003). According to Art. $5 \$ 1$ the decreet applies also to objects and collections owned by public authorities. Cf.: Draye, A.M., 2007, p. 390.

2139 Gesetz zur Ausführung des UNESCO-Übereinkommens vom 14. November 1970 über Maßnahmen zum Verbot und zur Verhütung der rechtswidrigen Einfuhr, Ausfuhr und Übereignung von Kulturgut (Ausführungsgesetz zum Kulturgutübereinkommen - KGÜAG) (BGBl. I S 757).

2140 \ 18 (2) of the Gesetz zum Schutz deutschen Kulturgutes gegen Abwanderung now reads: "Im öffentlichen Eigentum befindliches national wertvolles Kulturgut und Archivgut, auf das das Gesetz nach Absatz 1 keine Anwendung findet, kann von Amts wegen, auf Grund einer Anmeldung durch den jeweiligen Eigentümer oder auf Antrag der oder des Beauftragten der Bundesregierung für Kultur und Medien in das Verzeichnis national wertvollen Kulturgutes oder das Verzeichnis national wertvoller Archive eingetragen werden. Über die Eintragung entscheidet die oberste Landesbehörde nach diesem Gesetz".
} 
Code Committee and the SVCN Ethnological Ethics Committee into one ethics committee.

\section{§3. RELEVANCE FOR THE PROTECTION AND RETURN OF CULTURAL OBJECTS MORE IN GENERAL}

Having summarised the main findings of the research with regard to the return of Nazi spoliated art and human remains, we can now reflect on the relevance of the witnessed developments for cultural property in public collections more in general. Given the significant divide in protection, including restorative protection, between cultural objects removed during armed conflict and cultural objects removed during times of peace, we will concentrate on the latter as the lesser developed category. In particular, we will focus on the situation of objects that have been removed prior to the entry into force of the 1970 UNESCO Convention and the 1995 UNIDROIT Convention. This category includes also objects removed during the colonial era.

First of all, it can be concluded that the cases of Nazi spoliated art and human remains have not opened the "floodgates" leading to the return of all objects from public collections. It would be wrong to conclude that the return of a certain numbers of Nazi spoliated art works and human remains could result in the obligation to return all objects as is sometimes argued by museum directors or curators. However, the developments with regard to Nazi looted art and human remains do indicate a certain re-orientation with regard to the standards applied in deciding upon restitution by not focusing solely on the question in how far an acquisition might have been illegal, but by according relevance also to the question in how far the continued presence of an object in a museum is (still) appropriate.

Secondly, the findings of the present research indicate that the chances for the adoption of an internationally binding treaty providing for the return of cultural property acquired prior to the emergence of legally binding rules on the protection against the illicit trade are very small if not absent. In fact, the hesitation to create new legally enforceable rights could already be deducted from the difficult process of adopting and ratifying the 1970 UNESCO Convention and 1995 UNIDROIT Convention. However, the developments with regard to Nazi spoliated art and human remains poignantly confirm this point: neither the instruments adopted by the various international fora nor any of the solutions adopted at the national level introduced new legally binding rights for the return of Nazi spoliated art or human remains. Taking into account that both Nazi spoliated art and human remains are rather well delimited categories given their legal-historical circumstances (as for Nazi spoliated art) respectively their substance matter (as for human remains) the refusal to go down the legal path even in these cases suggests that the adoption of a legally binding treaty providing for the return of cultural property more in general is inconceivable. The subject matter is too complex and sensitive for the formulation of positive legal rules at the national or international level. The former colonial powers avoid sending out signals 
suggesting the illegality of their colonial past for fear of being exposed to blame by the international ocmmunity and eventually having to pay huge sums of compensation payments.

On the one hand, the implausibility of the introduction of clear-cut legal rules is deplorable in that positive legal rules provide for legal certainty. On the other hand, the role and function of positive legal rules must also not be overrated: the prognosis that no legally binding treaty will be adopted providing for the return of cultural objects removed prior to the entry into force of the 1970 UNESCO Convention and 1995 UNIDROIT Convent does not mean that no objects will be returned. After all, the analysis revealed that the fact that states are wary to create new legally enforceable rights does not mean that they necessarily oppose the return of cultural objects. With regard to Nazi spoliated art and human remains the analysis revealed that the two cases rely significantly on alternative solutions, such as the introduction of advisory committees, assistance in the production of evidence, as well as concessions with regard to the evidence required. Individually, the solutions might be insignificant. Taken together, these solutions, which have been introduced by soft law instruments, have contributed to a more return-friendly-climate. Consequently, a greater emphasis on the adoption of soft law instruments must not be dismissed as ineffective with regard to the return of cultural property from public collections more in general.

Finally, the impact of the cases of Nazi spoliated art and human remains with regard to new acquisitions and the ethics of collecting must be mentioned. While this aspect is less relevant for already existing collections, it is of crucial importance for the future protection of cultural property. The returns of Nazi spoliated art and human remains are clear signifiers that morality changes over time. While curators, private collectors and art dealers might presently accord little relevance to the question whether an object has been illegally excavated or exported, provenance is becoming of ever greater relevance. Provenance research is an important tool to prevent illicitly traded objects from entering public collection and may, over the long run, contribute to curtailing the illicit trade by limiting the demand of unprovenanced objects.

Current claims for the return of objects acquired in the past are powerful ambassadors of history and past injustices. If we follow the philosopher Walter Benjamin, the past is important in shaping the present and the future. According to Benjamin, it is memories of enslaved ancestors, not dreams of liberated grandchildren that drive men and women to revolt. ${ }^{2141}$ However, according to Benjamin, we should strive for an operative history, rather than a nostalgic one and direct our focus to the 'liberated grandchildren'. ${ }^{2142}$ If we apply Benjamin's philosophy to current claims for the

2141 Benjamin, W., 1980, XII (p. 700). Benjamin completed his text in spring 1940, shortly before his attempt to escape from Vichy France, where Jewish and Marxist German refugees were handed over by the government to the Gestapo. Benjamin's 'theses on the philosophy of history' were published by Max Horkheimer and Theodor W. Adorno in a mimeographed bookled entitled 'Walter Benjamin zum Gedächtnis'.

2142 Polsky, S., 2005, p. 80. 
return of cultural objects, we can perceive them as chances and challenges to recognise the past and shape the future. In standing up to this task we need to adopt an open mind and attitude of thinking not only along the lines of return in the strict sense but also in terms of loans and other forms of cooperation such as travelling exhibitions. 



\section{Epilogue}

The month of June 2009 was marked by two events that are important for the future course of the restitution debate: the recommendation issued by the UK Spoliation Advisory Panel in the Glaser case ${ }^{2143}$ and so-called Terezin Declaration on Holocaust Era Assets and Related Issues. While the recommendation and the declaration were issued too late to be integrated in the main body of research, we would nevertheless like to reflect at this point on their relevance for the future course of the restitution debate. While both events belong to the realm of Nazi looted art, they might be relevant for the future course of restitution more in general. In the following, we will first introduce the recommendation and the declaration before positioning them in the restitution debate.

\section{$\S 1$. The Spoliation Advisory Panel's recommandation on the Glaser CASE}

On 24 June 2009, the UK Spoliation Advisory Panel (hereinafter: "the Panel”) issued its recommendation on the Glaser case. The case concerned eight drawings from the former Glaser Collection, now in the possession of the Samuel Courtauld Trust. ${ }^{2144}$ The Glaser collection, including works by Munch, Beckmann and Corinth was set up by Professor Dr. Curt Glaser and his first wife Elsa, who deceased in July 1932. Glaser sold the bulk of the collection in two auction sales on 9 May and on 18 / 19 May 1933. The

\footnotetext{
2143 Spoliation Advisory Panel, 2009. The recommendation was published on 24 June 2009.

2144 The drawings comprise the following: an Architectural Sketch, attributed to Domenico Fossati, pen and ink, 21.8 x 24 cms; a Kitchen Still-Life, Domenico Piola, pen and ink and chalk, 18 x 28.9 cms; Saint Charles Borromeo, Giovanni Battista Crosato, pen and ink, watercolour and graphite, 21 x $17.4 \mathrm{cms}$; a Group of Figures with Bacchus, Giuseppe Bernardino Bison, pen and ink, watercolour and red chalk, 26.4 x $19.8 \mathrm{cms}$; the Flight into Egypt, Giuseppe Bernardino Bison, pen and ink and watercolour, 23.7 x $18.2 \mathrm{cms}$; Centaurs Embracing 1911, Lovis Corinth, graphite, 48.3 × 33.4 cms; Laundresses, Pierre Auguste Renoir, graphite and pen and ink, 31.4 x $22.5 \mathrm{cms}$; and The Lamentation, Italian School, 17th Century, black chalk, pen and ink and watercolour, $9 \mathrm{x} 12.7 \mathrm{cms}$.
} 
eight drawings that are the subject of the claim were acquired by Count Antoine Seilern. In 1978, the drawings were part of Seilern's bequest to the Home House Society, to which the Courtauld is the successor body.

Before discussing the merits of the claim and the recommendation by the Panel we need to give some more details on the circumstances in which Glaser sold part of his collection. The auctions were held at the 'Internationales Kunst - und Auctions-Haus G.m.b.H.' and at Max Perl Auction House. Both sales were advertised in advance and were accompanied by detailed catalogues including guide prices for each work. Based on Glaser's expertise, it is assumed that he himself compiled the catalogues. With regard to the guide prices mentioned in the catalogues and the prices ultimately fetched in the auction there exists evidence that the prices reflected the general market situation and were not depressed by circumstances attributable to the Nazi regime. ${ }^{2145}$

The auction date in May 1933 postdates the Nazi's rise to power on 30 January 1933 and Glaser's suspension from his position as Director of the State Art Library on 7 April 1933. The dismissal, which was confirmed in September 1933, was based on the Law for the Reestablishment of the Professional Civil Service. ${ }^{2146}$ The law had drastic impacts on the economic situation of the Jewish population in Germany. Glaser, who was Jewish by birth, had converted to Protestantism in 1914 but was nevertheless affected by the law. He did receive a pension equivalent to $75 \%$ of his final salary from January 1934 until at least November 1935. On 4 April 1933, three days before his dismissal as Director of the State Art Library, his apartment in the Prinz-Albert Strasse was seized by the Gestapo together with the other apartments in the building.

Shortly after the auction, on 30 May 1933, Glaser married his second wife Marie. In June or early July 1933 they left Germany for Switzerland, where they rented a house near Ascona. Glaser had 14 large crates, containing art objects, silver, porcelain, and carpets etc., shipped from Berlin to their new address. In addition, Glaser was able to transfer a number of valuable paintings from Germany to Switzerland, which had been on loan to the National Galerie. In May 1941, Glaser and his second wife emigrated to the United States and settled in New York, where Glaser died in 1943.

In the 1950 s and 1960s, Marie, who remarried Dr. Ernest Ash, submitted claims under German compensation laws for the loss of her first husband's job, and for the loss of his art collection. In October 1958, she was awarded 25,839.81 DM in damages for the loss in earnings and pension benefits. ${ }^{2147}$ In a settlement dated 6 December 1963 ,

\footnotetext{
2145 The evidence is based on a letter and annotated catalogue by the art historian Ludwig Burchard. Burchard, who was a friend both of Glaser and Seilern, who acquired the drawings concerned, wrote in a letter to Seilern dated 14 May that the prices at the first auction had been "correctly established". His annotations in the catalogue indicate that there were no significant deviations between the guide prices and the prices ultimately fetched in the auction.

2146 Gesetz zur Wiederherstellung des Berufsbeamtentums vom 7 April 1933. See further on laws providing for the removal of Jews from other profession, e.g.: Edelheit, A.J. / Edelheit, H., 1994.

2147 In 1959, the exchange rate dollar - deutschmark (DM) was $1 \$=4,18$ DM. See further: Bidwell, R.L., 1970, pp. 22-24.
} 
Marie agreed to a fee of 7,100 DM for the monetary loss realized from the auction sales. ${ }^{2148}$ Both she and her sister-in-law Elly Glaser had testified to the German authorities that the results of the 1933 auction had been far below market price.

Marie died on 9 August 1981. The claimants seeking the return of the drawings from the Courtauld are relatives of Marie via her surviving and her deceased sister and descendants of her second husband.

In its recommendation the Panel acts on the assumption that the Courtauld has proper legal title to the drawings and focuses on the question whether the moral strength of the claimants' case prompts the return of the drawings. In analyzing this question, the Panel takes the following aspects into account: whether the sale in 1933 must be considered as forced sale, whether the prices realized in the auctions were negatively affected by the Nazi oppression, the fact that compensation had been awarded to Glaser's second wife in the 1950s and 1960s and the conduct of the Courtauld in acquiring the drawings in the 1970 s.

The Panel concludes that while Glaser's decision to sell the bulk of his collection and to leave Germany was based on mixed motives, including the wish to make a fresh start, free from the attachments of his old life, the predominant reason for the sale of the drawings was the Nazi persecution. The Panel subsequently balances the finding that the sale qualifies as a forced sale with other relevant circumstances. With regard to the prices fetched in auction, the Panel reaches the conclusion that the prices were reasonable market prices at the time being and were not negatively affected by the Nazi oppression. Furthermore, the Panel emphasises the fact that Glaser's second wife had been awarded compensation after the war by the German authorities for the loss of the art collection. Squaring the findings of a forced sale on the one hand with the findings concerning the prices fetched in auction and the compensation awarded, the Panel reached the conclusion that the moral claim is insufficiently strong to warrant the transfer of the drawings: "[ $t$ ]ransfer of the drawings would therefore confer on the claimants double recompense". 2149

As final consideration, the Panel reflected upon the conduct of Seilern, who acquired the drawings at the auction in 1933, and the conduct of the Courtauld when accepting Seilern's bequest in 1978. For both parties, the Panel did not see any grounds for criticism. Consequently, the conduct of Seilern and the Courtauld does not change the Panel's finding that the moral claim of the claimants is insufficiently strong to warrant the transfer of the drawings. This does not take away that the Panel recommended that whenever any of the drawings is on show, the Courtauld should display alongside it a brief account of its history and provenance during and since the Nazi era, with special reference to the claimants' relationship with and historical interest in the drawings.

\footnotetext{
2148 In 1963, the exchange rate dollar - deutschmark (DM) was $1 \$=3.97$ DM. See further: Ibid. 2149 Spoliation Advisory Panel, 2009, para. 43.
} 


\section{$\S 2$. The Terezin Declaration on Holocaust era assets and Related ISSUES}

Within a week after the recommendation by the UK Panel on the Glaser case had been published, the Terezin Declaration on Holocaust Era Assets and Related Issues (hereinafter: "the Terezin Declaration") was adopted. The Terezin Declaration was the result of the Holocaust Era Assets Conference, which was convened in Prague on June 26-30 2009 by the Government of the Czech Republic, in cooperation with a number of organisations. $^{2150}$ The conference was attended by representatives of almost fifty countries, as well as representatives from interest groups, cultural institutions and practitioners working in the field of restitution. The conference was set up as a followup to the 1998 Washington Conference on Holocaust Era Assets. ${ }^{2151}$ Different from the Washington Conference, it did not focus solely on the recovery of looted art and objects of cultural, historical and religious value, but addressed the restitution and financial compensation schemes for Jewish and other victims of the Nazi reign more in general. In further introducing the Terezin Declaration, we will focus on the declaration in as far as it is relevant for the return of cultural objects.

The Terezin Declaration recognises the tangible achievements of the 1998 Washington Conference, in particular the progress that has been made in research, identification, and restitution of cultural property by governmental and nongovernmental institutions in some states since the 1998 Washington Conference and affirms the need to strengthen and sustain the efforts in order to ensure just and fair solutions regarding cultural property, including Judaica that was looted or displaced during or as a result of the Holocaust (Shoah). ${ }^{2152}$ The Terezin Declaration reaffirms the signatory states' support for the 1998 Washington Principles and encourages states, public and private institutions and individuals to apply them. More in particular, the Terezin Declaration stresses the importance of continued and intensified systematic provenance research, the need to establish mechanisms to assist claimants and to facilitate just and fair solutions with regard to Nazi spoliated art in the form of alternative dispute resolution. ${ }^{2153}$ It does not stipulate any concrete measures.

If one compares the Terezin Declaration with the achievements of the 1998 Washington Principles and the other principles, declarations and resolutions adopted in the last decade it becomes evident that the declaration does not have any (additional) normative value: similar to the instruments discussed above in Chapter 2.\$1.III, the

\footnotetext{
2150 The Documentation Centre of Property Transfers of Cultural Assets of WW II Victims, the Federation of Jewish Communities in the Czech Republic, the Jewish Museum in Prague, the Terezín Memorial, the Institute of Jewish Studies at the Hussite Theological Faculty of the Charles University in Prague and the Forum 2000 Foundation.

2151 The Washington Conference and the Washington Principles that resulted from the conference are discussed in detail in chp. 2.\$1.III.1.

2152 Terezin Declaration, para. 3.

${ }^{2153}$ Terezin Declaration, section 'Nazi-Confiscated and Looted Art'.
} 
Terezin Declaration does not create any legally enforceable rights. To the contrary, in its preamble, the Terezin Declaration explicitly recognises its legally non-binding nature and the supremacy of international law and obligations. As a typical soft law instrument, the Terezin Declaration may - at the utmost - denote "values, guidelines, ideas and proposals that may develop into rules of international law but have not yet done so" 2154 and may add further urgency and legitimacy for government action. ${ }^{2155}$

In as far as the (alternative) solutions proposed by the Terezin Declaration are concerned; the most relevant question in the light of the present research is whether the declaration touches upon the issue of financial compensation payments that might have been received by the original owners or their heirs during the direct post-war era. Having analysed the instruments adopted by different fora since the mid-1990s on the return of Nazi spoliated art, as well as national policies, the present research indicates that the issue of financial compensation payments possibly received by (the heirs of) the former owner during the post WWII period is not yet integrated in the restitution debate. Consequently, one of the recommendations of this research is to re-open the debate on just and fair solutions for cases dealing with cultural objects spoliated during the Third Reich. More in particular, it is suggested to add greater weight to the reflection upon the relevance of past compensation payments. While it could be argued that "just and fair solutions" demand the physical return of an object regardless of any compensation payments received, this cannot be presumed but must be discussed. One possibility to trigger such a public debate is the re-drafting of the 1998 Washington Principles as the most prominent soft-law instrument adopted in reaction to Nazi spoliated art. While the Terezin Declaration is construed as a follow up to the Washington Conference, its relevance is limited to reinforcing the 1998 Washington Principles. It does not reflect upon the relevance of past financial compensation payments received nor does it deepen the debate on the return of spoliated cultural objects in any other regard. The Terezin Declaration is limited to reiterating the need to facilitate the production of evidence and to arrive at just and fair solutions in the form of alternative dispute resolution mechanisms. ${ }^{2156} \mathrm{In}$ as far as the return of Nazi spoliated art is concerned, the Terezin Declaration's relevance and expected impact is thus limited. One could state that the declaration "codifies" the present state and awareness of the restitution discourse but does not further it in any respect.

\section{$\S 3$. DiRECTIONS FOR THE FUTURE}

While I hope of course that the present research will contribute to deepening and furthering the debate, in particular in view of the past compensation payments received, it might be more realistic to count on the aftermath of the Glaser case. As introduced

\footnotetext{
2154 Cf.: Dixon, M., 2007, p. 50.

2155 Cf. above in chp. 2. $\$ 3$ on the status and relevance of soft law. See also: Renold, M.-A., 2009, p. 62. 2156 Cf.: chp. 2.\$1.III.3.II.2.
} 
above, in deciding upon the claim for the return of works of art from the Glaser collection, the UK Spoliation Advisory Panel balanced the finding that the loss of the paintings was (predominantly) a forced sale with the facts that the prices fetched in auction were not unreasonably low and that Glaser's second wife had been awarded compensation after the war by the German authorities for the loss of the art collection. The Glaser case consequently constitutes the first case in which compensation payments were accorded a significant role in the decision making process of the Spoliation Advisory Panel. While the case is not the first case ever to accord such relevance to compensation payments ${ }^{2157}$ it is prominent enough to trigger the debate. ${ }^{2158}$ This is even more the case given the reaction of the Glaser claimants to the Panel's recommendation:

The Glaser claimants criticised the recommendation and asked the Panel to reconsider it. ${ }^{2159}$ When the Panel informed the heirs that it saw no reason to review its recommendation ${ }^{2160}$ the claimants wrote to UK culture secretary Barbara Follett, to ask her to reject the recommendation of the Panel. ${ }^{2161}$ The Glaser case is thus not only the first case in which the Panel accorded a significant role to compensation payments received but also marks the first time that a recommendation of the Panel has not been accepted by one of the parties.

It will be interesting to see how the media, the general public and academic debate will react to the Glaser case and the aspect of financial compensation payments. The debate on the return and restitution of cultural objects is standing at the crossroads. In Chapter 2. \$1. IV we concluded that the absence of any discussion on this point must be noted as lamentable and not contributing to the transparency and legitimacy of the current practices. While the outcome of such discussion might still be physical restitution is the only just and fair solution given the atrocities of the Nazi-era, in spite of any financial compensations received, it is nevertheless crucial to have this discussion for a fuller comprehension of the subject matter and the legitimacy of solutions pursued. Finally, the explicit recognition of physical restitution as the only just and fair solution

\footnotetext{
2157 See in this respect also the decision-making framework of the Commission pour l'indemnisation des victimes de spoliations intervenues du fait des législations antisémites en vigueur pendant l'Occupation' (CIVS) discussed in chp. 4.\$1.III.3. CIVS checks whether the claims submitted have not already been the subject of compensation by France under the 1946 Act on War Damage or under the German Federal Restitution Law (BRüG).

${ }^{2158}$ See, e.g. the speech by Olaf S. Ossmann at the recent Terezin Conference titled 'One Collection, One Persecution, One Deseizin - but Different ideas of "Just and Fair Solutions": Hurdles in Different National Processes for Heirs of Art Collections' where he refers to the decision of the Panel in the Glaser case as "tragic and (...) wrong and misleaing decision".

2159 Letter dated 8 July 2009. Available online at: http://www.commartrecovery.org/docs/ltr-07-08-09SAP.pdf .

${ }^{2160}$ Letter dated 23 July 2009. Available online at:

http://www.commartrecovery.org/docs/DCMSDE1.PDF .

${ }^{2161}$ Bailey, M., 26 August 20092009.

http://www.theartnewspaper.com/articles/Glaser\%20heirs\%20reject $\% 20$ UK $\% 20$ spoliation $\% 20$ ruling/186 93
} 
regardless of any compensation payments received will have an impact on the discourse on the return of cultural property more in general. 



\section{Bibliography}

Aalders, G., Roof. De ontvreemding van Joods bezit tijdens de Tweede Wereldoorlog, (Den Haag) (1999).

Aalders, G., Berooid: De beroofde joden en het Nederlandse restitutiebeleid sinds 1945, (Amsterdam, Boom) (2001).

Aarts, B., Een lijk in de kast? Teruggave van menselijke resten in de collecties van volkenkundige musea (Afstudeerscriptie Reinwardt Academie), (Amsterdam) (2000).

Abramson, R. / Huttler, S., The legal response to the illicit movement of cultural property, (1973), Law and policy in international business, 932-970.

Abtahi, H., The Protection of Cultural Property in Times of Armed Conflict: The Practice of the International Criminal Tribunal for the Former Yugoslavia, (2001), The Harvard Human Rights Journal, 1-32.

Afrasiabi, P.R., Property Rights in Ancient Human Skeletal Remains, (1997), Southern California law review, 805-840.

Akinsha, K. / Grigorii, K., The Soviet War Treasures: A Growing Controversy, (1991a), ARTnews, 112-119.

Akinsha, K. / Grigorii, K., Spoils of War: The Soviet Union's Hidden Art Treasures, (1991b), ARTnews, 130-141.

Albers, J., Poems and Drawings, (London, Tate Publishing) (2006).

Alda, K., Reversing Course on Restitution - Regional museums in the Czech Republic are resisting court orders to return looted paintings, (2006), ART News, 74.

Amiel, O., A Maori Head: Public Domain?, (2008), International Journal of Cultural Property, 371-375.

Andorno, R., The Invaluable Role of Soft Law in the Development of Universal Norms in Bioethics, presentation at a Workshop jointly organized by the German Ministry of Foreign Affairs and the German UNESCO Commission, Berlin, 15 February 2007, (2007).

Angenendt, A., Heilige und Reliquien: die Geschichte ihres Kultes vom frühen Christentum bis zur Gegenwart, (München, C.H. Beck) (1994).

Anglade, L., Art, Law and the Holocaust: the French Situation, (1999), Art, Antiquity and Law, 301-311.

Anglade, L., A special Jurisdiction: France and the Mattéoli Mission, in: Palmer, N. (Ed.) Museums and the Holocaust: Law, Principles and Practice, (Leicester, Institute of Art and Law) (2000), 150-157.

Anzilotti, D., Cours de droit international, (Paris, Sirey) (1929).

Arnold, D., Indian artifacts: where do they rightfully belong?, The Boston Globe, 2 April 1990, 27-28.

Ashcroft, B., et al. (Eds.), Post-Colonial Studies: The Key Concepts, (London, Routledge) (2003).

Asser, C. / Perrick, S., Mr. C. Asser's handleiding tot de beoefening van het Nederlands burgerlijk recht = Asser serie, (Deventer, Kluwer) (2002).

Aubry, C.M.B.A., et al., Droit civil français: Biens, actions possessoires, propriété, (Paris, Librairies Techniques) (1961). 
Aufderheide, A.C. / Rodriguez-Martin, C. (Eds.), The Cambridge Encyclopedia of Human Paleopathology, (Cambridge, University Press) (1998).

Aust, A., Handbook of International Law, (Cambridge, University Press) (2005).

Awekotuku, N.T., He Maimai Aroha: A Disgusting Traffic for Collectors: the colonial trade in preserved human heads in Aotearoa, New Zealand, in: Kiendl, A. (Ed.) Obsession, Compulsion, Collection: on objects, display culture and interpretation, (Banff, Banff International Curatorial Institute) (2004), 77-91.

Baan, E. / Valk, W.L., Artikel 258 (6.5.3.11), in: Hondius, E.H. (Ed.) Verbintenissenrecht (Groene Losbladige Serie), (Deventer, Kluwer) (2008).

Baer, M., Eine Kopfjagd: Deutsche in Ostafrika, Spuren kolonialer Herrschaft, (Berlin, Ch. Links Verlag) (2001).

Baikie, G., What Do Labrador Inuit want?, (1993), Inuit Art Quarterly, 8-13.

Bailey, M., Giving back the loot: Nazi-era claims against UK Museums, (2005), Apollo: a journal of the arts, 5663.

Bailey, M., Glaser heirs reject UK spoliation ruling - Claimed drawings will remain at the Courtauld in London, The Art Newspaper, 26 August 2009

Barkan, E., The Guilt of Nations: Restitution and Negotiating Historical Injustices, (Baltimore and London, The John Hopkins University Press) (2000).

Barker, I., The Protection of Cultural Heritage Items in New Zealand, in: Hoffmann, B.T. (Ed.) Art and Cultural Heritage: Law, Policy and Practice, (Cambridge, University Press) (2006), 145-147.

Barron, S., "Degenerate Art": The Fate of the Avant-Garde in Nazi Germany, (Los Angeles, Los Angeles County Museum of Art) (1991).

Barr-Smith, A., United Kingdom: National Report on Topic 1. Freedom of museums to sell, trade or otherwise dispose of objects of art in their collections, in: Briat, M. / Freedberg, J., A. (Eds.), International Sales of Works of Art: International Art Trade and Law, (Deventer, Boston, Kluwer) (1991), 147-152.

Bator, P.M., The International Trade in Art, (Chicago, University of Chicago Press) (1993).

Bazyler, M., Crimes against Humanity, in: Charny, I.W. (Ed.) Encyclopedia of genocide, (ABC-CLIO) (1999), 153-154.

Bazyler, M., Nuremberg in America: Litigating the Holocaust in United States Courts, (2001), University of Richmond Law Review, 1-284.

Becher, K., On the obligation of subjects of international law to return cultural property to its permanent place, (1974), Annuaire de l'Association des Anciens Auditeurs de l'Acadëmie de La Haye, 96-99.

Becker, A., Das Museum: Sein Raum in der Zeit und die Zeit seines Raumes, in: Wunderkammer des Abendlandes. Museum und Sammlung im Spiegel der Zeit, (Bonn, Kunst- und Austellungshalle der Bundesrepublik Deutschland GmbH) (1994), 16-21.

Beekhuis, C.H., De eerbiediging van de wens dat het stoffelijk overschot wordt verbrand (slot), (1955), Nederlands Juristenblad, 853-864.

Bekvalac, J., et al., Scientific Research on Archaeological Human Remains in the United Kingdom: Current Trends and Future Possibilities, in: Lohman, J. / Goodnow, K. (Eds.), Human Remains and Museum Practice, (UNESCO) (2006), 111-116.

Bel, M., et al., Case Note: Administrative Tribunal of Rouen, Decision NO. 702737, December 27, 2007 (Maori Head case), (2008), International Journal of Cultural Property, 223-226.

Bell, C., Aboriginal Claims to Cultural Property in Canada: A Comparative Examination of the Repatriation Debate, (1992/1993), American Indian Law Review, 457-521. 
Benjamin, W., Über den Begriff der Geschichte, in Gesammelte Schriften I-2. Ed. Rolf Tiedemann \& Hermann Schweppenhäuser, (Frankfurt am Main, Suhrkamp) (1980), 691-704.

Bennett, B., Dead bodies on display: El Negro in cross-cultural perspective, (2002), Pula: Botswana Journal of African Studies (Special Issue: 'El Negro and the Hottentot Venus: Issues of Repatriation'), 813.

Benoit-Rohmer, F. / Klebes, H., Council of Europe law - Towards a pan-European legal area, (Strasbourg) (2005).

Bentwich, N., International Aspects of Restitution and Compensation for Victims of Nazis, (1955-56), British Yearbook of International Law, 204-217.

Berber, F., Lehrbuch des Völkerrechts (I), (München, C.H. Beck) (1975).

Berenbaum, M. / Kramer, A., The world must know: the history of the Holocaust as told in the United States Holocaust Memorial Museum, (Baltimore, Md /London, Johns Hopkins University Press) (2006).

Berezowski, C., Ochrona prawnomiedzynarodowa zabytkow i dziel sztuki w czasie wojny (International Legal Protection of Historic Monuments and Works of Art during War), (Warsaw) (1948).

Berg, J.W., et al., Informed consent: legal theory and clinical practice, (Oxford, University Press) (2001).

Berndt, J., Internationaler Kulturgüterschutz, (Köln, Carl Heymanns Verlag KG) (1998).

Bettenhaussen, P., Eerlijk omgaan met restitutieverzoeken, (2000), Museumvisie, II-VI.

Bevers, A.M. / Halbertsma, M.E., Behouden is kiezen: over het verzamelen, selecteren en wijzigen van museale collecties: verslag van een onderzoek naar de opvattingen en ervaringen van museumdeskundigen, (1991).

Bibas, S., The Case against Statutes of Limitations for Stolen Art, (1996), International Journal of Cultural Property, 73-110.

Bidwell, R.L., Currency Conversion Tables: A Hundred Years of Change, (London, Rex Collings) (1970).

Bila, J., Nationaler Kulturgüterschutz in der Europäischen Union, (Bonn, University Bonn) (1997).

Birov, V.A., Prize or Plunder?: The Pillage of Works of Art and the International Law of War, (1998), New York University Journal of International Law and Politics, 201-249.

Bleckmann, A., Decolonization, in: Bindschedler, R.L. (Ed.) Encyclopedia of public international law: Part: 10: States, responsibility of states, international law and municipal law, (Amsterdam, NorthHolland) (1987), 75-79.

Blom, J., Laying Claim to Long-Lost Art: The Hoge Raad of the Netherlands and the Question of Limitation Periods, (2000), International Journal of Cultural Property, 138-150.

Blume Huttenlauch, A., Street Scenes and other Scenes from Berlin - Legal Issues in the Restitution of Art after the Third Reich, (2006), German Law Journal.

Bluntschli, J., Das moderne Völkerrecht der civilisirten Staaten, (Nördlingen) (1878).

Boekel, J.v. / Groot, G.d., '... en daarom moet je lichaam vervallen, als de ziel het verlaat': Tentoonstelling: Botje bij Botje, (1998/1999), Arctica: Bulletin van Arctic Peoples Alert, 1, 7-9.

Boekel, J.v. / Groot, G.d., Ik heet geen IJsbrand: '... en daarom moet je lichaam vervallen, als de ziel het verlaat', (1999), Arctica: Bulletin van Arctic Peoples Alert, 21-25.

Boele-Woelki, K., et al., Dutch Private International Law at the End of the 20th Century: Pluralism of Methods, in: Netherlands Reports to the Fifteenth International Congress of Comparative Law, (Bristol / Antwerpen / Groningen) (2004), 203-227.

Boer, J.d., Mr. C. Asser's Handleiding tot de Beoefening van het Nederlands Burgerlijk Recht. Personen- en Familierecht, (Deventer, Kluwer) (2006). 
Boguslavsky, M., M, Der Begriff des Kulturguts und seine rechtliche Relevanz, in: Dolzer, R., et al. (Eds.), Rechtsfragen des internationalen Kulturgüterschutzes, (Heidelberg, C.F. Müller) (1994), 3-12.

Boll, J., M., 'Compositie met twee lijnen' ofwel 'het eigen-aardige karakter van het eigendomsrecht van overheidslichamen op kunstvoorwerpen' en de 'Wet Cultuurbezit', (1989), R.M. Themis, 125-134.

Bollen, C.J.M. / de Groot, G.R., Verknoeit het Europese recht ons Burgerlijk Wetboek?, (1995), Nederlands Tijdschrift voor Burgerlijk Recht, 1-9.

Borg, L.t. / Rottenberg, H., Mr. B. J. Asscher: 'Ik kon Donner niet overtuigen', (2006), Vrij Nederland.

Borries, R.v. / Zacker, C. (Eds.), Europarecht von A-Z. Das Recht der Europäischen Union nach dem Vertrag von Nizza, (München, dtv) (2002).

Bos, D., et al. (Eds.), Harmonie in Holland: het poldermodel van 1500 tot nu, (Amsterdam, Bert Bakker) (2007).

Bossuyt, M.J.M. / Wouters, J., Grondlijnen van internationaal recht, (Antwerpen, Intersentia) (2005).

Boström, H.-O., Philipp Hainhofer and Gustavus Adolphus' Kunstschrank in Uppsala, in: Impey, O. / MacGregor, A. (Eds.), The Origins of Museums: The Cabinet of Curiosities in sixteenth- and seventeenth-century Europe, (London, House of Stratus) (2001), 121-136.

Bostyn, S., J.R., The legal protection of biological material / La protection juridique du matériel biologique, in: Hondius, E.H. (Ed.) Netherlands Reports to the Fifteenth International Congress of Comparative Law, (Antwerpen / Groningen, Intersentia Rechtswetenschappen) (1998).

Bothe, M., Legal and Non-Legal Norms - A Meaningful. Distinction in International Relations?, (1980), Netherlands Yearbook of International Law, 65-95.

Bottom, W.P., Essence of Conflict: Cognitive Illusions, War Guilt, and the Origins of Appeasement. IACM 17th Annual Conference Paper. Available at SSRN: http://ssrn.com/abstract $=602007$.

Boulet-Sautel, M., De Choppin à Proudhon: Naissance de la notion moderne de domaine public, (1995), Droit, 91-102.

Bourlet, M., Le statut juridique des MNR, in: Fohr, R. / de La Broise, G. (Eds.), Pillages et restitutions: le destin des Oeuvres d'art sorties de France pendant la Seconde Guerre Mondiale: actes du colloque organisé par la Direction des musées de France le 17 novembre 1996 à l'amphithéatre Rohan de l'école du Louvre sous la présidence de Françoise Cachin, directeur des musées de France, (Paris, Direction des musées de France / Adam Biro) (1997), 107-115.

Boylan, P.J., Review of the Convention for the Protection of Cultural Property in the Event of Armed Conflict: the Hague Convention of 1954, (1993), available at: http://unesdoc.unesco.org/images/0010/001001/100159eo.pdf.

Braillard, P., Switzerland and the Crisis of the Dormant Assets and Nazi Gold, (London and New York, Kegan Paul International) (2000).

Bredekamp, J., The Politics of Human Remains: The Case of Sarah Bartmann, in: Lohman, J. / Goodnow, K. (Eds.), Human Remains and Museum Practice, (UNESCO) (2006), 25-32.

A Brief History of the Creation by UNESCO of an Intergovernmental Committee for Promoting the Return of Cultural Property to its Countries of Origin or its Restitution in Case of Illicit Appropriation, (1979), Museum (special issue on the "Return and Restitution of Cultural Property").

Bristol Royal Infirmary Inquiry, Interim Report: Removal and Retention of Human Material (May 2000), available at: http://www.bristolinquiry.org.uk/interim_report/report.htm.

Bristow, M., Human Remains in Museums Today: A Symposium, (2008), Art Antiquity \& Law, 207-223.

British Broadcasting Corporation (BBC), How art made the world, (2006).

Brouwer, D., Verslag over den toestand van het West-Friesch Museum te Hoorn, (Hoorn) (1890). 
Brouwer, D., Catalogus van het West-Friesch Museum, (Hoorn) (1891).

Brown, M.F., Who owns native culture?, (Cambridge, Harvard University Press) (2003).

Brown, M.F. / Bruchac, M.M., NAGPRA from the Middle Distance. Legal Puzzles and Unintended Consequences, in: Merryman, J.H. (Ed.) Imperialism, art and restitution, (2006), 193-217.

Brownlie, I., System of the Law of Nations: State Responsibility, Part I, (Oxford) (1983).

Brownlie, I., Principles of Public International Law, (Oxford, University Press) (2003).

Brownlie, I., Principles of Public International Law, (Oxford, University Press) (2008).

Brunner, C.J.H., Dief wordt eigenaar, in: Quod Licet, Bundel aangeboden aan Prof. mr. W.M. Kleijn ter gelegenheid van zijn afscheid als hooglerraar burgerlijk recht e notarieel recht aan de Rijksuniversiteit te Leiden, (Deventer) (1992), 45-53.

Bulmer, S., Archaeology and indigenous rights: The World Archaeological Congress' code of ethics form an archaeologist's point of view, (1991), Archaeology in New Zealand, 55-58.

Buomberger, T., Raubkunst / Kunstraub. Die Schweiz und der Handel mit gestohlenen Kulturgütern zur Zeit des Zweiten Weltkriegs, (Zürich, Orell Füssli) (1998).

Burchardi, K., Der deutsch-russische Streit um die kriegsbedingt verlagerten Kulturgüter, (Baden-Baden, Nomos) (2000).

Burton, J.W., Representing Africa: Colonial Anthropology Revisited, (1992), Journal of Asian and African Studies, 181-201.

Calhoun, A., De-accessioning: Why not?, (1985), Agmanz, 14-15.

Campen, J.v., De Haagse jurist Jean Theodore Royer (1737-1807) en zijn verzameling Chinese voorwerpen, (Hilversum, Verloren) (2000).

Campfens, E., et al., Recht auf Umwegen: die niederländische Restitutionskommission, in: Osteuropa - 56. Jahrgangsheft, (2006), 415-432.

Carducci, G., La restitution internationale des biens culturels et des objets d'art. Droit commun, Directive CEE, Convention de l'UNESCO et d'UNIDROIT, (Paris, LGDJ) (1997).

Carrier, D., Museum skepticism, (Durham, Duke University Press) (2006).

Cassese, A., International Law, (Oxford, University Press) (2005).

CB, Aan MT (Management Team). Betreft voorstel antwoord aan Te Papa en als aanhangsel de verschillende overwegingen die hieraan ten grondslag liggen.

Chamberlain, K., Repatriation of Human Remains and the Human Rights Act, in: United Kingdom Working Group on Human Remains (Ed.) Report of the Working Group on Human Remains, (2003), 205-235.

Chamberlin, R., Loot! The Heritage of Plunder, (London, Thames and Hudson Ltd.) (1983).

Chandler, D.G., The timechart of military history, (Edison, N.J, Chartwell Books) (2003).

Chase-Riboud, B., Hottentot Venus: A novel, (Doubleday) (2003).

Chatelain, F., France: Rapport national sur le sujet 1. Liberté des musées de procéder à des transactions d'objets d'art, in: Briat, M. / Freedberg, J., A. (Eds.), International Sales of Works of Art: International Art Trade and Law, (Deventer, Boston, Kluwer) (1991), 109-112.

Chatelain, F., et al., Oeuvres d'art et objets de collection en droit français, (Nancy, Berger-Levrault) (1997).

Chatelain, J. / Chatelain, F., Oeuvres d'art et objets de collection en droit français, (Paris, Berger-Levrault) (1990).

Chernela, J., M., Draft Declaration on the Rights of Indigenous Peoples, in: Leonard, T.M. (Ed.) Encyclopedia of the Developing World, (Routledge) (2006), 487-488. 
Chesnoff, R.Z., Pack of Thieves: How Hitler and Europe Plundered the Jews and Committed the Greatest Theft in History, (UK, Weidenfeld and Nicholson) (2000).

Chief Medical Officer, Report of a Census of Organs and Tissues Retained by Pathology Services in England, January 2001, available online at:

http://www.dh.gov.uk/en/Publicationsandstatistics/Publications/PublicationsStatistics/DH_40 06720 .

Chirac, J., Allocution prononcée lors des cérémonies commémorant la grande rafle des 16 et 17 juillet 1942 (17 Juillet), (1995).

Choi, S., The Legal Landscape of the International Art Market After Republic of Austria v. Altmann, (2005), Nortbwestern Journal of International Law \& Business, 167-199.

Clay, L.D., Entscheidung in Deutschland, (Frankfurt am Main, Verlag der Frankfurter Hefte) (1950).

Coalitie blijft bij besluit over teruggeven mummie, (2000), Dagblad van West-Friesland.

Codd, E.F., A Relational Model of Data for Large Shared Data Banks, (1970), Communications of the ACM, $377-387$.

Cohan, A., An Examination of Archaeological Ethics and the Repatriation Movement Respecting Cultural Property (Part Two), (2004), Environs: Environmental Law and Policy Journal, 4-115.

Committee on Legal Affairs and the Internal Market, Report on a legal framework for free movement within the internal market of goods whose ownership is likely to be contested (2002/2114(INI)) Rapporteur: Willy C.E.H. De Clercq, (2003), available at: http://www.europarl.europa.eu/omk/sipade3?SAME_LEVEL=1\&LEVEL=3\&NAV=X\&DET $\mathrm{AIL}=\& \mathrm{PUBREF}=-/ / \mathrm{EP} / / \mathrm{TEXT}+\mathrm{REPORT}+\mathrm{A} 5-2003-0408+0+\mathrm{DOC}+\mathrm{XML}+\mathrm{V} 0 / / \mathrm{EN}$.

Concern over 'Hottentot Venus' of 1810: Griquas want to bury the remains of Khoi woman displayed in France as a freak, The Star, 13 December 1995, 11.

The Concise Oxford English Dictionary, (Oxford University Press) (2004).

Cook, B., The Elgin Marbles, (London, British Museum Paperbacks) (1984).

Copping, J., National galleries to hand back Nazi art - Artworks looted by the Nazis during the Second World War and now held in Britain's national museums and galleries are to be handed back to their owners, Telegraph, 18 October 2008.

Cornu, M., Le droit culturel des biens - L'intérêt culturel juridiquement protégé, (Brussels, Bruylant) (1996).

Cornu, M., The Impact of Uniform Laws on the Protection of Cultural Heritage and the Preservation of Cultural Heritage in the 21st Century - Country Report on France prepared for the Session on 15 November, 2008 on the Protection of Cultural Objects at the Congress of the International Academy of Comparative Law Mexico City 13.-15.11.2008) (publication by Martinus Nijhoff Publishers pending), (2008).

Cornu, M. / Mallet-Poujol, N., Droit, oeuvres d'art et musées: protection et valorisation des collections, (Paris) (2001).

Cornu, M. / Mallet-Poujol, N., Droit, oeuvres d'art et musées: Protection et valorisation des collections, (Paris, CNRS) (2006).

Country Reports of the conference "Spoils of War and Restitutions. The Destiny of French Works of Art During the Second World War", Paris, 17 November 1996, available at: http://www.dhh3.de/biblio/bremen/sow3/crfrance.htm.

Craig, P. / De Búrca, G., EU Law. Text, Cases, and Materials, (Oxford, Oxford University Press) (2008).

Craufurd Smith, R., Community Intervention in the Cultural Field: Continuity or Change?, in: Craufurd Smith, R. (Ed.) Culture and European Union law, (Oxford, Oxford University Press) (2004), 1978. 
Crawford, J., The International Law Commission's Articles on State Responsibility, (Cambridge) (2002).

Cuvier, G., Extrait d'observations faites sur le cadavre d'une femme connue à Paris et à Londres sous le nom de Vénus Hottentotte, in: Mémoires du Musée d'histoire naturelle, (1817), 259-274.

Cuvier, Georges, Baron (2005). In Encyclopædia Britannica. Retrieved October 18, 2005, from Encyclopædia Britannica Online, available at: http://www.search.eb.com/eb/article-9028345.

Daniel, G., Editorial, (1982), Antiquity, 1-7.

David, R., The International Unification of Private Law, (1971), International Encyclopedia of Comparative Law.

Davie, L., Living History: Sarah Baartman, at rest at last, (2002), available at: http://www.southafrica.info/about/history/saartjie.htm.

Davies, P., The Return of Treasures to Indigenous Peoples, (2004), Art Antiquity \& Law, 78-98.

De Bastier, M., Re: questions en concernant le service de CIVS à propos de la restitution / l'indemnification des objets d'arts. Email dated 23 June 2009 on file with the author.

"de-accession, v." The Oxford English Dictionary, 2nd ed. 1989, OED Online, Oxford University Press, 29 June 2009.

Deacon, H.J. / Deacon, J., Human Beginnings in South Africa: Uncovering the Secrets of the Stone Age, (Altamira Press) (1999).

Debbasch, C., et al., Droit administratif des biens, (Paris, Presses Universitaires de France) (1994).

Delingpole, J., What are museums for?, Times Online, March 172006.

Depta, S., L., Twice saved or Twice Stolen?: The Trophy Art Tug-of-War between Russia and Germany, (1996), Temple International and Comparative Law Journal, 371-194.

Desch, T., The Second Protocol to the 1954 Hague Convention for the Protection of Cultural Property in the event of armed conflict, (1999).

Destruction of cultural property report (Annex XI) to the Final report of the United Nations Commission of Experts established pursuant to Security Council Resolution 780 (1992) S/1994/674/Add.2 (Vol. V), (1994), available at: http://www.ess.uwe.ac.uk/comexpert/XI.htm.

Detling, K.J., Eternal Silence: the Destruction of Cultural Property in Yugoslavia, (1993), The Maryland Journal of International Law \& Trade, 41-75.

Deutscher Bundestag (Ausschuss für Kultur und Medien), Wortprotokoll der Öffentliche Anhörung von Sachverständigen bezügl. der Anwendung der Grundsätze der Washingtoner Erklärung in Deutschland und im internationalen Vergleich. Anhörung zu Erfahrungen im Bereich der Restitution von NS-verfolgungsbedingt entzogenen Kulturgütern und der Provenienzforschung (Protokoll Nr. 16/31), (2007), available at: http://www.bundestag.de/ausschuesse/a22/anhoerungen/raubkunst/a22_Prot31.pdf.

Dixon, M., Textbook on international law, (Oxford, Oxford University Press) (2007).

Doehring, K., War die Universität Heidelberg verpflichtet die Bibliotheca Palatina dem Vatikan zurückzugeben?, (1987), Ruperto Carola, 138-142.

Dölle, H. / Zweigert, K., Gesetz Nr. 52: über Sperre und Beaufsichtigung von Vermögen: Kommentar, (Stuttgart) (1947).

Donders, Y.M., Towards a Right to Cultural Identity?, (Antwerpen, Intersentia) (2002).

Doumas, C., Archaeological Ethics and the Treatment of the Dead, (1990), World Archaeological Bulletin, 2122.

Dousset, L., Introduction to Australian Indigenous Social Organisation: transforming concepts, (2002), available at: http://www.ausanthrop.net/research/kinship/kinship2.php. 
Draye, A.M., De Bescherming van het Roerend en Onroerend Erfgoed. Wet-, Decreet- en Regelgeving van kracht binnen het Vlaamse Gewest / de Vlaamse Gemeenschap, (Brussel, De Boeck \& Larcier) (2007).

Dufau, J., Le domaine public, (Paris, Le moniteur) (1993).

Dunné, J.M.v., Narrative coherence and its function in judicial decision making and legislation, (1996), American Journal of Comparative Law, 463-486.

Dutch return Ghana chief's severed head, (2009), available at: http://www.nrc.nl/international/Features/article2309332.ece/Dutch_return_Ghana_chiefs_seve red_head.

Duuren, D.v., et al., Physical anthropology reconsidered. Human remains at the Tropenmuseum, (Amsterdam, KIT Publishers) (2007).

Edelheit, A.J. / Edelheit, H., Legislation, Anti-Jewish, in: History of the Holocaust: A Handbook and Dictionary, (Boulder, Westview Press) (1994), 299-331.

Edelson, S., Concerted international effort in the trade of cultural property, (1984), Law and policy in international business, 1249-1273.

Effert, R.A.H.D., Volkenkundig Verzamelen. Het Koninklijk Kabinet van Zeldzaamheden en het Rijks Ethnographisch Museum 1816-1883, (2003).

Effert, R.A.H.D., Onderzoek mbt Toi Moko ter bepaling van de tijd waarin dit voorwerp bij het Koninklijk Kabinet van Zeldzaamheden terecht is gekomen (unpublished document dated 21 October 2005. On file at the archive of the RMV.), (2005).

Effert, R.A.H.D., Royal Cabinets and Auxiliary Branches. Origins of the National Museum of Ethnology 1816-1883, (Leiden, CNWS Publications) (2008).

Eirinberg, K.W., The United States Reconsiders the 1954 Hague Convention, (1994), International Journal of Cultural Property, 27-35.

Eizenstat, S.E., Imperfect Justice: Looted Assets, Slave Labor and the Unfinished Business of World War II, (New York, PublicAffairs) (2003).

El-Bitar, J., Der deutsche und der französische Kulturgüterschutz nach der Umsetzung der Kulturgüterrückgaberichtlinie. Eine materiellrechtliche und kollisionsrechtliche Untersuchung, (Frankfurt am Main, Peter Lang) (2006).

El-Bitar, J., Der Schutz von Kulturgut als res extra commercium in Frankreich: Ein Vorbild für Deutschland?, in: Koordinierungstelle für Kulturgutverluste (Ed.) Im Labyrinth des Rechts? Wege zum Kulturgüterschutz, (Magdeburg, Koordinierungstelle für Kulturgutverluste) (2007), 175-207.

Elmer, T., G., A Question of Dignity: An Equitable Solution to the Trophy Art Debate, (2000), New York Law School Journal of International and Comparative Law, 117-135.

Engelsman, S., Letter by Steven Engelsman to State Secretary of Culture Van Leeuwen re: "Maori-hoofd 360-555763", 7 May 2003.

Engelsman, S., Letter to State Secretary of Culture Van Leeuwen, 23 October.

Engelsman, S., Email to Catherine Nesus requesting information about the Karanga Aotearoa Repatriation Programme and availability of the Toi Moko for serious research, (Leiden) (2004a).

Engelsman, S., Letter to Mrs. Catherine Nesus - Repatriation Project Leader of the Te Papa, (Leiden) (2004b).

Engelsman, S., Letter to Mrs. Catherine Nesus - Repatriation Project Leader of the Te Papa.

Engelsman, S., Letter to the Dutch State Secretary of Culture Van der Laan 11 August 2005, (2005). 
Engstler, L., Die territoriale Bindung von Kulturgütern im Rahmen des Völkerrechts, (Cologne, Heymann) (1964).

Ermacora, F., Colonies and Colonial Regime, in: Bindschedler, R.L. (Ed.) Encyclopedia of public international law: Part: 10: States, responsibility of states, international law and municipal law, (Amsterdam, North-Holland) (1987), 40-45.

European Commission, I.M.D., Guide to the concept and practical application of articles 28-30 EC, (2001), available at:

http://ec.europa.eu/enterprise/regulation/goods/docs/art2830/guideart2830_en.pdf.

Falconer, K.A., When Honor will not suffice: The need for a legally binding international agreement regarding ownership of nazi-looted art, (2000), University of Pennsylvania Journal of International Economic Law, 383-426.

Falke, O.v., Die Majolikasammlung Alfred Pringsheim, augmented reprint with articles by Tjark Hausman, Carmen Ravanelli-Guidotti and Timothy Wilson, (Ferrara) (1994).

Farmer, W.I., The Safekeepers: A Memoir of the Arts at the End of World War II, (Berlin and New York, Walter de Gruyter) (2000).

Fawkes, H., Netherlands hails return of stolen art, BBCnews, 20 April 2004, available at: http://news.bbc.co.uk/1/hi/entertainment/3640951.stm.

Fechner, F.G., The fundamental aims of cultural property law, (1998), International Journal of Cultural Property, 376-394.

Feliciano, H., Le musée disparu: enquête sur le pillage des oeuvres d'art en France par les nazis, (Paris) (1995).

Feliciano, H., The Lost Museum: the Nazi Conspiracy to Steal the World's Greatest Works of Art, (New York, Basic Books) (1997).

Ferencz, B.B., Less than slaves: Jewish forced labor and the quest for compensation, (Bloomington, Indiana University Press in association with the United States Holocaust Museum) (2002).

Ferguson, G., Signs and Symbols in Christian Art, (New York, Oxford University Press) (1954).

Ferid, M. / Sonnenberger, H.J., Das französische Zivilrecht, Bd. 2 Schuldrecht, Sachenrecht, (Heidelberg) (1986).

Ferris, N. / Leclair, L., The Authority of the Missing One Tenth: Issues of Archaeological Artifact Ownership, (Brantford, OAS Annual Meetings) (1998).

Ferrus, D., De thuiskomst van Sara Baartman, (2004), Armada: tijdschrift voor wereldliteratuur, 27-32.

Fiedler, W., State Succession, in: Bindschedler, R.L. (Ed.) Encyclopedia of public international law: Part: 10: States, responsibility of states, international law and municipal law, (Amsterdam, North-Holland) (1987), 446-456.

Fiedler, W., Zur Entwicklung des Völkergewohnheitsrechts im Bereich des internationalen

Kulturgüterschutzes, in: Hailbronner, K., et al. (Eds.), Staat und Völkerrechtsordnung: Festschrift für Karl Doehring, (Berlin, Springer) (1989), 199-218.

Fiedler, W., Kulturgüter als Kriegsbeute? Rechtliche Probleme der Rückführung deutscher Kulturgüter aus Rußland, (Heidelberg, C.F. Müller Verlag) (1995).

Fiedler, W., Zwischen Kriegsbeute und internationaler Verantwortung - Kulturgüter im Internationalen Recht der Gegenwart. Plädoyer für eine zeitgemäße Praxis des Internationalen Rechts, in: Reichelt, G. (Ed.) Neues Recht zum Schutz von Kulturgut. Internationaler Kulturgüterschutz: EG- Richtlinie, UNIDROIT-Konvention und Folgerecht, (Wien, Manzsche Verlags- und Universitätsbuchhandlung) (1997), 147-160. 
Fisher, D., Tribes get a victory in Kennewick Man battle but U.S. ruling may clear way for anthropologists' lawsuit seeking to study the skeleton, (2000), Seattle Post-Intelligencer.

Fitzmaurice, G., The future of public international law and the international legal system in the circumstances of today, in: Livre du Centenaire de l'Institut de Droit International 1873-1973, (Institut de Droit International) (1973), 196-238.

Flessas, T., The Repatriation Debate and the Discourse of the Commons, (2007), LSE Law, Society and Economy Working Papers 10/2007.

Flood, M., A., "Kennewick Man" or "Ancient One"? - A matter of interpretation, (2002), Montana Law Review, 39-90.

Forder, C., The Bredius Museum Case: Public Interest and Private International Law, (1993), International Journal of Cultural Property, 117-125.

Forder, C., Legislation: The Museums and Galleries Act 1992, (1994), International Journal of Cultural Property, 131-158.

Foreign \& Commonwealth Office (Ed.), Nazi Gold - The London Conference, 2-4 December 1997, (London, The Stationary Office) (1998).

Francioni, F., Diversity or Cacophony?: New Sources of Norms in International Law Symposium: Beyond State Sovereignty: The Protection of Cultural Heritage as a shared Interest of Humanity, (2004), Michigan Journal of International Law, 1209-1228.

Francioni, F., Culture, Heritage and Human Rights: an Introduction, in: Francioni, F. / Scheinin, M. (Eds.), Cultural Human Rights, (Leiden / Boston, Martinus Nijhoff) (2008), 1-15.

Francioni, F. / Scheinin, M., Cultural Human Rights, (Leiden / Boston, Martinus Nijhoff) (2008).

Fraoua, R., Le trafic illicite des biens culturels et leur restitution: analyse des réglementations nationales et internationales: critique et propositions, (Fribourg, Editions Universitaire Fribourg Suisse) (1985).

Frazer, J.G., The Golden Bough - A Study in Magic and Religion, (London, MacMillan) (1890).

Freeman, A.V., Responsibility of States for Unlawful Acts of their Armed Forces, (1955), Recueil des Cours vol. 88 Part 2, 263-416.

Freytag, C., "Cultural Heritage": Rückgabeansprüche von Ursprungsländern auf "ihr" Kulturgut?, in: Fechner, F.G., et al. (Eds.), Prinzipien des Kulturgüterschutzes. Ansätze im deutschen, europäischen, und internationalen Recht, (Berlin) (1996), 175-200.

Friedlander, S., Probing the Limits of Representation: Nazism and the "Final Solution", (Cambridge, Mass., Harvard University Press) (1992).

Friedmann, E. / Weissberb, R., The French Holocaust Era Claims Process, in: Bazyler, M. / Alford, R., P. (Eds.), Holocaust Restitution: Perspectives on the Litigation and Its Legacy, (New York / London, New York University Press) (2006), 133-144.

Frier, P.-L., Droit du patrimoine culturel, (Paris, PUF) (1997).

Frigo, M., Looted art and public international law: General principles and international conventions, in: Renold, M.-A. / Gabus, P. (Eds.), Claims for the Restitution of Looted Art, (Geneva, Schulthess) (2004), 47-70.

Frigo, M., The International Symposium "From anatomic Collections to Objects of Worship: Conservation and Exhibition of Human Remains in Museums", Paris, February 22-23, 2008, (2008), International Journal of Cultural Property, 437-439.

Fuhrmann, M. (Ed.), Die Reden gegen Verres = In C. Verrem: lateinisch-deutsch / Marcus Tullius Cicero, (Darmstadt, Wissenschaftliche Buchgesellschaft) (1995). 
Ganslmayr, H., Wem gehört die Benin-Maske? Die Forderung nach Rückgabe von Kulturgut an die Ursprungsländer, (1980), Vereinte Nationen: Zeitschrift für die Vereinten Nationen und ibre Sonderorganisationen, 88-92.

Garner, B., A. (Ed.), Black's Law Dictionary, (St. Paul, West Group) (1999).

Garner, B., A. (Ed.), Black's Law Dictionary, (St. Paul, Thomsson West) (2004).

Garner, J., International Law and the World War I (Vol. 2), (London) (1920).

Garrett, R.L., Time for a Change? Restoring Nazi-Looted artwork to its rightful Owners, (2000), Pace International Law Review, 367-395.

Gattini, A., Restitution by Russia of Works of Art Removed from German Territory at the End of the Second World War, (1996), European Journal of International Law, 1-88.

Geluwe, H.v., Belgium's contribution to the Zairian cultural heritage, (1979), Museum (special issue on the "Return and Restitution of Cultural Property"), 32-37.

Geoffroy, Étienne-François (2005). In Encyclopædia Britannica. Retrieved October 18, 2005, from Encyclopædia Britannica Online, available at: http://www.search.eb.com/eb/article-9036458.

German East Africa (2008). In Encyclopædia Britannica. Retrieved May 15, 2008, from Encyclopædia Britannica Online, available at: http://www.search.eb.com/eb/article-9036569.

German restitution for National Socialist crimes, in: Foreign \& Commonwealth Office (Ed.) Nazi Gold The London Conference, 2-4 December 1997, (London, The Stationary Office) (1998), 286-292.

Germans Can't Return Sultan Makaua's Head; Say African Trophy Was Retaken Years Ago, The New York Times, 10 September 1920, available at:

http://query.nytimes.com/gst/abstract.html?res=9A04E0D61E3CEE3ABC4952DFBF66838B6 39EDE.

Germany. (2008). In Encyclopædia Britannica. Retrieved June 24, 2008, from Encyclopædia Britannica Online, available at: http://www.britannica.com/eb/article-58214.

Gerstenblith, P., Ownership and Protection of Heritage: Cultural Property Rights for the 21st Century: The Public Interest in the Restitution of Cultural Objects, (2001), Connecticut Journal of International Law.

Gerstenblith, P., United States v. Schultz, (2002), Culture Without Context.

Gerstenblith, P., The McClain/Schultz doctrine: another step against trade in stolen antiquities, (2003), Culture Without Context.

Gevers, J.K.M., Beschikken over cellen en weefsels, (Deventer, Kluwer) (1990).

Gheyn, C.v.d., Les tribulations de l'agneau mystique, (1945), Revue belge d'archéologie et d'bistoire de l'art, 25-46.

Giblin, J.C., The Riddle of the Rosetta Stone. Key to Ancient Egypt, (New York) (1992).

Gioia, A., The development of international law relating to the protection of cultural property in the event of armed conflict: the second protocol to the 1954 Hague Convention, (2003).

Giovannini, T., The Holocaust and Looted Art, (2002), Art Antiquity \& Law, 263-280.

Gollin, R. / Schoonenboom, M., Lakmoesproef voor Ruimhartigheid - Juridisch steekspel in de zaak Goudstikker, de Volkskrant, 9 February 2006, 2-3.

Gordon, R., The life and times of Sara Baartman: The Hottentot Venus, (2000), The American anthropologist, 605-607.

Goschler, C., et al., Raub und Restitution: "Arisierung" und Rückerstattung des jüdischen Eigentums in Europa, (Frankfurt am Main, Fischer) (2003).

Gould, C., Trophy of Conquest, in: Merryman, J.H. (Ed.) Law, Ethics and the Visual Arts, (Alphen aan den Rijn, Kluwer) (2007), 4-6. 
Gould, S.J., The Flamingo's Smile: Reflections in Natural History, (London) (1987).

Goy, R., Le retour et la restitution des biens culturels à leur pays d'origine en cas d'appropriation illégale, (1979), Revue Générale de Droit International Public, 962-985.

Graham, G.M., Protection and Reversion of Cultural Property: Issues of Definition and Justification, (1987), The international lawyer, 755-793.

Greenfield, J., The Return of Cultural Treasures, (Cambridge, Cambridge University Press) (1989).

Greenfield, J., The Return of Cultural Treasures, (Cambridge, Cambridge University Press) (1996).

Greenfield, J., The Return of Cultural Treasures, (Cambridge, Cambridge University Press) (2007).

Griqua (2005). In Encyclopædia Britannica. Retrieved December 14, 2005, from Encyclopædia Britannica Online, available at: http://www.search.eb.com/eb/article-9038148.

Grotius, H., De jure belli ac pacis (German translation from 1950), (Tübingen) (1625).

Guinnane, T.W., Financial Vergangenheitsbewaeltigung: The 1953 London Debt Agreement, (2004), Yale University Economic Growth Center Discussion Paper No. 880 (Available at SSRN: http://ssrn.com/abstract=493802).

Guzman, A.T., The Design of International Agreements, (2005), European Journal of International Law, 579612.

Haanappel, P.P.C. / MacKaay, E., Nieuw Nederlands Burgerlijk Wetboek: het vermogensrecht (zakenrecht, verbintenissenrecht en bijzondere overeenkomsten) / New Netherlands Civil Code: patrimonial law (property, obligations and special contracts), (Deventer, Kluwer) (1990).

Hagens, G.v., Gruselleichen, Gestaltplastinate und Bestattungszwang, in: Hagens, G.v. (Ed.) Körperwelten. Die Faszination des Echten, (Heidelberg) (1999a), 40-84.

Hagens, G.v., Körperwelten. Die Faszination des Echten, (Heidelberg) (1999b).

Hall, A.R., The Recovery of Cultural Objects dispersed during World War II, (1951), Department State Bulletin, 337-345.

Hammer, F., Die geschichtliche Entwicklung des Denkmalrechts in Deutschland, (Tübingen, J.C.B. Mohr (Paul Siebeck)) (1995).

Harclerode, P. / Brendan, P., The Lost Masters: The Looting of Europe's Treasure Houses, (London, Victor Gollancz) (1999).

Hardcastle, R., Law and the human body: property rights, ownership and control, (Oxford, Hart) (2007).

Harting, P., Het eiland Urk, zijn bodem, voortbrengselen en bewoners, (Utrecht) (1853).

Hartkamp, A.S., Wijziging en opheffing van bij erfstelling of legaat gemaakte bedingen: van Museumwet tot Nieuw BW, in: Gerver, P.H.M. (Ed.) Ars notariatus, 90, (Amsterdam / Deventer, Stichting tot Bevordering der Notariele Wetenschap / Kluwer) (1999), 15-27.

Hartung, H., Kunstraub in Krieg und Verfolgung: die Restitution der Beute- und Raubkunst im Kollisionsund Völkerrecht, (Berlin, De Gruyter Recht) (2005).

Hattenhauer, H. / Bernert, G., Allgemeines Landrecht für die Preussischen Staaten von 1794: Textausgabe, (Frankfurt am Main, Alfred Metzner) (1970).

Hedjaz. (2008). In Encyclopædia Britannica. Retrieved June 12, 2008, from Encyclopædia Britannica Online, available at: http://www.britannica.com/EBchecked/topic/259797/Hejaz.

Hedrick, L., Xenophon's Cyrus the Great: the arts of leadership and war, (New York, St. Martin's) (2006).

Henckaerts, J.-M. / Comité international de la Croix-Rouge, Customary international humanitarian law, (Cambridge, Cambridge University Press) (2005). 
Henry, M., 55 years later, restitution is an art - Germany is in a unique position to provide data which would facilitate claims for Nazi-looted artworks, The Jerusalem Post, 8 September 2007.

Herman, D., "I do not attach great significance to it": Taking note of "The Holocaust" in English Case Law, (2008), Social and Legal Studies, 427-452.

Hershkovitch, C., Offene Rechnungen: die Restitution von Kunstwerken in Frankreich, in: Osteuropa - 56. Jahrgangsheft, (2006), 441-446.

Herten, J.H.S.v., De rechtspositie van lichaam, lijk, stoffelijke resten, organen en niet-menselijke implantaten, (1984), Weekblad voor Privaatrecht, Notaris-ambt en Registratie, 155-164.

Hervé, B., A quoi sert le domaine public mobilier, L'exemple des biens culturels, (1993), AJDA, 675.

Hesselink, M.W., De redelijkheid en billijkheid in het Europese privaatrecht, (Deventer, Kluwer) (1999).

Heuer, C.-H., Die Kunstraubzüge der Nationalsozialisten und ihre Rückabwicklung, (1999), Neue Juristische Wochenscbrift (NJW), 2558-2264.

Heyting, L., Schilderij Toorop blijft in Zeeland, NRC Handelsblad, 29 May 2000, 9.

Hilberg, R., The destruction of the European Jews, (New York, Holmes \& Meier) (1985).

Hillgenberg, H., A Fresh Look at Soft law, (2004), European Journal of International Law, 499-515.

Hipp, A., Schutz von Kulturgütern in Deutschland, (Berlin, de Gruyter) (2000).

Hirsch, M. / Majer, D. (Eds.), Recht, Verwaltung und Justiz im Nationalsozialismus: ausgewählte Schriften, Gesetze und Gerichtsentscheidungen von 1933 bis 1945 mit ausführlichen Erläuterungen und Kommentierungen, (Baden-Baden, Nomos Verlagsgesellschaft) (1997).

Hladík, J., Diplomatic Conference on the Second Protocol to the Hague Convention for the Protection of Cultural Property in the Event of Armed Conflict, The Hague, Netherlands (March 15-26), (1999).

Hladík, J., The control system under the Hague Convention for the Protection of Cultural Property in the Event of Armed Conflict 1954 and its Second Protocol, (2004).

Hoffmann, G., Protectorates, in: Bindschedler, R.L. (Ed.) Encyclopedia of public international law: Part: 10: States, responsibility of states, international law and municipal law, (Amsterdam, North-Holland) (1987), 336-339.

Hollander, B., The international law of art: for lawyers, collectors and artists, (London, Bowes \& Bowes) (1959).

Hollander, P.d., De zaak Goudstikker, (Amsterdam, Meulenhoff) (1988).

Homo heidelbergensis (2009). In Encyclopædia Britannica. Retrieved April 1, 2009, from Encyclopædia Britannica Online, available at: http://www.search.eb.com/eb/article-9040898.

Hubert, J., Dry Bones or Living Ancestors? Conflicting Perceptions of Life, Death and the Universe, (1992), International Journal of Cultural Property, 105-127.

Hudson, M.O. (Ed.), International Legislation. A Collection of the Texts of Multipartite International Instruments of General Interest, (Washington) (1972).

Huijgen, W.G., Compendium erfrecht, (Deventer, Kluwer) (2005).

ICOM Code of Ethics for Museums (as approved by the 21st General Assembly of ICOM in Seoul, Republic of Korea, 8 October 2004), International Journal of Cultural Property, 393-408.

'IJsbrand' nu op bordje Groenland, Noordhollands Dagblad, 23 September 2000.

Impey, O. / MacGregor, A., The Origins of Museums: The Cabinet of Curiosities in sixteenth- and seventeenth-century Europe, (London, House of Stratus) (2001). 
Information Brochure: Commission for the Compensation of Victims of Spoliation Resulting from the Anti-Semitic Legislation in Force during the Occupation (CIVS).

Institute of Forensic Medicine, Report on the Examination of Human Remains of an alleged Greenlandic Inuk housed at Hoorn Musuem, Hoorn, Holland, (2001).

Instituut Collectie Nederland, Netherlands guidelines for deaccessioning of museum objects, (2006).

International Law Association (ILA), Statement of Principles Applicable to the Formation of General Customary International Law, (2000), International Law Association Report of the Sixty-Ninth Conference.

International Law Commission, Responsibility of States for Internationally Wrongful Acts, (2001), Yearbook of the International Law Commission, 20-143.

Ipsen, K., Völkerrecht, (München, C.H. Beck) (2004).

Israel, F.L., et al., Major peace treaties of modern history 1648-1967, (New York, Chelsea House Publishers etc. \& McGraw-Hill) (1967).

Jansen, J.E., Reactie op "Dief wordt vaak geen eigenaar" van mr. A.C. van Schaik, (2005), WPNR (6639), 801-803.

Jayme, E., Die Washingtoner Erklärung über Nazi-Enteignungen von Kunstwerken der Holocaustopfer: Narrative Normen im Kunstrecht, in: Häder, U. (Ed.) Museen im Zwielicht: Ankaufpolitik 19331945 (Kolloquium vom 11. und 12. Dezember 2001 in Köln.) Die eigene Geschichte: Provenienzforschung an deutschen Kunstmuseen im internationalen Vergleich (Tagung vom 20. bis 22. Februar 2002 in Hamburg), (Koordinierungsstelle für Kulturgutverluste Magdeburg) (2002), 247-257.

Jellinek, G., Allgemeine Staatslehre, (Berlin, O. Häring) (1914).

Jennings, R.Y., The Judiciary, International and National, and the Development of International Law, (1996), International Comparative Law Quarterly, 1-12.

Jenschke, C., Der völkerrechtliche Rückgabeanspruch auf in Kriegszeiten widerrechtlich verbrachte Kulturgüter, (Berlin, Duncker\&Humblot) (2005).

Jessup, P.C.J., General Report: Topic 1: Freedom of Museums to sell, trade or otherwise dispose of objects of art in their collections, in: Briat, M. / Freedberg, J., A. (Eds.), International Sales of Works of Art: International Art Trade and Law, (Deventer, Boston, Kluwer) (1991), 67-72.

Joffe, J., Reviewed work(s): West German Reparations to Israel by Nicholas Balabkins, (1977), The American Political Science Review, 1274-1275.

Johansen, B.E., Kennewick Man: the Facts, the Fantasies, and the Stakes, in: Johansen, B.E. (Ed.) Enduring legacies: native American treaties and contemporary controversies, (Westport, Praeger) (2004), 283-303.

Jote, K., International Legal Protection of Cultural Heritage, (Stockholm, Juristförlaget) (1994).

Joyce, R., Cultural Treasures and Slippery Slopes, available at: http://www.uk.digiserve.com/mentor/marbles/ethics.htm.

Kaam, A.v., Hoofd van Maori gaat terug, Leidsch Dagblad, 9 November 2005.

Kabwe cranium. (2008). In Encyclopædia Britannica. Retrieved December 9, 2008, from Encyclopædia Britannica Online, available at: http://www.search.eb.com/eb/article-9044260.

Kalfon, L., Entschädigung in Frankreich: Lucien Kalfon über die Tätigkei der französischen Entschädigungskommission, in: Osteuropa - 56. Jahrgangsheft, (2006), 433-440.

Karasik, M., Problems of Compensation and Restitution in Germany and Austria, (1951), Law and Contemporary Problems, 448-468. 
Kass, L.R., Thinking about the Body, (1985), The Hastings Center Report, 20-30.

Kastenberg, J., E., The Legal Regime for Protecting Cultural Property During Armed Conflict, (1997), The Air Force Law Review, 277-303.

Kaye, L., M., Cultural Property Theft during War: Application of the Statute of Limitations, in: Briat, M., \& Freedberg, Judith, A. (Ed.) Legal Aspects of International Trade in Art, (The Hague, Kluwer) (1996a), 217-230.

Kaye, L., M., The Future of the Past: Recovering Cultural Property, (1996b), Cardozo Journal of International Law \& Comparative Law, 23-41.

Kaye, L., M., Laws in Force at the Dawn of World War II: International Conventions and National Laws, in: Simpson, E. (Ed.) The Spoils of War - World War II and Its Aftermath: the Loss, Reappearance, and Recovery of Cultural Property, (New York, Harry N. Abrams) (1997), 100105.

Keane, D., The Failure to Protect Cultural Property in Wartime, (2004), DePaul Journal of Art and Entertainment Law, 1-38.

Kelly, M., A Skeleton in the Legal Closet: The Discovery of "Kennewick Man" Crystallises the Debate Over Federal Law Governing Disposal of Ancient Human Remains, (1999), Hawaii Law Review, 41-72.

Kelsen, Principles of International Law, (New York, Holt, Rinehart \& Winston) (1967).

Kemenade, J.A.v., Deel I van het rapport “Roof en Restitutie Joods Vermogen”, uitgebracht aan de Contactgroep Tegoeden Wereldoorlog II, (1999a), available at: http://www.minfin.nl/binaries/minfin/assets/pdf/dossiers/diversen/tegoeden-woii/0_roof-enrestitutie-joods-vermogen--deel-i.pdf.

Kemenade, J.A.v., Deel II van het rapport "Roof en Restitutie Joods Vermogen", uitgebracht aan de Contactgroep Tegoeden Wereldoorlog II, (1999b), available at: http://www.minfin.nl/binaries/minfin/assets/pdf/dossiers/diversen/tegoeden-woii/roof-enrestitutie-joods-vermogen--deel-ii-.pdf.

Kempster, N., Tracking the Nazi Plunder, (1998), L.A. Times, F1.

Kennon, H., Take a picture, it may last longer if Guggenheim becomes the law of the land: the repatriation of fine art, (1996), St. Thomas law review, 373-422.

Kirby, C.L., Stolen Cultural Property; Available Museum Responses to an international Dilemma, (2000), Dickinson Law Review, 729-748.

Kline, T., R., Legal Issues relating to the recovery of the Quedlinburg Treasures, in: Simpson, E. (Ed.) The Spoils of War. World War II and its Aftermath: The Loss, Reappearance, and recovery of Cultural Property, (New York, Harry N Abrams) (1997), 156-158.

Klomp, R.J.Q., Dieven met geduld. Over verkrijgende verjaring te kwader trouw, in: Brand, I., et al. (Eds.), Tijd en onzekerkeid. BW-krant jaarboek 16, (Deventer, Gouda Quint) (2000), 59-74.

Koenigs, C.F., Under Duress: The Sale of the Franz Koenigs Collection, in: Simpson, E. (Ed.) The Spoils of War. World War II and its Aftermath: The Loss, Reappearance, and recovery of Cultural Property, (New York, Harry N. Abrams) (1997), 237-240.

Kogelfranz, S. / Korte, W., A., Quedlinburg-Texas und zurück. Schwarzhandel mit geraubter Kunst, (München, Droemersche Verlagsanstalt Th. Knaur Nachf.) (1996).

Kohn, M., "Colonialism", The Stanford Encyclopedia of Philosophy (Summer 2006 Edition), Edward N. Zalta (ed.), (2006), available at: http://plato.stanford.edu/archives/sum2006/entries/colonialism/.

Kolkman, W.D. (Ed.), Erfrecht: de tekst van Boek 4 van het Burgerlijk Wetboek en aanverwante wetten voorzien van commentaar, (Deventer, Kluwer) (2006). 
König, H., The Implementation of the Washington Principles - Some Legal Aspects, available at: http://www.badv.bund.de/002_menue_oben/007_english/004_provenance/index.html.

König, H., Grundlagen der Rückerstattung. Das deutsche Wiedergutmachungsrecht, in: Osteuropa (Ed.) Kunst im Konflikt. Kriegsfolgen und Kooperationsfelder in Europa [Art in conflict], (2006), 371 381.

Körbs, H., Der internationale Schutz von Kulturgütern: Ein Rückblick, (1996), Humanitäres Völkerrecbt, 138148.

Kortmann, C.A.J.M., Boekbeschouwing J.M.E. Derks, De Grondwet en delegatie. Het delegatievraagstuk inconstitutioneel perspectief, (1996), RM Themis, 344-345.

Kortmann, S.C.J.J., et al., Vertegenwoordiging en tussenpersonen, (Deventer, W.E.J. Tjeenk Willink) (1999).

Kowalski, W.W., Introduction to the International Law on the Restitution of Works of Art Looted During armed Conflicts. Part I, (1996a), Spoils of War, 1-2.

Kowalski, W.W., Introduction to the International Law on the Restitution of Works of Art Looted during Armed Conflicts. Part II, (1996b), Spoils of War, 4-6.

Kowalski, W.W., Art Treasures and War. A Study on the Restitution of Looted Cultural Property, pursuant to Public International Law, (Leicester, Institute of Art and Law) (1998).

Kowalski, W.W., The Machinery of Nazi Art Looting. The Nazi Law on the Confiscation of Cultural Property. Poland: a Case Study, (2000), Art, Antiquity and Law, 217-231.

Kowalski, W.W., Repatriation of Cultural Property following a Cession of Territory or Dissolution of Multinational States, (2001), Art, Antiquity and Law, 139-166.

Kowalski, W.W., Claims for Works of Art and their Legal Nature, in: The International Bureau of the Permanent Court of Arbitration (Ed.) Resolution of Cultural Property Disputes. Papers emanating from the seventh PCA International Law Seminar May 23, 2003, (The Hague, Kluwer Law International \& Schulthess) (2004), 31-51.

Krause, K.-J., Denkmalschutz im Altertum, (1986), Die alte Stadt. Vierteljahreszeitschrift für Stadtgeschichte, Stadtsoziologie und Denkmalpflege, 267-285.

Kuitenbrouwer, F., Onduidelijke regeling. De commissie-Polak doet de zaken eenvoudiger voor dan ze zijn. Nieuwe claims zullen weer problemen opleveren, NRC Handelsblad, 18 April 2002.

Kuitenbrouwer, F., Gestolen kunst gedijt goed - De bezwaren tegen het Unidroit-verdrag, NRC Handelsblad, 16 May 2003, 22.

Kuitenbrouwer, F., Besluit teruggave 'Goudstikkers' is juridische spagaat, NRC Handelsblad, 7 February 2006, 8.

Kunze, H.H., Restitution "Entarteter Kunst". Sachenrecht und Internationales Privatrecht, (Berlin \& New York, de Gruyter) (2000).

Kurtz, M., J., The End of the War and the Occupation of Germany, 1944-52. Laws and Conventions enacted to counter German Appropriations: The Allied Control Council, in: Simpson, E. (Ed.) The spoilsof war. World War II and Its Aftermath: The Loss, Reappearance, and Recovery of Cultural Property, (New York, Harry N. Abrams) (1997), 112-116.

Kurtz, M.J., Nazi Contraband: American Policy on the Return of European Cultural Treasures, 1945-1955, (New York \& London, Garland Publishing) (1985).

Kurtz, M.J., Inheritance of Jewish Property, (1998), Cardozo Law Review, 625-655.

Kurtz, M.J., America and the return of Nazi contraband: the recovery of Europe's cultural treasures, (Cambridge, Cambridge University Press) (2006).

Kuyvenhoven, F. (Ed.), Developments in Dutch Museum Policy, (Amsterdam, Instituut Collectie Nederland) (2001). 
LaCapra, D., Representing the Holocaust: history, theory, trauma, (Ithaca, Cornell University Press) (1994).

Lalive, P., Une Convention internationale qui dérange: la Convention UNIDROIT sur les biens culturels, in: Dupuy, R.-J. (Ed.) Mélanges en l'honneur de Nicolas Valticos, (Paris, A. Pedone) (1999), 177-188.

Langaney, A., Collections humaines et sciences inhumaines: échantillons et reliques, in: Bancel, N., et al. (Eds.), Zoos Humains: de la vénus hottentote aux reality shows, (Paris, éditions La Découverte) (2002), 374-380.

Lannan, R., W., Anthropology and restless Spirits: the Native American Graves Protection and Repatriation Act, and the unresolved Issues of Prehistoric Human Remains, (1998), Harvard Environmental Law Review, 369-439.

Lanzmann, C., Shoah (Le films Aleph), (1985).

Larsen, C.S., Bioarchaeology: Interpreting behaviour from the human skeleton, (New York, Cambridge University Press) (1997).

Lauterpacht, Recognition of Insurgents as a de facto Government, (1939-1940), Modern Law Review, 1-20.

Leenen, H.J.J., et al., Handboek gezondheidsrecht: Deel I - Rechten van mensen in de gezondheidszorg, (Houten, Bohn Stafleu Van Loghum) (2007).

Legassick, M. / Rassool, C., Skeletons in the Cupboard - South African museums and the trade in human remains, 1907 - 1917, (South African Museum \& McGregor Museum) (2000).

Legêne, S., et al., Notitie over de omgang met menselijke resten in volkenkundige musea, (2001).

Leiden geeft hoofd Badu Bonsu II terug, NRC Handelsblad, 21 March 2009.

Leistra, J., A Short History of Art Loss and Art Recovery in the Netherlands, in: Simpson, E. (Ed.) The Spoils of War. World War II and Its Aftermath: the Loss, Reappearance, and Recovery of Cultural Property, (New York, Harry N. Abrams) (1997), 53-57.

Lepaulle, P., Traité théorique et pratique des trusts en droit interne, en droit fiscal et en droit international, (Paris, Rousseau) (1932).

Lerner, R., E., The Nazi Art Theft Problem And The Role Of The Museum: A Proposed Solution To Disputes Over Title, (1998), New York University Journal of International Law and Politics, 15-41.

Lesaffer, R.C. / Broers, E.-J., Private Property in the Dutch-Spanish Peace Treaty of Münster (30 January 1648), (2007), available at: http://ssrn.com/paper=1002389.

Less, S., International Administration of Holocaust Compensation: The International Commission on Holocaust Era Insurance Claims (ICHEIC), (2008), German Law Journal, 1651-1692.

Levy, D. / Sznaider, N., Erinnerung im globalen Zeitalter: Der Holocaust, (Frankfurt am Main) (2001).

Levy, D., et al., The Holocaust and memory in the global age, (Philadelphia, Temple University Press) (2005).

Lichfield, J., Robbery that followed the Holocaust, The Independent, 28 January 1997.

Lijkresten gevonden in depot Tropenmuseum, (2007), Netwerk.

Lillie, S., Was Einmal War: Handbuch der enteigneten Kunstsammlungen Wiens, (Vienna, Czernin Verlag) (2003).

Lillteicher, J., Westdeutschland und die Restitution jüdischen Eigentums in Europa, in: Goschler, C., et al. (Eds.), Raub und Restitution: "Arisierung" und Rückerstattung des jüdischen Eigentums in Europa, (Frankfurt am Main, Fischer) (2003), 92-107.

Lipman, R., Jewish Cultural Reconstruction Reconsidered - Should the Jewish Religious Objects Distributed Around the World After WWII be Returned to Europe?, (2006), Kunst und Recht - Journal für Kunstrecht, Urheberrecht und Kulturpolitik, 89 - 93. 
Lohman, J., Introduction, in: Lohman, J. / Goodnow, K. (Eds.), Human Remains and Museum Practice, (UNESCO) (2006a), 10-15.

Lohman, J., Parading the Dead, Policing the Living, in: Lohman, J. / Goodnow, K. (Eds.), Human Remains and Museum Practice, (UNESCO) (2006b).

Lokin, J.H.A. / Zwalve, W.J., Hoofdstukken uit de Europese Codificatiegeschiedenis, (Groningen, WoltersNoordhoff/Egbert Forsten) (1992).

Lowenthal, C., The Role of IFAR and the Art Loss Register in the Repatriation of Cultural Property displaced in World War II, (1996), Spoils of War, 8-10.

Lubina, K.R.M., The Aftermath of the Second World War: Restitution of Looted Art (unpublished dissertation), (2002).

Lubina, K.R.M., Human remains in the KIT Tropenmuseum collection - Summary of meeting of experts on 23-24 February 2006, in: van Duuren, D. (Ed.) Physical anthropology reconsidered: Human remains at the Tropenmuseum, (Amsterdam, KIT Publishers) (2007), 83-95.

Lubina, K.R.M., Sotheby's Restitution Symposium: Sotheby's Amsterdam, The Netherlands (January 30, 2008): Conference Reports, (2008), International Journal of Cultural Property, 429-431.

Lufkin, M., The Subpoena heard round the World. The Schiele Case and other Legal Immunities for Art Loaned into the US, (1999), Art Antiquity \& Law, 364-372.

Lufkin, M., Criminal Liability for Receiving State-Claimed Antiquities in the United States: The 'Schultz' Case, (2003), Art Antiquity \& Law.

Luijten, E.A.A., Rechterlijk ingrijpen in testatmentaire beschikkingen (I), (1994a), Stichting \& Vereniging, 105107.

Luijten, E.A.A., Rechterlijk ingrijpen in testatmentaire beschikkingen (II), (1994b), Sticbting \& Vereniging, 135-138.

Luijten, E.A.A. / Meijer, W.R., Huwelijksgoederen- en erfrecht (Deel 2: Erfrecht), (Deventer, Kluwer) (2003).

Lust, J., International Symposium in Kiev, (1996), Spoils of War.

Lustig, A.J., Cabinets and collections, in: Heilbron, J.L. (Ed.) The Oxford Companion to the History of Modern Science, (Oxford, Oxford University Press) (2003), 117-119.

Lyotard, J.-F., Heidegger et les juifs, (Paris, Éditions Galilée) (1988).

M.B., List Reveals Names of Nazi-Era Looters, Washington Post, November 7 1998, C3.

Mackenzie, S., Going, Going, Gone: Regulating the Market in Illicit Antiquities, (Leicester, Institute of Art and Law.) (2005).

Mak, G.L., Rembrandt en Jan Six: contouren van een vriendschap, (Amsterdam, pAn Amsterdam) (2005).

Malanczuk, P. / Akehurst, M.B., Akehurst's modern introduction to international law, (London, Routledge) (1997).

Maori (2009), In Encyclopædia Britannica. Retreived April 17, 2009, from Encyclopædia Britannica Online.

Marchisotto, The Protection of Art in Transnational Law, (1974), Vanderbilt Journal of Transnational Law, 689724.

Mark, L.F., The recovery of cultural artifacts: the legacy of our archeological heritage, (1990), Case Western Reserve Journal of International Law, 165-182.

Maseko, Z., On l'appelait la Venus Hottentote (documentary), (1998).

Mastalir, R.W., A Proposal for Protecting the "Cultural" and "Property" Aspects of Cultural Property under International Law, (1993), Fordham international law journal, 1033-1093. 
Mastroberardino, M.M., The Last Prisoners of World War II, (1997), Pace International Law Review, 315-356.

Matthews, M., Repatriation of Koiwi Tangata Maori (Maori Ancestral Human Remains) (personal communication to Seddon Bennington), (2004).

Maurer, C.H.M., Die Ausfuhr von Kulturgütern in der Europäischen Union, (Frankfurt am Main, Haag + Herchen) (1997).

Maurice, C. / Turnor, R., The Export Licensing Rules in the United Kingdom and the Waverley Criteria, (1992), International Journal of Cultural Property, 273-295.

Mauriès, P., Cabinets of Curiosities, (London, Thames \& Hudson Ltd) (2002).

McAleese, K., The Reinterment of the Thule Inuit Burials and Associated Artifacts - IdCr-14 Rose Island, Saglek Bay, Labrador, (1998), Études Inuit/Inuit Studies, 41-52.

McAndrew, C. / O'Hagan, J., Export Restrictions, Tax Incentives and the National Artistic Patrimony, (2000), Trinity Economics Papers.

McClellan, A., Inventing the Louvres. Art, Politics and the Origins of the Modern Museum in eighteenthcentury Paris, (Cambridge) (1994).

McGuire, T., African Antiquities removed during colonialism: restoring a stolen cultural legacy, (1990), Detroit College of Law Review, 31-69.

Meijer, K., E 100 en de naoorlogse rechtspraak met betrekking tot onroerend goed, (Nijmegen, Wolf Legal Publishers) (2008).

Meng, W., War, in: Bindschedler, R.L. (Ed.) Encyclopedia of public international law: Part: 4: Use of Force, War and Neutrality, Peace Treaties, (Amsterdam, North-Holland) (1982), 282-290.

Mercillon, H., L'évolution du commerce mondial de l'art - Problématique de la France, in: Briat, M. (Ed.) International sales of works of art, (Paris, ICC Publishing) (1990), 49-56.

Merryman, J.H., Two ways of thinking about cultural property, (1986), The American Journal of International Law, 831-853.

Merryman, J.H., Cultural Property, International Trade and Human Rights, (2000a), Occasional Papers in Intellectual Property, New York, NY, Benjamin N. Cardozo School of Law, Yeshiva University, $n^{\circ} 9$.

Merryman, J.H., Thinking about the Elgin marbles: Critical Essays on Cultural Property, Art and Law, (The Hague, Kluwer Law International) (2000b).

Merryman, J.H., Law, Ethics and the Visual Arts, (London, Kluwer Law International) (2002).

Merryman, J.H., Cultural Property Internationalism, (2005), International Journal of Cultural Property, 11-39.

Merryman, J.H., Law, Ethics and the Visual Arts, (London, Kluwer Law International) (2007).

Messer, K., Two sides of the same coin: the memory of the holocaust at war with a survivor, (1008), Northern Kentucky Law Review.

Meyer, K.E., The plundered past; the traffic in art treasures, (Harmondsworth, Penguin) (1977).

Meyer, T., Soft Law as Delegation (July 26). Available at SSRN: http://ssrn.com/abstract=1214422, (2008).

Meyer-Landrut, J., Die Behandlung von staatlichen Archiven und Registraturen nach Völkerrecht, (1953), Archivalische Zeitschrift, 45-120.

Michiels, F.C.M.A., Boekbespreking H.E. Bröring, Richtlijnen, (1994), $M$ en R, 226-229.

Michielsen, J., The 'Nazification' and 'Denazification' of the Courts in Belgium, Luxembourg and The Netherlands - The Belgian, Luxembourg and Netherlands courts and their reactions to occupation measures and measures from their governments returning form exile, (Maastricht, Universitaire Pers Maastricht) (2004). 
Miller, D.L.C.M., David W. \&Cowe, Anne L., Restitution of Art and Cultural Objects: a Re-Assessment of the Role of Limitation, (2001), Art, Antiquity and Law, 1-17.

Minister wint zaak Koenigs-collectie, de Volkskrant, 1 February 2007.

Ministerie van Welzijn Volksgezondheid en Cultuur, Kiezen voor kwaliteit: beleidsnota over de toegankelijkheid en het behoud van het museale erfgoed, (1990).

Moffett, J.P., Handbook of Tanganyika, (Dar es Salaam, Government Printer) (1958).

Moriori (2009). In Encyclopædia Britannica. Retrieved April 17, 2009 from Encyclopædia Britannica Online.

Mulheron, R., The class action in common law legal systems: a comparative perspective, (Oxford, Hart) (2004).

Muller, E. / Schretlen, H., Betwist Bezit. De Stichting Nederlands Kunstbezit en de teruggave van roofkunst na 1945, (Zwolle, Waanders Uitgevers) (2002).

Müller-Graff, Artikel 34, in: Groeben, H.v.d., et al. (Eds.), Kommentar zum EU-EG-Vertrag, Band 1, (Baden-Baden) (1997a).

Müller-Graff, Artikel 36, in: Groeben, H.v.d., et al. (Eds.), Kommentar zum EU-EG-Vertrag, Band 1, (Baden-Baden) (1997b).

Müller-Katzenburg, A., Internationale Standards im Kulturgüterverkehr und ihre Bedeutung für das Sachund Kollisionsrecht, (Berlin, Duncker \& Humblot) (1996).

Müller-Katzenburg, A., Possession and Ownership of stolen or otherwise lost Works of Art, (2000), Art, Antiquity and Law, 105-123.

Müller-Marsall, M. / Coenen, M., Deutschland 1949 bis 1999 - Band 1: April 1948 - 1953, (Sankt Augustin, Siegler Verlag) (2000).

Mulongo, A.H., Return and restitution of cultural property, The Broken Hill skull: a Zambian case, (1992), Museum International, 103-104.

Mulvaney, D.J., Reflections on the Murray Black Collection, (1989), Australian Natural History, 66-73.

Mulvaney, D.J., Bones of Contention, (1990), The Bulletin, 104-107.

Müntz, Les annexions de collections d'art ou de bibliothèques et leur role dans les relations internationales, principalement pendant la Révolution Française (Suite), (1895), Revue d'Histoire Diplomatique, 375393.

Museen: Kontroverse um Kinderknochen, Der Spiegel, 2 February 2009, 125.

Muséum de Rouen, Communiqué de presse: La Ville de Rouen restitue une tête maorie au gouvernement néo-zélandais (Available online at: http://rouen.blogs.com/tetemaori/files/dp_maori_07.pdf Last visited: 22 January 2008), (2007).

Museumonderzoek Museale Verwervingen 1933-1940 en 1948-heden, (2009), Museumbericbten.

Museums Australia Inc, Continuous Cultures, Ongoing Responsibilities - Principles and guidelines for Australian museums working with Aboriginal and Torres Strait Islander cultural heritage, (2005).

Museums Libraries and Archives Council Notice, UK Export Licensing for Cultural Goods - Procedures and guidance for exporters of works of art and other cultural goods, (2008).

Nachenius, A.d.B., Letter to the Director of the Museum van Volkenkunde - subject: Maori head and Te Papa, 18 February.

Nafziger, J.A.R., An Anthro-Apology for Managing the International Flow of Cultural Property, (1982), Houston Journal of International Law, 189-201.

Nafziger, J.A.R., The New International Legal Framework for the Return, Restitution or Forfeiture of Cultural Property, (1983), NYU Journal of International Law and Politics, 789. 
Nahlik, S.E., Grabiez dziel sztuki, Rodowód zbrodni miedzynarodowej (The plunder of works of art. History of an international crime), (Wroclaw-Krakow, Ossolineum) (1958).

Nahlik, S.E., La Protection Internationale des Biens Culturels en Cas de Conflit Armé, in: Recueil des cours = Collected courses of The Hague Academy of International Law, (1967), 61-163.

Nahlik, S.E., International Law and the Protection of Cultural Property in Armed Conflict, (1976), The Hastings Law Review, 1069-1087.

National Museum Directors' Conference, Too much stuff? Disposal from museums, (2003).

National Museum Directors' Conference (NMDC), Spoliation of works of art during the Holocaust and World War II period: Statement of principles and proposed actions, (1998).

Nelson, L.D.M., The North Sea Continental Shelf Cases and Law-Making Conventions, (1972), The modern law review, 52-56.

Nicholas, L., H., The Rape of Europa: The Fate of Europe's Treasures in the Third Reich and the Second World War, (London, Macmillan) (1995).

Nicholas, L., H., World War II and the Displacement of Art and Cultural Property, in: Simpson, E. (Ed.) The Spoils of War. World War II and Its Aftermath: the Loss, Reappearance, and Recovery of Cultural Property, (New York, Harry N. Abrams) (1997), 39-45.

Nieskens-Isphording, Boekbeschouwing T. Hartlief, Ontbinding, (1996), RM Themis, 148-150.

Niewyk, D.L., The Columbia Guide to the Holocaust, (New York, Columbia University Press) (2000).

Nollkaemper, A., Decisions of National Courts as Sources of International Law: An Analysis of the Practice of the ICTY, in: Boas, G. / Schabas, W. (Eds.), International Criminal Law Developments in the Case Law of the ICTY, (Martinus Nijhoff Publishers,) (2003), 277-296.

Nooter, G., Old kayaks in the Netherlands, (Leiden, Brill) (1971).

Novick, P., The Holocaust in American life, (Boston, Houghton Mifflin) (1999).

O’Donoghue, G., Precatory Executive Statements and Permissible Judicial Responses in the Context of Holocaust-Claims Litigation, (2006), Columbia Law Review, 1119-1164.

Odendahl, K., Kulturgüterschutz. Entwicklung, Struktur und Dogmatik eines ebenenübergreifenden Normensystems, (Tübingen, Mohr) (2005).

O'Keefe, P., Maoris claim head, (1992), International Journal of Cultural Property, 393.

O'Keefe, P., The Draft Resolution on looted Jewish Cultural Property produced by the Parliamentary Assembly of the Council of Europe, (1999a), Art, Antiquity, and Law, 313-322.

O'Keefe, P., The Meaning of 'Cultural Property' under the 1954 Hague Convention, (1999b), Netherlands International Law Review, 26-56.

O'Keefe, P., Vilnius International Forum on Holocaust-Era Looted Cultural Assets, Vilnius, Lithuania (October 3-5, 2000), (conference report), (2001), International Journal of Cultural Property, 127-133.

O'Keefe, P., European Developments in the Return of Nazi Looted Cultural Heritage, in: Häder, U. (Ed.) Museen im Zwielicht: Ankaufpolitik 1933-1945 (Kolloquium vom 11. und 12. Dezember 2001 in Köln.) Die eigene Geschichte: Provenienzforschung an deutschen Kunstmuseen im internationalen Vergleich (Tagung vom 20. bis 22. Februar 2002 in Hamburg), (Koordinierungsstelle für Kulturgutverluste Magdeburg) (2002), 263-275.

Olmi, G., Science - Honour - Metapor: Italian Cabinets of the Sixteenth and Seventeenth Centuries, in: Impey, O. / MacGregor, A. (Eds.), The Origins of Museums: The Cabinet of Curiosities in sixteenth- and seventeenth-century Europe, (London, House of Stratus) (2001), 1-18.

O'Neill, M., Enlightenment museums: universal or merely global?, (2004), Museum and Society, 190-202. 
Örücü, A.E., Methodology of comparative law, in: Smits, J.M. (Ed.) Elgar encyclopedia of comparative law, (Edward Elgar Publishing) (2006), 442-454.

The Oxford English Dictionary. 2nd ed. 1989. OED Online. Oxford University Press: "spoliate, v."

Oyer III, H.E., The 1954 Hague Convention for the Protection of Cultural Property in the Event of Armed Conflict - Is It Working? A Case Study: The Persian Gulf War Experience, (1999), Columbia VLA Journal of Law \& the Arts, 49-65.

Paas, S. / Mertens, S. (Eds.), Beutekunst unter Napoleon: die "französische Schenkung" an Mainz 1803 (Ausstellungskatalog im Landesmuseum Mainz, 25. Okt. 2003-14. März 2004), (Mainz, von Zabern) (2003).

Paczensky, G.v. / Ganslmayr, H., Nofretete will nach Hause: Europe - Schatzhaus der "Dritten Welt", (München, C. Bertelsmann) (1984).

Palmer, N., The Body as Property, (1996), Art, Antiquity and Law, 414-416.

Palmer, N., Artists, Corpses, Property and Theft, (1998a), Art, Antiquity and Law, 299-305.

Palmer, N., Conversion, trespass and title to art works, in: Palmer, N. (Ed.) The Recovery of Stolen Art: a collection of essays, (London, Kluwer Law International) (1998b).

Palmer, N., Museums and the Holocaust: Law, Principles and Practice, (Leicester, Institute of Art and Law) (2000a).

Palmer, N., Sending them Home: Some Observations on the Relocation Cultural Objects from UK Museums Collections, (2000b), Art, Antiquity \& Law, 343-354.

Palmer, N., Repatriation and Deaccessioning of Cultural Property: Reflections on the Resolution of Art Disputes, (2001), Current Legal Problems, 475-532.

Palmer, N., Spoliation and Holocaust-related cultural objects - Legal and ethical models for the resolution of claims, (Moscow, (2005).

Pancaldi, G., Museum, in: Heilbron, J.L. (Ed.) The Oxford Companion to the History of Modern Science, (Oxford, Oxford University Press) (2003), 550-551.

Park, G.S., De-accessioning, (1985), Agman₹, 12-14.

Parks, S.-L., Venus, (New York, Theatre Communication Group) (1997).

Parsons, N., El Negro/ El Negre of Banyoles: Bushman from Bechuanaland, or Bechuana from Bushmanland?, (2000).

Parsons, N. / Sebobye, A., Kelo, Missing persons and stolen bodies: the repatriation of 'El Negro' to Botswana, in: Fforde, C., et al. (Eds.), The dead and their possessions: repatriation in principle, policy and practice, (London, Routledge) (2002), 245-255.

Partsch, K.J., Individuals in International Law, in: Bindschedler, R.L. (Ed.) Encyclopedia of public international law: Part: 10: States, responsibility of states, international law and municipal law, (Amsterdam, North-Holland) (1987), 316-321.

Pearce, S.M., On Collecting. An investigation into collecting in the European tradition, (London / New York, Routledge) (1995).

Peers, L. / Brown, A.K., Museums and Source Communities. A Routledge Reader, (London, Routledge) (2003).

Peresztegi, Á. Reparations for Holocaust-Era Human Rights Violations, (2005), Jewish Studies Yearbook, 135146.

Petit, C., Lichaam en lijk als voorwerp van rechtsbetrekking, (1950), Rechtsgeleerd Magazijn, 428-435.

Petropoulos, J., Art as Politics in the Third Reich, (University of North Carolina Press) (1996). 
Petropoulos, J., German Laws and Directives bearing on the Appropriation of Cultural Property in the Third Reich, in: Simpson, E. (Ed.) The Spoils of War. World War II and Its Aftermath: the Loss, Reappearance, and Recovery of Cultural Property, (New York, Harry N. Abrams) (1997), 106111.

Petropoulos, J., Art Looting during the Third Reich: Overview with Recommendations for Further Research, (1999), Proceedings of the Washington Conference On Holocaust-Era Assets (Released by the Office of the Coordinator for the Washington Conference on Holocaust-Era Assets, Washington, DC, April 1999) Available online at: http://www.state.gov/www/regions/eur/holocaust/heac4.pdf (last visited: August 30, 2006).

Petropoulos, J., Evidence submitted to the Parliamentary Inquiry on Cultural Property, 'Return and Illicit Trade', (2000).

Peya, A., Die Ausfuhr von Kulturgütern im nationalen und Gemeinschaftsrecht, (Frankfurt a.M., Lang) (2002).

Phuong, C., The Protection of Iraqi Cultural Property, (2004), International and Comparative Law Quarterly, 985-998.

Pickering, M., Policy and Research Issues Affecting Human Remains in Australian Museum Collections, in: Lohman, J. / Goodnow, K. (Eds.), Human Remains and Museum Practice, (UNESCO) (2006), $42-47$.

Piper, E. / Swamy, U. (Eds.), Gibt es wirklich eine Holocaust-Industrie? Zur Auseinandersetzung um Norman Finkelstein, (Zürich, Pendo) (2001).

Pitlo, A., et al., Erfrecht, (Deventer, Gouda Quint) (1997).

Plehwe, T.v., Verjährung des dinglichen Herausgabeanspruchs und Ersitzung in Fällen abhanden gekommener Kulturgüter - Zur Notwendigkeit einer Reform, (2001), Kunstrecht und Urheberrecht, 49-61.

Polak, J.M., Boekbespreking M.J.C. Leijten, Tuchtrecht getoetst, (1992), N.J.B., 1176-1178.

Poli, J.-F., La protection des biens culturels meubles, (Paris, LGDJ) (1996).

Polonsky, M. / Canat, J.-F., The British and French System of Control of the Export of Works of Art, (1996), International and Comparative Law Quarterly, 5557-5591.

Polsky, S., Down the K. Hole: Walter Benjamin's Destructive Land-surveying of History, in: Benjamin, A. (Ed.) Walter Benjamin and History, (London, Continuum) (2005), 69-87.

Pomian, K., Collectors and Curiosities: Paris and Venice, 1500-1800, (Cambridge, Polity Press) (1990).

Pomian, K., Der Ursprung des Museums. Vom Sammeln, (Berlin, Klaus Wagenbach) (1998).

Pott, P.H. / Sutaarga, M.A., Arrangements concluded or in progress for the return of objects: the Netherlands-Indonesia, (1979), Museum (special issue on the "Return and Restitution of Cultural Property"), 38-42.

Poulos, A., Helleni, The 1954 Hague Convention for the Protection of Cultural Property in the event of Armed Conflict: An Historic Analysis, (2000), International Journal of Legal Information, 1-44.

Price, D., The Human Tissue Act 2004, (2005), Modern Law Review, 798-821.

Price III, H.M., Bones of Contention: Reburial of Human Remains under RS MO. 194.400-410, (1988), Mo. Archaeol. Soc. Q.

Price III, H.M., Disputing the dead: U. S. law on aboriginal remains and grave goods, (Columbia, University of Missouri Press) (1991).

Prince, M.v., Eine deutsche Frau im Innern Deutsch-Ostafrikas, (Berlin, Ernst Siegfried Mittler \& Sohn) (1908). 
Pritchard, S., Der völkerrechtliche Minderheitenschutz: historische und neuere Entwicklungen, (Berlin, Duncker \& Humblot) (2001).

Prott, L.V., Problems of Private International Law for the Protection of the Cultural Heritage, in: Recueil des cours de l’Académie de droit international de La Haye 217, (1989), 219-317.

Prott, L.V., The History and Development of Processes for the Recovery of Cultural Heritage, (2008), Art Antiquity \& Law, 175-198.

Prott, L.V. / O'Keefe, P., Law and the Cultural Heritage. Volume I, Discovery and Excavation, (Abingdon, Professional Books) (1984).

Prott, L.V. / O'Keefe, P.J., Law and the cultural heritage (Vol. 3 - Movement), (London, Butterworths) (1989).

Prott, L.V. / O'Keefe, P.J., "Cultural Heritage" or "Cultural Property", (1992), International Journal of Cultural Property, 307-320.

Proudhon, V., Traité du domaine public ou de la distinction des biens considérés principalement par rapport au domaine public, (1833).

Psychogiopoulou, E., The Cultural Mainstreaming Clause of Article 151(4) EC: Protection and Promotion of Cultural Diversity or Hidden Cultural Agenda?, (2006), European Law Journal, 575-592.

Psychogiopoulou, E., The Integration of Cultural Considerations in EU Law and Policies, (Leiden / Boston, Martinus Nijhoff) (2008).

Pullar, G.L., The Qikertarmiut and the Scientist: Fifty years of clashing world views, in: Bray, T.L. / Killion, T.W. (Eds.), Reckoning with the Dead: The Larsen Bay Repatriation and the Smithsonian Institute, (Washington, D.C., Smithsonian Institution Press) (1994), 15-25.

Putten, W.G.H.M.v.d., Handboek Wet op de lijkbezorging, (Lelystad, Koninklijke Vermande) (1993).

Quaedvlieg, A.A., The Netherlands: Introduction, in: Briat, M. / Freedberg, J., A. (Eds.), International Sales of Works of Art: International Art Trade and Law, (Deventer, Boston, Kluwer) (1991a), pp. 4552.

Quaedvlieg, A.A., The Netherlands: National Report on Topic 1. Freedom of museums to sell, trade or otherwise dispose of objects of art in their collections, in: Briat, M. / Freedberg, J., A. (Eds.), International Sales of Works of Art: International Art Trade and Law, (Deventer, Boston, Kluwer) (1991b), 123-125.

Quatremère de Quincy, Lettres à Mirande sur le déplacement des d'Art de l'Italie.

Qureshi, S., Displaying Sara Baartman, the 'Hottentot Venus', (2004), History of Science, 233-257.

Quynn, D.M., The Art Confiscations of the Napoléonic Wars, in: Merryman, J.H. (Ed.) Law, Ethics and the Visual Arts, (Alphen aan den Rijn, Kluwer) (2007), 6-9.

Raby, J., Exotica from Islam, in: Impey, O. / MacGregor, A. (Eds.), The Origins of Museums: The Cabinet of Curiosities in sixteenth- and seventeenth-century Europe, (London, House of Stratus) (2001), 345-354.

Ramjohn, M., Text, Cases and Materials on Equity and Trusts, (New York, Routledge) (2008).

Range, D., Deaccessioning and Its Costs in the Holocaust Art Context: The United States and Great Britain, (2004), Texas International Law Journal, 665.

Rapport omtrent prijzenverloop kunstwerken op kunstveilingen etc. opgesteld door drie deskundigen voor de Raad voor het Rechtsherstel, Afdeling Rechtspraak Amsterdam, 29 October 1947).

Rascher, A.F.G., The Washington Conference on Holocaust-Era Assets (November 30 - December 3 , 1998), (1999), International Journal of Cultural Property, 338-343. 
Ratliff, W., British-Hedjaz Agreement of 1916, in: Oslson, J.S. / Shadle, R. (Eds.), Historical Dictionary of the British Empire, (Westport, Greewood Publishing) (1996).

Réau, L., Iconographie de l'art chrétien: Iconographie des saints (G-O), (Paris, Presses Universitaires de France) (1958).

Redmond-Cooper, R., Handling Stolen Goods: The Civil Law, (British Museum, Transacting in Art: The Legal Pitfalls) (1996).

Redmond-Cooper, R., Time Limits in Actions to Recover Stolen Art, in: Palmer, N. (Ed.) The Recovery of Stolen Art: a collection of essays, (London, Kluwer Law International) (1998).

Redmond-Cooper, R., Time Limits in Art and Antiquity Claims (Part I), (1999), Art Antiquity \& Law, 323346.

Redmond-Cooper, R., Time Limits in Art and Antiquity Claims (Part II), (2000), Art Antiquity \& Law, 185208.

Reichelt, G., Die Vereinheitlichung des privatrechtlichen Kulturgüterschutzes nach dem UNIDROITVertragsentwurf, in: Dolzer, R., et al. (Eds.), Rechtsfragen des internationalen Kulturgüterschutzes, (Heidelberg, C.F. Müller) (1994), 67-81.

Renold, M.-A., Editorial: The Adoption of the Terezin Declaration on June 30, 2009, (2009), Kunstrecbtspiegel, 62.

"Repatriation" The Oxford English Dictionary. 2nd ed. 1989. OED Online. Oxford University Press. 17 May 2007, available at: http://dictionary.oed.com.

Report of the working group established in accordance with Commission on Human Rights resolution 1995/32 of 3 March 1995 on its eleventh session (E/CN.4/2006/79 - 22 March 2006), (2006), available at:

http://daccessdds.un.org/doc/UNDOC/GEN/G06/119/46/PDF/G0611946.pdf?OpenEleme nt.

Reppas II, M.J., The Deflowering of the Parthenon: A Legal and Moral Analysis on why the Elgin Marbles must be Returned to Greece, (1999), The Fordham Intellectual Property, Media and Entertainment Law Journal, 911-998.

Rijghard, R., Twist over aard rechtsherstel erven-Goudstikker, NRC Handelsblad, 7 February 2006, 8.

Rijk retourneert Goudstikkers', NRC Handelsblad, 4 February 2006, 1 \& 7.

Riley, A.R., Indian Remains, Human Rights: Reconsidering Entitlement under the Native American Graves Protection and Repatriation Act, (2002), Columbia Human Rights Law Review, 49-94.

Rings, W., Raubgold aus Deutschland. Die 'Golddrehscheibe' Schweiz im Zweiten Weltkrieg, (Zürich, München) (1985).

Roberts, G.K., What is comparative politics?, (London, Macmillan) (1972).

Robertson, A.H., The Council of Europe - Its Structure, Functions and Achievements, (London, Stevens \& Sons Limited) (1961).

Roede, M.J., A History of Physical Anthropology in the Netherlands, in: Vermeulen, H. / Kommers, J. (Eds.), Tales from Academia: history of anthropology in the Netherlands, Part II, (Saarbrücken) (2002), 1033-1094.

Rotter, M., Staat, in: Seidl-Hohenveldern, I. (Ed.) Lexikon des Rechts: Völkerrecht, (Neuwied, Luchterhand Verlag) (1982).

Rousseau, J.-J., Du contrat social, (1762).

The Royal Liverpool Children's Inquiry Report (The Stationery Office 2001) H.C. [Session 2000-1]; 112-II, available at: 
http://www.dh.gov.uk/en/Publicationsandstatistics/Publications/PublicationsPolicyAndGuidan ce/DH_4005937.

Rudolf, W., Über den internationalen Schutz von Kulturgütern, in: Hailbronner, K., et al. (Eds.), Staat und Völkerrechtsordnung: Festschrift für Karl Doehring, (Berlin, Springer) (1989).

Rudolph, S., Restitution von Kunstwerken aus jüdischem Besitz. Dingliche Herausgabeansprüche nach deutschem Recht, (De Gruyter) (2007).

Rutherford, L. / Bone, S. (Eds.), Osborn's Concise Law Dictionary, (London, Sweet \& Maxwell) (1993).

Ruzié, D., Entschädigung der Opfer von Enteignungen aufgrund antisemitischer Gesetzgebung während der Okkupationszeit in Frankreich, (2004), available at:

www.civs.gouv.fr/IMG/pdf/Livret_Ruzie_avril_07.pdf (originally published in: Liberté, justice, tolérance - Mélanges en l'honneur du Doyen Gérard Cohen-Jonathan (pp.1351-1370).

Salomons, A.F., Reactie op "Dief wordt vaak geen eigenaar" van mr. A.C. van Schaik, (2005), WPNR (6639), 803-806.

Salomons, A.F., Richtlijn 93/7/EEG betreffende de teruggave van cultuurgoederen die op onrechtmatige wijze buiten het grondgebied van een lidstaat zijn gebracht, in: Hartkamp, A.S., et al. (Eds.), De invloed van het Europese recht op het Nederlandse privaatrecht, (Deventer, Kluwer) (2007), pp. 153-177.

San. (2005). In Encyclopædia Britannica. Retrieved December 14, 2005, from Encyclopædia Britannica Online, available at: http://www.search.eb.com/eb/article-9065258.

Sandholtz, W., Dynamics of International Norm Change: Rules against Wartime Plunder, (2008), European Journal of International Relations, 101-131.

Savoy, B., "An Bildern schleppt ihr hin und her..." Restitutionen und Emotionen in historischer Perspektive, in: Koldehoff, S., et al. (Eds.), Kunst-Transfers - Thesen und Visionen zur Restitution von Kunstwerken, (München / Berlin, Deutscher Kunstverlag) (2009), 85-102.

Schaik, A.C.v., Dief wordt vaak geen eigenaar, (2005), WPNR (6617), 289 - 290.

Schaik, A.C.v., Naschrift. Verbergende dieven usucapiëren niet, (2005), WPNR (6639), 806-808.

Scheicher, E., The Collection of Archduke Ferdinand II at Schloss Ambras: Its Purpose, Composition and Evolution, in: Impey, O. / MacGregor, A. (Eds.), The Origins of Museums: The Cabinet of Curiosities in sixteenth- and seventeenth-century Europe, (London, House of Stratus) (2001), 3750.

Schindler, D. / Toman, J., The laws of armed conflicts: a collection of conventions, resolutions, and other documents, (Leiden, Nijhoff) (2004).

Schiphof, T., Schenkingen, erfstellingen en legaten, in: Beunen, A. (Ed.) Museumrechtwijzer: Juridisch handboek voor musea, (Amsterdam, Boekmanstichting) (2000), 204-217.

Schivelbusch, W., Die Bibliothek von Löwen: eine Episode aus der Zeit der Weltkriege, (München, Hanser) (1988).

Schleunes, K.A., The Twisted Road to Auschwitz: Nazi Policy Toward German Jews, 1933-1939, (Urbana, University of Illinois Press) (1970).

Schmahl, S., Die Kulturkompetenz der Europäischen Gemeinschaft, (Baden-Baden, Nomos) (1996).

Schmidt, W., The Loss of German Artistic Property as a Result of World War II, in: Simpson, E. (Ed.) The Spoils of War. World War II and Its Aftermath: The Loss, Reappearance, and Recovery of Cultural Property, (New York, Harry N. Abrams) (1997), 95-98.

Schmitt, J.-M., La colonne Vendôme interdite de sortie du territoire, (2004), Le Journal des Arts.

Schmoller, G.v., et al., Handbuch des Besatzungsrechts, (Tübingen) (1957). 
Schnabel, G. / Tatzkow, M., Nazi Looted Art. Handbuch Kunstrestitution weltweit, (Berlin, ProprietasVerlag) (2007).

Schönenberger, B., Restitution von Kulturgut. Anspruchsgrundlagen - Restitutionshindernisse Entwicklung, (Bern, Stämpfli Verlag) (2009).

Schoordijk, H., C.F., De Goudstikker-Zaak: Regels van privaatrecht zijn door het beheersinstituut nooit toegepast, zo eenvoudig is het, (2006), Nederlands Juristenblad, 743-748.

Schorlemer, S.v., Internationaler Kulturgüterschutz: Ansätze zur Prävention im Frieden sowie im bewaffneten Konflikt, (Berlin, Duncker \& Humblot) (1992).

Schorlemer, S.v., Der internationale Schutz von Kulturgütern gegen Umwelteinflüsse - Vom kurativen zum präventiven Kulturgüterschutz, in: Fechner, F.G., et al. (Eds.), Prinzipien des Kulturgüterschutzes. Ansätze im deutschen, europäischen, und internationalen Recht, (Berlin) (1996), 225-256.

Schorlemer, S.v., Stolen art, in: German Yearbook of International Law, (Berlin, Duncker \& Humblot) (1998), 317-343.

Schrage, E.J.H., De Regelen der Kunst III, (Amsterdam / Den Haag, Russell Advocaten) (2007).

Schulze, D., Die Restitution von Kunstwerken zur Völkerrechtlichen Dimension der Restitutionsresolutionen der Generalversammlung der Vereinten Nationen, (Bremen, Herbert Ganslmayr) (1983).

Schwarz, W., Rückerstattung nach den Gesetzen der Alliierten Mächte. Die Wiedergutmachung nationalsozialistischen Unrechts durch die Bundesrepublik Deutschland (Bd. I. ), (München) (1974).

Schwarze, J., Der Schutz nationalen Kulturguts im europäischen Binnenmarkt, (1994), JZ, 111-117.

Seferiades, S., La question du repatriement des Marbres d'Elgin considérée plus spécialement au point de vue du Droit des Gens, (1932), Revue de droit international, 51-78.

Segobye, A., Missing persons, stolen bodies and issues of patrimony: the El Negro story, (2002), Pula: Botswana Journal of African Studies (Special Issue: 'El Negro and the Hottentot Venus: Issues of Repatriation'), 14-18.

Seidemann, R.M., Time for a Change? The Kennewick Man Case and its implications for the future of the Native American Graves Protection and Repatriation Act, (2003), West Virginia Law Review, 149176.

Seidemann, R.M., Bones of Contention: A comparative examination of law governing human remains from archaeological contexts in formerly colonial countries, (2004), Lonisiana Law Review, 545-587.

Seligman, T.K., The Murals of Teotihuacán: a Case Study of Negotiated Restitution, (Albuquerque, NM, University of New Mexico Press) (1999).

Selle, C.v. / Szchunke, U., Ein Weg, wo kein Wille ist?, in: Osteuropa - 56. Jahrgangsheft, (2006), 383-392.

Shaw, M., N., International Law, (Cambridge, University Press) (2003).

Shaw, M., N., International Law, (Cambridge, University Press) (2008).

Shek, T., Can Dust Remain Dust? English Law and Indigenous Human Remains, (2000), Art, Antiquity and Law, 265-293.

Shelbourn, C., Bringing the Skeletons out of the Closet? The Law and Human Remains in Art, Archaeology and Museum Collections, (2006), Art Antiquity and Law, 179-198.

Shyllon, F., The Right to a Cultural Past: African Viewpoints, in: Institute of Art and Law (Ed.) Cultural Rights and Wrongs. A collection of essays in commemoration of the 50th anniversary of the Universal Declaration of Human Rights, (Paris/ London, IAL \& UNESCO Publishing) (1998), 103-119. 
Shyllon, F., The Nigerian and African Experience on Looting and Trafficking in Cultural Objects, in: Hoffmann, B.T. (Ed.) Art and Cultural Heritage: Law, Policy and Practice, (Cambridge, University Press) (2006), 137-144.

Siehr, K., Manuscript of the Quedlinburg Cathedral back in Germany, (1992a), International Journal of Cultural Property, 215-217.

Siehr, K., Preliminary Draft Unidroit Convention on Stolen or Illegally Exported Cultural Objects (approved by the UNIDROIT Study Group on the International Protection of Cultural Property at its Third Session on 26 January 1990), (1992b), International Journal of Cultural Property, 252-256.

Siehr, K., The UNIDROIT Draft Convention on International Protection of Cultural Property, (1992c), International Journal of Cultural Property, 321-330.

Siehr, K., International Art Trade and the Law, (Academie de droit international) (1993).

Siehr, K., Chronicles, (1998), International Journal of Cultural Property, 272-282.

Siehr, K., Herausgabe gestohlener Kunst, in: Schmid, N. / Ackermann, J.-B. (Eds.), Wiedererlangung widerrechtlich entzogener Vermögenswerte mit Instrumenten des Straf-, Zivil-, Vollstreckungsund internationalen Rechts, (Zürich, Schulthess Juristische Medien) (1999), 1-17.

Siehr, K., Verjährt ein Anspruch auf Herausgabe des Eigentums? - Deutsches Verjährungsrecht vor englischem Gericht, in: Carl, M., H. \& Güttler, Herbert, \& Siehr, Kurt (Ed.) Kunstdiebstahl vor Gericht: City of Gotha v. Sotheby's Cobert finance S.A., (Berlin, Walter de Gruyter) (2001), 5375.

Siehr, K.G., Globalization and National Culture: Recent Trends Toward a Liberal Exchange of Cultural Objects, (2005), Vanderbilt Journal of Transnational Law, 1067-1096.

Siehr, K.G., The Beautiful one has come - to return. The Return of the Bust of Nefertiti from Berlin to Cairo, in: Merryman, J.H. (Ed.) Imperialism, art and restitution, (2006), 114-134.

Simpson, E., The Spoils of War - World War II and Its Aftermath: The Loss, Reappearance and Recovery of Cultural Property, (New York, Harry N. Abrams) (1997).

Simpson, J.A. / Weiner, E.S.C. (Eds.), The Oxford English Dictionary, (Oxford, Clarendon Press) (1989).

Simpson, M., Museums and Repatriation: An Account of Contested Items in Museum Collections in the UK, with Comparative Material from Other Countries, (London) (1997).

Simpson, M.G., Making Representations: Museums in the Post-colonial Era, (London, Routledge) (1996).

Sjouke, P.S., Het behoud van cultuurgoederen: twee werelden, twee visies (The Preservation of Cultural Property, Two Worlds, Two Views), (Nijmegen, Ars Aequi Libri) (1999).

Sjouke, P.S., Wet tot behoud van cultuurbezit / P.S. Sjouke, (Deventer, Kluwer) (2007).

Smyth, C., Hugh, Repatriation of Art from the Collecting Point in Munich after World War II, (Maarssen / The Hague, Gary Schwartz / SDU Publisher) (1988).

Snijders, H.J. / Rank-Berenschot, E.B., Goederenrecht, (Deventer, Kluwer) (2007).

Snijders, M.Y. / Meier, G.J., Nederlands Burgerlijk Procesrecht, (Deventer, Kluwer) (2002).

Sorbara, J.-G., Le domaine public mobilier au regard du code général de la propriété des personnes publiques, (2007), AJDA, 619.

Specht, J., The Australian Museum and the return of artefacts to Pacific Island countries, (1979), Museum (special issue on the "Return and Restitution of Cultural Property"), 28-30.

Specht, J., Book review: Ana Filipa Vrdoljak, International Law, Museums and the Return of Cultural Objects, (2008), International Journal of Cultural Property, 447-451.

Stake, R.E., The Art of Case Study Research, (Thousand Oaks, Sage) (1995). 
Stapp, D.C. / Longenecker, J.G., Reclaiming the Ancient One: addressing the conflicts between American Indians and archaeologists over protection of cultural places, in: Smith, C. / Wobst, M.H. (Eds.), Indigenous archaeologies: decolonising theory and practice., (London, Routledge) (2005), 171186.

Steckel, R., et al., The Scientific Value of Human Remains in studying the Global History of Health, in: Lohman, J. / Goodnow, K. (Eds.), Human Remains and Museum Practice, (UNESCO) (2006), 60-70.

Steel, P., Close to the bone, (2004), Museums Journal, 22-25.

Stengel Freiherr von, K., Die Rechtsverhältnisse der deutschen Schutzgebiete, (1901).

Steur, J.C.v.d., Grenzen van rechtsobjecten - Een onderzoek naar de grenzen van objecten van eigendomsrechten en intellectuele eigendomsrechten, (Kluwer) (2003).

Stone, L., Introduction: Theoretical Implications of New Directions in Anthropological Kinship, in: Stone, L. (Ed.) New directions in anthropological kinship, (Lanham, Rowman \& Littlefield) (2001), 2-20.

Strebel, H., Die Haager Konvention zum Schutze der Kulturgüter im Falle eines bewaffneten Konfliktes vom 14. Mai 1954, (1955/56), Zeitschrift für ausländisches öffentliches Recht und Völkerrecht, 35-75.

Strother, Z.S., Display of the Body Hottentot, in: Lindfors, B. (Ed.) Africans on stage: studies in ethnological show business, (Bloomington, IN, Indiana University Press) (1999), 1-61.

Stuers, V.E.L.d., Holland op zijn smalst, (1873), De Gids.

Stuurgroep Evaluatie Dualisering Gemeentebestuur, Aangelegd om in vrijheid samen te werken dualisering: bijsturing geboden (Rapport van de Stuurgroep Evaluatie Dualisering Gemeentebestuur, (2004).

Sumner, I. / Warendorf, H.C.S., Inheritance law legislation of the Netherlands: a translation of Book 4 of the Dutch Civil Code, procedural provisions and private international law legislation, (Antwerp, Intersentia) (2005).

Szasz, P., International Norm-Making, in: Weiss, E.B. (Ed.) Environmental Change and International Law: New Challenges and Dimensions, (UN University Press) (1992), 41-70.

Tanzania (2008). In Encyclopædia Britannica. Retrieved May 16, 2008, from Encyclopædia Britannica Online, available at: http://www.search.eb.com/eb/article-37594.

Taylor, R.E., Amino Acid Composition and Stable Carbon Isotope Values on Kennewick Skeleton Bone. Attachment B, in: Report on the DNA Testing Results of the Kennewick Human Remains from Columbia Park, Kennewick, Washington, (Washington, D.C., National Park Service) (2001).

Te Herekiekie, H., The Museum of New Zealand Te Papa Tongarewa (Te Papa) and the Repatriation of Köiwi Tangata (Maori and Moriori skeletal remains) and Toi Moko (Mummified Maori Tattooed Heads), (2008), International Journal of Cultural Property, 405-406.

Te Puni, J. / Nesus, C., Letter to the Director of the Museum van Volkenkunde - subject: Maori ancestral remains, 30 June.

Thalheimer, S., Der Genter Altar, (München, Beck) (1967).

The Museum of New Zealand Te Papa Tongarewa, Repatriation of Human Remains and Te Papa Background Paper for Overseas Institutions.

The Museum of New Zealand Te Papa Tongarewa, Working Group on Human Remains - Submission by The Museum of New Zealand Te Papa Tongarewa, (2001).

The Museum of New Zealand Te Papa Tongarewa, Letter to Steven Engelsman with the subject

"Repatriation - Human Remains", 16 September. 
The National Monuments Council, New Legislation for National Heritage Resources - Celebrating our achievements and redressing past inequities, available at: http://www.nationalmonuments.co.za/e.htm.

Thomas, D.H., The skull wars: Kennewick man, archaeology, and the Battle for Native American identity, (New York, Basic Books) (2000).

Thomason, D., Rolling Back History: The UN and the Right to Cultural Property, (1990), Case Western Reserve Journal of International Law, 47-96.

Thonke, C., Hitlers langer Schatten. Der mühevolle Weg zur Entschädigung der NS-Opfer, (Wien) (2004).

Thorn, B., Internationaler Kulturgüterschutz nach der UNIDROIT-Konvention, (Berlin, Walter de Gruyter) (2005).

Thornberry, P., Indigenous Peoples and Human Rights, (Manchester University Press) (2002).

Thornton, R., Repatriation as healing the wounds of the trauma of history: cases of Native Americans in the United States of America, in: Fforde, C., et al. (Eds.), The dead and their possessions: repatriation in principle, policy and practice, (London, Routledge) (2002), 17-24.

Thürer, Self-Determination (Addendum), in: Bernhardt, R. (Ed.) Encyclopedia of Public International Law (EPIL), (Amsterdam, North-Holland) (2000), 364-374.

Timmer, P.M.Y. / Gubbels, G.J., Niets gaat verloren: twintig jaar selectie en afstoting uit Nederlandse museale collecties, (Amsterdam, Instituut Collectie Nederland, Boekmanstudies) (2007).

Tobias, P.V., Saartje Baartman: her life, her remains, and the negotiations for their repatriation from France to South Africa, (2002), South African Journal of Science, 107-110.

Toman, J., The Protection of Cultural Property in the Event of Armed Conflict, (Dartmouth, UNESCO Publishing) (1996).

Toorop terug naar Zeeuws Museum, de Volkskrant, 28 November 2008.

Torsen, M.A., National Reactions to Cultural Property Looting in Nazi Germany: A Window on Individual Effort and International Disarray, (2005), available at: http://www.ejcl.org/94/art94-1.html.

Trienens, H.J., Landscape with Smokestacks: The Case of the Allegedly Plundered Degas, (Northwestern University) (2000).

Trope, J., F. / Echo-Hawk, W., R., The Native American Graves Protection and Repatriation Act: Background and Legislative History, in: Mihesuah, D., A. (Ed.) Repatriation Reader: Who owns American Indian Remains?, (Lincoln/ London, University of Nebraska Press) (2000), 123-168.

Tsosie, R., Privileging Claims to the Past: Ancient Human Remains and Contemporary Cultural Values, (1999), Arizona State Law Journal, 583-677.

Tupara, N., "Sacred Places" to the Maori, (2000), Heritage New Zealand Magazine.

Turnbull, P., Ramsay's Regime: The Australian Museum and the procurement of Aboriginal Bodies, (1991), Aboriginal history, 108-121.

Turner, C.G.I., What is Lost with Skeletal Reburial? I. Adaptation, (1986), Quarterly Review of Archaeology, 1-2.

Turner, M.I., The Innocent Buyer of Art Looted During World War II, (1999), Vanderbilt Journal of Transnational Law, 1511 - 1548.

Turner, S., Das Restitutionsrecht des Staates nach illegaler Ausfuhr von Kulturgütern: Eigentumsordnung und völkerrechtliche Zuordnung, (Berlin, Walter de Gruyter) (2002).

Twining, E., A Chief's Skull returned to His People, (1954), Times British Colonial Review.

Uhl, A.-K., Der Handel mit Kunstwerken im europäischen Binnenmarkt: freier Warenverkehr versus nationaler Kulturgutschutz, (Berlin, Duncker \& Humblot) (1993). 
UNESCO, Information Kit on the Restitution of Cultural Property, available at: http://unesdoc.unesco.org/images/0013/001394/139407eb.pdf.

UNIDROIT Convention on Stolen or Illegally Exported Cultural Objects: Explanatory Report prepared by the UNIDROIT Secretariat, (2001), available at: http://www.unidroit.org/english/conventions/1995culturalproperty/1995culturalpropertyexplanatoryreport-e.pdf.

Van der Ploeg volgt advies commissie. Oorlogskunst uit rijksbezit naar erven, NRC Handelsblad, 18 April 2002.

Vane, C. (Ed.), Memoirs And Correspondence Of Viscount Castlereagh (X), (London) (1852).

Vattel, The law of Nations or the Principles of Natural Law, applied to the Conduct and to the Affairs of Nations and of Sovereigns (Available online at: http://www.lonang.com/exlibris/vattel/vatt309.htm Last visited 14 May 2008), (1758).

Veen, G.A.v.d., Openbare zaken: betekenis van het aloude publiek domein na vestiging van het primaat van het publiekrecht, (Deventer, W.E.J. Tjeenk Willink) (1997).

Velten, A.A.v., Juridische verwikkelingen rond de voormalige collectie Goudstikker (I), (2006a), Weekblad voor Privaatrecht, Notariaat en Registratie, 233-243.

Velten, A.A.v., Juridische verwikkelingen rond de voormalige collectie Goudstikker (II), (2006b), Weekblad voor Privaatrecht, Notariaat en Registratie, 257-265.

Veraart, W., Ontrechting en rechtsherstel in Nederland en Frankrijk in de jaren van bezetting en wederopbouw, (Kluwer) (2005).

Verdross, Entstehungsweisen und Geltungsgrund des universellen völkerrechtlichen Gewohnheitsrechts, (1969), Zeitschrift für ausländisches öffentliches Recht und Völkerrecht, 635-653.

The Vermillion Accord on Human Remains, adopted by the South Dakota WAC Inter-Congress in 1989.

Vernon, C., Common Cultural Property: The Search for Rights of Protective Intervention, (1994), Case Western Reserve Journal of International Law, 435-479.

Verslag Ethische Commissie van de SVCN d.d. 3 april 2003 (on file with the author).

Versteden, C.J.N., et al., De gemeentewet en haar toepassing, (Deventer, Kluwer) (2008).

Villiger, M.E., Customary international law and treaties: a study of their interactions and interrelations with special consideration of the 1969 Vienna convention on the law of treaties, (Dordrecht \& Boston, M. Nijhoff) (1985).

Visscher, C.d., La protection internationale des objets d'art et des monuments historiques, (1935), Revue des droits international et de législation comparée, 32-74.

Vitrano, V.J., Comments: Protecting cultural objects in an internal border-free EC: The EC Directive and Regulation for the Protection and Return of Cultural Objects., (1994), Fordham international law journal, 1164-1200.

Vlies, I.C.v.d., et al., Kunst, recht en beleid, (Den Haag, Boom Juridische uitgevers) (2009).

Vliet, L.P.W.v., The Boundaries of Property Rights: Netherlands National Report 2006, vol. 11.1, (2007), Electronic Journal of Comparative Law (available online at: http://www.ejcl.org/111/art111-20.doc Last visited: 14 November 2007.

Vloten, F.v., Von Ihrem Freund Jan Toorop - Toorop, Domburg en de zaak Flersheim, (2001), Zeeuns Tijdschrift, 41-58.

Vogt, H., Die Kunstbeschlagnahmen im Zeitalter Napoleons, (Göttingen) (1956).

Vrdoljak, A.P., International Law, Museums and the Return of Cultural Objects, (Cambridge, Cambridge University Press) (2006). 
Vrdoljak, A.P., Self-Determination and Cultural Rights, in: Francioni, F. / Scheinin, M. (Eds.), Cultural Human Rights, (Leiden / Boston, Martinus Nijhoff) (2008), 41-78.

Vries, W.d., The "Sonderstab Musik" of the "Einsatzstab Reichsleiter Rosenberg" 1940-1945, (1995), Spoils of War, 4-7.

Waidacher, F., Vom Wert der Museen., (2000), Museologie Online, 1-20.

Walker, P.L., Bioarchaeological Ethics: A Historical Perspective on the Value of Human Remains, in: Katzenberg, M.A. / Saunders, S.R. (Eds.), Biological Anthropology of the Human Skeleton, (New York, Wiley-Liss) (2000), 3-39.

Walter, B., Rückführung von Kulturgut im internationalen Recht, (Bremen, Herbert Ganslmayr) (1988).

Watkins, J., et al., Accountability: Responsibilities of archeologists to other interest groups, in: Lynott, M. / Wylie, A. (Eds.), Ethics in American archaeology: Challenges for the 1990s., (Washington D.C., Society of American Archaeology) (1995), 33-37.

Watson, N., The Repatriation of Indigenous Remains in the United States of America and Australia: a comparative analysis, (2003), Australian Indigenous Law Reporter, 33-44.

Watt, R., J., Museums as Sacred Repositories for Human Remains: The New Zealand Experience, (1989), Bulletin of the Conference of Museum Antbropologists, 97-111.

Watt, R., J., Museums can never own the remains of other people but they can care for them, (1995), University of British Columbia Law Review, 77-89.

Weber, M., Unveräußerliches Kulturgut im nationalen und internationalen Rechtsverkehr, (Berlin, de Gruyter) (2002).

Webster, C., The foreign policy of Castlereagh. Part: I: 1812-1815: Britain and the reconstruction of Europe, (London, Bell) (1947-1950).

Weeks, J. / Bott, V., Scoping Survey of Historic Human Remains in English Museums undertaken on behalf of the Ministerial Working Group on Human Remains, (London) (2003).

Weidner, A., Schriften zum Kulturgüterschutz - Kulturgüter als res extra commercium im internationalen Sachenrecht, (Berlin, de Gruyter) (2001).

Weil, S., The American legal response to the problem of Holocaust art, (1999), Art, Antiquity and Law, 285300.

Weil, S., A deaccession reader, (Washington D.C., American Association of Museums) (2000).

Weiss, L.J., The Role of Museums in sustaining the Illicit Trade in Cultural Property, (2007), Cardozo Arts \& Entertainment Law Journal, 837-875.

Wescher, P., Kunstraub unter Napoleon, (Berlin, Mann) (1976).

Westermarck, E., The Origin and Development of the Moral Ideas, (London, Macmillan and Co.) (1926).

Wetz, F.J. / Tag, B. (Eds.), Schöne neue Körperwelten, (Stuttgart, Klett-Cotta) (2001).

Wilske, S., International Law and the Spoils of War: To the Victor the Right of Spoils?, (1998), UCLA Journal of International Law \& Foreign Affairs, 223-282.

Wilson, D.M., The British Museum: purpose and politics, (London, British Museum Publications Ltd) (1989).

Wilson, G.G., Changing Field of International Law, (1939), The American Journal of International Law, 337-338.

Winans, E.V., The Head of the King: Museums and the Path to Resistance, (1994), Comparative Studies in Society and History, 221-241.

Wolfrum, R., Reparation for internationally wrongful acts, in: Bindschedler, R.L. (Ed.) Encyclopedia of public international law: Part: 10: States, responsibility of states, international law and municipal law, (Amsterdam, North-Holland) (1987), 352-353. 
Wood, J.N., The Authorities of the American Art museum, in: Cuno, J.B., et al. (Eds.), Whose muse?: art museums and the public trust, (Princeton University Pres) (2003), 103-128.

Woodhead, C., C., A Debate which crosses all Borders: the Repatriation of Human Remains: more than just a legal Question, (2002), Art, Antiquity and Law, 317-347.

Woodhead, C., C., Summary of the report of the working group on human remains in museum collections, (2004), Art Antiquity \& Law, 178-201.

Wyss, M.P., Kultur als eine Dimension der Völkerrechtsordnung: vom Kulturgüterschutz zur internationalen kulturellen Kooperation, (Zürich, Schulthess) (1992).

Wyss, M.P., Kulturgüter: Ziel und Opfer der Gewalt - Kriegsrechtliche Schutzbestimmungen und neue Initiativen der UNESCO, (1994), Vereinte Nationen: Zeitscbrift fïr die Vereinten Nationen und ibre Sonderorganisationen, 92-97.

Yeide, N.H., et al., The AAM Guide to Provenance Research, (Washington, DC, American Association of Museums) (2001).

Zamoyski, A., Rites of Peace: The Fall of Napoleon and the Congress of Vienna, (Harper Collins) (2007).

Zelig, J.M., Recovering Iraq's Cultural Property: what can be done to prevent Illicit Trafficking, (2005), Brooklyn Journal of International Law, 289-323.

Ziff, B.H. / Pratima, V.R., Borrowed Power, (New Brunswick, New Jersey, Rutgers University Press) (1997).

Zimmerman, L., Anthropology and Responses to the Reburial Issue, in: Zimmerman, L. / Biolsi, T. (Eds.), Indians and Anthropologists: Vine Deloria Jr. and the Critique of Anthropology, (Tuscon, University of Arizona Press) (1997), 92-112.

Zimmerman, L.J. / Clinton, R.N., Case Notes: Kennewick Man and Native American Graves Protection and Repatriation Act Woes, (1999), International Journal of Cultural Property, 212-228.

Zingeris, E.R., Looted Jewish cultural property (Doc. 85636 ) - Report Committee on Culture and Education, (1999).

Zschiedrich, K. / Hoffmann, E., Völkerrechtlicher Schutz der Kulturgüter vor Wegnahme und illegaler Verbringung ins Ausland, (1984), Neue Justiz, 86-91.

\section{International treaties and soft law instruments}

Agreement between Israel and the Federal Republic of Germany, No. 4961, signed at Luxembourg, on 10 September 1952, available at: http://untreaty.un.org/unts/1_60000/10/12/00018584.pdf.

Agreement on Cultural Cooperation between the Government of Spain and the Government of the Republic of Venezuela. No. 14947, signed at Madrid on 28 June 1973, available at: http://untreaty.un.org/unts/1_60000/28/36/00055772.pdf (last visited: 13 July 2009).

Agreement on German External Debts, February 27, 1953, 4 U.S.T. 445, 449.

Convention (II) with Respect to the Laws and Customs of War on Land and its annex: Regulations concerning the Laws and Customs of War on Land. The Hague, 29 July 1899.

Convention (IV) respecting the Laws and Customs of War on Land and its annex: Regulations concerning the Laws and Customs of War on Land. The Hague, 18 October 1907.

Convention for the Protection of Cultural Property in the Event of Armed Conflict, signed at The Hague, 14 May 1954 (249 UNTS 215), available at:

http://www.unesco.org/culture/laws/hague/html_eng/fulltext.htm. 
Convention for the Safeguarding of the Intangible Cultural Heritage, Paris, 17 November 2003, UNESCO Doc.MISC/2003/CLT/CH/14.

Convention on relations between the Three Powers and the Federal Republic of Germany (Vertrag über die Beziehungen zwischen der Bundesrepublik Deutschland und den Drei Mächten), signed at Bonn, 26 May 1952 (Bundesgesetzblatt 1955 II. 29.03.1954, No 3), p. 61-67.

Die Westfälischen Friedensverträge vom 24. Oktober 1648. Texte und Übersetzungen. Anonymous English Translation from 1710 (available online at: http://www.paxwestphalica.de/ipmipo/pdf/m_1710en-treatys.pdf Last visited 14 May 2008), (2004).

European Convention on Offences relating to Cultural Property, signed at Delphi, 23 June 1985 (ETS No. 119).

Final Act and Annex of the Paris Conference on Reparations, 14 January 1946, Annex: Resolution on the Subject of Restitution, 40.

Inter-Allied Declaration Against Acts of Dispossession Committed in Territories Under Enemy Occupation or Control, 8 Dep't St. Bull. 21 (1943).

Protocol to the Hague Convention for the Protection of Cultural Property in the Event of Armed Conflict, signed at The Hague, 14 May 1954 (249 UNTS 358), available at:

http://www.unesco.org/culture/laws/hague/html_eng/fulltext.htm.

Resolution 4. 413, adopted by the General Conference of UNESCO at its twelfth session.

Roerich Pact: Protection of Artistic and Scientific Institutions and Historic Monuments, Montevideo, April, 15, 1935, 49 Stat. 3267, TS No. 899, 167 LNTS 279, available at: http://www.roerich.org/Roerich_Pact.html.

Russian Memoir from 1815, which included a memoir of Lord Castlereagh), Public Record Office (United Kingdom), CAB 154/1\&2, p. 263 (PRO pagination).

Second Protocol to the Hague Convention of 1954 for the Protection of Cultural Property in the Event of Armed Conflict, signed at The Hague, 26 March 1999.

Security Council Resolution 1483, P 7, U.N. Doc. S/RES/1483 (May 22, 2003).

Treaty of Cooperation between the United States of America and the United Mexican States Providing for the Recovery and Return of Stolen Archaeological, Historical and Cultural Properties, available at: http://untreaty.un.org/unts/1_60000/22/37/00043809.pdf (last visited: 23 July 2008).

Treaty of Peace between Poland, Russia, and Ukraine signed at Riga, 18 March 1921.

Treaty of Peace between the Allied and Associated Powers and Austria; Protocol, Declaration and Special Declaration signed at St. Germain-en-Laye, 10 September 1919, available at: http://www.austlii.edu.au/au/other/dfat/treaties/1920/3.html.

Treaty of Peace between the Allied and Associated Powers and Germany signed at Versailles, June 28th, 1919, available at: http://www.yale.edu/lawweb/avalon/imt/menu.htm.

Treaty of Peace Between The Allied and Associated Powers and Hungary; Protocol and Declaration signed at Trianon, 4 June 1920.

Treaty on the Protection of Movable Property of Historic Value, April 15, 1935, OASTS 28.

UNESCO Convention on the Means of Prohibiting and Preventing the Illicit Import, Export and Transfer of Ownership of Cultural Property, Nov. 14, 1970 (823 U.N.T.S. 231).

UNIDROIT Convention on Stolen or Illegally Exported Cultural Objects signed at Rome, 24 June 1995.

United Nations Declaration on the Rights of Indigenous Peoples, 13 September 2007, (A/RES/61/295).

Vienna Convention on Succession of States in respect of State Property, Archives and Debts. Done at Vienna on 8 April 1983. 
Washington Conference on Holocaust-Era Assets, Washington Conference Principles on Nazi-Confiscated Art, (1998).

\section{EC Legislation}

Council Directive 93/7/EEC of 15 March 1993 on the return of cultural objects unlawfully removed from the territory of a Member State, OJ No L 74, 27.3.1993, p. 74.

Council Regulation (EC) No 974/2001 of 14 May 2001 amending Regulation (EEC) No $3911 / 92$ on the export of cultural goods.

Council Regulation (EC) No 1210/2003 of 7 July 2003.

Council Regulation (EEC) No 3911/92 of 9 December 1992 on the export of cultural goods, OJ No L 395, 31.12.1992, p. 1, as amended by information of 27 March 1993, OJ No L 74, 27.3.1993, p. 80.

\section{National legislation and policy instruments}

\section{The Netherlands}

Besluit herindeling ministeriële taak recuperatie weggevoerde kunstvoorwerpen, Stb. 233, (1988) available at: http://wetten.overheid.nl/BWBR0004319/geldigheidsdatum_20-05-2009.

Besluit van de Staatssecretaris van Onderwijs, Cultuur en Wetenschappen tot instelling van een tijdelijk adviescollege, 20 September 1999, WJZ/1999/31477 (8091).

Besluit van de Staatssecretaris van Onderwijs, Cultuur en Wetenschappen, dr. F. van der Ploeg, houdende Instelling van een commissie die adviseert over verzoeken om teruggave van cultuurgoederen waarover de oorspronkelijke eigenaar door omstandigheden die direct verband hielden met het nazi-regime onvrijwillig het bezit heeft verloren en die zich thans in bezit van de Staat der Nederlanden bevinden (Besluit adviescommissie restitutieverzoeken cultuurgoederen en Tweede Wereldoorlog) WJZ/2001/45374(8123) 16 November 2001.

Brief en regeringsnotitie inzake restitutie en recuperatie van cultuurgoederen (letter and government memorandum in respect of restitution and recuperation of items of cultural value) d.d. 14 juli 2000, Tweede Kamer, vergaderjaar 1999-2000, 25 839, nr. 16.

Commissie Ekkart, Herkomst Gezoch / Origins Unknown: Eindrapportage Commissie Ekkart / Final Report Ekkart Committee, (Zwolle, Waanders in cooperation with Bureau Herkomst Gezocht) (2006).

De staatssecretaris van Onderwijs Cultuur en Wetenschap, Brief aan de voorzitter van de Tweede Kamer der Staten-Generaal. Onderwerp: Informatie over het verzoek tot teruggave Goudstikker collectie. (Bijlage(n): Kopie advies en onderzoeksrapport Restitutiecommissie inzake Goudstikker) Kenmerk: DCE/06/5640, (2006).

Decree issued by the State Secretary for Education, Culture and Science, F. van der Ploeg, establishing a committee to advise the government on the restitution of items of cultural value of which the original owners involuntarily lost possession due to circumstances directly related to the Nazi regime and which are currently in the possession of the State of the Netherlands, 16 November 2001 (Reference WJZ/2001/45374(8123), (2001).

Deviezenorder 1945, Stb. F 222.

Ekkart Committee, Aanbevelingen restitutie kunstwerken van kunsthandelaren, (2003).

Ekkart Committee, Begeleidingscommissie Herkomst Gezocht - Slotaanbevelingen, (2004). 
Ekkart Committee (Supervisory committee Origins Unknown/Herkomst Gezocht), Origins Unknown: Recommendations for the restitution of works of art, (2001).

Herkomst Gezocht / Origins Unknown, Rapport van het proefonderzoek naar de herkomst van de onder beheer van het Rijk gebleven uit Duitsland gerecupereerde kunstwerken / Report on the pilot study into the provenance of works of art recovered from Germany and currently under the custodianship of the State of the Netherlands, (1998).

Herkomst Gezocht / Origins Unknown, Deelrapportage 1 (oktober 1999) / Interim report I (October 1999), (1999).

Herkomst Gezocht / Origins Unknown, Deelrapportage 2 (oktober 2000) / Interim report II (October 2000), (2000).

Herkomst Gezocht / Origins Unknown, Deelrapportage 3 (februari 2002) / Interim report III (February 2002), (2002).

KB 17 juni 1987 nr 7, Stb. 344 houdende schorsing van het besluit van de gemeenteraad van Hilversum tot verkoop van een schilderij.

Letter [in Dutch] from the State Secretary for Education, Culture and Science to the House of Representatives dated 5 December 2003 in respect of the second series of recommendations made by the Ekkart Commitee, parliamentary year 2003-2004, 25 839, nr. 34.

Letter [in Dutch] from the State Secretary for Education, Culture and Science to the House of Representatives dated 8 March 2005 in respect of the final recommendations made by the Ekkart Commitee, parliamentary year 2004-2005, 25 839, nr. 36.

Letter [in Dutch] from the State Secretary for Education, Culture and Science to the House of Representatives dated 16 November 2001 in respect of recommendations made by the Ekkart Commitee, parliamentary year 2001-2002, 25 839, nr. 27.

Letter [in Dutch] from the State Secretary for Education, Culture and Science to the House of Representatives dated 20 May 1998, parliamentary year 1997-1998, 25013, nr. 23.

Letter [in Dutch] from the State Secretary for Education, Culture and Science to the House of Representatives dated 29 June 2001 in respect of recommendations made by the Ekkart Commitee, parliamentary year 2000-2001, 25 839, nr. 26.

Raad voor Cultuur, Advies Actualisering WBC-lijst (kenmerk wbc-2000.1785/2), 13 december, (2001), available at: http://www.minocw.nl/documenten/brief2k-2002-doc-8733b.pdf (last visited 8 April 2009).

Wet van 1 februari 1984 houdende vaststelling van de Wet tot behoud van cultuurbezit, Stb. 1984, 49.

Wet van 1 mei 1925 tot herziening in het algemeen belang van bij erfstelling of legaat gemaakte bedingen, Stb. 174.

Wet van 13 juli 2002 tot vaststelling van de Wet inzake het beheer van de financiën van het Rijk, Stb. 2002, 414.

Wet van 18 April 2002 tot vaststelling van de Invoeringswet Boek 4 en Titel 3 van Boek 7 van het nieuwe Burgerlijk Wetboek, vierde gedeelte (aanpassing van de wetgeving aan het nieuwe erfrecht en schenkingsrecht), Stb. 230.

Wet van 21 december 2006 tot wijziging van de Monumentenwet 1988 en enkele andere wetten ten behoeve van de archeologische monumentenzorg mede in verband met de implementatie van het Verdrag van Valletta (Wet op de archeologische monumentenzorg), Stb. 2007, 42.

Wet van 22 juni 1961 houdende voorzieningen in het belang van het behoud van monumenten van geschiedenis en kunst, Stb. 200.

Wet van 23 december 1988 tot vervanging van de Monumentenwet, Stb. 638. 
Wet van 24 juni 1993, houdende de verzelfstandiging van de rijksmuseale diensten, Stb. 1993, 398.

Wet van 28 mei 1980, Stb. 321.

\section{The United Kingdom}

British Library Act 1972 (c.54), London: The Stationery Office.

British Military Government Law No. 59 on the "Restitution of Identifiable Property to Victims of Nazi Oppression', Control Commission for Germany. B.E. Law No. 59: "Restitution of Identifiable Property to Victims of Nazi Oppression', Military Government Gazette (British Zone of Control), No. 28.

British Museum Act 1963, London: The Stationery Office.

County of Lancashire Act 1984, London: The Stationery Office.

Department for Culture Media and Sport, Summary Paper - Response to the Consultation on the Care of Historic Human Remains.

Department for Culture Media and Sport, Quinquennial Review of the Reviewing Committee on the Export of Works of Art, (2003).

Department for Culture Media and Sport, Care of Historic Human Remains: A Consultation on the Report of the Working Group on Human Remains, (2004a).

Department for Culture Media and Sport, Response to the Quinquennial Review of the Reviewing Committee on the Export of Works of Art, (2004b).

Department for Culture Media and Sport, Guidance for the Care of Human Remains in Museums, (2005).

Department for Culture Media and Sport, Restitution of Objects Spoliated in the Nazi-Era: A Consultation Document, (2006a).

Department for Culture Media and Sport, Restitution of Objects Spoliated in the Nazi-Era: A Consultation Document (July 2006), (2006b).

Department for Culture Media and Sport, Report of the Reviewing Committee on the Export of Works of Art and Objects of Cultural Interest 2006-07, (2007).

Department of Health, Human Bodies, Human Choices: The Law on Human Organs \& Tissue in England \& Wales - A Consultation Report, (2002).

Export Control Act 2002 (c. 28), London: The Stationery Office.

The Export of Objects of Cultural Interest (Control) Order 2003, London: The Stationery Office.

Greater Manchester Act 1981, London: The Stationery Office.

Imperial War Museum Act 1920 (c.16), London: The Stationery Office.

Merseyside Museums and Galleries Order 1986, (as amended by the Museums and Galleries Act 1992),

London: The Stationery Office.

Museum of London Act 1965 (c. 17), London: The Stationery Office.

Museums and Galleries Act 1992 (c. 44), London: The Stationery Office.

National Heritage Act 1983, London: The Stationery Office.

National Maritime Museum Act 1934 (c.43), London: The Stationery Office.

Public Libraries and Museums Act 1964 (c.75), London: The Stationery Office.

Select Committee on Culture Media and Sport, Minutes of Evidence for its Seventh Report (VOLUME II (HC 371-II)), (2000). 
Seventh Report of the House of Commons Select Committee on Culture Media and Sport, Cultural Property: Return and Illicit Trade, (2000), available at: http://www.publications.parliament.uk/pa/cm199900/cmselect/cmcumeds/371/37102.htm.

Stat. 43 Eliz. 1, c4 (1601).

The Reviewing Committee on the Export of Works of Art \& Objects of Cultural Interest (RCEWA), Report, (1979-1980).

United Kingdom Parliament, Explanatory Notes of Export Control Act 2002, (2002).

Waverley Committee, Report of the Committee on the Export of Works of Art etc., (1952).

Working Group on Human Remains, Report of the Working Group on Human Remains, (2003).

\section{France}

Assemblée Nationale, 2eme Séance du jeudi 21 Février 2002, (Paris) (2002).

Décret de 29.1.1993 relatif aux biens culturels soumis à certaines restrictions, JO 30 janvier 1993, p. 1600.

Décret $n^{\circ} 45-2075$ du 31 août 1945 portant application de l'ordonnance relative à l'organisation provisoire des musées des beaux-arts, JO 14 juin 1945, p. 4343.

Décret n $86-1370$ du 30 décembre 1986 fixant les dispositions statutaires applicables à certains emplois de la direction des musées de France, JO 1 janvier 1987, p. 65.

Décret $\mathrm{n}^{\circ} 93-124$ du 29 janvier 1993 relatif aux biens culturels soumis à certaines restrictions de circulation, JO b30 janvier 1993, p. 1600.

Décret n²001-894 du 26 septembre 2001 modifiant le décret n 93-124 du 29 janvier 1993 relatif aux biens culturels soumis à certaines restrictions de circulation, JO 29 septembre 2001, p. 15393.

Décret n²001-894 du 26 septembre 2001, JO 29 septembre 2001, p. 15393.

Décret n²002-628 du 25 avril 2002 modifié pris pour l'application de la loi 2002-5 du 4 Janvier 2002 relative aux musées de France, JO 28 avril 2002, p. 7742.

Décret no 95-24 du 9 janvier 1995 modifiant le décret no 93-124 du 29 janvier 1993 relatif aux biens culturels soumis à certaines restrictions de circulation, JO 11 janvier 1995.

Le Garrec, J., Rapport fait au nom de la commission des affaires Culturelles, familiales et sociales sur la proposition de loi, adoptée par le sénat, relative a la restitution par la France de la dépouille mortelle de Saartjie Baartman à l'Afrique du Sud of 30 Janvier 2002, (Paris), (2002).

Le Masne de Chermont, I. / Schulmann, D., Le Pillage de l'Art en France pendant l'Occupation et la Situation des 2,000 Oeuvres confiées aux Musées nationaux, (2000), available at: http://lesrapports.ladocumentationfrancaise.fr/BRP/004001389/0000.pdf (last visited 20 January 2009).

Loi du 1 mai 1920 prohibant l'exportation des objets d'art et ameublement anciens et soumettant à des droit de sortie ceux des ces objets dont l'exportation aura été autorisé.

Loi du 9 décembre 1905 concernant la séparation des Églises et de l'État, JO 11 décembre 1905.

Loi du 23 juin 1941 relative à l'exportation des oeuvres d'art, JO 19 juin 1941.

Loi du 30 mars 1887 relative à la conservation des monuments et object d'art ayant un intérêt historique et artistique, JO, 31 mars 1887, Bull. ${ }^{\circ} 17739$.

Loi du 31 décembre 1913 sur les monuments historiques, JO 1 janvier 1914, p. 129.

Loi du 31 décembre 1921 portant fixation du budget général de l'exercice.

Loi nº $79-18$ du 3 janvier 1979 sur les archives, JO 5 janvier 1979, p. 43. 
Loi n²-546 du 20 juin 1992 relative au dépôt légal, JO 23 juin 1992, p. 8167.

Loi n 2002-5 du 4 janvier 2002 relative aux musées de France, JO 5 janvier 2002, p. 305.

Loi nº2003-591 du 2 juillet 2003 habilitant le Gouvernement à simplifier le droit du 2 juillet 2003, JO 3 juillet 2003, p. 11192.

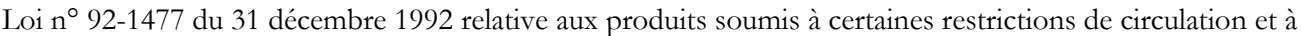
la complémentarité entre les services de police, de gendarmerie et de douane, disposition relatives aux biens culturels, JO 5 janvier 1993, p. 198.

Loi n $95-877$ du 3 août 1995 portant transposition de la directive 93/7 du 15 mars 1993 du Conseil des Communautés européennes relative à la restitution des biens culturels ayant quitté illicitement le territoire d'un État membre de la Communauté européenne, JO 4 août 1995, p. 11664.

Marché, J.-P., Rapport fait au nom de la commission de la production et des échanges sur le projet de loi ( ${ }^{\circ}$ 3076) relatif aux produits soumis a certaines restrictions de circulation, Assemblée nationale, première session ordinaire de 1992-1993, nº 3110.

Mission d'étude sur la spoliation des Juifs de France: rapport d'étape: janvier - décembre 1998, (1999).

Mission-Mattéoli, Mission d'étude sur la spoliation des Juifs de France - Rapport Général, (2000).

Ordonnance nº5-1546 du 13 juillet 1945 modifiée portant organisation provisoire des musées des BeauxArts.

Ordonnance $\mathrm{n}^{\circ}$ 2004-178 du 20 février 2004 relative à la partie législative du code du patrimoine, JO 24.2.2004.

Proposition de loi autorisant la restitution par la France de la dépouille mortelle de Saartjie Baartman, dite "Vénus hottentote" à l'Afrique du Sud, présentée par M. Nicolas About, Sénateur., (2001).

Richert, P., Rapport 177 (2001-2002) - fait sur la proposition de loi de M. Nicolas About autorisant la restitution par la France de la dépouille mortelle de Saartjie Baartman, dite "Vénus hottentote" à l'Afrique du Sud, (2002).

Sénat, Restitution de la Dépouille Mortelle de Saartjie Baartman à L'Afrique du Sud: Adoption des conclusions du rapport d'une commission, (2002a).

Sénat, Séance du 29 Janvier 2002, (Paris) (2002b).

Study Mission on the Spoliation of Jews in France: Mattéoli Commission Final Report (Mission d'etude sur la spoliation des Juifs de France. Rapport Général), (2000).

Troisième Chambre de la Cour des Comptes, Rapport confidentiel de la Cour des Comptes sur les oeuvres ou objets d'art saisis pendant l'Occupation en France (7 Décembre), (1995).

\section{Other Jurisdictions}

Aboriginal and Torres Strait Islander Heritage Protection Act (ATSIHPA), No. 79, 1984.

Bundesrückerstattungsgesetz (BRüG) 19 July 1957, BGBl. I-734.

Gesetz über die Einziehung volks- und staatsfeindlichen Vermögens vom 14. Juli 1933 (RGBl. I. S. 479).

Gesetz zur Wiederherstellung des Berufsbeamtentums vom 7 April 1933.

Military Government for Germany, U.S. Are of Control, Law No. 59: 'Restitution of Identifiable Property', Military Government Gazette (Germany. U.S. Zone. Issue G) No. 10, November 1947.

Military Government for Germany. U.S. Zone. Law No. 52: 'Blocking and control of property', Military

Government Gazette (Germany, U.S. Zone, issue A). 1 June 1946.

Museums (Aboriginal Remains) Act 1984 (Tas.) (No. 75 of 1984). 
The Native American Graves Protection and Repatriation Act (NAGPRA) 25 U.S.C.3001 - 13 (1994).

US Statute on the Importation of Pre-Columbian Monumental or Architectural Sculpture or Murals, 19 USCA \2091-2095 (1976).

Verordnung über den Einsatz des jüdischen Vermögens (RGBl. 1938 I. S. 1709) vom 3. Dezember 1938.

\section{International Case Law}

Anglo-Norwegian Fisheries Case ICJ Reports, 1951, p. 116.

Asylum Case (Colombia v. Peru), ICJ Reports, 1950, p. 266.

Case Concerning Delimitation of the Maritime Boundary in the Gulf of Maine Area (Canada/United States of America), ICJ Reports, 1984, p. 246.

Case Concerning Military and Paramilitary Activities in and against Nicaragua (Nicaragua v. United States of America), ICJ Reports, 1986, p. 14.

Chorzów Factory Case (Germany v. Poland) PCIJ, Series A, No. 17, 1928, p. 29.

International Military Tribunal (Nuremberg), Judgment and Sentences, 1st October 1946, (1947), The American Journal of International Law, 172-333.

Island of Palmas case (The Netherlands v. USA, 1928), 2 RIAA, p. 829.

Jurisdiction of the European Commission of the Danube between Galatz and Braila, Advisory Opinion, PCIJ, Series B, No. 14 (1927), p. 105.

Lotus Case PCIJ, Series A, No. 10, 1827, p. 18.

North Sea Continental Shelf cases, ICJ Reports, 1969, p. 3.

\section{EC Case Law}

46/67 Baubuis v. Netherlands [1977] ECR 5.

C- 252/84 Collector Guns v Hauptzollamt Koblenz [1985] ECR 3387.

Case 7/68 Commission v. Italy [1968] ECR 423.

Case 8/74 Procureur du Roi v. Dassonville [1974] ECR 837.

Case 68/76, Commission v. French Republic [1977] ECR 515.

Cases 51-54/71, International Fruit Company v. Produktschap voor Groenten en Fruit (No 2) [1971] ECR 1107.

\section{National Case Law}

\section{The Netherlands}

Appeal Court The Hague, 26 November 1987, KG 1988, 72.

ARRS 8 juni 1994, AB 1995/25, m.nt. Chris Backes.

Gerechtshof Den Haag, eerste civiele kamer, 16 december 1999, req. nr. 98/298.

Hoge Raad 16 maart 1990, NJ 1991, 575.

Hoge Raad 30 januari 1976, NJ 1976, 564.

Hoge Raad, 4 oktober 1996, NJ 1998, 397. 
HR 8 May 1998, 1st Chamber, Nos. 16.546, C97/025; NJ 1999, No.44, annotated by Th. M. de Boer. HR, 20 mei 1994, NJ 1995, 691, noot Brunner.

President District Court The Hague, 14 July 1987, KG 1987-315.

2007, Uitspraak op het hoger beroep van de Staatssecretaris van Onderwijs, Cultuur en Wetenschap, thans de Minister van Onderwijs, Cultuur en Wetenschap,

appellant, tegen de uitspraak in zaak no. AWB 04/4576 van de rechtbank Amsterdam van 7 juni 2006 $(200605289 / 1)$.

\section{The United Kingdom}

High Court (England and Wales), September, 9 1998, City of Gotha and Federal Republic of Germany v. Sotheby's and Cobert Finance S.A.

Dobson v North Tyneside Health Authority [1997] 1 WLR 596 (CA).

Forster v Dodd (1867) L.R. 3 QB 67.

Government of Islamic Repub. of Iran v. The Barakat Galleries Ltd., [2007] EWHC 705 (Q.B.D. 2007), March 29.

Haynes's Case (1614) 12 Co Rep 113; 77 ER 1389.

The High Court judgement of 24th May 2005 [2005] EWCH 1089 (Attorney-General v. Trustees of the British Museum).

Islamic Republic of Iran v. The Barakat Galleries Ltd [2007] EWCA Civ 1374, 21 December, [2008] 1 All E. R. 1177.

Kingdom of Spain v. Christie, Manson \& Woods Ldt. [1986] 1 W.L.R. 1120 (Ch.D).

Lancashire and Yorkshire Ry v MacNicholl, (1919) 88 L.J.K.B. 601.

R v Kelly and another [1999] QB 621 (CA).

R v Lynn (1788) 2 T.R. 733, 100 E.R. 394.

Snowden, decd, In re [1970] Ch 700.

Winkworth v. Christie, Manson \& Woods Ltd., [1980] 1 All ER 1121.

\section{France}

Administrative Tribunal of Rouen, December 27th, 2007, no. 702737, Prefect of Seine-Maritime: Juris-Data no. 2007-350713.

Cour de Cassation, 10.8.1841 (Cousin c. la liste civile et les héritiers de Mallié), p. 1841, I, 742, Bull.civ. 1841, no. 104.

Cour de Cassation, decision of 2.4.1963, AJDA 1963.

Richard de Vesvrotte v. l'État Dijon, Decision of 3.3.1886, D.P. 1887, II, 253.

Tribunal administratif de Paris, 9 avril 2004.

\section{Other Jurisdictions}

Attorney General of New Zealand v. Ortiz [1984] 1 A.C 1, 35 (H.L.). 
Bonnichsen v. United States, 969 F. Supp. 614 (D. Or. 1997).

Complaint, Weisshaus v. Union Bank of Switzerland, No. CV-96-4849 (E.D.N.Y. filed October 3, 1996).

Doodeward v. Spence (1908) 6 C.L.R. 406.

Goodman v. Searle, No. 96-C-6459 (N.D. Ill., filed Sept. 24, 1996).

Government of Peru v Benjamin Johnson 720 F. Supp. 810 (C.D. Cal. 1989).

Jelderks, J., Opinion and Order Civil No. 96-1481-JE United States District Court for the District of Oregon, (2002).

Krakauer v. Federal Republic of Germany, LG (District Court) Bonn, 10 134/92.

R v Sharpe (Sharpe's Case (1856-1857) Dears \& Bell 160; 169 ER 959.

Smith v Tamworth City Council (1997) 41 N.S.W.L.R. 680.

Solomon R. Guggenheim Found. v. Lubell, 569 N.E.2d 42, 431 (N.Y.1991).

United States v. McClain 545 F.2d 988 (5th Cir. 1977) and 593 F.2d 658 (5th Cir. 1979) (decided in two stages).

United States v. Portrait of Wally, a Painting by Egon Schiele, No. 99 Civ. 9940--MBM, 2002 WL 553532 (S.D.N.Y. Apr. 12, 2002). In re Application to Quash Grand Jury Subpoena Duces Tecum Served on Museum of Modern Art, 677N.Y.S.2d 872 (N.Y. 1998), rev'd, 719 N.E.2d 897 (N.Y. 1999).

US v. Schultz 178 F. Supp. 2d 445 (S.D.N.Y. 2002); 333 F.2d 393 (2nd Cir. 2003). 147 L.Ed 2d 891 (2004).

\section{Recommendations by Advisory Committees}

\section{The Netherlands}

Advisory Committee for Restitution Applications for Items of Cultural Value and the Second World War, Recommendation concerning the application for restitution of the Gutmann Collection (Case number RC 1.2), (2002).

Advisory Committee for Restitution Applications for Items of Cultural Value and the Second World War, Advice concerning the application for the restitution of: Koenigs collection (Case number RC 1.6), (2003a).

Advisory Committee for Restitution Applications for Items of Cultural Value and the Second World War, Annual Report, (2003b).

Advisory Committee for Restitution Applications for Items of Cultural Value and the Second World War, Recommendation Regarding the Application by Amsterdamse Negotiatie Compagnie NV in Liquidation for the Restitution of 267 Works of Art from the Dutch National Art Collection (Case number RC 1.15), (2005a).

Advisory Committee for Restitution Applications for Items of Cultural Value and the Second World War, Report regarding the Application by Amsterdamse Negotiatie Compagnie NV in Liquidation for the Restitution of 267 Works of Art from the Dutch National Art Collection (Case number RC 1.15), (2005b).

Advisory Committee for Restitution Applications for Items of Cultural Value and the Second World War, Annual Report, (2007).

Advisory Committee for Restitution Applications for Items of Cultural Value and the Second World War, Binding advice concerning the dispute over the restitution of: A Prayer before Supper by Jan Toorop from the estate of E. Flersheim (RC 3.45) currently in the possession of the Zeeuwse Museum Foundation, (2008). 
Commissie Museale Gedragslijn, Advies over de z.g. Groenlandse eskimo in het Westfries Museum te Hoorn, (1999).

Commissie Museale Gedragslijn, Advies inzake aanspraak op 'Het Gebed' van Jan Toorop van dr. W.A. Eberstadt, wonende te New York, (2000).

\section{The United Kingdom}

Spoliation Advisory Panel, Report in respect of a painting now in the possession of the Tate Gallery (HC 111), (2001), available at: http://www.culture.gov.uk/images/publications/galleriesspoliation.pdf (last visited 17 July 2009).

Spoliation Advisory Panel, Report in respect of a painting now in the possession of Glasgow City Council (HC 10), (2004), available at:

http://www.culture.gov.uk/images/publications/991224Spoliation.pdf (last visited 17 July 2009).

Spoliation Advisory Panel, Report in respect of a 12th century manuscript now in the possession of the British Library (HC 406), (2005), available at:

http://www.culture.gov.uk/images/publications/spreport_hc406.pdf (last visited 17 July 2009).

Spoliation Advisory Panel, Report in respect of a painting held by the Ashmolean Museum in Oxford (HC 890), (2006a), available at:

http://www.culture.gov.uk/images/publications/ReportoftheSpoliationAdvisoryPanel.pdf (last visited 17 July 2009).

Spoliation Advisory Panel, Report in respect of four drawings now in the possession of the British Museum, (2006b), available at: http://www.culture.gov.uk/images/publications/HC1052_SAPreport.pdf (last visited 17 July 2009).

Spoliation Advisory Panel, Report in respect of three drawings now in the possession of the Courtauld Institute of Art (HC 200), (2007a), available at:

http://www.culture.gov.uk/images/publications/SixthReportSAPHC200.pdf (last visited 17 July 2009).

Spoliation Advisory Panel, Report in respect of three Rubens Paintings now in the possession of the Courtauld Institute of Art, London (HC 63), (2007b), available at: http://www.culture.gov.uk/images/publications/reportsapH63nov2007.pdf (last visited 17 July 2009).

Spoliation Advisory Panel, Report in respect of pieces of porcelain now in he possession of the British Museum, London and the Fitzwilliam Museum, Cambridge, (2008), available at: http://www.official-documents.gov.uk/document/hc0708/hc06/0602/0602.pdf (last visited 17 July 2009).

Spoliation Advisory Panel, Report in respect of eight drawings now in the possession of the Samuel Courtauld Trust (HC 757), (2009), available at: http://www.culture.gov.uk/images/publications/429961_HC757_PROOF.pdf (last visited 17 July 2009).

\section{France}

Commission pour l'indemnisation des victimes de spoliations intervenues du fait des législations antisémites en vigueur pendant l'Occupation' (CIVS), Report to the Public on the Work of the Commission in 2006 (December 31, 2006). 


\section{2 | CONTESTED CULTURAL PROPERTY}

Commission pour l'indemnisation des victimes de spoliations intervenues du fait des législations antisémites en vigueur pendant l'Occupation' (CIVS), Report to the Public on the Work of the Commission in 2007 (December 31, 2007).

Commission pour l'indemnisation des victimes de spoliations intervenues du fait des législations antisémites en vigueur pendant l'Occupation' (CIVS), Report to the Public on the Work of the Commission in 2008 (December 31, 2008). 


\section{Samenvatting}

Dit proefschrift biedt een overzicht van, en reflectie op, de huidige wetten en rechtspraktijk op het gebied van de teruggave van cultuurbezit uit publieke (museum)collecties. Dit gebeurt aan de hand van twee casussen: de teruggave van nazi roofkunst en de omgang met menselijke resten.

Er is hernieuwde belangstelling voor kunst die door de nazi's werd geroofd, of die door vervolgden onder druk moest worden afgestaan. Terwijl in de jaren '60 de teruggave van geroofde kunst algemeen als afgerond werd beschouwd, is in de laatste twintig jaar een toegenomen gevoeligheid ontstaan voor de complexe gevolgen van de massale roof van kunstwerken door de nazi's. In Nederland heeft met name de zaak Goudstikker veel aandacht gekregen.

De teruggave van menselijke resten kreeg een belangrijk impuls door het aannemen van een federale wet in de VS in 1990. De wet geeft inheemse stammen het recht om menselijke resten en grafobjecten terug te eisen uit musea die geld van de federale overheid ontvangen. De meeste claims richten zich sindsdien op de teruggave van menselijke resten uit voormalige koloniën. Het is echter niet de eerste keer dat vertegenwoordigers van voormalige koloniën proberen objecten uit Westerse verzamelingen terug te halen. $\mathrm{Na}$ de dekolonisatie in de jaren ' 70 was er een eerste golf van pogingen om cultuurgoederen terug te eisen, zonder veel succes. Gezien de toename van internationale claims voor de teruggave van menselijke resten was het geen verrassing dat ook Nederlandse musea zulke verzoeken ontvingen. In 1998 ontving het Westfries Museum een verzoek tot teruggave van menselijke resten. Een verzoek aan het Rijksmuseum voor Volkenkunde resulteerde in 2005 in de overdracht van een Māori hoofd aan het Nieuw-Zeelands Te Papa museum.

Om een integraal beeld van het juridisch kader van de restitutieproblematiek te schetsen strekt het onderzoek zich uit over verschillende rechtsgebieden. Ten eerste is een analyse gemaakt van het internationaal publieksrecht met betrekking tot cultuurgoederen. $\mathrm{Na}$ het uiteenzetten van de bestaande rechtsregels met betrekking tot de bescherming en teruggave van cultuurgoederen, worden de twee casussen nader geïntroduceerd en in de context van reeds bestaande rechtsregels geplaatst. Hierop volgt een analyse van relevante 'soft law' instrumenten, zoals resoluties, declaraties en 'principles', die in reactie op de toename van restitutieverzoeken zijn aangenomen. Het beeld wordt gecompleteerd door aandacht te besteden aan de nationale wetgeving: verzoeken tot teruggave komen niet in een rechtsvrije ruimte terecht en juist objecten in museale collecties genieten vaak bijzondere bescherming als cultuurgoederen. Daarom 
worden de nationale systemen van Nederland, Frankrijk en het Verenigd Koninkrijk nader bestudeerd. De keuze voor deze jurisdicties berust op het samenspel van een aantal aspecten. Historisch gezien hebben deze landen een rol gespeeld in de opkomst van het instituut museum als zodanig. Verder hebben deze landen in het verleden grote koloniale rijken overzee bezeten, en waren zij betrokken in de Tweede Wereldoorlog en de gevolgen daarvan. De keuze voor deze landen berust echter niet alleen op deze overeenkomsten maar houdt ook rekening met de verschillende nationale benaderingen van de bescherming van cultuurgoederen. De kern van het onderzoek ligt in de analyse van de nationale (rechts-)praktijken: hoe wordt in de drie jurisdicties gereageerd op de toename in verzoeken tot restitutie? Welke oplossingen worden gevolgd en wat kan hieruit worden afgeleid voor de restitutieproblematiek meer in het algemeen?

De resultaten van het onderzoek worden hieronder per hoofdstuk samengevat. Ze worden gevolgd door gerichte aanbevelingen.

\section{HOOFDSTUK 1: VAN IUS PRAEDAE (RECHT OP PLUNDERING) NAAR ERFGOED VAN DE MENSHEID: TOENEMENDE BESCHERMING VAN CULTUURGOEDEREN ALS CULTUURBEZIT, MET RECHT OP TERUGGAVE, MAAR ZONDER TERUGWERKENDE KRACHT}

De analyse van het internationaal publieksrecht met betrekking tot de bescherming en teruggave van cultuurgoederen maakt duidelijk dat sinds de oudheid, toen het buitmaken van cultuurgoed gebruikelijk was, zich een geleidelijke ontwikkeling heeft voltrokken naar het erkennen van de verplichting tot teruggave van cultuurgoederen.

Deze verplichting is het verst voortgeschreden in de context van gewapende conflicten. Het van kracht worden in 1900 van het verbod op het buitmaken van cultuurgoederen, zoals vastgesteld in de Haagse Conventie van 1899, vormt een waterscheiding op dit terrein. Tegelijk met de invoering van het verbod op het buitmaken van cultuurgoederen ontstond de verplichting tot teruggave van objecten die in weerwil van het verbod geroofd werden. Deze verplichting vloeit voort uit de combinatie van het algemene beginsel van aansprakelijkheid voor schendingen van het internationaal recht en de voorrang van fysieke teruggave boven andere vormen van rechtsherstel. Dit primaat van fysieke teruggave, in het bijzonder met betrekking tot cultuurgoederen, werd bekrachtigd tijdens het proces van rechtsherstel na de Tweede Wereldoorlog. Bij het uitbreken van de oorlog in 1939 waren het verbod op roofbuit en de verplichting tot teruggave van cultuurgoederen niet alleen van toepassing op de aangesloten staten van de Haagse Conventies van 1899 en 1907, zij golden inmiddels evenzeer als regels van het gewoonterecht. Waar fysieke teruggave van cultuurgoederen niet mogelijk was als gevolg van vernietiging of vermissing, werden financiële vergoedingen toegekend. De nadruk op fysieke teruggave en de betaling van schadevergoeding waar fysieke teruggave niet mogelijk was, bleef niet beperkt tot de relatie tussen Duitsland en de voormalig bezette landen (externe restitutie). De geallieerde machten weken af van het beginsel van nationale soevereiniteit, waarnaar het 
binnenlands rechtsherstel uitsluitend een zaak van de Duitse staat zou zijn geweest. In plaats daarvan kozen zij ervoor om de reikwijdte en de uitgangspunten van teruggave ook toe te passen op de vormen van rechtsontzetting die hadden plaatsgevonden binnen Duitsland na de machtsovername door de nazi's in 1933 (interne restitutie). Het beleid voor de interne restitutie werd gebaseerd op de aanname dat alle transacties in de periode 1933-1945 waarbij een persoon was betrokken die behoorde tot een vervolgde groepering, beschouwd moesten worden als een confiscatie. Bovendien bestond dit recht op restitutie onafhankelijk van enig belang van een koper die een goed eventueel te goeder trouw verkregen zou kunnen hebben. Door zo te handelen schiepen zij nieuwe afdwingbare grondslagen voor de teruggave van cultuurgoederen

In 1954, toen het rechtsherstel in de nasleep van WO II nog volop gaande was, makkte de bescherming van cultuurgoederen tijdens gewapende conflicten een sprong voorwaarts als gevolg van de aanvaarding van de Haagse Conventie van 1954 met het bijbehorende (Eerste) Protocol. Dit Protocol is bijzonder relevant gebleken voor de teruggave van cultureel eigendom: in de eerste plaats omdat de verplichting tot teruggave van cultuurgoederen zich uitstrekt tot alle aangesloten staten in plaats van alleen tot de agressor-staat. Ten tweede is de verplichting niet beperkt tot een gelimiteerd tijdsbestek. Tenslotte geldt de verplichting los van enige rechtstitel die in de tussentijd zou kunnen zijn verworven door een bonafide koper. In dit opzicht weerspiegelt de verplichting van het Protocol de kenmerken van het restitutiebeleid van na de Tweede Wereldoorlog. Hoewel de Haagse Conventie van 1954 minder vergaand is waar het er om gaat aangesloten staten te verplichten tot restitutie van cultuurbezit, moet het belang ervan voor de bescherming van cultuurgoederen niet onderschat worden: als eerste internationaal verdrag dat uitdrukkelijk en uitsluitend gericht is op bescherming van cultuurgoederen droeg de Haagse Conventie van 1954 in algemene zin bij aan het gewicht dat werd gehecht aan de bescherming van cultuurbezit.

De bescherming van cultuurgoederen in vredestijd middels internationale verdragen begon in 1970 met de vaststelling van het UNESCO verdrag. In 1995 volgde het UNIDROIT verdrag. Het UNESCO verdrag 1970 verplicht aangesloten staten tot het teruggeven van cultuurgoederen die zijn gestolen uit een museum of een overeenkomstige instelling. Het verdrag is echter niet 'self-executive': het kan niet uit zichzelf nieuwe afdwingbare rechten op restitutie creëren maar is afhankelijke van de nationale implementaties. Het UNIDROIT verdrag 1995 is daarentegen wel 'selfexecutive' en schiep nieuwe afdwingbare rechten, die zowel betrekking hebben op teruggave van gestolen cultuurgoederen als op illegaal uitgevoerde cultuurgoederen. De voorzieningen die betrekking hebben op de terugkeer van illegaal geëxporteerde cultuurgoederen zijn echter aanzienlijk beperkter van reikwijdte dan de toegekende rechten op teruggave van gestolen cultuurgoederen. Landen blijven terughoudend waar het gaat om het erkennen van verplichtingen om illegaal uitgevoerde cultuurgoederen terug te geven. Deze terughoudendheid impliceert echter niet dat staten weinig belang stellen in de bescherming van het cultuurbezit van een ander land. Hoewel staten zich ervan onthouden vreemd publiekrecht toe te passen, blijkt uit mijn analyse algemene 
steun voor het teruggeven van cultuurgoederen aan landen van waaruit zij illegaal geëxporteerd zijn. Meer specifiek is een tendens te ontwaren om dergelijke zaken, voor zover het vreemde nationale rechtsstelsel het toelaat, te benaderen als zaken van gestolen cultuurbezit.

Hoewel de teruggave van objecten die in het koloniale tijdperk werden weggehaald strikt genomen behoort tot de categorie van objecten die in "vredestijd" werden weggehaald, heb ik bijzondere aandacht besteed aan de vraag of er mogelijk specifieke rechten bestaan die voorzien in teruggave van zulke goederen. De reden daarvoor is tweeledig: ten eerste heeft een aantal auteurs betoogd dat er een regel van gewoonterecht is ontstaan die voorziet in de teruggave van cultuurgoederen die zijn weggehaald uit voormalige koloniën. De tweede reden is gelegen in het feit dat het tijdperk waarin de grondslagen werden gelegd van de huidige collecties van menselijke resten samenvalt met het hoogtepunt van de Europese dominantie over de rest van de wereld.

Deze analyse betrof de vraag of en in hoeverre een rechtsbasis voor teruggave voortkomt uit de resoluties die zijn aangenomen binnen het kader van de UNESCO en uit de regels voor statenopvolging. Ook ben ik nagegaan of de omstandigheden van verwerving tijdens het koloniale tijdperk het mogelijk maken deze als een schending van internationaal recht te bestempelen. Geen van deze drie benaderingen heeft echter geleid tot de identificatie van een rechtsbasis die voorziet in teruggave van cultuurgoederen die zijn weggehaald in de koloniale tijd.

De laatste constellatie die ik onderzocht betreft de teruggave van cultuurgoederen aan een volk. Onderzoek leverde een aantal gevallen op waarin cultuurgoederen aan een volk werden geretourneerd. Deze gevallen van teruggave waren echter indirect van aard en vallen niet los te zien van het meer omvattende rechtsherstel dat volgde op de Tweede Wereldoorlog. Er is onvoldoende grond om te spreken van een algemene verplichting om cultuurgoederen aan een volk terug te geven.

Mijn conclusie luidt dat uitdrukkelijke rechten op teruggave van cultuurgoederen nog steeds in hoofdzaak beperkt blijven tot situaties die kunnen worden omschreven als gewapende conflicten. Waar het niet gaat om gewapende conflicten zijn landen terughoudend bij het scheppen of erkennen van rechtsgrondslagen voor teruggave van cultuurgoederen. Dit betekent overigens niet dat zij ook gekant zijn tegen het teruggeven van cultuurgoederen.

\section{HOOFDSTUK 2: HET ONTSTAAN VAN DE HUIDIGE CLAIMS EN HUN POSITIE VANUIT JURIDISCH PERSPECTIEF}

De bevindingen in Hoofdstuk 1 aangaande de terughoudendheid van staten om nieuwe rechtsgronden te creëren voor de teruggave van cultuurgoederen, hoewel zij sympathie koesteren voor de achterliggende motieven, gaan evenzeer op voor de twee detailonderzoeken naar nazi roofkunst en de omgang met menselijke resten in publieke collecties. 


\section{Nazi roofkunst}

Met betrekking tot nazi roofkunst blijkt dat huidige claims niet langer gebaseerd kunnen worden op de naoorlogse rechten op terugvordering. Hoewel goederen nog steeds teruggevorderd kunnen worden waar het een geschil tussen staten betreft, kunnen natuurlijke (of rechts)personen zich niet langer beroepen op de rechten zoals die bestonden, dan wel gecreëerd werden na afloop van de Tweede Wereldoorlog, vanwege het verstrijken van de aanvraagtermijnen. Wat betreft de beginselen, resoluties, en verklaringen die zijn aangenomen vanaf het einde van de jaren ' 90 , met de Washington Principles van 1998 als voornaamste, bleek dat deze instrumenten, vanwege hun karakter van 'soft law', geen nieuwe afdwingbare rechten hebben voortgebracht. De relevantie van deze instrumenten ligt dan ook voornamelijk in het toegenomen bewustzijn van dit probleem en in het voorbereiden van oplossingen op nationaal niveau. De voorgestelde oplossingen zijn te verdelen in twee categorieën. De eerste categorie bestaat uit oplossingen die gericht zijn op het doen herleven van al bestaande wettelijke normen. Oplossingen in deze categorie zijn erop gericht de obstakels aan te pakken die maken dat eisers zich niet kunnen baseren op eerder in het leven geroepen wettelijke grondslagen. Zij richten zich in het bijzonder op juridische instituten als verkrijgende en vernietigende verjaring, en verwerving te goeder trouw. De 'soft-law' instrumenten deden geen suggesties voor invoering van nieuwe rechtsgrondslagen voor de teruggave van nazi roofkunst. Ook oplossingen die gericht zijn op het wegnemen van obstakels als het verbod op het verwijderen of exporteren van objecten uit publieke collecties horen in deze categorie thuis. De tweede categorie van oplossingen richt zich niet op de verbetering van de positie van eisers door juridische hervormingen, maar draagt andere middelen aan om teruggave te bewerkstelligen. Deze zijn in hoofdzaak gericht op het beschikbaar maken van bewijsmateriaal ten faveure van indieners van claims, en bepleiten het instellen van alternatieve manieren om geschillen te beslechten. Wat dit laatste betreft, bepleiten de instrumenten de instelling van bijzondere commissies die claims kunnen onderzoeken en zich richten op "redelijke en billijke" oplossingen in plaats van een puur positiefrechtelijke aanpak. De vraag wat onder "redelijk en billijk" verstaan moet worden, wordt echter niet verder uitgewerkt. In vergelijking met de bevindingen in het eerste hoofdstuk valt op dat niet wordt gerefereerd aan de mogelijkheid dat (de erfgenamen van) de voormalige eigenaar in de periode na WO II financiële compensatie zouden kunnen hebben ontvangen.

\section{Menselijke resten}

Wat betreft de omgang met menselijke resten blijkt uit het onderzoek dat deze voldoen aan de kenmerken van het begrip van cultuurgoederen en dus vallen onder de reikwijdte van internationale verdragen inzake de bescherming van cultuurbezit. Als gevolg daarvan zijn menselijke resten, met name in publieke collecties, beschermd tegen diefstal en illegale uitvoer, wat inhoudt dat zij na een mogelijke verwijdering teruggebracht dienen te worden naar het land van herkomst. Het bestaande kader van het internationaal publiekrecht voorziet daarentegen niet in rechten op het terugeisen 
van menselijke resten die in het verleden verworven zijn. Deze bevinding gaat ook op voor de 'soft law' instrumenten die zijn aangenomen door de verschillende fora die zich hebben uitgesproken over de teruggave van menselijke resten. Dit ondanks het feit dat de instrumenten meer belang toekennen aan teruggave van menselijke resten dan aan de teruggave van cultuurgoederen in het algemeen. Het Vermillion Accord on Human Remains, de Mataatua Declaratie en de ICOM Code komen niet in aanmerking als normstellende instrumenten omdat zij niet zijn aangenomen op basis van bevoegdheden tot verdragssluiting, terwijl aan de VN-verklaring over de rechten van inheemse volken als verklaring de van staten vereiste wil om gebonden te worden ontbreekt. Alleen de UNESCO-conventie voor de bescherming van immaterieel cultureel erfgoed zou in een dergelijk recht kunnen hebben voorzien. De relevantie van deze instrumenten is dan ook met name gelegen in het doen van suggesties voor toekomstige regelgeving. De instrumenten suggereren twee wegen waarlangs op nationaal niveau oplossingen kunnen worden gezocht: een zuiver wettelijke, die bestaat uit het scheppen van afdwingbare rechten zoals in de Amerikaanse federale wet ter bescherming en teruggave van graven van 'native Americans' (NAGPRA), en alternatieve oplossingen in de vorm van billijke en transparante besluitvormingsprocedures en het beschikbaar maken van (betere) inventarissen van collecties.

\section{Overeenkomsten en verschillen tussen nazi roofkunst en menselijke resten}

Een vergelijking van door internationale fora aangedragen oplossingen voor recente claims op teruggave van nazi roofkunst en van menselijke resten leert het volgende. Alle instrumenten hebben gemeen dat zij geen nieuwe grondslag voor teruggave scheppen. Als 'soft law' instrumenten reiken zij alleen waarden, ideeën en voorstellen aan die zich tot (inter)nationale rechtsregels zouden kunnen ontwikkelen. Voorstellen met betrekking tot menselijke resten benadrukken vooral het belang van het scheppen van nieuwe rechtsgrondslagen voor teruggave, terwijl bij nazi roofkunst de nadruk ligt op alternatieve manieren om geschillen te beslechten. Waar instrumenten met betrekking to nazi roofkunst wetswijzigingen voorstellen gaat het niet om de creatie van nieuwe rechtsgronden. Dit betekent dat zowel alternatieve oplossingen als wetswijzigingen op het gebied van nazi roofkunst zoeken naar wegen om de juridische gevolgen van het verstrijken van de tijd ongedaan te maken. Deze bevinding is begrijpelijk tegen de achtergrond van het internationaal publieksrecht: gezien de verreikende inspanningen om geroofde kunstwerken terug te geven tijdens de periode van rechtsherstel na WO II, inclusief de invoering van nieuwe wettelijke normen, vinden huidige pogingen een goed uitgangspunt in deze rechten op teruggave uit het verleden. Met betrekking tot menselijke resten ontbreekt een vergelijkbare grondslag, zodat de roep om het creëren van nieuwe juridische grondslagen voor teruggave de enige optie is.

\section{HOOFDSTUK 3: HET JURIDISCH KADER}

Uit onderzoek van de nationale regels die op publieke collecties van toepassing zijn, blijkt dat teruggave onmogelijk gemaakt kan worden door regelgeving die voorziet 
in de bescherming van voorwerpen in publieke collecties. Zowel het Britse als het Franse bestel worden gekenmerkt door een algemeen verbod op de vervreemding van goederen uit publieke collecties. Waar echter het verbod op vervreemding van objecten uit Engelse nationale collecties voortkomt uit beperkingen van de rechten van de eigenaar, geldt voor de Franse situatie dat het verbod voortkomt uit res extra commercium wetgeving (wetgeving waarna bepaalde goederen aan het handelsverkeer worden onttrokken). Anders gesteld, terwijl het verbod voor Engelse nationale collecties voortkomt uit externe factoren, komt de onmogelijkheid om goederen over te dragen uit Franse publieke collecties voort uit een inherente karakteristiek van die goederen zelf. Dit inherente kenmerk is echter niet absoluut. Het kan worden gewijzigd middels de procedure tot declassificatie die nu is geregeld in Artikel L. 451-5 CHC (de Franse wet op het cultureel erfgoed). Dit betekent dat vanuit theoretisch oogpunt het verbod op vervreemding van goederen uit Franse publieke collecties minder absoluut is dan zijn Britse tegenhanger, omdat het voorziet in een achterdeur om dit verbod ongedaan te maken. Uit praktisch oogpunt is het Franse verbod even ongenaakbaar als het Britse, omdat alle maatregelen ontbreken voor de invoering van Artikel L. 451-5 CHC. Wat betreft de Nederlandse situatie blijkt uit analyse dat er geen formele beperkingen bestaan voor het vervreemden van objecten uit publieke collecties. In een beperkt aantal gevallen moet vervreemding echter als uitgesloten beschouwd worden op grond van toepassing van de criteria van de Wet tot behoud cultuurbezit in analogie.

Behalve de algemene verbodsbepalingen met betrekking tot vervreemding kunnen er nog verdergaande beperkingen van kracht zijn voor goederen die door schenking of legaat verworven zijn. De onmogelijkheid om deze objecten te declassificeren komt voort uit de wens om toekomstige schenkingen en legaten niet te ontmoedigen. Opnieuw is het Franse stelsel het meest drastisch in het beperken van de mogelijkheden om een object te vervreemden. Volgens Artikel L. 451-7 CHC kunnen objecten die zijn verworven via schenking of legaat niet gedeclassificeerd worden. Terwijl Nederland en Engeland ook beperkingen kennen voor het vervreemden van objecten die door schenking of bij legaat zijn verworven, komen bijkomstige beperkingen van de mogelijkheden van vervreemding alleen dan voor wanneer deze expliciet of impliciet zijn gestipuleerd in de termen van de schenking of de testamentaire beschikking. Maar zelfs wanneer de bepalingen van de overeenkomst vervreemding uitsluiten of beperken, maken zij een voorgenomen teruggave niet volstrekt onmogelijk. Wat betreft Engeland is het mogelijk dat de statuten van de desbetreffende nationale collectie uitdrukkelijk voorzien in de mogelijkheid om afspraken baserend op 'trusts' en andere niet-statutaire verplichtingen terzijde te schuiven. In Nederland voorziet de zogenaamde imprévisionregeling van Artikel 6:258 Burgerlijk Wetboek in de mogelijkheid om gedoneerde objecten te vervreemden. Wat betreft testamentaire bepalingen heeft de hervorming van het erfrecht in 2003 de mogelijkheden verruimd om toepasselijke bepalingen te wijzigen, met inbegrip van beperkingen op het vervreemden.

Op het gebied van uitvoerbepalingen heeft het onderzoek geen onoverkomelijke obstakels aan het licht gebracht voor teruggave van een object aan een buitenlandse 
eiser. Uitvoerbepalingen kunnen teruggave wel binden aan administratieve vereisten zoals een exportvergunning.

\section{HOOFDSTUK 4: NATIONALE OPLOSSINGEN INZAKE TERUGGAVE VAN NAZI ROOFKUNST EN MENSELIJKE RESTEN; VERSCHILLENDE ETHISCHE PREMISSEN}

Dit hoofdstuk geeft een overzicht van de verschillende nationale benaderingen, die geen wetswijziging blijken in te houden maar uiteenlopende oplossingen aandragen binnen het bestaande juridische kader. De enige uitzondering hierop is de Britse "Human Tissue Act" van 2004, met name sectie 47, waardoor het vervreemden van menselijke resten uit nationale collecties mogelijk wordt gemaakt, iets wat voorheen was uitgesloten door de regelgeving.

Waar het gaat om teruggave van nazi roofkunst ligt het zwaartepunt bij de instelling van commissies die over individuele gevallen adviseren. Deze commissies blijken in meerdere of mindere mate het beleid inzake teruggave van kunstwerken vorm te geven. In het Verenigd Koninkrijk werkt het Spoliation Advisory Panel op basis van zeer algemene richtlijnen; de Nederlandse Restitutie Commissie werkt op basis van aanzienlijk nauwer omschreven beleidslijnen, maar blijkt toch aanzienlijke invloed te hebben op de uitvoering van het beleid.

Er zijn geen adviescommissies ingesteld om aanbevelingen te doen over de teruggave van menselijke resten. Oplossingen op dit terrein gaan uit van niet-bindende richtlijnen voor de besluitvorming binnen museale instellingen. Hoewel deze richtlijnen benadrukken dat menselijke resten met respect en gevoel behandeld moeten worden, pleiten zij niet noodzakelijkerwijs voor teruggave. In plaats daarvan bieden zij handreikingen voor een goedgeïnformeerde en afgewogen besluitvorming.

De instelling van adviescommissies voor nazi roofkunst enerzijds, en niet-bindende richtlijnen voor teruggave van menselijke resten anderzijds, lijkt te zijn voortgekomen uit een verschillende onderliggende visie op beide zaken. De teruggave van nazi roofkunst wordt beschouwd als een ethische imperatief die in abstracto geldig is. Deze imperatief strekt zich zelfs uit tot gevallen waarin de eiser in het verleden al herstelbetaling heeft ontvangen. Een overeenkomstige in abstracto geldige imperatief tot teruggave van menselijke resten wordt niet als zodanig gepercipieerd. Het loutere feit dat deze overblijfselen restanten zijn van ooit levende mensen wordt net zo min als de omstandigheden waarin deze resten zijn verworven beschouwd als een dwingende reden om ze terug te geven. In plaats daarvan wordt gekozen voor oplossingen die een optimaal besluitvormingsproces in specifieke gevallen mogelijk maken, zonder de balans bij voorbaat te laten doorslaan naar teruggave. Hoewel op deze twee gebieden sprake is van grote overeenkomsten voor wat betreft de noodzaak van sensibiliteit, herkenning en respect, gaan de huidige ontwikkelingen op het gebied van teruggave uit van verschillende ethische vooronderstellingen. 


\section{AAnBEVELINGEN}

\section{HeROPENING VAN HET DEBAT OVER DE REDELIJKE EN BILLIJKE OMGANG MET NAZI ROOFKUNST}

Nadat in de jaren '70 en '80 er nauwelijks aandacht bestond voor de kunstroof door de nazi's, is men zich nu algemeen bewust van het feit dat er lang gehandeld is in kunst die door nazi's was geroofd of onder druk verkocht zonder dat er aandacht werd besteed aan deze herkomst. Er is grondig onderzoek verricht naar de geschiedenis van kunstwerken en naar het lot van de eigenaren voor en tijdens de Tweede Wereldoorlog, maar de naoorlogse ontwikkelingen hebben verhoudingsgewijs weinig aandacht gekregen. In het huidige debat wordt te weinig aandacht besteed aan het gegeven dat na WO II regels zijn opgesteld voor financiële compensatie in gevallen waar fysieke teruggave onmogelijk was. Dit leidt tot een eenzijdige benadering. Hoewel men zou kunnen argumenteren dat het redelijk en billijk is dat kunstwerken altijd worden teruggegeven, ongeacht al ontvangen herstelbetalingen, mag dit niet zonder meer worden aangenomen maar dient dit onderwerp te zijn van een publiek debat waarin alle relevante aspecten, inclusief naoorlogse schadeloosstelling, worden meegewogen.

Een deel van de verklaring voor deze eenzijdigheid kan worden gevonden in de wijze waarop tegenwoordig onderzoek naar de herkomst ('provenance') van kunstwerken wordt verricht. In het verleden werd de geschiedenis van een kunstwerk in de eerste plaats onderzocht om de authenticiteit van een werk te helpen vaststellen: in het ideale geval slaagde de onderzoeker er in een ononderbroken keten vast te stellen van de huidige eigenaar tot de kunstenaar zelf, als ultiem bewijs dat het werk door de kunstenaar eigenhandig was gemaakt. Tegenwoordig ligt de nadruk in herkomstonderzoek op het vaststellen van de lotgevallen van een kunstwerk in de jaren 1933-1945. Ongeachte de grote deskundigheid van de onderzoekers kent het provenance onderzoek twee problematische aspecten: er is geen heldere methodologie, en onderzoek wordt meestal uitgevoerd op grond van een particulier belang. Als gevolg hiervan wordt in dit onderzoek niet genoeg aandacht besteed aan de naoorlogse geschiedenis: de bevinding dat een werk afkomstig is uit roof besluit het onderzoek.

Mijn eerste aanbeveling luidt daarom het debat te heropenen over de vraag wat redelijk en billijk is en welke relevantie er moet worden toegekend aan al door de naoorlogse Duitse overheid betaalde financiële compensatie. Dit is natuurlijk niet alleen een taak voor onderzoekers van de herkomst van kunstwerken, maar vooral voor academici, de media en het openbaar debat. Het belang van zo'n debat ligt niet alleen in het voorkomen van een latere terugslag die de legitimiteit van beleid inzake teruggave zou aantasten, maar ook in het verbreden van het palet van mogelijke remedies. Een veelgeprezen maar zelden toegepaste oplossing bestaat eruit dat de eiser financieel schadeloos wordt gesteld terwijl het werk in de publieke collectie blijft, waar een bijschrift het publiek herinnert aan de geschiedenis van het werk en het lot van de voormalige eigenaren. Zulke bijschriften vormen een indringende herinnering aan de 
gruwelen van het nazi-regime die ook zichtbaar zal blijven wanneer het debat over roofkunst is geluwd.

\section{a) Herziening van de 1998 'Washington Principles'}

Om dit publieke debat te stimuleren, stel ik een herziening voor van de richtlijnen inzake door nazi's geconfisqueerde kunst zoals neergelegd in de 'Washington Principles' van 1998. Deze 'principles' zijn het meest invloedrijke 'soft law' instrument op dit gebied; zij waren van doorslaggevende invloed op het beginnen van rechtszaken om kunstwerken uit publieke museumcollecties te laten teruggeven aan voormalige eigenaren of hun erfgenamen.

De revisie van de 'Washington Principles' zou de volgende wijzigingen moeten omvatten. Ten eerste zou de titel moeten veranderen van 'Washington Conference Principles on Nazi-Confiscated Art' in 'General Principles on Nazi-Spoliated Art', om zo de huidige praktijk te codificeren, die zich niet beperkt tot kunstwerken die door de nazi's zijn geconfisqueerd maar ook onvrijwillige verliezen omvat die beschouwd moeten worden als door het nazi regime bespoedigd. Ten tweede moeten de 'principles' betreffende documenten en archieven die informatie kunnen bevatten over nazi roofkunst ook van toepassing zijn op de naoorlogse processen van rechtsherstel; dit heeft ook betrekking op de middelen en het personeel die ter beschikking worden gesteld om de geschiedenis te ontsluiten. Ten derde zouden de 'principles' die vragen om een redelijke en billijke oplossing moeten oproepen tot een onvooringenomen afweging van de feiten en omstandigheden van individuele gevallen, daaronder begrepen ook de ontvangen herstelbetalingen uit het verleden.

\section{Menselijke ReSten: OPEN Dialoog En COMMON SENSE}

Het onderzoek leidt op dit terrein niet tot specifieke aanbevelingen, aangezien de richtlijnen die in verschillende rechtsgebieden worden gehanteerd te uiteenlopend en te vaag zijn. De conclusie luidt daarom dat open dialoog en common sense de beste raadgevers zijn voor publieke collecties die worden geconfronteerd met claims tot teruggave van menselijke resten. Bij de behandeling van zulke claims is het belangrijk de eisers serieus te nemen en zich bewust te zijn van de relevantie van het hele proces, in plaats van de enkele beslissing of de menselijke resten al dan niet teruggegeven worden. Het ideaal is hierbij dat de eisers betrokken worden bij het opstellen van de criteria op basis waarvan besloten wordt. Zo wordt het proces een werkelijke dialoog en een leerproces voor beide partijen. Het handelen van publieke collecties zou niet mogen worden gemotiveerd door de angst om een stuk uit de collectie te verliezen, maar door de wens om meer te leren van de cultuur van de verzoekende partij. Hoewel het overdreven is te stellen dat een claim op teruggave bijdraagt aan de bescherming zoals bedoeld in het UNESCO verdrag ter bescherming van immaterieel cultureel erfgoed van 2003, zal een dialoog met indieners van een claim ongetwijfeld bijdragen aan een grotere kennis van begrafenisceremonieën en uitvaartrituelen. Dit leerproces hoeft niet beperkt 
te blijven tot de opvatting van de specifieke cultuur inzake de doden maar kan verder de vorm aannemen van toekomstige samenwerking in onderzoek en tentoonstellingen.

\section{GEWEKTE VERWACHTINGEN WAARMAKEN DOOR TERUGGAVE MOGELIJK TE MAKEN}

Uit het onderzoek blijkt duidelijk dat er een kloof blijft bestaan tussen de oplossingen zoals voorgesteld in de 'soft law' instrumenten en de wettelijke mogelijkheden om deze oplossingen door te voeren. Dit geldt in het bijzonder voor het Verenigd Koninkrijk en Frankrijk, waar publieke collecties worden beschermd door een algemeen verbod om objecten te vervreemden. In het Verenigd Koninkrijk heeft sectie 47 van de Human Tissue Act van 2004 als uitzondering de teruggave van menselijke resten mogelijk gemaakt, maar vergelijkbare wetgeving die betrekking heeft op nazi roofkunst ontbreekt tot op de dag van vandaag. Als gevolg daarvan kunnen in het Verenigd Koninkrijk aanbevelingen van het Spoliation Advisory Panel om cultuurgoederen terug te geven niet worden uitgevoerd. Alle hoop is op dit moment gevestigd op een initiatiefwet (Private Member's bill), de Holocaust (Stolen Art) Restitution Bill, die bij afsluiting van deze studie nog niet definitief aangenomen was. Mocht deze wet niet worden aangenomen, dan wordt de Britse regering aanbevolen snel te handelen om ten langen leste wetgeving in te voeren die teruggave van nazi roofkunst mogelijk maakt.

Wat Frankrijk betreft, heeft de voornaamste aanbeveling betrekking op de regeling voor declassificatie zoals ingevoerd onder de Wet op de Franse Musea van 2002. In onze context is de regeling in het bijzonder relevant voor de teruggave van menselijke resten uit collecties die zijn aangemerkt als Musée de France. Hij is minder toepasselijk voor nazi roofkunst omdat de werken die als zodanig zijn aangemerkt in de inventarisatie van de Musées Nationaux Récupération (MNR-collectie) geen eigendom zijn geworden van de musea waarin zij bewaard worden. Hoewel de invoering van een regeling voor declassificatie als zodanig geprezen verdient te worden, bleek uit het onderzoek dat deze procedure nog niet in praktijk is gebracht. Frankrijk dient dus te zorgen voor de implementatie van deze regeling door criteria op te stellen die teruggave van cultuurgoederen effectief mogelijk maken. Bovendien zou de Franse wetgever moeten overwegen het vervreemden van objecten die zijn verworven bij schenking of legaat te vergemakkelijken. Het categorische verbod hierop is buiten proportie. Een laatste aanbeveling betreft nazi roofkunst in Franse publieke collecties die geen deel uitmaken van de MNR-collectie. De huidige inspanningen zijn exclusief gericht op de goederen die na de oorlog officieel zijn teruggevorderd door Frankrijk en nu deel uitmaken van de MNR-collectie en op objecten die nog steeds niet teruggevonden zijn. Het is echter voorstelbaar dat ook geroofde objecten in de Franse publieke collecties terechtgekomen zijn die niet tot een van deze categorieën behoren. Dit betekent, nogmaals, dat een effectieve regeling voor declassificatie onder de Franse wet op het cultureel erfgoed van kracht dient te worden. 


\section{NEEM DE BESCHERMING VAN OBJECTEN IN PUBLIEKE COLLECTIES SERIEUS}

Voor Nederland gelden andere aanbevelingen. Omdat in dit land het beheer van publieke collecties liberaal is, bestaan er weinig problemen die betrekking hebben op het vervreemden van goederen uit publieke collecties. In tegenstelling tot het Verenigd Koninkrijk en Frankrijk zou Nederland juist moeten overwegen de bescherming van publieke collecties te versterken. De reikwijdte van de Wet tot Behoud Cultuurbezit is beperkt tot cultuurgoederen in privébezit. Voor publiek cultuurgoed geldt de wet slechts in analogie. In het licht van de Mondriaan-zaak en de toenemende druk op musea om zich als culturele ondernemers op te stellen, zou de Nederlandse wetgever moeten overwegen het toepassingsgebied van de Wet tot Behoud Cultuurbezit uit te breiden tot publiek cultuurbezit. Inspiratie zou kunnen worden gevonden in de recente veranderingen in de Duitse Wet tot voorkoming van de uitvoer van cultuurgoed, die sinds 2007 ook cultuurgoederen in publiek bezit omvat, en in het Vlaams Topstukkendecreet van 2003.

Een tweede aanbeveling heeft betrekking op de adviescommissies in de museumsector, die bij ontstentenis van wetgeving een regulerende taak vervullen. Er is momenteel een aantal adviserende of ethische commissies actief, en uit het onderzoek is gebleken dat hun aanbevelingen ver uiteenlopen en elkaar soms zelfs tegenspreken. Aangezien de waarde van de adviezen van zulke commissies berust op hun moreel gezag zijn conflicterende adviezen onwenselijk. Ook betekent het bestaan van een veelheid aan commissies dat iedere commissie minder gevallen ter behandeling krijgt, en dus minder gelegenheid heeft om zijn oordelen te toetsen en te verfijnen. Het verdient daarom aanbeveling de ethische commissie en adviescommissies die actief zijn op het gebied van publieke museumcollecties in Nederland samen te voegen.

\section{Relevantie voor bescherming en teruggave van cultuurgoederen in het algemeen}

Het onderzoek naar deze twee specifieke casussen roept de vraag op of zij een meer algemene relevantie hebben, vooral voor objecten die zijn weggehaald in vredestijd, en dan met name voor het van kracht worden van het UNESCO verdrag 1970 en het UNIDROIT verdrag 1995. Dit omvat ook de cultuurgoederen die in het koloniale tijdperk zijn weggehaald.

Als eerste kan worden vastgesteld dat de toegenomen aandacht voor nazi roofkunst en voor menselijke resten niet "de sluizen heeft opengezet" voor het teruggeven van alle betreffende goederen uit publieke collecties. Het is onjuist te concluderen dat teruggave van een bepaald aantal werken uit deze groepen zou kunnen leiden tot de verplichting om alles terug te geven, zoals door museumdirecties en conservatoren soms is beweerd. Maar de ontwikkelingen op de terreinen van nazi roofkunst en menselijke resten wijzen wel op een heroriëntatie die niet beperkt is tot een heroverweging van de wettigheid van een verwerving, maar die ook leidt tot een nieuwe afweging van de vraag in hoeverre de voortgezette aanwezigheid van objecten in een collectie nog gepast is. 
Ten tweede: er is weinig tot geen kans op invoering van een internationaal bindend verdrag tot teruggave van cultuurgoederen die zijn verworven voorafgaand aan de regulering van de kunst- en antiekhandel in 1970. De aarzeling om nieuwe wettelijk afdwingbare rechten te scheppen viel al af te leiden uit de moeizame totstandkoming en ratificatie van het UNESCO verdrag 1970 en het UNIDROIT verdrag 1995. Zelfs in de verhoudingsgewijs goed afgebakende gevallen van nazi roofkunst en van menselijke resten is gebleken dat noch in de internationale fora, noch in nationale wetgeving er nieuwe afdwingbare rechten op teruggave zijn gecreëerd. Een afdwingbare regeling voor teruggave van cultuurgoederen meer in het algemeen is onvoorstelbaar: het onderwerp is te complex en te gevoelig om op nationaal of internationaal niveau in positieve rechtsregels te worden geformuleerd. De voormalige koloniale machten vermijden het geven van signalen die zouden kunnen suggereren dat hun koloniaal verleden onwettig is geweest, uit angst om zich bloot te stellen aan beschuldigingen door de internationale gemeenschap en om eventueel enorme bedragen aan herstelbetalingen te moeten spenderen.

Enerzijds is dit te betreuren, omdat heldere juridische regelingen wettelijke zekerheid bieden. Anderzijds moet de functie van zulke regelingen niet worden overschat: de prognose dat er geen wettelijk bindend verdrag zal komen voor de teruggave van cultuurgoederen die zijn weggehaald voordat de UNESCO en UNIDROIT verdragen van kracht werden, betekent niet dat er geen cultuurgoederen teruggegeven zullen worden. Uit de bestudeerde casussen bleek het grote belang van alternatieve oplossingen als het instellen van adviescommissies, hulp bij het vergaren van bewijs, en concessies inzake de te hanteren bewijsstandaard. Zulke oplossingen, het resultaat van 'soft law', hebben bijgedragen aan een klimaat dat positiever staat tegenover teruggave. Het invoeren van 'soft law' moet niet als ineffectief van de hand worden gewezen als het gaat om teruggave van cultuurgoederen uit publieke collecties in het algemeen.

Tenslotte laten de omgang met nazi roofkunst en met menselijke resten zien dat er veranderingen plaatsvinden in de ethiek van het verzamelen. Zelfs indien conservatoren, particuliere verzamelaars en kunsthandelaren weinig belang toekennen aan de vraag of goederen illegaal zijn opgegraven of uitgevoerd, wordt de relevantie van provenance steeds groter. Onderzoek naar provenance van cultuurgoederen is een belangrijk instrument om het opnemen van illegaal verhandelde objecten in publieke collecties te voorkomen en kan op de lange duur bijdragen aan het terugdringen van de illegale handel.

Het verleden vormt het heden en de toekomst, en als wij de thesen over de filosofie van de geschiedenis van Walter Benjamin volgen, is het het beeld van geknechte voorouders, niet het ideaal van vrijgemaakte kleinkinderen, dat een onderworpen klasse in verzet brengt. Benjamins filosofie daagt ons uit de geschiedenis zo onder ogen te zien dat onrecht uit het verleden niet verwatert, maar dient om het heden en daarmee de toekomst anders vorm te geven. Om tegen deze taak opgewassen te zijn dienen we ons niet slechts open te stellen voor teruggave in de strikte zin, maar ook voor 
546 | CONTESTED CULTURAL PROPERTY

samenwerking bij het uitlenen van cultuurgoederen en bij het samenstellen van reizende tentoonstellingen. 


\section{Acknowledgments}

Zeile für Zeile

Meine eigene Wüste

Zeile für Zeile

Mein Paradies

Marie Luise Kaschnitz

These lines very well capture my experience of writing this dissertation. At times, the research and writing process came close to a paradisiacal state. More often, however, it felt like going through a dry spell. Luckily, I was never alone and I would like to express my sincere gratitude to those people who have been crucial during my past years as $\mathrm{PhD}$ researcher and as a person more in general.

First of all, I am very much indebted to my supervisors Hildegard Schneider and René de Groot - "meine Doktoreltern". At times, I had longed for less freedom in pursuing my research but with hindsight I am grateful for the path I was ushered down. I am immensely grateful for their enthusiasm for the subject of my research and their guidance that was and is characterized by continuous trust, support and hospitality. Discussing the case of human remains over dinner at their house is one my slightly bizarre but very fond memories.

I am grateful to my colleagues at the faculty, especially at the department of International and European Law, METRO, and the department of Foundations and Methods for their support and collegiality. Also, I would like to thank the people "behind the scenes", in particular the staff of the Maastricht University Library whose helpfulness went beyond the call of duty. Furthermore, I would like to thank the faculty for allowing me to take two years leave from my $\mathrm{PhD}$ position to seize the opportunity of complementing my research with practical experience from working as researcher in the Historic Claims Department at the Art Loss Register, London. Working in the art market in close collaboration with auction houses, dealers, art fairs was a fantastic experience and contributed to my research in many (un)foreseen ways. I am grateful to my colleagues at the Art Loss Register, in particular to Julian Radcliffe, Sarah Jackson and Victorine Stille, for showing me the tricks of the trade and the techniques of provenance research.

Further to direct colleagues my (academic) experience has been enriched by academics and practitioners. In no particular order I am grateful to Norman Palmer, 
Tony Doubleday, Steven Engelsmann, Susan Legêne, Sabine Gimbrère, Margot Llompert, Jan Hladík, Sophie Vigneron, Julia El-Bitar, Lucy Lambrecht, Marie Cornu, Thomas Mertens, and Lucky Belder.

A person deserving special mentioning is Ida Wendt with whom I shared a lot more than a room, countless passages from our works in progress, and the ups and downs that come with writing a dissertation. Every $\mathrm{PhD}$ candidate deserves a colleague and friend as Ida.

I know I am privileged for the friends I have: Eva Hener, Henriette Lundgren, Pauline Kruiniger, Martin Smit (tijd voor een nieuw ontwikkelingsplan nu de "scriptie" af is....), Irene en Ewout Voskamp, Judith Maas, Maaike van Stolk, Christel Grimbergen, Marieke Broekhoff, Rianne Reijs, Michiel van Hoorn, Remco de Vos, Morag Goodwin, Miriam Haritz (let's toast with an Affligem beer!), Mare van der Eden, Conrad Schmidt-Bens, Carla Dielen, Mara Wantuch, and Jenny Orfuss. I am grateful for their friendship, support and care, which helped me overcome setbacks and kept me from disintegrating. Credit and sincere thanks for the editing of this book goes to Josh Moll and Sytze Steenstra.

The last and most important words of gratitude are owed to my family - ancestors and contemporaries, to whom this work is dedicated. Meinen Eltern möchte ich danken für ihre Liebe, Fürsorge und Unterstützung auf meinem gesamten Lebensweg. Ich wünschte, Mama hätte den erfolgreichen Abschluss dieser Lebensphase miterleben dürfen. Papa, danke für alles, von A wie Ansporn bis Z wie Zuhause (nicht zu vergessen das $K$ von Kochtipps). Felix und Alex - danke für Eure brüderliche Unterstützung. Auch für Euch brechen neue Lebensphasen an - auf zu neuen Taten!

Tenslotte: Stefaan, mijn steun en toeverlaat. Bedankt voor je liefde, je steun en het vertrouwen in de toekomst. Het motto van jouw familie, in wie ik een lieve schoonfamilie heb gevonden, is "streef naar een zilveren medaille op het werk en naar een gouden in privé aangelegenheden". In jou heb ik mijn gouden medaille gevonden en ik kijk uit naar de nieuwe uitdagingen die voor ons liggen.

Maastricht, October 2009

Katja Lubina 


\section{Curriculum vitae}

Katja Lubina was born in Bottrop, Germany, on September 19, 1977. She completed her secondary school at the Josef-Albers-Gymnasium in Bottrop in 1997. She studied law and culture and science studies in Maastricht and Berlin. She received her Master's degrees in 2002 (law), respectively 2004 (culture and science studies). Her master thesis entitled "The Aftermath of the Second World War - Restitution of Looted Art" was awarded the 'scriptieprijs', the award for the best thesis at the Law Faculty of Maastricht University in 2002.

In September 2003 Katja Lubina joined the Law Faculty as Junior Researcher. She has been lecturing a variety of courses ranging from 'Law and Art: The Free Movement of Cultural Property' to 'States, Markets and European Integration'. From 2006 - 2007 she took unpaid leave to work as researcher in the Historic Claims Department at the Art Loss Register, London to complement her research with practical experience. During her stay in the UK she also received the diploma in 'Art Law and Policy Management' by the Institute of Art \& Law, Leicester.

Katja Lubina now works as lecturer (universitair docent) at the Law Faculty of Maastricht University. Her interest for future research projects include the perception of art works and cultural heritage in law, the role and relevance of legal instruments in protecting the cultural heritage and the role of cultural heritage in international relations. 